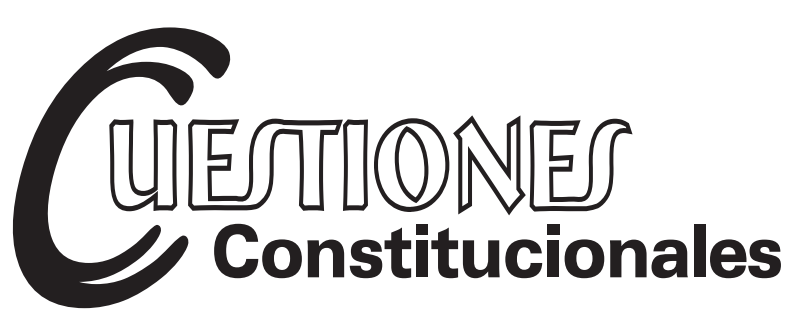

Revista Mexicana de Derecho Constitucional
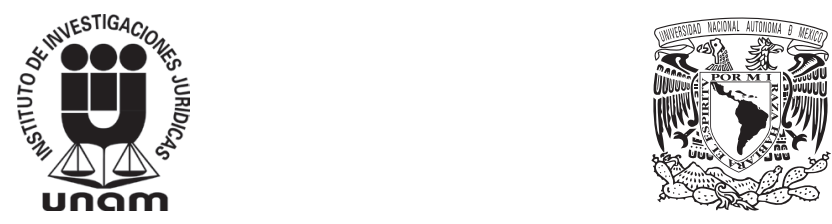

Número 43, Julio-Diciembre de 2020

INSTITUTO DE INVESTIGACIONES JURÍDICAS

UNIVERSIDAD NACIONAL AUTÓNOMA DE MÉXICO 


\title{
INSTITUTO DE INVESTIGACIONES JURÍDICAS
}

\author{
Dr. Pedro Salazar Ugarte \\ Director \\ Dra. Issa Luna Pla \\ Secretaria académica \\ Lic. Raúl Márquez Romero \\ Secretario técnico \\ Mtra. Wendy Vanesa Rocha Cacho \\ Jefa del Departamento de Publicaciones
}

De las opiniones sustentadas en los trabajos firmados responden exclusivamente sus autores. El hecho de su publicación no implica en manera alguna que esta revista, Cuestiones Constitucionales, se solidarice con su contenido.

Cuidado de la edición: Miguel López Ruiz

Formación en computadora: José Antonio Bautista Sánchez

Asistente de la revista: Jessica Janeth Padilla Márquez 


\title{
CUESTIONES CONSTITUCIONALES \\ Revista Mexicana de Derecho Constitucional
}

Dr. Edgar Corzo Sosa

Director

\author{
Mtra. Wendy Vanesa Rocha Cacho \\ Coordinadora editorial
}

\section{CONSEJO EDITORIAL}

Jorge Adame Goddard (México, UNAM-IIJ); José Afonso da Silva (Brasil, Universidad de São Paulo); Manuel Aragón Reyes (España, Universidad Autónoma de Madrid); Carlos M. Ayala Corao (Venezuela, presidente de la Comisión Andina de Juristas); Jorge Carpizo † (México, UNAM-IIJ); Krystian Complak (Polonia, Wydzial Prawa i Administracji Uniwersytet Wroclawski); José Ramón Cossío Díaz (México, SCJN); Ronald Dworkin † (Estados Unidos de América-Inglaterra, New York University / University College London); Héctor Fix-Zamudio (México, UNAM-IIJ); Imer Flores Mendoza (México, UNAM-IIJ); Domingo García Belaúnde (Perú, Universidad Peruana Los Andes); Jorge Mario García Laguardia (Guatemala, Universidad de San Carlos); Sergio García Ramírez (México, UNAM-IIJ); José Joaquim Gomes Canotilho (Portugal, Universidade de Coimbra); Ángel J. Gómez Montoro (España, Universidad de Navarra); Raúl González Schmal (México, Universidad Iberoamericana); Héctor Gros Espiell (Uruguay, Universidad de la República); Rubén Hernández Valle (Costa Rica, Universidad de Costa Rica); Hans-Rudolf Horn (Alemania, Universidad de Mainz); Roberto Ibáñez Mariel (México, Universidad Panamericana); John Anthony Jolowicz (Inglaterra, Universidad de Oxford); Alonso Lujambio Irazábal † (México, ITAM); Jorge Madrazo Cuéllar (México, UNAM-IIJ); Víctor Manuel Martínez Bullé-Goyri (México, UNAM-IIJ); Mario Melgar Adalid (México, UNAM-IIJ); Ricardo Méndez Silva (México, UNAM-IIJ); Jorge Miranda (Portugal, Universidad de Lisboa e Da Universidade Católica Portuguesa); Franck Moderne (Francia, Université de Pau et des Pays de l'Adour); Dieter Nohlen (Alemania, University of Heidelberg); José Alfredo de Oliveira Baracho $\dagger$ (Brasil, Universidad Federal de Minas Gerais); José de Jesús Orozco Henríquez (México, UNAM-IIJ); Carlos Restrepo Piedrahita (Colombia, Universidad Externado de Colombia); Luis Carlos Sáchica (Colombia, Colegio Mayor de Nuestra Señora del Rosario); Giovanni Sartori † (Italia-Estados Unidos de América, Columbia University in the City of New York / Universidad de Florencia); Fernando Serrano Migallón (México, UNAM); José Luis Soberanes Fernández (México, UNAMIIJ); Graciela Soriano de García Pelayo (Venezuela, Fundación Manuel García Pelayo); Manuel Suárez Muñoz (México, Instituto de Estudios Constitucionales 
del Estado de Querétaro); Diego Valadés (México, UNAM-IIJ); Salvador Valencia Carmona (México, UNAM-IIJ); Jorge Reinaldo Vanossi (Argentina, Instituto de Derecho Constitucional de la Academia Nacional de Derecho y Ciencias Sociales de Buenos Aires); Pedro de Vega (España, Universidad Complutense de Madrid); Francisco Venegas Trejo (México, UNAM); Giuseppe de Vergottini (Italia, Universidad de Bolonia); Gustavo Zagrebelsky (Italia, Universidad de Turín).

\section{CONSEJO ASESOR}

Victoria Adato Green (México, SCJN); César Iván Astudillo Reyes (México, UNAM-IIJ); Miguel Carbonell Sánchez (México, UNAM-IIJ); Héctor FixFierro † (México, UNAM-IIJ); Rodrigo Gutiérrez Rivas (México, UNAM-IIJ); María del Pilar Hernández (México, UNAM-IIJ); Sergio López-Ayllón (México, CIDE); Cecilia Mora-Donatto (México, UNAM-IIJ); Susana Pedroza de la Llave (México, UNAM-IIJ); Miguel Pérez López (México, UAM); Juan José Ríos Estavillo (México, Escuela Libre de Derecho); Alfredo Sánchez-Castañeda (México, UNAM-IIJ); José María Serna de la Garza (México, UNAM-IIJ); José Luis Vázquez Alfaro (México, UNAM); Juan Vega Gómez (México, UNAM-IIJ). 
Cuestiones Constitucionales. Revista Mexicana de Derecho Constitucional, núm. 43, julio-diciembre de 2020, es una publicación semestral editada por la Universidad Nacional Autónoma de México, Ciudad Universitaria, alcaldía Coyoacán, 04510 Ciudad de México, a través del Instituto de Investigaciones Jurídicas, Circuito Maestro Mario de la Cueva s/n, Ciudad de la Investigación en Humanidades, Ciudad Universitaria, 04510 Ciudad de México, teléfono 5622 7474, correo electrónico: rmdc.iij@unam.mx. Editor responsable: Edgar Corzo Sosa. Número de reserva al título en Derechos de Autor: 04-2003-051211533300-102. Número de reserva al título (versión electrónica): 04-2015-091716464800-203. ISSN (versión electrónica) 2448-4881. Número de certificado de licitud de título: 11210. Número de certificado de licitud de contenido: 7831. Dirección electrónica: http://revistas.juridicas.unam.mx/index.php/cuestiones-constitucionales/.

Cuestiones Constitucionales se encuentra registrada en los siguientes índices y bases de datos:

Sistema de Clasificación de Revistas Mexicanas de Ciencia y Tecnología (Conacyt, México). SCOPUS. Latindex. Bibliojurídica. Clase. Dialnet. Redalyc. SCIELO México. Ulrichs Web, Global Serials Directory. Hollis (Red de Revistas Científicas de la Universidad de Harvard). 
Cuestiones Constitucionales. Revista Mexicana de Derecho Constitucional por Universidad Nacional Autónoma de México, Instituto de Investigaciones Jurídicas, se distribuye bajo una Licencia Creative Commons Atribución-NoComercial-Sin Derivar 4.0 Internacional (CC BY-NC-ND 4.0).

Primera edición: 10 de noviembre de 2020

Universidad Nacional Autónoma de México

INSTITUTO DE INVESTIGACIONES JURÍDICAS

Circuito Maestro Mario de la Cueva s/n, Ciudad de la Investigación en Humanidades Ciudad Universitaria, Coyoacán, 04510 Ciudad de México

Hecho en México

ISSN (versión electrónica): 2448-4881 


\section{CONTENIDO}

\section{ARTÍCULOS DOCTRINALES}

La naturaleza tutelar de las medidas cautelares en la Jurisdicción Especial para la Paz . . . . . . . . . . . . . . .

The Protective Nature of the Provisional Measures in the Colombian Special Peace Jurisdiction

Paola Andrea AcOSTA-ALVARADO

Derecho intrafederal y los nuevos estándares en las relaciones fiscales intergubernamentales en el federalismo argentino. Un análisis a 25 años de la reforma constitucional nacional

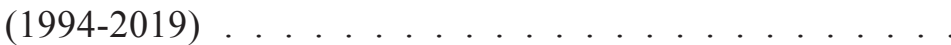

Intrafederal Law and the New Standards on Intergovernmental Fiscal Relations in the Argentine Federalism. An Analysis after 25 years of the National Constitutional Reform (1994-2019)

Cristian ALtaviLla

A era dos deveres: a necessidade de um estatuto da pessoa humana para a eficácia social dos direitos fundamentais . . . .

The era of duties: the need for a complete statute of the human person for the social effectiveness of rights

José Francisco DiAs DA COSTA LYRA

Marco Antônio PREIS

Julio Homem DE SiQUeIRA

Daury Cesar FABRIZ

La frontera móvil entre constitucionalidad y legalidad en la procedencia del amparo directo en revisión . . . . . . . . .

The moving boundary between constitutionality and legality within the "amparo directo en revisión" Roberto LARA CHAGOYÁN 
Hacia una sistematización de los usos semánticos del concepto de dignidad humana en la protección internacional de derechos humanos: una revisión doctrinaria . . . . . . . . . . . . .

Towards a systematization of the semantic uses of the concept of human dignity in the international protection of human rights: a doctrinal review

Jorge Nicolás LAFFERRIERE Helga LELL

Límites a la responsabilidad patrimonial por daño moral . . . .

Limits to patrimonial liability for moral damage

Oscar Antonio LEÓN OYOSA

El olvido previo a Internet: los orígenes del actual derecho al olvido digital . . . . . . . . . . . . . . . .

Forget Before Internet: the Origins of the Right to be Forgotten Ángela MORENO BOBADILlA

El derecho de identidad de personas transgénero en procedimientos de corrección de actas del registro civil. Una propuesta de sentencia estructural de la Suprema Corte de Justicia de la Nación . . . . . . . . . . . . . . . . . . . .

The right of Identity for transgender people in procedures for correcting civil registry records. A proposal for a structural sentence of the Supreme Court of Justice of the Nation Jesús Manuel OrOzCo PULIDO

Argumentación jurídica de las sentencias de los tribunales constitucionales como método para lograr la constitucionalización del proceso jurisdiccional (Una lectura a partir de la acción de tutela en Colombia) . . . . . . . . . . .

Legal argumentation of the rulings of the rulings of the constitutional courts as a means to achieve the constitutionalization of the jurisdictional process (An approach to the tutela action in Colombia)

Liliana Damaris PABÓN GIRALDO

Luis Orlando TORO GARZÓN

Andrés Felipe ZULUAGA JARAMILlO 
Las normas de ius cogens como imperativo en los procesos de justicia transicional. Estudio relativo al Tribunal de Jurisdicción Especial para la Paz en Colombia . . . . . . . . . .

The rules of ius cogens as an imperative in transitional justice processes: a study relating to Colombia's Special Jurisdiction for Peace Tribunal Yennesit Palacios VALENCIA

Ponderações e críticas sobre a eficácia vinculante dos motivos determinantes. ....................................

Ponderation and criticism on the binding effectiveness of the determinants

Flávio PANSIERI

Otávio Augusto BAPTISTA DA LUZ

La democracia participativa, respuesta a la crisis de la democracia representativa. . . . . . . . . . . . 351

Participatory democracy, a response to the crisis of representative democracry

Emilio RABASA GAMBOA

El precedente judicial en México. Fundamento constitucional y problemas básicos . . . . . . . . . . . . .

Judicial precedent in Mexico. Constitutional basis and basic problems

Rubén SÁNCHEZ GIL

El amparo judicial y la reforma al sistema de justicia en México (1987-2018) . . . . . . . . . . . . . .

Judicial amparo and the judicial reform in Mexico (1987-2018)

Alberto Abad SuÁREz ÁvilA 


\section{COMENTARIOS JURISPRUDENCIALES}

El matrimonio infantil y la dispensa de edad . . . . . . . . . 465

Judicial child marriage and age dispensation Juan Luis GONZÁLEZ AlCÁNTARA

Caso Marielle Franco - Tensão entre o segredo de justiça e a liberdade de imprensa (proposta de distensionamento entre os princípios constitucionais) . . . . . . . . . . . . .

Marielle Franco Case - Tension between the secret of justice and press freedom (proposal for socio-legal dialogue between constitutional principles)

Artur César SouzA

O Supremo Tribunal Federal do Brasil e o caso das terras ocupadas pelos remanescentes quilombolas. Estudo de caso a partir da acao direta de inconstitucionalidade n. 3.239-DF . . . . .

The Supreme Federal Court of Brazil and the case of the lands occupied by the kilombolan remanescents. Case study from the direct action of unconstitutionality n. 3.239-DF

Frederico Ribeiro de Freitas MENDES

Matheus Felipe DE CASTRO

\section{COMENTARIOS LEGISLATIVOS}

La falta de garantía de los derechos sexuales en Colombia: ¿cuestión de ineficacia normativa? . . . . . . . . . . . .

The lack of guarantee of sexual rights in Colombia: a matter of normative inefficiency?

Alirio Jesús AlZATE JARAMILlo

Carlos Alberto MOJICA ARAQUE

\section{RESEÑAS BIBLIOGRÁFICAS}

GARCíA RocA, Javier, La transformación constitucional del Convenio Europeo de Derechos Humanos, Civitas-Thomson Reuters. . . . . . . . . . . . . . . . . Adam KRZYWOŃ 
SAntos Loyola, R., Carlos, Estado y religión. Comentarios a la Ley de Libertad Religiosa . . . . . . . . . . . . . . . . . . . 595 Javier SALDAÑA SERRANO

FLORES CALDAS, Edgar C., Libertad religiosa y enseñanza de la religión católica en el ordenamiento jurídico peruano y en el acuerdo con la Santa Sede de 1980 . . . . . . . . . . . . . Efrén CHÁvEZ HERNÁNDEZ 
Esta revista forma parte del acervo de la Biblioteca Jurídica Virtual del Instituto de Investigaciones Jurídicas de la UNAM http://www.juridicas.unam.mx

https://biblio.juridicas.unam.mx

https://revistas.juridicas.unam.mx

DOI: http://dx.doi.org/10.22201/iij.24484881e.2020.43.15198

\section{ARTÍCULOS \\ DOCTRINALES}




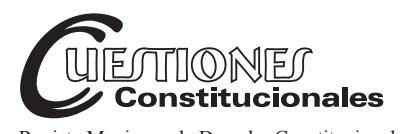

Revista Mexicana de Derecho Constitucional Núm. 43, julio-diciembre 2020

\section{La naturaleza tutelar de las medidas cautelares en la Jurisdicción Especial para la Paz*}

\section{The protective nature of the provisional measures in the colombian Special Peace Jurisdiction}

\section{Paola Andrea AcOSTA-AlVARADO**}

RESUMEN: En la teoría procesal, las medidas cautelares son herramientas judiciales que suelen concebirse como instrumentos para asegurar el buen desarrollo del proceso y el cumplimiento de las sentencias. Sin embargo, en el ámbito del derecho internacional de los derechos humanos (DIDH) la figura de las medidas cautelares ha venido desarrollando un rol tutelar, que tiene como fin último la protección de los derechos fundamentales.

Este texto tiene como objetivo poner de presente la transformación que estas medidas han experimentado, a través del trabajo puntual de la Jurisdicción Especial para la Paz, órgano transicional que sigue el perfil del DIDH. Al demostrar esta nueva naturaleza tutelar de las medidas cautelares se quiere resaltar su importante papel en la tutela de los individuos y, más aún, en el éxito de la justicia transicional, que en Colombia tiene además perfil restaurativo.

Palabras clave: medidas cautelares, justicia transicional, justicia restuarativa.
ABSTRACT: In procedural theory, precautionary measures are judicial tools that are usually conceived as instruments to ensure the proper development of the process and compliance with sentences. However, in the field of international human rights law (IHRL) the figure of precautionary measures has been developing a protective role, whose ultimate goal is protection of human rights.

This text aims to present the transformation that these measures have undergone, through the work of the Colombian Special Jurisdiction for Peace, a transitional body that follows the profile of the IHRL. In demonstrating this new tutelary nature of precautionary measures, we aim to highlight their important role in the protection of individuals and, moreover, in the success of transitional justice that, in Colombia, also has a restorative profile.

Keywords: provisional measures, transitional justice, restaurative justice.

* El análisis que se presenta responde de forma exclusiva a la opinión personal de la autora; en ninguna medida compromete a la institución para la que trabaja.

** Doctora en derecho internacional y relaciones internacionales. Docente investigadora de la Universidad Externado de Colombia. Colombia. ORCID: 0000-0002-5851400X Correo electrónico: paola.acosta@uexternado.edu.co. 
SUMARIO: I. Introducción. II. Del uso instrumental a la naturaleza tutelar de las medidas cautelares. III. Las medidas cautelares en la Jurisdicción Especial para la Paz: avances y desafios. IV. Conclusión.

\section{INTRODUCCIÓN}

En el mundo jurídico la figura de las medidas cautelares suele estar asociada al proceso, en particular, a la eficacia de lo que se decida en el marco de este. ${ }^{1}$ Pese a ello, en ciertos ámbitos este tipo de medidas han evolucionado hasta el punto de ampliar su naturaleza y alcances, por lo que ya no se trata de una herramienta meramente cautelar, sino también tutelar.

Este cambio se ha dado en particular, pero no exclusivamente, debido al uso de las medidas cautelares en el ámbito del derecho internacional de los derechos humanos (DIDH), ${ }^{2}$ y en el caso colombiano se hace evidente gracias al reciente trabajo de la Jurisdicción Especial para la Paz $(\mathrm{JEP})^{3}$ en torno a este asunto.

En las líneas que siguen se hará una breve descripción de esta evolución justamente desde el ejemplo particular de las medidas cautelares que decreta la JEP. Con esto no sólo se pretende demostrar el cambio de paradigma en torno a la naturaleza y uso de dicha herramienta procesal, sino, sobre todo, las consecuencias y los retos que ello implica. Al exponer este asunto, pretendemos resaltar la oportunidad que ofrecen dichas medidas cuando se trata de la garantía de derechos fundamentales, y, más aún, de la eficacia de la justicia transicional.

Para abordar este asunto se hará una somera introducción sobre el uso tradicional de las medidas cautelares (II) y cómo ese uso adquiere una connotación particular en el DIDH (III). A partir de allí, se podrá estudiar el régimen de las medidas cautelares en la Jurisdicción Especial a la luz de los asuntos que hasta el momento se han tramitado (IV). Hecho esto, se enlistarán los logros y los retos del uso de las medidas cautelares en la JEP (V). Se concluirá con unas reflexiones sobre las consecuencias de esa naturaleza tutelar, que, además, en el caso de la JEP, se entiende restaurativa.

\footnotetext{
Infra, apartado II.

2 Infra, apartado III.

3 Infra, apartado IV.
}

Esta obra está bajo una Licencia Creative Commons

Atribución-NoComercial-SinDerivar 4.0 Internacional, IIJ-UNAM. 


\section{DEL USO INSTRUMENTAL A LA NATURALEZA TUTELAR DE LAS MEDIDAS CAUTELARES}

En las líneas que siguen se hará un somero recuento de los diversos conceptos y usos de las medidas cautelares en el derecho procesal nacional y en el DIDH. Debe advertirse que no se abordará todo el régimen procesal de las medidas cautelares; para efectos de lo que interesa a nuestra hipótesis de trabajo, bastará con hacer referencia a la definición y a los alcances que se atribuyen a esta herramienta en los escenarios que se estudian.

A partir de allí, podremos ver cómo, más allá de lo que tradicionalmente se piensa, además de su uso instrumental, esta herramienta también tiene vocación tutelar. De entrada, vale la pena aclarar que este nuevo perfil de las medidas no excluye su uso tradicional; por el contrario, se suma a él para potenciar sus alcances.

\section{En derecho procesal}

En teoría clásica del derecho procesal, las medidas cautelares aparecen ante la necesidad de prevenir la afectación que puede causar la prolongada duración de un proceso. Tanto Carnelutti ${ }^{4}$ como Calamadrei ${ }^{5}$ coinciden en que estas medidas provisionales buscan evitar un daño mayor, a causa del paso del tiempo, al derecho que está en litigio.

En Colombia, las primeras regulaciones de las medidas cautelares daban cuenta de esa lógica instrumental, según la cual esta herramienta se activa sólo en el marco de un proceso y ante la necesidad de asegurar la sentencia o de evitar que el derecho en litigio se viera aún más afectado. Ello puede leerse tanto en la regulación del Código Civil ${ }^{6}$ como en el antiguo Código de Procedimiento Civil, ${ }^{7}$ así como en la doctrina procesalista. ${ }^{8}$

4 Carnelutti, Francesco, Sistema de derecho procesal civil, vol. I, Buenos Aires, Uteha, 1944, pp. 387 y ss.

5 Calamandrei, Piero, Instituciones de derecho procesal civil, vol. I, Buenos Aires, Ediciones Jurídicas Europa-América, p. 157.

6 Véase, entre otros, los artículos 158, 958, 2273 y ss.

7 En general, véase el libro cuarto, título XXXIV, pero también los artículos 385, 513 y ss. y el artículo 575 .

8 López Blanco definió esta institución en los siguientes términos: la medida cautelar es aquella "que busca precaver o prevenir las contingencias que puedan sobrevenir 
Bajo esta lógica instrumental, en 2004 la Corte Constitucional definió las medidas cautelares en los siguientes términos:

Para la Corte, las medidas cautelares, son aquellos instrumentos con los cuales el ordenamiento protege, de manera provisional, y mientras dura el proceso, la integridad de un derecho que es controvertido en ese mismo proceso. De esa manera el ordenamiento protege preventivamente a quien acude a las autoridades judiciales a reclamar un derecho, con el fin de garantizar que la decisión adoptada sea materialmente ejecutada. Por ello, esta Corporación señaló, en casos anteriores, que estas medidas buscan asegurar el cumplimiento de la decisión que se adopte, porque los fallos serían ilusorios si la ley no estableciera mecanismos para asegurar sus resultados, impidiendo la destrucción o afectación del derecho controvertido. ${ }^{9}$

Pese a las recientes reformas del régimen procesal colombiano (tanto civil ${ }^{10}$ como administrativo y contencioso administrativo), ${ }^{11}$ la regulación actual mantiene la naturaleza procesal de las medidas cautelares; es decir, estas herramientas siguen siendo accesorias al proceso, y con ellas se busca la salvaguarda de los bienes o derechos objeto de litigio. ${ }^{12}$

En sentencia T-206 de 2017, la Corte Constitucional señala que

Las medidas cautelares encuentran su razón de ser en la necesidad de prevenir las contingencias que puedan sobrevenir sobre las personas y/o los bienes, de manera tal que se asegure la ejecución del fallo correspondiente.

sobre las personas o los bienes, o sobre los medios de prueba mientras se inicia o se adelanta un proceso". López Blanco, Hernán Fabio, Instituciones de derecho procesal civil colombiano, t. II, Parte especial, pp. - 882. También dijo: "Providencias que, ya de oficio, o a petición de parte, puede adoptar el juez respecto de personas, pruebas o bienes que resulten afectados por la demora y tendientes a asegurar el cabal cumplimiento de las determinaciones que se adopten por el juez y, especialmente, de la sentencia una vez ejecutoriada". López Blanco, Hernán Fabio, ibidem, p. 81, Dupré, 2004. Jaime Azula las define como "El conjunto de actuaciones que tienden a... evitar que los resultados perseguidos en un proceso sean ilusorios o ineficaces". Azula Camacho, Jaime, Manual de derecho procesal, t. I: Teoría general del proceso, Temis, 2000, p. 61.

9 Corte Constitucional, sentencia C- 379 de 2004.

10 Ley 1564 de 2012.

11 Ley 1437 de 2011.

12 Sobre el régimen del Código General del Proceso véase Álvarez Gómez, Marco Antonio, Las medidas cautelares en el Código General del Proceso. Módulo de aprendizaje autodirigido, Plan de Formación de la Rama Judicial, Consejo Superior de la Judicatura, 2014.

Esta obra está bajo una Licencia Creative Commons

Atribución-NoComercial-SinDerivar 4.0 Internacional, IIJ-UNAM. 
Con base en lo anterior, es pertinente recordar que las medidas cautelares comportan las siguientes características, las cuales se deducen de su definición y naturaleza: ${ }^{13}$ (i) Son actos procesales, toda vez que con ellas se busca asegurar el cumplimiento de las decisiones del juez, lo cual es una de las funciones esenciales del proceso. (ii) Son actuaciones de carácter judicial, propias de un proceso. (iii) Son instrumentales, esto es, sólo encuentran asidero cuando se dictan en función de un proceso al cual acceden. (iv) Son provisionales, y tienen como duración máxima el tiempo en el que subsista el proceso al cual acceden, por lo que una vez culminado éste, la medida necesariamente deja de tener efecto. (v) son taxativas, es decir, se encuentran consagradas en la ley, la cual señala el proceso dentro del cual proceden. ${ }^{14}$

...Igualmente, la Corte Constitucional ha establecido que las medidas cautelares guardan relación directa con el derecho de acceso a la administración de justicia, puesto que esta garantía fundamental, en cierta medida, asegura que las decisiones de los jueces sean ejecutadas y cumplidas. No obstante, esta Corporación ha considerado que "su decreto y ejecución por parte de las autoridades públicas debe conciliarse con el postulado superior relativo al respeto de los derechos fundamentales de las personas" ${ }^{15}$ (cursivas fuera del texto original).

En sentido similar, el Consejo de Estado apunta:

Los artículos 229 y siguientes del CPAyCA instituyen un amplio y novedoso sistema de medidas cautelares en el procedimiento contencioso administrativo que son aplicables en aquellos casos en que se consideren "necesarias para proteger y garantizar, provisionalmente, el objeto del proceso y la efectividad de la sentencia", conforme a las notas del mismo artículo, de donde se infiere que la institución cautelar es una manifestación legislativa concreta de la garantía de efectividad del derecho al acceso a la administración de justicia; comoquiera que se busca evitar que la duración del proceso afecte a quien que acude a la jurisdicción, a tal punto que para el momento de obtener una decisión favorable se torne en ilusorio el ejercicio del derecho reconocido, pues al decir de Chiovenda "la necesidad de servirse del proceso para conseguir la razón no debe convertirse en daño para quien tiene la razón”. El

13 López Blanco, Hernán Fabio, Procedimiento civil, 9a. ed., t. I, Parte general, Dupre Editores, 2007.

14 Reiterado en sentencia T-172 de 2016.

15 Sentencia T-788 de 2013.

Esta obra está bajo una Licencia Creative Commons Atribución-NoComercial-SinDerivar 4.0 Internacional, IIJ-UNAM. 
anterior aserto se sustenta en que a través de la tutela cautelar se protege de manera provisional e inmediata una posición jurídica en concreto (bien sea particular o general) que es objeto de litigio ante la jurisdicción contenciosa administrativa y que encuentra en entredicho su ejercicio a plenitud en razón a la amenaza que supone, en general, la acción de la administración pública, bien sea a partir de una decisión administrativa, una acción u omisión, etc.; por citar algunas manifestaciones particulares del accionar de la administración $^{16}$ (cursivas fuera del texto original).

Además de la regulación de los regímenes procesales generales, las medidas cautelares también están contempladas en varios procedimientos especializados, y allí también su vocación es instrumental. Así, por ejemplo, las medidas cautelares en los procesos de competencia desleal por violación de normas ${ }^{17} \mathrm{o}$ en los procesos por infracción de derechos de propiedad industrial. ${ }^{18}$

Así las cosas, en el régimen procesal actual las medidas cautelares se entienden como una herramienta vinculada a un proceso (judicial o administrativo) cuyo objetivo es instrumental, toda vez que con ellas se busca asegurar la efectividad de la tutela judicial.

\section{En el DIDH}

En buena medida, la regulación de la figura cautelar en el DIDH siguió los pasos del derecho internacional público general, ${ }^{19}$ que a su vez se apoyó en la teoría procesal clásica. Así, el reglamento del Comité de Derechos Humanos de las Naciones Unidas, ${ }^{20}$ el del Tribunal Europeo de

16 Consejo de Estado. Sala de lo Contencioso Administrativo, sección tercera, subsección C. Consejero ponente: Jaime Orlando Santofimio Gamboa. Bogotá, D. C., trece (13) de mayo de dos mil quince (2015). Radicación: 11001-03-26-000-2015-0002200(53057). En sentido similar: Consejo de Estado. Sala de lo Contencioso Administrativo, sección cuarta. Consejero ponente: Martha Teresa Briceño de Valencia. Bogotá, D. C., veintidós (22) de febrero de dos mil dieciséis (2016). Radicación: 11001-03-27-0002013-00032-00(20631)

17 Ley 256 de 1996, artículo 31.

18 Comunidad Andina de Naciones, decisión 486 de 2000, artículos 245 y ss.

19 Artículo 41.1 del Estatuto de la Corte Internacional de Justicia, artículo 75 del Reglamento de la Corte Internacional de Justicia.

20 Reglamento del Comité de Derechos Humanos de las Naciones Unidas, "Artículo 92: El Comité podrá, antes de transmitir su dictamen sobre la comunicación al Estado 
Derechos Humanos ${ }^{21}$ y el de la Comisión Africana de Derechos Humanos $^{22}$ prevén la posibilidad de decretar medidas en el marco de los procesos que adelanta, con el fin de asegurar "el buen desarrollo" de éstos o un daño mayor "a la víctima de la violación denunciada".

Sin embargo, la regulación del sistema interamericano de protección de los derechos humanos (el Sistema), así como el de la Corte Africana, ${ }^{23}$ prevé el uso de las medidas cautelares fuera del proceso. En el caso interamericano, que por ser el más cercano y el que nos resulta vinculante es el que nos interesa, las medidas fueron pensadas y son usadas como una herramienta independiente del trámite, bien sea cuasi-judicial o judicial, de la Comisión o de la Corte Interamericana, respectivamente.

El artículo 63.2 de la Convención Americana sobre Derechos Humanos (CADH o Convención) contempla la posibilidad de que

[e]n casos de extrema gravedad y urgencia, y cuando se haga necesario evitar daños irreparables a las personas, la Corte [Interamericana], en los asuntos que esté conociendo, podrá tomar las medidas provisionales que considere pertinentes. Si se tratare de asuntos que aún no estén sometidos a su conocimiento, podrá actuar a solicitud de la Comisión.

parte interesado, comunicar a ese Estado su opinión sobre la conveniencia de adoptar medidas provisionales para evitar un daño irreparable a la víctima de la violación denunciada. En tal caso, el Comité informará al Estado parte interesado de que esa expresión de su opinión sobre las medidas provisionales no implica ninguna decisión sobre el fondo de la comunicación".

21 Reglamento del Tribunal Europeo de Derechos Humanos, "Artículo 39: La Sala o, en su caso, el Presidente de la Sección o el Juez de guardia designado de conformidad con el apartado 4 del presente artículo podrán, ya sea a instancia de parte o de cualquier otra persona interesada, o de oficio, indicar a las partes cualquier medida cautelar que consideren deba ser adoptada en interés de las partes o del buen desarrollo del procedimiento". (cursivas fuera del texto original).

22 Reglamento de la Comisión Africana de Derechos Humanos, artículo 98: "Provisional Measures: 1. At any time after the receipt of a Communication and before a determination on the merits, the Commission may, on its initiative or at the request of a party to the Communication, request that the State concerned adopt Provisional Measures to prevent irreparable harm to the victim or victims of the alleged violation as urgently as the situation demands".

23 Por ejemplo, el artículo 27, párrafo 2, del Protocolo de la Carta Africana de Derechos Humanos y de los Pueblos para el Establecimiento de una Corte Africana de Derechos Humanos y de los Pueblos ("In case of extreme gravity and urgency, and when necessary to avoid irreparable harm to persons, the Court shall adopt such provisional measures as it deems necessary"). 
De acuerdo con el desarrollo reglamentario de esta disposición, la Comisión Interamericana de Derechos Humanos (Comisión o CIDH) ${ }^{24}$ y la Corte Interamericana de Derechos Humanos (Corte IDH ${ }^{25}$ pueden decretar medidas de protección, que en el caso de la Comisión se llaman "cautelares", y de la Corte IDH "provisionales", independientemente de la existencia de un proceso, siempre que con ellas se busque evitar que una amenaza se concrete o lograr que un daño cese.

\section{Tal como lo señala la CIDH:}

La Comisión Interamericana y la Corte Interamericana de Derechos Humanos ... han establecido de manera reiterada que las medidas cautelares y provisionales tienen un doble carácter, uno cautelar y otro tutelar. Respecto del carácter tutelar, las medidas buscan evitar un daño irreparable y preservar el ejercicio de los derechos humanos. Con respecto al carácter cautelar, las medidas cautelares tienen como propósito preservar una situación jurídica mientras está siendo considerada por la CIDH. El carácter cautelar tiene por objeto y fin preservar los derechos en posible riesgo hasta tanto se resuelva la petición que se encuentra bajo conocimiento en el Sistema Interamericano. Su objeto y fin son los de asegurar la integridad y la efectividad de la decisión de fondo y, de esta manera, evitar que se lesionen los derechos alegados, situación que podría hacer inocua o desvirtuar el efecto útil (effet utile) de la decisión final. En tal sentido, las medidas cautelares o provisionales per-

24 Reglamento de la CIDH, artículo 25.1, "Con fundamento en los artículos 106 de la Carta de la Organización de los Estados Americanos, 41.b de la Convención Americana sobre Derechos Humanos, 18.b del Estatuto de la Comisión y XIII de la Convención Interamericana sobre Desaparición Forzada de Personas, la Comisión podrá, a iniciativa propia o a solicitud de parte, solicitar que un Estado adopte medidas cautelares. Tales medidas, ya sea que guarden o no conexidad con una petición o caso, se relacionarán con situaciones de gravedad y urgencia que presenten un riesgo de daño irreparable a las personas o al objeto de una petición o caso pendiente ante los órganos del Sistema Interamericano".

25 Reglamento de la Corte IDH, artículo 27: "1. En cualquier estado del procedimiento, siempre que se trate de casos de extrema gravedad y urgencia y cuando sea necesario para evitar daños irreparables a las personas, la Corte, de oficio, podrá ordenar las medidas provisionales que considere pertinentes, en los términos del artículo 63.2 de la Convención. 2. Si se tratare de asuntos aún no sometidos a su conocimiento, la Corte podrá actuar a solicitud de la Comisión. 3. En los casos contenciosos que se encuentren en conocimiento de la Corte, las víctimas o las presuntas víctimas, o sus representantes, podrán presentar directamente a ésta una solicitud de medidas provisionales, las que deberán tener relación con el objeto del caso". 
miten así que el Estado en cuestión pueda cumplir la decisión final y, de ser necesario, cumplir con las reparaciones ordenadas. ${ }^{26}$

\section{En el mismo sentido, la Corte IDH ha declarado:}

El Tribunal ha señalado que las medidas provisionales tienen dos caracteres: uno cautelar y otro tutelar. El carácter cautelar de las medidas provisionales está vinculado al marco de los contenciosos internacionales. En tal sentido, estas medidas tienen por objeto y fin preservar los derechos en posible riesgo hasta tanto no se resuelva la controversia. Su objeto y fin son los de asegurar la integridad y la efectividad de la decisión de fondo y de esta manera evitar que se lesionen los derechos en litigio, situación que podría hacer inocua o desvirtuar el efecto útil de la decisión final. Las medidas provisionales permiten así que el Estado en cuestión pueda cumplir la decisión final y, en su caso, proceder a las reparaciones ordenadas. En cuanto al carácter tutelar de las medidas provisionales esta Corte ha señalado que éstas se transforman en una verdadera garantía jurisdiccional de carácter preventivo, por cuanto protegen derechos humanos, en la medida que buscan evitar daños irreparables a las personas. ${ }^{27}$

Los datos estadísticos en torno a las medidas cautelares y provisionales refuerzan esta lectura de los órganos del Sistema, toda vez que buena parte de las medidas decretadas en la última década se ordenaron fuera de un proceso, y en un alto porcentaje de ellas se buscó la salvaguarda de los derechos a la vida e integridad personal. Los datos de los casos colombianos de medidas cautelares y provisionales dan cuenta de ello: diez de los 198 casos de medidas provisionales fueron decretados fuera de un proceso contencioso, y el 99\% de ellos tienen relación con la protección de los derechos a la vida y a la integridad personal. ${ }^{28}$

26 Comisión Interamericana de Derechos Humanos. Resolución 69/2019. Medida cautelar 1581-18. Jorge David Glas Espinel respecto de Ecuador, 31 de diciembre de 2019.

27 Corte IDH. Asunto Giraldo Cardona respecto de Colombia. Medidas provisionales, Resolución de la Corte Interamericana de Derechos Humanos del 2 de febrero de 2010. En sentido similar, Resolución del Presidente de la Corte Interamericana de Derechos Humanos caso Gutiérrez Soler, 27 de noviembre de 2007. "Que en el Derecho Internacional de los Derechos Humanos, las medidas urgentes y provisionales sirven, además, al propósito de proteger derechos humanos fundamentales, evitando daños irreparables a las personas".

28 Los datos se pueden consultar en www.corteidh.or.cr. 
Así las cosas, además de la histórica vocación instrumental en el marco de un proceso particular, desde la práctica interamericana las medidas cautelares o provisionales tienen una naturaleza tutelar.

\section{LAS MEDIDAS CAUTELARES EN LA JURISDICCIÓN ESPECIAL PARA LA PAZ: AVANCES Y DESAFÍOS}

En este apartado se hará una breve mención del régimen de las medidas cautelares en la Jurisdicción Especial para la Paz, se dará cuenta del perfil que se le ha atribuido a este tipo de medidas a la luz de los casos que ha tramitado el Juez Especial (A.), se expondrán los logros y se enlistarán los retos que le esperan a la JEP en esta materia (B.).

\section{Las medidas cautelares en la JEP}

El marco normativo que regula el trabajo de la Jurisdicción Especial para la Paz (JEP) contempla la posibilidad de que las salas y secciones decreten medidas cautelares. ${ }^{29}$

De acuerdo con el artículo 22 de la Ley 1922 de 2018:

En todos los procesos que se adelanten ante la JEP, en cualquier estado del proceso, de oficio o por petición debidamente sustentada, podrá la Sala o Sección de conocimiento decretar, en providencia motivada, las medidas cautelares que considere necesarias relacionadas con situaciones de gravedad y urgencia, para:

1. Evitar daños irreparables a personas y colectivos.

2. Proteger y garantizar el acceso a la información que se encuentra en riesgo inminente de daño, destrucción y/o alteración.

3. Garantizar la efectividad de las decisiones.

4. La protección de las víctimas y el real restablecimiento de sus derechos

5. Las medidas judiciales necesarias para la asistencia de las víctimas, su protección y el restablecimiento de sus derechos.

Si bien esta norma se refiere al uso de las medidas en el marco de los procesos adelantados por la Jurisdicción, la práctica en torno a este asunto

29 Acuerdo final, apartado 5.1.2, párrafo 51, literal c; párrafo 54, literal f; artículo transitorio 7 del Acto Legislativo 1, de 2017; artículos 87, 93, 109117 de la Ley Estatutaria de Administración de Justicia en la JEP; artículos 22-26 de la Ley 1922 de 2018. 
permite ver que la interpretación del juez especial se acerca a la experiencia interamericana en la medida en que además de las medidas decretadas dentro de un caso también se ha servido de este mecanismo de forma independiente.

De acuerdo con el informe de gestión de $2018,{ }^{30}$ ese año se tramitaron cinco medidas cautelares, dos por la Sala de Definición de Situaciones Jurídicas (SDSJ) y tres por la Sección de Ausencia de Reconocimiento de Verdad y Responsabilidad (SARVR). Según el informe de gestión de $2019,{ }^{31}$ en su segundo año de trabajo la Jurisdicción dio trámite a veintiún medidas cautelares, y al finalizar el año tenía pendientes por resolver 35 solicitudes más; ${ }^{32}$ diecinueve de las veintiún medidas en trámite tienen relación con los macro casos que adelanta la Sala de Reconocimiento de Verdad y Responsabilidad (SRVR) y buscan la protección de las partes en el proceso o de la información que interesan a éste. ${ }^{33}$

Al momento de decretar estas medidas, la Jurisdicción invocó el perfil instrumental de esta herramienta, ${ }^{34}$ pero también se preocupó por resaltar que ésta también tiene vocación de protección, ya no del proceso, sino de las personas en sí mismas. En este sentido, en el auto 175 de 2019 de la SRVR se afirma: ${ }^{35}$

35. Así las cosas, el fin último de las medidas cautelares es la protección de los derechos fundamentales de las víctimas a la justicia, verdad, reparación y no repetición, para lo cual, en virtud de la interdependencia entre los derechos, se preservan como objetivo inmediato los derechos a la vida, libertad, integridad y seguridad personales de las víctimas, condición necesaria para ejercer su derecho a la participación ante la JEP.

30 Disponible en: https://www.jep.gov.co/Paginas/Transparencia/Planeacion/Informes-de-gestion.aspx.

31 Disponible en: https://www.jep.gov.co/Paginas/Transparencia/Planeacion/informes-de-gestion-2019.aspx.

32 En el marco de los casos la Sala de Reconocimiento de Verdad y Responsabilidad (SRVR) decretó siete medidas cautelares, tiene en trámite doce y debe atender 35 peticiones más. Por su parte, la Sección de Ausencia de Reconocimiento de Verdad y Responsabilidad (SARVR) informó que había tramitado dos asuntos cautelares, uno de los cuales sigue su curso. Ninguna otra sala o sección reportó trámite de medidas.

33 Jurisdicción Especial para la Paz. Sala de Reconocimiento de Verdad y Responsabilidad. Auto 175 de 2019.

34 Jurisdicción Especial para la Paz, sección de Revisión, Auto SRT-CC 001 de 2018.

35 Jurisdicción Especial para la Paz, Sala de Reconocimiento de Verdad y Responsabilidad, Auto 215 de 2019. 
37. Dada la conexión intrínseca entre estos derechos, es razonable concebir que el riesgo para una serie de garantías fundamentales (p. ej., para la vida, integridad, libertad y seguridad personal) supone una amenaza coetánea para los otros (justicia, verdad, reparación y no repetición, así como la participación en el proceso).

En este sentido podría decirse que pese a que las medidas se den en el seno del proceso y con ellas se busque que el mismo llegue a buen puerto, también se usan como una herramienta de protección de derechos fundamentales, que en buena parte de los casos son esenciales (vida e integridad personal) (cursivas fuera del texto original).

En este mismo sentido, en el auto 181 de 2019 la SRVR hizo una lectura sistemática de las normas que regulan el trabajo de la Jurisdicción, para concluir que es su deber decretar medidas cautelares, incluso de oficio, cuando están en riesgo de los derechos de las víctimas. ${ }^{36}$

Ahora bien, además de las medidas decretadas en el marco de un caso, la Jurisdicción ha tramitado tres grandes asuntos de forma independiente, es decir, allende un caso ya en marcha. Uno de ellos lo inició el secretario ejecutivo, y dos más la Sección de Ausencia de Reconocimiento de Verdad y Responsabilidad (SARVR). Veamos.

La primera de estas medidas fue ordenada por el secretario ejecutivo a la luz del mandato previsto en el párrafo segundo del artículo transitorio 7 del Acto Legislativo 1 de 20017; con ella se pretendía la protección de los archivos de inteligencia, contrainteligencia y gastos reservados del extinto Departamento Administrativo de Seguridad - DAS — con el fin de preservar todos los documentos relacionados con el conflicto armado. ${ }^{37}$

Este trámite inició cuando aún no estaba en vigor el régimen procesal que regula el trabajo de la Jurisdicción, pero durante su desarrollo entró en vigor la Ley 1922 de 2018, por lo que buena parte del procedimiento se rigió por este marco normativo. A la luz de dicha norma, y siguiendo la jurisprudencia constitucional y contenciosa sobre la materia, el juez especial caracterizó las medidas cautelares desde la lógica instrumental descrita en el primer apartado de este capítulo. ${ }^{38}$

\footnotetext{
36 Jurisdicción Especial para la Paz, Sala de Reconocimiento de Verdad y Responsabilidad, Auto 181 de 2019. Acápite sobre competencia.

37 Jurisdicción Especial para la Paz. Secretaría Ejecutiva, Auto 001 de 2018.

38 Jurisdicción Especial para la Paz, Sección de Revisión. Auto SRT-CC-001/2018. Apartado 3.1.
} 
Al respecto, vale la pena aclarar que si bien esta medida cautelar no se dio en el marco de un único caso, sí tenía vocación instrumental, toda vez que con ella se buscaba asegurar una información esencial para el buen transcurrir de los procesos adelantados por la Jurisdicción.

Por el contrario, el segundo asunto independiente tenía una vocación más tutelar que instrumental, y así lo entendió el juez especial. Se trata de las medidas decretadas por la SARVR con las que se buscaba la protección de los bienes contenidos en el inventario entregado por las FARC-EP. ${ }^{39}$

Cronológicamente hablando, éste fue el primer asunto en el que la Jurisdicción tuvo la oportunidad de pronunciarse sobre la naturaleza de las medidas cautelares, y para hacerlo se sirvió de una interpretación sistémica y teleológica ${ }^{40}$ de las normas que consagran los objetivos, los principios y la naturaleza especial de la Jurisdicción, así como de las normas puntuales sobre esta herramienta judicial.

A partir de allí, el juez transicional determinó que también las víctimas pueden solicitar las medidas, ${ }^{41}$ toda vez que éstas tienen como vocación principal la salvaguarda de sus derechos. En sus palabras:

39 Jurisdicción Especial para la Paz, Sección de Ausencia de Reconocimiento de Verdad y Responsabilidad. MC 001 de 2018, Auto 001 de 2018.

40 Jurisdicción Especial para la Paz Sección de Ausencia de Reconocimiento de Verdad y Responsabilidad. MC 001 de 2018, Auto 005 de 2018. “1.5. En conclusión, para esta Sección es una premisa y un hecho jurídico que los derechos de las víctimas del conflicto armado son el objeto y el fundamento de todas las actuaciones que se adelantan ante la JEP, por ende, dando primacía al derecho sustancial, todas las normas de procedimiento que rijan su proceder deben interpretarse teleológicamente con miras a garantizar los derechos de las víctimas a la verdad, a la justicia, a la reparación y a la no repetición".

41 Jurisdicción Especial para la Paz Sección de Ausencia de Reconocimiento de Verdad y Responsabilidad. MC 001 de 2018, Auto 005 de 2018. “3.2 (..) A lo anterior se puede agregar que, si ya en el proceso ordinario, y esto por exigencia constitucional, las víctimas tienen derecho a solicitar medidas cautelares (como también puede hacerlo el Ministerio Público), con mucha más razón deben poder hacerlo en el marco de un proceso de justicia transicional donde ellas precisamente son el centro y sus derechos fin central del sistema". "3.3... Para esta sección es claro que la lectura correcta de la normativa del SIVJRNR es a partir de los principios consagrados constitucionalmente y por ello debe evitarse todo ejercicio reducido, exegéticamente limitado y fraccionado que conduzca, en consecuencia, a interpretaciones en total contravía del sentido de la norma y el origen del sistema. Las disposiciones referidas guardan completa coherencia no sólo con la centralidad de los derechos de las víctimas (Ley 1922, libro primero, título primero), sino que además que corresponden directamente con el hecho de que algunas de las causales de procedencia de las medidas cautelares en la JEP específicamente son, como antes se 
En conclusión, para esta Sección desde el punto constitucional y legal, atendiendo a una perspectiva teleológica y partiendo, como lo es debido, de la centralidad de las víctimas, ${ }^{42}$ así como a los principios pro homine y pro víctima como criterios interpretativos, ${ }^{43}$ no puede concluirse nada distinto a que las medidas cautelares que puede adoptar la JEP persiguen principal y exclusivamente, la garantía de los derechos de las víctimas, incluyendo claro está, su derecho a la reparación integral ${ }^{44}$ (cursiva fuera del texto original).

Finalmente, está el caso más significativo en términos de la vocación tutelar de las medidas cautelares; se trata del asunto relativo al cuidado, la protección y la preservación de varios lugares del territorio nacional en los que presuntamente se encuentran inhumados de forma irregular personas dadas por desaparecidas. ${ }^{45}$

En esta oportunidad, para reforzar las reflexiones hechas en torno a la naturaleza y alcance de las medidas cautelares, el juez especial echó mano también de la reflexión de la Corte Constitucional en torno a las finalidades de la JEP, según la cual ésta debe aportar a la satisfacción de los derechos de las víctimas allende los casos concretos, cuestión que fue plasmada también en las Reglas de Procedimiento y en el Reglamento Interno de la Jurisdicción. ${ }^{46}$

Estas reflexiones en torno a la naturaleza y alcance de las medidas cautelares en la práctica se tradujeron en el uso de éstas para la concreción del perfil restaurativo del trabajo de la Jurisdicción a partir de la garantía efectiva de los derechos de las víctimas, no sólo en términos del resultado final del trámite, sino como la esencia misma de este.

En otras palabras, el trámite de estas medidas cautelares se ha desarrollado teniendo en mente que éstas buscan adoptar providencias que per-

anotaba, "la protección de las víctimas y el restablecimiento de sus derechos" (artículo 22 , numeral 4, cursivas fuera del texto)".

42 Ley 1922 de 2018, libro primero, título primero: "Centralidad de las víctimas".

43 Artículo 1o., literal d: “d) Principios pro homine y pro-víctima. En casos de duda en la interpretación y aplicación de las normas de la justicia transicional, las Salas y Secciones de la JEP deberán observar los principios pro homine y pro-víctima".

44 Jurisdicción Especial para la Paz, sección de Ausencia de Reconocimiento de Verdad y Responsabilidad. MC 001 de 2018, Auto 005 de 2018, Apartado 3.5.

45 Jurisdicción Especial para la Paz. Especial para la Paz, sección de Ausencia de Reconocimiento de Verdad y Responsabilidad. MC 002 de 2018, Auto 001 de 2018.

46 Ibidem, considerando 1. 
mitan la garantía de los derechos de las víctimas, pero también bajo el presupuesto de que el trámite procesal debe ser per se restaurativo.

Sobre este asunto, la SARVR dijo:

Las medidas cautelares ofrecen una oportunidad para materializar el perfil restaurativo del trabajo de la Jurisdicción. Por una parte, sus objetivos (evitar daños irreparables, proteger información, lugares, personas y asegurar su participación) son en sí mismos propósitos restaurativos que apuntan a la satisfacción de derechos y a la garantía de no repetición. Por la otra, su trámite ofrece la oportunidad de reconocer las voces de los individuos y las comunidades, de hacerlos partícipes. Esto revela el rol de la JEP en la materialización de las tesis centrales de la justicia restaurativa que se resumen en su carácter relacional, el protagonismo de las víctimas, así como en su vocación preventiva, concientizadora y transformadora, dialógica, participativa y arraigada en territorios y comunidades.

...En este contexto, surge un catálogo de principios restaurativos que deben guiar (y en este caso han guiado) este trámite cautelar, a saber:

a. La escucha como primera acción restauradora

b. La presencia territorial

c. La participación y el acuerdo sobre cómo llevarla a cabo en el desarrollo del proceso

d. La acción sin daño a lo largo de toda intervención

e. La prevención de nuevas afectaciones

f. El reconocimiento de la interlocución y, con ello, de los interlocutores, de su voz y del dolor en ella. Sufrimiento que se vive desde el daño originado por la inacción, la acción indebida o incompleta del Estado. ${ }^{47}$

Esta lectura ha significado no sólo que las víctimas pueden solicitar las medidas, y que éstas proceden incluso sin la existencia de un caso, sino también ha traído consigo la adopción de una serie de estrategias de participación, que permiten que el proceso cautelar sea en sí mismo restaurador.

Así, por ejemplo, en el marco de este proceso cautelar se han celebrado tres audiencias públicas, cuya práctica ha estado precedida por varias reuniones preparatorias con las víctimas, en las que se diseñan los espacios restaurativos que tendrán lugar a lo largo de las audiencias. Así, el talante

47 Jurisdicción Especial para la Paz, sección de Ausencia de Reconocimiento de Verdad y Responsabilidad. MC 001 de 2018, Auto AI 011 de 2019 de 2018, párrafos 37 y 39. 
restaurativo de la audiencia se ha traducido, entre otras, en formas particulares de instalarla, en la necesidad de prever espacios a lo largo de ésta para que las víctimas expresen su dolor, sus necesidades y sus peticiones, en la visita a los lugares en los que presuntamente están inhumadas las víctimas directas, con la intención de visibilizar lo que pasó, y de resignificar los espacios. ${ }^{48}$

Sobre esta vocación restaurativa de las Audiencias, el juez especial dijo: "Así las cosas, este Auto no solo da cuenta de los argumentos que sustentan la adopción de medidas restaurativas en la Audiencia, también reconoce que ésta constituye en sí misma una medida y acción restauradora a la luz de los señalado por la Corte Constitucional y la propia Jurisdicción". ${ }^{49}$

Además, también durante las audiencias se han tomado medidas no sólo de naturaleza preventiva, ${ }^{50}$ sino también restaurativa. Así ocurrió en la audiencia pública celebrada en Cartagena de Indias los días 20 y 21 de noviembre de 2019 con ocasión del asunto San Onofre de dicho trámite cautelar. En ese momento se leyó el Auto AI 011 de 2019, primer auto de medidas restaurativas que decreta la Jurisdicción, y con el que se buscó que las medidas permitieran no sólo la participación y el acceso a la justicia, sino "resignificar [los lugares de inhumación] o, por lo menos, ofrecer las garantías para que dicha resignificación pueda ocurrir". ${ }^{51}$

En palabras de la SARVR:

En el caso que nos ocupa el objeto principal de la protección solicitada son los lugares. Sin embargo, la salvaguarda de esas locaciones implica, a su vez, evitar daños irreparables, proteger información en riesgo, garantizar la efectividad de las decisiones, proteger la integridad misma de las víctimas y restablecer sus derechos. No se trata pues de un mero cuidado locativo sino de una protección integral que tiene como fin último restaurar y en la que, por lo tanto, se debe involucrar, necesariamente, a la comunidad.

48 Los videos de las audiencias públicas celebradas en el marco de este caso se pueden consultar en el canal de la Jurisdicción: https://www.youtube.com/channel/UCay5m clHBbWQTQ8fhoNCWow.

49 Jurisdicción Especial para la Paz, sección de Ausencia de Reconocimiento de Verdad y Responsabilidad. MC 001 de 2018, Auto AI 011 de 2019 de 2018, párrafo 28.

50 Jurisdicción Especial para la Paz, sección de Ausencia de Reconocimiento de Verdad y Responsabilidad. Autos AI 010 de 2019, AI 012 de 2019, AI 013, AI 014 de 2019 y AI 2015 de 2019.

51 Ibidem, párrafo 42.

Esta obra está bajo una Licencia Creative Commons

Atribución-NoComercial-SinDerivar 4.0 Internacional, IIJ-UNAM. 
Esto encuentra justificación en la noción de que un lugar no solamente es un espacio físico demarcado sino un entramado social, que incluye comportamientos, formas de habitar y recorrer el espacio. ${ }^{52}$ En este sentido, la protección de lugares supone el acceso, uso y apropiación social de los mismos, razón por la cual no pueden entonces contemplarse medidas de protección disociadas de la experiencia y participación de quienes invocan interés sobre estos espacios. La consecuencia principal de esta interpretación es que la protección de los lugares exige necesariamente la protección de relaciones y prácticas sociales; plantea una continuidad entre cuerpo físico y cuerpo social, entre cuerpo inhumado y cuerpo vivo. Así, dado que un lugar tiene dimensiones materiales y simbólicas, su protección debe ocurrir en ambas esferas.

En este contexto, un lugar donde presuntamente yacen restos de personas desaparecidas es, por tanto, un lugar de relevancia forense y de importancia mnemónica; en otras palabras, es un lugar de intervención judicial y un lugar de memoria, acciones mutuamente dependientes. Así las cosas, la protección de un espacio de inhumación exige que se asegure el lugar y la posibilidad de recordar en él. Por ello, se debe proteger el espacio y el cuerpo que en él yace; el cuerpo que recuerda, el recuerdo que trae a la memoria y la acción y posibilidad de su evocación. La consecuencia última de esta línea hermenéutica es que proteger lugares a través de medidas cautelares que permitan la participación y el acceso a la justicia, es también resignificar o, por lo menos, ofrecer las garantías para que dicha resignificación pueda ocurrir. ${ }^{53}$

Como se observa, el alcance de las medidas en la práctica de la Jurisdicción es mucho mayor que el meramente instrumental, atado a la tutela judicial efectiva. En este sentido, la práctica de las medidas cautelares en la justicia especial se acerca a la regulación propia del DIDH. Si bien buena parte de ellas se han tramitado en el seno de un caso, con ellas se persigue la protección de las personas y sus derechos, además de la tutela del proceso; por otra parte, algunos de los trámites cautelares son independientes y tienen más vocación tutelar que instrumental, e incluso adquieren un marcado talante restaurativo a la luz de la vocación del trabajo del juez transicional.

52 Un lugar se considera identificatorio, relacional e histórico. Augé, M., Los no lugares; espacios del anonimato. Una antropología de la sobremodernidad, Barcelona, Gedisa, 1992, p. 58.

53 Ibidem, párrafos 40-42. 


\section{Logros y desafios en materia de medidas cautelares en la JEP}

La Jurisdicción Especial para la Paz acaba de cumplir tan sólo dos años de funcionamiento, por lo que sacar conclusiones contundentes respecto de su trabajo no parece responsable. Sin embargo, en materia de medidas cautelares se pueden dar algunos pincelazos sobre lo que se ha logrado y los retos que se avizoran.

Desde nuestro punto de vista, el mayor logro del juez especial en materia de medidas cautelares es haber reconocido su naturaleza tutelar, $\mathrm{y}$, por lo tanto, haber desligado su uso del ámbito exclusivo de los casos en marcha.

Este paso está en consonancia con los avances vistos en el DIDH. Si bien pareciera un asunto menor, es tan significativo, que a partir de este momento podríamos hablar de las medidas cautelares (por lo menos las de la JEP) como un mecanismo más del esquema multinivel de protección de derechos fundamentales.

De la mano con este reconocimiento, aparecen dos cuestiones fundamentales. Por una parte, la posibilidad de que las víctimas puedan solicitar medidas de protección incluso fuera del trámite de un caso particular (MC 002/18 de la SARVR). Por la otra, la reivindicación de la potestad del juez especial para iniciar trámites cautelares de oficio (MC 001/18 de la SARVR). Ambas cuestiones se justifican en la naturaleza tutelar de las medidas y traen consigo la oportunidad de dinamizar la protección de los derechos de las víctimas, toda vez que bastará confirmar la existencia de una situación grave y urgente respecto de la salvaguarda de los derechos fundamentales para activar el procedimiento cautelar, sin esperar a que un caso sea avocado por la Jurisdicción.

Esto último es muy importante, sobre todo si se atiende a la naturaleza restrictiva de la competencia de la JEP, es decir, a la necesidad de concentrar el trabajo del juez especial atendiendo al uso apropiado de sus recursos, en casos significativos cuya apertura depende de los criterios de priorización definidos por la Jurisdicción. ${ }^{54}$ Así, dado que la JEP no atiende todos los casos relacionados con el conflicto armado y que no puede dedicarse a los más significativos al mismo tiempo, pueda que la garantía

\footnotetext{
54 Jurisdicción Especial para la Paz, Criterios y metodología de priorización de casos y situaciones en la Sala de Reconocimiento de Verdad, de Responsabilidad y de Determinación de los Hechos y Conductas. Bogotá, 28 de junio de 2018.
} 
de los derechos de las víctimas sólo sea posible con el uso de medidas cautelares.

Veamos esto con un ejemplo. Por el momento, atendiendo a los procesos de priorización, la JEP no ha abierto un caso puntual sobre desaparición forzada. Si bien algunos de los casos territoriales (casos 002, 004 y 005) e incluso el caso sobre secuestro (caso 001) y el de muertes ilegítimamente presentadas como bajas en combate (caso 003) pueden abordar esta temática, por el momento no existe un proceso exclusivo sobre el terrible flagelo de la desaparición forzada que azotó a muchos territorios del país dejando una inconcebible cantidad víctimas. ${ }^{55}$ ¿Esto significa que las personas afectadas por este atroz fenómeno están indefensas? La respuesta es sin duda negativa, pues gracias al trámite de las medidas cautelares, MC 002/18 la SARVR ha adoptado importantes decisiones para la garantía de los derechos de las víctimas de desaparición forzada pese a la inexistencia de un caso sobre este particular.

Así las cosas, hecho de que el juez pueda iniciar de oficio un trámite cautelar o el que las víctimas lo puedan requerir sin la existencia de un caso potencia la posibilidad de ofrecer una garantía efectiva de los derechos de las víctimas.

Junto con el reconocimiento del perfil tutelar de las medidas, se dio la reivindicación de su vocación restaurativa. Éste es un asunto de suma importancia sobre el que ni siquiera el sistema interamericano se ha pronunciado, y del que se desprenden importantes consecuencias.

En primer lugar, tal como se señaló arriba, el juez especial reconoce la vocación performativa de los trámites que adelanta, incluidos los trámites

\footnotetext{
55 "Una de las graves violaciones a los derechos humanos que azota de manera contundente al país es la desaparición forzada. Si bien las cifras oficiales y no oficiales varían de forma significativa, los datos dan cuenta de la masividad y gravedad de este crimen y, peor aún, de la impunidad respecto del mismo. Según el estudio integral hecho por el Centro Nacional de Memoria Histórica, «[c]on fecha de corte al 31 de diciembre de 2012, el SIRDEC da cuenta, para el periodo 1970-2012, de 78.319 desapariciones, de las cuales 19.254 , que equivalen a un $25 \%$, fueron clasificadas como presuntamente forzadas. Entre tanto, la Unidad de Víctimas habla de 30.159 desapariciones forzadas. No obstante, esta fuente muestra un marcado subregistro en la fecha del hecho, mientras que la Fiscalía General de la Nación contabiliza 21.9000 víctimas por desaparición forzada desde el 2005 al 2012». En su informe sobre la Cartografía de la Desaparición Forzada en Colombia Human Rights Everywhere afirma que, a 2019, la UARIV reporta 47.762 víctimas directas, la Fiscalía General 54. 046, y el Centro Nacional de Memoria Histórica 80. 472”. Tomado del Jurisdicción Especial para la Paz, sección de Ausencia de Reconocimiento de Verdad y Responsabilidad. Auto AI 011 de 2019. Nota a pie 32.
} 
cautelares. Esto ha significado no sólo el que se deba reconocer un papel protagónico a las víctimas en las diligencias judiciales sino, más aún, el que ellas decidan cómo quieren que se traduzca el perfil restaurativo de los diversos actos procesales. En otras palabras, no se trata tan sólo de dejar participar a las víctimas (cosa que ya es permitida en los procesos ordinarios), sino de permitirles decidir cómo se llevan a cabo los trámites judiciales para que a través de ellos experimenten la materialización de sus derechos.

Esta vocación performativa, que se ha aplicado a otros trámites de la JEP, ha permitido que la Jurisdicción se acerque a la gente, y, con ello, se ha llevado al Estado a dónde y a quienes nunca antes tuvieron contacto con él o lo tuvieron en términos desafortunados. Así, también se materializa la vocación territorial y dialógica de la Justicia Especial. ${ }^{56}$

Gracias a este reconocimiento, y al trabajo que ha traído consigo, la Jurisdicción ha podido mostrar resultados fehacientes en cortísimo tiempo sin tener que esperar a la decisión de fondo de los casos, que sin dudas puede tardar mucho tiempo más. En un escenario en el que las víctimas llevan décadas esperando ser vistas, ser oídas, reconocidas y reivindicadas, este no es un logro menor, sino por el contrario, se trata de uno de los primeros grandes aportes de la JEP.

Algunos puristas procesales, abogados de antaño, se niegan a conceder la importancia que merece esta vocación restaurativa de las medidas cautelares y la relevancia de las audiencias que se celebran durante su trámite. A ellos, la invitación es a que se acompasen a las necesidades de los tiempos. Pueda que, desde su concepto, no sea necesario reunirse con las víctimas o practicar audiencias de la mano de éstas para decidir una medida cautelar; en un escenario ordinario podrían tener razón, pero cuando se trata de la justicia especial, que por mandato constitucional debe tener vocación restaurativa y ante los resultados que hasta el momento se han visto, esa lectura resulta cuando menos obtusa, si no no es que también inconstitucional.

Ahora bien, más allá de estos significativos logros, el juez especial aún debe enfrentarse a un importante reto en materia de medidas cautelares: la definición de los criterios de procedibilidad de las medidas cautelares. Este reto es, sobre todo, una oportunidad para aclarar por fin qué significa extrema gravedad, urgencia o daño irreparable.

56 De acuerdo con lo señalado en el artículo 5 del Acto Legislativo 1 de 2017, en la Ley 1957 de 2019 y en la Ley 1922 de 2018. 
Hasta la fecha el juez especial no se ha pronunciado de forma puntual sobre los requisitos de procedibilidad, ya que su referencia a ellos ha sido escueta. Sobre el particular, ha dicho:

Atendiendo a la protección de una presunta grave violación a los derechos humanos que reviste este caso, esta Sala acogerá las definiciones que sobre el particular ha desarrollado el Reglamento de la Comisión Interamericana de Derechos Humanos, al entender la gravedad como "el serio impacto que una acción u omisión puede tener sobre un derecho protegido..." mientras que la urgencia "se determina por la información que indica que el riesgo o la amenaza sean inminentes y puedan materializarse, requiriendo de esa manera acción preventiva o tutelar". ${ }^{57}$

Al respecto, vale la pena decir que si bien es cierto que el juez interamericano es quien más ha avanzado en la definición de los criterios de gravedad, urgencia e irreparabilidad, la verdad es que ni siquiera la Corte IDH ha precisado ninguno de estos conceptos. Veamos esto con un poco de detenimiento para que el juez especial tenga claro a lo que se enfrenta.

Sobre la urgencia de la situación, la Corte IDH se ha limitado a atar su valoración a las circunstancias particulares del $\mathrm{caso}^{58}$ (lo que incluye el contexto sociopolítico, histórico y cultural) ${ }^{59}$ o a la envergadura de los

57 Jurisdicción Especial para la Paz, sección de Ausencia de Reconocimiento de Verdad y Responsabilidad. MC 002 de 2028, Auto 039 de 2019, párr. 22.

58 Así, por ejemplo, en el asunto de la ampliación de medidas provisionales respecto en el caso 19, Comerciantes, el juez regional dijo "Que esta Presidencia estima indispensable adoptar medidas urgentes, en virtud de las circunstancias particulares de este caso y debido a que la información presentada por los representantes demuestra, prima facie, que los señores Wilmar Rodríguez Quintero y Yimmy Rodríguez Quintero se encuentran en una situación de extrema gravedad y urgencia, puesto que sus vidas e integridad personal se encuentran amenazadas y en grave riesgo. El estándar de apreciación prima facie en un caso y la aplicación de presunciones ante las necesidades de protección han llevado a esta Presidencia y a la Corte a ordenar medidas en distintas ocasiones". resolución del presidente de la Corte Interamericana de Derechos Humanos del 6 de febrero de 2007 solicitud de ampliación de medidas provisionales respecto de la república de Colombia, caso 19 comerciantes.

59 En resolución del 8 de julio de 2009, en el marco de las medidas provisionales adoptadas dentro del caso 19 Comerciantes, así como en la resolución del 2 de septiembre de 2010 sobre las medidas provisionales del caso Mapiripán, dijo “Que para determinar si la situación de extrema gravedad y urgencia de evitar daños irreparables existe o persiste, la Corte puede valorar el conjunto de factores o circunstancias políticas, históricas, culturales o de cualquier otra índole que afectan al beneficiario o lo colocan en una situación de vulnerabilidad en un determinado momento y lo expone a recibir lesiones a sus dere- 
derechos en riesgo, sin que quede claro qué significa lo primero, y sin especificar cómo ponderar lo segundo.

La única definición más o menos cierta de lo que el juez regional entiende por urgencia se lee en estos términos: "[e]l carácter urgente implica que el riesgo o amenaza involucrados sean inminentes, lo cual requiere que la respuesta para remediarlos sea inmediata". ${ }^{60}$ Ahora bien, ¿qué implica que una amenaza sea inminente? ¿Cómo se prueba y se valora esa inminencia? Esta definición parece más una tautología que una instrucción clara sobre los alcances del requisito de procedibilidad. En esta misma línea, el juez interamericano señala que

la urgencia requerida para la adopción de medidas provisionales alude a situaciones especiales y excepcionales que requieren y ameritan acciones y respuestas inmediatas orientadas a conjurar la amenaza. Se trata de circunstancias que por su propia naturaleza suponen un riesgo inminente. Se deriva del carácter urgente de la amenaza la naturaleza de la respuesta para remediarla. Esto debe suponer, ante todo, un carácter inmediato de la misma $\mathrm{y}$, en principio, temporal para hacer frente a tal situación, ya que una falta de respuesta implicaría per se un peligro. ${ }^{61}$

Frente a este pronunciamiento, las preguntas continúan: ¿cómo se sabe que una situación es especial y excepcional? Pareciera ser que la Corte IDH asocia la urgencia a la imposibilidad de esperar, así como a los resultados de la valoración que se haga "del problema planteado, la efectividad de las acciones estatales frente a la situación descrita y el grado de desprotección en que quedarían las personas sobre quienes se solicitan medidas en caso de que éstas no sean adoptadas". ${ }^{62}$ Sin embargo, no que-

chos. Esta situación puede crecer o decrecer en el tiempo dependiendo de un sinnúmero de variables, pero como fue señalado, únicamente las situaciones extremas y urgentes merecerán protección mediante medidas provisionales".

60 Corte IDH, Asunto de la Comisión Colombiana de Juristas respecto de Colombia. Medidas provisionales, resolución de la Corte Interamericana de Derechos Humanos, del 25 de noviembre de 2010; Corte IDH, caso Ávila Moreno y otros (caso Operación Génesis) vs. Colombia. Rechazo de la solicitud de medidas provisionales. Resolución de la Corte Interamericana de Derechos Humanos del 30 de mayo de 2013.

61 Corte IDH, asunto Mery Naranjo y otros respecto de Colombia. Medidas provisionales. Resolución de la Corte Interamericana de Derechos Humanos del 4 de marzo de 2011

62 Corte IDH, asunto Danilo Rueda respecto de Colombia. Solicitud de medidas provisionales. Resolución del presidente en ejercicio de la Corte Interamericana de Derechos Humanos del 2 de mayo de 2014. 
da claro qué se entiende por urgencia o cuáles son los parámetros para determinar que una situación es urgente.

Respecto de la gravedad, la Corte IDH ha sido aún más escueta, y si bien no la ha definido, sí la ha caracterizado, toda vez que señala que ésta debe ser "extrema", entendiendo por tal, el que se encuentre "en su grado más intenso o elevado". ${ }^{63}$ Además, tal como ocurre respecto de la urgencia, el juez regional afirma que la gravedad se valora atendiendo al contexto y a los derechos que estén involucrados. ${ }^{64}$ Así las cosas, tampoco hay parámetros claros sobre qué es una situación clara.

Finalmente, en cuanto al daño irreparable, la Corte IDH se ha limitado a decir que para que proceda la medida de protección "debe existir una probabilidad razonable de que [el daño] se materialice y no debe recaer en bienes o intereses jurídicos que puedan ser reparables". ${ }^{65}$ Si se atiende a la teoría sobre reparación integral de la propia Corte IDH, esta instrucción no tiene mucho sentido, pues aun cuando algunos derechos o situaciones no pueden ser restituidos, todo daño es - debe ser- reparable.

Como se observa, incluso el juez regional, que lleva ya varios años trabajando desde la naturaleza tutelar de las medidas con las que se busca evitar que una amenaza se concrete o que un daño se acreciente, ha omitido definir con claridad y suficiencia los requisitos de procedibilidad de este mecanismo de salvaguarda. Así las cosas, el juez especial tiene una oportunidad única entre sus manos. Definir estos conceptos permitirá no

63 Corte IDH, Asunto de la Comisión Intereclesial de Justicia y Paz respecto de Colombia. Medidas Provisionales. Resolución de la Corte Interamericana de Derechos Humanos del 22 de noviembre de 2010; Corte IDH, Asunto de la Comisión Colombiana de Juristas respecto de Colombia. Medidas provisionales. Resolución de la Corte Interamericana de Derechos Humanos del 25 de noviembre de 2010; Corte IDH, caso Ávila Moreno y otros (caso Operación Génesis) vs. Colombia. Rechazo de la solicitud de medidas provisionales. Resolución de la Corte Interamericana de Derechos Humanos de 30 de mayo de 2013 .

64 "en asuntos como el presente la extrema gravedad de la amenaza se debe evaluar en función del contexto específico, siendo evidente que si derechos fundamentales como la vida y la integridad física se encuentran comprometidos por dicho tipo de amenaza se está, en principio, ante un contexto que amerita considerar la adopción de medidas de protección”. Corte IDH, Asunto Mery Naranjo y otros respecto de Colombia. Medidas provisionales. Resolución de la Corte Interamericana de Derechos Humanos del 4 de marzo de 2011.

65 Corte IDH, caso Ávila Moreno y otros (caso Operación Génesis) vs. Colombia. Rechazo de la solicitud de medidas provisionales. Resolución de la Corte Interamericana de Derechos Humanos del 30 de mayo de 2013. 
sólo marcar el camino de otras jurisdicciones, sino, sobre todo, evitar el uso inapropiado de las medidas en un escenario en el que muchas situaciones podrían entenderse como graves y urgentes, pero los recursos para atenderlas son limitados.

\section{CONCLUSIÓN}

La Jurisdicción Especial para la Paz ha reconocido la naturaleza tutelar de las medidas cautelares que decreta. Gracias a ello, ha sido posible aclarar quiénes pueden impulsar las medidas, en qué supuestos se puede hacer uso de estas herramientas y cuál es su cometido último, dejándose claro, en todo caso, que no siempre deben estar atadas a un caso ni que se limitan a la salvaguarda de la tutela judicial efectiva.

En este contexto, el uso de las medidas cautelares como herramientas de tutela, cuyo trámite y desenlace tiene vocación restaurativa, les concede un papel fundamental a la hora de asegurar derechos fundamentales, y, más aún, al momento de propender por el éxito de la transición.

Pueda que por el momento no muchos sean conscientes de la posibilidad de usar las medidas cautelares de la Jurisdicción como una herramienta independiente de tutela, pero no resultaría extraño que a medida que los litigantes especializados y las propias víctimas descubran las posibilidades de protección que ofrece este mecanismo, la Jurisdicción se vea enfrentada a un mayor número de solicitudes de medidas cautelares. Por ello, resulta urgente que el juez especial se pronuncie pronto y de forma suficiente sobre el alcance de los requisitos de procedibilidad de este mecanismo de protección. Ello evitaría la banalización de su uso y serviría como derrotero para el trabajo de otras jurisdicciones.

Por el momento, basta aplaudir el trabajo de la JEP en torno al uso de las medidas cautelares y augurar el uso estratégico de esta herramienta en un escenario de alta demanda de protección de derechos, como el colombiano.

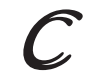

Fecha de recepción: 11 de febrero de 2020.

Fecha de aceptación: 20 de abril de 2020. 


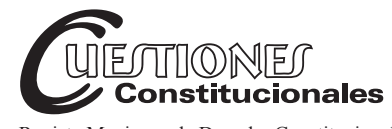

Revista Mexicana de Derecho Constitucional Núm. 43, julio-diciembre 2020

\section{Derecho intrafederal y los nuevos estándares en las relaciones fiscales intergubernamentales en el federalismo argentino. Un análisis a 25 años de la reforma constitucional nacional (1994-2019)}

\section{Intrafederal Law and the New Standards on Intergovernmental Fiscal Relations in the Argentine Federalism. An Analysis after 25 years of the National Constitutional Reform (1994-2019)}

\section{Cristian AltaVILla*}

RESUMEN: La federación argentina tiene una larga tradición en materia de pactos y acuerdos interjurisdiccionales - tradición que se remonta incluso a la etapa preconstituyente de la nación argentina-. Tales acuerdos son el resultado de largos y complejos procesos de negociaciones entre los niveles de gobierno implicados, y constituyen una fuente importante del derecho constitucional argentino, nacional y subacional. La Corte Suprema de Justicia de la Nación los he denominado "derecho intrafederal", y los mismos tienen una jerarquía superior a las leyes nacionales. Este particular tipo de normas ha tenido especial desarrollo en materia fiscal, aspecto sobre el que se centrará el presente trabajo.

Las relaciones intergubernamentales que dan origen a esta especial rama del derecho
ABSTRACT: Argentine federation has a long tradition in intergovernmental pacts and agreements - a tradition which goes back to the period of formation of the Argentine nation-. Those agreements are the result of long and complex processes of negotiations between both levels of government involved and they constitute an important source of the, national and subnational, constitutional law. The Supreme Court has called them Intrafederal Law (Derecho Intrafederal) and it recognizes them a higher hierarchy to national laws. This particular kind of norms has had an especial development in fiscal matters, an aspect on which this work will be focused.

The intergovernmental relations that give birth to this especial branch of public law

* Director de la carrera de abogacía, Decanato Ciencias del Derecho, Universidad Siglo 21 (UES21); profesor de la materia Derecho Público Provincial y Municipal y de Derecho Político, Facultad de Derecho - UNC y UES21. Argentina. ORCID: 0000-00016592-435X Correo electrónico: cristianaltavilla@hotmail.com. 
público se desenvuelven dentro de un determinado marco institucional, con determinadas reglas y criterios preestablecidos, aunque no siempre de manera clara o precisa. Con la reforma de 1994, el Constituyente Nacional fijó una serie importante de verdaderos estándares constitucionales que han de regir las relaciones fiscales intergubernamentales verticales nación-provincias a futuro. El objetivo de este trabajo es realizar un análisis del derecho intrafederal en materia fiscal y su significado en la federación argentina, para finalmente detectar y analizar aquellos nuevos estándares que rigen las relaciones fiscales intergubernamentales.

Palabras clave: derecho intrafederal, coparticipación federal de impuestos, relaciones intergubernamentales, acuerdos fiscales interjurisdiccionales. work within a given institutional setting, with determined rules and criteria, although not always in a clear and precise manner. With the 1994 National Constitutional Reform, a series of important true constitutional standards were fixed intended to govern the vertical fiscal intergovernmental relations among nation and provinces. The main aim of this paper is to analyze the intrafederal law in the fiscal field and its meaning in the Argentine federation in order to detect and analyze those new standards governing the fiscal intergovernmental relations.

Keywords: intrafederal law, federal coparticipation regime, Intergovernmental relations, fiscal intergovernmental agreements.

SUMARIO: I. La práctica institucional del pactismo fiscal en Argentina. II. Breve historia de las relaciones fiscales intergubernamentales y del régimen de coparticipación federal de impuestos en Argentina. III. El derecho intrafederal. IV. La “constitucionalización” del régimen de coparticipación federal de impuestos en la reforma constitucional de 1994. V. Los nuevos estándares en las relaciones fiscales intergubernamentales fijados para el constituyente con la "constitucionalización” del régimen de coparticipación federal de impuestos. VI. El incumplimiento de las disposiciones constitucionales. VII. Conclusiones: el rango constitucional del derecho intrafederal y nuevos estándares para las relaciones fiscales intergubernamentales.

\section{LA PRÁCTICA INSTITUCIONAL DEL PACTISMO FISCAL EN ARGENTINA}

\section{La federación argentina tiene una larga tradición en materia de pactos y acuerdos interjurisdiccionales; su origen mismo se basa en los pactos pre- existentes que la propia Constitución Nacional menciona en su preámbu-}


10. ${ }^{1}$ En materia fiscal, esta práctica ha caracterizado las relaciones fiscales intergubernamentales en Argentina desde 1935, cuando se sanciona el primer régimen de coparticipación federal de impuestos, que se implementa a través de una ley-contrato (como se la llamó originariamente) o leyconvenio (como pasó a ser más conocida posteriormente), que no es otra cosa que un acuerdo interjurisdiccional vertical (nación-provincias), con algunas modalidades que la caracterizan.

La coexistencia de múltiples niveles de gobierno en un Estado federal exige necesariamente de la presencia de instrumentos que posibiliten y faciliten las relaciones intergubernamentales, en busca de la convergencia de voluntades que tiendan a la coordinación de ciertas materias o competencias cuya titularidad pertenece en común a los distintos niveles (nacional y subnacionales). Ante ello, cobran impar importancia los instrumentos para la coordinación:

Si hablamos de una "relación federal" que supone ciertos elementos constitutivos (comunidades diversas, voluntad de vivir en común y voluntad de preservar la identidad y autonomía de cada una) y se asienta sobre ciertos principios básicos (solidaridad, subsidiariedad y participación), necesariamente los sujetos que son parte de ésta deben valerse de instrumentos para lograr sus fines, haciendo efectivo dichos principios. ${ }^{2}$

Se habla de "instrumentos" porque la naturaleza dinámica de la forma de Estado federal necesita de herramientas que le permitan avanzar hacia formas más eficaces y eficientes de organización y coordinación, a efectos de alcanzar los objetivos y finalidades propuestos a la hora de formular y ejecutar políticas públicas. ${ }^{3}$ Estos instrumentos son los que estructuran y permiten el desenvolvimiento de las tres relaciones típicas del federalismo: la

1 Hernández, Antonio M., "Federalismo argentino", en Hernández, Antonio M. y Guillermo Barrera Buteler (coord.), Derecho público provincial, Buenos Aires, AbeledoPerrot, 2011, pp. 23-53.

2 Barrera Buteler, Guillermo, Provincias y nación, Buenos Aires, Ciudad Argentina, 1996, p. 261.

3 Altavilla, Cristian, "Acuerdos interjurisdiccionales en materia tributaria. El pactismo fiscal" (1a. parte), Periódico Económico Tributario (PET), Buenos Aires, La Ley, 12 de junio, 2009, pp. 1 y 2 y “Acuerdos Interjurisdiccionales en materia tributaria. El pactismo fiscal" (2a. parte), Periódico Económico Tributario (PET), La Ley, 26 de junio, pp. 3-10, 2009. 
de subordinación, la de participación y la de coordinación, ${ }^{4}$ y posibilitan la materialización de los tres principios básicos del federalismo: solidaridad, participación y subsidiariedad. ${ }^{5}$

Estos instrumentos se materializan de diferentes maneras, y reciben distintas denominaciones: pacto, tratado, convenio, convención, acuerdo, consenso, ley-convenio - pero son todos sinónimos, según la Corte Suprema de Justicia de la Nación (CSJN) - , ya que significan "acuerdo para reglar o reglamentar intereses". En materia fiscal fue ampliamente utilizada una modalidad propia del federalismo argentino, una creación de la praxis constitucional vernácula: las denominadas leyes-convenio.

El ejercicio conjunto e indistinto en materia tributaria respecto de la creación de impuestos internos indirectos por nación y provincias ha tenido efectos perniciosos en la economía nacional, pero sobre todo en las regionales donde pesaba la superposición impositiva sobre determinados productos típicos de estas economías. Ello se solucionó a través de las denominadas leyes-convenios, las que fueron utilizadas para la coordinación de las potestades tributarias constitucionalmente previstas. En cambio, cuando se trató de coordinar políticas tendientes a lograr disciplina fiscal e instrumentar medios adecuados para superar determinadas crisis coyunturales, se recurrió a los pactos o acuerdos, a través de los cuales se intentaron implementar políticas públicas en materia fiscal, como instrumentos de coordinación para fijar pautas y obligaciones comunes.

La ley-convenio, al decir de Bidart Campos, "conjuga dos voluntades: la del estado federal que la dicta, y la de cada provincia que se integra al régimen por ella estatuido. Es - en la terminología trialista de Goldschmidt - un reparto autónomo". ${ }^{6}$ Son acuerdos interjurisdiccionales mixtos, con un particular modo de celebración, tendientes a regular y coordinar determinada potestad, cuya titularidad pertenece por igual a ambos niveles, a través de una ley del Congreso de la Nación, a la cual se adhieren las provincias por medio de leyes de sus respectivas legislaturas. Su principal peculiaridad es que reviste la forma de una ley, y no la de un acuerdo o tratado, que lo es en sustancia. Todos los regímenes de coparticipación

\footnotetext{
4 Bidart Campos, Germán, Manual de la Constitución reformada, t. I, Buenos Aires, Ediar, 1998.

5 Barrera Buteler, Guillermo, Provincias y nación, cit., p. 261.

6 Bidart Campos, Germán “«Leyes contrato» y derecho provincial”, El Derecho, t. 79, 1979 , p. 364.
} 
que han existido hasta la fecha han sido instaurados por medio de leyesconvenios. $^{7}$

Tal importancia ha adquirido esta modalidad, que en la reforma constitucional de 1994 se "constitucionalizó" este instrumento de concertación. Sin embargo, los lineamientos que surgen de la Constitución reformada parecen instrumentar un tipo de ley-convenio más consensual, en la que prevalecen los acuerdos previos, ya que establece expresamente la sanción de una "ley convenio, sobre la base de acuerdos entre la nación y las provincias". A diferencia de como ha ocurrido en la práctica, donde una ley dictada por el Congreso establece ab initio todos los derechos y obligaciones emergentes, proponiendo la posterior adhesión de las provincias "sin limitaciones ni reservas", y sin margen para la negociación (al menos formal) entre las partes, asemejándose más a una ley de adhesión, la ley-convenio de la Constitución Nacional es el resultado de "acuerdos previos", y no de la adhesión posterior de las provincias. En este sentido, podemos decir que no ha habido un verdadero federalismo de concertación, ya que la mayoría de las veces los procedimientos empleados para la implementación de éstas han tenido características centralistas.

Los pactos son, en cambio, acuerdos interjurisdiccionales de naturaleza mixta, revestidos de solemnidad (el articulado está precedido por preámbulos y son firmados personalmente por los representantes del Poder Ejecutivo de cada nivel de gobierno), abiertos a la posibilidad de adhesión posterior por parte de los restantes sujetos de la relación federal, y tratan, generalmente, asuntos de naturaleza política. Su carácter programático surge del hecho de que comúnmente establecen criterios y pautas para la fijación de políticas nacionales, y no derechos o deberes concretos, como en las leyes-convenio.

Estos pactos tuvieron una singular evolución a partir de la década de los noventa. Desde entonces comenzaron a firmarse una serie de acuerdos interjurisdiccionales con la finalidad de armonizar ciertas competencias concurrentes entre los niveles de gobierno en áreas como la economía, las potestades tributarias, sobre aspectos fiscales, ambientales, etcétera. Entre 1988 y 2002 se firmaron un total de nueve acuerdos interjurisdiccio-

7 El de 1935, por la Ley 12.139 (“Unificación de Impuestos Internos”), el de 1973 por la Ley 20.221 (Ley-convenio de Coparticipación de Impuestos Nacionales), y el actualmente vigente, por la Ley 23.548 ("Régimen Transitorio de Distribución de Recursos Fiscales"), de 1988. 
nales: la Ley-Convenio de Coparticipación Federal de Impuestos 23.548 de 1988, el Pacto Fiscal I de 1992, el Pacto Federal para el Empleo, la Producción y el Crecimiento (o Pacto Fiscal II) de 1993, el Compromiso Federal I de 1999, el Compromiso Federal para el Crecimiento y la Disciplina Fiscal y su primera Addenda (o Compromiso Federal II) en 2000, el Compromiso por la Independencia y el Apoyo Institucional para la Gobernabilidad de la República Argentina en 2001, la Segunda Addenda al Compromiso Federal II también en 2001 y el Acuerdo Nación-Provincias sobre Relación Financiera y Bases de un Régimen de Coparticipación Federal de Impuestos en 2002. A éstos cabe agregar dos pactos recientes: el Consenso Fiscal I firmado en noviembre de 2017 y el Consenso Fiscal II de septiembre de 2018.

\section{BREVE HISTORIA DE LAS RELACIONES FISCALES INTERGUBERNAMENTALES Y DEL RÉGIMEN DE COPARTICIPACIÓN FEDERAL DE IMPUESTOS EN ARGENTINA}

A los efectos de comprender mejor el derecho intrafederal, como particularidad del constitucionalismo argentino, resulta necesario realizar una somera referencia a la historia de las relaciones fiscales intergubernamentales y al origen del RCFI. ${ }^{8}$

La Constitución Nacional hace una distribución bastante escueta de las competencias tributarias entre el nivel federal de gobierno y los provinciales. En materia fiscal, el primer texto constitucional de 1853/60 estableció un sistema de coordinación de las facultades tributarias basado en la división de fuentes: el gobierno central tendría facultades exclusivas sobre los derechos de importación y exportación y una facultad excepcional de establecer impuestos directos bajo ciertos requisitos y por tiempo limitado. La Constitución nada decía respecto de los gobiernos provinciales, pero por aplicación del principio general en materia de deslinde de competencias contenida en el entonces artículo 104 (actual 121), según el cual "las provincias conservan todo el poder no delegado por esta Constitución al Go-

8 Para un análisis más detallado y exhaustivo de la historia de las relaciones fiscales intergubernamentales y, en particular, del régimen de coparticipación, se puede ver Altavilla, Cristian, "Conflicto y coordinación política en las relaciones intergubernamentales en Argentina. Un análisis neoinstitucional a través del régimen de coparticipación federal de impuestos", tesis doctoral, Universidad Nacional de Córdoba, 2016. 
bierno federal". En función de ello, las provincias conservaban el poder de recaudar todos los demás tipos de impuestos (directos e indirectos), como competencia propia, a excepción de los derechos de importación y exportación, que como competencia propia y exclusiva del gobierno federal les estaba vedado por el artículo 108 (actual 126), en tanto "las provincias no ejercen el Poder delegado a la Nación", entre los cuales el artículo cita expresamente el de "expedir leyes sobre comercio, o navegación interior o exterior". La misma disposición se encuentra reforzada por los artículos 9 , 10,11 y 12 , que prohíben el establecimiento de aduanas interiores, entendidas en el más amplio sentido.

La Constitución Nacional también previó mecanismos de transferencias de nación a provincias, contenida en el artículo 67, inciso 8o. (actual 75, inciso 9o.), que establece entre las atribuciones del Congreso la de "acordar subsidios del Tesoro Nacional a las Provincias, cuyas rentas no alcancen, según sus presupuestos, a cubrir sus gastos ordinarios". Sin embargo, el mecanismo fue escasamente utilizado durante este periodo: "En 1886 los «Aportes a las Provincias y a la Municipalidad de la Ciudad de Buenos Aires» fueron equivalentes al 1,4\% del gasto total del Gobierno Nacional; en 1887 al 1,9\%" (Porto 2003a:6). Estos mecanismos comenzarían a adquirir mayor importancia a partir del periodo posterior debido a la utilización por parte del gobierno nacional de fuentes tributarias que hasta entonces sólo percibían las provincias.

El periodo que va entre 1890 a 1935 se caracterizará por la concurrencia (de hecho) de fuentes (tanto en materia de impuestos indirectos [18901935] como de impuestos directos [entre 1930-1935]). El avance del poder tributario nacional sobre materias imponibles que hasta entonces eran exclusivas de las provincias produjo una superposición impositiva, que de acuerdo con la Constitución no resultaba ser inconstitucional, dado que se trataba de competencias concurrentes. ${ }^{9}$

Frente a la crisis económica mundial de 1890, el gobierno nacional recurrió a nuevas fuentes de financiamiento tributario, y creó los primeros impuestos internos nacionales, que se fueron prorrogando sucesivamente, y afectaron principalmente ciertos artículos de elaboración típica en ciertas regiones (alcohol, cervezas, fósforos, licores). Más tarde, otra vez en

9 Así lo declaró la CSJN, fallo "Sociedad Anónima Mataldi” (del 28/09/1927) con respecto a los impuestos indirectos al consumo interno, declarándolos competencias concurrentes entre la Nación y las provincias. 
un contexto de crisis económica mundial, esta vez la de 1929, el gobierno federal comienza a establecer impuestos directos. En 1931 se crean el impuesto a los réditos - tributo que será prorrogado indefinidamente hasta la actualidad, convirtiéndose, en la década de los setenta, en el actual impuesto a las ganancias y el impuesto a las transacciones.

Frente a esta situación de doble imposición, en 1935 se produce una reestructuración del sistema tributario argentino y se introduce por primera vez un mecanismo de coordinación de las potestades tributarias nacionales y provinciales: el denominado régimen de coparticipación federal de impuestos, creado mediante el novedoso sistema de ley-convenio (Ley 12.139 de 1935). A partir de entonces se inicia una nueva etapa en las relaciones fiscales nación-provincias. Este nuevo periodo puede subdividirse en tres grandes subperiodos, marcados cada uno de ellos por los tres regímenes de coparticipación: el primero se inicia con la Ley 12.139, en 1935 hasta 1972; el segundo, que comienza con la sanción de la Ley 20.221 en 1972 hasta su caducidad en 1984; y finalmente el último periodo, el de la Ley 23.548 de 1988, que se extenderá hasta la actualidad.

El régimen de coparticipación consiste, básicamente, en un acuerdo entre la nación y las provincias por el cual el gobierno nacional legisla y recauda sobre una determinada cantidad de impuestos que luego distribuirá en dos instancias: en una primera instancia (llamada distribución primaria) distribuye lo recaudado entre el gobierno federal y el conjunto de las provincias, y en una segunda instancia (distribución secundaria), ese porcentaje correspondiente al conjunto de las provincias se distribuye entre cada una de ellas. El número de impuestos que integran la masa coparticipable se fue acrecentando a medida que pasaban los años. Quedaban fuera de ella aquellos impuestos de jurisdicción exclusiva de cada nivel de gobierno (derechos de importación y exportación para el nivel nacional y los impuestos inmobiliario, automotor, ingresos brutos y de sellos para las provincias), aquellos cuya distribución se rigiera por otros regímenes de transferencias y aquellos que tuvieran una afectación específica, sea al momento de sancionarse el régimen o con posterioridad.

En 1994 se "constitucionaliza" este régimen, y es incorporado con la reforma constitucional en el artículo 75, inciso 2o., que establece que los impuestos directos e indirectos que recaude el gobierno federal serán coparticipables con las provincias. 
En los treinta años de vigencia del régimen de coparticipación de la ley 23.548 se produjeron un sinnúmero de modificaciones, que fueron haciendo del régimen un sistema cada vez más complejo, intrincado e incoherente. Dentro de estas modificaciones se encuentran tanto pactos y acuerdos entre ambos niveles de gobierno (mencionados en el punto anterior), así como importantes modificaciones unilaterales por parte del gobierno nacional (sea a través de decretos del Poder Ejecutivo o bien a través de leyes sancionadas por el Congreso de la Nación). ${ }^{10}$

\section{EL DERECHO INTRAFEDERAL}

El conjunto de estos acuerdos y pactos conforman el derecho intrafederal, definido también por la CSJN y por parte de la doctrina constitucionalista argentina. El término fue empleado por primera vez por la CSJN en la causa "Chevallier c/ Provincia de Buenos Aires" de 1991. ${ }^{11}$ Años más tarde, en 1999, precisaría este concepto en otro fallo, donde dirá que estos acuerdos interjurisdiccionales constituyen "manifestaciones positivas del llamado federalismo de concertación, inspirado en la búsqueda de un régimen concurrente en el cual las potestades provinciales y nacionales se unen en el objetivo superior de lograr una política uniforme en beneficio de los intereses del Estado Nacional y de las provincias". ${ }^{12}$

Esta rama particular del derecho es derivación y consecuencia directa de las relaciones intergubernamentales: "Dichos pactos fiscales, como las demás creaciones legales del federalismo de concertación, configuran el derecho intrafederal, y se incorporan una vez ratificados por las legis-

10 Para una larga enumeración de todos estos decretos y leyes, véase Bulit Goñi, Enrique, "Coparticipación federal de impuestos: el tironeo recurrente muestra como único camino el sinceramiento colectivo y una nueva concertación”, Impuestos 1992, t. L1-A, Buenos Aires, La Ley, pp. 3-12.

11 CSJN, "Transportes Automotores Chevallier S.A. c/ Provincia de Buenos Aires, s/ Acción Declarativa”, Fallos, 314:862, sentencia del 20/08/1991). Según Bulit Goñi, éste fue el primer fallo donde la Corte habla de derecho intrafederal (Bulit Goñi, Enrique, "En torno al llamado derecho intrafederal", en Asensio, Miguel Ángel y Pablo María Garat (coord.), "Federalismo fiscal - II", Revista de Derecho Comparado, Santa Fe, RubinzalCulzoni, 2010, pp. 95-112).

12 CSJN, causa "Asociación de Grandes Usuarios de Energía Eléctrica de la República Argentina (AGUEERA) c/ Provincia de Buenos Aires y Otro" (Fallos, 322:1781-1792, sentencia del 19.08.1999). 
laturas al derecho público interno de cada Estado provincial". ${ }^{13}$ En ese mismo fallo, la Corte llegó a una conclusión trascendental para el tema en análisis, y es que tales acuerdos ocupan un lugar jerárquico en la pirámide normativa. Así, estos acuerdos se incorporan al derecho público

aunque con la diversa jerarquía que les otorga su condición de ser expresión de la voluntad común de los órganos superiores de nuestra organización constitucional: nación y provincias. Esa gestación institucional los ubica con un rango normativo específico dentro del derecho federal. Prueba de su categoría singular es que no es posible su derogación unilateral por cualquiera de las partes. ${ }^{14}$

Estos mismos conceptos serán reiterados en varios otros pronunciamientos, pero sobre todo en los más recientes e importantes de ellos, en los casos "Santa Fe c/ Estado Nacional" del 2015, "San Luis c/ Estado Nacional" 16 y "Córdoba c/ Estado Nacional", ${ }^{17}$ pronunciamientos de la Corte que tendrán un impacto decisivo sobre las relaciones fiscales intergubernamentales y sobre el régimen de coparticipación federal de impuestos.

Estos acuerdos interjurisdiccionales generan derechos y deberes no sólo para los sujetos federados signatarios, sino que alcanzan también a sus habitantes..$^{18}$ Constituyen una fuente importante del derecho público argentino, y su jerarquía normativa se ubica por encima de las leyes nacionales y por debajo de la Constitución Nacional y los tratados internacionales. Aun cuando la Constitución no los prevé dentro del orden de prelación normativo del artículo $31 \mathrm{ni}$ como fuente de derecho, indiscutiblemente integran el llamado bloque de constitucionalidad. Los derechos, obligaciones y deberes emergentes de estos acuerdos integran lo que la literatura constitucionalista ha denominado el derecho intrafederal. ${ }^{19}$

\section{Idem.}

14 Idem.

15 CSJN, "Santa Fe, Provincia de c/ Estado Nacional s/ Acción Declarativa de Inconstitucionalidad" (Fallos 338:1362-1389) sentencia del 24/11/2015.

16 CSJN, "San Luis, Provincia de c/ Estado Nacional y otra s/ cobro de pesos" (Fallo CSJ 191/2009 (45-S)) sentencia del 24/11/2015.

17 CSJN, "Córdoba, Provincia de, c/ Estado Nacional y otro, s/ medida cautelar" (Fa1lo CSJ 786/2013 (49-C)) sentencia del 24/11/2015.

18 Barrera Buteler, Guillermo, Provincias y nación, cit.

19 Bidart Campos, Germán, Manual de la Constitución reformada, cit.; Barrera Buteler, Guillermo, Provincias y nación, cit.; Bulit Goñi, Enrique, "En torno al llamado 
Esta peculiar rama del derecho público constitucional argentino, producto de las relaciones entre niveles de gobierno, tiene una doble naturaleza, adquiere un "carácter ambivalente", ${ }^{20}$ ya que sus disposiciones pueden ser de naturaleza de derecho federal, de derecho común o de derecho local, dependiendo si tales acuerdos regulan relaciones entre sujetos federales y sus habitantes o de éstos entre sí, se considerará, de acuerdo con la Corte, ${ }^{21}$ como de derecho local, es decir, se convierte en legislación local, mientras que si regulan las relaciones entre los sujetos federales, el derecho intrafederal tendrá naturaleza federal. ${ }^{22}$

Como bien sostiene este autor, la determinación de la naturaleza del derecho federal no es una discusión bizantina, sino eminentemente práctica, ya que de ello depende, por un lado, la determinación de la competencia del órgano jurisdiccional para entender en causas regidas por acuerdos interjurisdiccionales, y por el otro, si su interpretación habilita o no el recurso extraordinario federal ante la CSJN.

La postura jurisprudencial de la Corte en este sensible tema fue variando a lo largo de los años. En un primer momento, las normas del derecho intrafederal no habilitaban la competencia originaria de la Corte (pues se entendía que la norma local no entraba en colusión con la Constitución, sino con otra norma local, la que se adhería al pacto o acuerdo interjurisdiccional), aunque en última instancia podía habilitar la cuestión federal como requisito para interponer el recurso extraordinario federal. Así lo sostuvo en el primer fallo donde la CSJN se refirió al derecho intrafederal. ${ }^{23}$ Pero con la constitucionalización del régimen de coparticipación en 1994, la Corte cambiará su postura (como se verá en el próximo acápite), constituyendo esta inserción un hecho fundamental para el derecho intrafederal y el federalismo argentino.

Para esa toma de decisión, la negociación se presenta — dado el diseño institucional que así lo prevé- como un elemento clave: tanto el gobierno nacional como cada una de las provincias deben acordar cualquier cambio

derecho intrafederal", cit.; Spisso, Rodolfo "El poder tributario y su distribución”, en García Belsunce, Horacio (dir.), Tratado de tributación, t. I, vol. 1, Buenos Aires, Astrea, 2009, pp. 1-25.

20 Barrera Buteler, Guillermo, Provincias y nación, cit., p. 361.

21 CSJN, “Armando Tomatti c/ Provincia de Buenos Aires" (Fallos 300:450), sentencia del 25 de abril de 1978.

22 Barrera Buteler, Guillermo, Provincias y nación, cit.

23 CSJN, "Transportes Automotores Chevallier S.A" citado anteriormente. 
que haya de operarse sobre el régimen de coparticipación federal de impuestos (RCFI). Al tratarse el RCFI de un mecanismo de coordinación de las potestades tributarias de ambos niveles de gobierno (nacional y provinciales), y al ser estas competencias constitucionalmente concurrentes entre ambos niveles, tanto la creación como cualquier ulterior modificación al mismo debe basarse en un acuerdo consensuado por todas las partes involucradas, bajo la pena de incurrir en inconstitucionalidad.

Asimismo, cabe recordar que la ley que establece el actual RCFI no es una ley ordinaria. La Ley 23.548 es una ley-convenio, y como tal, una especie dentro del amplio género de los acuerdos interjurisdiccionales. ${ }^{24}$ Estos acuerdos - aun cuando no estén mencionados por el artículo 31 de la Constitución - poseen un rango superior a las leyes nacionales (e inferior a la Constitución y los tratados internacionales), lo que significa que no pueden ser modificados unilateralmente por ninguna de las partes sin previo consentimiento. Así lo sostuvo la Corte Suprema, integrando lo que ella denominó - a través de una creación pretoriana - el "derecho intrafederal" (Corte Suprema de Justicia de la Nación, "Transportes Automotores Chevallier S.A. c/Buenos Aires, Provincia de s/acción declarativa", del 20/08/1991, Fallos, 314:862). Esta particular característica del diseño institucional del RCFI es uno de los factores que contribuyen a entender la dificultad de modificar el actual régimen y la demora en sancionar el nuevo que estatuye la Constitución en su artículo 75, inciso 2. Este diseño cae bajo lo que Fritz Scharpf denominó una "trampa de la decisión conjunta". ${ }^{25}$

\section{LA “CONSTITUCIONALIZACIÓN” DEL RÉGIMEN DE COPARTICIPACIÓN FEDERAL DE IMPUESTOS EN LA REFORMA CONSTITUCIONAL DE 1994}

La ley de declaración de la necesidad de reforma constitucional, Ley 24.309 (sancionada y publicada el 29 de diciembre de 1993), habilitaba

24 Altavilla, Cristian, "Acuerdos interjurisdiccionales en materia tributaria. El pactismo fiscal” (1a. parte), Periódico Económico Tributario, Buenos Aires, La Ley, 12 de junio, pp. 1 y 2, 2009, y “Acuerdos interjurisdiccionales en materia tributaria. El pactismo fiscal” (2a. parte) Periódico Económico Tributario, La Ley, 26 de junio, pp. 3-10, 2009.

25 Scharpf, Fritz, "The Joint-Decision Trap: Lessons from German Federalism and European Integration”, Public Administration, vol. 66, núm. 2, 1998, pp. 239-278. 
expresamente la posibilidad de la Convención de insertar en el texto constitucional el régimen de coparticipación. Por su artículo 30.

Se habilitan también para su debate y resolución en la Convención Constituyente los puntos que se explicitan y los artículos que se discriminan a continuación... A.- FORTALECIMIENTO DEL REGIMEN FEDERAL: Distribución de competencias entre la Nación y las provincias respecto de la prestación de servicios y en materia de gastos y recursos. Régimen de coparticipación.

El Constituyente insertó en el artículo 75 el régimen de coparticipación federal de impuestos entre la nación y las provincias, que se materializa a través de una ley-convenio, constitucionalizando así una práctica enraizada por más de cincuenta años en el derecho constitucional consuetudinario y en el federalismo de concertación argentinos.

El inciso 2o. de este artículo (atribuciones del Congreso de la Nación) tiene una técnica legislativa minuciosa y detallista, que se diferencia del resto de la Constitución. Este detalle y esta extensión denotan la importancia que la Convención Nacional Constituyente le dio a este tema, relevancia que siempre tuvo, desde los orígenes mismos del Estado federal argentino (Altavilla 2018). A ello cabe agregar, además, que dicha cláusula fue consensuada por tres comisiones de la Convención (la de Redacción, la de Competencias federales y la de Régimen federal) en las que participaron diez gobernadores de provincia en ese momento en ejercicio. ${ }^{26}$

El inciso 2o. comienza diciendo que es atribución del Congreso

Imponer contribuciones indirectas como facultad concurrente con las provincias. Imponer contribuciones directas, por tiempo determinado, proporcionalmente iguales en todo el territorio de la Nación, siempre que la defensa, seguridad común y bien general del Estado lo exijan. Las contribuciones previstas en este inciso, con excepción de la parte o el total de las que tengan asignación específica, son coparticipables.

26 Hernández, Antonio M., "Los fallos de la CSJN sobre los reclamos provinciales de San Luis, Santa Fe y Córdoba por detracciones a la masa coparticipable y la confirmación de una jurisprudencia federalista", Academia Nacional de Derecho y Ciencias Sociales de Córdoba, 2016, disponible en: http://www.acaderc.org.ar/doctrina/los-fallos-de-la-csjnsobre-los-reclamos-provinciales-de-san-luis-santa-fe-y-cordoba-por-detracciones-a-lamasa-coparticipable-y-la-confirmacion-de-una-jurisprudencia-federalista. 
En primer lugar, el Constituyente perfeccionó la redacción del viejo artículo 67, en cuanto dejó expresamente establecido que los impuestos indirectos serían concurrentes entre la nación y las provincias, cuestión que el texto de 1853/60 no especificaba, lo cual había generado importantes conflictos intergubernamentales, que finalmente fueron dirimidos por la Corte en favor de la concurrente de tal competencia. ${ }^{27}$

Siguiendo la tradición en materia de coparticipación, la disposición constitucional deja fuera de la masa coparticipable la parte de aquellos impuestos que tengan una asignación especifica - éstos son aquellos cuyo producido tiene una finalidad concreta declarada por el Congreso; nunca fueron coparticipados con las provincias, y en la práctica se evidenció como una de las formas más recurrentes para sustraer importantes contingentes de recursos de la masa coparticipable, perjudicando la distribución primaria de las provincias- ${ }^{28}$

La Constitución reformada sigue atribuyendo al Congreso esta facultad, pero ahora reglamenta su ejercicio. El inciso 3o. del artículo 75 establece que las asignaciones deben ser por tiempo determinado y establecidas por una ley especial aprobada por la mayoría absoluta de la totalidad de los miembros de cada Cámara.

E1 2o. párrafo institucionaliza el tipo de acuerdo interjurisdiccional que deberá emplearse para la creación del nuevo régimen de coparticipación, y establece específicamente la modalidad de la ley-convenio: "Una ley convenio, sobre la base de acuerdos entre la Nación y las provincias, instituirá regímenes de coparticipación de estas contribuciones, garantizando la automaticidad en la remisión de los fondos".

27 Por ejemplo, en el famoso fallo "Sociedad Anónima Mataldi Simón Limitada c/ Provincia de Buenos Aires por repetición pago impuestos" (Fallos, 149:260) sentencia del 28 de septiembre de 1927, basándose, a su vez, en otro fallo, mucho más anterior, "Fisco Nacional, contra el doctor Martín S. Berho, por infracción a la ley de impuestos internos" (Fallos, 121:264, véase sobre todo, pp. 271/2) del 1 de julio de 1915.

Con esta disposición se cerraba la eterna discusión acerca de si los impuestos indirectos eran concurrente o no, debate que había sido iniciado en el Congreso en 1895, adoptándose la postura defendida por el entonces ministro de economía José Antonio Terry.

28 Prácticamente todos los impuestos nacionales tienen alguna asignación específica; pueden mencionarse el impuesto a las ganancias, de cuyo producido se asigna un determinado porcentaje a la seguridad social y a los aportes del tesoro nacional (ATN); lo propio sucede con el IVA, los impuestos sobre cigarrillos, la Ley 23.562 de "Fondo Transitorio para financiar desequilibrios fiscales provinciales", la Ley 23.658 de Impuestos sobre intereses y ajustes de los depósitos a plazo fijo en beneficio de determinadas provincias, etcétera. 
Como se dijo anteriormente, una ley-convenio es una modalidad específica de acuerdo interjurisdiccional, son acuerdos interjurisdiccionales mixtos celebrados entre ambos niveles de gobierno, que reconoce como base un acuerdo celebrado entre los representantes ejecutivos de ambos niveles, el que es enviado al Congreso para que éste lo convierta en ley nacional, a la cual deben adherirse las provincias mediante las respectivas leyes emanadas de sus legislaturas. ${ }^{29}$

Lo novedoso del texto constitucional es que reconoce expresamente los acuerdos previos entre el presidente y los gobernadores como el primer paso para la sanción de este acuerdo, como sucede en la práctica con la firma y celebración de cualquier tratado o acuerdo interjurisdiccional. En la práctica constitucional previa, estos procesos de negociaciones siempre precedieron la sanción de la ley-convenio de coparticipación; a partir de 1994, éste será un paso formal en la creación y celebración del nuevo acuerdo, forman parte del proceso de formación y sanción de la ley. Con esto se fortalece un federalismo de concertación, pues busca el consenso previo de los poderes ejecutivos, y los reconoce como sujetos con capacidades de negociaciones y como actores institucionales relevantes en los procesos de concertación.

El convencional constituyente ha establecido así la participación en el proceso de toma de decisión de todos los actores relevantes del escenario político federal: el Congreso de la Nación, el presidente, los gobernadores, y finalmente, las legislaturas provinciales, en un proceso de negociaciones y acuerdos previos. Esta estructura imprime al nuevo régimen de coparticipación la fórmula de pluralismo institucional y exige un mayor grado de consenso y concertación, en particular de los poderes ejecutivos, cuyos acuerdos previos se erigen ahora como mecanismos formales para la concertación del régimen de coparticipación.

Esta disposición inserta al régimen de coparticipación dentro del espectro de competencias compartidas entre la nación y las provincias, ya que no podría implementarse de no mediar la voluntad expresa de todas las partes interesadas, con el mismo tenor y alcance que los artículos 30 . y 13 de la Constitución. Así, mientras los impuestos indirectos son competencias concurrentes - y por tanto de ejercicio indistinto y simultáneo de ambos niveles_-, el régimen de coparticipación es una competencia

29 Altavilla, Cristian, Conflicto y coordinación politica en las relaciones ntergubernamentales..., cit. 
compartida, entendida como "aquéllas cuyo ejercicio requiere un acto integratorio de los dos órdenes gubernamentales... es decir que hace falta la concurrencia de un órgano provincial y de un órgano del gobierno federal" para que la decisión (en el caso, la puesta en vigencia del régimen de coparticipación) pueda tener validez y vigencia.

Una vez logrado el acuerdo, el proyecto es enviado al Congreso, más específicamente a la Cámara de Senadores: "La ley convenio tendrá como Cámara de origen el Senado y deberá ser sancionada con la mayoría absoluta de la totalidad de los miembros de cada Cámara" (artículo 75, inciso 2o., 4o. párrafo).

A diferencia del artículo 52, que establece que la Cámara de Diputados es la cámara de origen en materia de contribuciones, siguiendo el principio no taxation without representation, el texto del artículo 75 establece que en materia de coparticipación lo será el Senado. Esta disposición no contradice la del artículo 52, ya que aquí no se trata de crear impuestos, sino de distribuirlos entre los distintos niveles de gobierno; se trata de coordinar las competencias fiscales de nación y provincias. La norma es acertada, ya que en esta cámara alta se encuentran representadas paritariamente las provincias como sujetos de la federación. Además, el texto exige una mayoría agravada (mayoría absoluta de la totalidad de los miembros de cada Cámara), con el objetivo de lograr un alto grado de consenso, ya que en la práctica resulta difícil alcanzar dicha mayoría; reafirma así la importancia de esta temática, e impide que mayorías circunstanciales puedan definirla a la ligera.

Esta ley-convenio es receptada con las características propias del derecho intrafederal: “...no podrá ser modificada unilateralmente, ni reglamentada y será aprobada por las provincias" (artículo 75, inciso 2o., 40. párrafo, in fine)". Cuando la norma está asignándole a esta ley-convenio una jerarquía superior a las leyes contempladas en el artículo 31 de la Constitución. El hecho de que no pueda ser reglamentada por el Poder Ejecutivo constituye una protección contra las arbitrariedades del presidente y denota la naturaleza contractual o convencional de esta ley, naturaleza que queda reafirmada con la aprobación de las legislaturas provinciales, tal como sucede con la firma de un acuerdo o tratado, sea en el orden interno o en el internacional — de ahí también que puedan aplicarse subsidiariamente las normas del derecho internacional público-. Ante la ausencia de regulación expresa, tanto la doctrina como la CSJN han considerado 
que resultan aplicables "por directa analogía" las costumbres del derecho internacional y los principios establecidos en ciertas convenciones internacionales, como es el caso de la Convención de Viena de 1969. ${ }^{30}$

La Constitución nada dice respecto de cuántas provincias deberán suscribir dicha ley para que el régimen pueda entrar en vigencia. Ante esta omisión, podría interpretarse que, como sucedería con cualquier otro acuerdo interjurisdiccional, tendría vigencia sólo para aquellas que lo suscriban, mientras que las restantes se seguirían rigiendo por la ley convenio vigente. ${ }^{31}$ Quiroga Lavié también entiende que deberá sancionarse una "ley orgánica sobre la coparticipación tributaria federal", ${ }^{32}$ a efectos de que regule el procedimiento a seguir para la aprobación de las provincias.

También ha surgido el interrogante de si la ley-convenio debe ser una única ley o si puede haber varias leyes (además de una que sirva de "leymarco"), que regulen un determinado tributo. Bidart Campos se inclina por la posibilidad de varias leyes-convenios, y sostiene que una interpretación literal rígida no infiere del singular ("una" ley) la imposibilidad de más de una. ${ }^{33}$ Además, la expresión en plural "regímenes" deja entrever la posibilidad de que puede existir más de un régimen de coparticipación, dejando así abierta la posibilidad de instaurar regímenes especiales, como viene sucediendo desde la década de 1930.

Todas estas formalidades que rodean a la ley-convenio tienen como finalidad afianzar el federalismo de concertación o de coordinación. El hecho de que tanto las autoridades nacionales como las provinciales participen en el debate sobre la distribución primaria y secundaria que formará la base de acuerdos sobre la coparticipación, obliga, indudablemente, a la concertación. El hecho, también significativo, de que se requiera la mayoría calificada a que alude el párrafo 4o. exige un alto grado de consenso entre los representantes del pueblo (Cámara de Diputados) y de las provincias (Cámara de Senadores). Y a ello debe sumarse la aprobación por parte de cada una de las provincias por medio de sus legislaturas provinciales.

30 Altavilla, Cristian, "El rol de la Corte Suprema en los conflictos intergubernamentales. Análisis del caso Prov. de La Pampa c/ Prov. de Mendoza”, Cuadernos de Federalismo, t. XXII, Córdoba, Academia Nacional de Derecho y Ciencias Sociales de Córdoba, Instituto de Federalismo, 2009, pp. 119-149.

31 Quiroga Lavié, Humberto, Constitución de la Nación Argentina comentada, Buenos Aires, Zavalía, 2003.

32 Ibidem, p. 370.

33 Bidart Campos, Germán, Manual de la Constitución reformada, cit., p. 175. 
El convencional, en este punto, ha querido fortalecer el federalismo, en particular sobre un tema tan significativo y a la vez conflicto como es el reparto de recursos, buscando una solución que establezca "un régimen definitivo con reglas claras, que permite un desarrollo equilibrado de la federación, en lugar de la arbitrariedad que ha signado la relación Naciónprovincias", ${ }^{34}$ aunque para otros autores esta cláusula constitucional debilita el gobierno central y torna muy dificultoso el trámite para su sanción. ${ }^{35}$

\section{LOS NUEVOS ESTÁNDARES EN LAS RELACIONES FISCALES INTERGUBERNAMENTALES FIJADOS} PARA EL CONSTITUYENTE CON LA “CONSTITUCIONALIZACIÓN" DEL RÉGIMEN DE COPARTICIPACIÓN FEDERAL DE IMPUESTOS

El nuevo texto constitucional contiene otras disposiciones, que van más allá de cuestiones técnicas y de procedimiento. El Constituyente nacional fijó además una serie de verdaderos estándares constitucionales que han de regir las relaciones fiscales intergubernamentales verticales naciónprovincias a futuro. Son verdaderos principios rectores específicos de las relaciones intergubernamentales que se agregan a las tres relaciones típicas en las que se basa el federalismo argentino: de participación, coordinación y de subordinación que menciona Bidart Campos (1998), gobernadas por sus respectivos principios (Barrera Buteler 1996 ${ }^{36}$ ): la relación de subordinación y su principio correlativo, el de solidaridad; la relación de participación (también llamado "de colaboración" o "de inordinación"), y su principio respectivo, el de participación y la relación de cooperación, regida por el principio de subsidiariedad. Además de éstos, la teoría constitucionalista argentina identifica una serie de subprincipios (la mayoría de ellos enunciados en fallos jurisprudenciales del más alto tribunal), que se

\footnotetext{
34 Hernández, Antonio M., "Los fallos de la CSJN sobre los reclamos provinciales...", cit., p. 8.

35 Gelli, María Angélica, Constitución de la Nación argentina. Comentada y concordada, Buenos Aires, La Ley, 2004, p. 544.

36 Barrera Buteler habla de principios de la "relación federal" (Provincias y nación, op. cit.), mientras que Bidart Campos habla de relaciones vertebrales de la estructura constitucional del federalismo argentino, que "son rasgos fundamentales de todos los estados federales" (Bidart Campos, Germán, Manual de la Constitución reformada, cit., p. 440).
}

Esta obra está bajo una Licencia Creative Commons

Atribución-NoComercial-SinDerivar 4.0 Internacional, IIJ-UNAM. 
derivan de aquellos tres principios rectores, tales como el subprincipio de cooperación, de adaptación, de prudencia y el de lealtad federal. ${ }^{37}$

Así, por ejemplo, la Corte Suprema ha sostenido que todas las relaciones de las provincias entre sí y con la nación, en función del destino común que deben afrontar, deben estar presididas por el principio de solidaridad, que es una aplicación del principio de lealtad federal (CSJN, caso "Provincia de Misiones c/ Nación Argentina”, Fallos 263:437)..$^{38}$ Para el autor, tal subprincipio significa "vallas a los egoísmos locales, exige que la Nación no privilegie ni postergue a unas provincias en perjuicio o beneficio de otras, y que todos estos centros de poder se comporten de buena fe". ${ }^{39}$

El Constituyente agrega principios específicos de las relaciones fiscales nación-provincias. La Constitución dispone que

la distribución entre la Nación, las provincias y la ciudad de Buenos Aires y entre éstas, se efectuará en relación directa a las competencias, servicios y funciones de cada una de ellas contemplando criterios objetivos de reparto; será equitativa, solidaria y dará prioridad al logro de un grado equivalente de desarrollo, calidad de vida e igualdad de oportunidades en todo el territorio nacional (artículo 75, inciso 2o., inciso 3o.).

La primera parte de esta cláusula se encuentra íntimamente vinculada con el 5o. párrafo del inciso 2o., en cuanto que esta norma está orientada a que la nueva ley de coparticipación tenga en cuenta, a la hora de la distribución, "las competencias, servicios y funciones" de cada una de las partes intervinientes, y con base en estas responsabilidades de las provincias, obviamente deberá asignarles los respectivos recursos para hacer frente a los gastos que demanden, pues "la distribución... se efectuará en relación directa" a ellas, y siguiendo los criterios que la misma norma fija en su consecuencia.

Estos criterios, que significan también un cauce por medio del cual se viabilizan las prescripciones del artículo 75, inciso 19, 20. párrafo, la "nueva" cláusula del Progreso, ${ }^{40}$ resultan obligatorios a la hora de proce-

37 Sagüés, Néstor P., Elementos de derecho constitucional, t. II, Buenos Aires, Astrea, 2003, pp. 41 y 42.

38 Sagüés Sagüés, Néstor P., op. cit., p. 23.

39 Ibidem, pp. 41 y 42

40 El cual dispone "Proveer al crecimiento armónico de la Nación y al poblamiento de su territorio; promover políticas diferenciadas que tiendan a equilibrar el desigual 
der a la distribución de los recursos fiscales. ${ }^{41}$ Pero, interpretamos, dichos principios no sólo han de ser aplicados cuando se sancione la ley de coparticipación, sino que son plenamente operativos para las relaciones fiscales en general.

Así, sostenemos que no sólo el régimen de coparticipación, sino en términos más generales las relaciones fiscales intergubernamentales verticales se encuentran, desde 1994, regidas por una serie de principios o estándares, entre los cuales se encuentran el de concertación, el de solidaridad, el de equidad, el de objetividad, el de automaticidad y el de funcionalidad.

El principio de concertación hace a las negociaciones y consensos que el Estado central y las provincias, incluida la ciudad autónoma de Buenos Aires (distribución primaria) y entre aquellas (distribución secundaria) deben entablar para lograr un acuerdo sobre la forma en que se distribuirán los recursos.

El principio de solidaridad hace a la repartición de la masa coparticipable de manera tal que logre beneficiar a aquellas provincias con mayores dificultades y con menor índice de progreso a efectos de alcanzar aquella meta constitucional de "proveer al crecimiento armónico de la Nación y... promover políticas diferenciadas que tiendan a equilibrar el desigual desarrollo relativo de provincias y regiones" establecido en la denominada "nueva cláusula del progreso" del artículo 75, inciso 19.

Dicho principio se ve atemperado, a modo de equilibrio, por el de equi$d a d$, según el cual a mayor capacidad contributiva o poblacional, mayor distribución. ${ }^{42}$ Ambos principios se complementan a efectos de que no se cometan injusticias con aquellas provincias que más aportan (equidad), pero al mismo tiempo se intenta lograr un desarrollo armónico entre todas las provincias a efectos de acortar las distancias de desarrollo entre las más ricas y las más pobres (solidaridad). El principio de objetividad tiende a que el reparto sea claramente determinado, razonable y exento de parcialidad, impidiendo que se establezcan diferencias no justificadas, es decir, de modo arbitral. El convencional ha querido así combinar dos sistemas de

desarrollo relativo de provincias y regiones. Para estas iniciativas, el Senado será Cámara de origen", y que también reconoce como cámara de origen a la de senadores.

41 Altavilla, Cristian, "Coparticipación y federalismo en la reforma constitucional de 1994”, La Ley - Periódico Económico Tributario, 14 de abril, 2008, pp. 6-10.

42 A diferencia del régimen actual impuesto por ley 23.548, artículo 3o., que distribuye el total de lo recaudado a cada provincia estableciéndose para cada una de ellas un porcentaje fijo. 
coparticipación en uno solo, un sistema distributivo, que da a cada cual lo que ha aportado, atemperado con un sistema redistributivo, orientado por la solidaridad, que permita dar un poco más a las que menos tienen.

El principio de la automaticidad en la remisión de los fondos (inciso 2o., 2o. párrafo in fine) tiene como objeto evitar el bloqueo de los recursos, utilizado comúnmente como herramienta de presión política. ${ }^{43} \mathrm{La}$ automaticidad representa para las provincias una importantísima garantía, ya que, ante el incumplimiento por parte de la nación de remitir los fondos, como ha venido sucediendo hasta ahora, permite a las provincias recurrir ante la CSJN por medio del amparo. Asimismo, la CN ordena la inclusión de dicha garantía en la ley convenio, y de no ser incluida por el legislador, corresponde al alto tribunal su implementación, ya que aquello constituiría una violación de la Constitución por omisión del legislador, ${ }^{44} \mathrm{y}$ además, según interpretamos, porque tales cláusulas son operativas por sí mismas, independientemente de que se sancione o no el régimen que ordena la nueva Constitución.

El principio de la irreductibilidad de los recursos provinciales contemplado en la cláusula transitoria sexta de la Constitución, que consideramos uno de los más importantes y con mayor vigencia y operatividad en la actualidad. La cláusula establece de manera expresa y clara que "la distribución de competencias, servicios y funciones vigentes a la sanción de esta reforma, no podrá modificarse sin la aprobación de la provincia interesada", y además, que "no podrá modificarse en desmedro de las provincias la distribución de recursos vigente a la sanción de esta reforma", en ambos, aclara, "hasta el dictado del mencionado régimen de coparticipación".

Por último, el principio de funcionalidad, contemplado en el 5o. párrafo del inciso 2o., el cual dispone que "no habrá transferencia de competencias, servicios o funciones sin la respectiva reasignación de recursos, aprobada por ley del Congreso cuando correspondiere y por la provincia interesada o la ciudad de Buenos Aires en su caso". Si alguna de las provincias se viera perjudicada en el reparto, cabría para ellas el control de razonabilidad por parte de los tribunales de justicia. ${ }^{45}$

Sin duda, un sistema de coparticipación erigido sobre estas bases favorece y fortalece la construcción de un estado federal, basado en principios de solidaridad y ayuda recíproca entre los distintos estados locales. En virtud de ello, queda sustituida en nuestra Constitución el principio se-

\footnotetext{
43 Gelli, María Angélica, op. cit., p. 543.

44 Quiroga Lavié, Humberto, op. cit., p. 368.

45 Ibidem, p. 369.
} 
gún el cual gasta quien recauda, mutándose por criterios de solidaridad y equidad a efectos de lograr un crecimiento igualitario y armónico de todas las provincias. ${ }^{46}$ Hernández opina que este sistema se asemeja al de la federación canadiense, en la que impera un sistema de igualación, programa federal por el cual las provincias pobres reciben más fondos del gobierno federal que las ricas, y donde hay transferencias de recursos de las provincias más ricas a las restantes. ${ }^{47}$ Otro factor a considerar, y que nutre nuestro sistema federal, es el hecho de que a partir de esta reforma se intenta, aunque lamentablemente en los hechos no se haya materializado aún, dejar de lado ciertas prácticas del gobierno federal, que resultaban ser lesivas al federalismo, entre otras las transferencias de competencias y servicios sin los respectivos recursos, las denominadas asignaciones específicas, etcétera.

La inserción de cada uno de estos principios o estándares de las relaciones intergubernamentales es fruto de las enseñanzas que ha dejado la experiencia. La extensión de este artículo y el detallismo utilizado (poco común en la técnica legislativa de la Constitución) pone de resalto el hecho de que la Convención fue más allá de lo originariamente previsto, y se traduce en un intento de evitar futuros comportamientos oportunistas del gobierno nacional; por otra parte, la percepción negativa que tenían del régimen de coparticipación los propios convencionales llevó a incluir en cada párrafo del inciso una garantía para las provincias: ${ }^{48}$ la automaticidad en la remisión de los fondos intenta frenar una vieja práctica del Ejecutivo de demorar el envío de recursos a las provincias a modo de castigo o presión política; la objetividad en el reparto de recursos busca precisamente evitar la discrecionalidad en la asignación de recursos, que permita favorecer o castigar según el color político.

La transferencia de competencias, servicios o funciones sin la respectiva reasignación de recursos responde a viejas prácticas oportunistas y pretende impedir procesos de descentralización reactivos y unilaterales, como sucedió en 1992 con el dictado de las leyes 24.049 y 24.061, por las que se transfirieron a las provincias, sin el consentimiento de estas, las

\footnotetext{
46 Gelli, María Angélica, op. cit., p. 541.
}

47 Hernández, Antonio M., "El federalismo a diez años de la reforma constitucional de 1994", 2004, disponible en: http://www.acaderc.org.ar/doctrina/articulos/artfederalismoadiezanosreformaconstitucional/at_download/file.

48 Altavilla, Cristian, Conflicto y coordinación politica en las relaciones intergubernamentales..., cit. 
escuelas secundarias y los hospitales nacionales, ${ }^{49}$ procesos que a su vez tuvieron como antecedente uno similar llevado a cabo en 1978 durante el último gobierno de facto. Para evitar futuros comportamientos oportunistas, se insertó expresamente la prohibición de modificar (en desmedro de las provincias) la distribución de recursos y de competencias vigentes a 1994, según lo establece la cláusula transitoria sexta.

Esta misma disposición establece que "la presente cláusula no afecta los reclamos administrativos o judiciales en trámite originados por diferencias por distribución de competencias, servicios, funciones o recursos entre la Nación y las provincias". Aquellos procesos de transferencia de servicios dejaron como saldo importantes conflictos intergubernamentales entre ambos niveles de gobierno, lo que se pone de resalto en estas disposiciones constitucionales.

La prohibición de modificaciones unilaterales y de reglamentaciones tiene su antecedente inmediato (para no mencionar los innumerables ejemplos que existen en la historia de las relaciones fiscales $)^{50}$ en el Decreto 879 , que disponía una quita del $20 \%$ del impuesto a las ganancias con destino al sistema previsional, y los decretos 559/92 y 701/92, que detraían de la masa coparticipable ciertos porcentajes para solventar los gastos de la Dirección General Impositiva (DGI).

Por último, la cláusula transitoria sexta estableció un plazo máximo dentro del cual la nación y las provincias deberían haber concertado el nuevo régimen: "un régimen de coparticipación conforme a lo dispuesto en el inc. 2 del art. 75 y la reglamentación del organismo fiscal federal, serán establecidos antes de la finalización del año 1996". Aunque desde 1988 la nación y las provincias celebraron una gran cantidad de acuerdos en esta materia (algunos incluso con disposiciones reñidas con las cláusulas de la nueva Constitución), jamás hubo una sola reunión entre el Presidente y los gobernadores en orden a discutir el nuevo régimen que la Constitución impone, ${ }^{51}$ sino que, por el contrario, los acuerdos posteriores

\footnotetext{
49 Tommasi, 2002, p. 68 y Falleti, 2001, p. 214.

50 Puede verse al respecto una larga enumeración en Altavilla, Cristian, Cooperación y conflicto..., cit., y en Bulit Goñi, Enrique, "Coparticipación federal de impuestos: el tironeo recurrente...", cit.; Altavilla, Cristian, "Un análisis de las relaciones intergubernamentales en el federalismo argentino a 200 años de su independencia (1816-2016)", Studia Politicae, núm. 45, primavera-verano 2018/2019, pp. 117-153.

51 Con posterioridad a la reforma constitucional, varios pactos han establecido la obligación de las partes intervinientes de cumplir con el mandato constitucional. Así, el
} 
a la nueva Constitución no sólo no cumplimentaron con la manda, sino que se acordaron modificaciones que van en contra de las nuevas disposiciones constitucionales.

\section{EL INCUMPLIMIENTO DE LAS DISPOSICIONES CONSTITUCIONALES}

A pesar del amplio consenso en lograr un federalismo de concertación, como ha quedado de resalto en los debates de la Convención Constituyente de 1994 y plasmados en el actual texto de la Constitución Nacional, la práctica política posterior puso de manifiesto un significativo desinterés no sólo por crear el nuevo régimen de coparticipación, sino incluso de respetar los nuevos parámetros y estándares constitucionales de aplicación directa a las relaciones intergubernamentales - los que, según nuestra hiótesis, son plenamente operativos y aplicables independientemente de la sanción de aquella ley-convenio que manda la Constitución-. Resulta llamativo, ya que esta constitucionalización implicó insertar en la norma fundamental todos aquellos reclamos y exigencias que se venían dando desde antaño, siendo la oportunidad más propicia para establecer criterios objetivos de reparto y estructurar un sistema estable y duradero que impida comportamientos oportunistas.

En efecto, en su cláusula transitoria sexta, la Constitución reformada dispone expresamente que el "régimen de coparticipación conforme a lo dispuesto en el inc. 2 del art. 75 y la reglamentación del organismo fiscal federal, serán establecidos antes de la finalización del año 1996". Esta obligación no se cumplió en el término previsto. Con posterioridad, varios pactos han establecido la obligación de las partes intervinientes de cumplir con el mandato constitucional: entre ellos el "Compromiso Federal para el Crecimiento y la Disciplina Fiscal” de 2000 estableció que las partes pre-

\footnotetext{
“Compromiso Federal para el Crecimiento y la Disciplina Fiscal” de 2000 estableció que las partes presentarían un proyecto de ley de coparticipación durante 2001 (Cl. II) y en 2002, el “Acuerdo Nación-Provincias sobre Relación Financiera y Bases de un Régimen de Coparticipación Federal de Impuestos", acordó entre sus propósitos, cumplir con el mandato constitucional de dar forma a un régimen de coparticipación definitivo "antes del 31 de diciembre de 2002" (artículo 7o.). A pesar de estas declaraciones, desde 1994 no hubo reuniones entre el presidente y los gobernadores con el objetivo de sancionar el nuevo régimen de coparticipación acorde a los preceptos constitucionales.
} 
sentarían un proyecto de ley de coparticipación durante 2001 (Cl. II); en 2002, el "Acuerdo Nación-Provincias sobre Relación Financiera y Bases de un Régimen de Coparticipación Federal de Impuestos" acordó entre sus propósitos cumplir con este mandato constitucional "antes del 31 de diciembre de 2002" (artículo 7o.), y finalmente en 2017 con el nuevo Consenso Fiscal (Cl. I, ap. "m") se establece como "compromisos comunes" la de "Consensuar una nueva ley de coparticipación federal de impuestos en el marco de la Comisión Federal de Impuestos", aunque esta vez no establece una fecha límite.

A lo largo de distintas oportunidades y contextos de reforma del régimen de coparticipación vigente, las partes involucradas no sólo no cumplieron estos compromisos, sino que incluso avanzaron en acuerdos reñidos con el nuevo texto constitucional y los nuevos estándares fijados por la Constitución en 1994: los dos pactos fiscales celebrados en 1992 y 1993 y los compromisos federales de 1999 y 2000 sustituyeron los porcentajes establecidos en el artículo 3o. de la Ley $23.548 / 88$ por sumas fijas, y en el Acuerdo RFyBRCFI de 2002 directamente dejó sin efecto la garantía del piso mínimo del $34 \%$ en la distribución primaria contenida en el artículo 7o. de aquella ley, en una clara violación de la normativa constitucional, que impide expresamente modificar la distribución de recursos vigentes en desmedro de las provincias (CT 6a., CN), el Consenso Fiscal de 2017 implicó una serie de restricciones a las transferencias federales hacia las provincias; por ejemplo, eliminando el 30\% del impuesto al cheque destinado a las provincias que desde 2002 se venía coparticipando - el único logro significativo en aquel proceso de negociaciones que tuvieron las provincias con la firma de uno de los acuerdos más centralistas que se firmaron en las últimas tres décadas - ${ }^{52}$

Esto demuestra que se ha dado una "proliferación de acuerdos de emergencia en reemplazo de esquemas estables de reparto",,$^{53}$ que importan modificaciones ad hoc al régimen frente a situaciones de crisis y sin perspectivas de largo plazo. El resultado final que dieron estos pactos formales

52 Altavilla, Cristian, "La coparticipación del impuesto al cheque. Un análisis de las relaciones intergubernamentales a través de un estudio de caso", Anuario XV (20132015) del CIJS (Centro de Investigaciones Jurídicas y Sociales), Facultad de Derecho, Universidad Nacional de Córdoba, pp. 3-25.

53 Cetrángolo, Óscar y Juan P. Jiménez, "Las relaciones entre niveles de gobierno en Argentina”, Revista de la CEPAL, Santiago, núm. 84, diciembre de 2004, pp. 117-134. 
celebrados entre ambos niveles de gobierno profundizó aún más la brecha existente ente la nación y el conjunto de las provincias, distorsionó el esquema de reparto y lo complejizó al extremo.

\section{CONCLUSIONES: EL RANGO CONSTITUCIONAL DEL DERECHO INTRAFEDERAL Y NUEVOS ESTÁNDARES PARA LAS RELACIONES FISCALES INTERGUBERNAMENTALES}

A raíz de lo analizado hasta aquí, podemos arribar a dos conclusiones importantes en esta materia crucial para el federalismo argentino. Por un lado, la inserción del régimen de coparticipación a través de una ley-convenio en el texto constitucional vino a dar rango constitucional al derecho intrafederal, y, en segundo lugar, la Constitución fijó nuevos parámetros y estándares, que deberán ser seguidos y respetados por los sujetos federales en sus relaciones recíprocas, al menos en materia fiscal.

El régimen de coparticipación a través de una ley-convenio es el primer acuerdo interjurisdiccional nación-provincias que se inserta en el texto constitucional. El texto de 1853 sólo preveía (explícitamente) la celebración de acuerdos horizontales, provincia-provincia, los llamados tratados interprovinciales. La introducción de este régimen en el texto constitucional vino a dar rango constitucional al derecho intrafederal. Esto constituye un hito importante, que incluso se ve reflejado en los nuevos lineamientos jurisprudenciales de la Corte Suprema de Justicia de la Nación.

Como se había visto, en un primer momento la Corte había negado su competencia originaria para tratar sobre acuerdos interjurisdiccionales (dejando abierta la vía del recurso extraordinario federal). Pero, más adelante, en 1999, en el fallo Agueera c/ Provincia de Buenos Aires, donde se discutía sobre el Pacto Fiscal II, la Corte no sólo reconoce su competencia originaria, sino que además realiza un interesante análisis doctrinario sobre el derecho intrafedeal y su especial jerarquía — como se vio anteriormente- En esta primera etapa jurisprudencial, la Corte extiende su competencia originaria a todo tipo de acuerdo interjurisdiccional: sean pactos fiscales, ${ }^{54}$ sea la

\footnotetext{
54 CSJN, causa "Asociación de Grandes Usuarios de Energía Eléctrica de la República Argentina (Agueera) c/ Provincia de Buenos Aires y Otro" (Fallos, 322:1781-1792, sentencia del 19.08.1999).
} 
ley de coparticipación federal de impuestos, ${ }^{55} \mathrm{o}$ bien el mismo convenio multilateral, ${ }^{56}$ un acuerdo interjurisdiccional horizontal provincia-provincia.

En fallos posteriores, ${ }^{57} \mathrm{sin}$ embargo, la Corte hará una distinción entre el régimen de coparticipación y los restantes acuerdos interjuridisccionales (v. $g r .$, los pactos y acuerdos fiscales), justamente porque el primero tiene rango constitucional, al estar expresamente previsto en la Constitución Nacional, no así los restantes, que serían de rango infraconstitucional, enmarcados dentro del derecho intrafederal.

Cinco años más tarde, la Corte directamente cambia de postura y vuelve al precedente originario, sentado en el caso Chevallier (1991), donde se sostuvo que el régimen de coparticipación y todos los acuerdos interjurisdiccionales corresponden al derecho local, no correspondiendo, en consecuencia, a su competencia originaria. ${ }^{58}$ En este fallo, la Corte expresamente deja sin efecto lo sentado en los casos "El Cóndor" (sobre ley de coparticipación federal) y en "Argencard" (respecto del convenio multilateral).

Hasta aquí, la Corte había dado un paso atrás en el reconocimiento del derecho intrafederal como materia federal. Sin embargo, en tres importantes precedentes muy recientes vuelve a dar primacía al derecho intrafederal. Se trata de los casos de Santa Fe, San Luis y Córdoba contra el Estado Nacional (citados anteriormente). Estos tres fallos son idénticos en cuanto a sus considerandos. En primer lugar, la Corte hace una mención acerca de la actual composición del "marco jurídico del sistema de distribución de la renta tributaria federal", diciendo que se integra con el Pacto Fiscal de 1992, el Pacto Federal de 1993, el Compromiso Federal de 1999 y el de

55 CSJN, causa "El Cóndor Empresa de Transportes S.A. c/ Buenos Aires, Provincia de s/ acción declarativa", Fallos, 324:4226, sentencia del 7 de diciembre de 2001, en especial, CSJN, considerando 11 .

56 CSJN, causa "Argencard S.A c. Pcia de Salta" (Fallos, 327:1473), del 27 de mayo de 2004, en especial, punto II del dictamen del procurador general (al cual la Corte, por razones de brevedad, comparte y falla en consecuencia), donde manifiesta que "el Convenio Multilateral [no] queda reducida al ámbito del derecho local... pues pertenece al derecho intrafederal definido por V.E. en Fallos: 314:862 [fallo «Transportes Automotores Chevallier S.A.»], que involucra más de una jurisdicción, y por ese solo hecho no puede ser sometida a los tribunales de una sola de ellas".

57 "Matadero y Frigorífico Merlo S. A. c/ Buenos Aires, Prov. de s/ acción declarativa de certeza", Fallos 327:1789, del 27/05/2004.

58 "Papel Misionero S.A.I.F.C. c/ Prov. de Misiones", Fallos, 332: 1007, del 5/05/2009 y “Cuyoplacas S. A. c/ Prov. de La Pampa”, Fallos, 332:998, del 5/05/2009. 
2000, "entre otros" (cons. 6o.). Esta mención resulta por demás importante, porque no circunscribe su análisis al régimen del artículo 75, inciso 2o., sino que habla del derecho intrafederal en toda su extensión y amplitud.

Resulta también importante la distinción que la propia Corte hace de los acuerdos interjurisdiccionales antes y después de la reforma de 1994: así, "los pactos fiscales suscriptos antes de la reforma constitucional del año 1994, han sido el mecanismo empleado para superar — en el marco del régimen de la ley-convenio 23.548 - los inconvenientes propios del sistema rígido de separación de fuentes tributarias", mientras que

Luego, han constituido la vía adecuada para estructurar un espacio institucional de concertación federal desde donde se flexibilizó, en un contexto de participación igualitaria, la distribución de la recaudación coparticipable, eliminando de esta manera la situación de incertidumbre jurídica generada por la falta de sanción del nuevo régimen de coparticipación conforme a las pautas fijadas en el artículo 75, inciso 2o. (cons. 7).

Reitera que estos acuerdos son "manifestaciones positivas del llamado federalismo de concertación, inspirado en la búsqueda de un régimen concurrente en el cual las potestades provinciales y nacionales se unen en el objetivo superior de lograr una política uniforme en beneficio de los intereses del Estado Nacional y de las provincias (Fallos: 322:1781)", y que

Dichos pactos fiscales, como las demás creaciones legales del federalismo de concertación, configuran el derecho intrafederal y se incorporan una vez ratificados por las legislaturas al derecho público interno de cada Estado provincial, aunque con la diversa jerarquia que les otorga su condición de ser expresión de la voluntad común de los órganos superiores de nuestra organización constitucional: nación y provincias. Esa gestación institucional los ubica con un rango normativo específico dentro del derecho federal. Prueba de su categoria singular es que no es posible su derogación unilateral por cualquiera de las partes (Fallos: 322: 1781 y sus citas) (cons. 7).

Además, fija las características esenciales de estos acuerdos: que la jerarquía superior que estos acuerdos tienen "es inherente a su propia naturaleza contractual"; que por esencia misma del derecho intrafederal, estos acuerdos "no se encuentran en una esfera de disponibilidad individual de las partes", y que "solo pueden ser modificados por otro acuerdo poste- 
rior de la misma naturaleza, debidamente ratificado por leyes emanadas de las jurisdicciones intervinientes", como así tampoco resulta admisible que "sea reglamentada por la Nación, que no es sino uno de esos Estados".

Dos cuestiones interesan resaltar de este trascendental fallo. En primer lugar, reconoce que estos mecanismos constituyen "la máxima expresión del federalismo de concertación, condición de la que se desprende su virtualidad para modificar... las relaciones interjurisdiccionales y reciprocas entre la Nación y las provincias", pero agrega que estas modificaciones se harán "siempre en el marco de la Ley Fundamental", entendiéndose el respeto de los nuevos estándares que se mencionaban con anterioridad; y que la imposibilidad de reglamentación o de modificación unilateral es una regla que "ha recibido expreso reconocimiento constitucional en el citado artículo 75, inciso cuarto párrafo" (cons. 8, in fine), y como aquí la Corte no se refiere a la futura ley de coparticipación que el Constituyente de 1994 ordenó sancionar, sino a todos los acuerdos y pactos interjurisdiccionales que componen el actual derecho intrafederal (los que cita, $v . g r$, en el cons. 6), esta postura de la Corte viene a corroborar nuestra hipótesis de trabajo, es decir, que el constituyente ha fijado estánderes de relacionmiento y pautas de coordinación independientemente de la virtual ley de coparticipación que manda el artículo 75, sino que son de aplicación directa a las relaciones nación-provincia.

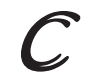

Fecha de recepción: 13 de septiembre de 2019.

Fecha de aceptación: 15 de enero de 2020. 


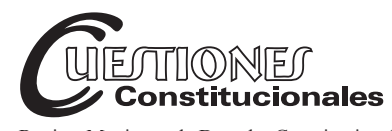

Revista Mexicana de Derecho Constitucional Núm. 43, julio-diciembre 2020

A era dos deveres: a necessidade de um estatuto da pessoa humana para a eficácia social dos direitos fundamentais*

\title{
The Era of Duties: the Need for a Complete Statute of the Human Person for the Social Effectiveness of Rights
}

\author{
José Francisco DiAS DA COSTA LYRA** \\ Marco Antônio PREIS*** \\ Julio HOMEM DE SIQUEIRA**** \\ Daury Cesar FABRIZ*****
}

\footnotetext{
* O presente trabalho é resultado de pesquisas desenvolvidas pelos autores nos grupos de pesquisas dos PPGD dos quais participam na URI - Santo Ângelo e na FDV e fazem parte de um projeto de rede de cooperação em pesquisa sobre os deveres fundamentais e a concretização dos direitos. Trata-se de um trabalho escrito, efetivamente, a oito mãos, de modo que a ordem dos autores é decorrente da necessidade, meramente formal, de listá-los. Assim, os dois primeiros autores escreveram a seção "O estatuto fundamental da pessoa humana", a qual foi revisada pelos dois últimos autores; enquanto que a seção "O papel dos deveres fundamentais na concretização da dignidade da pessoa humana" foi escrita pelos dois últimos autores, tendo sido revisada pelos dois primeiros autores. Críticas, sugestões e contribuições podem ser enviadas para o e-mail: deveresfundamentais@ gmail.com.

** Doutor em Direito pela UNISINOS. Mestre em Desenvolvimento, Cidadania e Gestão pela UNIJUÍ. Professor Titular do PPGD (Mestrado e Doutorado) e da Graduação e líder do Grupo de Pesquisa "Tutela dos Direitos e sua Efetividade" da URI - Santo Ângelo. Juiz de Direito no TJ/RS. Brasil. ORCID:0000-0003-1952-3365. Correo electrónico: jfdclyra@tjrs. jus.br.

*** Mestre em Direito e Pesquisador no Grupo de Pesquisa "Tutela dos Direitos e sua Efetividade" no PPGD da URI - Santo Ângelo. Especialista em Direito Público pela ESMESC-FURB. Juiz de Direito no TJ/RS. Brasil. ORCID: 0000-0002-2986-5388. Correo electrónico:mapreis@tjrs.jus.br.

**** Mestre em Direito pela FDV. Pesquisador no Grupo de Pesquisa "Estado, Democracia Constitucional e Direitos Fundamentais" do PPGD da FDV. Membro do Centro Local de Inteligência da JF/RJ. Servidor Público Federal na JF/RJ. ORCID: https://orcid. org/0000-0002-5592-0416 Correo electrónico:pesquisa.jpfhs@gmail.com.
} 
RESUMO: A eficácia dos direitos fundamentais passa, atualmente, por uma crise: os esforços pelo reconhecimento desses direitos não têm sido acompanhados pela sua real e efetiva concretização. O resultado é um grande número de direitos reconhecidos para os membros de uma sociedade que até obtém êxito ao reivindicá-los, mas não em deles usufruir de maneira adequada. A proposta deste trabalho é, a partir do uso do método dialógico, demonstrar como o cumprimento de deveres fundamentais pode contribuir para a cada vez maior concretização dos direitos. Para demonstrar essa tese, desenvolve-se, em primeiro lugar, a defesa sobre a necessidade de um estatuto da pessoa humana, baseado não apenas em seus direitos, mas também e principalmente, em seus deveres; em segundo lugar, agrega-se à ideia de um estatuto uma proposta de como operacionalizar a relação entre o cumprimento de deveres e a concretização de direitos de maneira cíclica. A conclusão alcançada com essa proposta é a de que o resgate da categoria dos deveres pode contribuir para o fortalecimento dos direitos para todos, superada a visão estritamente individual.

Palavras-chave: direito internacional, direito constitucional, direitos fundamentais, deveres fundamentais, eficácia, concretização.
ABSTRACT: The effectiveness of fundamental rights is currently undergoing on a crisis: the efforts to recognize such rights have not been accompanied by their real and effective implementation. The result is that, despite the lots of rights recognized for the members of a society that even succeeds in claiming them, but not in enjoying them adequately. The proposal of this work is, based on the use of the dialogical method, to demonstrate how the fulfilment of fundamental duties can contribute to an ever greater concretization of rights. In order to demonstrate this thesis, the defense of the need for a statute of the human person, based not only on his/her rights but also and especially on his/her duties, is developed firstly; secondly, the proposal for a statute proposes how to operationalize the relationship between the fulfilment of duties and the realization of rights in a cyclical way. The conclusion reached with such proposal is that the redemption of the category of duties can contribute to the strengthening of rights for all, surpassing the strictly individual view.

Keywords: international law, constitutional right, fundamental rights, fundamental duties, efficiency, implementation. SUMÁRIO: I. Introdução. II. O estatuto fundamental da pessoa
humana. III. O papel dos deveres fundamentais na concretiza-
ção da dignidade da pessoa humana. IV. Conclusão. V. Refe-
rências bibliográficas.

***** Doutor e Mestre em Direito pela UFMG. Professor doutor, nível I, do PPGD (mestrado e doutorado) e da Graduação e líder do Grupo de Pesquisa "Estado, Democracia Constitucional e Direitos Fundamentais" da FDV. Professor associado III da Graduação em Direito da UFES. Advogado e sociólogo. ORCID:0000-0002-3781-5890 E-mail: daury@terra.com.br.

Esta obra está bajo una Licencia Creative Commons

Atribución-NoComercial-SinDerivar 4.0 Internacional, IIJ-UNAM. 


\section{INTRODUÇÃO}

O constitucionalismo contemporâneo, especialmente pós-guerras, é profícuo em reconhecer e em declarar direitos; mas uma questão tem sido, entretanto, deixada de lado: em que sentido o reconhecimento dos direitos humanos contribuiu para melhorar a sociedade?

A pergunta é parcialmente respondida com a importância que as declarações internacionais e nacionais de direitos tiveram para o mundo com a derrota dos regimes totalitários da primeira metade do século XX. A partir do pós-guerra, houve uma conscientização sobre o risco que ditaduras totalitárias representavam para a dignidade do ser humano, tanto que é aí que surge com vigorosa força o princípio da dignidade da pessoa humana, o qual passa a figurar como a pedra fundamental dos Estados constitucionais.

Nos últimos 75 anos, lapso quase exato entre o final da guerra mundial (1945) e a publicação deste trabalho (2020), não mais houve um genocídio na proporção do holocausto, mas outras violências contra a humanidade, baseadas em motivos tão fúteis quanto, foram e permanecem sendo praticadas, como o caso, por exemplo, do genocídio de pessoas da etnia tutsi em 1994. Nas últimas décadas, não apenas na África, como também na Ásia, no Leste Europeu e na América do Sul, por exemplo, tem-se vivido uma escalada de violência e um respeito cada vez menor aos direitos das pessoas envolvidas.

Em 1990, o jurista italiano Norberto Bobbio ${ }^{1}$ publicou uma série de ensaios seus sob o título L'età dei diritti e registrou sua crítica ao excesso de direitos até então reconhecidos formalmente pelos Estados e pelos organismos internacionais, a ponto de destacar que, muito mais que formalizar a sua existência, é imprescindível a sua realização, a sua concretização. Para Bobbio, a expansão dos direitos e liberdades individuais é cercada de uma força retórica cuja tentativa de concretização se perfaz no uso dos direitos e liberdades como se fossem trunfos. Esse comportamento é, basicamente, o resultado de uma sociedade baseada no liberalismo individualista, mas que se utiliza levianamente da fachada social-democrática, e no positivismo de fundo formalista, cuja adoção nega até a queda do último

1 Bobbio, Norberto, L'età dei diritti, Torino, Giulio Einaudi Editore, 1990. Existe tradução para o português: Bobbio, Norberto, A era dos direitos, trad. Carlos Nelson Coutinho, Rio de Janeiro, Campus, 1992. 
argumento falacioso que emprega para evitar a imputação. Obviamente, a generalização não é possível, mas, na prática, a teoria é outra: a sociedade só entende que possui direitos caso eles estejam devidamente positivados, ou reconhecidos por decisões de órgãos do Estado ou da comunidade internacional. Assim, para Bobbio, a resposta à pergunta acima formulada é que "o reconhecimento dos direitos humanos contribuiu para que a sociedade se conscientizasse de que possui direitos". Mas, então, o jurista italiano coloca outra pergunta: "de que adianta ter direitos formais, mas não os ter concretizados?".

Em 1998, o escritor português José Saramago, ${ }^{2}$ na cerimônia de recebimento do Nobel de Literatura, trouxe a lume a mesma crítica quanto ao reconhecimento dos direitos. O literato registrou que os direitos somente podem subsistir quando as pessoas observarem também seus deveres, mas não se pode esperar que os Governos providenciem isso, é necessário que a sociedade, ela própria, com a mesma veemência que reivindica seus direitos, também cumpra seus deveres.

Embora Bobbio não tenha tido tempo de escrever ensaios ou um opúsculo à moda de L'età dei doveri, a sua crítica equipara-se à de Saramago, no sentido de que é imperioso substituir o "eu" pelo "nós", adotando-se uma postura mais cooperativa, solidária e fraterna. É chegada a hora, como propôs o escritor português, de uma declaração de deveres, a qual, no entanto, seja posta em prática.

A proposta deste trabalho é pensar a era dos deveres, uma vez que, ao adotar tal perspectiva, é possível tentar superar dois graves entraves à realização dos direitos: o egoísmo contingente e o policentrismo anárquico. O primeiro consiste na falta de senso de dever com o próximo, a não ser que daí se possa tirar algum benefício em favor de si próprio. O segundo se perfaz no excesso de centros de tomada de decisão, os quais não têm poder suficiente de mando, mas, para impedir o êxito das decisões alheias. O resultado disso é a grande ineficácia social dos direitos das pessoas. É dizer, a baixa eficácia e a falta de concretização da plêiade de direitos que a sociedade global tem reconhecido ao longo de sua existência é resultado de suas próprias escolhas: seja na escolha de representantes que

2 Saramago, José, Discurso de Estocolmo 10 de dezembro de 1998: uma proposta para a Declaração Universal dos Deveres Humanos, Lisboa, Fundação José Saramago, 1998. Disponível em: <https://pt.scribd.com/doc/269455895/Jose-Saramago-DiscursoPremio-Nobel>. Acesso em: 11 fev. 2018. 
não cumprem, quando no comando do maquinário estatal, os deveres e as obrigações que foram assumidas pelo Estado perante a comunidade internacional; seja para, por esforço próprio, se preocupar com o outro, tanto nas gerações presentes, quanto nas futuras. A era dos deveres é, ao mesmo tempo, o contraponto e o complemento da era dos direitos. É ela que estabelece os laços de que falava Saramago.

Todavia, até onde tem sido possível observar, falar sobre um tema como os deveres fundamentais é quase que um atrevimento, porque é um incômodo, uma pedra entre o pé e o chão de quem se acostumou a reivindicar direitos. Apesar disso, nenhuma civilização foi possível até hoje sem o reclamo dos deveres. Falar sobre deveres é, pois, procurar tratar uma ferida profunda com os instrumentos adequados, retirando a sociedade da sua letargia anestésica de acreditar que basta ter seus direitos realizados que a sociedade, em um passe de mágica, se tornará melhor. Portanto, na atualidade, já se sabe que "o reconhecimento dos direitos humanos muito pouco contribuiu para melhorar a sociedade", de maneira que outro é o questionamento que se impõe para agora e para o futuro dos direitos humanos: como os deveres podem contribuir para a cada vez maior concretização dos direitos?

Para fornecer uma resposta adequada, o trabalho é dividido em outras três seções. Na próxima seção, desenvolve-se a ideia de um estatuto da pessoa, baseado não apenas em seus direitos, mas também, e principalmente, em seus deveres fundamentais. Na seção subsequente, agrega-se à ideia de um estatuto de direitos e deveres, um modus operandi, ainda que inicialmente teórico, de como tornar cíclico o cumprimento dos deveres e a concretização dos direitos daí advinda. Por fim, na última seção, conclui-se o trabalho.

\section{O ESTATUTO FUNDAMENTAL DA PESSOA HUMANA}

As declarações de direitos e de deveres partem de um mesmo pressuposto: a dignidade da pessoa humana, a qual é o centro gravitacional de seu estatuto jusfundamental. A diferença é que enquanto houve uma proliferação ilimitada de direitos, os deveres permanecem à margem, como se os direitos dependessem única e exclusivamente de si próprios para sua concretização. É interessante que tudo o que é reconhecido em favor da dignidade humana se transforma em direito: o caso emblemático é o da cha- 
mada terceira geração ou dimensão de direitos, usualmente referida como direitos de solidariedade.

$\mathrm{O}$ que seriam tais direitos? O grupo dos direitos de solidariedade é o mais heterogêneo entre as três clássicas gerações ou dimensões e, por isso, é o único que não conta com um consenso quanto ao seu conteúdo. Em verdade, o que se chama de solidariedade não é um direito, mas um dever. Assim, pode-se dizer que os direitos que integram esse grupo (incluindo-se a quarta e a quinta dimensões), devem ser realocados como dimensões coletivas dos direitos de primeira e de segunda geração, de modo que, quando se fala em solidariedade e em fraternidade, a tônica deve ser a alteridade e, por isso, o mais adequado seria falar em deveres de solidariedade.

\section{Do exclusivismo dos direitos ao equilíbrio entre direitos e deveres}

Ao se tratar da concretização de direitos costuma-se cair sempre no mesmo reducionismo: reivindicar do Estado a realização de políticas públicas e o melhor uso dos recursos públicos, deixando de considerar que a concretização dos direitos depende de que os deveres sejam cumpridos em sociedade - a exemplo da aplicação de pesadas multas a empresas que não observam seu dever de proteger e preservar o meio ambiente serem, ao lado da ajuda altruística prestada a vítimas de doenças, fome e desastres naturais, uma exceção, a regra é de que os deveres têm recebido pouca atenção na sua exigibilidade de cada ser humano em sociedade.

Como aponta Pérez Luño, ${ }^{3}$ não se pode esquecer que, apesar das dificuldades e desafios, a ordem jurídica, tanto interna quanto internacional, não seria o que é sem o reconhecimento dos direitos fundamentais. A dignidade da pessoa humana teve, indubitavelmente, ganhos incalculáveis com os mais variados documentos que reconheceram direitos em prol de sua concretização. Todavia, paralelamente a esse processo, o qual jamais foi linear e para o qual não faltaram retrocessos nem contradições, se produziu uma progressiva recepção, em textos e documentos normativos, de um conjunto de deveres, o que não se mostrou suficiente para tratar da patologia

3 Pérez Luño, António-Enrique, Los derechos fundamentales, 11. ed., Madrid, Tecnos, 2013. 
social que se vive, com a conjugação incompatível de uma ideologia individualista sob viés demandista e reivindicatório de prestações do Estado.

Da mesma matriz hispânica, Peces-Barba Martínez ${ }^{4}$ destaca que, tal como tantos outros conceitos jurídicos, o conceito de dever surge, na História, nos âmbitos ético e religioso, mas é apenas na Modernidade que a ideia de dever passa a ter uma influência decisiva no Direito, de início com o humanismo jurídico, depois com o jusnaturalismo racionalista, quando, então, vai se firmando como um dever jurídico ao qual corresponde uma sanção. Nesse sentido, começam a surgir os diversos tipos de deveres, desde aqueles mais ligados com o âmbito ético e religioso até aqueles de cunho propriamente jurídico. Entretanto, como conta a História, aos deveres não se dedicaram tantas páginas da Ciência do Direito como em relação aos direitos.

A constante busca pelos direitos subjetivos, individuais, faculdades, potestades, enfim, o "meu" direito, ocupa o centro do cenário jurídico, como destaca Bandieri. ${ }^{5}$ Ao revés, das várias figuras jurídicas subjetivas a que mais permaneceu nas sombras, sem dúvida, é a figura dos deveres. Eles, ao contrário dos direitos, são mal vistos, associados a algo penoso e inconveniente, uma posição jurídica de desvantagem. Atitudes críticas frente ao forte individualismo utilitário que muito caracteriza a sociedade desde a Idade Moderna, autorizam a pensar o tema dos deveres de uma maneira mais contundente, como condição para a reparação de indignidades e para a concretização de direitos, de modo que se possa andar mais firmemente pelo caminho estreito dos deveres do que pela avenida larga dos direitos.

O Estado constitucional e a sociedade internacional contemporâneos, em pleno século XXI, ainda se regem pelo reconhecimento de um estatuto jusfundamental da pessoa humana desequilibrado, no qual há um plexo hipertrofiado de direitos, um tipo de massa em expansão, de onde se extraem princípios que permitem a constante e acumulativa irradiação de outros direitos, sem que se vislumbre qualquer limite.

4 Peces-Barba Martínez, Gregorio, "Los derechos humanos y los deberes fundamentales", en Soriano Díaz, Ramón e Alarcón Cabrera, Carlos e Mora Molina, Juan (coords.), Diccionario crítico de los derechos humanos I, Huelva, Universidad Internacional de Andalucía, 2000.

5 Bandieri, Luís María, "Derechos fundamentales ¿y deberes fundamentales?”, en Leite, George Salomão e Sarlet, Ingo Wolfgang e Carbonell, Miguel (org.), Direitos, deveres e garantias fundamentais, Salvador, JusPodivm, 2011. 
Assim, o direito subjetivo fundamental universalizado destrona e expulsa de sua centralidade no reino jurídico o direito objetivo, convertido agora em sua sombra. Trata-se de um processo desenvolvido essencialmente a partir da Idade Moderna, mas que assume caraterísticas ainda mais acentuadas na atualidade, resultando em uma tensão entre o subjetivismo dos direitos, caracterizado pela expressão mais repetida entre as pessoas "tenho direitos", e o objetivismo dos deveres, caracterizado pela expressão mais evitada: "tenho deveres".

A constatação é a de que a quase totalidade dos diplomas internacionais e constitucionais democráticos da atualidade consagraram, de alguma forma, direitos e os deveres fundamentais, mas uma questão se coloca: por que o tema dos deveres é importante o suficiente para ser positivado, mas não lhe é devotada a mesma relevância teórica em comparação com os direitos?

A preferência é patente nos textos de documentos internacionais, ainda que haja reconhecimento de alguns deveres, comumente genéricos e abstratos. A pouca atenção aos deveres não é suficiente para a sua fundamentação nem para a sua realização. $O$ fato de a Declaração Universal dos Direitos do Homem (DUDH) prever o dever de todos os seres humanos, dotados de razão e consciência, para com a comunidade, repetido com mais ênfase na Declaração Americana dos Direitos e Deveres do Homem (DADDH) - “o cumprimento do dever de cada um é exigência do direito de todos", de maneira que "se os direitos exaltam a liberdade individual, os deveres exprimem a dignidade dessa liberdade" - e na Convenção Europeia dos Direitos do Homem (CEDH) e no Tratado de Lisboa, que trazem uma cláusula geral no sentido de que exercício das liberdades implica responsabilidades e deveres, tanto com outros individuos, quanto com a comunidade humana e as gerações futuras.

Entre esses quatro documentos, apenas a DADDH possui um capítulo exclusivo dedicado ao reconhecimento de deveres, seguida pelos Pactos Internacionais de 1966 sobre Direitos Civis e Políticos e sobre Direitos Econômicos, Sociais e Culturais contemplaram, o primeiro, deveres específicos, como o registro obrigatório e imediato e a atribuição de um nome para as crianças recém-nascidas, e, o segundo, os deveres de todos os seres humanos com os seus semelhantes e com a coletividade a que pertencem. Isso, contudo, não permite concluir, por si, que a existência de um estatuto jusfundamental da pessoa seja um propósito internacional. 
Ao contrário, a leitura dos documentos internacionais permite observar a facilidade com que se enunciam direitos e o desconforto que causam os enunciados de deveres dirigidos às pessoas, o que evidencia o grau de irracionalidade e descompromisso com a concretização dos próprios direitos. Cabe dizer, sempre foi muito mais fácil enunciar direitos, sem se preocupar com sua aplicabilidade prática, sobretudo por quem não está em situação de vulnerabilidade e não depende de tais conteúdos para sobreviver, do que assumir deveres, dirigidos indistintamente a todos, mas especialmente àqueles que teriam maiores condições de cumpri-los.

Também da matriz do direito anglo-saxão, Chapman ${ }^{6}$ destaca que o equilíbrio entre a liberdade e a responsabilidade encoraja as pessoas a limitar suas pretensões de direitos quando isso possa ofender os direitos de outros, incluindo das futuras gerações, sendo que os deveres estendem e desenvolvem os padrões de eficácia dos direitos. No entanto, a histórica ênfase ocidental nos direitos tem sido utilizada como uma ferramenta para justificar interferências seletivas em outros países, ao passo que, em um mundo que vive uma crescente interdependência, é imprescindível a promoção de uma cultura da responsabilidade, baseada na conexão que existe entre direitos e deveres, ambos dirigidos à consagração da dignidade humana.

Contra possíveis abusos e excessos, também Saul ${ }^{7}$ aponta que a jurisprudência vem fixando alguns limites dos direitos e deveres ao longo das últimas décadas, pois o exercício das liberdades deve vir acompanhado de deveres, responsabilidades e, assim, deve se sujeitar a determinadas formalidades, condições, restrições e, eventualmente, sanções prescritas em lei, necessárias para a sociedade democrática como salvaguarda dos direitos de todos.

Nesse contexto, Carbone ${ }^{8}$ e Casalta Nabais ${ }^{9}$ apresentam o tema dos deveres como um dos mais esquecidos da literatura constitucional contem-

6 Chapman, Audrey R., "Reintegrating Rights and Responsibilities. Toward a New Human Rights Paradigm", en Hunter, Kenneth e Mack, Timothy (ed.), International Rights and Responsibilities for the Future, Connecticut, Praeger, 1996.

7 Saul, Ben, "In the Shadow of Human Rights: Human Duties, Obligations and Responsibilities", Columbia Human Rights Law Review, n. 32, 2001.

8 Carbone, Carmelo, I doveri pubblici individuali nella Constituzione, Milano, Giuffrè, 1968.

9 Casalta Nabais, José, O dever fundamental de pagar impostos: contributo para a compreensão constitucional do estado fiscal contemporâneo, Coimbra, Almedina, 2015. 
porânea, assim como o das demais situações jurídicas passivas, ou seja, sujeições, deveres, obrigações dos particulares no direito público. Ambos os autores convergem em apontar como a principal causa desse escasso desenvolvimento teórico a tensão no constitucionalismo atual entre o poder, que tem a dominação na essência, e o direito, cujo papel precípuo é justamente o de limitar o poder, de modo a assegurar aos cidadãos maior âmbito de liberdade e autonomia. Não se trata, contudo, de um consenso, uma vez que Siqueira, ${ }^{10}$ com base em extensa literatura recolhida sobre os deveres, superando o entendimento antes adotado, ${ }^{11}$ vê, atualmente, o tema com mais otimismo, assumindo que, embora a tese sobre o seu esquecimento seja falsa, não é aquela que diz ser um tema pouco desenvolvido, no sentido de que lhe falta uma sistematização.

O certo, e isso é consenso entre os autores pesquisados, é que o principal fator histórico desse pouco desenvolvimento é o fato de que a maior parte dos textos internacionais e também constitucionais é produto de movimentos sociais e políticos de superação de regimes autoritários, que atribuíam uma predominância absoluta ao status passivo (ou status subjectionis) do cidadão frente ao Estado, tendo nas declarações de direitos uma forma de exorcizar a herança de tais regimes e de evitar aberturas interpretativas para novas formas de regimes totalitários.

O protagonismo dos direitos foi, então, a resposta adequada, relegando os deveres a uma posição secundária, já que foram contemplados alguns deveres mínimos, essenciais para a vida em sociedade, para a fundação e manutenção de comunidades políticas organizadas, tais como os deveres de contribuir financeiramente para a manutenção da coisa pública, de votar em um regime democrático, de colaborar com a Justiça, de preservar o meio ambiente e o patrimônio histórico-artístico para as futuras gerações da humanidade.

A compreensível suspeita e medo que se tem dessa gramática dos deveres, como prestes a suprimir direitos, se deve fundamentalmente à experiência histórica recente, especialmente em razão do trauma coletivo e da associação quase inconsciente dos deveres dirigidos ao Estado de

10 Siqueira, Julio Homem de, "Elementos para uma teoria dos deveres fundamentais: uma perspectiva jurídica", Revista de Direito Constitucional e Internacional, vol. 95, 2016.

11 Siqueira, Julio Homem de, "Deveres como condição para a concretização de direitos", Revista de Direito Constitucional e Internacional, vol. 79, 2012. 
ideologia totalitária e autoritária. Todavia, é importante destacar que nenhum conceito jurídico está imune a manipulações político-ideológicas. O caso dos direitos é tão emblemático quanto o dos deveres - Saul ${ }^{12}$ ilustra isso com os marcos históricos da Revolução Inglesa de 1688, quando se transferiu a soberania ao Parlamento, mas não ao povo, de modo que desigualdades sociais, de propriedade e de gênero permaneceram. No mesmo sentido, as Revoluções Americana de 1776 e Francesa de 1789 foram forjadas para que certos privilégios fossem mantidos com os colonos, no primeiro caso, ou estendidos aos burgueses, no segundo, mas sempre sem nada ser dado ao povo.

A propósito, Carbone ${ }^{13}$ aponta que não faltam previsões de que o exercício dos direitos fundamentais implica observância de deveres para salvaguarda das exigências da vida coletiva, mas apenas como enunciados fugazes e desprovidos de garantias idôneas. No mesmo sentido, Alegre ${ }^{14}$ aponta que a referência aos deveres até existe, mas normalmente é tão somente de passagem, ou, ainda, como anota Busch, ${ }^{15}$ essa referência aparece mais como um recurso de retórica ou um adorno.

Tais apontamentos são mais claramente vistos a partir da análise histórica, especialmente da tríade liberté, égalité et fraternité insculpida na Declaração francesa de 1789. Do tríplice slogan, apenas a liberdade e a igualdade foram e continuam sendo objeto de minuciosa regulamentação jurídica, ao passo que as previsões em torno da fraternidade sempre constituíram afirmações genéricas, a promessa esquecida do ideário revolucionário.

Não é possível estabelecer em abstrato se os direitos constituem um prius em relação aos deveres ou se estes têm precedência sobre os primeiros. Aliás, tal fato não deve ser objeto de preocupação de nenhuma pesquisa séria que se possa fazer sobre o tema dos deveres. O que se deve ter sempre em mente é que a relação entre direitos e deveres há de observar um equilíbrio de tratamento - o que não significa simetria nem aderir ao senso comum de que "a todo o direito corresponde um dever", pois há uma relativa autonomia teórica e independência científica entre ambas as categorias.

\footnotetext{
12 Saul, Ben, "In the Shadow...", cit.

13 Carbone, Carmelo, I doveri..., cit.

14 Alegre Martínez, Miguel Ángel, "Los deberes en la Constitución española: esencialidad y problemática", Teoría y Realidad Constitucional, n. 23, 2009.

15 Busch Ventur, Tania, "Deberes constitucionales", Revista de la Facultad de Ciencias Jurídicas de la Universidad Catolica de Salta, n. 1, 2011.
} 
Todavia, não é isso que se tem observado nos documentos, nacionais e internacionais, que reconhecem e declaram os direitos. Boa parte das declarações de direitos que adota o louvável objetivo de concretizar os direitos sem entraves de fundamentação teórica, deixa como consequência uma concretização exponencial de direitos de toda a índole, catapultando a ideia de direitos a lugares de fundamentação vaga e de qualquer pretensão individual, como o aventado "direito ao orgasmo"16 ou mesmo o inexistente "direito ao afeto". ${ }^{17}$

O caso dos deveres fundamentais é diferente. Não há demasiadas declarações nem profusão de registros constitucionais, tampouco a literatura jurídica e os operadores do direito lançam mão de suas habilidades inventivas para criar deveres antes nunca vistos. A sua ausência sequer é sentida nos cenários internacional e constitucional. E isso se deve à ideia geral de serem a formulação inversa dos direitos, como o negativo da fotografia ou como o lado oculto dos direitos, bem como à desvinculação com as reivindicações históricas de direitos por parte de movimentos sociais, e, ainda, pela técnica legislativa, que parece entender pela suficiência da obrigação genérica de obedecer às leis e às autoridades.

A perspectiva do indivíduo como portador de direitos subjetivos, exigíveis em face de todos contra todos, que acompanhou o processo de construção dos direitos é o que se busca superar por meio da emergência de uma ideia de ser humano integral como pessoa, fundada na dignidade da pessoa humana. A pessoa como ser equilibrado, dotado de uma plêiade de direitos e deveres com a coletividade onde vive, tendo como pressuposto a liberdade individual com responsabilidade social e, entre todos, a igualdade na distribuição dos encargos. É nessa interseção entre os papéis de súdito e de sujeito de direitos que se constrói a noção de pessoa. Há sempre uma parcela de submissão legítima e devida por todos os que vivem em uma sociedade organizada e é sobre essa parcela de submissão legítima que se voltam as atenções deste estudo.

Toda a interpretação acerca dos deveres deve seguir essa articulação entre deveres, direitos e dignidade humana, ou seja, deve-se aplicar a norma

16 Maino, Carlos Alberto Gabriel, "Derechos fundamentales y la necesidad de recuperar los deberes: aproximación a la luz del pensamiento de Francisco Puy", en Leite, George Salomão e Sarlet, Ingo Wolfgang e Carbonell, Miguel (org.), Direitos, deveres e garantias fundamentais, Salvador, JusPodivm, 2011.

17 Preis, Marco Antônio e Preis, Marcéli da Silva Serafim e Siqueira, Julio Homem de, "Deveres fundamentais e direito ao afeto", Derecho y Cambio Social, n. 54, 2018. 
jusfundamental de modo a dar-se máxima concreção ao dever fundamental, sem afetação ao núcleo essencial de direitos, observada a finalidade de melhor atender às exigências da dignidade humana. Nesses termos, se esboçam as principais linhas de contributos que se projetam com a proposta de inserção dos deveres fundamentais no léxico do constitucionalismo contemporâneo, como o elemento jurídico-constitucional que faltava para o ajuste institucional e político da posição da pessoa em sociedade.

\section{A importância de uma teoria dos deveres fundamentais}

Importante, a essa altura, estabelecer um acordo semântico mínimo com o leitor sobre o que se consideram deveres fundamentais, a partir das contribuições de todos os autores trabalhados, em síntese, adotando-se conceito o instituto jurídico-constitucional com relativa autonomia em relação aos direitos, que exige juridicamente de todas as pessoas (físicas, jurídicas e coletivos despersonalizados) determinados comportamentos (fazer, não fazer, dar), umas perante as outras e todas perante a comunidade politicamente organizada a que fazem parte (Estado, inclusive), indistintamente, independentemente de capacidade (civil, penal, administrativa) e passíveis de sanção jurídica em virtude do seu descumprimento injustificado, voltadas a proporcionar as bases materiais para existência e funcionamento da sociedade e para a concretização dos direitos fundamentais de todos, decorrentes de uma ordem jurídica democrática, com posição de primazia normativa e controle de revisão (fundamentalidade formal), cujos conteúdos integram o estatuto da pessoa, formado por direitos e deveres fundamentais e orientado pela dignidade da pessoa humana (fundamentalidade material).

A fim de especificar alguns dos deveres fundamentais em espécie considerados quando do desenvolvimento deste trabalho, cita-se, a título ilustrativo, que a Constituição da República Federativa do Brasil (1988) inaugura a seção jusfundamental com o capítulo sobre os direitos e deveres individuais e coletivos e, em seu corpo, institui o alistamento e voto obrigatórios (artigo 14), o serviço militar compulsório (artigo 143), a segurança pública como responsabilidade de todos (artigo 144), o dever geral de pagar impostos (artigo 145), a educação como dever familiar (artigo 205), educação básica compulsória (artigo 208, I), o meio ambiente ecologicamente equilibrado como dever de defesa e preservação por parte 
de todos (artigo 225), dever geral de proteção das crianças, adolescentes e jovens (artigo 227), deveres recíprocos de amparo entre pais e filhos (artigo 229), dever geral de amparo às pessoas idosas (artigo 230) entre outros.

$\mathrm{Na}$ trilha da lição do jurista alemão Kirste, ${ }^{18}$ ser sujeito de direitos e deveres é possuir a maior dignidade que o Direito proporciona: significa ter a capacidade de fazer uso jurídico da própria liberdade. Assim, a liberdade está na raiz tanto dos direitos como dos deveres, pois quem não tem liberdade, não tem direitos nem deveres, pois é um mero objeto nas mãos do poder, não um sujeito responsável e autodeterminado. Essa é uma lição clássica de Duguit, ${ }^{19}$ que, em 1901, já ensinava que só pessoas livres podem ser sujeitos e direitos e deveres jurídicos, pois os direitos de liberdade correspondem ao ser humano não enquanto tal, mas porque tem o dever de desenvolver sua atividade em conformidade com as regras da solidariedade social.

Peces-Barba Martínez ${ }^{20}$ considera possível encontrar uma teoria dos deveres na própria origem do sistema político moderno, pois a justificação contratualista clássica, em que pesem as diferenças entre os autores, foi construída sobre uma ficção racional, à qual se acrescentam posições mais recentes e plurais, sobre a existência de um modelo de deveres recíprocos, dos cidadãos e governantes, em uma situação comunicativa ideal: ao dever de governar de modo justo e correto para salvaguardar em maior medida os direitos das pessoas, acresce-se o dever de obedecer ao direito, o que é controlado por um sistema de garantias, remédios e sanções, a fim de manter a harmonia e o equilíbrio social.

Variando de deveres negativos de abstenção estatal a deveres positivos de prestação estatal, essa estrutura se manteve estável até o segundo pós-guerra, quando o tema da obediência ao direito adquiriu novos contornos, de viés democrático, com o desenvolvimento de teorias que justificam a desobediência civil e a objeção de consciência frente a um direito injusto.

Apresentados dessa forma, os deveres poderiam ser observados sob o mesmo critério dos direitos, como status negativus quando o Estado exige uma omissão do cidadão (v. g., dever geral de obediência às normas);

18 Kirste, Stephan, "A dignidade humana e o conceito de pessoa de direito", trad. Luis Marcos Sander, en Sarlet, Ingo Wolfgang (org.), Dimensões da dignidade: ensaio de filosofia do direito e direito constitucional, 2a. ed., Porto Alegre, Livraria do Advogado, 2013.

19 Duguit, Léon, L'état, le droit objectif et la loi positive, Paris, Dalloz, 2003.

20 Peces-Barba Martínez, Gregorio, "Los deberes fundamentales”, Doxa, n. 4, 1987. 
como status positivus quando se exige do cidadão prestações de coisa, dinheiro ou serviço (v. g., dever dos pais na educação dos filhos, dever de pagar impostos e dever do alistamento militar); como status activus quando se exige participação política do cidadão (v. g., dever de voto), categorização que remete à clássica formulação de Jellinek ${ }^{21}$ sobre as quatro sucessivas etapas de afirmação dos direitos públicos subjetivos, como estados ou situações jurídicas subjetivas voltadas ao bem-estar que permite participação ativa comunitária.

Assim, os deveres constituem uma exigência estrutural inerente a qualquer estatuto jurídico, nacional ou internacional, da pessoa humana, porque mais do que visarem a condutas particulares, legitimam a intervenção dos poderes públicos em determinadas relações sociais e em determinados âmbitos da autonomia pessoal dos cidadãos, a tal ponto que Biscaretti di Ruffìa ${ }^{22}$ afirma que sem deveres não há direitos e Díaz, ${ }^{23}$ que tratar o tema dos deveres é também afirmar o respeito aos direitos dos demais, à sua eficácia social e aos fundamentos da ordem política e da paz social, de maneira que, como aponta Castanheira Neves, ${ }^{24}$ esquecer dos deveres significa perder de vista a ideia de responsabilidade comunitária, o que faz dos indivíduos seres simultaneamente livres e responsáveis, ou seja, pessoas autônomas.

Segundo Robles, ${ }^{25}$ a consequência de ver os direitos sem enxergar os deveres será a ideia da penetração histórica dessa perspectiva equivocada na mentalidade social dos povos ocidentais. Um fato social evidente é que nas sociedades atuais o sentimento de dever pessoal é algo obscuro, parece extinto, enquanto que o sentimento reivindicatório de direitos e bens (que muitas vezes apenas se supõe possuir) alcança máxima intensidade, o que se traduz em um decréscimo da solidariedade e em uma justificação

21 Jellinek, Georg, Teoría general del Estado, Madrid, Fondo de Cultura Económica de España, 2012.

22 Biscaretti di Ruffìa, Paolo, Diritto costituzionale: istituzioni di diritto pubblico, Napoli, Jovene Editore, 1989.

23 Díaz Revorio, Francisco Javier, "Derechos humanos y deberes fundamentales: sobre el concepto de deber constitucional y los deberes en la Constitución española de 1978", Revista del Instituto de Ciencias Jurídicas de Puebla, n. 28, 2011.

24 Castanheira Neves, A., "Pessoa, direito e responsabilidade", Revista Portuguesa de Ciência Criminal, n. 1, 1996.

25 Robles Morchón, Gregorio, Os direitos fundamentais e a ética na sociedade atual, São Paulo, Editora Manole, 2005. 
do hedonismo sob o manto dos direitos. Em geral, as pessoas se sentem portadores naturais de direitos que todos devem reconhecer, como credores do Estado, consumidores de prestações, mas dificilmente se pensa que, para isso, também há deveres a serem cumpridos.

Essa hipertrofia dos direitos, paralelamente à invisibilidade dos deveres, causa um nocivo efeito nas bases estruturais da sociedade, pois a ideia de solidariedade se esvazia e frustram-se as expectativas de concretização dos direitos. É dizer, os deveres delimitam os direitos porque remetem a um marco antropológico e ético que reforça os direitos. Por isso, compartilhar os deveres recíprocos mobiliza muito mais do que a mera reivindicação de direitos. É necessário, portanto, quebrar o pacto de silêncio sobre os deveres.

A quebra desse pacto não passa pelo esquecimento dos direitos. Aliás, como aponta Estévez, ${ }^{26}$ o reconhecimento dos direitos, sem dúvida, constituiu um avanço para a emancipação humana, a qual, no entanto, não obterá concretização plena unicamente por meio dos direitos, de novos direitos, de sempre mais e mais direitos, pois eles não transformam as bases da sociedade, salvo para gerar desigualdades, já que é muito rara concretização em bases iguais de um mesmo direito para todos os seus possíveis titulares. Assim, a prática de firmar um estatuto fundamental da pessoa humana sobre um excessivo número de direitos tende a reproduzir exatamente as desigualdades que o reconhecimento de direitos objetiva afastar. ${ }^{27}$

Logo, a quebra do pacto transita por uma proposta focada em substituir a estratégia inflacionária de traduzir qualquer expectativa social em direitos e em trabalhar com a gramática dos deveres e responsabilidades, com o cuidado de que não se caia na mesma armadilha do reconhecimento excessivo. E resulta, portanto, no reconhecimento de que deveres e direitos estão no mesmo plano jusfundamental, uma vez que integram o estatuto da pessoa humana.

26 Estévez Araújo, José A., "La privatización de los derechos", en Estévez Araújo, José A. (org.), El libro de los deberes: las debilidades e insuficiencias de la estrategia de los derechos, Madrid, Trotta, 2013.

27 Sánchez Rubio, David, Encantos e desencantos dos direitos humanos: de emancipações, libertações e dominações, trad. Ivone Lixa e Helena Henkin, Porto Alegre, Livraria do Advogado, 2014; Mercado Pacheco, Pedro, "Derechos insostenibles", en Estévez Araújo, José A. (org.), El libro de los deberes: las debilidades e insuficiencias de la estrategia de los derechos, Madrid, Trotta, 2013. 
A presente proposta se alinha, então, à de Häberle, ${ }^{28}$ que prevê para o futuro a necessidade do desenvolvimento mais reforçado dos deveres e obrigações decorrentes da dignidade humana, com fundamento especialmente na dimensão comunitária, atualizada como limite ao crescimento do Estado social. É chegada, pois, a era dos deveres, a qual é um complemento à era dos direitos, na busca por equilibrar a balança democrática entre direitos e deveres.

Alinhados a essa perspectiva, Rodotà ${ }^{29}$ e Violante ${ }^{30}$ propõem que haja uma valorização dos deveres para a superação da fragmentação individualística da sociedade e em defesa da democracia política, diminuindo os riscos de um governo totalitário. Os direitos só se tornam instrumentos de democracia e de satisfação de legítimas pretensões individuais quando podem contar com a unidade política e com deveres de solidariedade como valores que fundam e desenvolvem o processo civilizatório. Do contrário, o que se terá será a prática de um comportamento contraditório: de um lado, os cidadãos exigem bons costumes dos políticos, mas se esquecem de seus próprios deveres; por outro lado, os políticos não exigem dos cidadãos o cumprimento dos deveres, por se tratar de algo impopular, prejudicando o bom funcionamento do Estado.

A crítica formulada por Violante ${ }^{31}$ é contundente, pois direcionada a uma política das liberdades individuais que conduz a uma disputa descomprometida com sua ambiência coletiva de solidariedade, própria dos Estados contemporâneos, reproduzindo uma perspectiva liberal onde as pessoas perdem a ideia de pertencimento a uma comunidade, agem no interesse exclusivo valendo-se dos direitos subjetivos como armas apontadas uns contra os outros. É necessário retomar o equilíbrio entre direitos e deveres, o que não significa um antagonismo à política dos direitos, mas uma visão mais fiel à solidariedade, à fraternidade, à empatia e à alteridade, que permita a criação de condições para que todos possam realizar o pleno desenvolvimento da própria personalidade no âmbito da comunidade em que vivem.

\footnotetext{
28 Häberle, Peter, "A dignidade humana como fundamento da comunidade estatal", en Sarlet, Ingo Wolfgang (org.), Dimensões da dignidade: ensaios de filosofia do direito e direito constitucional, 2a. ed., Porto Alegre, Livraria do Advogado, 2013.

29 Rodotà, Stefano, Il diritto di avere diritti, Roma-Bari, Laterza, 2012.

30 Violante, Luciano, Il doveri di avere doveri, Torino, Giulio Einaudi Editore, 2014.

31 Idem.
} 
Nesse sentido, cabe a advertência de que os direitos devem funcionar como contrapesos desse resgate e vice-versa. Cabe dizer, é importante amadurecer a consciência de que direitos e deveres não podem ser tomados e interpretados separadamente, mas somente na realização conjunta na experiência concreta é que adquirem o genuíno e qualificado significado para a vida da comunidade, ou seja, pelo menos na mesma proporção que os direitos são exigidos os deveres devem ser cumpridos.

Isso não significa, ao contrário do que afirmado por Alegre, ${ }^{32}$ que todos os direitos geram deveres e, assim, falar de direitos é falar de deveres. $\mathrm{O}$ mais adequado seria dizer, no sentido dado por Siqueira, ${ }^{33}$ que todos os direitos decorrem de deveres, embora nem todos os deveres gerem direitos. Tal entendimento faz mais sentido porque a reivindicação de qualquer direito depende do cumprimento de ao menos um dever, tanto para os poderes públicos (deveres de proteção) como para as pessoas (deveres fundamentais) - e, nesse último caso, os deveres das pessoas geram ainda mais deveres aos poderes públicos, como o exemplo do dever de pagar impostos, que gera o dever de administrar os recursos públicos de maneira transparente, honesta, austera e eficaz.

Os deveres aparecem, assim, como uma posição jurídica passiva, mas com importante perfil ativo, porque se concretizam em obrigações de dar, fazer ou não fazer, atribuíveis a todos, e que têm como resultado a concretização de direitos ou, em alguns casos, tão somente a perpetuação do bem-estar, sem que haja direitos sendo efetivados. Nesse passo é que se pode dizer que os deveres, tendo por base as formulações de Gonçalves e Fabriz ${ }^{34}$ e de Siqueira, ${ }^{35}$ são um elemento jurídico que se funda em valores como solidariedade, cooperação, fraternidade, responsabilidade e alteridade, e que tem como propósito não apenas promovê-los, mas também contribuir para a concretização de direitos e para uma sociedade com um nível de bem-estar cada vez maior, realizando o principal vetor dos documentos internacionais e constitucionais de proteção à pessoa: a dignidade humana.

\footnotetext{
32 Alegre Martínez, Miguel Ángel, "Los deberes...", cit.

33 Siqueira, Julio Homem de, "Elementos para uma teoria...", cit.

34 Gonçalves, Luísa Cortat Simonetti e Fabriz, Daury César, "Dever fundamental: a construção de um conceito", en De Marco, Cristhian Magnus e Pazzella, Maria Cristina Cereser e Steinmetz, Wilson (org.), Direitos fundamentais civis: teoria geral e mecanismos de efetividade no Brasil e na Espanha: tomo I, Joaçaba, Unoesc, 2013.

35 Siqueira, Julio Homem de. "Elementos para uma teoria...", cit.
} 
É a partir desse entendimento que se propõe pensar um estatuto da pessoa baseado em direitos e em deveres fundamentais. A proposta desse estatuto assume a necessidade de se superar, por meio da emergência de um novo paradigma, o viés unilateral dos direitos. O que se propõe é que o ser humano seja visto efetiva e realmente como um sujeito de direitos e deveres. Em outras palavras, deve-se resgatar o senso de liberdade individual com responsabilidade social, no sentido de que haja comprometimento social com as pessoas em desvantagem para haver um aumento no nível de bem-estar da sociedade.

A contribuição dos deveres para a construção de uma sociedade livre, justa e solidária tem como nota eficacial mais importante direcionar a interpretação dos textos jurídicos ao completo entendimento dos institutos, não apenas sobre a feição delimitadora dos direitos, mas também apoiada em sua característica de imposição constitucional essencial à viabilização da sociedade almejada.

Conforme Lombardi, ${ }^{36}$ em coordenação dinâmica com os direitos, os deveres são responsáveis por parametrizar a leitura das relações jurídicas. É nesse sentido que Casalta Nabais ${ }^{37}$ reúne as duas faces do estatuto da pessoa, a face dos direitos e a dos deveres, ancorando-se na ideia de que o ser humano é simultaneamente livre e responsável, titular de direitos e encarregado de deveres.

Pode-se, assim, dizer que não há direitos sem deveres, porque os direitos só podem ser adequadamente desfrutados se houver uma base sólida de comprometimento social pela sua manutenção; e, também, não há deveres sem direitos, porque não é concebível uma sociedade democrática assentada na exigência unilateral de deveres, sem o amparo nas mais elementares exigências de justiça e de respeito aos direitos. É esse o equilíbrio invocado por Saramago em 1998, e é ela que determina a realização efetiva da dignidade da pessoa humana.

Como registra Alegre, ${ }^{38}$ o resgate dos deveres não significa tão somente equilibrar uma hipotética balança em que direitos e deveres estariam em lados opostos, mas de superar essa dicotomia e oferecer uma visão

\footnotetext{
36 Lombardi, Giorgio, Contributo allo studio dei doveri constituzionali, Milano, Giuffrè, 1967.

37 Casalta Nabais, José, Por uma liberdade com responsabilidade: estudos sobre direitos e deveres fundamentais, Coimbra, Coimbra Editora, 2007.

38 Alegre Martínez, Miguel Ángel, "Los deberes...", cit.
} 
integrada, capaz de aproximar os deveres dos direitos, como instrumentos essenciais para sua eficácia —é nesse sentido, aliás, que Siqueira e Fabriz $^{39}$ e Siqueira ${ }^{40}$ defendem a perspectiva dos deveres como condição para a concretização dos direitos. Não se trata de um mero exercício de especulação teórica, mas da busca por uma dimensão humana e social dos direitos e deveres e da aplicação conjunta de ambos como pedra angular da convivência social e da busca pelo bem-estar. Essas considerações estão a serviço de uma concepção integral de proteção da dignidade da pessoa humana, para além da mera proteção de seus direitos subjetivos.

A compreensão do que é um direito não se encerra no egoísmo da individualidade, mas se abre para a reciprocidade, para a solidariedade, encontrando nos deveres sua lógica compartilhada. Portanto, os deveres correspondem a um imperativo de liberdade, porque se trata da condição de possibilidade de concretização das promessas de direitos, especialmente os de cunho social, pois a privação de condições mínimas de sobrevivência acarreta a privação da própria liberdade e uma exposição constante a riscos.

É por isso que Casalta Nabais ${ }^{41}$ destaca a necessidade de exigir-se que o Estado produza continuamente as condições materiais de liberdade para os que não a têm, relativizando a desigualdade social que o próprio exercício da liberdade reproduz. Se os direitos fundamentais surgiram para superar um paradigma de irresponsabilidade do Estado soberano e alcançar um modelo equilibrado pela limitação promovida pelos direitos, os deveres fundamentais vêm superar o paradigma atual de irresponsabilidade do "indivíduo absoluto", que transfere suas decisões ao Estado e dele se torna dependente, para alcançar um modelo equilibrado do estatuto jurídico humano pela limitação promovida pelos deveres.

Nesse passo, direitos e deveres são componentes do estatuto da pessoa, e não itens de um consumo individual, como titular ou o proprietário de um ou outro direito. A ideia de um estatuto da pessoa remete a uma concepção mais essencial e estrutural do ser humano, como protagonista de sua formação, e não mais como dependente de concessões estatais. É

39 Siqueira, Julio Homem de e Fabriz, Daury César, "Os deveres e a eficácia dos direitos fundamentais”, en Bussinguer, Elda Coelho de Azevedo (org.), Direitos fundamentais: pesquisas, Curitiba, CRV Ed., 2011.

40 Siqueira, Julio Homem de, "Deveres como condição...", cit.

41 Casalta Nabais, José, Por uma liberdade..., cit. 
possível, assim, compreender os deveres por uma perspectiva diversa da mera coercibilidade, centrado nas obrigações do ser humano inserido em uma coletividade.

A partir da constatação de que a dignidade da pessoa humana é o coração do patrimônio jurídico-moral da pessoa humana, ${ }^{42}$ tem-se que o estatuto jusfundamental da pessoa humana é formado, grosso modo, por essa relação entre direitos e deveres humanos à luz da dignidade.

\section{O PAPEL DOS DEVERES FUNDAMENTAIS NA CONCRETIZAÇÃO \\ DA DIGNIDADE DA PESSOA HUMANA}

As discussões sobre a contribuição dos direitos na realização da dignidade da pessoa humana são um lugar comum na grande maioria das pesquisas sobre o tema, enquanto que as discussões sobre a contribuição dos deveres são praticamente evitadas, porque fora do pensamento convencional, o pensamento sobre os deveres é muito rico e tem a aptidão para promover a transformação que todos os partidários da dignidade humana ambicionam: solucionar os problemas do mundo. Ele se propõe a exatamente incitar o ser humano a colocar em prática o seu fundamental estatuto e exercer a sua capacidade de ser solidário, fraterno e altruísta.

A defesa da existência de um estatuto da pessoa humana não significa que se deva dar atenção tão somente ao indivíduo e discutir quais seriam os seus direitos e deveres, porque assim se incidiria no mesmo equívoco do pensamento convencional: a manutenção de uma discussão vazia baseada no "eu", e não no "outro". O pensamento não convencional ou dos deveres se insere naquilo que Sousa Santos ${ }^{43}$ chama de paradigma do conhecimento prudente para uma vida decente, também identificado por Siqueira, ${ }^{44}$ que o denomina por meio de vários nomes como paradigma da cooperação, da solidariedade, da alteridade, da fraternidade ou da responsabilidade. Note-se que não se trata de um paradigma dos deveres, pois, então, se cairia, de novo, no mesmo equívoco: pensar o todo a partir da parte, e não o indivíduo a partir da sociedade.

\footnotetext{
42 Rocha, Cármen Lúcia Antunes, "O princípio da dignidade da pessoa humana e a exclusão social", Interesse Público, n. 4, 1999.

43 Sousa Santos, Boaventura de, Para um novo senso comum: a ciência, o direito e a política na transição paradigmática, 8a. ed., São Paulo, Cortez, 2011, vol. 1.

44 Siqueira, Julio Homem de, "Elementos para uma teoria...", cit.
} 
O que se busca, portanto, não é apenas discutir se este ou aquele grupo de direitos e deveres faz parte do estatuto da pessoa humana e em que medida podem ser exigidos ou reivindicados. O propósito é entender, como aponta Sen, ${ }^{45}$ que arranjos são possíveis quando a cooperação é praticada e produz ganhos. Isso porque esses ganhos são direcionados de acordo com a forma como as instituições estão organizadas, quer dizer, é possível que os benefícios resultantes sejam atribuídos a pessoas que deles não necessitam, mas que, por uma questão de "quanto mais melhor", ou de falta de compromisso social, deles se apropriam.

A cooperação, nesses casos, não é falsa, falso é o propósito das pessoas que, ao cumprirem seus deveres, esperam uma compensação na forma de concretização de seus direitos —é o sistema das recompensas. Isso é uma decorrência da equivocada percepção de que haveria uma simetria entre direitos e deveres, que a todo direito correspondesse um dever e que não há deveres sem direitos. O resultado desse tipo de cooperação é o aumento das desigualdades, a falta de oportunidades e, paradoxalmente, para o pensamento convencional, a redução das liberdades e da concretização de direitos.

A proposta de um pensamento a partir dos deveres, considerado dentro de uma era dos deveres, é a de pensar um estatuto da pessoa humana baseado no que $\mathrm{Sen}^{46}$ denomina de padrões de vida sustentáveis, que nada têm a ver com o conjunto de coisas que as pessoas valorizam ou consideram importantes, mas que tudo têm a ver com a responsabilidade de cada um associada à capacidade de fazer coisas que influenciam, positiva ou negativamente, a vida dos outros. A responsabilidade é, aqui, dupla, ou seja, ela se revela tanto em relação à própria pessoa quanto em relação às outras pessoas. Isso quer dizer que a responsabilidade se revela tanto no estatuto pessoal quanto no estatuto alheio e que, portanto, há mais de um estatuto a ser considerado.

\footnotetext{
45 Sen, Amartya, "Como julgar a globalização", en Sen, Amartya e Kliksberg, Bernardo, As pessoas em primeiro lugar: a ética do desenvolvimento e os problemas do mundo globalizado, trad. Bernardo Ajzemberg e Carlos Eduardo Lins da Silva, São Paulo, Companhia das Letras, 2010.

46 Sen, Amartya, "Por que devemos preservar a coruja pintada", en Sen, Amartya e Kliksberg, Bernardo, As pessoas em primeiro lugar: a ética do desenvolvimento e os problemas do mundo globalizado, trad. Bernardo Ajzemberg e Carlos Eduardo Lins da Silva, São Paulo, Companhia das Letras, 2010a.
} 
Na verdade, quando se fala em um estatuto da pessoa humana, utiliza-se de um recurso teórico muito próximo, senão igual, à posição original de Rawls, ${ }^{47}$ que serve tão somente para lançar as suas bases, mas que, enquanto tal, não possui aplicação prática, até mesmo porque não se pode pensar em um único estatuto, aplicável a todas as pessoas, caso se considere a diversidade de situações em que cada uma delas pode se encontrar.

Nesse sentido, quanto se discute sobre o cumprimento de deveres e a concretização de direitos, não se pode furtar à análise da multiplicidade de questões que envolvem cada uma das sociedades consideradas e, também, os específicos padrões de vida sustentáveis. Assim, o atingimento desses padrões envolve, segundo Anand e Sen, ${ }^{48}$ não apenas a carência de recursos para o bem-estar material, como a ausência de oportunidades para se viver uma vida tolerável, isto é, de usufruir de uma condição de bem-estar.

Logo, de acordo com Sen, ${ }^{49}$ a abordagem mais adequada para identificar um padrão de vida sustentável depende de que se identifique quem a ele está sujeito e de que se agregue ou combine o que falta ou o que pode ser feito, num determinado espaço e tempo, para que esse padrão se torne factível.

Conforme Sen, ${ }^{50}$ a partir das operações de identificação e de agregação, viabiliza-se a formulação de critérios que contemplem o atendimento das necessidades básicas dos indivíduos dentro de condições específicas para que ele atinja ou se aproxime do padrão de vida sustentável válido nos respectivos tempo e espaço. A especificação das coisas que compõem esse padrão e do valor que elas assumem dentro de cada comunidade é fundamental para determinar a condição individual, indicando, assim, que o estatuto da pessoa humana, concreta e não hipoteticamente considerado, não possui uma lista canônica e imutável de direitos e deveres, mas que variam com a época e a região. Assim, a avaliação do padrão de vida em

47 Rawls, John, A theory of justice: revised edition, Cambridge, The Belknap Press of Harvard University Press, 1999.

48 Anand, Sudhir e Sen, Amartya, "Concepts of Human Development and Poverty: a Multidimensional Perspective", Human Development Papers, 1997.

49 Sen, Amartya, "Poverty: an Ordinal Approach to Measurement", Econometrica, vol. 44, n. 2, 1976; Sen, Amartya, "Issues in the Measurement of Poverty", The Scandinavian Journal of Economics, vol. 81, n. 2, 1979.

50 Sen, Amartya, "Poor, Relatively Speaking", Oxford Economic Papers, vol. 35, n. 2,1983 . 
uma determinada região deve recair, defende Sen, não sobre mercadorias, suas características ou utilidade, mas sobre as capacidades das pessoas.

A abordagem das capacidades, como aponta Robeyns, ${ }^{51}$ não é uma teoria que procura explicar o bem-estar, mas uma ferramenta ou esquema para conceituar e para avaliar tal fenômeno, trabalhando a partir da ideia, segundo Sen, ${ }^{52}$ de que o que constitui o padrão de vida não é o bem nem suas características, e sim a aptidão de fazer várias coisas utilizando tal bem ou características, o que se reflete, mais que a reação mental àquela aptidão na forma de felicidade, no padrão de vida. Trata-se, assim, de uma perspectiva de análise que vislumbra a necessidade de criar oportunidades para que as pessoas atinjam um determinado padrão de vida mediante o exercício de suas capacidades, desfrutando, pois, de bem-estar.

A partir dessa abordagem, considera-se que as causas de as pessoas não terem atingido todas elas o mesmo padrão de vida previsto em um determinado estatuto da pessoa humana são várias e que podem estar associadas a processos de exclusão, de inclusão limitada ou de não inclusão, dependendo da sociedade considerada, os quais têm todos, em maior ou menor grau, o mesmo efeito, isto é, promover uma ausência ou uma deficiência de acesso a direitos sociais, os quais geram as oportunidades para o exercício das capacidades, que permitem aos indivíduos desfrutar de suas liberdades.

Daí se poder afirmar que a baixa eficácia social dos direitos, independentemente do processo que lhe seja subjacente, liga-se à ausência de oportunidades para o desempenho de capacidades e, consequentemente, de liberdades. Por isso $\operatorname{Sen}^{53}$ afirma que a falta de liberdades impede que as pessoas usufruam de um padrão de vida minimamente satisfatório. Logo, por essa perspectiva, pode-se afirmar que a falta de acesso aos direitos sociais leva à inexistência do bem-estar social.

A busca aqui proposta da concretização do bem-estar social como resultante de uma reformulação do estatuto da pessoa humana, baseado não apenas nos direitos, mas também nos deveres, baseia-se na necessária criação de capital humano para a interrupção do ciclo da desigualdade,

51 Robeyns, Ingrid, "The Capability Approach: a Theoretical Survey”, Journal of Human Development, vol. 6, n. 1, 2005.

52 Sen, Amartya, "Poor, Relatively...", cit.

53 Sen, Amartya, "Prefácio", en Green, Duncan, Da pobreza ao poder: como cidadãos ativos e Estados efetivos podem mudar o mundo, São Paulo, Cortez, 2009. 
a qual, seja na era dos direitos, seja na era dos deveres, continua a ser a grande preocupação de todas as sociedades, nacionais ou internacional. E, nesse passo, a abordagem seniana das capacidades possibilita analisar como a melhor distribuição de oportunidades e como o empoderamento das pessoas, mediante a potencialização de seus ativos, invés de lhes fazer caridade, permite o atingimento do bem-estar social.

Trata-se, então, de uma proposta de colocar em prática o discurso da era dos deveres. Para isso, a teoria seniana é trabalhada a partir de um conjunto cíclico de três perspectivas voltadas para alcançar o bem-estar social: da solidariedade ou da fraternidade (pressupõe um comprometimento social, que se baseia na ideia fundamental de que o cumprimento de deveres é condição para concretizar direitos), do empoderamento ou da igualdade (pressupõe a existência de cidadãos ativos, que efetivamente participem dos processos de escolhas públicas) e do bem-estar ou da liberdade (pressupõe a possibilidade de as pessoas exercitarem suas capacidades para que possam transformar as suas oportunidades no padrão de vida que desejam para si próprias, ou seja, naquilo que lhes proporcione bem-estar). ${ }^{54}$

\section{A perspectiva da fraternidade}

A primeira perspectiva para uma concretização cada vez maior dos direitos, com a redução das desigualdades sociais e o atingimento do bem-estar social, é a perspectiva da fraternidade ou da solidariedade. Por essa perspectiva procura-se entender como cada indivíduo pode contribuir para a melhoria da sociedade em que vive. Adota-se o argumento, baseado na teoria de Sen, ${ }^{55}$ de que cada pessoa atua para alcançar algo que seja de seu interesse e que contribua para o seu próprio bem-estar, o que pode gerar um comportamento voltado apenas para o próprio indivíduo (ego) como também voltado, direta ou indiretamente, para o outro (alter), permitindo a cooperação social orientada para o bom atendimento dos interesses da

54 Para um aprofundamento, véase Siqueira, Julio Homem de e Vermelho, Schamyr Pancieri e Fabriz, Daury Cesar, "Leaving no parentes behind: a proteção internacional humanitária dos direitos das pessoas idosas em zonas de conflito na perspectiva dos deveres", Revista de Direito Constitucional e Internacional, vol. 118, 2020.

55 Sen, Amartya, Desenvolvimento como liberdade, trad. Laura Teixeira Motta, São Paulo, Companhia das Letras, 2007; Sen, Amartya, Desigualdade reexaminada, 2a. ed., trad. Ricardo Doninelli Mendes, Rio de Janeiro, Record, 2008. 
coletividade, assumindo-se uma condição de responsável por si e pelo próximo. Solidariedade é isso: comprometimento e responsabilidade sociais.

Quando os indivíduos escolhem se comprometer socialmente isso não quer dizer que têm apenas direitos. Essa é uma visão equivocada. A perspectiva da solidariedade tem relação com o sentido de responsabilidade, pelo qual se deve entender que as escolhas individuais poderão ter, além de consequências para o próprio indivíduo, consequências para a coletividade. Um efetivo compromisso com a solidariedade permite que sejam produzidas oportunidades, que, mediante o empoderamento das pessoas, lhes dá a possibilidade de escolher como exercer as suas capacidades para, usufruindo de liberdades, transformar oportunidades em bem-estar -isso quer dizer que, geralmente, o bem-estar de cada um depende mediatamente de como as outras pessoas se conduzem e imediatamente de como o próprio indivíduo se comporta.

O significado intrínseco de liberdade está aí contido: trata-se da possibilidade de escolher que tipo de vida levar. Assim, pela perspectiva da solidariedade a concretização dos direitos depende essencialmente de escolhas. Como escolher depende da oportunidade de escolher, ter esse tipo de oportunidade depende de que ele seja criado. Daí se poder afirmar que ter mais liberdades e ter mais oportunidades depende fundamentalmente do cumprimento de deveres, ou seja, a concretização de direitos depende de que os deveres sejam cumpridos.

Na contramão disso, os deveres têm sido colocados de lado pela inflação do catálogo de direitos, decorrente de uma mania de se transformar tudo em direitos. ${ }^{56}$ Assim, a redução da importância dada aos deveres, tem como resultado a baixa eficácia prática do extenso rol de direitos,${ }^{57}$ gerando mecanismos de duvidosa legitimidade para explicar o motivo dessa baixa concretização (como o discurso da reserva do possível e o argumento do mínimo existencial).

Aliás, como escreve Laws,$^{58}$ o reconhecimento de direitos padece de um vício intrínseco terrível: embora vistos como antídoto contra as arbitrariedades estatais, eles acabam sendo utilizados como mecanismos le-

\footnotetext{
56 Baxi, Upendra, "Too Many, or too few, Human Rights?", Human Rights Law Review, vol. 1, n. 1, 2001.

57 Bobbio, Norberto, A era..., cit.; Mantovani, Ferrando, "La proclamazione di diritti umani e la non effetività dei diritti umani”, Rivista Italiana di Diritto e Procedura Penale, vol. 51, n. 1, 2008.
}

58 Laws, John, "Beyond rights", Oxford Journal of Legal Studies, vol. 23, n. 2, 2003. 
gitimadores dos interesses dos que estão no poder, em vez dos interesses de toda a sociedade — ou seja, acabam sendo utilizados como trunfos, ou, mais propriamente, como privilégios- - Disso decorrem um paradoxo e uma incongruência, para o pensamento convencional.

Pelo lado da incongruência, tem-se que a solidariedade, que sempre foi um dever, ${ }^{59}$ é tratada, utilizando-se o terceiro elemento do lema franco-revolucionário (fraternité) como um representativo dos direitos de terceira geração. Pelo lado do paradoxo está que a imensa quantidade de direitos ou de bens exigíveis torna cada vez mais distante a noção de bem-estar, sob o argumento de que diante de uma necessidade de se realizar melhor os direitos há que se amputar o catálogo tornado fundamental no estatuto da pessoa humana (máxime por meio do argumento do mínimo existencial em conjunto com o da reserva do possível).

Reconhecer na solidariedade um dever é reconhecer a cooperação social enquanto fator viabilizador do bem-estar, de maneira que aqueles indivíduos que puderam transformar mais facilmente suas oportunidades em bem-estar se comprometam a ajudar as pessoas que não tiveram a mesma sorte mediante o seu empoderamento. Portanto, a solidariedade não é nem o último nem o primeiro grau de exercício dos direitos, mas um aspecto necessário para o seu exercício. O cumprimento de deveres só adquire importância com o comprometimento social assumido pelos membros de uma sociedade, espontaneamente — do contrário, quando há uma imposição estatal compelindo os indivíduos a cumprirem deveres, não há como neles criar um senso de responsabilidade pelo bem-estar social. ${ }^{60}$

Sentir-se responsável pelo bem-estar social é a conclusão da primeira etapa do ciclo de concretização dos direitos, traduzindo-se em uma maior facilidade para empoderar as pessoas e para produzir oportunidades de bem-estar.

\section{A perspectiva da igualdade}

O empoderamento é a segunda perspectiva e pressupõe que as pessoas possam influenciar os fatores que determinam a direção que suas vidas vão

59 No mesmo sentido: Diniz, Marcio Augusto de Vasconcelos, "Estado social e princípio da solidariedade", Revista de Direitos e Garantias Fundamentais, n. 3, 2008; Rosso, Paulo Sergio, "Solidariedade e direitos fundamentais na Constituição brasileira de 1988", Revista de Direitos e Garantias Fundamentais, n. 3, 2008.

60 Laws, John, "Beyond rights", cit. 
tomar. ${ }^{61}$ Empoderar é um processo social pelo qual as pessoas adquirem ou aumentam o seu poder em nível pessoal, interpessoal, político e econômico, podendo agir, mediante escolhas racionais (orientadas para uma finalidade), para conquistar um maior controle sobre as suas vidas. ${ }^{62}$

Trata-se da inclusão ampla na construção e nos resultados da sociedade, fazendo com que seus membros confiem e acreditem em suas próprias escolhas como sendo aquelas que trarão bem-estar, permitindo-lhes, então, em relação a outros indivíduos, tanto negociar quanto influenciar nos processos decisórios. ${ }^{63}$

A perspectiva do empoderamento trabalha, então, com duas premissas decorrentes da perspectiva do comprometimento, vistas, na abordagem das capacidades com os nomes de condição de agente (agency), quando o indivíduo possui compromissos voltados para realizar deveres cujos efeitos não necessariamente contribuirão para o seu bem-estar, e de condição de bem-estar pessoal (well-being), em que o indivíduo possui ambições que podem ou não abranger os padrões de vida ou de bem-estar de outras pessoas. ${ }^{64}$

Verifica-se, portanto, que a condição de agente tem maior amplitude que a condição de bem-estar pessoal. ${ }^{65}$ Diante disso, tanto o ato de comprometer-se quanto o ato de responsabilizar-se, que são, no mais, duas faces da mesma moeda, significam compartilhar objetivos e valores que vão além da busca apenas do próprio bem-estar pessoal.

Assumir a condição de agente significa assumir um compromisso social. E uma pessoa só se coloca, geralmente, na condição de agente quando já alcançou o seu bem-estar pessoal. Ao assumir uma condição de agente, as pessoas não fazem apenas escolhas autodirecionadas, mas também escolhas alterdirecionadas. No fim, é sempre uma questão de escolhas. Tem-se a opção de converter ou não uma oportunidade em bem-estar (autointeresse) ou em agência (solidariedade), ou mesmo em ambos.

61 Green, Duncan, Da pobreza ao poder: como cidadãos ativos e Estados efetivos podem mudar o mundo, São Paulo, Cortez, 2009.

62 Boehm, Amnon e Staples, Lee H., "Empowerment: the Point of View of Consumers", Families in Society, vol. 85, n. 2, 2004.

63 Green, Duncan, Da pobreza ao poder..., cit.

64 Kerstenetzky, Celia Lessa, "Desigualdade e pobreza: lições de Sen", Revista Brasileira de Ciências Sociais, vol. 15, n. 42, 2000.

65 Sen, Amartya. Desigualdade reexaminada, cit. 
Sen ${ }^{66}$ entende que não há mal algum se a pessoa optar por tão-somente transformar suas oportunidades em seu próprio padrão de vida, o que ele denomina, inclusive, de condição do padrão de vida (standard of living condition), isto é, quando o indivíduo possui ambições que dizem respeito apenas a si próprio, sem envolver as expectativas quanto ao padrão vida de outros ${ }^{67}$ A questão é que, se todos os indivíduos ou a maioria deles fizer tal opção, o empoderamento das pessoas poderá ser mais difícil, embora não se torne impossível, o mesmo acontecendo com a concretização de direitos.

Não há como se tornar impossível porque, independentemente de cada pessoa assumir um compromisso social (condição de agente), há ainda dois tipos de comprometimento dos quais não se pode escapar. O primeiro é o comprometimento compulsório determinado pelo Estado a ser cumprido pelos indivíduos mediante o pagamento de tributos —o que pode ser evitado ou reduzido mediante técnicas elisivas, elusivas ou evasivas. $\mathrm{O}$ segundo consiste no compromisso constitucional do próprio Estado com a sociedade - do que não se pode, teoricamente, abrir mão, sendo, portanto, definitivo.

Com esses dois tipos de compromisso (compulsório e definitivo), tem-se o que Green ${ }^{68}$ baseado na teoria de Sen, chama de Estado efetivo: um poder público que garanta a participação de todas aquelas pessoas que vivam num território politicamente delimitado no processo desenvolvimento experimentado pela sociedade. Trata-se de um Estado cuja organização e atuação, mediante investimentos na sociedade, especialmente por meio de políticas públicas, permitam que pessoas cujos direitos ainda não foram concretizados tomem consciência deles possam se organizar e exigir que haja mudanças e melhorias, isto é, oportunidades para que, no uso de suas capacidades, inatas ou adquiridas, transformem novas oportunidades em bem-estar, ou mesmo assumam a condição de agentes.

Pela perspectiva do empoderamento objetiva-se, assim, combater a vulnerabilidade de determinados grupos sociais, evitando que eles não superem, por falta de oportunidades, eventos ou situações de estresse a que estão expostos, mediante exatamente a criação de oportunidades, isto é, de

66 Sen, Amartya, The Standard of Living (The Tanner Lectures on Human Values), Cambridge, Cambridge University Press, 1985.

67 Kerstenetzky, Celia Lessa, "Desigualdade e pobreza...", cit.

68 Green, Duncan, Da pobreza ao poder..., cit. 
ativos que lhes permitam administrar e superar fatores de vulnerabilidade ${ }^{69}$ Esses ativos podem tanto ser externos (recursos naturais disponíveis para uso comum, infraestrutura básica e acesso a serviços básicos, recursos financeiros estatais, bem como instituições políticas e sociais de agregação e de participação) quanto ser internos (pertencem aos indivíduos ou são por eles desenvolvidos a partir das oportunidades que lhe são dadas). Os ativos internos representam aquilo a que se chama de capital humano.

O capital humano, para Becker, ${ }^{70}$ é o conjunto de conhecimentos, habilidades, saúde e valores que proporcionam ao indivíduo ganhos imateriais. $\mathrm{Na}$ teoria seniana, os aspectos que formam o capital humano são chamados funcionamentos (functionings), os quais revelam a capacidade individual de escolher transformar oportunidades em bem-estar pessoal (well-being) atingindo um determinado padrão de vida (standard of living). Isto é, o conjunto capacitário (capabilities) de um indivíduo fornece informações sobre os funcionamentos que podem ser por ele alcançados ao realizar tal transformação, independente da caracterização do bem-estar ou do padrão de vida atingidos. ${ }^{71} \mathrm{Se}$ os funcionamentos fazem parte tanto do bem-estar pessoal quanto do padrão de vida, então o capital humano, aliado a ações positivas do Estado, é essencial para determinar a efetiva concretização de direitos.

Então, para que as pessoas em situação de vulnerabilidade alcancem funcionamentos e bem-estar, é necessário seu empoderamento, bem como o oferecimento de oportunidades. Ou seja, de acordo com Sen, ${ }^{72}$ um Estado efetivo deve direcionar as suas escolhas para as políticas públicas cujo papel é o de implantar as metas, os objetivos e as prioridades em prol do interesse público, facilitando e garantido uma discussão pública mais completa, mediante a formação de cidadãos ativos. A questão passa a ser que valores, que afirmações, que metas, que prioridade, que objetivos são estes? Ou, resumidamente, que oportunidades são estas?

Essas oportunidades têm sido denominadas de várias maneiras pela literatura, e os juristas se apropriaram talvez da pior delas: mínimo existencial. Isso porque fora o problema no que se refere à sua conceituação, a

\section{Idem.}

70 Becker, Gary S., Human Capital: a Theoretical and Empirical Analysis with Special Reference to Education, 3a. ed., Chicago, The University of Chicago Press, 1993.

71 Sen, Amartya, Sobre ética e economia, trad. Laura Teixeira Motta, São Paulo, Companhia das Letras, 2008a.

72 Sen, Amartya, Desenvolvimento como liberdade, cit. 
expressão dá a falsa impressão de que o cumprimento do mínimo tem a ver tão somente com a simples existência individual, prescindindo-se de uma participação do indivíduo na sociedade. Melhor seria utilizar necessidades decorrentes de um padrão de vida sustentável suportado por um determinado estatuto da pessoa humana, que seria menos problemático, referindo-se ao conjunto de oportunidades dado às pessoas para que possam desenvolver seu conjunto capacitário e, com ele, transformar novas oportunidades em bem-estar pessoal, atingindo seus planos ou padrões de vida.

Todavia, ainda que as pessoas sejam empoderadas com um conjunto determinado de oportunidades, é comum que algumas não convertam (da melhor maneira) oportunidades em bem-estar ou em padrão de vida, o que pode advir basicamente de dois fatores independentes: escolhas malfeitas ou défice capacitário, o que as privaria de bem-estar. Partindo-se do ponto de que os compromissos assumidos (espontâneo, compulsório e definitivo) podem contribuir para a remoção dos principais fatores de privação de bem-estar individual, ${ }^{73}$ o que se deve medir em termos de aproveitamento (escolhas) ou de suficiências (capacidades) em relação ao que cada pessoa pode realizar. $^{74}$

Assim, as oportunidades devem ser avaliadas em termos de como elas podem servir às pessoas para que, desenvolvendo suas capacidades, as possam utilizar na transformação de oportunidades em bem-estar e padrão de vida. Afasta-se, no entanto, a mensuração da igualdade em termos de aproveitamento, já que seria útil apenas se todos os indivíduos considerados pudessem exercer suas capacidades igualmente. Todavia, como aponta Sen, ${ }^{75}$ se o seu bem-estar dependesse apenas de suas próprias escolhas e que elas fossem sempre iguais, isto é, que ninguém fizesse boas escolhas ou que ninguém fizesse escolhas ruins, tal fato seria tão ineficiente quão contraproducente, já que nivelaria todos a partir daquele que não soube fazer uso de suas oportunidades.

A medida da igualdade e, portanto, das oportunidades a serem oferecidas, deve ser feita em termos de suficiências, considerando-se diversidades individuais e circunstâncias sociais, excluindo-se a aplicação de qualquer artifício com o mesmo propósito de, por exemplo, um véu de ignorância.

\footnotetext{
73 Idem.

74 Sen, Amartya, Desigualdade reexaminada, cit.

75 Idem.
} 
Obviamente que não se pode considerar, por outro lado, todo o conjunto de diversidades, já que as exigências práticas requerem a consideração das diversidades as mais importantes, evitando-se uma confusão empírica inconclusiva e frágil, ${ }^{76}$ devendo-se identificar quem são as pessoas em situação de vulnerabilidade e que diversidades são determinantes para retirá-las dessa situação em curto, em médio e em longo prazos.

A determinação das diversidades mais importantes que permitam retirar as pessoas de sua condição de vulnerabilidade restringe o rol de oportunidades a serem geradas mediante as políticas públicas. Entretanto, ainda assim não é possível estabelecer uma lista fixa e pré-determinada sobre que oportunidades seriam essas, já que a lista é limitada no espaço e no tempo, não podendo ser aplicada indistintamente, pois se for genérica não focalizará o problema que se pretende combater, devendo, pois, ser feita com base nas necessidades das pessoas de uma determinada comunidade numa determinada época. A escolha sobre quais as oportunidades a serem oferecidas é determinante para a formação de capital humano; porém, a impossibilidade de fazer escolhas diante da falta de oportunidades é, na contramão, o principal óbice para superar a condição de vulnerabilidade. ${ }^{77}$

Destacar quais oportunidades, em determinadas condições de tempo e de espaço, devam ser proporcionadas depende da existência de uma base informacional em que sejam levadas em conta as diversidades individuais e sociais mais importantes num determinado contexto: a perspectiva do empoderamento é central na concretização de direitos e na busca pelo bem-estar das pessoas. Trata-se, portanto, de fazer as escolhas certas para atingir o terceiro degrau do ciclo: a perspectiva do bem-estar.

\section{A perspectiva da liberdade}

A perspectiva do bem-estar assume que não apenas recursos materiais têm importância para o bem-estar (well-being condition) ou para a qualidade de vida (standard of living condition) dos indivíduos, mas que também e principalmente as oportunidades que lhes são propiciadas para que possam fazer suas próprias escolhas, a partir de seu conjunto capacitário (capabilities), influenciam bastante no tipo de vida (standard of living) escolhido e fruído. Dentro do conjunto de oportunidades estão facilidades

\footnotetext{
76 Idem.

77 Green, Duncan, Da pobreza ao poder..., cit.
} 
como, por exemplo, serviços básicos de saúde, tratamento de água, educação, assistência social e saneamento; facilidades que permitem a potencialização do acerto das escolhas individuais, permitindo que as pessoas atinjam com maior facilidade o seu próprio bem-estar, o que é crucial para formar capital humano e para aproveitar os conjuntos capacitários. ${ }^{78}$

Isso faz com que se retome a importância da abordagem da capacidade enquanto teoria que pretende fornecer um amplo quadro normativo e de ferramentas para avaliar os aspectos que influenciam no bem-estar das pessoas. Em suma, trata-se de uma abordagem que prioriza o empoderamento, além do desenvolvimento da capacidade de os indivíduos fazerem escolhas corretas a partir daquelas oportunidades que eles próprios criam ou que lhes são oferecidas para a realização daqueles funcionamentos que consideram valiosos para promover o seu bem-estar, os seus objetivos de vida. ${ }^{79}$ A abordagem das capacidades (capability approach) preconiza, portanto, a liberdade de escolha das pessoas.

E é essa liberdade de escolha que proporciona o acesso a outros tipos de liberdade, tanto no que se refere ao bem-estar pessoal quanto no que diz respeito à assunção de sua condição de agente. A partir da possibilidade de escolher transformar uma oportunidade em bem-estar e exercer uma liberdade faz com que haja uma expansão do conjunto capacitário das pessoas: "ter mais liberdade melhora o potencial das pessoas para cuidar de si mesmas e para influenciar o mundo, questões centrais para o processo de desenvolvimento", ${ }^{80} \mathrm{e}$, obviamente, para o alcance do bem-estar e dos objetivos de vida pessoais. Assim, com cada vez um maior número de indivíduos alcançando funcionamentos que permitam desenvolver capacidades para a transformação de oportunidades em bem-estar, a tendência será a melhoria da condição humana para que todos tenham uma vida mais longa, saudável e completa.

Portanto, as três perspectivas estabelecem uma rede virtuosa de relações que permitem um alcance mais efetivo do bem-estar pessoal resultante do empoderamento dos indivíduos e da disponibilização de oportunidades. Ao dispor de capacidades que sejam necessárias para que se possa transformar oportunidades em bem-estar, os indivíduos tendem a fazer escolhas

\footnotetext{
78 Sen, Amartya, Desenvolvimento como liberdade, cit.

79 Idem; Sen, Amartya, Desigualdade reexaminada, cit.; Sen, Amartya, Sobre ética..., cit.

80 Sen, Amartya, Desenvolvimento como liberdade, cit.
}

Esta obra está bajo una Licencia Creative Commons Atribución-NoComercial-SinDerivar 4.0 Internacional, IIJ-UNAM. 
que lhe permitam usufruir melhor os direitos que lhes são assegurados. Isso faz com que sejam geradas oportunidades para eles próprios e para outras pessoas, bem como que seja alargado o espectro de suas responsabilidades. Assim, oportunidades resultam na expansão de liberdades, cujo exercício redunda em deveres e em oportunidades de atingir o bem-estar pessoal e social. Logo, só a fraternidade permite a igualdade e somente em um mundo sem desigualdade haverá liberdade.

\section{CONCLUSÃO}

A conclusão fundamental que o presente trabalho permite alcançar é a de que a indagação sobre o papel dos deveres fundamentais no processo de construção de um estatuto jusfundamental da pessoa contribui para a reflexão não apenas do resgate dessa categoria jurídica como também para o fortalecimento dos direitos em sua dimensão objetiva, superada a visão estritamente individual.

O tema dos deveres é, assim, complementar, mas não acessório ao dos direitos. Como destacado nas seções anteriores, embora não seja, pelo menos não mais, um tema esquecido, é, na verdade, pouco tratado, quando se compara com o volume dos trabalhos desenvolvidos sobre os direitos. A propósito, pode-se afirmar que o esquecimento está, atualmente, no fato de que livros de direito constitucional muito pouco tratam sobre deveres e, quando o fazem, é tão somente de passagem. Isso significa que não há, em geral, uma preocupação com o estatuto da pessoa humana, mas tão somente com os direitos.

Com base nessa constatação, também se pode concluir que a concretização dos deveres segue por um caminho que é praticamente o inverso dos direitos. Em outros termos, enquanto o pensamento focado nos direitos fala em liberdade, igualdade e fraternidade, como dimensões sucessivas, o pensamento baseado nos deveres inverte a lógica, para determinar que a fraternidade é que gera a igualdade e a liberdade, e que a igualdade quando efetivada potencializa a liberdade.

Nesse passo, diante da agravada crise pela qual passa a concretização dos direitos fundamentais, optou-se, não só por revelar a importância dos deveres e sua relação com os direitos dentro de um estatuto jusfundamental da pessoa humana, mas também por construir um caminho a partir do qual seja possível, a partir dos deveres, melhor concretizar os direitos. Em 
outras palavras, o que se faz é reafirmar a conclusão de que os deveres são condição para a concretização de direitos.

Portanto, o trabalho aponta novas condições e possibilidades que os deveres podem proporcionar, com o enriquecimento do léxico do constitucionalismo contemporâneo. Não se tem a pretensão de conduzir a conclusões exatas, mas desenvolver uma hipótese distinta para indicar diferentes caminhos para o processo argumentativo e para a reflexão crítica, com contribuições para diversos âmbitos jurídicos, pois quem pretende desenvolver uma pesquisa científica em direito tributário não pode prescindir de uma sólida base teórica sobre o dever fundamental de pagar tributos, o mesmo se diga em relação às pesquisas na área ambiental, ligando os direitos aos deveres fundamentais de preservação e em diversas outras áreas do universo jurídico. Por isso a importância do desenvolvimento de uma teoria dos deveres fundamentais e, assim, promover um equilíbrio entre direitos e deveres na análise e interpretação do fenômeno jurídico.

Longe de representar um menosprezo ao processo histórico e político de conquista dos direitos, parte-se da constatação de que os mais importantes diplomas normativos que regem a nossa vida em sociedade veiculam deveres que vinculam a todos, indistintamente, independentemente das vontades das pessoas e é preciso compreendê-los, saber interpretá-los para, assim, poder fixar parâmetros racionais e legítimos de incidência. É preciso compreender criticamente as deficiências da estratégia unilateral dos direitos e a importância da inserção dos deveres nesse sistema normativo. Esse outro olhar sobre o fenômeno jurídico, com as lentes de uma figura nova ao constitucionalismo contemporâneo, é a razão de ser e o objetivo geral deste trabalho, de modo a permitir novas reflexões e interpretações para as questões mais importantes à vida em sociedade.

\section{REFERÊNCIAS BIBLIOGRÁFICAS}

Alegre Martínez, Miguel Ángel, "Los deberes en la Constitución española: esencialidad y problemática", Teoría y Realidad Constitucional, n. 23, 2009.

Anand, Sudhir e SEN, Amartya, "Concepts of Human Development and Poverty: a Multidimensional Perspective", Human Development Papers, 1997. 
BANDIERI, Luís María, "Derechos fundamentales ¿y deberes fundamentales?", en LEITE, George Salomão e SARLET, Ingo Wolfgang e CARBONELL, Miguel (org.), Direitos, deveres e garantias fundamentais, Salvador, JusPodivm, 2011.

BAXI, Upendra, “Too Many, or too few, Human Rights?”, Human Rights Law Review, vol. 1, n. 1, 2001.

BECKER, Gary S., Human Capital: a Theoretical and Empirical Analysis with Special Reference to Education, 3a. ed., Chicago, The University of Chicago Press, 1993.

BISCARETTI DI RUfFìA, Paolo, Diritto costituzionale: istituzioni di diritto pubblico, Napoli, Jovene Editore, 1989.

BobBio, Norberto, A era dos direitos, trad. Carlos Nelson Coutinho, Rio de Janeiro, Campus, 1992.

BoBbio, Norberto, L'età dei diritti, Torino, Giulio Einaudi Editore, 1990.

BoEHM, Amnon e Staples, Lee H., "Empowerment: the Point of View of Consumers", Families in Society, vol. 85, n. 2, 2004.

Busch Ventur, Tania, "Deberes constitucionales”, Revista de la Facultad de Ciencias Jurídicas de la Universidad Catolica de Salta, n. 1, 2011.

CARBone, Carmelo, I doveri pubblici individuali nella Costituzione, Milano, Giuffrè, 1968.

CASAlTA NABAIS, José, O dever fundamental de pagar impostos: contributo para a compreensão constitucional do estado fiscal contemporâneo, Coimbra, Almedina, 2015.

CASAlta Nabais, José, Por uma liberdade com responsabilidade: estudos sobre direitos e deveres fundamentais, Coimbra, Coimbra Editora, 2007.

Castanheira Neves, A., "Pessoa, direito e responsabilidade", Revista Portuguesa de Ciência Criminal, n. 1, 1996.

CHAPMAN, Audrey R., "Reintegrating Rights and Responsibilities: toward a New Human Rights Paradigm", en HunTER, Kenneth e MACK, Timothy (ed.), International Rights and Responsibilities for the Future, Connecticut, Praeger, 1996.

DíAz REvorio, Francisco Javier, "Derechos humanos y deberes fundamentales: sobre el concepto de deber constitucional y los deberes en 
la Constitución española de 1978", Revista del Instituto de Ciencias Jurídicas de Puebla, n. 28, 2011.

DinIZ, Marcio Augusto de Vasconcelos, "Estado social e princípio da solidariedade", Revista de Direitos e Garantias Fundamentais, n. 3, 2008.

Duguit, Léon, L'état, le droit objectif et la loi positive, Paris, Dalloz, 2003.

EstÉvez ArAúJo, José A., "La privatización de los derechos”, en EstéVEZ ARAúJO, José A. (org.), El libro de los deberes: las debilidades e insuficiencias de la estrategia de los derechos, Madrid, Trotta, 2013.

GonÇALves, Luísa Cortat Simonetti e FABRIZ, Daury César, "Dever fundamental: a construção de um conceito", en DE MARCO, Cristhian Magnus e PAzzella, Maria Cristina Cereser e SteinMetz, Wilson (org.), Direitos fundamentais civis: teoria geral e mecanismos de efetividade no Brasil e na Espanha: tomo I, Joaçaba, Unoesc, 2013.

GREEN, Duncan, Da pobreza ao poder: como cidadãos ativos e Estados efetivos podem mudar o mundo, São Paulo, Cortez, 2009.

HÄBERLE, Peter, "A dignidade humana como fundamento da comunidade estatal", en SARLET, Ingo Wolfgang (org.), Dimensões da dignidade: ensaios de filosofia do direito e direito constitucional, 2a. ed., Porto Alegre, Livraria do Advogado, 2013.

JELLINEK, Georg, Teoría general del Estado, Madrid, Fondo de Cultura Económica de España, 2012.

KerstenetzKy, Celia Lessa, "Desigualdade e pobreza: lições de Sen", Revista Brasileira de Ciências Sociais, vol. 15, n. 42, 2000.

KIRSTE, Stephan, "A dignidade humana e o conceito de pessoa de direito", trad. Luis Marcos Sander, en SARLET, Ingo Wolfgang (org.), Dimensões da dignidade: ensaio de filosofia do direito e direito constitucional, $2 \mathrm{a}$. ed., Porto Alegre, Livraria do Advogado, 2013.

LAWS, John, "Beyond rights", Oxford Journal of Legal Studies, vol. 23, n. 2, 2003.

LOMBARDI, Giorgio, Contributo allo studio dei doveri constituzionali, Milano, Giuffrè, 1967.

MAINO, Carlos Alberto Gabriel, "Derechos fundamentales y la necesidad de recuperar los deberes: aproximación a la luz del pensamiento de Francisco Puy”, en LEITE, George Salomão e SARLET, Ingo Wolfgang e 
CARBonell, Miguel (org.), Direitos, deveres e garantias fundamentais, Salvador, JusPodivm, 2011.

MANTOVANI, Ferrando, "La proclamazione di diritti umani e la non effetività dei diritti umani", Rivista Italiana di Diritto e Procedura Penale, vol. 51, n. 1, 2008.

Mercado Pacheco, Pedro, "Derechos insostenibles”, en Estévez AraúJO, José A. (org.), El libro de los deberes: las debilidades e insuficiencias de la estrategia de los derechos, Madrid, Editorial Trotta, 2013.

Peces-BARba Martínez, Gregorio, "Los deberes fundamentales", Doxa, n. 4, 1987.

PeCes-BARba MARTínez, Gregorio, "Los derechos humanos y los deberes fundamentales”, en SORIANO DÍAZ, Ramón e ALARCÓn CABRERA, Carlos e Mora Molina, Juan (coord.), Diccionario crítico de los derechos humanos I, Huelva, Ed. Universidad Internacional de Andalucía, 2000.

PÉREZ LuÑO, António-Enrique, Los derechos fundamentales, 11a. ed., Madrid, Tecnos, 2013.

PrEIS, Marco Antônio e PREIS, Marcéli da Silva Serafim e SIQUEIRA, Julio Homem de, "Deveres fundamentais e direito ao afeto", Derecho y Cambo Social, n. 54, 2018.

RAWLS, John, A Theory of Justice: Revised Edition, Cambridge, The Belknap Press of Harvard University Press, 1999.

RoBEYns, Ingrid, “The Capability Approach: a Theoretical Survey”, Journal of Human Development, vol. 6, n. 1, 2005.

ROBles Morchón, Gregorio, Os direitos fundamentais e a ética na sociedade atual, São Paulo, Editora Manole, 2005.

RochA, Cármen Lúcia Antunes, "O princípio da dignidade da pessoa humana e a exclusão social”, Interesse Público, n. 4, 1999.

RodotÀ, Stefano, Il diritto di avere diritti, Roma-Bari, Laterza, 2012.

Rosso, Paulo Sergio, "Solidariedade e direitos fundamentais na Constituição brasileira de 1988", Revista de Direitos e Garantias Fundamentais, n. 3, 2008.

SARAMAgo, José, Discurso de Estocolmo 10 de dezembro de 1998: uma proposta para a Declaração Universal dos Deveres Humanos, Lisboa, Fundação José Saramago, 1998. Disponível em: <https://pt.scribd.com/ 
doc/269455895/Jose-Saramago-Discurso-Premio-Nobel>. Acesso em: 11 fev. 2018.

SÁNCHEZ Rubio, David, Encantos e desencantos dos direitos humanos: de emancipações, libertações e dominações, trad. Ivone Lixa e Helena Henkin, Porto Alegre, Livraria do Advogado, 2014.

SAul, Ben, "In the Shadow of Human Rights: Human Duties, Obligations and Responsibilities", Columbia Human Rights Law Review, n. 32, 2001.

SEN, Amartya, "Como julgar a globalização", en SEN, Amartya e KLIKSBERG, Bernardo, As pessoas em primeiro lugar: a ética do desenvolvimento e os problemas do mundo globalizado, trad. Bernardo Ajzemberg e Carlos Eduardo Lins da Silva, São Paulo, Companhia das Letras, 2010.

SEN, Amartya, Desenvolvimento como liberdade, trad. Laura Teixeira Motta, São Paulo, Companhia das Letras, 2007.

SEn, Amartya, Desigualdade reexaminada, trad. Ricardo Doninelli Mendes, 2. ed., Rio de Janeiro, Record, 2008.

SEN, Amartya, "Issues in the Measurement of Poverty", The Scandinavian Journal of Economics, vol. 81, n. 2, 1979.

SEN, Amartya, "Poor, Relatively Speaking", Oxford Economic Papers, vol. 35, n. 2, 1983.

SEN, Amartya, "Por que devemos preservar a coruja pintada", en SEN, Amartya e KliKsBerG, Bernardo, As pessoas em primeiro lugar: a ética do desenvolvimento e os problemas do mundo globalizado, trad. Bernardo Ajzemberg e Carlos Eduardo Lins da Silva, São Paulo, Companhia das Letras, 2010a.

SEN, Amartya, "Poverty: an Ordinal Approach to Measurement", Econometrica, vol. 44, n. 2, 1976.

SEN, Amartya, "Prefácio", en GREen, Duncan, Da pobreza ao poder: como cidadãos ativos e Estados efetivos podem mudar o mundo, São Paulo, Cortez, 2009.

SEN, Amartya, Sobre ética e economia, trad. Laura Teixeira Motta, São Paulo, Companhia das Letras, 2008a.

SEN, Amartya, The Standard of Living (The Tanner Lectures on Human Values). Cambridge, Cambridge University Press, 1985. 
SiQUEIRA, Julio Homem de, "Deveres como condição para a concretização de direitos", Revista de Direito Constitucional e Internacional, vol. 79, 2012.

SiqueIRA, Julio Homem de, "Elementos para uma teoria dos deveres fundamentais: uma perspectiva jurídica”, Revista de Direito Constitucional e Internacional, vol. 95, 2016.

SiQUEIRA, Julio Homem de e FABRIZ, Daury César, "Os deveres e a eficácia dos direitos fundamentais", en Bussinguer, Elda Coelho de Azevedo (org.), Direitos fundamentais: pesquisas, Curitiba, CRV Ed., 2011.

SiqueIra, Julio Homem de e Vermelho, Schamyr Pancieri e FABriz, Daury Cesar, "Leaving no parentes behind: a proteção internacional humanitária dos direitos das pessoas idosas em zonas de conflito na perspectiva dos deveres", Revista de Direito Constitucional e Internacional, vol. 118, 2020.

Sousa SAntos, Boaventura de, Para um novo senso comum: a ciência, o direito e a política na transição paradigmática, 8a. ed., São Paulo, Cortez, 2011, vol. 1.

Violante, Luciano, Il doveri di avere doveri, Torino, Giulio Einaudi Editore, 2014.

Fecha de recepción: 10 de octubre de 2018.

Fecha de aceptación: 20 de mayo de 2019.

Esta obra está bajo una Licencia Creative Commons

Atribución-NoComercial-SinDerivar 4.0 Internacional, IIJ-UNAM. 


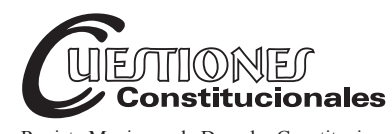

Revista Mexicana de Derecho Constitucional Núm. 43, julio-diciembre 2020

\title{
La frontera móvil entre constitucionalidad y legalidad en la procedencia del amparo directo en revisión
}

\author{
The moving boundary between constitutionality and legality \\ within the "amparo directo en revisión"
}

\section{Roberto LARA CHAGOYÁN*}

A José Ramón Cossio Díaz, con gratitud y admiración.

RESUMEN: El presente artículo se ocupa de plantear, denunciar y analizar un problema relacionado con la enorme discrecionalidad que se genera a la hora en que la Corte Suprema de nuestro país decide la procedencia de un recurso de revisión en amparo directo. Demostraré que el enunciado "La Suprema Corte, en su papel de tribunal constitucional, sólo debe ocuparse de cuestiones propiamente constitucionales" es manifiestamente falso, porque la propia legislación y la jurisprudencia aplicables permiten que la procedencia de dicho recurso dependa más de la discrecionalidad de los ministros - tolerada por el propio sistema- que de reglas precisas y objetivas.

Asimismo, expondré las razones que a mi juicio han provocado esta situación y las consecuencias nocivas que genera, especialmente con relación al principio de igualdad.
ABSTRACT: This paper focuses on presenting, exposing and analysing a problem concerning a great deal of discretion generated when our country's Supreme Court decides on the admissibility of a "amparo directo en revision". I will demonstrate that the following sentence: "The Supreme Court, as a Constitutional Court, should only concern itself with actual constitutional issues", is manifestly untrue, because the applicable law and the judicial precedents enable the admissibility of such motion of review at the discretion of the Ministers - tolerated by the system itself - more so than by specific and objective laws.

Moreover, I will set out the reasons that, in my opinion, have caused this situation, as well as the negative impacts it generates, especially related to the principle of equality.

* Profesor-investigador en el Departamento de Derecho del Tecnológico de Monterrey, campus Santa Fe, en la Ciudad de México. México. ORCID: 0000-0003-1692-8826. Correo electrónico: roberto.larac@gmail.com.

Agradezco los comentarios críticos y agudos de Dulce Alejandra Camacho Ortiz y Camilo Emiliano Saavedra Herrera, sin los cuales las sucesivas versiones de este trabajo no habrían visto evolución alguna. 
Palabras clave: constitucionalidad, legalidad, amparo directo, procedencia, jurisprudencia, constitucionalismo, formalismo, activismo judicial, regla de justicia formal.
Keywords: constitutionality, legality, "amparo directo", admissibility, jurisprudence, constitutionalism, formalism, judicial activism, formal justice rule.

SUMARIO: I. Introducción. II. Planteamiento del problema. III. El origen histórico de la confusión terminológica y una propuesta de clarificación. IV. Una frontera móvil en la jurisprudencia mexicana. V. Rastreando las causas que explican el fenómeno. VI. Conclusiones. VII. Bibliohemerografía.

\section{INTRODUCCIÓN}

En los tiempos que corren, en los que los sistemas jurídicos están "absolutamente impregnados de constitucionalidad", ${ }^{1}$ no sólo es deseable, sino también exigible, que los conflictos que se resuelven mediante la aplicación de normas tengan como brújula los valores constitucionales en sentido amplio, es decir, incluyendo los que se recogen en los bloques de constitucionalidad o parámetros de control de la regularidad constitucional. El Poder Constituyente Permanente parece haberse tomado en serio este propósito al haber reformado el 10 de junio de 2011 el artículo 1o. de la Constitución mexicana, mediante una serie de cláusulas que reflejan un compromiso fuerte con la cultura de los derechos humanos, para lo cual se establecieron una serie de obligaciones consistentes en promover, respetar, proteger y garantizar los derechos humanos.

Sin embargo, bien entendido, ese noble fin no puede significar que los operadores jurídicos desconozcan o dejen de atender, sin más, lo que ordenan las leyes ordinarias, a menos que éstas contradigan aquellos valores. En otras palabras, el advenimiento del llamado paradigma constitucionalista no puede ser entendido como un permiso fuerte para dejar de seguir los procedimientos o cumplir los deberes que imponen las normas secundarias, ya que, por el contrario, atenderlas — cuando en sí mismas no constituyen desobediencia constitucional - contribuye al cumplimiento de los fines constitucionalmente protegidos.

1 Favoreau, Louis, Legalidad y constitucionalidad. La constitucionlización del derecho, traducción de Magdalena Correa Heano, Bogotá, Universidad Externado de Colombia, Instituto de Estudios Constitucionales Carlos Restrepo Piedrahita, 2000, p. 69. 
El juez, a diferencia del jurista teórico, debe aplicar el derecho vigente cada día para realizar su trabajo, y por ello experimenta con mayor nitidez algunas tensiones que pueden darse entre la "constitucionalización" del sistema y los límites que los textos legales le imponen para actuar.

Uno de estos casos es el que analizaré en este trabajo. Se trata de la procedencia del recurso de revisión en el amparo directo que corresponde conocer en exclusiva a la Suprema Corte de Justicia de la Nación (SCJN), quien decide si un recurso resulta o no procedente, lo cual depende básicamente del tipo de problema de que se trate: si es de legalidad, entonces resultará improcedente, y, por lo tanto, deberá desecharse; en cambio, si es de constitucionalidad, entonces resultará procedente, será admitido y se analizará de fondo. ${ }^{2}$

Como se verá, en este tipo de decisiones los operadores jurídicos deben tomar en cuenta elementos normativos, provenientes de reglas constitutivas (deben analizar si un determinado recurso reúne una serie de características definidas en el sistema jurídico para ser considerado como procedente), pero también aspectos valorativos (ejercicios discrecionales) mediante los cuales debe complementar la decisión sobre la procedencia. Los elementos normativos se refieren a que la sentencia recurrida trate de la posible inconstitucionalidad de una norma general o de la interpretación directa de la Constitución, mientras que los elementos valorativos están relacionados con la importancia y trascendencia de la decisión que resulte.

La mezcla de estos elementos ha generado que en la práctica se haya trazado una frontera móvil entre la legalidad y la constitucionalidad, que condiciona la procedencia. Dicha movilidad genera que no siempre se respete la regla de justicia formal, según la cual debe otorgarse un trato igual a los seres pertenecientes a una misma categoría. ${ }^{3}$ Esta situación es particularmente importante si se toma en cuenta que en nuestro juicio de amparo es más benéfico para el interesado que su asunto sea tratado como un tema de constitucionalidad, que si se lo trata como uno de legalidad.

2 El desechamiento "de plano", es decir, sin resolución, corresponde a la presidencia de la Corte, pero el auto correspondiente puede ser impugnado mediante un recurso de reclamación en el que se determina si el tema es de legalidad o de constitucionalidad (artículo 104 de la Ley de Amparo). Todavía las Salas de la Corte o el tribunal pleno pueden volver a discutir la procedencia y actuar en consecuencia.

3 Perelman, Chaïm y Olbretchs-Tyteca, Lucie, Tratado de la argumentación. La nueva retórica, traducción de Julia Sevilla Muñoz, Madrid, Gredos, 1989, p. 340. 
Así pues, uno de los propósitos que persigo en este trabajo es poner en evidencia la movilidad de la frontera entre legalidad y constitucionalidad en los hechos. El otro propósito es mostrar las razones que están detrás de esas variaciones.

El contexto de descubrimiento de este análisis se remonta a mis años como secretario de estudio y cuenta (letrado) en la SCJN, entre 2004 y 2015, cuando tuve que analizar la procedencia de este tipo de recursos. Durante esos años, la perplejidad que me causó el hecho de que un mismo tipo de caso pudiera caer en el sector de la legalidad o de la constitucionalidad me llevó a reflexionar sobre las razones que podían explicar este juego de significados, cuyas consecuencias no eran menores.

Procederé de la siguiente manera: en primer lugar (II, infra), plantearé los extremos del problema que voy a analizar; en un segundo apartado (III, infra), describiré cómo se generó la confusión entre los términos legalidad y constitucionalidad, mediante una breve reseña del llamado amparo casación o de legalidad; en tercer lugar (IV, infra) describiré cómo, de hecho, la Corte ha venido usando las categorías legalidad y constitucionalidad en un periodo determinado; en seguida ( $\mathrm{V}$, infra), expondré las razones que a mi juicio explican el fenómeno, así como las consecuencias negativas de esta práctica; finalmente, en el apartado de conclusiones (VI, infra), aislaré los hallazgos encontrados, y esbozaré apenas algunas pinceladas orientadas a reflexionar en torno a posibles soluciones para estabilizar la frontera móvil entre legalidad y constitucionalidad.

\section{PLANTEAMIENTO DEL PROBLEMA}

Es un tópico en el derecho mexicano considerar que la materia del recurso de revisión en el amparo directo, a cargo de la SCJN, debe limitarse a la decisión de las "cuestiones propiamente constitucionales". Y lo es, porque más allá de que así lo disponga la propia Constitución (artículo 107, fracción IX), nuestra evolución constitucional ha buscado consolidar a la Corte como un auténtico tribunal constitucional.

La fracción IX del artículo 107, a partir de la adición al texto de la Constitución, del 19 de febrero de 1951, estableció que la regla para determinar en qué casos procedía el recurso de revisión en amparo directo ante la Suprema Corte de Justicia de la Nación se reducía a determinar si la sentencia recurrida decidía sobre la inconstitucionalidad de una ley o establecía la interpretación directa de la Constitución. 
El 11 de junio de 1999 se publicó en el Diario Oficial de la Federación $(D O F)$ una reforma a este precepto, impulsada por el presidente Ernesto Zedillo, mediante la cual se agregó un requisito más: que la decisión "entrañe" un criterio de importancia y trascendencia, a juicio de la Suprema Corte de la Nación, en cumplimiento de sus acuerdos generales. La más reciente reforma a la misma disposición tuvo lugar el 6 de junio de 2011 durante el sexenio de Felipe Calderón; en ella se cambió ligeramente la redacción en el sentido de que lo que se debe determinar - a fin de que el recurso resulte procedente - es si las sentencias recurridas (en plural) deciden sobre la constitucionalidad de una ley (anteriormente decía inconstitucionalidad) o establecen la interpretación directa de un precepto de la Constitución, u omiten decidir sobre tales cuestiones cuando hubieren sido planteadas. Como puede verse, con esta última reforma se aumentaron los supuestos de procedencia, ya que ahora no sólo procede el recurso en contra de sentencias que resuelven que un precepto legal es inconstitucional, sino también en contra de sentencias que declaran que un precepto determinado resulta constitucionalmente válido; asimismo, ahora el recurso procede no sólo contra sentencias que decidan sobre tales cuestiones, sino también contra aquellas que omitan hacerlo.

Con todo, lo más relevante de esta serie de prescripciones es el criterio valorativo de importancia y trascendencia. Esto quiere decir que a partir de la reforma de 1999 la SCJN está constitucionalmente facultada para desechar recursos de revisión en amparo directo que no consideren importantes y trascendentes aun cuando en la sentencia contra la que se dirigen se hubiera decidido sobre la constitucionalidad de una ley o se hubiera llevado a cabo la interpretación directa de algún precepto constitucional.

El texto vigente de la Constitución que regula la procedencia del recurso de revisión en amparo directo es el siguiente (se añade énfasis):

Artículo 107. Las controversias de que habla el artículo 103 de esta Constitución, con excepción de aquellas en materia electoral, se sujetarán a los procedimientos que determine la ley reglamentaria, de acuerdo con las bases siguientes:

IX. En materia de amparo directo procede el recurso de revisión en contra de las sentencias que resuelvan sobre la constitucionalidad de normas generales, establezcan la interpretación directa de un precepto de esta Constitución u omitan decidir sobre tales cuestiones cuando hubieren sido planteadas, siempre que fijen un criterio de importancia y trascendencia, 
según lo disponga la Suprema Corte de Justicia de la Nación, en cumplimiento de los acuerdos generales del Pleno. La materia del recurso se limitará a la decisión de las cuestiones propiamente constitucionales, sin poder comprender otras. ${ }^{4}$

El más reciente acuerdo general que regula la procedencia del amparo directo es el 9/2015. En él, además de repetirse las mismas reglas contenidas en la Constitución y en la Ley de Amparo, se establece que la importancia y trascendencia se deriva de los siguientes supuestos: a) cuando la resolución de que se trate dé lugar a “...un pronunciamiento novedoso o de relevancia para el orden jurídico nacional (énfasis añadido)", y b) cuando en la resolución se desconozca algún criterio de la SCJN. Al intentar definir importancia y trascendencia, el acuerdo referido fracasa, pues sencillamente refiere que lo "importante y trascendente" debe entenderse como lo "novedoso o relevante". El acuerdo, pues, viola la regla de la definición, según la cual el definiens debe ser más claro que el definendum.

Llamaré requisitos conceptuales a los relacionados con la constitucionalidad de normas generales y la interpretación directa de la Constitución, y requisito discrecional al relacionado con la nota de importancia y trascendencia. De este modo, de acuerdo con la normatividad aplicable, para que un recurso de revisión resulte procedente no basta con agotar alguno de los requisitos conceptuales (que son los más intuitivos), sino que además es necesario que se cumpla el discrecional. Lo anterior se traduce en que un determinado caso puede ser conceptualmente constitucional, pero si discrecionalmente no resulta importante o trascendente, entonces puede no resultar procedente. Esto significa, al contrario de la intuición general, que el requisito discrecional (importancia y trascendencia) constituye una condición necesaria y suficiente de la constitucionalidad, mientras que los requisitos conceptuales son meramente contingentes. Sobra decir que la vaguedad de los conceptos importancia y trascendencia permite que los operadores jurídicos seleccionen los casos con un enorme grado de discrecionalidad, lo que provoca la movilidad de la frontera entre lo procedente y lo improcedente, que no siempre se corresponde con el binomio conceptual constitucionalidad-legalidad.

4 Esta norma constitucional fue reproducida textualmente en la Ley de Amparo, concretamente, en el último párrafo del artículo 81, fracción II. 
¿De qué depende entonces la decisión de la procedencia? ¿De la correcta aplicación de una regla? ¿Del resultado de un análisis conceptual según el cual el caso X reúne o no las características del concepto constitucionalidad (connotación) o de si X entra o no en el campo de aplicación de dicho concepto (denotación)? La respuesta es que de ninguna de ellas es determinante. La nota definitoria, se insiste, es más bien la valoración derivada de los conceptos importancia y trascendencia, más vagos aún que los de constitucionalidad o legalidad. Todos estos elementos permiten a los ministros de la SCJN “convertir" un caso que en pureza era de legalidad en constitucionalidad, y viceversa. Importancia y trascendencia son entonces conceptos valorativos, que para su utilización no dependen de la aplicación de una regla, sino de un ejercicio de discrecionalidad, del que a veces se abusa.

\section{EL ORIGEN HISTÓRICO DE LA CONFUSIÓN TERMINOLÓGICA Y UNA PROPUESTA DE CLARIFICACIÓN}

¿Cómo se ha entendido históricamente la constitucionalidad y la legalidad en esta materia? Para responder esta pregunta debemos remontarnos al siglo XIX, en los albores del juicio de amparo, cuando éste no procedía en contra de sentencias emitidas por los tribunales ordinarios, es decir, no existía el llamado amparo judicial o amparo casación (el actual amparo directo). En efecto, el artículo 8o. de la Ley de Amparo de 1869 lo prohibía expresamente. ${ }^{5}$ Pero esa prohibición no impidió que la SCJN, mediante la que algunos consideran una "desafortunada" interpretación del artículo 14 de la Constitución de 1857, abriera la puerta al amparo judicial. Dicha interpretación condicionaría el desarrollo y la evolución de nuestro juicio de amparo. Para algunos, provocó que se "desdibujara la original ideal del juicio de amparo", ${ }^{6}$ y más que eso: supuso la "corrupción del juicio de amparo". 7

5 Serna de la Garaza, José María, "El amparo-casación en el pensamiento de Emilio Rabasa”, en González Martín, Nuria (comp.), Estudios jurídicos en homenaje a Marta Morineau, t. I: Derecho romano. Historia del derecho, México, UNAM, Instituto de Investigaciones Jurídicas, 2006, p. 488.

6 Fix-Zamudio, Héctor, "El amparo mexicano como instrumento protector de los derechos humanos", en Garantías jurisdiccionales para la defensa de los derechos, México, UNAM, 1993, p. 256.

7 Rabasa, Emilio, El artículo 14 y el juicio constitucional, México, Porrúa 1993, p. 313 . 
El enunciado a interpretar, contenido en el artículo 14 de la Constitución de 1857, era el siguiente: "Nadie podrá ser juzgado ni sentenciado sino por leyes dadas con anterioridad al hecho y exactamente aplicadas a él por el tribunal que previamente haya establecido la ley" (énfasis añadido). ${ }^{8} \mathrm{De}$ acuerdo con Fix Zamudio, la Corte de aquel tiempo entendió que la palabra "exactamente" significaba "indebidamente", por lo que concluyó que la inexacta aplicación de la ley ordinaria suponía una violación constitucional. ${ }^{9}$ En palabras de Fix Zamudio:

[C]uando un juez de cualquier jerarquía, de la esfera federal o de carácter local aplicara 'inexactamente' (es decir, indebidamente), un precepto legal secundario en un proceso concreto, por ese hecho infringía ese precepto constitucional [el 14] y por lo tanto 'violaba una garantía individual', lo que determinó que la propia Corte llegara a concentrar por conducto del juicio de amparo contra resoluciones judiciales, todas las sentencias de todos los jueces y tribunales del país. ${ }^{10}$

8 El caso es conocido como Amparo Vega, y fue resuelto por la Corte el 29 de abril de 1869. Manuel Vega — un juez de Mazatlán al que se le había sido suspendido en el ejercicio profesional de abogado, como sanción por haber dictado sentencias contra el texto expreso de la ley- promovió un juicio de amparo por considerar injustificada la sanción (no estaba contemplada como tal, ya que a su conducta habría correspondido una suspensión o la destitución como juez, pero no la inhabilitación para ejercer como abogado). El juez de distrito negó el amparo, debido a que el artículo 8 de la Ley vigente prohibía la procedencia del juicio en asuntos judiciales. La SCJN revisó el fallo y lo revocó, concediendo el amparo a Manuel Vega. Cfr. González Oropeza, Manuel, "El amparo en negocios judiciales. El caso de Manuel Vega", Anuario Mexicano de Historia del Derecho, vol. X, México, 1998, pp. 394 y 395. De acuerdo con los expertos, la sentencia fue muy escueta y mal fundamentada; tanto, que desató un debate político, que conminaría a la Corte a enviar un informe al Congreso, en el que se vio obligada a explicar que, a su juicio, el artículo 8 de la Ley de Amparo era inconstitucional, porque desconocía el contenido de los artículos 101 y 102 de la misma Ley, según los cuales el amparo era procedente contra todo acto o ley de cualquier autoridad que infringiera las "garantías individuales", por lo que no podían quedar excluidas las decisiones judiciales. Cfr. Fix Zamudio, Héctor, "El amparo mexicano como instrumento protector de los derechos humanos", cit., p. 258.

9 Un lector atento puede entender que lo que el constituyente de 1857 prescribió en esta disposición fue el respeto al principio de taxatividad (o legalidad) en materia penal (lex certa), que consiste en la prohibición de que se impongan penas por conductas que no están estrictamente (exactamente) contempladas como delitos.

10 Fix-Zamudio, Héctor, "El amparo mexicano como instrumento protector de los derechos humanos", cit., pp. 256 y 257. 
De este modo, el llamado amparo casación (o amparo judicial, que después se llamaría directo) nació con la única finalidad de controlar constitucionalmente la actividad judicial. Sin embargo, dado que lo que se controlaba era la "inexacta" o "indebida" aplicación de la ley, empezó a ser llamado "control de legalidad". De aquí parte una confusión que sorprende a propios y extraños cuando se escuchan o se leen frases como "ese asunto no es de constitucionalidad, porque en él únicamente se violaron los artículos 14 y 16 de la Constitución”, como si tal afirmación fuera lógicamente posible.

Volviendo a la historia, son bien conocidos los vaticinios de Rabasa con respecto a lo que él consideró un desafortunado error interpretativo del artículo 14 de la Constitución de 1857, a cargo de la SCJN. ${ }^{11}$ De manera particular, vaticinó que la Corte sufriría un desprestigio derivado, entre otros factores, del enorme rezago que se generaría. La historia le dio la razón en ese aspecto: la Corte se sobresaturó de asuntos, porque se convirtió en la última instancia de prácticamente todos los juicios celebrados a lo largo y ancho del país; sin embargo, el amparo judicial continuó.

En el Congreso Constituyente de 1917 se planteó revertir esta situación, pero no se logró. ${ }^{12}$ A lo largo del siglo XX, el número de asuntos continuó creciendo al tiempo en que lo hizo la Corte, que pasó de once a dieciséis ministros en 1928, y de dieciséis a veintiuno en 1934. Para 1951 fue necesario establecer una Sala Auxiliar, con cinco ministros supernumerarios. En ese mismo año se crearon los primeros tribunales colegiados de circuito precisamente para paliar el rezago, a los que se transfirió la competencia para conocer de los amparos directos; sin embargo, tampoco fue suficiente.

La reforma constitucional de 1967 supuso un importante esfuerzo para disminuir la carga de la SCJN, ya que a partir de entonces ésta dejó de ser competente para conocer los amparos directos, y se quedó solamente con una pequeña parte: ciertos asuntos sociales y económicos trascendentes. Un segundo esfuerzo se llevó a cabo con la reforma constitucional de

11 Rabasa, Emilio, El artículo 14 y el juicio constitucional, cit., p. 123.

12 Fix-Fierro, Héctor, "El amparo judicial y la «imposible tarea» del Poder Judicial de la Federación. Perspectivas en el centenario de la Constitución de Querétaro", en Ferrer Mac-Gregor, Eduardo y Herrera García, Alfonso (coords.), El juicio de amparo en el centenario de la Constitución mexicana de 1917, t. I, México, UNAM, Instituto de Investigaciones Jurídicas, 2017, p. 484. 
1987-1988, mediante la cual se delegó definitivamente toda la competencia a los tribuales colegiados de circuito. Fue entonces cuando se estableció que la Corte sólo debía resolver temas de constitucionalidad, puesto que los de legalidad quedaban reservados a los tribunales colegiados. ${ }^{13}$ ¿Cuáles eran estos temas? ¿Qué se dejó a la Corte y qué a los tribunales colegiados?

A los tribunales colegiados se les otorgó en definitiva la competencia para resolver prácticamente todos los temas de legalidad ${ }^{14}$ mediante el amparo directo, mientras que a la SCJN se le permitió revisar, en una segunda instancia extraordinaria, algunos de esos amparos que tuvieran ciertas características, a saber: aquellos en los que se hubiera reclamado la constitucionalidad de una norma general, así como aquellos en los que los nuevos tribunales colegiados realizaran interpretaciones directas de la Constitución. Es en este momento cuando nacen las cuestiones "propiamente constitucionales".

Así las cosas, no es que los problemas que se resuelven mediante el amparo judicial o directo no sean temas constitucionales; lo son, porque el parámetro de control se encuentra en la Constitución (especialmente en los artículos 14 y 16); sin embargo, se les llama "amparos de legalidad" porque históricamente se ha utilizado este término para designar un tipo muy especial de control constitucional: el relacionado con la exacta aplicación de la ley.

Por ello, las confusiones que se dan en la práctica a la hora de determinar si un determinado recurso de revisión en amparo directo debe o no ser considerado como procedente se derivan de la ambigüedad de término legalidad, que puede significar dos cosas muy diferentes: 1) legalidad como conformidad $^{15}$ de una determinada conducta con lo descrito en una ley, y

\footnotetext{
13 Ibidem, p. 486.
}

14 Existe otro mecanismo adicional mediante el cual la SCJN podría revisar casos de legalidad: la facultad de atracción prevista en el artículo 40 de la Ley de Amparo. Por desgracia, no resulta en absoluto extraño que en el juicio de amparo mexicano existan tantas y tan variadas excepciones (y excepciones de las excepciones); de ahí que se le considere como uno de los procesos más complcados y engorrosos de la región. Cfr. Pou Giménez, Francisca, "El nuevo amparo mexicano y la protección de los derechos: ¿ni tan nuevo ni tan protector?", Anuario de Derechos Humanos, Santiago, Centro de Derechos Humanos de la Facultad de Derecho de la Universidad de Chile, 2014, p. 93.

15 El término legalidad es ambiguo, ya que puede ser entendido, al menos, en tres sentidos distintos: a) como criterio clasificatorio, es decir, como una propiedad que comparten todos los entes jurídicos: instituciones, actos, eventos, funcionarios y textos ("Si 
2) legalidad como violación constitucional derivada de una incorrecta adjudicación, que tiene como consecuencia la violación de algunas normas constitucionales (especialmente los artículos 14 y 16, aunque pueden ser otros).

Si esto es así, entonces ¿qué se decide realmente a la hora de resolver la procedencia de un recurso de amparo directo? La respuesta a la pregunta es que, siguiendo el mandato constitucional y legal, la SCJN debe analizar cada recurso de revisión y descartar aquellos que sean de legalidad en cualquiera de los dos sentidos señalados. Y más aún: pueden descartar otros que sean realmente de constitucionalidad, pero que no considere importantes y trascendentes, como hemos ido señalando.

En suma, la reforma constitucional de 1987-1988 no inventó el control de legalidad (que es en realidad un tipo de constitucionalidad), pues éste viene de antiguo ligado al amparo casación; más bien la reforma creó un nuevo tipo de constitucionalidad: las cuestiones propiamente constitucionales.

El siguiente esquema, con sugerencias terminológicas, podría ayudar a entenderlo mejor (elaboración propia):

$\mathrm{X}$ está regulado por la ley, entonces X es legal"); b) como conformidad, es decir, como criterio para determinar si un determinado acto ha sido emitido de acuerdo con el derecho ("el acto X es legal porque es conforme a derecho"), y c) como valor o principio, esto es, como uno de los pilares del Estado de derecho bajo el cual deben actuar los titulares del poder ("el funcionario Y debe conducirse dentro de los márgenes de la legalidad"). Cfr. Shapiro, Scott, Legality, The Belknap Press of Harvard University Press, traducción castellana de Diego M. Papayannis y Lorena Ramírez Ludeña, Legalidad, Madrid, Marcial Pons, 2011, pp. 23 y 24. 


\section{Cuadro 1 \\ LEGALIDAD Y CONSTITUCIONALIDAD COMO CUESTIONES \\ EN EL AMPARO}

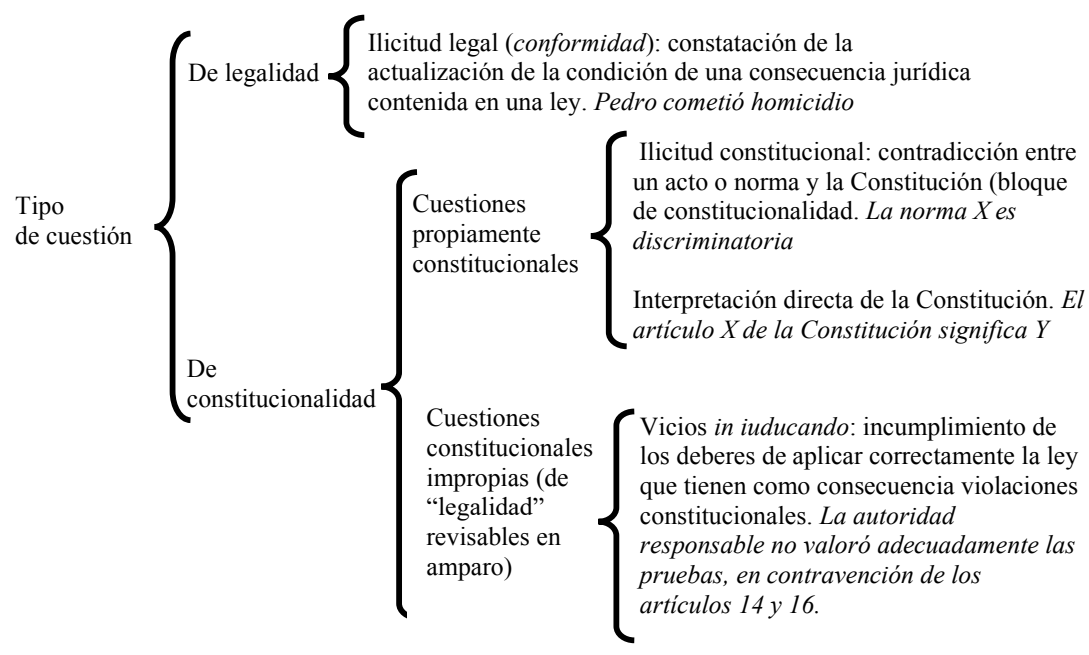

Como puede verse, la palabra legalidad es ambigua, ya que, por un lado, se usa para designar aquellas cuestiones que se resuelven mediante el contraste entre un hecho determinado y un supuesto jurídico contenido en una disposición legal, con la finalidad de establecer la consecuencia jurídica correspondiente; mientras que, por otro lado, se usa para designar los vicios in iudicando, propios de la casación que suponen, indirectamente, cierto tipo de violaciones constitucionales.

Ante este panorama, y dado que se ha buscado consolidar a la SCJN como un auténtico tribunal constitucional, se han hecho esfuerzos a nivel constitucional y legal para que la Corte no resuelva cuestiones de legalidad, que son en realidad constitucionales, pero no en sentido propio. De ahí que tenga sentido la distinción tan conocida entre cuestiones propiamente constitucionales y cuestiones de legalidad (cuestiones constitucionales impropias).

En suma, la SCJN es legalmente competente para decidir cuándo un recurso de revisión es procedente y cuándo no, para lo cual ha de resolver previamente si el caso es de legalidad o de constitucionalidad en los tér- 
minos expuestos. Sin embargo, la infraestructura legal con la que cuenta para realizar semejante juicio de valor le permite colocar lícitamente un mismo tipo de caso en uno u otro casillero, con lo cual es posible afirmar que el propio sistema hace posible el incumplimiento de la regla de justicia formal. Consecuentemente, este laxo sistema de selección de casos ha contribuido a que en México tengamos una auténtica frontera móvil entre legalidad y constitucionalidad, gracias a la cual los ministros pueden colocar un caso en el lado que les apetezca, sin que ello suponga ilicitud alguna. La movilidad de la frontera no es algo baladí, ya que se generan dos tipos de situaciones. La primera es que la SCJN, de hecho, resuelve asuntos que puede, pero no debería resolver, con lo cual se aleja de la aspiración de consolidarse como un auténtico tribunal constitucional. La segunda es que, al desechar casos que no debiera haber desechado, cumple con una regla, pero desconoce un principio: el de igualdad. ${ }^{16}$

\section{UNA FRONTERA MÓVIL EN LA JURISPRUDENCIA MEXICANA}

De un universo acotado, pero suficientemente orientador, de criterios contenidos en el Semanario Judicial de la Federación, relativos al amparo directo en revisión, específicamente la novena época y lo que va de la décima, pude detectar que, al interpretar los conceptos de legalidad, constitucionalidad e importancia y trascendencia, la SCJN ha construido las siguientes cuatro categorías: ${ }^{17}$ a) cuestiones de "mera legalidad"; b) cues-

16 En efecto, cualquier decisión comprendida en ese marco (procedencia/improcedencia) está prima facie permitida. No obstante, cuando la movilidad de la frontera entre legalidad y constitucionalidad genera tratos desiguales injustificados entre los quejosos, entonces podemos estar asistiendo a lo que Manuel Atienza y Juan Ruiz Manero llaman "ilícito atípico", concretamente un "fraude a la ley". De acuerdo con ellos, el fraude a la ley tiene lugar cuando una conducta que aparentemente es conforme a una norma ("norma de cobertura"), produce en realidad un resultado contrario a otra norma ("norma defraudada"), que siempre es un principio. Así, en nuestro caso, la conducta de la SCJN aparentemente es conforme a los artículos 107, fracción IX, de la Constitución; 81, fracción II, de la Ley de Amparo y el Acuerdo General 9/2015; sin embargo, un caso es calificado como procedente y otro del mismo tipo como improcedente, se viola el principio de igualdad. Atienza, Manuel y Ruiz Manero, Juan, Ilícitos atípicos, Madrid, Trotta, 2000, pp. 74 y 75.

17 He construido estas categorías a partir de mi experiencia como secretario de estudio y cuenta en la SCJN. No pretendo exhaustividad, sino claridad. He delimitado esta investigación a la novena y a la décima épocas de la jurisprudencia porque puedo analizar 
tiones "propiamente constitucionales"; c) cuestiones que, siendo prima facie constitucionales, terminan siendo de legalidad (las llamaré "cuestiones de legalidad forzada"), y d) cuestiones que, siendo prima facie de legalidad, terminan siendo constitucionales (las llamaré "cuestiones de constitucionalidad forzada").

El método de búsqueda que utilicé fue en realidad muy sencillo y rudimentario: en el motor de búsqueda del Semanario Judicial de la Federación tecleé frases como "legalidad", "constitucionalidad", "improcedente", "agravios inoperantes", entre otras. En total, detecté 44 criterios: catorce tesis de jurisprudencia y treinta tesis aisladas, que pude clasificar en las cuatro categorías mencionadas. Una vez organizada la información, me di a la tarea de construir el siguiente cuadro, que muestra la distribución de los criterios detectados en función de dos variables: 1) el órgano emisor, y 2) si se trata de un criterio aislado (TA) o de una jurisprudencia obligatoria (J). De este modo, se muestra cuántos criterios aislados y cuántos de jurisprudencia fueron detectados por cada una de las Salas y por el tribunal pleno:

\section{Cuadro 2}

DISTRIBUCIÓN DE TESIS A PARTIR DE LOS CRITERIOS

DE LEGALIDAD Y CONSTITUCIONALIDAD

\begin{tabular}{|l|c|c|c|c|c|c|c|c|c|}
\hline \multicolumn{1}{|c|}{ Categoría } & \multicolumn{2}{c|}{$\begin{array}{c}\text { Primera } \\
\text { Sala }\end{array}$} & \multicolumn{2}{c|}{$\begin{array}{c}\text { Segunda } \\
\text { Sala }\end{array}$} & \multicolumn{2}{c|}{ Pleno } & \multicolumn{3}{c|}{ Total } \\
\hline & $\mathrm{J}$ & TA & $\mathrm{J}$ & TA & J & TA & J & TA & Total \\
\hline Mera legalidad & 2 & 9 & 0 & 1 & 1 & 1 & 3 & 11 & 14 \\
\hline $\begin{array}{l}\text { Propiamente } \\
\text { constitucionales }\end{array}$ & 1 & 1 & 2 & 1 & 1 & 0 & 4 & 2 & 6 \\
\hline Legalidad forzada & 2 & 3 & 1 & 1 & 0 & 1 & 3 & 5 & 8 \\
\hline $\begin{array}{l}\text { Constitucionalidad } \\
\text { forzada }\end{array}$ & 2 & 6 & 1 & 4 & 1 & 2 & 4 & 12 & 16 \\
\hline Total & 7 & 19 & 4 & 7 & 3 & 4 & 14 & 30 & 44 \\
\hline $\begin{array}{l}\text { Fuente: elaboración propia. } \\
\text { Nota: J = jurisprudencia; TA = tesis aislada. }\end{array}$
\end{tabular}

con mayor facilidad este segmento del tiempo, que, además, coincide parcialmente con mi experiencia práctica.

Esta obra está bajo una Licencia Creative Commons

Atribución-NoComercial-SinDerivar 4.0 Internacional, IIJ-UNAM. 
¿Qué nos dicen estos datos? En principio, se advierte una mayor actividad de la Primera Sala en la emisión de los criterios sobre ambas cuestiones. La primera sala, además, es la que emite mayores criterios "forzados" en uno y otro sentido. Por su parte, la Segunda Sala, aunque presenta una "actividad" menor, se inclina sobre todo forzar la constitucionalidad, inclinación que también se nota en la Primera.

Si indagamos más profundamente, los datos nos dicen mucho más. Los catorce ejemplos de la mera legalidad ${ }^{18}$ demuestran cómo la Corte parecía estar invirtiendo su energía en detectar casos para desecharlos, sin hacer demasiado esfuerzo para determinar si en algún aspecto merecía la pena admitirlo. Los ocho casos de legalidad forzada confirman este diagnóstico. ${ }^{19}$

En la tesis aislada 1a. CLXXXIX/2016 (10a.), por ejemplo, la propia SCJN consideró que para determinar la procedencia del recurso el énfasis no se coloca ni en la interpretación directa ni en la presunta inconstitucionalidad de una norma general, sino en que los casos sean relevantes y trascendentes para el orden nacional. El rubro de la tesis es: "Revisión en amparo directo. Si al analizar su procedencia se advierte que con la resolución del recurso no se fijará un criterio de importancia y trascendencia, debe desecharse aunque se actualice hipotéticamente una cuestión constitucional". En esencia, la Primera Sala señala que una cuestión constitucional no es más que "un requisito técnico" cuyo control debe obviarse si no resulta ni importante ni trascendente. Asimismo, sostiene que la centralidad de las notas de importancia y trascendencia se fundamenta en la "determinación del Constituyente de reservar la decisión de la admisión del recurso a un ámbito de política judicial de la Corte" (énfasis añadido).

18 Los catorce criterios de mera legalidad son los siguientes: 1a./J. 13/2017 (10a.); 1a./J. 1/2015 (10a); 1a./J. 56/2007; 1a. LIX/2009; 1a. CCXLV/2011 (9a); 1a. CCCXXI/2013 (10a); 1a. CLXXXVII/2014 (10a.); 1a. CXIV/2016 (10a); 1a. CXIV/2016 (10a); 1a. CCCXXVIII/2014 (10a); 1a. CLXXXVII/2014 (10a); 2a. 1/97; P./J. 34/98; y P. IV/2017 (10a.). Lo que tienen en común todos estos criterios queda representado por la tesis aislada 1a. CXIV/2016 (10a.), de rubro "Amparo directo en revisión. Entre las cuestiones de legalidad que lo hacen improcedente, se encuentran las referidas a la indebida valoración de pruebas, la acreditación de los elementos del tipo penal y lo relativo a la individualización de la pena". Sucintamente, el criterio dice que las argumentaciones referidas a la indebida valoración de pruebas, la acreditación de los elementos del tipo penal y la individualización de la pena, son cuestiones de mera legalidad.

19 Los ocho casos de legalidad forzada son los siguientes; 1a./J. 103/2011; 1a./J. 13/2017 (10a.); 1a. CLXXXIX/2016 (10a.); 1a. LIII/2011; 1a. LXIX/2015 (10a.); 2a./J. 5/2013 (10a.); 2a. LVIII/2014 (10a.); y P. XLV/2007. 
Lo interesante y al mismo tiempo cuestionable de este criterio es que establece un permiso fuerte para convertir un caso de constitucionalidad en uno de legalidad. Con ello, los ministros se autorizan a sí mismos a tener por justificada una determinada decisión de procedencia con base en criterios más políticos que jurídicos. Lo paradójico es que este permiso jurisprudencial juridifica la posibilidad de utilizar razones políticas para admitir o desechar un determinado recurso. Con semejante liberalidad, la Corte perfectamente podría utilizar este criterio para deshacerse de recursos indeseables o incómodos, aun cuando se tratara de genuinos casos de constitucionalidad, al menos en cuanto a lo que aquí he llamado "requisitos conceptuales". El requisito referido a la importancia y trascendencia (requisito discrecional) puede funcionar como salvoconducto político para evadir la responsabilidad de los ministros. Imaginemos "casos hipotéticos" en los que la Corte prefiera no pronunciarse sobre tortura o desaparición forzada, para evitar un conflicto político con el gobierno de turno. Esta tendencia al desechamiento se confirma si contrastamos las cifras de mera legalidad y legalidad forzada, que en conjunto suman veintidós asuntos, contra los escasos seis casos de la categoría cuestiones propiamente constitucionales. ${ }^{20}$

En contraste con lo anterior, en la categoría de constitucionalidad for$z a d a$ encontramos quince casos, ${ }^{21}$ en los que se advierte el rompimiento de paradigmas llevado a cabo por algunos ministros audaces que entendieron mejor el nuevo carácter de la Corte como tribunal constitucional y no sólo admitieron, sino resolvieron de fondo importantes asuntos en materia de derechos humanos (algunos de ellos, derechos sociales) mediante el juicio de amparo directo en revisión e, incluso, mediante el amparo indirecto. ${ }^{22}$

20 Los seis casos de cuestiones propiamente constitucionales son los siguientes: 1a./J. 64/2014 (10a.); 1a. CCCIII/2014 (10a.); 2a./J. 46/98; 2a./J. 114/2006; 2a. XXXIV/2007; y P./J. 71/2009.

21 Los dieciséis casos de constitucionalidad forzada son los siguientes: 1a. CXCVIII/2018 (10a.); 1a./J. 8/2012; 1a./J. 80/2010; 1a. XXI/2010; 1a. XLIX/2010; 1a. XIX/2010; 1a. CCCLXIX/2013 (10a.); 1a. XXXVI/2016 (10a.); 2a./J. 114/2018; 2a. LXXXII/2016 (10a.); 2a. IX/2014; 2a. LXXII/2019; 2a. IXI/2013 (10a.); P./J. 22/2014 (10a.); P. LXXVII/2000; y P III/2002.

22 Los siguientes casos son ejemplos de amparos que fueron resueltos por la Corte, antes de la reforma constitucional de 2011, con un perfil de auténtico tribunal constitucional y no de mera casación: 1) ADR 935/2006, "caso Barajas", sobre mayoría de edad penal; 2) AD 6/2008, "caso Transexual", sobre derecho a la no discriminación"; 3) ADR 2044/2008, “caso Acámbaro", sobre libertad de expresión; 4) ADR 1492/2007, "caso 
En estos asuntos es posible advertir interpretaciones que van más allá de los textos legales con componentes de derecho internacional de los derechos humanos, incluso antes de la reforma de 2011.

Una vez implementada esa reforma, la cultura litigiosa en el país cambió, y la forma de tocar las puertas de la Corte dio un giro de 180 grados, porque para impugnar la violación de algún derecho se dejó de utilizar de forma predominante el cajón de sastre en el que se habían convertido los artículos 14 y 16 constitucionales. Fue entonces cuando nos fuimos al otro extremo: prácticamente cualquier tipo de asunto es presentado como un tema de constitucionalidad, aunque realmente no lo sea; por ejemplo, cuestiones relacionadas con la constitución de sociedades mercantiles, la firma de un contrato privado, una acción reivindicatoria, etcétera ${ }^{23}$ (temas de legalidad en el sentido de conformidad). ${ }^{24}$

La Corte - especialmente la Primera Sala, dedicada a los asuntos civiles y penales - había abierto sus puertas — quizá demasiado — a la procedencia de prácticamente cualquier tipo de asunto. Una de las consecuencias de esta situación fue el alud de amparos que incrementó de manera significativa el número de casos: entre 2009 y 2016, el número de asuntos resueltos pasó de 4,000 a 16,139; es decir, el número se multiplicó por cuatro, de los cuales un alto porcentaje corresponde a amparos directos en revisión. ${ }^{25}$

Un buen ejemplo de esta apertura es la jurisprudencia P./J. 22/2014 (10a.), clasificada en este trabajo como "constitucionalidad forzada", cuyo

Toxicómanos", sobre derecho a la salud, y 5) AD 912/2008, “caso Acteal", sobre derecho a la libertad personal". Incluso, en amparo indirecto, la Corte mostró esa apertura, al resolver los siguientes casos: 1) AR 2676/2003, "caso Bandera", sobre libertad de expresión; y 2) AR 2146/2005, "caso Militares con VIH”, cobre derecho a la salud y a la no discriminación.

23 Existe un caso paradigmático en el cual se resolvió un amparo derivado de la nulidad de un contrato de promesa de compraventa de un departamento de lujo en una playa del estado de Jalisco. El derecho alegado como violado fue el "derecho a una vivienda digna", porque el departamento no tenía ventanas con vista al mar en una de las habitaciones. La SCJN consideró que el ADR era procedente, y resolvió centralmente el problema, consistente en determinar si el derecho social a una vivienda digna se debe o no aplicar a una vivienda de lujo. La Corte concedió el amparo.

24 Shapiro, Scott, Legalidad, cit. Véase también el cuadro 1, supra.

25 SCJN, Informe Anual de Labores, presentado por el ministro presidente, Luis María Aguilar Morales en diciembre de 2016. Publicación en línea: https://www.scjn.gob. $\mathrm{mx} /$ sites/default/files/informe_labores_transparencia/version/2016-12/INFORME\%20 MINISTRO\%20PRESIDENTE\%202016.pdf, pp. 12 у 13. 
rubro es: "CUESTIÓN CONSTITUCIONAL. PARA EFECTOS DE LA PROCEDENCIA DEL RECURSO DE REVISIÓN EN AMPARO DIRECTO, SE SURTE CUANDO SU MATERIA VERSA SOBRE LA COLISIÓN ENTRE UNA LEY SECUNDARIA Y UN TRATADO INTERNACIONAL, O LA INTERPRETACIÓN DE UNA NORMA DE FUENTE CONVENCIONAL, Y SE ADVIERTA PRIMA FACIE QUE EXISTE UN DERECHO HUMANO EN JUEGO". En este asunto, la Sala determinó que cuando se presente una colisión de este tipo, y sea necesario fijar el sentido de un derecho humano para resolverla, entonces debe concluirse que sí existe una cuestión propiamente constitucional. Lo anterior, porque detrás de esa operación subyace un juicio de "relevancia jurídica" fundado en la idea de coherencia normativa; de este modo, es necesario "...verificar la coherencia del orden constitucional como una unidad dotada de sentido protector o promocional de los derechos humanos, el cual se remite a argumentos sustanciales y no a razonamientos de índole formal".

En el mismo sentido, la tesis aislada 1a. CXCVIII/2018 (10a.) es un buen ejemplo de constitucionalidad forzada, ya que admite la procedencia sin tomar en cuenta los requisitos constitucionales y legales; en su lugar, la Sala, admitiendo que no hay fundamento legal para ello, incorpora los instrumentos de sotf law como parámetro de admisibilidad. El rubro de la tesis es "REVISIÓn EN AMPARO DIRECTO. PROCEDE EL RECURSO SI EN LA SENTENCIA RECURRIDA SE APLICARON INSTRUMENTOS NORMATIVOS DE «SOFT LAW» PARA INTERPRETAR EL CONTENIDO DE UN DERECHO HUMANO DE RANGO CONSTITUCIONAL". En síntesis, la Sala sostiene que, aunque tales instrumentos no forman parte del parámetro de control de regularidad constitucional, ello no impide que su contenido pueda ser empleado como un "....criterio orientador en sentido amplio, al tratarse de una doctrina especializada desarrollada por un organismo internacional de derechos humanos". De este modo, cuando el tribunal colegiado lleva a cabo un ejercicio de este tipo, tal actividad debe ser calificada como “... una interpretación directa de la Constitución para efectos de la procedencia del recurso de revisión en los juicios de amparo directo, no por el valor jurídico del instrumento mismo, sino por el impacto que tuvo en la decisión de un órgano jurisdiccional al momento de resolver un asunto".

Si hacemos un balance de lo anterior, podemos decir que la Corte mexicana ha incurrido en ciertas inconsistencias a la hora de resolver la procedencia de algunos recursos de revisión en el amparo directo, sin que ello suponga, en principio, violar la ley. El uso discrecional de las 
categorías que hemos detectado, aunque fueron propuestas con arreglo a reglas válidas y con el fin legítimo de mantener las competencias constitucionales de la SCJN, no deja de levantar sospechas de sesgo a cargo de los ministros.

En uno de los extremos, podemos apreciar que mediante el abuso del requisito discrecional (importancia y trascendencia) se puede disminuir la brecha de la constitucionalidad y, por ende, ensanchar la de la legalidad; en el otro extremo se produce el efecto contrario: al abusar de los criterios conceptuales (constitucionalidad de normas generales o interpretación directa de algún precepto constitucional), se disminuye la brecha de la legalidad y se ensancha la de constitucionalidad. De este modo, la SCJN termina convirtiendo problemas de simple adjudicación legal en complejos y enredados casos en los que se mezclan fuentes nacionales e internacionales y se ensayan estrategias como el test de proporcionalidad, derecho comparado, y todo lo que pueda sonar interesante o novedoso. Con ello, se olvida que un problema simple demanda una solución simple; que la argumentación persigue el fin de resolver problemas de forma sencilla, y que complicar un asunto no es un signo de buena salud argumentativa.

No me preocupa tanto el hecho de que este juego de significados provoque que varios casos terminen constitucionalizándose (a final de cuentas es eso lo que pretende la constitucionalización), sino que se viole la regla de justicia formal, al no otorgarse un trato igual a los seres pertenecientes a una misma categoría, ya que es posible que dos quejosos interpongan un mismo tipo de recurso y uno de ellos caiga en el terreno de la legalidad y el otro en el de la constitucionalidad, debido a que, por ejemplo, el segundo estuvo en mejores condiciones políticas para lograrlo. ${ }^{26}$

Asimismo, no es deseable que la Corte siga resolviendo casos que no debería resolver, porque, como he sostenido, con ello se aleja de la aspiración de consolidarse como un auténtico tribunal constitucional, y tampoco lo es que deje de resolver asuntos que debía resolver, ya que con ello incumple su misión como tribunal protector de derechos o defensor de la Constitución.

26 Infra, apartado V, punto 2. Razones políticas.

Esta obra está bajo una Licencia Creative Commons Atribución-NoComercial-SinDerivar 4.0 Internacional, IIJ-UNAM. 


\section{RASTREANDO LAS CAUSAS QUE EXPLICAN \\ EL FENÓMENO}

\section{El comportamiento de los ministros asociado a su concepción del derecho}

La actuación de los ministros refleja alguna preferencia teórica en cuanto a su concepción del derecho, y ello no tiene nada de particular, ya que no todos los operadores jurídicos lo entienden de la misma forma. ¿Es posible asociar alguna concepción del derecho con la actitud de los operadores jurídicos cuando hablamos de legalidad y constitucionalidad en los términos de este trabajo? A mi juicio, existen buenas razones para responder afirmativamente esta pregunta bajo los rubros del formalismo jurídico y el activismo judicial, entendidos a la manera de Manuel Atienza:

Por formalismo estoy entendiendo una concepción que ve el Derecho única o muy preferentemente como un conjunto de reglas y que rechaza interpretar las normas acudiendo a lo que son sus razones subyacentes. La desviación consiste por ello en prescindir de los fines y valores que dan sentido a la práctica jurídica (al para qué interpretar).

Y el activismo se caracteriza por ver en el Derecho únicamente esta última dimensión (valorativa), dejando pues de lado que el Derecho es también una práctica autoritativa, en la que las reglas juegan un papel esencial. La desviación consiste aquí en prescindir de los medios, de las formas; en no tomar en cuenta que si la interpretación es tan relevante en el Derecho, ello se debe precisamente al papel que juega en él la autoridad (donde no hay autoridades, como ocurre en el caso de la moral — la moral no heterónoma-, la necesidad de interpretación prácticamente desaparece). ${ }^{27}$

Considero que no sería muy descabellado afirmar que, al menos en los casos en los que se detectaron excesos, es posible clasificar a los ministros de la SCJN en alguna de esas dos categorías. Así, los ministros que, abusando de la discrecionalidad, se sienten más cómodos convirtiendo casos de legalidad en casos de constitucionalidad pueden asociarse, sin generalizar, con el activismo; mientras que los que — también abusando

27 Atienza, Manuel, "Siete tesis sobre activismo judicial", tesis quinta, en http://lamiradadepeitho.blogspot.com/2018/10/siete-tesis-sobre-el-activismo-judicial.html. 
de la discrecionalidad - prefieren realizar la conversión inversa podrían asociarse con el formalismo.

Afirmo lo anterior, porque para el primer grupo de ministros la función del tribunal constitucional consiste precisamente en ensanchar el terreno de la constitucionalidad aprovechando la ductilidad del derecho, en pro de los derechos humanos y de los fines que persigue el llamado constitucionalismo. ${ }^{28}$ Por su parte, el segundo grupo tiende a colocar más casos en el terreno de la legalidad, porque supone que lo correcto es ceñirse a la aplicación de las fuentes formales del derecho, como la mejor garantía para preservar el orden jurídico, mediante la salvaguarda de los principios de seguridad y certeza jurídicas; asimismo, consideran como valioso reducir al mínimo el margen de discrecionalidad del juzgador o, en su defecto, utilizar esa discrecionalidad para transformar casos de constitucionalidad en casos de legalidad.

Con todo, es más sencillo detectar las credenciales teóricas de un jurista teórico que las de un jurista práctico, porque algunos de estos últimos o no tienen una clara conciencia de lo que significa ser, por ejemplo, formalista o activista, o bien sencillamente prefieren no hacerla explícita. Naturalmente, no pretendo generalizar, porque hay jueces, magistrados y ministros que también son académicos, y en algunos casos excepcionales llegan a tener más conciencia teórica que algunos colegas de la academia.

La falta de conciencia teórica, a su vez, se explica en gran medida por la deficiente formación y capacitación que por lo general tienen los opera-

28 Soy consciente de la ambigüedad del término "constitucionalismo", pero no es mi propósito despejarla en este trabajo. Optaré por el significado sugerido por Manuel Atienza, para quien se trata de una nueva concepción del derecho, cuyas principales notas características serían las siguientes: a) el derecho no es una realidad ya dada, sino una práctica social compleja que incorpora una pretensión de corrección o justificación; b) supone una mayor demanda de argumentación; c) implica cierto objetivismo valorativo; d) la interpretación debe ser entendida más como actividad que como producto; e) supone otorgar cierta prioridad al elemento valorativo del derecho sobre el autoritativo, y f) el razonamiento jurídico no puede ser insular, ya que tiene un componente moral y político, sin que estas tres esferas lleguen a confundirse. Atienza, Manuel, Curso de argumentación jurídica, Madrid, Trotta, 2013, pp. 29 y 30. Para no confundirlo con el "neoconstitucionalismo", véase Atienza, Manuel, "Ni positivismo jurídico ni neoconstitucionalismo. Una defensa del constitucionalismo postpositivista", Revista Argentina de Teoría Jurídica, Argentina, Universidad Torcuato di Tella, vol. 15, núm. 2, diciembre 2014, pp. 194 y ss. Asimismo, véase Pozzolo, Susana, "Neoconstitucionalismo y especificidad de la interpretación constitucional”, Doxa. Cuadernos de Filosofía del Derecho, núm. 21, vol. II, España, Universidad de Alicante, pp. 339-354.

Esta obra está bajo una Licencia Creative Commons Atribución-NoComercial-SinDerivar 4.0 Internacional, IIJ-UNAM. 
dores judiciales y sus equipos, con honrosas excepciones. La capacitación judicial de nuestros tiempos implica una orientación muy distinta a la de los programas tradicionales de formación jurídica basados exclusivamente en la memorización de textos y procedimientos, lo que contribuye a la perpetuación del formalismo. ${ }^{29} \mathrm{~A}$ mi juicio, conviene sembrar en los juristas prácticos una conciencia teórica que les permita entender mejor cuáles son los fines últimos de la práctica jurídica. Con una adecuada conciencia teórica podrían matizarse los excesos del formalismo y el activismo, y con ello podrían reconocerse en su justa dimensión los casos de legalidad y los de constitucionalidad. De este modo, la "legalidad forzada" y la "constitucionalidad forzada" no tendrían que ser categorías autónomas, sino más bien, casos aislados y excepcionalmente difíciles.

\section{Razones políticas}

No puedo dejar de mencionar que existen razones extrasistemáticas -que son las más preocupantes-, que influyen decididamente en el movimiento de la frontera entre legalidad y constitucionalidad. En México no es trivial que un amparo directo en revisión resulte procedente y, por ende, sea revisado por la Suprema Corte de Justicia de la Nación. La procedencia supone, por decir lo menos, un triunfo para los litigantes (que tendrán una buena razón para aumentar sus honorarios), aun cuando el asunto se pierda en el fondo.

Asimismo, la procedencia del recurso abre la posibilidad de cabildeo, es decir, de que los abogados accedan de manera informal a las oficinas de algunos ministros a "preguntar por su asunto". No es extraño ver por los pasillos de la Suprema Corte a litigantes, autoridades administrativas, militares y público en general solicitando "audiencia" a los ministros (situación que, dicho sea de paso no está — pero debería estar - prevista por la ley). Esta práctica se conoce como "alegato de oreja". ${ }^{30}$

Desgraciadamente, esta práctica está tan generalizada en la SCJN, ${ }^{31}$ que podríamos calificarla como "normal", ya que a casi nadie parece extrañarle,

\footnotetext{
29 Atienza, Manuel, "Siete tesis sobre activismo judicial", cit., tesis sexta.

30 Mayer-Serra Carlos Elizondo y Magaloni, Ana Laura, "El «alegato de oreja», inequidad y mediocridad”, Boletín Mexicano de Derecho Comparado, México, 2015.

31 Mención aparte merece la Sala Superior del Tribunal Electoral del Poder Judicial de la Federación, la otra alta corte mexicana, en donde, en un clima de transparencia, 
ni se conocen oposiciones serias al respecto. Así, recibir periódicamente en sus oficinas a litigantes y autoridades forma parte de las agendas de los ministros. Con todo, el alegato de oreja no es algo que cualquiera pueda lograr con facilidad, ya que acceder a un ministro depende de "buenas relaciones", de tener contactos, influencias; en fin, depende de condiciones objetivas de poder. En este sentido, no es de extrañarse que algunos asuntos de legalidad sean "convertidos" artificiosamente en temas de constitucionalidad, o viceversa. Y, naturalmente, esto no depende ni de las instituciones procesales ni de las preferencias teóricas de los ministros, sino de una forma laxa de entender la independencia judicial.

En efecto, existen al menos tres formas de entender la independencia judicial: como conjunto de garantías institucionales indispensables para el adecuado ejercicio de la función jurisdiccional, ${ }^{32}$ como virtud judicial ${ }^{33} \mathrm{y}$ como deber. ${ }^{34}$ La primera de ellas es la que impera en México, y es, por decir lo menos, débil, cuando no evidentemente falsa. La carrera judicial, la irreductibilidad salarial o la inamovilidad de los jueces son ciertamente condiciones necesarias, pero no suficientes, para que el ejercicio de la jurisdicción sea realmente independiente. Este conjunto de condiciones constituye, en todo caso, el marco institucional adecuado para ejercer la independencia, pero no es, sin más, la independencia; se trata más bien del autogobierno de

las visitas de los litigantes se han formalizado como genuinas audiencias, en las que las partes (no una sola, como en la Corte) acuden a ver a los magistrados y sus equipos para discutir sobre el asunto.

32 La jurisprudencia mexicana ha acuñado esa definición a través de varias tesis. Por todas, véase la número P./J. 115/2009, del Tribunal Pleno de la Suprema Corte de Justicia de la Nación, en la que se distinguen las siguientes garantías: 1) la idoneidad en la designación de los jueces y magistrados; 2) la consagración de la carrera judicial; 3) la seguridad económica de jueces y magistrados (remuneración adecuada, irrenunciable e irreductible); 4) la estabilidad o seguridad en el ejercicio del cargo, que comprende: a) la determinación objetiva del tiempo de duración en el ejercicio del cargo; b) la posibilidad de ratificación, y c) la inamovilidad judicial para los que hayan sido ratificados, y 5) la autonomía de la gestión presupuestal.

33 De acuerdo con el artículo 2 del Código Modelo Iberoamericano de Ética Judicial, de 2006, "el juez independiente es aquel que determina desde el Derecho vigente la decisión justa, sin dejarse influir real o aparentemente por factores ajenos al Derecho mismo".

34 La independencia es un deber del juez correlativo al derecho de los ciudadanos a ser juzgados desde el derecho. Aguiló Regla, Josep, "Independencia e imparcialidad de los jueces y argumentación jurídica”, Isonomía, Revista de Teoría y Filosofía del Derecho, México, núm. 6, abril de 1997, pp. 75-77. 
los jueces. ${ }^{35}$ Por desgracia, un sector importante de la judicatura mexicana identifica la independencia con estas garantías a favor y en beneficio de los jueces, al grado de considerarlas como auténticos derechos. ${ }^{36}$

Resulta un tanto inquietante que en la jurisprudencia mexicana que, como se sabe, es obligatoria para los jueces, no se haya recogido el concepto de independencia judicial contenido tanto en el Código Iberoamericano de Ética Judicial como en los Principios de Bangalore sobre conducta judicial, ambos suscritos por la SCJN. En estos documentos la independencia se entiende como una exigencia moral a los jueces o como un auténtico deber. ${ }^{37}$ Desde mi punto de vista, estos documentos contienen una mejor concepción de independencia judicial, tanto por sus conceptos como por su carácter normativo; sin embargo, al tratarse de soft law no han logrado permear adecuadamente en la conducta de la mayoría de los jueces.

Considero que la SCJN tiene la gran oportunidad de convertir en hard law tales contenidos mediante su jurisprudencia obligatoria, que es seguida fielmente por los jueces. Naturalmente, una de las reglas concretas mediante las cuales se podría cristalizar el principio de independencia judicial sería la de prohibir las entrevistas informales con los ministros, sin la presencia de ambas partes. O bien podrían regularse tales visitas mediante pautas claras y respetuosas del equilibrio procesal y la igualdad

\footnotetext{
35 Idem.

36 Ejemplo de ello son los amparos promovidos, en tiempos recientes, por los jueces en contra de la posible reducción salarial. Si van al amparo, es poque consideran que la irreductibilidad salarial es un derecho. Véase, por ejemplo: https://www.jornada.com. $m x / 2018 / 11 / 22 /$ politica/014n2pol.

37 El Código Iberoamericano de Ética Judicial señala: "Los «principios éticos» configuran el repertorio de las exigencias nucleares de la excelencia judicial, pero como tales pueden justificar diferentes normas en donde se especifiquen distintas conductas en relación a determinadas circunstancias. Así, por ejemplo, la independencia es inequívocamente uno de esos «principios», y desde ella es posible delinear normas que, de manera más concreta, modalicen conductas exigibles". Cfr. Cumbre Judicial IberoamericanaComisión Iberoamericana de Ética Judicial, Código Iberoamericano de Ética Judicial, disponible en http://www.poderjudicial.es/cgpj/es/CIEJ/Codigo-Iberoamericano-de-EticaJudicial/, p. 6. Por su parte, en el artículo 1.1. de los Principios de Bangalore se establece: "Un juez deberá ejercer su función judicial de forma independiente, partiendo de su valoración de los hechos y en virtud de una comprensión consciente de la ley, libre de cualquier influencia ajena, de instigaciones, presiones, amenazas o interferencias, sean directas o indirectas, provenientes de cualquier fuente o por cualquier razón". Comentario relativo a los Principios de Bangalore sobre la conducta judicial, Viena, Oficina de las Naciones Unidas contra la Droga y el Delito, UNODC, 2013, p. 36.
} 
de armas en el proceso. Mientras esto no suceda, las influencias de carácter político seguirán incidiendo en el movimiento irregular de la frontera entre legalidad y constitucionalidad.

\section{CONCLUSIONES}

1. El primer hallazgo de este trabajo es que la importancia y trascendencia de un asunto es considerada por la propia legislación como condición necesaria y suficiente de la procedencia del recurso de revisión en el amparo directo, y no como debería de ser: que dicha condición fuera la constitucionalidad en sentido propio. En efecto, de conformidad con las reglas del sistema, no basta con que se acredite cualquiera de dos requisitos conceptuales (constitucionalidad de normas generales o la interpretación directa de la Constitución), sino que resulta necesario que además el caso revista el carácter de importante y trascendente (requisito discrecional). A final de cuentas, es este último requisito el que permite "mover la frontera" hacia el terreno que los ministros prefieran: la legalidad o la constitucionalidad.

De este modo, la procedencia del recurso de revisión en el amparo directo no depende en realidad de que el tema sea genuinamente constitucional, sino sobre todo de que el caso sea considerado por la SCJN como importante y trascendente. La vaguedad de estos conceptos permite que los operadores jurídicos ejerzan una enorme discrecionalidad a la hora de seleccionar los casos. Una de las consecuencias de dicha discrecionalidad es que mediante una profusa emisión de criterios de jurisprudencia y aislados en México se ha creado una auténtica frontera móvil entre la legalidad y la constitucionalidad.

2. Un segundo hallazgo tiene que ver con la ambigüedad del término "legalidad". En sus inicios, el amparo no procedía en contra de sentencias emitidas por los tribunales ordinarios, es decir, no existía el llamado amparo judicial o amparo casación (el actual amparo directo). A partir del famoso "amparo Vega", en el que la SCJN llevó a cabo una interpretación del artículo 14 de la Constitución de 1857, nació un tipo de control constitucional, consistente en vigilar la "exacta" aplicación de la ley, que terminó llamándose control de legalidad. Con el tiempo, todos los juicios del país terminaron federalizándose mediante el amparo casación, lo cual provocó un enorme rezago en la SCJN. Para paliarlo, se crearon los tribunales colegiados, mediante una reforma constitucional (1987-1988), los 
que se encargaron desde entonces de los amparos-casación (actualmente llamados amparos directos).

No obstante, a la Corte se le permitió revisar, en una segunda instancia, algunos amparos directos que tuvieran ciertas características extraordinarias, a saber: aquellos en los que se hubiera reclamado la constitucionalidad de una norma general o en los que se realizara alguna interpretación directa de la Constitución. Es aquí donde nacen las cuestiones "propiamente constitucionales", en contraste de las "cuestiones constitucionales impropias" o de legalidad. Consecuentemente, en México los conceptos legalidad y constitucionalidad se prestan a distintas confusiones. Por legalidad se entiende: a) conformidad entre leyes y actos, y b) un tipo de control constitucional, vía amparo directo, mediante el cual se detectan vicios in iudicando que producen violaciones a la Constitución; mientras que por constitucionalidad, se entiende: c) cuestiones propiamente constitucionales (constitucionalidad de normas generales e interpretación directa de la Constitución), y d) cuestiones de constitucionalidad impropia, que coinciden con las cuestiones de legalidad identificadas con la letra b).

3. Otro aspecto importante a destacar es que la movilidad de la frontera no es inocua, ya que pone en entredicho el principio de justicia formal, dado que, de hecho, no siempre se trata de la misma forma a seres pertenecientes a una misma categoría: los quejosos. Esta situación, si bien no constituye un ilícito típico, sí puede calificar como uno atípico (un fraude a la ley), en el que lo que se viola no es una regla sino un principio: el de igualdad.

4. En cuarto lugar, en el Semanario Judicial de la Federación existen cuatro - y no dos - categorías de casos relacionadas con la procedencia del recurso de revisión en el amparo directo; a saber: 1) cuestiones propiamente constitucionales; 2) cuestiones de mera legalidad; 3) cuestiones de constitucionalidad forzada, y 4) cuestiones de legalidad forzada. Las dos primeras representan las zonas de claridad de uno y otro concepto, mientras que las restantes, la zona de penumbra. La movilidad de la frontera, se insiste, no es algo baladí, ya que muchos asuntos que la Corte no debiera resolver, los termina resolviendo, con lo cual se aleja de la aspiración de consolidarse cono un auténtico tribunal constitucional; por el contrario, cuando deja de resolver asuntos que tenía la obligación de atender, incumple su misión como tribunal protector de derechos o defensor de la Constitución. 
5. En quinto lugar, detecté dos causas que generan la movilidad de la frontera: 1) el comportamiento de los ministros asociado a sus preferencias teóricas, y 2) algunas razones políticas. La primera causa tiene que ver con las preferencias y el grado de conciencia teórica de los ministros que han venido integrando la SCJN. La jurisprudencia de la Corte revela un comportamiento teóricamente heterogéneo, derivado naturalmente de las preferencias de cada uno de sus miembros. Ello no tendría nada de particular - al contrario, nos hablaría de un sano pluralismo - si no se detectaran - en no pocas ocasiones - excesos y errores derivados del uso ideológico de determinadas concepciones, tales como el formalismo y el activismo. La segunda causa es de carácter político. No podemos cerrar los ojos ante la evidente influencia que desde el exterior condiciona, o al menos influye, en las decisiones sobre procedencia o improcedencia de un amparo directo en revisión. Esas decisiones no dependen únicamente del talento académico o del dominio del método jurídico del operador, sino también de los factores reales de poder - especialmente económicos y políticosque inciden en algunas decisiones de la Corte, ante una débil concepción de independencia judicial. Más que entenderla como un auténtico deber o como una virtud judicial, la independencia judicial es entendida como una serie de garantías, beneficios, o incluso "derechos" a favor del juez. Nada más alejado de la realidad, puesto que tales garantías no son sino el marco institucional adecuado para que los jueces ejerzan su independencia. Más que un derecho o un privilegio, la independencia es un deber correlativo al derecho de los ciudadanos a ser juzgados estricta y exclusivamente desde el derecho.

6. Más allá de los anteriores hallazgos, conviene preguntarnos: ¿qué reflexiones se derivan de todo lo anterior? En primer lugar, conviene preguntarnos cómo debería ser la procedencia del recurso de revisión en aras de paliar la desigualdad que actualmente se genera a causa de la discrecionalidad. ¿Debería eliminarse toda posibilidad de que la SCJN resolviera cuestiones de legalidad, como se pretendió inicialmente, mediante la eliminación de la cláusula de la importancia y trascendencia? O, por el contrario ¿debería permitirse que la SCJN decidiera libremente qué tipo de asunto, sin importar si es de legalidad o de constitucionalidad?

Soy consciente de que la solución que llegara a elegirse debería perseguir una mayor estabilidad en el sistema, es decir, un modelo normativo que disminuyera razonablemente el grado de indeterminación para que, por regla general, los casos seleccionados para ser analizados de fondo 
por la SCJN fueran del mismo tipo. La estabilidad de un sistema jurídico depende en gran medida de la seguridad, que por regla general refleja la aplicación del derecho en la resolución de los conflictos sociales. Los casos excepcionales siempre y en todos lados seguirán existiendo, pero hay buenas razones para preocuparse cuando la excepcionalidad prevista por el propio sistema crece de forma irracional.

7. Una segunda reflexión tiene que ver con los cambios legislativos que necesita la legislación sobre el juicio de amparo. Uno de los múltiples ajustes urgentes son reglas claras sobre la procedencia del amparo directo en revisión. Una fórmula que se ha discutido recientemente para paliar ese problema por algunos ministros (Aguilar Morales, Ortiz Mena o el ministro en retiro Cossío Díaz) es el establecimiento de un mecanismo de selección discrecional y no recurrible de asuntos relevantes a cargo de la propia Corte, a manera de certiorari. Quizá no sea descabellado tratar de emular lo que les ha funcionado a las altas cortes de algunos países como Estados Unidos, España, Colombia o Argentina. Con ello, la Corte mexicana resolvería el problema de la oscuridad de los criterios para elegir, y se dedicaría en exclusiva a generar una doctrina constitucional propiamente dicha, lo cual traería beneficios incuestionables, tales como la disminución del formalismo, la consolidación de la supremacía constitucional, el fortalecimiento del sistema de precedentes, el aumento de la coherencia en sus decisiones, el crecimiento de la certeza y la seguridad jurídica y, en general, una mejor defensa de los valores constitucionales.

8. En tercer lugar, es preciso mejorar la capacitación de los operadores judiciales y sus equipos. La capacitación judicial propia del paradigma constitucionalista implica una orientación muy distinta a la de los programas tradicionales de formación jurídica basados casi exclusivamente en la memorización de textos y procedimientos. A mi juicio, conviene sembrar una conciencia teórica en los juristas prácticos que les permita entender mejor cuáles son los fines últimos de la práctica jurídica.

9. Finalmente, resulta indispensable repensar la idea de jurisprudencia, que, como sabemos, en nuestro país está muy lejos de ser un genuino sistema de precedentes. Las reglas jurisprudenciales se multiplican cada día, formando un universo inabarcable, y no siempre coherente, que se suman al ya de por sí extenso conjunto de leyes y tratados. El principal problema de nuestra jurisprudencia es que las reglas son abstractas, es decir, separadas de los hechos que originaron el conflicto, que se aplican por los jueces 
sin haber constatado la analogía entre el caso que originó la regla y el caso que va a resolverse con ella.

\section{BIBLIOHEMEROGRAFÍA}

Aguiló Regla, Josep, “Independencia e imparcialidad de los jueces y argumentación jurídica”, Isonomía. Revista de Teoría y Filosofía del Derecho, México, núm. 6, abril de 1997.

AtIENZA RodríGUEZ, Manuel, "Siete tesis sobre activismo judicial", 2018, disponible en: http://lamiradadepeitho.blogspot.com/2018/10/ siete-tesis-sobre-el-activismo-judicial.html.

ATIENZA RodRÍGUEZ, Manuel, "Ni positivismo jurídico ni neoconstitucionalismo. Una defensa del constitucionalismo postpositivista", Revista Argentina de Teoría Jurídica, Argentina, Universidad Torcuato di Tella, vol. 15, núm. 2, diciembre 2014.

AtienZA Rodríguez, Manuel, Curso de argumentación jurídica, Madrid, Trotta, 2013.

Atienza Rodríguez, Manuel y Ruiz Manero, Juan, Ilícitos atípicos, Madrid, Trotta, 2000.

Código Iberoamericano de Ética Judicial, publicación en línea: http:// www.poderjudicial.es/cgpj/es/CIEJ/Codigo-Iberoamericano-de-EticaJudicial/.

FAVOREAU, Louis, Legalidad y constitucionalidad. La constitucionlización del derecho, traducción de Magdalena Correa Heano, Bogotá, Universidad Externado de Colombia, Instituto de Estudios Constitucionales Carlos Restrepo Piedrahita, 2000.

FIX-FIERRO, Héctor, "El amparo judicial y la «imposible tarea» del Poder Judicial de la Federación. Perspectivas en el centenario de la Constitución de Querétaro", en FERRER MAC-GREGOR, Eduardo y HERRERA GARCÍA, Alfonso (coords.), El juicio de amparo en el centenario de la Constitución mexicana de 1917, t. I, México, UNAM, Instituto de Investigaciones Jurídicas, 1917.

FIX-ZAMUDIO, Héctor, "El amparo mexicano como instrumento protector de los derechos humanos", en Garantías jurisdiccionales para la defensa de los derechos, México, UNAM, 1993. 
GONZÁLEZ OropeZA, Manuel, "El amparo en negocios judiciales. El caso de Manuel Vega", Anuario Mexicano de Historia del Derecho, vol. X, México, 1998.

Mayer-Serra, Carlos Elizondo y Magaloni KerPel, Ana Laura, "El «alegato de oreja» inequidad y mediocridad", Boletín Mexicano de Derecho Comparado, México, 2015.

Oficina de las Naciones Unidas CONTRA la DROGA Y El Delito (UNODC), Comentario relativo a los Principios de Bangalore sobre la conducta judicial, Viena, 2013.

Perelman, Chaïm y OlBretchs-TyteCA, Lucie, Tratado de la argumentación. La nueva retórica, traducción de Julia Sevilla Muñoz, Madrid, Gredos, 1989.

Pozzolo, Susana, "Neoconstitucionalismo y especificidad de la interpretación constitucional", Doxa 21, vol. II, España, Universidad de Alicante, 1998.

Pou GiMÉnEZ, Francisca, "El nuevo amparo mexicano y la protección de los derechos: ¿ni tan nuevo ni tan protector?”, Anuario de Derechos Humanos, Santiago, Centro de Derechos Humanos de la Facultad de Derecho de la Universidad de Chile, 2014.

RABASA, Emilio, El artículo 14 y el juicio constitucional, México, Porrúa, 1993.

Suprema CoRTE de Justicia de la NACión, Informe Anual de Labores, presentado por el ministro presidente, Luis María Aguilar Morales en diciembre de 2016, disponible en: https://www.scjn.gob.mx/sites/default/ files/informe_labores_transparencia/version/2016-12/IN FORME\%20 MINISTRO\%20PRESIDENTE\%202016.pdf.

Suprema Corte de Justicia de la NAción, Acuerdo General número 9/2015, de ocho de junio de dos mil quince, del Pleno de la Suprema Corte de Justicia de la Nación, que establece las bases generales para la procedencia y tramitación de los recursos de revisión en amparo directo, disponible en: http://dof.gob.mx/nota_detalle.php? codigo $=5396550$ \&fech $a=12 / 06 / 2015$.

SERNA DE LA GARZA, José María, "El amparo-casación en el pensamiento de Emilio Rabasa”, en GonZÁlez MARTíN, Nuria (comp.), Estudios jurídicos en homenaje a Marta Morineau, t. I: Derecho romano. Historia del derecho, México, UNAM, Instituto de Investigaciones Jurídicas, 2006. 
SHAPIRO, Scott, Legality, The Belknap Press of Harvard University Press, 2011. Existe una versión castellana: Legalidad, traducida por Diego M. Papayannis y Lorena Ramírez Ludeña, Madrid, Marcial Pons, 2014.

Fecha de recepción: 1 de octubre de 2019.

Fecha de aceptación: 16 de enero de 2020. 


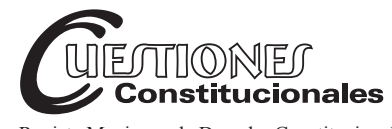

Revista Mexicana de Derecho Constitucional Núm. 43, julio-diciembre 2020

\title{
Hacia una sistematización de los usos semánticos del concepto de dignidad humana en la protección internacional de derechos humanos: una revisión doctrinaria*
}

\author{
Towards a systematization of the semantic uses of the concept \\ of human dignity in the international protection of human rights: \\ a doctrinal review
}

\section{Jorge Nicolás LAFFERRIERE** Helga LELL***}

\begin{abstract}
RESUMEN: este artículo se enmarca en un proyecto de investigación que indaga en la multiplicidad semántica que reviste el término "dignidad" en los casos contenciosos y en las opiniones consultivas de la Corte Interamericana de Derechos Humanos. Ello implica partir de la hipótesis de que dicha variedad de significados existe, y de que el análisis de este tópico es relevante, por cuanto permite clarificar el impacto de las posturas tomadas sobre la concreción de derechos.
\end{abstract}

ABSTRACT: This article is part of a research project that analyzes the semantic variety that have been provided to the term "dignity" in cases and opinions of the InterAmerican Court of Human Rights. This implies departing from the hypothesis that this variety of meanings exists and that the study of this topic is relevant because it allows clarifying the impact of the positions taken on concreting rights.

* Este trabajo se enmarca en el PICTO-UCA 2017-0032 “El concepto de Dignidad Humana según la Corte Interamericana de Derechos Humanos. Análisis de los casos contenciosos y de las opiniones consultivas", cofinanciado por ANPCyT y UCA (Argentina). Los aportes de los integrantes del equipo de investigación han hecho este trabajo posible.

** Pontificia Universidad Católica Argentina, Facultad de Derecho, director del proyecto PICTO 2017-0032; profesor titular ordinario. Universidad de Buenos Aires, Facultad de Derecho, profesor regular adjunto. Argentina. ORCID: 0000-0003-2600-2226 Correo electrónico: jorgelafferriere@derecho.uba.ar.

*** CONICET; Universidad Nacional de La Pampa, Facultad de Ciencias Económicas y Jurídicas, Centro de Investigación en Ciencias Jurídicas. Argentina. Integrante del proyecto PICTO 2017-0032. Argentina. ORCID:0000-0001-7703-634. Correo electrónico: helgalell@cpenet.com.ar. 
El trabajo que aquí presentamos constituye una primera aproximación al estado de la cuestión a partir de una revisión de las posiciones doctrinarias respecto de qué significados puede tener el término "dignidad", con especial referencia a las normas e interpretación jurisprudencial en el ámbito de los derechos humanos. Esta revisión es útil para realizar una propuesta de sistematización y clasificación de esos posibles usos para futuros trabajos de investigación jurisprudencial.

Palabras clave: dignidad, Corte Interamericana de Derechos Humanos, semántica, sistematización.
The paper we present here constitutes a first approach to the state of the matter from a review of the doctrinal positions regarding which meanings the term "dignity" may have. To do so, we emphasize in norms and jurisprudence in the matter of human rights. This review is useful in order to make a proposal for systematization and classification of these possible uses for future research work.

Keywords: dignity, Inter-American Human Rights Court, semantics systematization.

\begin{abstract}
SUMARIO: I. Introducción. II. La noción de "dignidad" en los documentos de protección de derechos humanos. III. Estudios doctrinarios sobre el uso de la dignidad en los cuerpos normativos. IV. Los usos de la dignidad por el Tribunal Europeo de Derechos Humanos. V. Estudios doctrinarios sobre la dignidad en el sistema interamericano de derechos humanos. VI. Estudios sobre los usos de la dignidad por los tribunales nacionales. VII. Una propuesta de sistematización de los usos de la dignidad. VIII. Consideraciones finales. IX. Referencias bibliográficas.
\end{abstract}

\title{
I. INTRODUCCIÓN
}

En el derecho internacional de los derechos humanos, la noción "dignidad humana" ocupa un lugar central. El sistema interamericano de derechos humanos (en adelante "Sistema IDH") no es una excepción, y la dignidad es mencionada en los más importantes cuerpos normativos. A pesar de ello, la forma abstracta en la que se enuncia pareciera dar lugar a una falta de claridad en lo que quiere denotarse mediante este término. Aunque su uso es constante, el significado de esta unidad lingüística sería un campo de crecientes disputas — que, además, muchas veces no parecieran ser conscientes o intencionales-. 
Este artículo se enmarca en un proyecto de investigación que indaga en la multiplicidad semántica que reviste el término "dignidad" en los casos contenciosos y en las opiniones consultivas de la Corte Interamericana de Derechos Humanos (en adelante, Corte IDH). Por supuesto, ello implica partir de la hipótesis de que dicha variedad de significados existe, y de que el análisis de este tópico es relevante, por cuanto permite clarificar el impacto de las posturas tomadas sobre la concreción de derechos. El proyecto de investigación se orienta a contribuir con una sistematización de los distintos significados que recibe la expresión "dignidad humana" en los usos por parte de la Corte IDH y la realización de una propuesta hermenéutica superadora que dé unidad a la utilización argumentativa del termino. Al ser un valor fundante, el hecho de que su semántica no sea clara generaría un problema en la comprensión de los derechos vigentes en el sistema, y, por ello, reclama un estudio sistemático del lugar que ocupa la dignidad humana en el discurso jurídico de la Corte IDH.

Las dificultades en la aplicación de la noción de dignidad, por la disparidad de criterios en torno a su significado, han generado una fuerte tensión en torno a su alcance y utilidad. ${ }^{1}$ Para Waldron, no es sorprendente que haya disenso sobre la caracterización de la dignidad, y ello no menoscaba la idea de que dicho valor es fundamento de derechos humanos, pues considera que se trata de un proceso o trabajo en elaboración que nos lleva a prestar atención a preguntas sobre los derechos. ${ }^{2}$ En tal sentido, no ingresaremos aquí en el debate de fondo sobre el fundamento de la dignidad. ${ }^{3}$

En ese contexto, el trabajo que aquí presentamos constituye una primera aproximación al estado de la cuestión a partir de una revisión de las

1 Calo, Zacharie "Human Dignity and Health Law: Personhood in recent bioethical debates", Notre Dame Journal Laaw Ethics \& Pub, vol. 1, núm. 2, 2012, pp. 473-499; Dilley, Stephen y Palpant, Nathan, Human Dignity in Bioethics: From Worldviews to the Public Square, Londres, Routledge, 2012; Andorno, Roberto, "The Paradoxical Notion of Human Dignity”, Rivista Internazionale di Filosofia del Diritto, vol. 78, núm. 2, 2001, pp. 151-168; Kateb, George, Human Dignity, Cambridge, Harvard University Press, 2011; Meltzer Henry, Leslie, "The Jurisprudence of Dignity", University of Pennsylvania Law Review, vol. 160, núm. 1, 2011, pp. 169-233.

2 Waldron, Jeremy, “Is Dignity the Foundation of Human Rights?”, NYU School of Law, Public Law Research Paper, 12-73, 2013, pp. 1-30.

3 Sobre este tema remitimos a otros estudios: Herrera, Daniel, La persona y el fundamento de los derechos humanos, Buenos Aires, EdUCA, 2012, pp. 333-337; Massini Correas, Carlos Ignacio, Filosofía del Derecho, I - El derecho, los derechos humanos y el derecho natural, 2a. ed., Buenos Aires, Lexis-Nexis, 2005, pp. 138-141. 
posiciones doctrinarias respecto de qué significados puede tener el término "dignidad", con especial referencia a las normas e interpretación jurisprudencial en el ámbito de los derechos humanos. Ello contribuye a comprender la complejidad del tema, no sólo para el sistema interamericano, sino para todo tipo de estudio o aplicación jurídica que involucre a esta noción. De esta manera, las próximas páginas anticipan las clasificaciones que distintos autores han postulado a la luz de la interpretación de documentos jurídicos internacionales y constitucionales.

En una primera instancia, nos detendremos en una rápida enumeración acerca de cómo la noción de "dignidad" aparece en los principales instrumentos de derechos humanos. En segundo término, efectuaremos el recorrido por las presentaciones doctrinarias referidas a los usos de la dignidad en general, distinguiendo los estudios centrados en el análisis de los cuerpos normativos, y los estudios que se dedican al Tribunal Europeo de Derechos Humanos, al sistema interamericano de derechos humanos y a los tribunales nacionales. Esta revisión del estado de la cuestión nos servirá para realizar una propuesta de sistematización y clasificación de esos posibles usos para futuros trabajos de investigación jurisprudencial.

\section{LA NOCIÓN DE “DIGNIDAD” EN LOS DOCUMENTOS DE PROTECCIÓN DE DERECHOS HUMANOS}

La noción de "dignidad" aparece en gran parte de los documentos tutelares de derechos humanos a nivel internacional, ${ }^{4}$ tanto en aquellos que poseen naturaleza vinculante para los Estados parte como para aquellos que constituyen soft law. A continuación, nos detendremos brevemente en algunos de los principales instrumentos en los diferentes sistemas.

En el marco del sistema universal de los derechos humanos, la dignidad es mencionada en diversas oportunidades con un sentido semejante: como un elemento propio de la naturaleza humana. Ya en la Carta de las Naciones Unidas 5 aparece mencionada en el preámbulo cuando reafirma "la fe en los derechos fundamentales del hombre, en la dignidad y el valor de la

4 Gros Espiell, Héctor, "La dignidad humana en los instrumentos internacionales sobre derechos humanos", Anuario de Derechos Humanos, nueva época, 4, 2003, pp. 193-223.

5 ONU, Carta de las Naciones Unidas (San Francisco, 1945), disponible en https:// www.un.org/es/charter-united-nations. 
persona humana, en la igualdad de derechos de hombres y mujeres y de las naciones grandes y pequeñas". En la Declaración Universal de Derechos Humanos, ${ }^{6}$ aparece en el preámbulo, al señalarse que la libertad, la justicia y la paz tienen por base el reconocimiento de la dignidad intrínseca de los seres humanos, y que los pueblos de las Naciones Unidas han reafirmado su fe en la dignidad de la persona humana. Por otro lado, en el artículo 1 se establece que todos los seres humanos nacen libres e iguales en dignidad; en el artículo 22 se menciona a la dignidad como una guía para la satisfacción de derechos económicos, sociales y culturales, y en el artículo 23, como un estándar al cual adecuar los derechos sociales y laborales. Por otro lado, en el Pacto Internacional de Derechos Civiles y Políticos, ${ }^{7}$ en el Pacto Internacional de Derechos Económicos, Sociales y Culturales, ${ }^{8}$ en la Convención Internacional sobre las Personas con Discapacidad ${ }^{9}$ y en la Convención Internacional sobre los Derechos del Niño ${ }^{10}$ la dignidad figura como una nota inherente al ser humano.

En el sistema europeo, en el artículo 26 de la Carta Social Europea, ${ }^{11}$ se la menciona como una nota del trabajo, y en el preámbulo, en el título I (artículos 1 a 5$)^{12}$ y artículo 31 de la Carta de los Derechos Fundamentales de la Unión Europea, ${ }^{13}$ como una característica propia del ser humano. ${ }^{14}$ Por otro lado, en el Convenio Europeo para la Protección de los Derechos

6 ONU, Declaración Universal de Derechos Humanos, 1948, disponible en: https:// www.un.org/es/universal-declaration-human-rights.

7 ONU, Pacto Internacional de Derechos Civiles y Politicos, 1976, disponible en: https://www.ohchr.org/SP/ProfessionalInterest/Pages/CCPR.aspx.

8 ONU, Pacto Internacional de Derechos Económicos, Sociales y Culturales, 1976, disponible en: https://www.ohchrorg/SP/ProfessionalInterest/Pages/CESCR.aspx.

9 ONU, Convención Internacional sobre los Derechos de las Personas con Discapacidad, 2006, disponible en: https://www.un.org/esa/socdev/enable/documents/tccconvs. $p d f$.

10 ONU, Convención Internacional sobre los Derechos del Niño, 1989, disponible en: https://www.un.org/es/events/childrenday/pdf/derechos.pdf.

11 Consejo de Europa, Carta Social Europea (Estrasburgo, 1961), disponible en: https://www.acnur.org/fileadmin/Documentos $/$ BDL/2002/1934.pdf?file $=t 3 /$ fileadmin $/$ Documentos/BDL/2002/1934.

12 Este título se denomina "Dignidad", y el artículo 1 se refiere específicamente a la dignidad humana.

13 Unión Europea, Carta de los Derechos Fundamentales de la Unión Europea, 2000, disponible en: http://www.europarl.europa.eu/charter/pdf/text_es.pdf.

14 Cabe destacar que el artículo 31 se refiere a la dignidad humana del trabajador. 
Humanos y de las Libertades Fundamentales,${ }^{15}$ este término no aparece, aunque sí es mencionado en los considerandos del Protocolo núm. 13, relativo a la abolición de la pena de muerte en cualquier circunstancia, ${ }^{16} \mathrm{con}$ el mismo sentido que el de la Carta de Derechos Fundamentales.

En el sistema africano, la Carta Africana sobre Derechos Humanos y de los Pueblos ${ }^{17}$ se refiere a la dignidad en su preámbulo en dos oportunidades. En la primera de ellas, menciona que la dignidad (no especifica si se aplica al ser humano como individuo, a condiciones de desarrollo o a las comunidades) es un objetivo esencial para la realización de las legítimas aspiraciones de los pueblos africanos. En la segunda, claramente hace alusión a una nota de los pueblos africanos que luchan "por su dignidad y genuina independencia". Por otro lado, este mismo documento, en el artículo 5, se refiere a la dignidad humana como propiedad de los individuos. La Carta Africana sobre los Derechos y el Bienestar del Niño ${ }^{18}$ menciona a la dignidad en seis oportunidades, todas ellas como un elemento inherente del ser humano y como un valor intangible.

Asimismo, en el sistema americano de tutela de los derechos humanos, en el preámbulo de la Declaración Americana de los Derechos y Deberes del Hombre, ${ }^{19}$ se menciona que todos los hombres nacen libres e iguales en dignidad y derechos, y que si los derechos exaltan la libertad individual, los deberes expresan la dignidad de dicha libertad. Finalmente, en el artículo XXIII se menciona el derecho a la propiedad privada en el marco de una vida decorosa que contribuya a mantener la dignidad de la persona. Para Quintana, “desde una perspectiva filosófica política, pero

15 Consejo de Europa, Convenio Europeo para la Protección de los Derechos Humanos y de las Libertades Fundamentales, 1950, disponible en: https://www.echr.coe.int/ Documents/Convention_SPA.pdf.

16 Consejo de Europa, Protocolo núm. 13 al Convenio para la Protección de los Derechos Humanos y de las Libertades Fundamentales, relativo a la abolición de la pena de muerte en cualquier circunstancia, 2002, disponible en: https://www.echr.coe.int/Documents/Convention_SPA.pdf.

17 Organización para la Unidad Africana, Carta Africana sobre Derechos Humanos $y$ de los Pueblos, 1981, disponible en: https://www.acnur.org/fileadmin/Documentos/ BDL/2002/1297.pdf.

18 Organización para la Unidad Africana, Carta Africana sobre los Derechos y el Bienestar del Niño, 1990, disponible en: https://www.acnur.org/fileadmin/Documentos/ BDL/2010/8025.pdf?view.

19 OEA, Declaración Americana de los Derechos y Deberes del Hombre, 1948, disponible en: http://www.oas.org/es/cidh/mandato/Basicos/declaracion.asp. 
también jurídica, su Preámbulo es un paradigma de sociabilidad difícil de superar". ${ }^{20}$

Por su parte, en el marco de la Convención Americana sobre Derechos Humanos ${ }^{21}$ el término "dignidad" aparece como una nota inherente al ser humano en el marco del derecho a la integridad personal (artículo 5), al mencionar que ésta no debe ser afectada por el trabajo forzoso (artículo 6) y al establecer el derecho a su reconocimiento (artículo 11). Ferrer MacGregor y Pelayo Möller señalan que

si bien en el Preámbulo de la CADH no hay una referencia explícita a la dignidad de la persona humana, fácilmente puede advertirse que este es el sentido de la justificación de los derechos de la Convención a la que se hace referencia en las expresiones "fundado en el respeto a los derechos esenciales del hombre", "los derechos esenciales del hombre no nacen del hecho de ser nacional de determinado Estado" y "tienen como fundamento los atributos de la persona humana". ${ }^{22}$

El Protocolo Adicional a la Convención Americana sobre Derechos Humanos en materia de Derechos Económicos, Sociales y Culturales ${ }^{23}$ menciona a la dignidad en el preámbulo al garantizar su reconocimiento en relación con los derechos económicos, sociales y culturales, por un lado, y los civiles y políticos, por el otro, y en el artículo 13, al remarcar que la educación debe capacitar para lograr una subsistencia digna.

La Convención Interamericana para Prevenir y Sancionar la Tortura ${ }^{24}$ trae a colación la dignidad humana en el preámbulo, al reafirmar que todo acto de tortura o tratos crueles, inhumanos o degradantes constituyen ofensas a ella.

20 Quintana, Eduardo, "Dignidad y deberes humanos", Prudentia Iuris, vol. 83, núm. 2, 2017, p. 91.

21 OEA, Convención Americana sobre Derechos Humanos, 1969, disponible en: https://www.oas.org/dil/esp/tratados_b-32_convencion_americana_sobre_derechos_humanos.htm.

22 Mac-Gregor, Eduardo y Pelayo Möller, Carlos María, "Preámbulo", Convención Americana sobre Derechos Humanos comentada, ed. Christian Steiner y Patricia Uribe, 2014, p. 38.

23 OEA, Protocolo Adicional a la Convención Americana sobre Derechos Humanos en materia de Derechos Económicos, Sociales y Culturales, 1988, disponible en: https:// www.oas.org/juridico/spanish/tratados/a-52.html.

24 OEA, Convención Interamericana para Prevenir y Sancionar la Tortura, 1987, disponible en https://www.oas.org/juridico/spanish/tratados/a-51.html. 
La Convención Interamericana sobre Desaparición Forzada de Perso$\operatorname{nas}^{25}$ y la Convención Interamericana para la Prevención, Sanción y Erradicación de la Violencia ${ }^{26}$ mencionan, en sus respectivos preámbulos, que los delitos a los cuales se abocan constituyen graves ofensas a la dignidad. La Convención Interamericana para Prevenir, Sancionar y Erradicar la Violencia contra la Mujer ${ }^{27}$ menciona el término en tres oportunidades, en dos de ellas en relación con la dignidad como inherente a la naturaleza humana, y en una para hacer referencia a la dignidad de la mujer.

\section{ESTUDIOS DOCTRINARIOS SOBRE EL USO DE LA DIGNIDAD EN LOS CUERPOS NORMATIVOS}

La interpretación del término "dignidad" se presenta como un tema de actualidad y de decisiva significación para el derecho internacional de los derechos humanos. Según Shulztiner y Carmi, la dignidad humana es un concepto central del constitucionalismo posterior a la Segunda Guerra Mundial. ${ }^{28}$ Antes de 1945 sólo cinco países lo tenían en sus Constituciones (México, Weimar, Finlandia, Irlanda, y Cuba), y después de diciembre de 2012, ciento sesenta y dos países lo han incorporado; esto es, el $84 \%$ de los 193 que componen las Naciones Unidas (los primeros tres en incorporarlo fueron Alemania Occidental, Japón e Italia). Estos autores realizan un análisis cuantitativo y cualitativo del término "dignidad" en los textos constitucionales.

Además del estudio del uso del término a lo largo del tiempo, resulta interesante el análisis de las causas o influencias que dieron lugar al incremento del uso del término, entre las que los autores ubican la decisiva influencia de la Carta de las Naciones Unidas y la Declaración Universal de Derechos Humanos, la difusión de la democracia (120 países a fines

\footnotetext{
25 OEA, Convención Interamericana sobre Desaparición Forzada de Personas, 1994, disponible en: https://www.oas.org/juridico/spanish/tratados/a-60.html.

26 OEA, Convención Interamericana para la Prevención, Sanción y Erradicación de la Violencia, 1994, disponible en: https://www.oas.org/juridico/spanish/tratados/a-61.html.

27 OEA, Convención Interamericana para Prevenir, Sancionar y Erradicar la Violencia contra la Mujer, 1994, disponible en: http://www.corteidh.or.cr/sitios/libros/todos/ docs/documentosbasicos2018.pdf.

28 Shulztiner, Doron y Carmi, Guy, "Human Dignity in National Constitutions: Functions, Promises and Dangers", American Journal of Comparative Law, vol. 62, núm. 2, 2014, p. 461.
}

Esta obra está bajo una Licencia Creative Commons

Atribución-NoComercial-SinDerivar 4.0 Internacional, IJJ-UNAM. 
del siglo XX, o sea, el 63\%) y la caída de la cortina de hierro. Entre los motivos del trasplante del término se destacan su prestigio, la presión internacional, una cuestión de ahorro de tiempo, la situación poscolonial y los usos a nivel regional. También hay influencia de quienes no la usan: en especial Estados Unidos, Gran Bretaña y Francia.

Shulztiner y Carmi identifican tres usos de la dignidad en las distintas Constituciones:

a) Simbólico-declarativos: este uso se constata principalmente en preámbulos y declaraciones de principios, y la dignidad aparece como un valor general y un fundamento genérico de toda la Constitución y sin un significado operativo. Entre los ejemplos de este uso ubican a Brasil, Perú y Timor Oriental.

b) Guía para la implementación de derechos: señalan que en el articulado de las Constituciones la dignidad aparece vinculada con derechos para ofrecer una guía a los jueces en sus sentencias. Identifican: i. estipulaciones para preservar la dignidad de personas que tienen una restricción a su libertad (Armenia, Finlandia, Nicaragua, Malawi); ii. Cuestiones laborales (veintitrés países: Portugal, Cabo Verde, Angola, Mozambique, Colombia, Argentina, Paraguay, Costa Rica, Nicaragua, Ecuador, Dominicana, Corea del Sur); iii. Cuestiones vinculadas al bienestar (niños, ancianos, discapacitados) (Timor Oriental, Kenia, Venezuela, Bolivia).

c) Guía para la limitación de derechos: los autores entienden que, en un uso propio de países no democráticos o de países subdesarrollados, se utiliza la dignidad como una fuente de deberes de los ciudadanos. Entienden que es un uso "no liberal" ('illiberal'). Como ejemplos mencionan el Líbano: "La educación es libre en la medida que no interfiera con la dignidad de ninguna religión o credo"; Laos, que utiliza la dignidad para cortapisar el derecho de libre expresión cultural y de los medios de comunicación; Mozambique, que dice que el ejercicio de los derechos está regulado por la ley, que debe velar por la dignidad de la persona humana. Algunos países de la ex-URSS la utilizan para limitar el derecho de propiedad. Israel, Canadá y Alemania la utilizan para restringir el derecho de libre expresión. China, Corea del Norte y Sierra Leona establecen deberes hacia el Estado basados en la dignidad. Bahrain, Kuwait y Tanzania establecen el deber de trabajar de los ciudadanos fundado en la dignidad. 
Para Lucy Michael, las distintas definiciones de dignidad son complementarias, y pueden reconducirse a dos categorías: la dignidad inherente, que es una cualidad o valor que pertenece a todo ser humano sin admitir diferencias, y la dignidad no inherente, que es una condición adquirida y variable según las circunstancias o el comportamiento de una persona. ${ }^{29}$

La dignidad ocupa un lugar central en la Declaración Universal de Derechos Humanos. Entre los muchos autores que se refieren al tema cabe mencionar a Mary Ann Glendon, quien destaca la Declaración como el más importante punto de referencia para la discusión intercultural sobre la libertad y la dignidad humanas en el mundo actual. ${ }^{30}$

En cuanto al término "dignidad" en la Declaración Universal de Derechos Humanos, Glendon resalta el hecho de que en ella la noción en cuestión es considerada como "inherente", es "reconocida", al igual que los derechos, y no concedida, que los seres humanos nacen libres e iguales, dotados de razón y conciencia. Ante la pregunta de si la Declaración tiene un valor último y fundante, Glendon responde que el candidato obvio para tal valor es la dignidad humana, que goza de un lugar de privilegio en el texto: es afirmada al inicio del preámbulo antes que los derechos, tiene prioridad en el artículo 1, y es mencionada en otras tres partes claves. Aunque luego aclara que los redactores de la Declaración eran conscientes de que el principio de la dignidad no poseía una inmunidad especial contra su potencial deconstrucción, y que ningún documento estaba exento del peligro de la manipulación. ${ }^{31}$

En el sistema europeo de derechos humanos, la dignidad ha sido objeto de varios estudios a pesar de que la Convención Europea de Derechos Humanos no contiene expresamente el término "dignidad" en su articulado. En cambio, la Carta de Derechos Fundamentales de la Unión Europea (Carta de Niza, 2000) comienza afirmando en su artículo primero: "La dignidad humana es inviolable. Será respetada y protegida".

Un estudio de relevancia es el realizado por Malvestiti, ${ }^{32}$ quien desarrolla la evolución histórica del concepto de dignidad humana: en una prime-

29 Michael, Lucy, "Defining Dignity and Its Place in Human Rights", The New Bioethics, vol. 20, núm. 1, 2014, pp. 12-34.

30 Glendon, Mary Ann, "Knowing the Universal Declaration of Human Rights", The Notre Dame Law Review Review, vol. 73, núm. 5, 1998, 1153-1190 (p. 1153).

31 Idem.

32 Malvestiti, Bárbara, La dignità umana dopo la "Carta di Nizza”, Napoli-Salerno, Orthotes Editrice, 2015. 
ra etapa, asociada a las edades antigua y medieval, implicaba atribuir una cualidad a alguien que se distinguía del resto; una segunda etapa se inicia con Kant, en el siglo XVIII, donde se la concibe como una característica intrínseca del hombre en cuanto a la racionalidad, como un concepto moral que sigue implicando una distinción entre los seres humanos. Por último, a partir del siglo XX, el concepto de dignidad humana ingresa al ámbito jurídico cuando se pasó del plural (dignidades) al singular "dignidad", entendida como una cualidad intrínseca que pertenece a todo ser humano indistintamente. Así, la dignidad desde el punto de vista jurídico ingresó de la mano de la "igualdad". Para esta autora, la dignidad implica la negación del orden jerárquico, no admite grados, y no se necesita ninguna característica para definirse como un ser portador de dignidad, tan sólo la pertenencia al género humano. Es una dignidad "no relacional".

De acuerdo con Malvestiti, en la Carta de Niza hay tres significados del término "dignidad": como valor, como principio y como derecho. A su vez, desde el punto de vista de la interpretación jurídica, considera que la dignidad puede tener dos sentidos: como fundamento del derecho y como derecho. Finalmente, entiende que hay tres conceptos de dignidad que provienen desde afuera del derecho, pero que informan la interpretación jurídica: dignidad de la persona (implica tutela de la persona, tutela de la humanidad y límite a la autonomía); dignidad social y dignidad del individuo.

Esta autora entiende que la dignidad humana debe considerarse una "norma suprema" del ordenamiento jurídico, y ello puede plasmarse a su vez de tres formas: primero, como norma material suprema; segundo, como norma axiológica suprema fruto del acuerdo de los intérpretes, y tercero, como norma axiológica suprema in re. Para cada modo de concreción la autora muestra regulaciones jurídicas de diferentes Estados y jurisprudencia. ${ }^{33}$

En el marco del sistema interamericano, aunque desde una reflexión predominantemente iusfilosófica, Ilva Myriam Hoyos constata tres modos en que las normas jurídicas y los doctrinarios hacen referencia a la dignidad: 1) la dignidad funcional, es decir, aquella que refiere al merecimiento que corresponde a una persona por los papeles o funciones que desempeña o por las acciones que realiza en la sociedad; 2) la dignidad referida a la autonomía, de raíz kantiana, que adopta una perspectiva moral, y que coin-

\footnotetext{
33 Idem.
} 
cide con la libertad del hombre de hacer uso de su propia razón y determinar el sentido de sus actos responsablemente, y 3) la dignidad referida al ser, entendida como la eminencia que corresponde a la persona, es decir, quien subsiste en una naturaleza que de suyo dice perfección. ${ }^{34}$

Otro estudio, que involucró dieciséis países, advierte que términos como "dignidad humana", "dignidad de todos los miembros de la familia humana", "dignidad individual", "dignidad persona", "dignidad de los seres humanos" y "vida digna", son usados en forma alternativa o acumulativa, sin especificar las razones de su elección. La autora entiende que aunque no hay único significado del término, hay un interés universal en él, porque es capaz de promover y apoyar distintos tipos de reclamos, y ello ofrece una riqueza que es importante para el derecho e incluso la bioética. ${ }^{35}$ Este trabajo destaca cuatro usos de la dignidad como instrumento: i) declarativo para condenar la tiranía de los Estados; ii) para asegurar la efectividad de los derechos subjetivos; iii) para la transformación social; iv) para restringir la libertad. ${ }^{36}$

\section{LOS USOS DE LA DIGNIDAD POR EL TRIBUNAL Europeo DE DERECHOS Humanos}

El término "dignidad", además de figurar en cuerpos normativos, también es utilizado por diferentes instituciones judiciales, en donde los inconvenientes sobre la pluralidad semántica se replican. Así como en el proyecto de investigación en el que este artículo se enmarca se parte de la hipótesis de la no claridad en el uso del concepto, diferentes trabajos académicos describen un fenómeno similar en el Tribunal Europeo de Derechos Humanos (en lo sucesivo, TEDH).

Cabe agregar que existen aproximaciones a este fenómeno desde diferentes perspectivas, que van desde la mirada hermenéutica, ${ }^{37}$ hasta las preocupaciones por la concreción de la protección de los derechos que

\footnotetext{
34 Hoyos Castañeda, Ilva Myriam, De la dignidad y de los derechos humanos, Bogotá, Universidad de la Sabana, 2005.

35 Feuillet-Liger, Brigitte, "The Case for a Limited Use of Dignity as a Legal Principle”, Ius Gentium, núm. 71, 2018, pp. 292 у 293.

36 Idem.

37 Klatt, Matthias, "Juristische Hermeneutik", Handbuch Rechtshilosophie, J. B. Metzler, 2017, pp. 224-230. 
hacen a la dignidad humana, ${ }^{38}$ pasando por otras, como el análisis de las formas de coordinación que se da en el proceso de integración europeo, de manera tal que los organismos supraestatales no arrasen con la soberanía nacional sin por ello dejar de tutelar la dignidad, ${ }^{39}$ o la propuesta de una dimensión interpretativa europea como garantía de $\operatorname{los}$ derechos ${ }^{40}$ y el rol constitucional en los Estados europeos del concepto de dignidad. ${ }^{41}$ Por su parte, otro estudio que tiene como eje el sistema europeo señala tres aspectos de la dignidad que son relevantes jurídicamente: la obligación de respeto, la prohibición de tratar a otros como objetos y la prohibición de relaciones de dominación desproporcionadas entre seres humanos, por su igualdad ontológica. ${ }^{42}$

En cuanto a la multiplicidad de significados, Costa afirma que el TEDH recurre habitualmente a la dignidad como fundamento de su razonamiento legal, y analiza la dignidad en relación con la jurisprudencia a partir de los distintos derechos enunciados en la Convención Europea de Derechos Humanos. Este autor distingue el uso positivo del uso negativo. El primero utiliza la dignidad para reforzar un razonamiento que lleva a sostener la violación de un derecho de la Convención. El segundo, en cambio, recurre a la dignidad para rechazar planteos o pretensiones basados en argumentos que son en sí mismos contrarios a la dignidad. ${ }^{43}$

Un estudio de importancia es el que realizaron Kuteynikov y Boyashov, quienes analizaron 86,000 documentos relacionados con la $\mathrm{CEDH}$

38 Grabenwarter, Christoph y Struth, Katharina, "Justiz-und Verfahrensgrundrechte", en Ehlers, D. (ed.), Europäische Grundrechte und Grundfreiheiten, Göttingen, De Gruyter, 2014, pp. 198-236; Wallace, Helen, "Die Dynamik des EU-Institutionengefüges”, en Jachtenfuchs, M. y Kohler-Koch, B. (ed.), Europäische Integration, Springer Verlag, 2003, pp. 255-285.

39 Fischer, Joschka, "Vom Staatenverbund zur Föderation - Gedanken über die Finalität der europäischen Integration”, Intergation, vol. 23, núm.3, 2000, pp. 149-156.

40 Franzius, Claudio, "Die Europäische Dimension des Gewährleistungsstaates”, Der Staat, vol. 45, núm.4, 2006, pp. 547-581.

41 Federmann, Falco, Die Konstitutionalisierung der Europäischen Union. Überlegungen vor dem Hintergrund des andauernden europäischen Verfassungsprozesses, Köln, Eul Verlag, 2007.

42 Pereira-Menaut, Antonio-Carlo y Pereira-Sáez, María Carolina "Human Dignity and European Constitutionalism. Flatus Vocis or Ratio Decidendi?", Ius Gentium, vol. 52, 2016, pp. 215-234.

43 Costa, Jean-Paul, "Human Dignity in the Jurisprudence of the European Court of Human Rights”, en Understanding Human Dignity, Oxford, British Academy, 2013. 
(sentencias, decisiones, comunicaciones, opiniones consultivas y sumarios legales) publicados desde 1949 hasta 2015, de los cuales 1937 (1.9\%) contenían el término "dignidad". ${ }^{44}$ Según estos autores, el primer caso donde hubo referencia a la dignidad data de 1958, aunque los casos que sí la mencionan durante el siglo XX no superan los doce por año. Los autores constatan un notable incremento de sentencias que mencionan la dignidad a partir de 2000, con un promedio de cien decisiones por año que contienen la palabra "dignidad" entre 2004 y 2014. Las violaciones a la dignidad que fueron motivo de decisión del TEDH se vinculan con los siguientes temas: discriminación por razón de género, etnia o religión; malos o degradantes tratos para presos o personas internadas en hospitales; limitaciones en la libertad de elección del paciente; violaciones del honor y la reputación; trabajos forzados y extradición, expulsión y deportación..$^{45}$

Un estudio particularmente interesante por el efecto que menciona respecto del uso del concepto de dignidad sobre la concepción de los derechos clasificados como absolutos y relativos es el de Grewe, quien se enfoca en las técnicas legales utilizadas para invocar y proteger la dignidad en la jurisprudencia del TEDH. ${ }^{46}$ Desde el inicio, aclara que, en su parecer, la dignidad se invoca especialmente para forjar, fortalecer o ampliar un derecho, pero escasas veces o, más bien, nunca para limitar o "volverse" contra el titular de la dignidad. Grewe basa su análisis en cómo la invocación de la dignidad ha ayudado a borrar la distinción entre derechos absolutos (no derogables, intangibles) y derechos relativos (típica en el contexto europeo por la diferente forma en la que están redactados los artículos que protegen unos y otros derechos en el Convenio Europeo, en el que los derechos relativos están sujetos a cláusulas de limitación).

En relación con derechos que considera "absolutos", como el derecho a la vida (artículo 2), la prohibición de la tortura y tratos inhumanos o degradantes (artículo 3) y la prohibición de la esclavitud, la servidumbre y el trabajo forzoso (artículo 4), afirma la autora que la invocación de la dignidad podría parecer evidente, "natural", e incluso inútil. Sin embargo, sostener esto implica apartarse de la promoción de esos derechos. Esta

44 Kuteynikov, Alexander y Boyashov, Anatoly, "Dignity Before the European Court of Human Rights", en Edward Sieh y Judy McGregor (eds.), Human Dignity: Establishing Worth and Seeking Solutions, London, Palgrave MacMillan UK, 2017, pp. 83-101.

45 Idem.

46 Grewe, Constance, "La dignité de la personne humaine dans la jurisprudence de la Cour européenne des droits de l'homme”, Revue générale du droit, 2014, pp. 1-12. 
última tiene que ver, por un lado, con la ampliación de la protección de los derechos por parte de la jurisprudencia. El alcance del artículo 3 del Convenio Europeo, por ejemplo, se extiende ahora a las extradiciones y a las deportaciones, a las condiciones de detención, al tratamiento de las personas con discapacidades mentales. Por otro lado, la promoción de estos derechos conlleva no sólo una obligación de los Estados de no interferir, sino además una pluralidad de obligaciones positivas. ${ }^{47}$ De esta manera, se sometería a estos derechos implícitamente a un control de proporcionalidad, lo cual los acerca a los derechos relativos. ${ }^{48}$

Por el contrario, la invocación de la dignidad humana en el caso de los derechos relativos (derechos contemplados en los artículos 8, 9, 10 y 11) puede sorprender, pues no parecen ser intangibles ni articular valores fundamentales. Además, la técnica de balancear los derechos en juego (propia del examen de proporcionalidad que se aplica a los derechos relativos) no encaja bien con el concepto de dignidad (que simboliza lo universal, lo inmanente, lo inmutable y objetivo). ${ }^{49}$

Según Grewe, para resolver disputas difíciles, nuevas, "sociales" y complejas, la dignidad humana resulta ser un argumento particularmente propicio en tanto ayuda a enriquecer los derechos o a poner énfasis en sus aspectos sociales. Este argumento suele aparecer en el ámbito del artículo 8 , de protección del hogar, de la vida privada y familiar. La vida privada se extiende a la autonomía de la persona, a su identidad, a los derechos de la personalidad. El hogar tiende a abarcar el derecho a no ser expulsado de la vivienda, al menos en situaciones de precariedad o de estigma racial o étnico.

Grewe sostiene que la invocación de la dignidad en estos casos -incluso en presencia de los derechos absolutos- es impredecible, azarosa, evolutiva. La autora critica el carácter aleatorio de la invocación de la dignidad, y lo relaciona con las doctrinas del margen nacional de apreciación y de consenso regional. Cuando, en su opinión, no existe consenso, el TEDH se niega a utilizar el concepto de dignidad para promover un derecho. Esto se aplica bastante extensamente a los derechos sociales y a las cuestiones relacionadas con el comienzo de la vida o la muerte. Esto no sólo plantea problemas de seguridad jurídica, de coherencia jurispru-

\footnotetext{
47 Idem.

48 Ibidem, p. 5.

49 Ibidem, p. 6.
} 
dencial y de calidad de la argumentación de la sentencia, sino que también crea una tensión adicional en relación con el concepto de la dignidad (Grewe, 2014, pp. 6 y 7).

Finalmente, Grewe analiza la función que cumple la dignidad con relación a la tarea judicial. Así, cuando se trata de la dignidad, el Tribunal debe realizar un arbitraje "horizontal" entre la dignidad y otros valores. Así, entiende que cuando está en juego un valor explícito, el Tribunal ha considerado que es mejor referirse a él directamente. Así, incluso en el caso sobre la negación del holocausto, el TEDH ha preferido centrar su razonamiento en la aplicabilidad del artículo 17 sobre los valores de la paz y de la justicia más que sobre la dignidad. A su vez, hay un arbitraje "vertical" entre el derecho europeo y el derecho nacional, la ley del Estado demandado y los derechos de los particulares, el margen de apreciación y las normas europeas. Se presume que la ley del Estado corresponde a las exigencias de una sociedad democrática. A priori, no hay por lo tanto ninguna razón para dudar de la corrección de la legislación nacional, y mucho menos para decir que no respeta la dignidad humana. Esto se refleja en el margen de apreciación nacional. No obstante, la misión del Tribunal de salvaguardar y de desarrollar los derechos humanos incluye la interpretación dinámica del Convenio, así como la corrección de las leyes nacionales cuando no han respetado suficientemente los derechos individuales. El pluralismo y el respeto de las minorías desempeñan un papel importante a este respecto y dan a la legislación europea su carácter evolutivo. La autora finaliza afirmando que los valores y, en primer lugar, la dignidad humana, intervienen para dar, si es posible, una dirección general a la casuística predominante. Esto hace que sea más fácil entender la naturaleza impredecible e impredecible de la llamada a la dignidad sin excluir la crítica del estado actual de cosas (Grewe, 2014, p. 11)

\section{ESTUDIOS DOCTRINARIOS SOBRE LA DIGNIDAD \\ EN EL SISTEMA INTERAMERICANO DE DERECHOS HUMANOS}

Para el estudio de los usos del término "dignidad" en el Sistema IDH, resulta insoslayable la referencia a Antonio Augusto Cançado Trindade, quien fuera juez y presidente de la Corte IDH, y quien ha publicado como editor un trabajo titulado El respeto a la dignidad de la persona huma- 
$n a .^{50}$ En esa obra, César Landa, expresidente del Tribunal Constitucional de Perú, desglosa las siguientes funciones constitucionales de la dignidad: función legitimadora; ordenadora; temporal; esencial; integradora; limitadora, y libertaria. ${ }^{51}$

También podemos mencionar el estudio de Luis Amezcua sobre la dignidad en la jurisprudencia de la Corte IDH. Este autor analiza los contextos en que el tribunal hizo referencia al concepto de dignidad humana y observa que hasta ese momento, los contextos estaban relacionados en su mayoría con hechos relativos al derecho a la vida, desapariciones forzadas, privación ilegal de la libertad y torturas. Comenta que también se la menciona en casos relacionados con las comunidades indígenas en cuanto a su derecho de circulación y derecho de propiedad, el caso de las minorías lingüísticas, personas con discapacidad mental y los casos atinentes a la violencia sexual. Aunque gran parte de los fallos hasta ese momento tenían que ver con la protección de los derechos civiles y políticos, ya se vislumbraba la inclusión en el debate de los derechos económicos, sociales y culturales. ${ }^{52}$

Sobre el punto que cierra el párrafo anterior, Ibáñez Rivas estudia la dignidad y los derechos económicos, sociales y culturales (DESC) en la jurisprudencia contenciosa de la Corte IDH. Allí, partiendo de la sentencia "Velázquez Rodríguez vs. Honduras", ${ }^{53}$ en que la Corte IDH sostiene que "los derechos humanos son atributos inherentes a la dignidad humana", sistematiza los fallos desde de la distinción entre "protección directa" e "indirecta" de los DESC. ${ }^{54},{ }^{55}$ Sobre la protección directa, a su vez, se re-

50 Cançado Trindade, Anotnio Augusto y Barros Leal, César (eds.), El respeto a la dignidad de la persona humana, Fortaleza, Instituto Brasileño de Derechos Humanos, 2015.

51 Landa, César, "Dignidad de la persona humana", en Cançado Trindade, Anotnio Augusto y Barros Leal, César (eds.), El respeto a la dignidad de la persona humana, Fortaleza, Instituto Brasileño de Derechos Humanos, 2015

52 Amezcua, Luis, "Algunos puntos relevantes sobre la dignidad humana en la jurisprudencia de la Corte Interamericana de Derechos Humanos", Revista Iberoamericana de Derecho Procesal Constitucional, vol. 8, 2007, pp. 339-355.

53 Corte IDH, caso Velásquez Rodríguez vs. Honduras. Reparaciones y costas, sentencia del 21 de julio de 1989, serie C, núm. 7.

54 Esta clasificación no será receptada en aquella que los autores hemos efectuado en el último apartado de este trabajo dado que apunta a cómo la dignidad es utilizada para proteger derechos y no se enfoca en los usos del término en sí.

55 Ibáñez Rivas, Juana María, "La dignidad humana y los derechos económicos, so- 
fiere al artículo 26 de la $\mathrm{CADH}$, por un lado, y a otros derechos humanos con "contenido dual" que permiten la protección directa. En cuanto a la protección indirecta, distingue entre la protección indirecta general y la protección específica de los DESC. ${ }^{56}$ Igualmente, aunque su foco está puesto en el fundamento de la argumentación de la Corte y su vinculación con la igualdad material, cabe señalar la investigación de Mary Beloff y Laura Clérico sobre el derecho a condiciones de existencia digna y la vulnerabilidad en la jurisprudencia de la Corte IDH ${ }^{57}$.

Por su parte, en el estudio de Bohórquez y Román se analizan cinco sentencias de la Corte IDH en torno a la dignidad, y se concluye que "la dignidad aparece no solo como un derecho o un principio reconocido en los tratados internacionales sino además renace como criterio de interpretación a favor del sentido más amplio de los derechos humanos", 58 aunque señalan que aún quedan preguntas sin resolver tanto en el nivel teórico como en una valoración crítica de la jurisprudencia de la Corte IDH. Estos autores identifican tres tensiones en torno al concepto de dignidad: a) entre su carácter natural y artificial; b) entre su carácter abstracto y concreto; c) entre su carácter universal y particular. ${ }^{59}$ Ello supone tres preguntas o paradojas conceptuales de la dignidad: ${ }^{60}$ a) ¿es la dignidad humana un aspecto natural de los seres humanos, o es, por el contrario, un aspecto consensual creado por la voluntad política y legislativa de los Estados?; b) ¿es la dignidad humana un valor abstracto o, por el contrario, es posible definirlo en relación con aspectos concretos de la vida humana?, y c) ¿es la dignidad humana un valor absoluto y universal o, por el contrario, es un

ciales y culturales en la Jurisprudencia contenciosa de la Corte Interamericana de Derechos Humanos", en Cançado Trindade, Antonio Augusto y Barros Leal, César (eds.), El respeto a la dignidad de la persona humana, Fortaleza, Instituto Brasileño de Derechos Humanos, 2015, pp. 183-212.

56 Bohórquez Monsalve y Román, op. cit.

57 Beloff, Mary y Clérico, Laura, "Derecho a condiciones de existencia digna y situación de vulnerabilidad en la jurisprudencia de la Corte InterAmericana", Estudios Constitucionales, vol.14, núm. 1, 2016, pp. 139-178.

58 Bohórquez Monsalve \& Román, op. cit., p. 59.

59 Esta clasificación tampoco es receptada en la que los autores ofrecemos al final de este artículo porque enfatizan en una disquisición filosófica más que en los usos del término.

60 Torralba, Francesc, ¿Qué es la dignidad humana? Ensayo sobre Peter Singer, Hugo Tristram Engelhardt y John Harris, Barcelona, Herder, 2005; Bohórquez Monsalve y Román, op cit. 
valor particular dependiente de contextos históricos, culturales e, incluso, individuales?

Estos autores entienden que, respecto a la tensión entre el carácter natural o consensual de la dignidad, la respuesta varía según se parta desde el iusnaturalismo o del iuspositivismo. Para el iusnaturalismo, la dignidad es un rasgo natural del hombre, que lo tiene por el solo hecho de serlo y desde el momento de la concepción. Es una dignidad dada al hombre por la propia naturaleza o por Dios, independientemente de los accidentes de cada uno. Por el contrario, desde el punto de vista iuspositivista, la dignidad humana aparece como algo artificial, dada en forma consensual por los hombres. La dignidad sería una ficción política, moral y jurídica, realizada para mantener la paz y hacer posible la convivencia entre los hombres.

Respecto al carácter abstracto o concreto de la dignidad, estos autores entienden que hay un concepto abstracto de dignidad que implica considerarla un fin en sí mismo. Así, remiten a Kant, quien sostenía que todo ser humano con razón y libertad para seguir los imperativos morales está dotado por ese hecho de dignidad humana universal. Para los autores, este concepto está vacío de contenido y puede generar problemas a la hora de instrumentarlo en la práctica (por ejemplo, para ciertos trabajos, nivel de educación, etcétera), pues carece de contenido práctico. Por su parte, el concepto concreto, en cambio, ofrece a la dignidad humana aspectos más precisos y con más nivel de verificación; por ejemplo: la libertad de escoger la profesión implica también la garantía de recibir una remuneración justa por ella. Este concepto permite una aplicación práctica. Tiene que ver con la necesidad de que toda definición de dignidad humana pueda relacionarse claramente con aspectos concretos de la misma dignidad humana. En la dignidad humana está presente la idea del buen vivir: nadie aceptaría que fuera definida únicamente en términos formales y abstractos.

Finalmente, el carácter universal de la dignidad humana implica considerar que existe una sola dignidad aplicable a todo individuo, en todo tiempo y lugar. El problema es que si relacionamos este concepto con la idea del buen vivir se daría lugar a una contradicción, ya que para cada cultura "buen vivir" significa algo distinto. Por otro lado, el carácter particular de la dignidad humana consiste en considerar la existencia de muchas dignidades, una para cada grupo social y cultural. Este concepto atiende a las necesidades de cada persona en particular. ${ }^{61}$

61 Bohórquez Monsalve y Román, op. cit.

Esta obra está bajo una Licencia Creative Commons Atribución-NoComercial-SinDerivar 4.0 Internacional, IIJ-UNAM. 


\section{ESTUDIOS SOBRE LOS USOS DE LA DIGNIDAD POR LOS TRIBUNALES NACIONALES}

La doctrina se ha ocupado también de los usos de la dignidad por tribunales nacionales. Uno de los autores más influyentes en este tema es McCrudden, quien elabora un "contenido mínimo" de la dignidad que entiende incluye tres elementos: i) que todo ser humano posee un valor intrínseco, por el solo hecho de ser humano; ii) que este valor intrínseco debe ser reconocido y respetado por otros, y que algunas formas de trato por otros son inconsistentes, o son requeridas, por ese valor intrínseco; iii) reconocer el valor intrínseco de cada individuo requiere entender que el Estado existe para el bien del ser humano individual y no a la inversa. ${ }^{62}$ Este autor constata las diferencias en las concepciones de dignidad en la interpretación judicial, sobre todo entre las concepciones más individualistas y las comunitaristas, sobre el peso y el estatus de la dignidad, sobre la dignidad como soporte de derechos o como limitación de derechos, sobre la posibilidad de renunciar a la dignidad, sobre la dignidad de quién debe considerarse, y sobre quién debe juzgar o proteger la dignidad. ${ }^{63} \mathrm{Con}$ todo, McCrudden se muestra escéptico de que la dignidad pueda servir como base para alcanzar un consenso sustantivo sobre la noción de derechos humanos, en razón del carácter abierto y no específico que tiene el término, de la posibilidad de que sea manipulable y de su aparente universalidad que oculta la importancia de los distintos contextos culturales para determinar su contenido. ${ }^{64}$ Este autor rescata el uso institucional que tiene la dignidad en tanto proporciona un lenguaje en el que los jueces pueden aparecer justificando cómo resuelven tópicos tales como el balance de derechos, la aplicación a nivel local de los derechos y la generación de nuevos derechos. ${ }^{65}$

Rao tiene dos importantes trabajos sobre el tema. En el primero se refiere al uso y el abuso de la dignidad en el derecho constitucional, ${ }^{66} \mathrm{y}$ en

62 McCrudden, Christopher, "Human Dignity and Judicial Interpretation of Human Rights", European Journal of International Law, vol.19, núm. 4, 2008, p. 679.

63 Idem.

64 Ibidem, p. 710.

65 Ibidem, p. 724.

66 Rao, Neomi, "On the Use and Abuse of Dignity in Constitutional Law", Columbia Journal of European Law, 2008, pp. 201-256. 
un posterior estudio señala tres grandes conceptos de dignidad por la revisión de las sentencias de cortes constitucionales: la dignidad como valor inherente a cada individuo independiente de su inteligencia, moralidad o estatus social; la dignidad como expresión de valores sustantivos que se vinculan con formas de vida y conductas en una comunidad (como cuando las cortes en Francia prohíben el espectáculo del lanzamiento de personas enanas), y finalmente el uso de la dignidad como reconocimiento y respeto que implica la comprensión de la pluralidad individual a la luz de los diferentes colectivos que puede integrar un sujeto. ${ }^{67}$

Por su parte, Barroso sistematiza cuatro usos diferentes de la dignidad en la jurisprudencia: como valor fundamental, como principio constitucional, como fuente de derechos y obligaciones y como criterio de interpretación. ${ }^{68}$

Carozza, quien fuera presidente de la Comisión IDH entre 2008 y 2009, considera que el consenso no puede ser un determinante decisivo del mínimo contenido que corresponde al principio de la dignidad humana, y enfatiza la importancia del diálogo sobre el contenido sustantivo de la dignidad, sin quedarse en aspectos meramente procedimentales. ${ }^{69}$

Por su parte, Meltzer Henry identifica cinco concepciones de dignidad en la jurisprudencia de la Corte Suprema de Estados Unidos: ${ }^{70}$ la dignidad como estatus institucional (rango y jerarquía); la igualdad como dignidad; la libertad como dignidad; la integridad personal como dignidad, y la virtud colectiva como dignidad. La dignidad como estatus institucional es un concepto que depende de la existencia de jerarquía social, y se lo utiliza para naciones extranjeras y Estados, en relación con su inmunidad y la imposibilidad de ser llevados a juicio. La dignidad como igualdad se presenta como intrínseca y universal, no contingente. La expresión habitual es la "igual dignidad" de los seres humanos, y su uso ha sido fundante de la jurisprudencia antidiscriminatoria. La dignidad como libertad se presenta como contingente, y se posee en la medida en que se es capaz de tomar

67 Rao, Neomi, “Three Concepts of Dignity in Constitutional Law", Notre Dame Law Review, 2011, pp. 183-272.

68 Barroso, Luis Roberto, "Here, There, and Everywhere: Human Dignity in Contemporary Law and the Transnational Discourse", Boston College International and Comparative Law Review, vol. 35, 2012, pp. 331-393.

69 Carozza, Paolo, "Human Dignity and Judicial Interpretation of Human Rights: A Reply”, European Journal of International Law, vol.19, núm. 5, 2008, pp. 931-944.

70 Meltzer Henry, op. cit. 
decisiones con autonomía. Se la ha usado para legitimar decisiones personales individuales en temas controversiales vinculados con la sexualidad y la vida. La dignidad como integridad personal se vincula con la teoría de la virtud, y tiene que ver con la integridad como condición para perfeccionarse. Se ha utilizado para proteger la reputación y evitar tratos o intrusiones degradantes o humillantes (por ejemplo, la realización de un allanamiento de forma intrusiva y violenta o la obligación de realizar un análisis de orina de trabajadores de ciertas empresas con otra persona al lado escuchando). Finalmente, la dignidad como virtud colectiva está relacionada con la totalidad de la vida humana en una determinada sociedad, y su protección puede llegar a limitar la autonomía personal, en favor de la dignidad o de la virtud colectiva. Se ha usado contra la tortura, la práctica de arrojar enanos, la prostitución, la esclavitud, la pena de muerte, las condiciones carcelarias, y la práctica del aborto por nacimiento parcial. ${ }^{71}$ Este autor sigue la teoría lingüística de Wittgenstein, según la cual hay lenguajes naturales y otros referenciales (como la geometría), entendiendo que solo estos últimos pueden tener significados fijos. Considera que la dignidad entonces no es un concepto, sino muchas concepciones, que varían de acuerdo con el contexto. Y para saber cuáles son esas concepciones, hay que estudiar cómo se usa el término en el lenguaje.

Otra investigación publicada en el contexto norteamericano es la de Goodman, quien estudia la dignidad en la jurisprudencia constitucional de la Corte Suprema de los Estados Unidos y se refiere a ella como un "valor constitucional", que subyace ante algunos reclamos constitucionales, y propone estándares para determinar cuándo las demandas de la dignidad deben prevalecer. $^{72}$

También podemos mencionar a Jackson, para quien la dignidad funciona como un concepto básico unificador que se vincula tanto con las garantías de los derechos y libertades civiles negativos como con los conceptos positivos de derechos humanos para alcanzar adecuadamente las necesidades básicas de la vida. ${ }^{73}$

En un trabajo de 2017, Shulztiner aborda los desafíos que plantea el concepto de dignidad humana para la toma de decisiones judiciales, y pro-

\footnotetext{
71 Idem.

72 Goodman, Maxine, "Human Dignity in Supreme Court Constitutional Jurisprudence”, Nebraska Law Review, 2006, pp. 740-794.

73 Jackson, Vicki, "Constitutional Dialogue and Human Dignity: States and Transnational Constitutional Discourse”, Montana Law Review, V. 65, 2004, pp. 15-40.
} 
pone cuatro principios para su uso en tal ámbito: usar el concepto con estricta relación a la ley escrita; definir el concepto y su significado en las sentencias; ser consistentes en el uso del concepto en presentes y futuras decisiones, y usar el concepto únicamente para el progreso de los derechos humanos. ${ }^{74}$

Glensy indaga sobre el sentido del "derecho a la dignidad" en el contexto de Estados Unidos de América, y enuncia cuatro teorías sobre los usos de este concepto: el enfoque de los derechos positivos, que considera a la dignidad como un derecho sustantivo accionable; el de los derechos negativos (o de no interferencia), de modo que la dignidad funciona como una norma de soporte; el enfoque de refuerzo, en virtud del cual la dignidad tiene un uso heurístico para reforzar otros derechos, y el enfoque expresivo, en el que la dignidad es presentada como un valor retórico. ${ }^{75}$

En Canáda, Goubau considera que hay un uso muy frecuente y creciente del término "dignidad humana" en la legislación y la jurisprudencia, y encuentra las siguientes connotaciones del término: como un elemento de la estima personal que debe ser respetado por otros; como un límite a ciertas acciones, fundado en la común humanidad y la dignidad como expresión de la autonomía individual. ${ }^{76}$

En el contexto alemán de posguerra, el concepto de dignidad humana ha sido fundamental, ya que ha sido incorporado al artículo 1 de la Constitución (también conocida como "Ley Fundamental de Bonn") luego de los horrores de la Segunda Guerra Mundial. ${ }^{77}$ En la literatura italiana se destacan los trabajos del profesor Viola ${ }^{78}$ y la profesora Malvestiti, ${ }^{79}$ entre otros. ${ }^{80}$

74 Shulztiner, Doron, "Human Dignity in Judicial Decisions: Principles of Application and the Rule of Law", Cardozo Journal of International and Comparative Law, vol. 25, 2017, pp. 435-481.

75 Glensy, Rex, “The Right to Dignity”, Columbia Human Rights Law Review, vol. 43, 2011, pp. 65-142.

76 Goubau, Dominique, "Dignity in Canadian Law, a Popular but Ambiguous Notion”, Ius Gentium, vol. 71, 2018, pp. 191-201.

77 Broß, Siegfried, "Die Würde des Menschen bleibt unantastbar", en Robertson-von Trotha, Caroline., 60 Jahre Grundgesetz Nomos, 2009, pp. 41-51.

78 Viola, Francesco, "Lo statuto normativo della dignità umana", en Abignente, Angelo y Scamardella, Francesca (eds.). Dignità della persona. Riconoscimento dei diritti nella società multiculturali, Napoli, Editoriale Scientifica, 2013, pp. 283-295.

79 Malvestiti, op. cit.

80 Becchi, Paolo, "Dignità umana", en Pomarici, Ulderico (cur.), Filosofia del diritto. 
En Inglaterra, a pesar de ser un país sin una Constitución escrita o una tradición de codificación, los tribunales han invocado la dignidad con relación a los derechos de los presos y la condena perpetua; en materia laboral, con relación a la dignidad del empleado y las condiciones de trabajo, y en relación con la no discriminación, por orientación sexual ${ }^{81}$ En este sentido, Callus distingue dos grandes usos: la dignidad como principio de respeto por el intrínseco valor de cada ser humano, y la dignidad como principio al servicio de los derechos subjetivos, con particular referencia a la vida privada y la calidad de vida. Según este autor, en los últimos tiempos en ese país se ha pasado de una visión más comunitaria de la dignidad hacia una visión más liberal. ${ }^{82}$

En España, podemos mencionar un trabajo que profundiza en la dignidad como "valor constitucional" explícitamente presente en el artículo 10.1 de la Constitución, afirmando que ha cumplido tres funciones: una función fundamentadora del orden político, una función promocional y una función hermenéutica. ${ }^{83}$

La producción académica francesa también incluye trabajos de investigación sobre la dignidad similares a los aquí propuestos, entre los que se destacan el de Burgorgue-Larsen — centrado en la dignidad según los jueces europeos, de tribunales tanto domésticos como regionales de derechos humanos— ${ }^{84}$ Otros artículos científicos exploran el concepto de la

Concetti fondamentali, Torino, Giappichelli, 2007, pp. 153-181; Mastropietro, Andrea. "Diritto e dignità umana", Rivista internazionale di Filosofia del Diritto, V.2, 2010, 241261; Berardo, Fiammeta, "La dignitá umana è intangibile. il dibattito costituente sull 'art. 1 del Grundgesetz", Quaderni costituzionali, 2006, pp. 387-398; Mattioni, Angelo, "Profili costituzionali della dignità umana", Jus, 2008, pp. 251-291; Monaco, Giuseppe, "La tutela della dignità umana: sviluppi giurisprudenziali e difficoltà applicative", Politica del diritto, 2011, pp. 45-77; Piciocchi, Cinzia, La dignità come rappresentazione giuridica della condizione umana, Padova, CEDAM, 2013; Rolla, Giancarlo, "Il valore normativo del principio della dignità umana. Brevi considerazioni alla luce del costituzionalismo iberoamericano", Diritto pubblico comparato ed europeo, 2003, pp. 1870-1880.

81 Callus, Thérèse "Towards a Libertarian Application of Dignity in English Law: A Case Law Analysis", Ius Gentium, V.71, 2018, pp. 129-140.

82 Callus, op. cit.

83 Batista Jiménez, Fernando, "La dignidad de la persona en la Constitución española: naturaleza jurídica y funciones", Cuestiones Constitucionales. Revista Mexicana de Derecho Constitucional, 2006, pp. 3-20.

84 Burgorgue-Larsen, Laurence, La dignité saisie par les juges en Europe, Anthemis, 2011. 
dignidad de un modo más general, como concepto jurídico ${ }^{85}$ Finalmente, unos más lo consideran en relación con aspectos específicos. ${ }^{86}$

Barak profundiza en el uso del término "dignidad" en la Corte Suprema de Israel, y distingue la dignidad como valor constitucional de la dignidad como derecho constitucional. ${ }^{87}$ Ahora bien, en cuanto derecho constitucional, Barak señala el problema del "solapamiento" de la dignidad con otros derechos y trata de identificar el área que cubre la dignidad, para distinguirla del contenido de los otros derechos. Explica Barak que para la Corte Suprema de Israel la dignidad es un derecho que enmarca a otros derechos o un "derecho-madre" ("framework right" y "mother-right"). ${ }^{88}$

Un estudio publicado en 2018 da cuenta de los usos de la dignidad en China, y concluye que se trata de un concepto controvertido por razones semánticas vinculadas con las distintas traducciones del término. La dignidad personal mencionada en leyes positivas no puede ser entendida como un principio constitucional que sirva de base al régimen político o como principio fundante del ordenamiento jurídico, y en los tribunales la dignidad viene protegida como parte del derecho al honor o un derecho general a la personalidad. ${ }^{89}$

En el plano regional, podemos citar el trabajo de Chávez-Fernández Postigo, quien analiza algunas sentencias del Tribunal Constitucional peruano en torno a la forma de concebir la dignidad como fundamento de los derechos humanos. En el estudio, constata que el Tribunal Constitucional reconoce el fundamento de los derechos humanos en la dignidad humana, pero también concibe a la dignidad como un derecho autónomo. El jurista peruano señala que dado que "la dignidad es portadora de un contenido ético-jurídico amplio que incluye el de todos los derechos fundamentales -implícitos y explícitos - que sustenta y la expresan”, parece difícil jus-

85 Fierens, Jacques, "La dignité humaine comme concept juridique", Journal des tribunaux, 2002, p. 577-582; Menke, Christoph, "De la dignité de l'homme à la dignité humaine : le sujet des droits de l'homme", Revue franco-allemande de sciences humaines et sociales, V. 3, 2009, pp.1-20.

86 Maubernard, Christophe, "Le droit fondamental à la dignité humaine en droit communautaire: la brevetabilité du vivant à l'épreuve de la jurisprudence de la Cour de Justice", Revue trimestrielle des droits de l'homme, V. 54, 2003, pp. 483-513.

87 Barak, Aharon, "Human Dignity: The Constitutional Value and the Constitutional Right", Proceedings of the British Academy, V. 192, 2013, pp. 361-380.

88 Idem.

89 Zhang, Li, "The Emergence of Human Dignity in China: from a Private Right to a Constitutional Principle”, Ius Gentium, V. 71, 2018, pp. 231-244. 
tificar ese contenido autónomo. También observa que el Tribunal entiende a la dignidad desde dos concepciones que aparecen en tensión o antagonismo: la idea de una mera autonomía con cierta raigambre kantiana y la idea de una dignidad referida al ser u ontológica. ${ }^{90}$

En Argentina, podemos mencionar el trabajo de Estela Sacristán, quien luego de una pormenorizada recorrida por las menciones al término "dignidad" en el ordenamiento jurídico argentino analiza los usos que hace la CSJN sobre el término, tomando como eje las acepciones del término brindadas por el Diccionario de la lengua española:

(i) cualidad de digno (entendiéndose, por digno, merecedor de algo); correspondiente, proporcionado al mérito y condición de alguien o algo; que tiene dignidad o se comporta con ella; propio de la persona digna; que puede aceptarse o usarse sin desdoro, es decir, sin menoscabo en la reputación o el prestigio (salario digno, vivienda digna); de calidad aceptable; (ii) excelencia, realce; (iii) gravedad y decoro de las personas en la manera de comportarse; (iv) cargo o empleo honorífico y de autoridad; (v) en las catedrales y colegiatas, prebenda $-v$. gr., beneficio eclesiástico — que corresponde a un oficio honorífico y preeminente; prebenda del arzobispo u obispo; (vi) en las órdenes militares de caballería, cargo de maestre, trece, comendador mayor, clavero, etc. ${ }^{91}$

\section{UNA PROPUESTA DE SISTEMATIZACIÓN DE LOS USOS DE LA DIGNIDAD}

Luego de esta revisión de las clasificaciones sobre los usos de la dignidad que realizan los distintos autores, ya sea en su análisis de los cuerpos normativos como de los usos que realizan los tribunales, internacionales o nacionales, esbozamos a continuación una propuesta de sistematización, que constituye la base para el futuro análisis de los usos del término que realiza la Corte IDH, siguiendo cuatro criterios: a) dignidad en función del sujeto o elemento impersonal; b) dignidad en relación con la ponderación

90 Chávez Fernández Postigo, José, La dignidad como fundamento de los derechos humanos en las sentencias del Tribunal Constitucional peruano: la tensión entre la mera autonomía y la libertad ontológica, Lima, Palestra, 2012.

91 Sacristán, Estela, "El concepto de dignidad humana en la jurisprudencia de la Corte Suprema de Justicia de la Nación”, Prudentia Iuris, núm. 84, 2017, p. 44. 
en la implementación de derechos; c) dignidad en torno a la concepción del individuo; d) según el rol de la dignidad. Se trata de criterios que no necesariamente se excluyen, y que pueden resultar complementarios según el uso que se haya dado al término "dignidad".

\section{Dignidad en función del sujeto o elemento impersonal}

Una primera distinción sobre los usos de la dignidad se vincula al sujeto del que se predica la cualidad de "digno". En tal sentido, podemos distinguir los siguientes usos:

- La dignidad como estatus institucional: se aplica a cargos, Estados, personas jurídicas en general. Meltzer refiere a los orígenes del término "dignidad" en la antigua Roma, y cómo se vinculaba con las posiciones más destacadas en la jerarquía social. También señala la recepción de este uso en el lenguaje en Inglaterra en 1225 vinculado con el rango y la jerarquía. ${ }^{92}$ Tal origen permite comprender este uso que, aunque suele aparecer en diferentes documentos normativos, no es relevante a la hora de ver la relación con los derechos. Sin embargo, no puede obviarse por cuanto su inclusión permite ver en qué medida aparece (si es que se utiliza) o si ha sido dejado de lado por la Corte IDH.

- La dignidad como nota de las personas humanas: es el uso preponderante en los documentos internacionales de derechos humanos. Puede ser intrínseca o ser reconocida o atribuida en virtud de otra fuente según se explicite y según el criterio en torno a la concepción del individuo.

- La dignidad aplicada a otros elementos, que no son personas humanas, personas jurídicas o cargos. En este uso podemos ubicar el caso de la dignidad de los muertos en el fallo Comunidad Moiwana vs. Suriname de la Corte IDH (2005). Este uso puede ser de utilidad para observar cómo la concepción de este término puede ampliarse para receptar otras visiones culturales en la aplicación de derechos que podrían ser caracterizados como "occidentales".

92 Meltzer Henry, op. cit. 


\section{Dignidad en relación con la ponderación} en la implementación de derechos

Tomando como criterio el uso en relación con la ponderación en la implementación de los derechos, podemos distinguir:

- Uso ampliatorio: el concepto sirve para potenciar, fortalecer o respaldar el derecho que acompaña. Por ejemplo, en diversas ocasiones se puede encontrar la mención a "vida digna" o a "condiciones de trabajo dignas" o a "vivienda digna". Shulztiner y Carmi ofrecen distintos ejemplos de estos usos, ${ }^{93}$ mientras que McCrudden pone como ejemplo de este uso de la dignidad a la sentencia del 19 de noviembre 1999 de la Corte Interamericana de Derechos Humanos en el caso de los "Niños de la Calle" (Villagrán Morales y otros) vs. Guatemala (fondo), en el que la Corte sostuvo que "el derecho fundamental a la vida comprende, no sólo el derecho de todo ser humano de no ser privado de la vida arbitrariamente, sino también el derecho a que no se le impida el acceso a las condiciones que le garanticen una existencia digna" (n. 144). ${ }^{94}$

- Uso limitador: el concepto se utiliza para limitar los derechos que acompaña, para graduarlos en forma restrictiva o rechazar una demanda. Si bien, como se ha mencionado en la revisión bibliográfica, no es un uso frecuente, sí es posible hallar casos en la limitación de la libertad de expresión cuando afecta la dignidad humana de otro u otros sujetos (por ejemplo, la prohibición de un discurso de odio racial). Por ejemplo, según Goubau, la Corte Suprema de Canadá ha recurrido al principio de la dignidad humana para decidir sobre la legalidad de la prohibición o restricciones a la prostitución, a las publicaciones obscenas, al suicidio asistido o al acceso del acusado a información personal sobre la demanda en un caso de delito contra la integridad sexual. ${ }^{95}$ Meltzer menciona casos de la Suprema Corte de Israel que recurrió a la protección de la dignidad humana para abordar un caso referido al problema

\footnotetext{
93 Shulztiner y Carmi, op. cit.

94 McCrudden, op. cit.

95 Goubau, op. cit.
} 
de la pornografía en el cine o para limitar la libertad de expresión a fin de poner fin al racismo como una afrenta a la dignidad humana. ${ }^{96}$

\section{Dignidad en torno a la concepción del individuo}

El tercer criterio que proponemos para clasificar los usos del término refiere a la concepción del individuo subyacente al concepto de dignidad. Así, encontramos tres posibles usos:

- Dignidad como igualdad formal en libertad: se funda en la autonomía de los sujetos, y se reconoce a quienes tienen capacidad para tomar decisiones o formar un plan de vida. La atribución de un sentido basado en la igualdad formal o de corte liberal al término "dignidad" implica que éste actúa como un límite al actuar de terceros, y, en particular, del Estado que pudiera impedir el libre ejercicio de los propios derechos. Es decir, se trata de erradicar las interferencias de otros en materias que hacen al ejercicio irrestricto de las libertades individuales. Así, la dignidad es un fundamento para la autonomía personal, y se considera respetada cuando el individuo puede perseguir sus propios fines y metas (Rao, 2011). Este tipo de criterio, si bien expone una característica de la dignidad, no logra dar una definición de ella, ya que se concentra en los efectos prácticos de su reconocimiento en relación con el ejercicio de los derechos que se encuentran cuestionados en el caso concreto que llega ante los estrados.

- Dignidad como valor sustantivo: implica la consideración de una moral sustantiva y de la opción por un modelo de vida virtuoso que guía la concreción de una vida digna o de un trato digno. En contraste con el sentido anterior, que es pluralista, el sentido sustantivo promueve algún tipo de concepción de lo que se considera bueno, ya sea por estimar correcta la acción en sí misma o en relación con un fin externo a la conducta, y que se concretaría de manera mediata. Según Rao, las visiones sustantivas de la dignidad comprenden una visión particular sobre lo que constituye el

96 McCrudden, op. cit. 
bien para el ser humano y qué es aquello que permite que el individuo y la sociedad florezcan. ${ }^{97}$ Este uso de la dignidad ha estado vinculado, por ejemplo, a decisiones judiciales que avalaron la proscripción de la prostitución.

- Dignidad con concepto o fundamento no explícito: se puede constatar un uso de la dignidad que aspira a tutelar un mínimo de bienestar físico y psicológico de los sujetos para que puedan desarrollar su vida, pero no explicita en qué está fundada la dignidad. Este uso presupone un acuerdo en los aspectos prácticos de los derechos humanos o la dignidad, pero evita ingresar en el habitualmente controversial terreno del fundamento de tal acuerdo. Maritain relata, como ejemplo, que en una de las reuniones de la Comisión Nacional francesa de la UNESCO que discutía los derechos del hombre se señaló que había acuerdo en la redacción de los derechos entre personas partidarias de posturas claramente antagónicas siempre que no se les pregunte por qué están de acuerdo. ${ }^{98}$ En torno a la prohibición de las torturas podemos encontrar un claro ejemplo de este acuerdo sin que se explicite un fundamento de la dignidad.

\section{Según el rol de la dignidad}

El cuarto criterio refiere al rol que cumple la dignidad en relación con los derechos humanos. Los usos que encontramos en la doctrina son:

- La dignidad como fundamento de derechos: como explica Glendon, a partir de la Declaración Universal de Derechos Humanos, la dignidad se presenta como el valor fundante del sistema de protección de los derechos. En este sentido, advertimos distintos matices en este sentido, pues la dignidad puede ser reconocida como fundamento en términos genéricos, como principio fundante o como valor inspirador. Malvestiti realiza una sistematización interesante de las formas en que la dignidad se entiende como "norma suprema" y cómo ello se vincula también con la

\footnotetext{
97 Rao, "Three Concepts of Dignity in Constitutional Law".

98 Maritain, Jacques, "Introduction", en Human Rights: Comments and Interpretations. A Symposium edited by UNESCO, Paris, UNESCO, 1948, pp. I-IX.
} 
interpretación y los modos de concreción de la dignidad. ${ }^{99} \mathrm{El}$ trabajo de Chávez-Fernández Postigo ofrece una indagación incisiva sobre este uso de la dignidad por el Tribunal Constitucional peruano. ${ }^{100}$

- La dignidad como derecho a la dignidad: en diversos documentos y sentencias se menciona la dignidad como derecho de los sujetos. El trabajo de Barak realiza un agudo estudio de la dignidad como derecho y los problemas que se plantean en cuanto a sus alcances por la superposición que presenta este "derecho" con otros derechos con los que está vinculado. ${ }^{101}$ También debemos mencionar los cuatro enfoques que propone Glensy sobre el derecho a la dignidad y sus usos por parte de los tribunales. ${ }^{102}$

\section{CONSIDERACIONES FINALES}

El término "dignidad" es uno de los más relevantes en el marco de la protección internacional de los derechos humanos. Tan es así, que aparece reiteradamente en los principales documentos fundacionales de los diferentes sistemas. Asimismo, ha sido una preocupación de diversos doctrinarios esclarecer qué debe entenderse y qué se entiende por dicha noción. En este trabajo hemos presentado diferentes clasificaciones con la expectativa de poder mostrar la pluralidad semántica posible que encierra la "dignidad". En particular, hemos intentado concentrarnos en los sentidos que parecieran subsumir gran parte de las categorías postuladas por los autores.

Esta clasificación opera como una conclusión provisoria, que orientará la tarea de indagar los usos que hace del término "dignidad" la Corte IDH. Una vez realizada esa investigación, se podrá verificar si la sistematización propuesta ha sido útil o si hace falta alguna rectificación. Ello sin perjuicio de enfatizar que el objetivo central de la investigación será determinar si la Corte IDH realiza un uso unívoco de la noción de dignidad o bien si hay

99 Malvestiti, op. cit.

100 Chávez-Fernández Postigo, op. cit.

101 Barak, op. cit.

102 Glensy, op. cit. 
una variación semántica que genera problemas al momento de cumplir la tarea de resolver las controversias que se le plantean.

Como puede notarse, en el estado de la cuestión existen diversas formas de entender la dignidad en la práctica jurídica, es decir, ya sea en la normativa general o en las sentencias de los casos concretos. No obstante, a pesar de los diferentes usos, es posible que existan puntos en común. En abstracto, podemos ver lo dificultoso que puede resultar diferenciar tajantemente algunas de las clasificaciones que hemos propuesto. Creemos que en el análisis de los casos contenciosos y opiniones consultivas de la Corte IDH encontraremos solapamientos de las categorías antedichas, tanto si este organismo usa de manera indistinta como diferente al concepto de dignidad. Lejos de resultar un inconveniente, tal vez esto permita encontrar un sentido focal desde el cual podamos identificar definiciones analógicas. Precisamente, la búsqueda de un común denominador a partir de resaltar la diversidad (al menos en el plano teórico, en la investigación constataremos qué sucede en los hechos) puede ser el mayor aporte de las categorías que hemos propuesto y del estudio de los fallos y opiniones de la Corte IDH sobre la dignidad.

\section{REFERENCIAS BIBLIOGRÁFICAS}

AMEZCUA, Luis, "Algunos puntos relevantes sobre la dignidad humana en la Jurisprudencia de la Corte Interamericana de Derechos Humanos", Revista Iberoamericana de Derecho Procesal Constitucional, 8, 2007.

Andorno, Roberto, "The Paradoxical Notion of Human Dignity", Rivista Internazionale di Filosofia Del Diritto, 78, 2001.

BARAK, Aharon, "Human Dignity: The Constitutional Value and the Constitutional Right", Proceedings of the British Academy, 192, 2013.

BARroso, Luis Roberto, "Here, There, and Everywhere: Human Dignity in Contemporary Law and the Transnational Discourse", Boston College International and Comparative Law Review, 35, 2012.

BATista JimÉneZ, Fernando, "La dignidad de la persona en la Constitución española: naturaleza jurídica y funciones", Cuestiones Constitucionales. Revista Mexicana de Derecho Constitucional, 2006, disponible en: https://doi.org/10.22201/iij.24484881e.2006.14.5750. 
BeCCHI, Paolo, "Dignità umana", in Ulderico Pomarici (cur.), Filosofia del diritto. Concetti fondamentali, Torino, Giappichelli, 2007.

BELOFF, Mary y Clérico, Laura, "Derecho a condiciones de existencia digna y situación de vulnerabilidad en la jurisprudencia de la Corte InterAmericana", Estudios Constitucionales, 14 (2016), disponible en: https://doi.org/10.4067/S0718-52002016000100005.

BERARDO, Fiammetta, "La dignitá umana è intangibile. il dibattito costituente sull'art. 1 del Grundgesetz", Quaderni costituzionali, 2006.

Bohórquez MonsAlve, Viviana y Aguirre Román, Javier, "Las tensiones de la dignidad humana: conceptualización y aplicación en el derecho internacional de los derechos humanos", Sur. Revista Internacional de Derechos Humanos, 6, 2009.

BROß, Siegfried, "Die Würde des Menschen bleibt unantastbar", en CAROLINE Y. RoBERTSON-von TrothA (ed.), 60 Jahre Grundgesetz, Nomos, 2009, disponible en: https://doi.org/doi.org/10.5771/97838452203 45-41.

Burgorgue-LARSEN, Laurence, La dignité saisie par les juges en Europe, Anthemis, 2011.

CALlus, Thérèse, "Towards a Libertarian Application of Dignity in English Law: A Case Law Analysis”, Ius Gentium, 71, 2018, disponible en: https://doi.org/10.1007/978-3-319-99112-2_9.

CALO, Zacharie, "Human Dignity and Health Law: Personhood in recent bioethical debates", Notre Dame JL Ethics \& Pub. Pol'y, 1, 2012.

CAnÇAdo Trindade, Antonio Augusto y César Barros Leal (eds.), El respeto a la dignidad de la persona humana, Fortaleza, Instituto Brasileño de Derechos Humanos, 2015, disponible en: http://ibdh.org.br/ wp-content/uploads/2016/10/2015f-book.pdf.

CArozzA, P. G., "Human Dignity and Judicial Interpretation of Human Rights: A Reply", European Journal of International Law, 19, 2008, disponible en: https://doi.org/10.1093/ejil/chn059.

Chávez-Fernández Postigo, José, La dignidad como fundamento de los derechos humanos en las sentencias del Tribunal Constitucional peruano, Lima-Arequipa, Palestra Editores-Universidad Católica San Pablo, 2012.

Chávez Fernández Postigo, José, La dignidad como fundamento de los derechos humanos en las sentencias del Tribunal Constitucional 
peruano: la tensión entre la mera autonomía y la libertad ontológica, Lima, Palestra, 2012-

Consejo de Europa, Carta Social Europea, Estrasburgo, 1961, disponible en: https://www.acnur.org/fileadmin/Documentos/BDL/2002/1934. pdf?file $=t 3 /$ fileadmin $/$ Documentos $/ B D L / 2002 / 1934$.

Consejo de Europa, Convenio Europeo para la Protección de los Derechos Humanos y de las Libertades Fundamentales, 1950, disponible en: https://www.echr.coe.int/Documents/Convention_SPA.pdf.

Consejo DE EuROPA, Protocolo no. 13 al Convenio para la Protección de los Derechos Humanos y de las Libertades Fundamentales, relativo a la abolición de la pena de muerte en cualquier circunstancia, 2002, disponible en: https://www.echr.coe.int/Documents/Convention_SPA.pdf.

CostA, Jean-Paul, "Human Dignity in the Jurisprudence of the European Court of Human Rights", Understanding Human Dignity, Oxford, British Academy, 2013, disponible en: https://doi.org/10.5871/bacad/9780197265642.003.0022.

DiLley, Stephen y J. PALPANT, Nathan, Human Dignity in Bioethics: from Worldviews to the Public Square, ed. Stephen Dilley y Nathan J. Palpant. London, Routledge, 2012.

Federmann, Falco, Die Konstitutionalisierung der Europäischen Union. Überlegungen vor dem Hintergrund des andauernden europäischen Verfassungsprozesses, Köln, Eul Verlag, 2007.

Feuillet-Liger, Brigitte, "The Case for a Limited Use of Dignity as a Legal Principle", Ius Gentium, 71, 2018, disponible en: https://doi. org/10.1007/978-3-319-99112-2_22.

FIERENS, Jacques, "La dignité humaine comme concept juridique", Journal des tribunaux, 2002, disponible en: http://orbi.ulg.ac.be/bitstream/2268/200677/1/La dignité humaine comme concept juridique.pdf [accedido 4 julio 2017].

FISCHER, Joschka, "Vom Staatenverbund zur Föderation - Gedanken über die Finalität der europäischen Integration", Intergation, 23, 2000, disponible en: http://www.jstor.org/stable/24220578.

FranzIUS, Claudio, "Die Europäische Dimension des Gewährleistungsstaates", Der Staat, 45, 2006.

Glendon, Mary Ann, "Knowing the Universal Declaration of Human Rights", The Notre Dame Law Review Review, 73, 1998. 
Glensy, Rex D., "The Right to Dignity", Columbia Human Rights Law Review, 43, 2011.

Goodman, Maxine D., "Human Dignity in Supreme Court Constitutional Jurisprudence", Nebraska Law Review, 2006.

Goubau, Dominique, "Dignity in Canadian Law, a Popular but Ambiguous Notion”, Ius Gentium, 71, 2018, disponible en: https://doi. org/10.1007/978-3-319-99112-2_14.

Grabenwarter, Christoph y Struth, Katharina, "Justiz- und Verfahrensgrundrechte", en D. EHLERS (ed.), Europäische Grundrechte und Grundfreiheiten, Göttingen, De Gruyter, 2014.

MAC-Gregor, Eduardo y Pelayo Möller, Carlos María, "Preámbulo", en Christian SteINer y Patricia UriBe (eds.), Convención Americana sobre Derechos Humanos comentada, 2014.

GREWE, Constance, "La dignité de la personne humaine dans la jurisprudence de la Cour européenne des droits de l'homme", Revue générale du droit, 2014.

GROS ESPIELL, Héctor, "La dignidad humana en los instrumentos internacionales sobre derechos humanos", Anuario de Derechos Humanos, 4, 2003.

HERRERA, Daniel Alejandro, La persona y el fundamento de los derechos humanos, Buenos Aires, EDUCA, 2012.

Hoyos CASTAÑEDA, Ilva Myriam, De la dignidad y de los derechos humanos, Bogotá, Universidad de la Sabana, 2005.

IBÁÑEZ RIVAS, Juana María, "La dignidad humana y los derechos económicos, sociales y culturales en la jurisprudencia contenciosa de la Corte Interamericana de Derechos Humanos", en Antonio Augusto CANÇADO TRINDADE y César BARRos LEAL (eds.), El respeto a la dignidad de la persona humana, Fortaleza, Instituto Brasileño de Derechos Humanos, 2015.

JACKSON, Vicki C., "Constitutional Dialogue and Human Dignity: States and Transnational Constitutional Discourse", Montana Law Review, 65, 2004.

KATEB, George, Human Dignity, Cambridge, Harvard University Press, 2011.

KLATt, M., "Juristische Hermeneutik", en Handbuch Rechtshilosophie, J. B. Metzler, 2017. 
KutEynikov, Alexander, y Boyashov, Anatoly, "Dignity before the European Court of Human Rights", en Edward SIEH y Judy MCGREGOR (eds.), Human Dignity: Establishing Worth and Seeking Solutions, London, Palgrave MacMillan 2017, disponible en: https://doi. org/10.1057/978-1-137-56005-6_6.

LANDA, César, "Dignidad de la persona humana", en Antonio Augusto CANÇAdo TRINidAde y César BARRos LeAl (eds.), El respeto a la dignidad de la persona humana, Fortaleza, Instituto Brasileño de Derechos Humanos, 2015, disponible en: http://ibdh.org.br/wp-content/ uploads/2016/10/2015f-book.pdf.

MALVESTITI, Barbara, La dignità umana dopo la "Carta di Nizza”, Napoli-Salerno, Orthotes Editrice, 2015.

MARITAIN, Jacques, "Introduction", Human Rights: Comments and Interpretations. A Symposium edited by UNESCO, Pris, UNESCO, 1948.

MASsini Correas, Carlos Ignacio, Filosofía del derecho - I - El derecho, los derechos humanos y el derecho natural, 2a. ed., Buenos Aires, Lexis-Nexis, 2005.

MASTROPIETRO, Andrea, "Diritto e dignità umana", Rivista Internazionale di Filosofia del Diritto, 2, 2010.

Mattioni, Angelo, "Profili costituzionali della dignità umana", Jus, 2008.

MAUBERnARD, Christophe, "Le droit fondamental à la dignité humaine en droit communautaire : La brevetabilité du vivant à l'épreuve de la jurisprudence de la Cour de Justice", Revue trimestrielle des droits de l'homme, 54, 2003, disponible en: http://www.rtdh.eu/pdf/2003483.pdf [accedido 4 julio 2017].

MCCRUDDEN, Christopher, "Human Dignity and Judicial Interpretation of Human Rights", European Journal of International Law, 19, 2008, disponible en: https://doi.org/10.1093/ejil/chn043.

MELtzer Henry, Leslie, "The Jurisprudence of Dignity”, University of Pennsylvania Law Review, 160, 2011.

MenKe, Christoph, "De la dignité de l'homme à la dignité humaine : le sujet des droits de l'homme", Revue franco-allemande de sciences humaines et sociales, 3, 2009.

Michael, Lucy, "Defining Dignity and Its Place in Human Rights", The New Bioethics, 20, 2014, disponible en: https://doi.org/10.1179/20502 $87714 z .00000000041$. 
MONACO, Giuseppe, "La tutela della dignità umana: sviluppi giurisprudenziali e difficoltà applicative", Politica del diritto, 2011.

OEA, Convención Americana sobre Derechos Humanos, 1969, disponible en: https://www.oas.org/dil/esp/tratados_b-32_convencion_americana_sobre_derechos_humanos.htm.

OEA, Convención Interamericana para la Prevención, Sanción y Erradicación de la Violencia, 1994, disponible en: https://www.oas.org/juridico/spanish/tratados/a-61.html.

OEA, Convención Interamericana para Prevenir, Sancionar y Erradicar la Violencia contra la Mujer, 1994, disponible en: http://www.corteidh. or.cr/sitios/libros/todos/docs/documentosbasicos2018.pdf.

OEA, Convención Interamericana para Prevenir y Sancionar la Tortura, 1987, disponible en: https://www.oas.org/juridico/spanish/tratados/ a-51.html.

OEA, Convención Interamericana sobre Desaparición Forzada de Personas, 1994, disponible en: https://www.oas.org/juridico/spanish/trata dos/a-60.html.

OEA, Declaración Americana de los Derechos y Deberes del Hombre, 1948, disponible en: http://www.oas.org/es/cidh/mandato/Basicos/declaracion.asp.

OEA, Protocolo Adicional a la Convención Americana sobre Derechos Humanos en materia de Derechos Económicos, Sociales y Culturales, 1988, disponible en: https://www.oas.org/juridico/spanish/ tratados/a-52.html.

ONU, Carta de las Naciones Unidas (San Francisco, 1945), disponible en: https://www.un.org/es/charter-united-nations/.

ONU, Convención Internacional sobre los Derechos de las Personas con Discapacidad, 2006, disponible en: https://www.un.org/esa/socdev/ enable/documents/tccconvs.pdf.

ONU, Convención Internacional sobre los Derechos del Niño, 1989, disponible en: https://www.un.org/es/events/childrenday/pdf/derechos.pdf.

ONU, Declaración Universal de Derechos Humanos, 1948, disponible en: https://www.un.org/es/universal-declaration-human-rights/.

ONU, Pacto Internacional de Derechos Civiles y Politicos, 1976, disponible en: https://www.ohchr.org/SP/ProfessionalInterest/Pages/CCPR. aspx. 
ONU, Pacto Internacional de Derechos Económicos, Sociales y Culturales, 1976, disponible en: https://www.ohchrorg/SP/ProfessionalInterest/Pages/CESCR.aspx.

Organización para la UnidAd AfricAna, Carta Africana sobre Derechos Humanos y de los Pueblos, 1981, disponible en: https://www. acnur.org/fileadmin/Documentos/BDL/2002/1297.pdf.

ORganización PARA LA UNIDAD AFRICANA, Carta Africana sobre los Derechos y el Bienestar del Niño, 1990, disponible en: https://www. acnur.org/fileadmin/Documentos/BDL/2010/8025.pdf?view.

Pereira-Menaut, Antonio-Carlos y Pereira-SÁez, María-Carolina, "Human Dignity and European Constitutionalism. Flatus Vocis or Ratio Decidendi?", Ius Gentium, 52, 2016.

PICIOCCHI, Cinzia, La dignità come rappresentazione giuridica della condizione umana, Padova, CEDAM, 2013.

QuintanA, Eduardo, "Dignidad y deberes humanos", Prudentia Iuris2, 83, 2017.

RAO, Neomi, "On the Use and Abuse of Dignity in Constitutional Law", Columbia Journal of European Law, 2008.

RAO, Neomi, "Three Concepts of Dignity in Constitutional Law", Notre Dame Law Review, 2011.

RoLLA, Giancarlo, "Il valore normativo del principio della dignità umana. Brevi considerazioni alla luce del costituzionalismo iberoamericano", Diritto pubblico comparato ed europeo, 2003.

SACRISTÁN, Estela, "El concepto de dignidad humana en la jurisprudencia de la Corte Suprema de Justicia de la Nación", Prudentia Iuris, 84, 2017.

SHUlzTINER, Doron, "Human Dignity in Judicial Decisions: Principles of Application and the Rule of Law", Cardozo Journal of International and Comparative Law, 25, 2017.

ShulzTiner, Doron, y E. CARMI, Guy, "Human Dignity in National Constitutions: Functions, Promises and Dangers", American Journal of Comparative Law, 62, 2014, disponible en: https://doi.org/10.5131/ AJCL.2014.0003.

TORRALBA, Francesc, ¿Qué es la dignidad humana? Ensayo sobre Peter Singer, Hugo Tristram Engelhardt y John Harris, Barcelona, Herder, 2005.

Esta obra está bajo una Licencia Creative Commons

Atribución-NoComercial-SinDerivar 4.0 Internacional, IIJ-UNAM. 
Unión Europea, Carta de los Derechos Fundamentales de la Unión Europea, 2000, disponible en: http://www.europarl.europa.eu/charter/pdf/ text_es.pdf.

VIOLA, Francesco, "Lo statuto normativo della dignità umana", en Angelo ABIGNENTE y Francesca ScAmardella (eds.), Dignità della persona. Riconoscimento dei diritti nella società multiculturali, Napoli, Editoriale Scientifica, 2013.

WALDRON, Jeremy, "Is Dignity the Foundation of Human Rights?", $N Y U$ School of Law, Public Law Research Paper, 12-73, 2013, disponible en: https://doi.org/10.2139/ssrn.2196074.

Wallace, H., "Die Dynamik des EU-Institutionengefüges", en M JACHTENFUCHS y B. KOHLER-KOCH (ed.), Europäische Integration, Springer Verlag, 2003.

ZHANG, Li, "The Emergence of Human Dignity in China: From a Private Right to a Constitutional Principle", Ius Gentium, 71, 2018, disponible en: https://doi.org/10.1007/978-3-319-99112-2_17.

Fecha de recepción: 26 de agosto de 2019.

Fecha de aceptación: 10 de noviembre de 2019.

Esta obra está bajo una Licencia Creative Commons Atribución-NoComercial-SinDerivar 4.0 Internacional, IIJ-UNAM. 


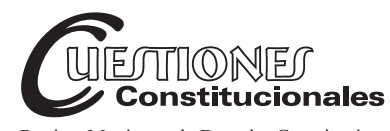

Revista Mexicana de Derecho Constitucional Núm. 43, julio-diciembre 2020

\title{
Límites a la responsabilidad patrimonial por daño moral
}

\author{
Limits to patrimonial liability for moral damage
}

\section{Oscar Antonio LEÓN OYOSA*}

RESUMEN: A partir del 14 de junio de 2002 la responsabilidad patrimonial del Estado en México no solamente fue elevada a categoría constitucional, sino que fue introducida con carácter objetivo y directo; esto es, para hacerla valer es necesario demostrar que se ha sufrido daño en la esfera jurídica del cual no se tiene el deber jurídico de soportar, sin necesidad de acreditar previamente el actuar ilícito del servidor público que lo causó, pues bajo esta figura el Estado es directamente responsable de los daños causados por sus agentes. Sin embargo, la redacción del texto constitucional cedió al legislador ordinario la imposición de límites a las indemnizaciones derivadas de la responsabilidad patrimonial, mismas que aquél estableció en la Ley Federal de Responsabilidad Patrimonial del Estado, publicada el 31 de diciembre de 2004 en el Diario Oficial de la Federación. Precisamente, tales límites serán motivo de análisis en el presente, con la finalidad de identificar si son constitucionales, o por el contrario, se apartan del fin buscado por la norma fundamental. De igual manera, se valorará la redac-
ABSTRACT: Since 14, 2002, the State's property liability in Mexico was not only elevated to a constitutional category, but was introduced with an objective and direct character, so, it's necessary to demonstrate that it has suffered in the legal sphere Which does not have the legal duty to support, without having to previously accredit the illicit action of the public servant who caused the damage, because under this figure the State is directly responsible for the damages caused by its agents. However, the wording of the constitutional text gave the ordinary legislator the imposition of limits on the indemnities derived from the patrimonial responsibility, which the same established in the Federal Law of Asset Liability of the State published on December 31, 2004 in the Official Gazette of The Federation. Precisely these limits will be the subject of analysis in the present, in order to identify whether they are constitutional, or on the contrary depart from the end sought by the Fundamental Standard. Likewise, the wording of the constitutional

* Maestro en Estudios (PNPC) por la Universidad Juárez Autónoma de Tabasco; estudiante del doctorado en Estudios Jurídicos (PNPC) impartido en la Universidad Juárez Autónoma de Tabasco. México. ORCID: 0000-0001-8178-4115. Correo electrónico: leon.oyosa@gmail.com. 
ción del texto constitucional con relación a las justificaciones para la imposición de límites respecto del daño moral.

Palabras clave: responsabilidad patrimonial, límites, daño moral. text in relation to the justifications for the imposition of limits, especially when dealing with moral damages, will be evaluated.

Keywords: asset liability, limits, moral damage.

\begin{abstract}
SUMARIO: I. Introducción. II. Definición de daño moral y alcance de las reparaciones conforme a la Convención Americana sobre Derechos Humanos. III. Limites a la indemnización por daño moral. IV. Pronunciamiento de la Suprema Corte: los límites previstos en la indemnización por daño moral son inconstitucionales. V. Límites idóneos para restringir reclamos injustificados. VI. Motivaciones para limitar las indemnizaciones en materia de responsabilidad patrimonial. VII. Análisis del voto disidente del ministro Gudiño Pelayo en el amparo en revisión 75/2009. VIII. Propuesta: pregunta lógico-jurídica para arribar a la conclusión de una indemnización justa por daño moral. IX. Criterios recientes de la Suprema Corte de Justicia de la Nación. X. Propuestas iniciales versus texto constitucional vigente. XI. Presunción del daño moral en el Consejo de Estado de Colombia. XII. Conclusiones. XIII. Bibliografía.
\end{abstract}

\title{
I. INTRODUCCIÓN
}

Sin duda alguna, el jurista Álvaro Castro Estrada ha sido uno de los principales impulsores de la inclusión de la institución de responsabilidad patrimonial a nivel constitucional en el Estado mexicano - con los elementos característicos que identifican la evolución de este principio en el nuevo régimen estatal—, ${ }^{1}$ logrando el aporte de la integración de un régimen de

1 El surgimiento del denominado Estado moderno en los siglos XVI y XVII consistió fundamentalmente en un fenómeno de concentración de poder por parte del rey. La evolución derivada de la concentración del poder llevó a excesos, que al paso de dos siglos intentaron corregirse con la Revolución francesa y el surgimiento del nuevo régimen. El nuevo régimen se construyó con base en dos grandes principios: el de legalidad y el de responsabilidad patrimonial del Estado, ambos destinados a limitar el ejercicio monopólico, y en ocasiones abusivo, del poder, en un sistema que ya no regresó a la descentralización propia del del antiguo régimen. Lozano Díez, José Antonio, "Límites

Esta obra está bajo una Licencia Creative Commons

Atribución-NoComercial-SinDerivar 4.0 Internacional, IIJ-UNAM. 
responsabilidad general, objetivo y directo. ${ }^{2}$ Así, la primera propuesta que desde la jurisprudencia dogmática hiciera el autor en noviembre de 1997, origen de la actual garantía constitucional, fue redactada en los términos siguientes:

Artículo $113 \ldots$ Todo aquel que sufra una lesión en sus bienes y derechos, con motivo de la actividad del Estado, tendrá derecho a ser indemnizado en forma proporcional y equitativa, conforme a lo dipuesto por las leyes que al efecto expidan el Congreso de la Unión y las Legislaturas de los Estados dentro del ámbito de sus respectivas competencias. Los tribunales contencioso-administrativos serán los competentes para conocer de las controversias derivadas de la aplicación de las mismas. ${ }^{3}$

Tal propuesta sufrió diversas modificaciones hasta el texto aprobado mediante la reforma constitucional del 14 de junio de 2002, publicada en el Diario Oficial de la Federación. Sin embargo, cabe destacar que la iniciativa promovida el 22 de abril de 1999 por el Partido Revolucionario Institucional, fiel al texto del jurista de mérito, incluyó la proporcionalidad y equidad en la indemnización; a su vez, la diversa promovida por el Partido Acción Nacional el 19 de junio de ese mismo año previó la equidad en la indemnización por los daños y perjuicios ocasionados por la actividad de la Federación.

Fue con la iniciativa propuesta el 14 de abril de 2000 por la Consejería Jurídica del Ejecutivo Federal, que respecto de la indemnización sería conforme a "las bases, límites y procedimientos que establecieran las leyes"; modificación tal que inclusive fue respaldada por Castro Estrada en su nueva sugerencia de redacción del 18 de abril de $2000 .{ }^{4}$

No cade duda que las iniciativas de reforma presentadas a partir del 19 de junio de 1999 tuvieron el aserto de incluir la figura de la responsabilidad objetiva y directa, lo que siginificó un gran logro y avance en el sistema

presupuestarios a la responsabilidad patrimonial del Estado en el sistema jurídico mexicano", en Rodriguez-Arana Muñoz, Jaime et al. (coords.), La responsabilidad patrimonial de la administración pública, México, Espress, 2014, t. I, pp. 15-24.

2 Castro Estrada, Álvaro, Responsabilidad patrimonial del Estado, México, Porrúa, 2006, p. XXIII.

3 Acosta García, Cristian Miguel, Responsabilidad patrimonial del estado. Teoría y casos prácticos, México, Novum, p. 150.

4 Ibidem, pp. 151-154. 
jurídico mexicano. No obstante la plausibilidad de ello, resulta necesario analizar la conveniencia o no, que a tal garantía, en propuestas iniciales, se incluyera una indemnización proporcional y equitativa, para modificarla posteriormente, por una indemnización "conforme a las bases, límites y procedimientos que establecieran las leyes"; sobre todo, en atención a los límites respecto del daño moral, impuestos por el legislador ordinario en la Ley Federal de Responsabilidad Patrimonial del Estado (LFRPE), y sobre los cuales la Suprema Corte de Justicia de la Nación se ha pronunciado por su inconstitucionalidad, que será motivo de análisis en el presente, en que abordamos su trascendencia y las implicaciones que el texto declarado inconstitucional continúe vigente.

\section{DEFINICIÓN DE DAÑO MORAL Y ALCANCE \\ DE LAS REPARACIONES CONFORME A LA CONVENCIÓN AMERICANA SOBRE DERECHOS HUMANOS}

El daño moral se vincula a la afectación espiritual de la persona a través de la lesión de los derechos de la personalidad, entendiendo por ello una categoría especial de derechos subjetivos que, fundados en la dignidad de la persona, garantiza el goce y respeto de su propia identidad e integridad en todas las manifestaciones físicas y propias del intelecto de esa persona. ${ }^{5}$

En lo tocante a la reparación por daños causados por el Estado, el concepto de reparación integral derivado del artículo 63.1 de la Convención Americana sobre Derechos Humanos, abarca la acreditación de daños en la esfera material e inmaterial y el otorgamiento de medidas tales como: a) la investigación de los hechos; b) la restitución de derechos, bienes y libertades; c) la rehabilitación física, psicológica o social; d) la satisfacción, mediante actos en beneficio de las víctimas; e) las garantías de no repetición de las violaciones, y f) la indemnización compensatoria por daño material e inmaterial. A través de esta facultad, la Corte Interamericana de Derechos Humanos (Corte IDH) ha ordenado medidas emblemáticas para muchos países de la región, que han colaborado en la consolidación del Estado de derecho y la vigencia de los derechos humanos. Dichas medi-

5 Pérez Fuentes, Gisela María, "Responsabilidad por daños a la persona: daño moral”, en Pérez Fuentes, Gisela María (coord.), Temas actuales de responsabilidad civil, México, Tirant lo Blanch, 2018, pp. 99-149. 
das en su dimensión individual han beneficiado a miles de personas en la región (a través de otorgamiento de becas educativas, atención médica y psicológica, actos de conmemoración, búsqueda de desaparecidos, y compensaciones económicas). La jurisprudencia de la Corte Interamericana al respecto, constituye uno de los avances más importantes en el desarrollo internacional de la reparación integral. ${ }^{6}$

De igual forma, el derecho moderno de daños pone énfasis en la protección a los derecho fundamentales, y así, la doctora Pérez, retomando los Criterios de la Corte Interamericana, precisa que el daño causado es el que determina la indemnización, y se caracteriza por:

a) El derecho a una reparación integral o justa indemnización, derecho sustantivo cuya extensión debe tutelarse en favor de los gobernados. c) El derecho moderno de daños mira a la naturaleza y extensión del daño, a las víctimas y no a los victimarios. Así su naturaleza y su monto dependen del daño ocasionado, de manera que las reparaciones no pueden implicar ni enriquecimiento ni empobrecimiento para la víctima o sus sucesores. d) Dicho derecho no debe restringirse en forma innecesaria. Se pretende que la responsabilidad no sea excesiva, ya que debe subordinarse a requisitos cualitativos. e) Una indemnización no es justa cuando se limita con topes o tarifas, cuando en lugar de ser el juez quien la cuantifique con base en criterios de razonabilidad, es el legislador quien, arbitrariamente, fija montos indemnizatorios, al margen del caso y su realidad. Sólo el juez, que conoce las particularidades del caso, puede cuantificar la indemnización con justicia y equidad.?

En el caso El Amparo vs. Venezuela, la Corte IDH argumentó que aun cuando una sentencia condenatoria puede constituir en sí misma una forma de reparación y satisfacción moral, en el caso en estudio no sería suficiente dada la específica gravedad de la violación al derecho a la vida y al sufrimiento moral causado a las víctimas y sus familias, que deben ser indemnizadas conforme a la equidad. ${ }^{8}$

6 Calderón Gamboa, Jorge F., "La reparación integral en la jurisprudencia de la Corte Interamericana de Derechos Humanos: estándares aplicables al nuevo paradigma mexicano", en Ferrer Mac-Gregor Poisot, Eduardo, Derechos humanos en la Constitución: comentarios de jurisprudencia constitucional e interamericana, México, Suprema Corte de Justicia de la Nación-UNAM-Fundación Konrad Adenauer, 2013, t. I, pp. 145-219.

7 Pérez Fuentes, Gisela María, op. cit., pp. 22 y 23.

8 Steiner, Christian y Uribe, Patricia, Convención Americana sobre Derechos Humanos comentada, México, Suprema Corte de Justicia de la Nación, p. 863. 
De lo anterior entendemos que si bien en el caso resuelto por la Corte IDH la sentencia no constituía una forma de reparación y satisfacción moral, pueden existir casos en que la sola sentencia sea suficiente para reparar el daño moral, claro está, ello depende de la gravedad de la violación, a lo que sumaríamos la particularidad de cada caso; es decir, no sería suficiente el criterio en el siguiente sentido "si el caso no reviste gravedad, será suficiente la sentencia condenatoria para repararlo", dado que, precisamente por la particularidad de cada asunto, habrá casos en que sea suficiente la sentencia condenatoria, y casos en los que el Estado deberá desplegar otro tipo de acciones para que la reparación moral sea completa, aunque la violación no sea grave.

La Corte ha evolucionado en su interpretación de qué comprende el daño moral, y ha modificado las exigencias que establece para reconocer las formas de padecimiento que deben ser indemnizadas; y en muchos casos presume la existencia de daños con base en la constatación de las violaciones. ${ }^{9}$ Esto último es de destacar con relación al principio pro homi$n e, \mathrm{y}$ hacemos mención especial, atendiendo a la complejidad que implica la demostración del daño moral, dada la subjetividad que entraña, por lo que consideramos atinada la presunción del daño una vez constatadas las violaciones, con lo cual ha de brindarse la protección más amplia. ${ }^{10}$

Derivado de casos resueltos por la Corte Interamericana ${ }^{11}$ en lo que respecta a la reparación del daño moral tanto a las víctimas como a sus familiares, elaboramos la siguiente estructura a partir de la identificación de criterios sostenidos en dicha materia:

Sufrimiento padecido por la víctima y/o familiares directos de la víctima:

a) Disposición de pago a la víctima:

- Pago directo: se realiza directamente con relación al sufrimiento o padecimiento de la víctima, cuyo monto es superior si la víctima sigue con vida.

9 Ibidem, p. 864.

10 Claro está, como se señaló en líneas anteriores, esto será atendiendo a las particularidades y circunstancias del caso concreto, pues la presunción no se traduce en un cheque en blanco para reclamar indemnizaciones no debidas, sino para resituir en la justa medida la afectación sufrida por la víctima o sus allegados.

11 Caso Velázquez Rodríguez vs. Honduras; caso Aloeboetoe vs. Surinam; caso Garrido y Baigorria vs. Argentina; caso Loaiza Tamayo vs. Perú; caso Castillo Páez vs. Perú, y caso de "Los Niños de la Calle" (Villagrán Morales y otros) vs. Guatemala. 
- Pago por herencia a sus familiares: se realiza directamente en relación con el padecimiento de la víctima, cuando ésta ha fallecido o privada de la vida, y toda vez que en la indemnización por herencia los familiares que reciben no necesitan comprobar el sufrimiento ni el grado afectivo, pues reciben a nombre de la víctima y por las violaciones irrogadas; es distinto el monto indemnizatorio que hayan de recibir los familiares por el sufrimiento padecido por éstos al que reciben por suceder a la víctima en su padecimiento.

b) Disposición de pago a familiares de la víctima

- Por el sufrimiento causado por el vínculo familiar: en estos casos ha tomado en cuenta la relación afectiva y el grado de convivencia de la vícitma con el familiar, para determinar el monto indemnizatorio.

- Por ser miembros de una familia integrada: respecto a los hermanos a veces son incluidos dependiendo el grado de cercanía; sin embargo, en el caso Laoyza Tamayo tomó en consideración a padres, hijos y hermanos, argumentando que como miembros de una familia integrada no podían ser indiferentes a las graves aflicciones de la víctima.

Respecto al tema, concluimos con la siguiente reflexión: si la finalidad de la indemnización por daño moral consiste en restituir en la medida de lo posible a las personas afectadas en dicho rubro respecto de la víctima, en sus resoluciones la Corte debería, al menos, analizar el sufrimiento de los integrantes que conforman las nuevas estructuras familiares, las cuales, sin tener vínculos sanguíneos, se encuentran unidos por lazos afectivos y padecen sufrimientos cuando uno de sus miembros resulta afectado. ${ }^{12}$

12 En la actualidad, el concepto de familia presenta una transformación sustancial en atención a los nuevos modelos sociales en que ésa se desarrolla; ya no se considera integrada exclusivamente por los parientes y los cónyuges como tradicionalmente se les identificaba; es decir, vinculada por matrimonio y relaciones parentales; ahora y en atención a la dinámica social, se contemplan otras formas de relaciones humanas, donde los miembros que la integran se encuentran vinculados por lazos de afecto, de respeto, de convivencia y de solidaridad... Se deja entonces abierto el debate social que permita despejar el horizonte teórico, al concebir familias disímiles con integrantes de iguales o diferentes sexos, de iguales o diferentes orígenes territoriales, así como de la misma 


\section{LÍMITES A LA INDEMNIZACIÓN POR DAÑO MORAL}

El artículo 14 de la Ley Federal de Responsabilidad Patrimonial del Estado, ${ }^{13}$ en su fracción II, dispone que en el caso de daño moral, la autoridad administrativa o jurisdiccional calculará el monto de la indemnización de acuerdo con los criterios establecidos por el Código Civil Federal, pero no excederá del equivalente a 20,000 veces el salario mínimo general diario ${ }^{14}$ vigente en el Distrito Federal por cada reclamante afectado.

Tal disposición derivó de la libertad configurativa dispuesta en el artículo 113 constitucional, ${ }^{15}$ en la cual el monto resarcitorio por los daños ${ }^{16}$ causados por el Estado sería conforme a los límites establecidos por las leyes. Así, el legislador federal prescribió que no obstante conforme al Código Civil el monto de la indemnización se calcurá conforme a dicho ordenamiento y los dictámenes periciales ofrecidos por el reclamante, aquélla no excederá de la cantidad antes señalada.

proveniencia biológica o no, unidos formal o informalmente, incluyéndose en el núcleo social elementos familiares mixtos, como los que se integran en las llamadas familias amalgamadas. Oliva Gómez, Eduardo y Villa Guardiola, Vera Judith, "Hacia un concepto interdisciplinario de la familia en la globalización”, Justicia Juris, vol. 10, núm. 1, enerojunio de 2014, pp. 11-20.

13 Publicada en el Diario Oficial de la Federación el 31 de diciembre de 2004, última reforma del 12 de junio de 2009.

14 Unidad de Medida y Actualización, conforme al artículo tercero transitorio del decreto de reforma en materia de desindexación del salario mínimo, publicado en el Diario Oficial de la Federación el 27 de enero de 2016.

15 Al día de hoy, la libertad configurativa la encontramos en el artículo 109 de la Constitución federal, pues el texto constitucional en el cual se consigna la responsabilidad patrimonial fue trasladado del artículo 109 al 113, en virtud de las reformas en materia de combate a la corrupción, publicadas en el Diario Oficial de la Federación el 27 de mayo de 2015.

16 Algunos autores sostienen que daño y lesión no son dos expresiones equivalentes. "Toda lesión implicaría un daño, pero no todo daño sería lesión”. Al respecto, el Tribunal Supremo de España, en sentencia del 24 de febrero de 2004 (rec. 10869/1998) se ha pronunciado: "Si bien toda lesión es integrante de un daño y perjuicio no todo daño y perjuicio es constitutivo de una lesión... pues esa antijuridicidad o licitud sólo se produce cuando el afectado no hubiera tenido la obligación de soportar el daño o perjuicio y ese deber de soportar el daño o el perjuicio sufrido se da en los supuestos en que la ley y el grupo normativo de ella derivado justifican dichos detrimentos de un modo expreso o implícito". Cfr. Manzanares Samaniego, José Luis, La responsabilidad patrimonial por el funcionamiento de la administración de justicia, Madrid, La Ley, 2012, pp. 247 y 248. 


\section{Pronunciamiento de la Suprema Corte: LOS LÍMITES PREVISTOS EN LA INDEMNIZACIÓN POR DAÑO MORAL SON INCONSTITUCIONALES}

Sin embargo, ante tal imperativo, la Suprema Corte de Justicia de la Nación se ha pronunciado por la inconstitucionalidad de dicho tope máximo, sustentado en el argumento consistente en que si bien la existencia de límites a las indemnizaciones de los daños causados por el Estado es un objetivo cubierto por la Constitución general de la República (hoy en día a través del artículo 109), la fijación del tope máximo no constituye una medida adecuada, porque ni garantiza por sí misma que los abusos no se den ni resulta necesaria para evitarlos, no siendo lo suficientemente ajustada a los fines que pretende conseguir, sino que, por el contrario, en algunos casos puede ocasionar limitaciones irrazonables al derecho a ser indemnizado, además de que contraviene las obligaciones internacionales suscritas por el Estado mexicano, y podría plantear posibles problemas para cumplir con lo dispuesto por la Corte Interamericana y con las recomendaciones de la Comisión Interamericana en materia de reparación del daño. ${ }^{17}$

El más alto tribunal en tesis diversa, reiteró que el establecimiento de un tope máximo a las indemnizaciones a que puede ser condenado el Estado por daño moral no es en sí mismo una garantía contra los reclamos injustificados y las indemnizaciones excesivas, y puede entrar en tensión con los objetivos destacados en la exposición de motivos de la ley de la materia: cumplir con un imperativo de justicia, fortalecer el Estado de derecho, elevar la calidad de los servicios públicos, y restablecer la confianza que el Estado merece a los gobernados. Por lo tanto, si el cálculo del monto está disciplinado por el tope máximo establecido en la LFRPE, "habrá daños desiguales que serán tratados de la misma manera, y los particualres deberán asumir el costo que supere el tope máximo, lo cual no sólo impedirá la reparación integral de la violación sufrida, sino que le permitirá al Estado no asumir parte de las consecuencias de los daños que causa". ${ }^{18}$

17 Tesis 1a. CLIV/2009, Semanario Judicial de la Federación y su Gaceta, Novena Época, t. XXX, septiembre de 2009, p. 454.

18 Tesis 1a. CLVI/2009, Semanario Judicial de la Federación y su Gaceta, Novena Época, t. XXX, septiembre de 2009, p. 456.

Esta obra está bajo una Licencia Creative Commons Atribución-NoComercial-SinDerivar 4.0 Internacional, IIJ-UNAM. 
Si bien los derechos constitucionales no son absolutos y admiten restricciones, éstas no deben ser desprorcionadas ni arbitrarias, y por lo tanto, para justificar una restricción a un derecho constitucional, el tribunal ha determinado que la medida legislativa debe superar tres pasos:

1) Debe ser admisible constitucionalmente; esto es, debe introducirse para la consecución de un objetivo contemplado en la Constitución.

2) Debe ser una medida idónea, lo que implica que la restricción debe ser necesaria para la consecución del fin inicialmente propuesto, $y$

3) Debe ser proporcional respecto a la afectación que hace en otros bienes o intereses constitucionales. ${ }^{19}$

En tales circunstancias, la Primera Sala del más alto tribunal concluyó que no obstante la restricción legislativa cumplió el primer requisito, no se actualizó tal cumplimiento en el segundo, toda vez que el límite establecido en la norma no es el instrumentalmente idóneo para lograr que se erradique la realidad de los reclamos injustificados ni impide que se emitan indemnizaciones excesivas, aunado a que tales fines se cumplen adecuadamente con otras dos medidas en la ley: 1) la estructura de procedencia de los reclamos que delimitan el trámite jurídico de las peticiones, y 2) los criterios individualizadores de las indemnizaciones que vinculan a la autoridad aplicadora para determinar indmenizaciones justas y proporcionales. ${ }^{20}$

Estamos de acuerdo con el criterio adoptado por el tribunal, en el sentido de que no era suficiente que el legislador expusiera que el límite establecido por el artículo 14, fracción II, segundo párrafo, de la LFRPE, buscara evitar reclamos injustificados e indemnizaciones excesivas, pues con ello se cumplió únicamente con un requisito puramente formal, declarativo, que al cotejarse con el segundo requisito de análisis para justificar la restricción a un derecho constitucional se concluyó que "no era instrumentalmente idóneo para erradicar las conductas antes descritas"; en otras palabras, no existe correspondencia entre el objetivo aducido por el legislador ordina-

19 Tesis 1a./J. 2/2012, Semanario Judicial de la Federación y su Gaceta, Décima Época, t. I, febrero de 2012, p. 533.

20 Amparo en revisión 75/2009 resuelto por la Primera Sala de la Suprema Corte de Justicia de la Nación (SCJN), quejosas: Blanca Delia Rentería Torres y otra, fecha: 18 de marzo de 2009. Mayoría de cuatro votos. Disidente: José de Jesús Gudiño Pelayo. Ponente: José Ramón Cossío Díaz. Secretaria: Francisca María Pou Giménez, pp. II y III. 


\section{rio y la medida decretada, consistente en limitar el monto indemnizatorio a cargo del Estado. ${ }^{21}$}

21 De importancia son los argumentos esgrimidos por la Primera Sala de la SCJN para arribar a esta determinación, en los cuales se tomaron en consideración los diversos por esa Primera Sala al resolver el amparo en revisión 903/2008, donde se interpretó el derecho de las personas contenido en el artículo 113 constitucional, enfatizando que la indemnización derivada de la actividad administrativa irregular del Estado es un derecho constitucional sustantivo. Por tanto, la interpretación del artículo 113, segundo párrafo, de la Constitución federal, debe realizarse teniendo en cuenta que el citado precepto pone el énfasis de su regulación en "el derecho de los particulares de obtener una indemnización por la actividad administrativa irregular del Estado"; y, por lo tanto, la consecuencia normativa que tiene el precepto constitucional, no es la delimitación de esferas competenciales concretas, sino aquella que impone de manera principal una norma constitucional que establece un derecho: consagrar una prerrogativa que, por una parte, se establece como la obligación de éstas de encauzar sus potestades públicas, entre ellas la de configuración normativa, para asegurar que sus titulares disfruten la totalidad de la extensión del derecho constitucional garantizado.

Continuando con el desarrollo de su resolución, la Sala precisó que el derecho a una indemnización por la actividad administrativa irregular del Estado tiene un ámbito material propio, que no puede ser limitado por el legislador ordinario al desplegar sus facultades de creación normativa. Por lo tanto, en el contexto legal que regula la responsabilidad patrimonial del Estado, se desprende que existen medidas que son suficientes por sí mismas para evitar la interposición de reclamos injustificados y la existencia de indemnizaciones excesivas, que se vinculan más con la estructura general del régimen de responsabilidad patrimonial del Estado, que con el límite máximo de las indemnizaciones a que se puede condenar a éste. En tal orden de ideas, los "reclamos injustificados" como las "indemnizaciones excesivas" son dos aspectos "cuya supresión, se logra a través de la regulación de los rasgos estructurantes del régimen de responsabilidad patrimonial del Estado, cuyos resultados dependen de las facultades de las autoridades encargadas de su aplicación y no de la conducta espontánea de los particulares". En otras palabras, si llegaran a existir indemnizaciones excesivas no es por una falta de un límite máximo, sino porque "no existe un esquema de criterios individualizadores que vinculen a la autoridad a decretar una indemnización proporcional y justa".

Finalmente, cabe destacar que se precisó que la cantidad de la indemnización en cumplimiento del artículo 12 de la Ley Federal de Responsabilidad Patrimonial del Estado se debe determinar no en función de la capacidad económica del sujeto actor, sino de acuerdo la naturaleza del daño ocasionado, el resultado de la valoración de los derechos lesionados y el grado de responsabilidad del sujeto responsable. En tal virtud "se considerará que las indemnizaciones no son excesivas si, por una parte, se atiende a la compensación del daño creado y, por el otro, al grado de causalidad real de la actividad administrativa irregular del Estado; esto es, en función del grado de responsabilidad del sujeto responsable y la naturaleza de los derechos lesionados. El daño causado es el que determina la reparación, nunca un monto prefijado puede establecer de manera previa la afectación máxima que se puede sufrir". Al respecto, véase el amparo en revisión 75/2009 resuelto por la Primera Sala de la SCJN, quejosas: Blanca Delia Rentería Torres y otra, 


\section{LÍMITES IDÓNEOS PARA RESTRINGIR RECLAMOS INJUSTIFICADOS}

En concordancia con lo expuesto por la Sala en el amparo en revisión 75/2009, la LFRPE establece límites idóneos que restringen las posibilidades de existencia de reclamos injustificados e indemnizaciones excesivas, con el fin de evitar consecuencias perjudiciales en las arcas del Estado:

1. Límites internos, ${ }^{22}$ contenidos en el artículo 4 , son aquellos requisitos relacionados con la estructura del régimen de responsabilidad; esto es, que para poder acceder a la indemnización correspondiente, debe acreditarse que el daño causado por la actividad administrativa irregular del Estado sea real, evaluable en dinero, individualizado en una o varias personas, desigual al que pudiera afectar al común de la población, e imputable al Estado. En consecuencia, al no acreditarse alguno de los requisitos anteriores, el particular no podrá acceder a la reparación o compensación pretendida; siendo éstos elementos un medio de control contra los reclamos injustificados.

2. Límites indemnizatorios, tienen su origen en el artículo 14, fracción II, primer párrafo de la LFRPE, misma que a su vez remite a los criterios establecidos en el Código Civil Federal señalados en su artículo 1916, que en su párrafo cuarto establece que el monto de la indemnización lo determinará el juez tomando en cuenta los derechos lesionados, el grado de responsabilidad, la situación económica del responsable y la de la víctima, así como las demás circunstancias del caso. Dicho límite tiene como finalidad evitar la determinación de indemnizaciones excesivas. ${ }^{23}$

fecha: 18 de marzo de 2009. Mayoría de cuatro votos. Disidente: José de Jesús Gudiño Pelayo. Ponente: José Ramón Cossío Díaz. Secretaria: Francisca María Pou Giménez.

22 Amparo en revisión 75/2009, resuelto por la Primera Sala de la Suprema Corte de Justicia de la Nación, p. 32.

23 “...Así, el daño causado es el que determina la naturaleza y el monto de la indemnización, de forma que las reparaciones no pueden implicar enriquecimiento ni empobrecimiento para la víctima o sus sucesores; además, no se pretende que la responsabilidad sea excesiva, ya que debe subordinarse a requisitos cualitativos. Por otro lado, una indemnización será excesiva cuando exceda del monto suficiente para compensar a la víctima...". Tesis 1a./J. 31/2017, Gaceta del Semanario Judicial de la Federación, Décima Época, t. I, abril de 2017, p. 752. 
3. Límites excepcionales,${ }^{24}$ contenidos en el artículo 3, son las excepciones al derecho de ser inmdenizado, claramente identificadas por el legislador en dicha porción normativa, y de actualizarse alguna de ellas, el reclamante no tendrá derecho a acceder a la reparación establecida en la Ley, siendo éstas: los casos fortuitos y de fuerza mayor; los daños y perjuicios que no sean consecuencia de la actividad administrativa irregular del Estado; los hechos y circunstancias que no se hubieran podido prever o evitar según el estado de los conocimientos de la ciencia o técnica existentes en el momento de su acaecimiento; y cuando el solicitante de la indemnización sea el único causante del daño. Dicho límite tiene como finalidad evitar que prosperen los reclamos injustificados, así como las indemnizaciones excesivas, entendidas éstas como el resarcimiento que excede del monto suficiente para compenzar a la víctima; o bien, en este caso, cualquier resarcimiento cuyo origen derive de un daño que no es imputable al Estado.

4. Límites presupuestarios, ${ }^{25}$ contenidos en los artículos 5,8 y 11 , prevén las circunstancias mediante las cuales al haberse decretado a favor del gobernado el pago de una indemnización por la actividad administrativa irregular del Estado, éste podrá omitir (total o parcialmente) el cumplimiento de cubrir tal indemnización si en el ejercicio fiscal en el cual nace la obligatoriedad de resarcir el daño, no existe la disponibilidad presupuestaria suficiente; ${ }^{26}$ ello con la finalidad de no afectar el cumplimiento de los objetivos de los programas aprobados en el Presupuesto de Egresos de la Federación; sin que signifique de forma alguna que el sujeto obligado quede excento de reparar el daño, pues de la interpretación del texto nor-

24 Los hemos identificado con esta denominación, toda vez que acorde a la redacción del legislador ordinario, constituyen de forma expresa "la excepción a la regla" de la prerrogativa constitucional; no obstante la existencia de otros límites y excepciones contenidos de forma implícita en el texto normativo.

25 Lozano Díez, José Antonio, op. cit., p. 19.

26 Ello no significa que la disponibilidad presupuestaria dependerá del arbitrio del Estado, pues debemos recordar que el artículo único transitorio del decreto de reforma al artículo 113 publicado el 14 de junio de 2002 en el Diario Oficial de la Federación, establece la obligatoriedad de la Federación de incluir en sus respectivos presupuestos, una partida para hacer frente a su responsabilidad patrimonial. Por lo tanto, la disponibilidad presupuestaria dependerá de la existencia suficiente o no de recursos en la partida de "responsabilidad patrimonial", y no de los diversos compromisos a los que tenga que hacer frente la Federación; esto, pues al quedar delimitados los recursos destinados a cubrir obligaciones de carácter patrimonial, no se afecta el cumplimiento de los programas previamente presupuestados en las partidas respectivas. 
mativo, se desprende que deberá progamarse para el ejercicio inmediato posterior el monto destinado a cubrir la indemnización correspondiente. ${ }^{27}$

5. Límites disuasorios ${ }^{28}$ penales, contenidos en el artículo 10 , se actualizan cuando los entes públicos denuncien ante el Ministerio Público a una persona que haya participado directa o indirectamente, coadyuvado, asistido o simulado la producción de daños, con el propósito de acreditar indebidamente la responsabilidad patrimonial del Estado, u obtener alguna indemnización por ello.

Atendiendo a lo antes expuesto, es evidente que la LFRPE cuenta con una serie de medidas tendientes a inhibir reclamos e indemnizaciones improcedentes, congruentes con una debida reglamentación de la institución, que dispone medios de prueba causal, legal y técnicos rigurosos, sin que hipertrofie la actividad de la administración pública ni genere mayores obligaciones que las que tienen los servidores públicos. No se pretende generar una cultura del reclamo, sino controlar y propiciar la elevación progresiva de la calidad de los servicios públicos, fomentando así una cultura de la responsabilidad. ${ }^{29}$

\section{MOTIVACIONES PARA LIMITAR LAS INDEMNIZACIONES EN MATERIA DE RESPONSABILIDAD PATRIMONIAL}

Los elementos de control contenidos en la LFRPE hacen que al calzar a la institución con la previsión de un monto máximo a erogar por parte del

27 Al respecto, José Antonio Lozano Díez señala que las disposiciones relacionadas con cargo a las partidas presupuestales dejan al particular en cierto estado de indefensión, ya que tienen que esperar a que existan los recursos presupuestarios suficientes para que el Estado pueda resarcir el daño; y si el Estado ha tenido un comportamiento ineficiente en ejercicios fiscales anteriores, y por lo mismo deudas más antiguas por este concepto, su espera puede ser demasiado larga, lo que va en contra de la idea neoconstitucional de derechos humanos adoptada en 2011, que coloca al principio pro homine como de interpretación preponderante. Lozano Díez, José Antonio, op. cit., p. 20.

28 La idea principal de este término ha sido tomada de Mabel Ivanega, precisando que la autora lo aplica en el contexto de las normas que tienden a evitar el actuar en forma irregular de los agentes públicos. Ivanega, Miriam Mabel, "De las consecuencias de la responsabilidad estatal. Dos supuestos: la responsabilidad de los funcionarios públicos y la limitación de recursos públicos”, en Rodriguez-Arana Muñoz, Jaime et al. (coords.), La responsabilidad patrimonial de la administración pública, México, Espress, 2014, t. II, pp. 487-504.

29 Castro Estrada, Álvaro, Nueva garantía constitucional. La responsabilidad patrimonial del Estado, México, Porrúa, 2005, pp. 120 y 121. 
Estado por concepto de reparación de daños y perjuicios sea injustificado; desprendiéndose que dicho límite coincida en mayor medida con el temor de que pudieran verse afectadas de manera importante las arcas públicas; cuando, por el contrario, dicho temor puede superarse con un tratamiento riguroso de la institución que logre fortalecer el Estado de derecho, la justicia y la seguridad jurídica, que es igual a libertad individual y justicia para la comunidad y para cada uno de sus integrantes. ${ }^{30}$ Tal aserto tiene su origen en la experiencia comparada, pues en palabras de Eduardo García de Enterría, catedrático de derecho administrativo e impulsor de la responsabilidad patrimonial del Estado en España, desde 1954, escribió que hasta antes de esa fecha

...el artículo 1903 del Código Civil de 1889 prohibía esa responsabilidad, prohibición que se justificaba de hecho en el temor de que su reconocimiento pudiese dar lugar a una sangría de las finanzas estatales. Más de cuarenta años después, cuando la responsabilidad del Estado ha pasado a desenvolverse con plena normalidad en nuestra práctica administrativa y en la jurisprudencia de nuestros Tribunales, ese temor se ha revelado poco fundado. Un tratamiento rigurosamente técnico de la institución, a lo que conduce, más bien, es a una depuración efectiva de la acción administrativa que no necesita, para ser eficaz, ir dejando a su paso un reguero de daños ocasionales repartidos arbitrariamente entre las diferentes personas de la comunidad de Derecho. ${ }^{31}$

\section{ANÁLISIS DEL VOTO DISIDENTE DEL MINISTRO GUDIÑO PELAYO EN EL AMPARO EN REVISIÓN 75/2009}

La pertinencia de este análisis es tal, pues no obstante el pronunciamiento de la Primera Sala de la Suprema Corte de Justicia de la Nación (SCJN), el texo que establece un límite a la reparación patrimonial - en consecuencia impone un límite injustificado a un derecho sustantivo - continúa vigente, y genera el riesgo de que la autoridad encargada de sustanciar el trámite de indemnización, por desconocimiento o conveniencia, se ciña a lo preceptuado por el segundo párrafo, fracción II, del artículo 14 de la norma señalada, y si bien el particular afectado muy probablemente obtenga un pronunciamento favorable a través de los diversos medios de

\footnotetext{
30 Ibidem, p. 119.

31 Ibidem, pp. 119 y 120.
} 
impugnación, aparte de los gastos que tendría que erogar para ser patrocinado legalmente ante las instancias respectivas, ${ }^{32}$ dicha situación actualizaría una reiterada y sistemática violación al principio de impartición de justicia pronta y expedita previsto en el artículo 17 constitucional, lo cual podría remediarse, tratándose del monto máximo de indemnización, con la derogación de tal porción normativa, en cumplimiento a la obligación dispuesta en el artículo 1o. constitucional:

Todas las autoridades, en el ámbito de sus competencias, tienen la obligación de promover, respetar, proteger y garantizar los derechos humanos de conformidad con los principios de universalidad, interdependencia, indivisibilidad y progresividad. En consecuencia, el Estado deberá prevenir, investigar, sancionar y reparar las violaciones a los derechos humanos, en los términos que establezca la ley.

Se insiste en la inconveniencia de la vigencia del texto limitativo en el monto de la reparación por daño moral, en el sentido de que la autoridad aplicadora, aun interpretando la norma constitucional en ejercicio del control difuso, ${ }^{33}$ podría validar dicho precepto jurídico por considerarlo acorde a la Constitución federal.

Lo anterior cobra relevancia ante el hecho de que a través del voto particular formulado por el entonces ministro José de Jesús Gudiño Pelayo, se tiene un antecedente y constancia de lo que los entes públicos, al tramitar una reclamación de responsabilidad patrimonial — aunado al desconocimiento de la norma para interpretarla y aplicarla -34 podrían considerar totalmente válido y constitucional, precisamente por la redacción de la norma fundamental. En este respecto, el jurista señalado consideró pertinente que la pregunta relevante para efectos de establecer si la regla del artículo 14, fracción II, es constitucional o inconstitucional, no es la que se plantea en el proyecto, sino la que se enuncia a continuación: ¿puede dejarse abierta, sin fijación de montos máximos, la indemnización a que puede ser condenado el Estado?

32 Recurso de revisión ante la autoridad responsable, con carácter optativo; juicio contencioso-administrativo ante el Tribunal Federal de Justicia Fiscal y Administrativa; juicio de amparo a la par de la revisión fiscal; amparo directo en revisión. Acosta García, Cristian Miguel, op. cit., p. 201.

33 Ibidem, p. 161.

34 Ibidem, p. 187.

Esta obra está bajo una Licencia Creative Commons

Atribución-NoComercial-SinDerivar 4.0 Internacional, IIJ-UNAM. 
Continúa reflexionando el ministro, que lo que está en tela de juicio es determinar si el derecho a la indemnización, en el caso específico del daño moral, puede dejarse abierto y sólo en manos de la discrecionalidad del juez, a lo que responde que no, aduciendo que el legislador puede válidamente establecer límites al monto de la indemnización, pues así se lo autoriza la parte final del artículo 113 constitucional: "Los particulares tendrán derecho a una indemnización conforme a las bases, límites y procedimientos que establezcan las leyes"; y la razón de esto, argumenta, está en que el Estado, si bien es solvente para todos los efectos legales, "no puede ver menoscabadas sus arcas con base en condenas excesivas, fijadas únicamente al arbitrio del juez", y por lo tanto, señala, es necesario poner un límite al poder discrecional del juzgador en este ámbito. ${ }^{35}$

Es claro que el temor de ver menoscabadas las arcas del Estado con la aplicación de la institución continúa vigente, y es dicha percepción lo que encauzaría a la entidad respectiva a aplicar la norma que impone un monto máximo a la reparación por daño moral; ello considerando el beneficio que representaría a la entidad respectiva si se está ante la presencia de afectaciones morales, que aplicando los parámetros establecidos en el artículo 1916 del Código Civil Federal ${ }^{36}$ pudiera ver notablemente rebasado el límite autorizado por el legislador federal.

Afortunadamente, y no obstante la vigencia del precepto limitario, ya es obligatorio el criterio de la Suprema Corte en el sentido de que limitar la responsabilidad fijando un techo cuantitativo implica marginar las circunstancias concretas del caso, el valor real de la reparación o de la salud deteriorada; esto es, una indemnización es injusta cuando se le limita con topes o tarifas, y en lugar de ser el juez quien la cuantifique justa y equitativamente con base en criterios de razonabilidad, al ser quien conoce las particularidades del caso, es el legislador quien, arbitrariamente, fija montos indemnizatorios, al margen del caso y de su realidad. Dicha obligatoriedad deriva de la circunstancia de que tal criterio es de rango

\footnotetext{
35 Voto particular que formula el ministro José de Jesús Gudiño Pelayo en el amparo en revisión 75/2009, interpuesto por Blanca Delia Renterría Torres y otra, pp. 5 y 6.

36 "El monto de la indemnización lo determinará el juez tomando en cuenta los derechos lesionados, el grado de responsabilidad, la situación económica del responsable, y la de la víctima, así como las demás circunstancias del caso". Código Civil Federal publicado en el Diario Oficial de la Federación en cuatro partes los días 26 de mayo, 14 de julio, 3 y 31 de agosto de 1928, última reforma publicada el 3 de junio de 2019.
} 
jurisprudencial, ${ }^{37}$ visibe en la tesis de rubro "Derecho fundamental a una reparación integral o justa indemnización. Su concepto y alcance". ${ }^{8}$

\author{
VIII. PROPUESTA: PREGUNTA LÓGICO-JURÍDICA \\ PARA ARRIBAR A LA CONCLUSIÓN DE UNA INDEMNIZACIÓN \\ JUSTA POR DAÑO MORAL
}

\begin{abstract}
¿Puede el particular afectado percibir una cuantía menor por concepto de indemnización en proporción al daño causado por el Estado? Dicha pregunta se formula en contraposición a la diversa realizada en el voto particular del entonces ministro Gudiño Pelayo: “¿Puede dejarse abierta, sin fijación de montos máximos, la indemnización a que puede ser condenado el Estado?". La respuesta a aquélla se encuentra implícita en la resolución del ya citado amparo en revisión 75/2009, cuando la Primera Sala adujo lo siguiente: "El daño causado es el que determina la reparación, nunca un monto prefijado puede establecer de manera previa la afectación máxima que se puede sufrir". ${ }^{39}$ De igual forma, al emitir la tesis CLVI/2009 determinó:
\end{abstract}

si el cálculo del monto está disciplinado no sólo por la entidad del daño y el grado de responsabilidad del sujeto que lo causa... sino también por el tope monetario máximo establecido en la fracción II del artículo 14 de la Ley Federal de Responsabilidad Patrimonial del Estado, habrá daños desiguales que serán tratados de la misma manera. En esta categoría de casos, los particulares deberán asumir el costo que supere el tope máximo, lo cual no sólo impedirá la reparación integral de la violación sufrida en sus derechos, sino que le permitirá al Estado no asumir parte de las consecuencias de los daños que causa, dejándolo sin los incentivos necesarios para adoptar medidas que eliminen o aminoren la mala calidad de los servicios públicos.

Finalmente, el citado criterio jurisprudencial 1a./J. 31/2017 reza que el derecho moderno de daños mira la naturaleza y extensión del daño a las víctimas y no a los victimarios, y así, el

37 Artículo 217 de la Ley de Amparo, Reglamentaria de los Artículos 103 y 107 de la Constitución Política de los Estados Unidos Mexicanos, publicada en el Diario Oficial de la Federación el 2 de abril de 2013, última reforma publicada el 15 de junio de 2018.

38 Tesis 1a./J. 31/2017, Gaceta del Semanario Judicial de la Federación, Décima Época, t. I, abril de 2017, p. 752.

39 Amparo en revisión 75/2009, resuelto por la Primera Sala de la Suprema Corte de Justicia de la Nación, p. 63. 
daño causado es el que determina la naturaleza y el monto de la indemnización, de forma que las reparaciones no pueden implicar enriquecimiento ni empobrecimiento para la víctima, pues no se pretende que la responsabilidad sea excesiva, ya que debe subordinarse a requisitos cualitativos, en el entenido que una indemnización será excesiva cuando exceda del monto suficiente para compensar a la víctima.

En el mismo sentido se ha pronunciado la doctrina, al referir que “...el fundamento es el daño en sí mismo, por ser antijurídico, ya que quebranta los principios de equidad, igualdad y bien común, por lo cual, cualquier conducta cometida por los servidores públicos, normal o anormal, culposa o no, lícita o ilícita, debe ser respondida por el Estado...", ${ }^{40}$ pues "no puede haber responsabilidad sin la existencia de un daño, el cual es la esencia de la responsabilidad...". 41

Así, dada la trascendencia del instituto de responsabilidad patrimonial, elevado a garantía constitucional, la lesión por falta de reparación del daño "no será a nivel patrimonial, sino al de derechos fundamentales". ${ }^{42}$

De esta manera, si bien indemnizaciones demasiado excesivas pueden provocar la paralización de una actividad o de un sector, de manera que es necesario acomodar su cuantía al nivel económico de un país, ello no es base ni justificación alguna para que no exista "el equilibrio entre compensación adecuada y la efectividad y viabilidad de los mecanismos de reparación". ${ }^{43}$

A nuestro criterio, y ante lo antes expuesto, la pregunta anterior: ¿puede el particular afectado percibir una cuantía menor por concepto de indemnización en proporción al daño causado por el Estado?, cobra revelencia ante la vigencia, insistimos, del inconstitucional límite dispuesto en el artículo 14, fracción II, de la LFRPE; y, por lo tanto, consideramos, es uno de los enunciados que podría formularse la autoridad encargada de determinar el monto indemnizatorio por la reparación del daño moral, para arribar a la conclusión de fijar una compensación justa, subordinada a criterios cualitativos, sin que ello se traduzca en que la resolución que tenga como base tales criterios esté resarciendo de forma excesiva al particular afectado.

\footnotetext{
40 Murillo Morales, Jaime, Responsabilidad patrimonial de la administración de justicia, México, Ubijus, 2014, p. 111.

41 Ibidem, p. 117.

42 Ibidem, p. 112.

43 Ibidem, p. 147
} 
Estamos conscientes de que la Suprema Corte ya se ha pronunciado por tal inconstitucionalidad, y que las mismas resoluciones constituyen herramientas obligatorias suficientes que deben llevar a la entidad facultada de resolver la cantidad compensatoria, a inclinarse por una decisión justa y proporcional al daño causado por el Estado. Sin embargo, la administración pública no cuenta con la preparación suficiente, ${ }^{44} \mathrm{o}$ bien desconoce el instituto de responsabildad patrimonial, lo cual puede traducirse en que la autoridad correspondiente opte por la aplicación íntegra del artículo 14, fracción II, de la LFRPE.

Por lo tanto, aun ante el desconocimiento del sistema de responsabilidad patrimonial, y en consecuencia, de los pronunciamientos de la Corte mexicana, el enunciado propuesto en forma de pregunta básica podría llevar al resolutor del caso respectivo a construir una resolución adecuada inaplicando la inconstitucional porción normativa del numeral señalado, e inclusive al conocimiento de los trascendentes pronunciamentos del alto tribunal, evitando determinaciones contrarias a derecho, que sólo generarían mayores cargas al gobernado en la búsqueda de la anulación de un resolución de tales características.

\section{Criterios ReCientes de la Suprema Corte DE JUSTICIA DE LA NACIÓN}

Uno de los criterios adoptados recientemente por la $\mathrm{SCJN}^{45}$ consiste en precisar las reglas cuando se tramiten dos vías distintas para reclamar

\footnotetext{
44 Castro Estrada señalaba: "En forma complementaria a los programas de desarrollo administrativo que deberán diseñarse a fin de preparar a la Administración Pública para este nuevo reto, será pertinente pensar en los ajustes... que tengan como finalidad establecer los procedimientos internos y las unidades administrativas que tendrán competencia para sustanciar las solicitudes... de reclamación; de manera tal que la desorganización o el desconcierto no se presenten al momento de entrar en vigor la reforma constitucional... La relevancia de estas acciones de preparación previa es manifiesta si se toma en cuenta que el el retraso o la desatención indebida de un reclamo de esta naturaleza podría traer consigo reclamos adicionales, en tanto que tal desatención conlleve nuevas afectaciones patrimoniales para el particular reclamente.

El punto de los presupuestos necesarios que deberán destinarse a organizar y establecer órganos nuevos $u$ ampliar los existentes... es, indudablemente, otro de los rubros indispensables que no pueden desatenderse so pena de hacer nugatoria la nueva garantía constitucional" [el resaltado es nuestro]. Castro Estrada, Álvaro, Nueva garantía constitucional..., cit., p. 246.

45 Tesis: 2a. XIX/2018 (10a.), Gaceta del Semanario Judicial de la Federación, Décima Época, t. II, marzo de 2018, p. 1439.
} 
indemnización por responsabilidad patrimonial, específicamente por las vías administrativa y jurisdiccional. El más alto tribunal separa los montos pecuniarios respectivos; sin embargo, al estar destinados para los mismos efectos, es decir, la reparación por la actividad irregular del Estado, determina que debe haber compensación.

Por una parte, y en protección de los intereses del gobernado, dispone que la autoridad que conozca de los casos, en el supuesto de acreditarse la responsabilidad patrimonial del Estado, entre al estudio de fondo y calcule la indemnización integral debida, sin que de un análisis preliminar pueda darse por satisfecha la repración integral del daño por el simple hecho de haberse entregado una indemnización previa, producto del trámite de una queja adsministrativa.

Sin embargo, por otra parte, y en aras del Estado, da plena validez a la indemnización decretada por la autoridad administrativa, por lo que de existir un pago por un concepto indemnizatorio obtenido en dicha vía y por los mismos hechos, la autoridad jurisdiccional deberá restarlo del monto de la reparación integral a pagar.

De igual forma, encontramos con criterio diverso, ${ }^{46}$ en el que la SCJN identificó un límite a la indemnización, distinto al tratado en el presente, pero que es importante destacar atendiendo a la protección federal que debe intervenir ante ciertas carencias respecto a la protección de la persona, plasmadas por el legislador ordinario, siendo el artículo controvertido, el 14, fracción I, inciso a), de la LFRPE, en razón de que

El precepto citado señala que los montos de las indemnizaciones en el caso de daños personales se calcularán conforme a lo dispuesto para riesgos de trabajo en la Ley Federal del Trabajo, lo que limita por consecuencia la posibilidad de indemnización a las personas que tengan una relación laboral... pues al utilizar el salario mínimo como parámetro de reparación económica, excluye los casos de aquellas personas que no perciben uno. Así, conforme al principio de igualdad, pesaba sobre el legislador el deber adicional de proteger la situación especial de los menores de 15 años... precisamente en que los daños derivados de un accidente o enfermedad no pueden calcularse... en función del perjuicio que sufrirán al dejar de trabajar, ya que existe una restricción constitucional que prohíbe cualquier tipo de trabajo de los menores de esa edad. Así... el artículo 14, fracción I, inciso a), de la Ley Federal de

46 Tesis: 2a. XXXI/2018 (10a.), Gaceta del Semanario Judicial de la Federación, Décima Época, t. I, abril de 2018, p. 861. 
Responsabilidad Patrimonial del Estado es inconstitucional al ser subinclusivo, porque excluye injustificadamente del acceso a una indemnización por daños personales, a individuos que se sitúan en condiciones iguales que otros respecto del daño producido por la actuación irregular del Estado, personas a las que, además, en atención a su situación especial por ser menores, tendría que haber protegido con mayor especialidad y alcance.

\section{Propuestas iniciales Versus texto CONSTITUCIONAL VIGENTE}

Tal como se señaló al inicio del presente, las propuestas iniciales de la institución incluían la proporcionalidad y equidad, ya en conjunto o alguna de ambas, con relación a la indemnización derivada de la lesión causada por el Estado. Sin embargo, respecto al monto por concepto de resarcimiento, el actual texto constitucional, en su artículo 109 precisa que "Los particulares tendrán derecho a una indemnización conforme a las bases, límites y procedimientos que establezcan las leyes".

Las razones de Castro Estrada para incluir dichas expresiones fueron las siguientes:

El sentido de la expresión proporcional y equitativa que aquí se usó fue el que tuvo en su origen, como criterio de justicia, y que permite dar un tratamiento igual a los iguales, y desigual a los desiguales. Se trata del criterio que yo he llamado de ponderación, en virtud del cual las indemnizaciones no deben ser iguales para todos, sino integrales para quienes menos ingresos tienen, y equitativas para quienes más ingresos perciben. Además, no considero que la indemnización proveniente de una actividad administrativa indebida deba ser la misma que una debida; la primera debe ser integral; y la segunda, equitativa (a pesar de que, en materia de responsabilidad objetiva, la conducta de los agentes públicos no es el dato relevante, sino la relación causa-efecto entre la actividad que se imputa al Estado y la lesión antijurídica ocasionada). En otras palabras, la intención de haber incluído la expresión proporcional y equitativa fue la de dar base constitucional a las indemnizaciones ponderadas o diferenciadas...

A pesar de lo dicho, considero que el razonamiento que se incluyó en el Dictamen de la H. Cámara de Diputados para prescindir de tal expresión, parece justificado, en cuanto a que, si bien en su expresión primigenia proporcional y equitativa era la de justicia, hoy la práctica impositiva fiscal le ha dado una significación técnica muy especializada para tales ámbitos 
(artícuo 31 fracción IV), por lo que se estima inconveniente su utilización en materia de responsabilidad patrimonial del Estado. Estoy de acuerdo en que todo aquello que pudiese generar alguna confusión debe omitirse, máxime que como dice el mencionado Dictamen: ' ...Por el sólo hecho de establecer que los particulares tendrán derecho a una indemnización, se implica que será justa, $\mathrm{y}$, siendo consecuentes con su auténtico significado, que será proporcional y equitativa'. ${ }^{47}$

Podemos constatar que el sentido de la expresión proporcional y equitativa se usó como criterio de justicia en relación con las indemnizaciones a las que los particulares tuvieran derecho.

Cabe resaltar que el jurista en mención, si bien considera que el dato relevante en materia de responsabilidad objetiva es la relación causa-efecto y la lesión antijurídica, también se inclina por el criterio de que las indemnizaciones serán en razón del grado del ingreso que la víctima perciba, haciendo - el tratadista - hincapié en que las indemnizaciones no deben ser iguales para todos, y manifiesta su postura en que, inclusive, la indemnización proveniente de una actividad administrativa indebida no debe ser la misma que una debida.

Compartimos el criterio de justicia que el tratadista le da como sentido a la expresión proporcional y equitativa; sin embargo, nos apartamos del resto de los argumentos que a continuación se señalan, por las siguientes razones:

1. Respecto a la proporcionalidad y equidad, Castro Estrada señala: "Se trata del criterio que yo he llamado de ponderación, en virtud del cual las indemnizaciones no deben ser iguales para todos, sino integrales para quienes menos ingresos tienen, y equitativas para quienes más ingresos perciben".

Tal y como apuntamos en la nota 13 del presente, compartimos el criterio sentado en el amparo en revisión 75/2009, que establece:

cabe destacar que se precisó que la cantidad de la indemnización en cumplimiento del artículo 12 de la Ley Federal de Responsabilidad Patrimonial del Estado, se debe determinar no en función de la capacidad económica del sujeto actor, sino en función de la naturaleza del daño ocasionado, el resultado de la valoración de los derechos lesionados y el grado de responsabilidad

47 Ibidem, pp. 194 y 195. 
del sujeto responsable. En tal virtud, se considerará que las indemnizaciones no son excesivas si, por una parte, se atiende a la compensación del daño creado... El daño causado es el que determina la reparación...

En tal sentido, existe contraposición entre los argumentos:

- las indemnizaciones deben ser integrales para quienes menos ingresos tienen, y equitativas para quienes más ingresos perciben.

- la indemnización se debe determinar como resultado de la valoración de los derechos lesionados.

Reiteramos que nos inclinamos por el razonamiento de la SCJN, precisamente porque restituir o indemnizar a la víctima en proporción al daño causado, y no en función de su capacidad económica, pone de relieve la justicia que puede identificarse con el bien común y con los derechos humanos que ocupa la centralidad axiológica del derecho, ${ }^{48}$ además de que sería discriminatorio privar a las víctimas de la reparación integral derivado del artículo 63.1 de la Convención Americana sobre Derechos Humanos, únicamente por su capacidad económica (el tratadista en análisis limita las indemnizaciones integrales únicamente para quienes menos ingresos tienen).

De igual forma, el artículo 12 de la LFRPE dispone que "Las indemnizaciones corresponderán a la reparación integral del daño" sin acotarlas sólo a las personas de escasos recursos, porque, precisamente, atendiendo a la restitución del daño causado, propusimos la pregunta: “¿puede el particular afectado percibir una cuantía menor por concepto de indemnización en proporción al daño causado por el Estado?". Situación que correría el riesgo de actualizarse, de aplicar el criterio que la indemnización debe ser en función de la capacidad económica de la víctima; es decir, que si el afectado resulta ser una persona considerada dentro del grupo de "quienes más ingresos reciben”, la restitución podría ser menor en proporción al daño causado, toda vez que no se aplicaría la restitutio in integrum.

2. La responsabilidad patrimonial del Estado como garantía constitucional: tomando en consideración la definición de garantía constitucional

\footnotetext{
48 Vigo, Rodolfo Luis, Constitucionalización y judicialización del derecho, México, Porrúa-Universidad Panamericana, 2016, p. 28.

Esta obra está bajo una Licencia Creative Commons

Atribución-NoComercial-SinDerivar 4.0 Internacional, IIJ-UNAM.
} 
de Eréndira Salgado Ledezma, tenemos que "son instrumentos de naturaleza procesal cuya finalidad es la restauración del orden constitucional cuando éste ha sido desconocido o violado por los órganos de poder y los instrumentos protectores no fueron suficientes para lograr el respeto de la Constitución y la vigencia del Principio de Supremacía". ${ }^{49}$

Compartimos la idea de que la responsabilidad patrimonial del Estado podría ser una garantía que proteja la integridad patrimonial, o bien la integridad en general del ser humano en todos sus aspectos respecto de actos del Estado, tomando en consideración que no se constriñe únicamente a cuestiones patrimoniales, sino que también incluye las extrapatrimoniales.

Sin embargo, en lo referente al criterio de que la proporcionalidad y equidad pueden llevar a una solución justa para mantener íntegro el patrimonio, consideramos bastante la idea antes apuntada, consistente en que "la indemnización se debe determinar como resultado de la valoración de los derechos lesionados", pues con ello se pone de relieve el principio de justicia.

Lo anterior, pues tal como quedó apuntado, Castro Estrada señala: "si bien en su expresión primigenia proporcional y equitativa era la de justicia, hoy la práctica impositiva fiscal le ha dado una significación técnica muy especializada". En dicho tenor, consideramos que acudir a la valoración de los daños para determinar la indemnización resolvería el tema de la justicia antes que el criterio de proporcionalidad y equidad, sobre todo tomando en consideración el criterio jurisdiccional, ${ }^{50}$ que establece que la proporcionalidad y equidad, desarrollados a partir del enfoque fiscal, deben atender a la capacidad económica, y reitera el argumento de Castro Estrada: trato igual a los iguales y desigual a los desiguales, cuando, conforme al razonamiento que hemos venido sosteniendo, las condiciones y circunstancias económicas de la víctima no pueden determinar el grado, cuantía o nivel de reparación, sino lo hará el daño, y, por lo tanto, los alcances de la afectación sufrida por el individuo afectado.

49 "México" (sic), Enciclopedia Jurídica Online, José Luis Soberanes, voz: "Garantías constitucionales", disponible en: https://mexico.leyderecho.org/garantias-constitucionales/ (fecha de consulta: 28 de junio de 2019).

50 Tesis P. XLI/93, Gaceta del Semanario Judicial de la Federación, octava época, julio de 1993, p. 25. 


\section{PRESUNCIÓN DEL DAÑO MORAL EN EL CONSEJO DE ESTADO DE COLOMBIA}

El perjuicio moral puede ser definido como aquel que impacta la órbita interna del sujeto, concretamente su esfera emotivo-espiritual, que generalmente se manifiesta en forma de dolor, congoja, pesadumbre, aflicción, intranquilidad o cualquier forma de alteración emocional. Sin embargo, es importante precisar que la alteración emocional no puede ser patológica, pues de serlo se estaría frente a un daño a la salud de tipo psicológico. ${ }^{51}$

En el ordenamiento jurídico colombiano el daño moral se reconoció por la Corte Suprema de Justicia en la sentencia de casación el 21 de julio de 1922, y en la sustitutiva del 22 de agosto de 1924, proferidas en el caso Villaveces. En éstas, la Corte reconoció indemnización por daño moral a favor del señor Villaveces por haber sido violentada la bóveda donde se encontraban los restos de su esposa, que fueron arrojados a una fosa común. ${ }^{52}$

Respecto a la presunción por daño moral, el Consejo de Estado, en su sentencia 6750 del 17 de julio de 1992, estableció que aplica para los parientes hasta el segundo grado por consanguinidad y primero civil, ya sean ascendientes, descendientes o colaterales, ocupándose, en específico en dicha sentencia, de los hermanos. ${ }^{53}$ Es decir, basta demostrar el vínculo familiar en el grado de parentesco estipulado, para convertirse en titular de la indemnización respectiva por el dolor o aflicción causado por el daño inferido a la víctima directa.

Si bien en la sentencia no se especifica si tal presunción admite prueba en contrario, consideramos que atendiendo a cada caso particular habrá de admitirse prueba en contrario por la parte a quien no beneficie tal presunción; lo anterior, tomando en cuenta que en el ordenamiento colombiano, dentro de las presunciones legales, se distinguen las iuris tantum — que admiten prueba en contrario-y las presunciones iuris et de iure - que no admiten prueba en contrario- - tomando como fundamento el artículo 176 del Código de Procedimiento Civil, que establece que "las presunciones

51 Martínez Benavides, "Análisis de la presunción de daño moral que beneficia a ciertas víctimas indirectas en la jurisdicción contencioso administrativa colombiana", Revista Derecho del Estado, Bogotá, núm. 42, enero-abril de 2019, pp. 181-210.

52 Idem.

53 Sentencia 6750, del Consejo de Estado - Sala de lo Contencioso Administrativo-, sección tercera, 17 de julio de 1992, disponible en: https://2019.vlex.com/\#vid/355912926 (fecha de consulta: 29 de junio de 2019) 
establecidas por la ley serán procedentes siempre que los hechos en que se funden estén debidamente probados. El hecho se tendrá por cierto pero admitirá prueba en contrario cuando la ley lo autorice". ${ }^{54}$

En el país objeto de análisis son dos las posturas respecto de la exigencia probatoria por daño moral. La primera y más antigua en el tiempo sostiene que el daño moral no requiere de prueba, y la segunda defiende que el daño moral, al igual que cualquier otro tipo de daño, debe ser probado por quien pretenda su reparación, destacando que ambas posturas conviven en las posturas de los tribunales de justicia. ${ }^{55}$

\section{CONCLUSIONES}

De acuerdo con lo expuesto, compartimos los criterios analizados en el presente, emitidos por la SCJN, con relación a que el daño causado es el que determina la naturaleza y el monto de la indemnización, así como el grado de responsabilidad del sujeto que lo causa, por lo cual nos apartamos de la postura que sostiene que el monto resarcitorio se defina con base en los ingresos del víctima, sin que ello signifique que estos factores no deban ser tomados en cuenta al momento de cuantificar la indemnización, pero que, insistimos, el factor principal y preponderante lo será el daño causado, y en consecuencia, los alcances y efectos de éste.

En cuanto a que el tratadista compartió que la H. Cámara de Diputados prescindiera de la expresión primigenia proporcional y equitativa, atendiendo a que todo aquello que pudiera generar alguna confusión debe omitirse, estimamos que, no obstante apartarnos ciertos alcances que el tratadista apoya respecto a la proporcionalidad y equidad, hubiera sido más conveniente a la vigente de hoy en día: "Los particulares tendrán derecho a una indemnización conforme a las bases, límites y procedimientos que establezcan las leyes"; esto es, porque aunque no estemos convencidos de que el monto de la indemnización sea definido — principalmente — en razón de los ingresos de las víctimas, el criterio de justicia contenido en la expresión referida hubiera tenido mayor protección a nivel constitucional tratándose

54 Sentencia C-731/05 de la Sala Plena de la Corte Constitucional de la República de Colombia del 12 de julio de 2005, disponible en: http://www.corteconstitucional.gov.co/ relatoria/2005/c-731-05.htm (fecha de consulta: 29 de junio de 2019)

55 Cárdenas Villarreal, Hugo A. y Gonález Vergara, Paulina V., "Notas en torno a la prueba del daño moral: un intento de sistematización", Revista Facultad de Derecho y Ciencias Políticas, Bogotá, vol. 37, núm. 106, enero-junio 2007, pp. 213-237. 
de los bienes y derechos de los afectados, sin que se permitiera — no constitucionalmente- que el legislador ordinario emitiera normas contrarias al principio de justicia, porque si bien tal vez el efecto de la expresión límites no sea de causar confusión, sí permite — en principio - que aquél cuente con las facultades constitucionales para fijar los límites que considere con relación a la reparación y compensación del daño, generando el desatino que el límite fijado en la ley sea inconstitucional e injusto. Por lo tanto, y toda vez que el daño causado es el que determina la naturaleza y el monto de la indemnización, nos remitimos a la propuesta realizada, consistente en la formulación de la pregunta "¿puede el particular afectado percibir una cuantía menor por concepto de indemnización en proporción al daño causado por el Estado?", a partir de la cual, dada la sencillez del planteamiento, se puede realizar la reflexión en torno a los alcances de la reparación, pasando por el concepto de reparación integral, llegando al conocimiento de los pronunciamientos acerca de la inconsticionalidad del artículo 14, fracción II, de la LFRPE, tomando en cuenta que la corriente actual atempera la cuantía de la indemnización a "los modos valorativos convencionales utilizados por las jurisdicciones civil, penal y laboral". ${ }^{56}$

Finalmente, reconocemos que no obstante la declaración de inconstitucionalidad del artículo 14, fracción II, de la LFRPE, continúan los problemas e inconvenientes respecto de su aplicación; esto es, porque su contenido, al ser replicado por legislaciones locales, pone de relieve que las autoridades locales, aun el criterio objeto de análisis del presente, han pretendido aplicar a la letra los límites a la indemnización por daño por daño moral, lo que ha dado lugar a la emisión de criterios de inconstitucionalidad, a través de amparos directos interpuestos ante las autoridades jurisdiccionales federales. ${ }^{57}$

\section{BIBLIOGRAFÍA}

Acosta García, Cristian Miguel, Responsabilidad patrimonial del Estado. Teoría y casos prácticos, México, Novum.

56 Delgado Sancho, Carlos David, La responsabilidad patrimonial de las administraciones públicas, España, Gomylex, 2013, p. 63.

57 Tesis III.10.A.34 A (10a.), Gaceta del Semanario Judicial de la Federación, Décima Época, t. II, diciembre de 2016, p. 1854; tesis: XVI.1o.A.109 A (10a.), Gaceta del Semanario Judicial de la Federación, décima época, t. IV, octubre de 2016, p. 3084; tesis III.5o.A.12 A (10a.), Gaceta del Semanario Judicial de la Federación, décima época, t. III, abril de 2016, p. 2548. 
CAStro EstradA, Álvaro, Nueva garantía constitucional. La responsabilidad patrimonial del Estado, México, Porrúa, 2005.

CAstro Estrada, Álvaro, Responsabilidad patrimonial del Estado, México, Porrúa, 2006.

Delgado SANCHO, Carlos David, La responsabilidad patrimonial de las administraciones públicas, España, Gomylex, 2013.

MANZANARES SAMANIEGO, José Luis, La responsabilidad patrimonial por el funcionamiento de la administración de justicia, Madrid, La Ley, 2012.

MARTÍNEZ BENAVIDES, “Análisis de la presunción de daño moral que beneficia a ciertas víctimas indirectas en la jurisdicción contencioso administrativa colombiana", Revista Derecho del Estado, Bogotá, Universidad Externado de Colombia, núm. 42, enero-abril de 2019

Mendoza Martínez, Lucía Alejandra, La acción civil del daño moral, México, UNAM, Instituto de Investigaciones Jurídicas, 2014.

Murillo Morales, Jaime, Responsabilidad patrimonial de la administración de justicia, México, Ubijus, 2014.

PÉREZ FuENTES, Gisela María (coord.), Temas actuales de responsabilidad civil, México, Tirant lo Blanch, 2018.

RODRIGUEZ-ArANA MuÑOZ, Jaime et al. (coords.), t. I: La responsabilidad patrimonial de la administración pública, México, Espress, 2014.

RODRIGUEZ-ARANA MUÑOZ, Jaime et al. (coords.), t. II: La responsabilidad patrimonial de la administración pública, México, Espress, 2014.

SteIner, Christian y URIBE, Patricia, Convención Americana sobre Derechos Humanos comentada, México, Suprema Corte de Justicia de la Nación.

Oliva Gómez, Eduardo y Villa GuARDiola, Vera Judith, "Hacia un concepto interdisciplinario de la familia en la globalización", Justicia Juris, vol. 10, núm.1, enero-junio de 2014.

Vigo, Rodolfo Luis, Constitucionalización y judicialización del derecho, México, Porrúa-Universidad Panamericana, 2016.

Fecha de recepción: 28 de agosto de 2017.

Fecha de aceptación: 28 de mayo de 2019.

Esta obra está bajo una Licencia Creative Commons Atribución-NoComercial-SinDerivar 4.0 Internacional, IIJ-UNAM. 


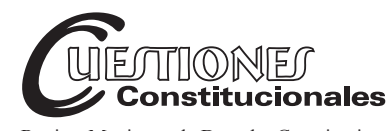

Revista Mexicana de Derecho Constitucional Núm. 43, julio-diciembre 2020

\title{
El olvido previo a Internet: los orígenes del actual derecho al olvido digital*
}

\author{
Forget Before Internet: the Origins of the Right \\ to be Forgotten
}

Ángela Moreno BoBADILLA**

RESUMEN: El derecho al olvido digital se ha convertido en cuestión de capital importancia, debido a la ausencia de fronteras espaciales y temporales propias de Internet. Para poder comprender todo lo relacionado con este derecho emergente, es necesario analizar cuál es su verdadero origen, que es previo a la era digital. La principal finalidad que tiene llevar a cabo este background es tener un conocimiento más profundo y exhaustivo de sus orígenes, que se remontan a finales del siglo XIX, y que se encuentran, principalmente, en Estados Unidos y en Francia.

Palabras clave: derecho al olvido, intimidad, privacidad, protección de datos personales, common law, sistemas civilistas, derechos digitales.
ABSTRACT: The right to be forgotten has become a matter of capital importance, due to the absence of spatial and temporal borders of the Internet. In order to understand everything related to this emerging right, it is necessary to analyze what is its true origin, which is prior to the digital age. The main purpose of carrying out this background is to have a deeper and more exhaustive knowledge of its origins that go back to the end of the 19th century, and which are mainly found in the United States and France.

Keywords: the right to be forgotten, privacy, data protection, common law, civil systems, digital rights.

* Artículo financiado por el Proyecto Fondecyt Iniciación 11180172 “Aspectos fundamentales para la configuración y el desarrollo del derecho al olvido digital en Chile".

** Directora de posgrados de la Facultad de Derecho de la Universidad Andrés Bello, y profesora de Derecho Constitucional de la Facultad de Derecho de la Universidad Andrés Bello. Chile. ORCID: 0000-0003-0828-7459. Correo electrónico: angela.moreno@ unab.cl. 
SUMARIO: I. Introducción. II. Estados Unidos: olvido en el pasado, recuerdo en el presente. III. La primacía de la privacidad en Europa. IV. Conclusiones. V. Bibliografía.

\section{INTRODUCCIÓN}

Desde la antigüedad, el ser humano ha necesitado perdón y rendición. Ha reclamado por tener derecho a una segunda oportunidad. Esta necesidad de volver a comenzar, a pesar de que parece un debate propio de la actualidad, en realidad es anterior a la creación de Internet. ${ }^{1}$

Concretamente, sus orígenes se remontan a finales del siglo XIX y principios del siglo XX, cuando los ciudadanos comienzan a clamar por mantener su vida privada alejada de miradas indiscretas. En palabras de María Álvarez Caro: "El derecho al olvido encuentra sus raíces en el derecho a la intimidad (the right to privacy en su denominación en inglés) y en el derecho a la protección de datos personales, pudiendo considerarse que el derecho al olvido deriva de ellos". ${ }^{2}$

No obstante, antes de la creación de Internet, la memoria humana imperaba sobre la memoria virtual, provocando que el mero transcurso del tiempo convirtiera ciertos datos en irrelevantes.

Sin embargo, en la actualidad este debate ha cobrado una gran relevancia, debido a la inmediatez y la ausencia de fronteras espaciales y temporales, que hacen que cualquier dato del pasado pueda volver al presente. Esto ha provocado que se abra con fuerza el debate relativo al derecho al olvido digital, es decir, a si cada vez que alguien teclee nuestro nombre y apellidos en un buscador puede o debe aparecer cualquier información relacionada con nuestro pasado. ${ }^{3}$

1 González Fuster, Gloria, The Emergence of Personal Data Protection as a Fundamental Right of the EU, Suiza, Springer, 2014, p. 22.

2 Álvarez Caro, María, Derecho al olvido en Internet: el nuevo paradigma de la privacidad en la era digital, Madrid, Reus, 2015, p. 27.

3 De Terwangne, Cecile, "Privacidad en Internet y el derecho a ser olvido/al olvido", Revista de Internet, Derecho y Política, núm. 13, febrero, 2012, pp. 53-66, disponible en: http://doi.org/10.7238/idp.v0i13.1400.

La autora explica las tres facetas que tiene el derecho al olvido, entre las que menciona el derecho al olvido al pasado judicial, el derecho al olvido establecido en la legislación de la protección de datos y el derecho al olvido como equivalente a atribuir una fecha 
Con objeto de poder comprender todo lo relacionado con este derecho emergente, es necesario analizar cuál es el verdadero origen del derecho al olvido, que es previo a la era digital. La principal finalidad que tiene llevar a cabo este background es tener un conocimiento más profundo y exhaustivo de sus orígenes, que se remontan a finales del siglo XIX.

Para ello, el artículo desarrolla un estudio comparado, en donde se parte examinando la evolución que ha habido en esta materia en Estados Unidos, por ser este el país donde nació uno de los derechos con los que guarda una mayor relación: el derecho a la privacidad. A continuación, se estudia su evolución en el continente europeo, que en la actualidad es el punto que tiene un mayor desarrollo en esta cuestión. Concretamente, se analiza el caso de Francia, donde se encuentran los primeros supuestos que siembran los orígenes del derecho al olvido.

Dos visiones muy diferentes, debido a que su germen, la privacidad, en los sistemas del common law, principalmente en Estados Unidos, se basa en la libertad de los individuos para decidir, mientras que en los países de tradición civilista, como España, Alemania, Francia o Italia, entre otros, está basada en la idea de dignidad. ${ }^{4}$

\section{ESTADOS UNIDOS: OLVIDO EN EL PASADO, RECUERDO EN EL PRESENTE}

En el país que se ha convertido en la cuna de la tecnología mundial, se encuentran algunos de los hitos jurisprudenciales más determinantes en materia de derecho al olvido, y que están directamente relacionados con dos momentos que marcaron el inicio del actual debate: el artículo de los

de caducidad a los datos personales, pero que es solamente aplicable al contexto de las redes sociales.

4 Werro, Franz, "The Right to Inform v. the Right to be Forgotten: a Transatlantic Clash", Georgetown University. Center for Transnational Legal Studies Colloquium, núm. 2, 2009, p. 286: "The two Western cultures seem on irreconcilable paths when it comes to the recognition and enforcement of a right to be forgotten". Whitman, James Q., "The Two Western Cultures of Privacy: Dignity Versus Liberty", Yale Law Journal, vol. 113, 2017, disponible en: file://D:/DERECHO\%20AL\%20OLVIDO/UF/OLVIDO\%20 Y\%20PRIVACIDAD/ARTÍCULOS/WHITMAN.pdf, p. 1161: "Continental privacy protections are, at their core, a form of protection of a right to respect and personal dignity... By contrast, America, in this as in so many things, is much more oriented toward values of liberty against the state". 
académicos Samuel Warren y Louis Brandeis y la creación de la teoría de los cuatro torts de William Prosser.

El estudio de estos hitos va a poner en evidencia la cambiante postura de Estados Unidos en esta materia, y que ayuda a comprender el posicionamiento jurídico que hay en la actualidad respecto del derecho al olvido digital en este país. Si bien durante finales del siglo XIX y las primeras décadas del siglo XX la jurisprudencia daba una mayor y acertada preeminencia al derecho a la intimidad de los ciudadanos, llegando a convertirse en un ejemplo para los tribunales europeos, la Corte Suprema cambió el rumbo a finales de los años sesenta, y dio un injustificado valor, prácticamente absoluto, al derecho a la información. Como resultado, hoy en día no hay ni olvido ni perdón en el país norteamericano, sin importar las informaciones protagonizadas por menores, por aquellas personas que han sido protagonistas involuntarias de una noticia, dígase, por ejemplo, una mujer que ha sido víctima de violencia de género, y un sinfín de casos en los que la privacidad de los ciudadanos se ha visto perdida para siempre.

\section{Finales del siglo XIX: the right to privacy}

Hasta 1890 la privacidad en Estados Unidos era concebida como un derecho intangible de propiedad, pero a raíz del célebre artículo "The Right to Privacy", publicado en la Harvard Law Review, ${ }^{5}$ comienza a forjarse la tesis de que cada persona debe tener un reducto de intimidad que sea inaccesible para los demás, siempre y cuando no haya interés público o consentimiento por parte de la persona afectada. ${ }^{6}$

A pesar de que marcó un antes y un después, este artículo ha sido criticado por una parte de la doctrina norteamericana, al afirmar que en realidad lo único que hicieron estos autores fue trasplantar la idea de privacidad que se estaba comenzando a desarrollar en la Europa continental, concretamente en Alemania.

5 Warren y Brandeis sientan las bases de un verdadero derecho a la intimidad, ya que muestran al mundo una nueva concepción respecto de su significación jurídica y social. Su artículo es uno de los más citados de la literatura jurídica a nivel mundial.

6 Moreno Bobadilla, Ángela, Intimidad y menores, Madrid, Centro de Estudios Políticos y Constitucionales, 2017, p. 86. 
En palabras de Schwartz y Peifer:

Their intention seems to have been to draw on continental philosophy to suggest that each person deserves protection against certain kinds of mental harms simply as a consequence of her status as a human. Precisely this idea proved to be highly influential in German law as well as European human rights jurisprudence. ${ }^{7}$

En realidad, este artículo sirvió para que los tribunales estadounidenses comenzaran a ver este derecho como susceptible de protección, y que de forma inconsciente se comenzara a hablar de que la privacidad está relacionada con el derecho al olvido, o sea, con el derecho a tener una segunda oportunidad, haciendo que ciertas informaciones que pertenecen al pasado, y que ya no tienen interés público en el presente, vuelvan a la esfera de la intimidad. ${ }^{8}$

Es relevante resaltar la importancia de estos dos visionarios del derecho, que no solamente elevaron la privacidad a la categoría de derecho, sino que además y gracias a su estudio, determinaron que su importancia radicaba en que su contenido era intangible, alejándolo del derecho de propiedad. Una acertada postura, más cercana al derecho continental que al common law.

Pocos años después de su publicación, se dictó en California la primera ley en materia de privacidad, concretamente en 1899, relativa a la publicación de retratos sin consentimiento, aunque desafortunadamente no tuvo ninguna aplicación práctica, y fue derogada en 1915.

En el ámbito de la jurisprudencia, uno de los primeros casos es el de Robertson v. Rochester Felding Box Co. de 1902, en donde la demandante solicitó el retiro de un anuncio publicitario de una marca de harina que usaba su imagen. A pesar de que la sentencia le fue adversa, se creó un

7 Schwartz, Paul M. y Piefer, Karl-Nikolaus, "Prosser's Privacy and the German Right of Personality: are Four Privacy Torts better than one Unitary Concept?", California Law Review, vol. 98, 2010, disponible en: https://scholarship.law.berkeley.edu/cgi/ viewcontent.cgi? article $=2755 \&$ context $=$ facpubs, p. 1944 .

8 Barbas, Samantha, "The Death of the Public Disclosure Tort: A Historical Perspective", Yale Journal of Law and the Humanities, vol. 22, num. 2, 2013, p. 173: "I trace the privacy tort's death to the period between roughly 1920 and 1940, an era that saw the rapid growth and transformation of both old and new media, including newspapers, magazines, radio and motion pictures". La autora explica cómo a raíz de los medios de comunicación se produjo la muerte del public disclosure of private facts. 
precedente legal, que provocó la aprobación de una ley en el estado de Nueva York, en 1903, que prohibía estas situaciones.

Ya en 1905, en el caso Pavest v. New England Life Insurance Co. se encuentran los primeros precedentes donde se defiende el derecho a la privacidad establecido en el artículo de Warren y Brandeis. La foto del artista Pavesich apareció en un anuncio de una compañía de seguros, y fue publicado en el Atlanta Constitution. A pesar de que posó para la instantánea, no dio su consentimiento, por lo que la Corte de Georgia consideró que se había producido una invasión en la privacidad del demandante.

Inmediatamente después de este caso, se produjeron otros similares, en los que se usaba la imagen de personas para anuncios publicitarios sin que mediara el consentimiento oportuno. Y los tribunales fallaron a favor de los afectados, porque consideraron que estos hechos constituían una invasión para la privacidad de los demandantes (véanse en este sentido los siguientes casos: Henry v. Cherry y Webb de 1909; Foster Millburn Co. v. Chinn de 1909; Munden v. Harris de 1911).

Todos estos fallos demuestran la favorable postura que mantuvieron los tribunales estadounidenses durante estos años a favor de la privacidad, gracias al positivo efecto que produjo en el ordenamiento jurídico el artículo de Samuel Warren y Louis Brandeis, donde además de contemplar la intimidad como un derecho fundamental, era prioritario tener en cuenta si el afectado había manifestado el consentimiento oportuno.

También es importante el caso Olmstead v. United States de 1928. Los hechos estaban relacionados con unas escuchas telefónicas que había realizado el gobierno, debido a las sospechas que tenían de que se podían estar incumpliendo algunas leyes en materia de importación, almacenamiento y venta de bebidas alcohólicas. Todos los miembros del tribunal, excepto uno, consideraron que no se había producido violación del derecho a la privacidad.

Pero Brandeis, que en ese momento ya se había convertido en juez de la Corte Suprema, emitió un voto disidente bajo la idea de que el modo en el que se estaba utilizando la tecnología para obtener una prueba constituía una invasión al right to privacy, calificando esta conducta de "dirty business". Incidió en el hecho de que los nuevos avances tecnológicos pueden suponer un peligro para los derechos de la personalidad, denunciando la potencial invasión que sufre la privacidad conforme avanza la tecnología.

Esto es precisamente una visión del desmedro que comenzó a sufrir este derecho dentro del entorno digital. De ahí la necesidad de que al proteger- 
se la intimidad, se tenga en cuenta que para ello en algunas ocasiones se tiene que producir el olvido de ciertas informaciones. ${ }^{9}$

A pesar de que este último caso no es concretamente un antecedente en sentido estricto del derecho al olvido previo a la era digital, se ha considerado importante hacer un repaso de los primeros antecedentes sobre los que tuvieron que pronunciarse los tribunales estadounidenses en materia de privacidad, para poder comprender en profundidad el objeto de estudio del artículo.

En definitiva, desde la publicación del artículo de Warren y Brandeis y durante las dos primeras décadas del siglo XX, en Estados Unidos se empezó a forjar una postura favorable hacia la protección de este derecho, que dio paso a que en los años treinta ya se puedan encontrar los primeros indicios en los que los ciudadanos no solamente reclaman por su privacidad, sino también por el olvido.

\section{De la privacidad al olvido: los cimientos de la actualidad}

Fue Estados Unidos uno de los primeros países en resolver un caso de derecho al olvido anterior a la era digital: Melvin v. Reid en 1931.

Los llamativos hechos comenzaron en 1918, cuando Gabrielle Darley, de profesión prostituta, comenzó una relación amorosa con el deportista Leonard Tropp. Tras un tiempo de noviazgo, ella le dio dinero para que le comprara un anillo de bodas, sin saber que, en realidad, él planeaba casarse con otra mujer, a la que le regaló la mencionada sortija que había comprado con el dinero de Gabrielle. A consecuencia de este hecho, Gabrielle le disparó al deportista en la calle y él murió. En el juicio, ella fue declarada inocente, debido a que convenció al jurado de que el revólver se había disparado accidentalmente. Años más tarde, Adela Rogers, hija de Leonard, escribió una historia, The Red Kimono, contando todos los hechos ocurridos y dando los nombres reales de los protagonistas. Ésta fue llevada al cine en 1927. Como consecuencia, Gabrielle demandó a Adela por invasión de su derecho a la privacidad, ya que ella había rehecho su

9 Zárate Rojas, Sebastián, "La problemática entre el derecho al olvido y la libertad de prensa", Derecom, núm. 13, marzo-mayo, 2013, disponible en: file:///D:/DERECHO\%20 AL\%20OLVIDO/ARTÍCULOS/SUDAMÉRICA/CHILE/SEBASTIÁN\%20ZÁRATE\%20 ROJAS.pdf, p. 8: "El derecho al olvido, no consiste en reescribir la historia, sino en impedir que información personal circule y siga siendo procesada". 
vida y clamaba por una segunda oportunidad. La Corte de California consideró que los hechos habían producido una violación en la privacidad de la señora Darley, y que las personas deben tener derecho a olvidar y a ser perdonadas.

Éste se convirtió en uno de los casos más emblemáticos de Estados Unidos, ya que se puede considerar que es un reconocimiento judicial del derecho al olvido, del derecho a tener una segunda oportunidad, donde se pueden olvidar los hechos del pasado cuando ya no tienen relevancia para la conformación de la opinión pública del presente..$^{10}$

En este caso comienzan a establecerse los orígenes del derecho al olvido previos a la era digital: ciudadanos que quieren volver a recuperar su privacidad, pero siempre guardando el delicado equilibrio que es necesario mantener entre este derecho y el derecho a la información. Tal como explica Meg Leta Jones: "After Melvin, the rehabilitive function of privacy began to dwindle, and the definition of newsworthiness began to grow". ${ }^{11}$

Éste fue precisamente el primer supuesto claro que se puede encontrar en Estados Unidos relativo al derecho al olvido previo a la era digital. De hecho, es el caso que sirvió para ejemplificar una de las teorías más consolidadas relativas a la privacidad. La teoría de los cuatro torts que William Prosser consiguió plasmar en su célebre trabajo "Privacy", ${ }^{12}$ y que marcó un antes y un después, ya que ayudó a complejizar el concepto acuñado setenta años atrás por Warren y Brandeis.

Concretamente, el segundo de los cuatro torts, relativo a la revelación de hechos privados, parte para su explicación del caso Melvin v. Reid.

La importancia de este fallo radica en que de su argumentación se desprende una postura favorable hacia el derecho al olvido, como un derecho relacionado con la privacidad, y que pertenece al ámbito de los derechos fundamentales de los ciudadanos. Una visión muy certera y que permite guardar un equilibrio entre información e intimidad, teniendo en cuenta

10 Friedman, Laurence, Guarding Life's Dark Secrets: Legal and Social Controls over Reputation, Propriety, and Privacy, California, Standford University Press, 2007.

11 Jones, Meg Leta, Crtl Z The Right to be Forgotten, Nueva York, NYU Press, 2016, p. 59.

12 Prosser, William, "Privacy", California Law Review, vol. 48, num. 3, 1960, disponible en: https://doi.org/10.3145/epi.2017.mar.17, p. 389: "These four torts may be describe as follows: 1. Intrusion upon the plaintiff's seclusion or solitude, or into his private affairs. 2. Public disclosure of embarrassing private facts about the plaintiff. 3 . Publicity which places the plaintiff in a false light in the public eye. 4. Appropiation, for the defendant's advantage, of the plaintiff's name or likeness". 
en cada caso sus particularidades para poder establecer hacia dónde debe inclinarse la balanza.

Sin embargo, durante las décadas posteriores, tal como se va a analizar a continuación, la jurisprudencia y la doctrina cambiaron de rumbo hasta consolidar la actual visión que existe en Estados Unidos, y que se ha extendido a los principales países cuyo sistema jurídico está basado en el common law, dando una prioridad, casi absoluta, al derecho a la información, ${ }^{13}$ a pesar de que es defendido entre los constitucionalistas que no hay ningún derecho que deba ser absoluto. ${ }^{14}$

\section{La figura pública involuntaria: un antes y un después para el derecho al olvido}

Esta tendencia fue revertida en el caso Time Inc. v. Hill de 1967, en el que se comenzó a hablar de las figuras públicas involuntarias.

La familia Hill fue secuestrada en su casa en 1952 por tres criminales convictos. A raíz de estos hechos, el matrimonio y sus cinco hijos se mudaron de Pennsylvania, con objeto de poder volver a tener una vida de anonimato. La revista Time publicó un reportaje sobre el caso, debido a que también se había creado una obra de teatro en Broadway con el nombre The Desperate Hours, adaptación del libro escrito por Joseph Haye. La Corte Suprema entendió que no había violación en la privacidad de la familia Hill, sentando el criterio jurisprudencial de la figura pública involuntaria por su implicación en hechos noticiosos, y provocando que no haya olvido para ninguna persona sin importar la situación.

$\mathrm{Y}$ es que, tal como afirma Ignacio Covarrubias, el tribunal supremo añadió un nuevo argumento constitucional sobre la prevalencia de la libertad de expresión respecto del derecho a la intimidad, al expresar que la primera enmienda ya no estaba destinada a proteger únicamente la expresión política o el comentario de los asuntos públicos, sino también la información noticiosa. ${ }^{15}$

13 Moreno Bobadilla, Ángela, "El derecho al olvido digital: una brecha entre Europa y Estados Unidos", Revista de Comunicación, vol. 18, núm. 1, 2019, disponible en: https://doi.org/10.26441/RC18.1-2019-A13, p. 267.

14 Gómez Sánchez, Yolanda, Constitucionalismo multinivel. Derechos fundamentales, Sanz y Torres, 2011, pp. 55 y ss.

15 Covarrubias Cuevas, Ignacio, La vida privada de las figuras públicas. El interés público como argumento que legitima la intromisión en la vida privada, Santiago de 
Esta jurisprudencia ha sido corroborada en casos posteriores, como el de Briscoe v. Reader's Digest Assoc. de 1971, en los que los tribunales consideraron que un personaje público no se vuelve a convertir en persona privada por el mero transcurso del paso del tiempo. En este caso, el máximo tribunal del país revirtió una sentencia de la Corte de Apelaciones de California, en la que había dado la razón al señor Briscoe, que demandó a la revista Reader's Digest por publicar un reportaje sobre su pasado criminal. Pero la Corte Suprema confirmó el criterio de que una persona que se ha convertido en pública nunca más vuelve a ser privada.

Estos casos ejemplifican una postura contraria a lo defendido en el artículo de Warren y Brandeis, y a la tendencia de los tribunales durante las primeras décadas del siglo XX. Desafortunadamente, la privacidad y el olvido pierden peso frente a la información, al verlos como derechos antagónicos entre sí, cuando en realidad son dos derechos complementarios en cualquier sistema democrático: los ciudadanos necesitan información para desarrollar sus obligaciones para con el sistema democrático, y también necesitan privacidad para su vida cotidiana, porque hay ciertos asuntos que no son información, sino mero morbo o sensacionalismo.

\section{Estados Unidos: ni olvido ni perdón}

A pesar de ser uno de los primeros países en dictar una sentencia que reconoce el derecho a las segundas oportunidades, la jurisprudencia cambió de rumbo, y asentó dos criterios que impiden que en la actualidad se pueda configurar un derecho al olvido digital: una noticia de interés público siempre lo será, con independencia del tiempo transcurrido, y una persona que se convierte en pública (con independencia de las circunstancias) nunca más vuelve a ser privada. ${ }^{16}$

Y es que el país donde radica Silicon Valley encuentra que la configuración de un derecho de estas características podría suponer una violación de la primera enmienda constitucional, donde se recoge la libertad de prensa

Chile, Thomson-Reuters, 2013, p. 270: "Con este avance en perjuicio de la intimidad, el Tribunal otorga escudo constitucional a la prensa para reportear la vida de personas privadas involucradas involuntariamente en hechos noticiosos".

16 Abril, Patricia y Pizarro, Eugenio, "La intimidad europea frente a la privacidad americana. Una visión comparativa del derecho al olvido", Indret. Revista para el Análisis del Derecho, núm. 1, 2014, disponible en: http://www.indret.com/pdf/1031.pdf, pp. 21 y ss. 
y de expresión, y que además proscribe expresamente que el Congreso pueda adoptar cualquier ley que limite la libertad de expresión.

Aunque en realidad la cuestión del derecho al olvido no es del todo ajena para Estados Unidos, desde que en enero de 2015 se publicara en California una ley, California Senate Bill 568 2013, que permite a todos los menores de dieciocho años borrar (que no desindexar, sino borrar de forma permanente) toda la información que ellos mismos hayan subido a las redes sociales. Es decir, se está reconociendo the right to erase para un colectivo en concreto.

Pero esta situación, al menos hasta la fecha, todavía no es extrapolable al ámbito de los medios de comunicación on line, que seguirá mostrándose desfavorable a cualquier forma de manifestación del derecho al olvido.

\section{LA PRIMACÍA DE LA PRIVACIDAD EN EUROPA}

El viejo continente se ha erigido en la actualidad como el firme defensor del derecho al olvido digital, y es que, tal como afirma Meg Leta Jones, "Europe has a long history of privacy regulation, much of which is relevant to the right to be forgotten". ${ }^{17}$

Esta postura asentada en Europa permite guardar el equilibrio entre información y privacidad, gracias a que desde hace varias décadas la evolución jurisprudencial se ha mantenido firme y estable, y se ha adaptado a los nuevos cambios sociales que se han implementado, pero con una clara línea jurisprudencial: cuando la información carece de interés público, debe prevalecer la intimidad.

Por ello, en los países continentales de tradición románica, principalmente en Francia, antes de la creación de Internet ya se pueden encontrar los primeros antecedentes en esta materia.

\section{Los sistemas civilistas de influencia francesa:}

la cuna de la innovación jurídica

Ya en la segunda mitad del siglo XVIII, incluso antes de la publicación del artículo de Warren y Brandeis, existe jurisprudencia que empezó a reconocer el derecho a la privacidad.

17 Jones, Meg Leta, op. cit., nota 12, p. 27.

Esta obra está bajo una Licencia Creative Commons Atribución-NoComercial-SinDerivar 4.0 Internacional, IIJ-UNAM. 
En 1867, Alejandro Dumas, autor de Los tres mosqueteros, reclamó por unas fotografías que se habían publicado sobre él. A pesar de que dio su consentimiento inicial, posteriormente lo retiró. La Corte francesa le dio la razón, porque encontró que cuando el consentimiento es retirado, hay una intrusión a la privacidad. Como se puede comprobar a través de este prematuro caso, Francia se convirtió desde hace más de dos siglos en uno de los países precursores del derecho a la intimidad, ${ }^{18}$ donde uno de sus principales elementos, cuando la información no tiene interés público, es el consentimiento de la persona afectada.

A esto hay que añadir una ley de 1868 , Loi relative à la presse, en la que se prohibía la publicación de hechos relativos a la vida privada de las personas, excepto que esa información ya fuera pública o hubiera mediado el consentimiento oportuno.

Otro de los primeros antecedentes en materia de olvido previo a la era digital se encuentra en Quebec, Canadá, donde el derecho privado sigue la tradición civilista, mientras que el derecho público, la del common law.

Concretamente, es el caso Goyette c. Rodier, que se remonta a 1889, y que está basado en el principio de responsabilidad por culpa. ${ }^{19}$ Los hechos se relacionan con una información que publicó un diario local de la época, y que provocó que una persona anónima que había sido objeto de ciertas acusaciones en el pasado volviera a convertirse en persona pública. El tribunal canadiense dictaminó que los hechos que han sido de interés público en el pasado, pero que ya no tienen relevancia en el presente, pueden ocasionar un daño en la vida privada de las personas, y que por lo tanto, ya no deben ser considerados como noticiosos, debido a que han perdido su actualidad.

Esta sentencia siembra un verdadero precedente en materia de olvido para todos los países de tradición jurídica civilista, al establecer que cuando una información, relacionada con una persona privada, vuelve a publicarse nuevamente ante la opinión pública, se está impidiendo que sus protagonistas puedan tener derecho a una segunda oportunidad. Es

\footnotetext{
18 Ost, François, El tiempo del derecho, México, Siglo XXI Editores, 2005.

19 Simón Castellano, Pere, El reconocimiento del derecho al olvido digital en España y en la UE, Barcelona, Bosch, 2015, p. 107: "En cualquier caso, se observa como la doctrina y la jurisprudencia francesa y del Quebec, han entendido que el derecho general al olvido comporta también un deber de olvidar por parte de los demás, que se concreta más exactamente en un deber de no divulgar hechos pasados que puedan condicionar el futuro de las personas".
} 
importante resaltar en este punto, que esto dice relación con que el interés público de una información no es perpetuo, porque en caso contrario el derecho a la intimidad siempre se vería perjudicado, impidiendo que se cumpla un principio básico del derecho penal, como es la reinserción social de los individuos.

\section{La jurisprudencia francesa como ejemplo para el continente}

Entre los años sesenta y ochenta los tribunales franceses dictaron varias sentencias relativas a esta materia, mediante las que se posicionaron como un firme defensor de las segundas oportunidades.

Un ejemplo es la sentencia del Tribunal de Gran Instancia de Sena, del 4 de octubre de 1965, pionera al reconocer el derecho de los ciudadanos a tener una segunda oportunidad. Resolvió una demanda de una de las amantes del famoso asesino en serie Henri Landru, porque su relación sentimental fue representada en una película muchos años después de que el noviazgo hubiera finalizado. A pesar de que finalmente el órgano jurisdiccional francés rechazó la demanda, ya que la actora había publicitado su relación con el señor Landru, se comienza a hablar del droit a l'oublie, sembrándose los orígenes europeos del derecho al olvido previo a la era digital.

El mismo criterio se utilizó frente a la publicación de la autobiografía del famoso delincuente Mesrine, cuya expareja reclamaba que el libro perjudicaba su reinserción social. Este caso se puede ver en la sentencia del Tribunal de Gran Instancia de París, del 6 de diciembre de 1979.

Otro ejemplo es el caso Mme. M. c. Filipacchi et Cogedipresse, de 1983, que también defendió que las personas privadas que se hayan visto involucradas en acontecimientos públicos pueden reivindicar el derecho al olvido cuando la información ya no tenga interés para la conformación de la opinión pública. Esto debido a que el recuerdo de esos acontecimientos, cuando no esté fundado en necesidades históricas o si su naturaleza es tal que puede herir su sensibilidad, no se puede considerar legítimo.

Todos éstos, son tan sólo algunos de los ejemplos de la importante y sólida jurisprudencia que se sentó en Francia relativa al olvido en el caso de informaciones protagonizadas por personas privadas, que se han convertido en irrelevantes debido al paso del tiempo, por lo que sus protagonistas tienen derecho a volver a comenzar, jurisprudencia acorde con el ideal de 
dignidad y del libre desarrollo de la personalidad del que nacen todos los derechos de la personalidad.

\section{La intimidad como pilar fundamental de los sistemas europeos}

El gran desarrollo jurisprudencial que ha tenido esta materia en Francia, y por influencia en la mayor parte de los países de la Europa continental, ha propiciado el importante desarrollo que tiene el derecho al olvido en la actualidad. ${ }^{20} \mathrm{Y}$ en todos los Estados existe un pilar común: su derivación del derecho a la intimidad, así como de la protección de datos personales. ${ }^{21}$

El punto de inflexión en Europa se produjo en 2014 con la sentencia del caso Costeja, dictada por el TJUE 22 (comúnmente conocido como Tribunal de Luxemburgo), que no hace sino consolidar el derecho al olvido europeo y fomentar su oposición dentro de uno de los principales exponentes del common law. Mientras que en el viejo continente se empieza a considerar que los motores de búsqueda, dígase Google, Yahoo o Bing, entre otros, son responsables por el tratamiento de datos, el país donde radica Silicon Valley se alza contra esta postura.

El señor Costeja, reputado empresario catalán, había sido protagonista de una noticia en el periódico español de La Vanguardia, porque figuraba en un anuncio de una subasta de inmuebles relacionada con un embargo de deudas a la seguridad social. Estos hechos habían tenido lugar mientras desarrollaba sus actividades empresariales, en las que dejó de pagar las cuotas a la seguridad social, que tuvieron como consecuencia el menciona-

20 Trudel, Pierre, "L' oubli en tant que droit et obligation dan les systèmes juridiques civilistes", Faculté de droit, Université de Montréal, 2013, pp. 1-5.

21 Corral Talciani, Hernán, "El derecho al olvido en Internet: antecedentes y bases para su configuración jurídica", Revista Jurídica Digital UANDES, núm. 1, 2017, disponible en: http://rjd.uandes.cl/index.php/rjduandes/article/view/7/39, p. 57: "A nuestro entender el derecho al olvido está en proceso de configuración como un derecho de la personalidad. Como es sabido, la protección de bienes extrapatrimoniales de la persona se inició en la doctrina alemana por medio del llamado Derecho General de la Personalidad que se planteaba como un único derecho que podía adaptarse para hacer frente a las diversas agresiones que podía sufrir el individuo humano en el ámbito no patrimonial”. Cotino Hueso, Lorenzo, "Google y el derecho al olvido en Europa. Algunos «olvidos» y otras tendencias negativas respecto de las libertades informativas en Internet", en Labrador, María José y Carter, Edward (coords.), Google: derecho al olvido y desafíos éticos en el escenario mediático digital, Santiago, Ril Editorial, 2018, pp. 129-168.

22 Tribunal de Justicia de la Unión Europea. 
do embargo. El hecho de que cada vez que se introducía su nombre y apellidos en un buscador apareciera la mencionada información, le impedían que tuviera una segunda oportunidad. Además, argumentaba que la noticia ya no tenía interés público en la actualidad, y solicitaba que ésta no fuera accesible cuando su nombre se escribía en un buscador.

El litigio se basaba en saber si Google estaba obligada a borrar de Internet todos los datos personales de la noticia, y que se recuperaban a través del motor de búsqueda. Dicha información pertenecía al pasado de la vida privada del ciudadano.

El tribunal determinó que los ciudadanos pueden solicitar la eliminación de datos personales contenidos en la Red cuando su tratamiento sea ilegítimo, o sea, que no sea adecuado, pertinente o excesivo en relación con los fines y el tiempo transcurrido. Por lo tanto, se pronunció a favor del ciudadano, y exigió la desindexación de la información tanto de Google Inc como de Google Spain. ${ }^{23}$

No obstante, la información sigue accesible en el universo virtual cuando ésta se busca a través de parámetros diferentes del nombre del señor Costeja, no implicando que la información quede suprimida de la fuente original. La única consecuencia práctica es que el dato (o información no deseada) quede desvinculado del nombre concreto cuando se realiza una búsqueda. Esto, para guardar un equilibrio entre el derecho al olvido y el derecho a la información, tal como manifiesta el tribunal de Luxemburgo en la sentencia aludida.

En la actualidad, a raíz de la entrada en vigor del Reglamento (UE) 2016/679 del Parlamento Europeo y del Consejo, del 27 de abril de 2016, relativo a la protección de las personas físicas en lo que respecta al tratamiento de datos personales y a la libre circulación de éstos, que es aplicable desde el 25 de mayo de 2018, y en cuyo artículo 17 se recoge de forma expresa el derecho al olvido como un derecho de cancelación, los ciudadanos europeos tienen la oportunidad de solicitar ante los respectivos órganos de sus países nacionales que se produzca la desindexación de informaciones que aparecen en los buscadores cuando se introduce su nombre. ${ }^{24}$

23 Rallo Lombarte, Artemi, El derecho al olvido en internet. Google versus España, Madrid, Centro de Estudios Políticos y Constitucionales, 2014. El exdirector de la AEPD hace un exhaustivo análisis de esta sentencia.

24 Martínez-Martínez, Dolores Fuensanta, "Unificación de la protección de datos 
Todo gracias al prematuro desarrollo jurisprudencial que hubo sobre esta materia en los países europeos, que han construido una sólida doctrina en torno a la protección de la privacidad de los ciudadanos en el entorno digital, cuyos orígenes se remontan a la era previa de la creación de Internet.

\section{CONCLUSIONES}

Fue mucho antes de la revolución tecnológica cuando las personas comenzaron a reclamar tanto por su privacidad como por su derecho a volver a comenzar.

Esta necesidad de perdón y rendición se denominó "derecho al olvido" y se sentó como criterio jurisprudencial tanto en Estados Unidos como en Francia, lo que contribuyó a conformar los orígenes del emergente derecho tan debatido en la actualidad.

Todos los casos analizados cuentan con un pilar común: personas privadas, que debido a diversas circunstancias ajenas a su voluntad se han convertido en públicas. Como consecuencia, solicitan que las mencionadas informaciones desaparezcan del radar de la opinión pública, bajo el argumento de que el transcurso del tiempo las ha convertido en irrelevantes.

Ante una misma situación, las decisiones jurisprudenciales varían de forma considerable. En Estados Unidos, a pesar de que se comenzó a aceptar esta posibilidad, desde los años treinta la jurisprudencia se posiciona firmemente en contra, al establecer que las noticias públicas, así como sus protagonistas, nunca más vuelven a ser privadas.

Sin embargo, en Francia se asienta el criterio opuesto. Cuando la información ya no es actual, deja de ser considerada como susceptible de protegerse bajo el criterio del interés público, por lo que sus protagonistas tienen derecho a reclamar su derecho al olvido.

Estos dos países sirvieron de ejemplo para que en cada uno de sus respectivos sistemas jurídicos se asentaran dos visiones contrapuestas de una misma cuestión, sembrando los orígenes de dos visiones antagónicas respecto del derecho al olvido: en Estados Unidos se considera que vulnera la libertad de expresión, mientras que en Europa se ha construido como un derecho derivado de la privacidad y de la protección de datos personales.

personales en la Unión Europea: desafíos e implicaciones", El Profesional de la Información, vol. 27, núm. 1, enero-febrero, 2018, disponible en: https://doi.org/10.3145/ epi.2018.ene.17, pp. 185-194. 


\section{BIBLIOGRAFÍA}

ABril, Patricia y PiZARro, Eugenio, "La intimidad europea frente a la privacidad americana. Una visión comparativa del derecho al olvido", Indret: Revista para el Análisis del Derecho, núm. 1, 2014, disponible en: $h t t p: / / w w w . i n d r e t . c o m / p d f / 1031 . p d f$.

Álvarez CARo, María, Derecho al olvido en internet: el nuevo paradigma de la privacidad en la era digital, Madrid, Reus, 2015.

BARBAS, Samantha, "The Death of the Public Disclosure Tort: a Historical Perspective", Yale Journal of Law and the Humanities, vol. 22, núm. 2, 2013.

CORRAL TALCIANI, Hernán, "El derecho al olvido en Internet: antecedentes y bases para su configuración jurídica", Revista Jurídica Digital UANDES, num. 1, 2017, disponible en: http://rjd.uandes.cl/index.php/ rjduandes/article/view/7/39.

Cotino Hueso, Lorenzo, "Google y el derecho al olvido en Europa. Algunos «olvidos», y otras tendencias negativas respecto de las libertades informativas en Internet", en LABRADOR, María José y CARTER, Edward (coords.), Google: derecho al olvido y desafíos éticos en el escenario mediático digital, Santiago, Ril Editorial, 2018.

CovarRubias Cuevas, Ignacio, La vida privada de las figuras públicas. El interés público como argumento que legitima la intromisión en la vida privada, Santiago, Thomson-Reuters, 2013.

De Terwagne, Cecile, "Privacidad en Internet y el derecho a ser olvido/ al olvido", Revista de Internet, Derecho y Política, núm. 13, febrero de 2012, disponible en: http://doi.org/10.7238/idp.v0i13.1400.

FRIEDMAN, Laurence, Guarding Life's Dark Secrets: Legal and Social Controls over Reputation, Propiety, and Privacy, California, Standford University Press, 2007.

GómEz SÁnCHEZ, Yolanda, Constitucionalismo multinivel. Derechos fundamentales, Sanz y Torres, 2011.

GonZÁlez Fuster, Gloria, The Emergence of Personal Data Protection as a Fundamental Right of the EU, Suiza, Springer, 2014.

JONES, Meg Leta, Crtl Z The right to be forgotten, Nueva York, NYU Press, 2016. 
MARTÍNEZ- MARTÍNEZ, Dolores Fuensanta, "Unificación de la protección de datos personales en la Unión Europea: desafíos e implicaciones", El Profesional de la Información, vol. 27, núm. 1, enero-febrero de 2018, https://doi.org/10.3145/epi.2018.ene.17.

MAYER- SchÖNBERGER, Viktor, Delete. The Virtue of Forgetting in the Digital Age, Princeton, Princeton University Press, 2009.

Moreno BobAdilla, Ángela, "El derecho al olvido digital: una brecha entre Europa y Estados Unidos", Revista de Comunicación, vol. 18, núm. 1, 2019, disponible en: https://doi.org/10.26441/RC18.1-2019-A13.

Moreno Bobadilla, Ángela, Intimidad y menores, Madrid, Centro de Estudios Políticos y Constitucionales, 2017.

OST, François, El tiempo del derecho, México, Siglo XXI Editores, 2005.

Prosser, William, "Privacy", California Law Review, vol. 48, núm. 3, 1960.

Rallo LOMBARTE, Artemi, "Del derecho a la protección de datos a la garantía de nuevos derechos digitales", en RALlo LOMBARTE, Artemi (dir.), Tratado de protección de datos. Actualizado con la Ley Orgánica $3 / 2018$, de 5 de diciembre, de protección de datos personales y garantía de los derechos digitales, Valencia, Tirant lo Blanch, 2019.

RAllo LOMBARTE, Artemi, El derecho al olvido en Internet. Google versus España, Madrid, Centro de Estudios Políticos y Constitucionales, 2014.

SANTín, Marina, "La problemática del derecho al olvido desde la perspectiva histórica de la autorregulación periodística", El Profesional de la Información, marzo-abril, vol. 26, núm. 2, 2017, disponible en: https:// doi.org/10.3145/epi.2017.mar.17.

Schwartz, Paul M. y Piefer, Karl-Nikolaus, "Prosser's Privacy and the German Rright of Personality: are four Privacy Torts better than one Unitary Concept?", California Law Review, vol. 98, 2010, disponible en: https://scholarship.law.berkeley.edu/cgi/viewcontent.cgi? article =2 $755 \&$ context $=$ facpubs.

Simón CAStellano, Pere, El reconocimiento del derecho al olvido digital en España y en la UE, Barcelona, Bosch, 2015.

Simón CASTELlanO, Pere, "El carácter relativo del derecho al olvido en la red y su relación con otros derechos, garantías e intereses legítimos", en Corredoira y Alfonso, Loreto y Cotino Hueso, Lorenzo (dirs.), Libertad 
de expresión e información en Internet. Amenazas y protección de los derechos personales, Madrid, Centro de Estudios Políticos y Constitucionales, 2013.

TRUDEL, Pierre, "L' oubli en tant que droit et obligation dan les systèmes juridiques civilistes", Faculté de droit, Université de Montréal, 2013.

WARren, Samuel y BrandeIs, Louis, "The Right to Privacy", Harvard Law Review, vol. 4, núm. 5, 1890.

Werro, Franz, "The Right to Inform v. the Right to be Forgotten: a Transatlantic Clash", Georgetown University. Center for Transnational Legal Studies Colloquium, núm. 2, 2009.

Whitman, James Q., “The Two Western Cultures of Privacy: Dignity Versus Liberty", Yale Law Journal, vol. 113, 2017, disponible en: file:///D:/ DERECHO\%20AL\%20OLVIDO/UF/OLVIDO\%20Y\%20PRIVACIDAD/ARTÍCULOS/WHITMAN.pdf.

ZÁRATE RoJAS, Sebastián, "La problemática entre el derecho al olvido y la libertad de prensa", Derecom, núm. 13, marzo-mayo, disponible en: file://D:/DERECHO\%20AL\%20OLVIDO/ARTÍCULOS/SUDAMÉRI CA/CHILE/SEBASTIÁN\%20ZÁRATE\%20ROJAS.pdf.

Fecha de recepción: 29 de abril de 2020.

Fecha de aceptación: 20 de abril de 2020.

Esta obra está bajo una Licencia Creative Commons Atribución-NoComercial-SinDerivar 4.0 Internacional, IIJ-UNAM. 


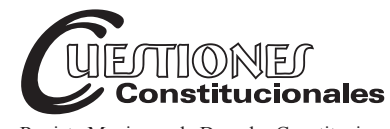

Revista Mexicana de Derecho Constitucional Núm. 43, julio-diciembre 2020

\title{
El derecho de identidad de personas transgénero en procedimientos de corrección de actas del registro civil. Una propuesta de sentencia estructural de la Suprema Corte de Justicia de la Nación
}

\author{
The right of identity for transgender people in procedures \\ for correcting civil registry records. A proposal for a structural \\ sentence of the Supreme Court of Justice of the Nation
}

\section{Jesús Manuel Orozco PULIDO*}

\begin{abstract}
RESUMEN: El derecho a la identidad es un derecho humano de suma importancia. Las personas de la comunidad trans han encontrado obstáculos para corregir sus documentos personales a fin de adecuarlos a la identidad de género que viven. La falta de normas jurídicas y el dictado de sentencias individuales de amparo han mostrado la insuficiente protección de los derechos de este grupo social, que usualmente padece discriminación. Esta investigación propone que la Suprema Corte mexicana, ejerciendo como tribunal constitucional, emita una sentencia estructural que haga visible la necesidad de regular el tema. A través de los contenidos constitucionales que actualmente están previstos en la Constitución mexicana, es posible emitir un fallo de esa naturaleza.
\end{abstract}

Palabras clave: derecho a la identidad, registro civil, personas transgénero, Suprema Corte de Justicia de la Nación, sentencias estructurales.
ABSTRACT: The right to personal identity is a crucial human right. In order to correct personal documents that fits with personal identity, transgender people have struggled. Lack of regulation and individual cases by judiciary, have shown that there are no sufficient means to protect rights of a community that has been discriminated. This research proposes that Mexican Supreme Court, acting as a constitutional court, issues a structural injunction in order to make visible the need to regulate this issue. Constitutional clauses that are already set on Mexican constitution are sufficient to issue the proposed resolution.

Keywords: right to personal identity, civil registers, transgender people, Mexican Supreme Court, structural injunctions.

* Maestro en derecho parlamentario y redacción normativa (LUISS Guido Carli, Universidad Complutense de Madrid y University of London). Fundador de la firma Orozco \& Pulido's Abogados. México. ORCID: 0000-0002-4691-1710 Contacto: orozco. jesusmanuel@gmail.com. 
SUMARIO: I. Introducción. II. Conceptos relacionados con la comunidad trans. III. Normativa en México. IV. Precedentes judiciales en México. V. Experiencia normativa y judicial en países extranjeros. VI. Hacia una sentencia estructural de la Suprema Corte de Justicia de la Nación. VII. Epílogo. VIII. Bibliografía.

\section{INTRODUCCIÓN}

Los derechos humanos están en el centro del debate jurídico del siglo XXI. En México, la reforma constitucional del 10 de junio de 2011 puso el acento sobre la importancia de tutelar más amplios niveles de protección a los derechos inherentes a la dignidad del ser humano, a fin de mejorar la calidad de vida de las personas. Basta mirar la décima época del Semanario Judicial de la Federación para advertir que las tesis de la Suprema Corte y tribunales federales tienen un eje argumentativo distinto. Se pasó de una pluralidad de criterios sobre fundamentación y motivación, seguridad jurídica o indefensión, hacia una doctrina constitucional, que desarrolla los derechos fundamentales y emplea técnicas de avanzada, como el juicio de proporcionalidad o la interpretación conforme.

Un derecho humano que aún está pendiente por explorar con más detalle es el derecho a la identidad. Somos personas en la medida en que desplegamos libremente nuestros rasgos identitarios, lo cual precisa el reconocimiento de terceros y del Estado para disfrutar plenamente los atributos de nuestra persona. Nombre, parentesco, sexo, edad, género y cultura son cuestiones que atañen al derecho a la identidad.

No confundir identidad con personalidad. La doctrina jurídica mexicana ha entendido la personalidad en términos de representación, cuando los actos que alguien efectúa como persona legitimada para actuar en nombre de otro. ${ }^{1}$ Por su parte, la identidad es un derecho fundamental que se reconoció constitucionalmente en la reforma publicada el 17 de junio de 2014, insertándolo en el artículo 4o., octavo párrafo.

En la fijación de los linderos de la identidad han intervenido asiduamente los tribunales, como en Italia o Argentina, donde los fallos de la jurisdic-

\footnotetext{
1 Soberón Mainero, Miguel, "Personalidad", Diccionario jurídico mexicano, México, t. VII, P-Reo, UNAM, 1984, p. 104. 
ción enmarcan específicas actividades de las personas como expresiones de su propia identidad. Por ejemplo, los caracteres físicos y morales, la profesión o eventos abstractos que expresan la cultura de cada pueblo se entienden como parte integral del derecho a la identidad. ${ }^{2}$

La identidad de género es un tema que poco ha sido explorado en la tradición jurídica mexicana. De inicio, existen pocas normas jurídicas que atienden el tema en cuanto a los procedimientos ante el registro civil para la reasignación de sexo. En la Gaceta Oficial del entonces Distrito Federal, el 10 de octubre de 2008, se incorporó en el Código Civil un mecanismo para la reasignación sexo genérica de personas trans. Empero, no existe regulación sobre matrimonio o adopción, de acceso a pensiones de viudez.

John Stuart Mill incorporó la idea de que el Estado tiene límites para entrar en la personalidad y cuerpo de una persona. ${ }^{3}$ Este sino libertario lleva a repensar las normas jurídicas y prácticas judiciales mexicanas que impiden a las personas transgénero el libre ejercicio de su derecho a la identidad. Indudablemente, es el reconocimiento que el Estado realiza hacia la identidad de género de cada persona el primer eslabón para ejercitar plenamente el resto de atributos jurídicos de la persona. La ausencia de regulación sobre la materia revela una intención del Estado mexicano para invisibilizar a un grupo social que padece discriminación. ${ }^{4}$ En la medida en que no se mira una situación de inseguridad jurídica que vulnera derechos humanos, se evitan también las miradas de lobbys políticos o la comunidad internacional.

De manera casuística existen casos aislados en que se concede el amparo a personas transgénero contra actos del registro civil, o resoluciones judiciales que omiten realizar procedimientos para rectificar sus actas del registro civil, a fin de que correspondan con su nueva identidad de género.

La fórmula de Otero impide que las sentencias de amparo surtan efectos favorecedores hacia terceras personas que no participaron en la litis de ese específico proceso. Sin embargo, hay técnicas del derecho procesal constitucional que permitirían que la Suprema Corte, ejerciendo como el tribunal constitucional mexicano, dicte una sentencia estructural que coadyuve

2 Cantoral Domínguez, Karla, "El derecho a la identidad del menor: el caso de México”, Revista Boliviana de Derecho, La Paz, núm. 20, 2015, pp. 56-75.

3 Mill, John Stuart, Sobre la libertad, trad. Pablo de Azcárate et al., México, Gernika, 1991.

4 Guilabert, Aurelien, "Identidad y salud Transerval", nota publicada en El Sol de México, 12 de agosto de 2019. 
a que personas transgénero accedan a la rectificación de sus documentos personales sin excesivas complicaciones.

Cuando los derechos fundamentales se ejercen, emergen dinámicas estatales y privadas problemáticas. En relaciones inter partes hay derechos antagónicos, que, al colisionar, uno cede ante el otro. En relaciones con el aparato estatal, el derecho humano encuentra mermadas sus posibilidades por legislación restrictiva, lagunas o antimonias legales, o prácticas estatales que vulneran flagrantemente el contenido del derecho.

Lamentablemente, los escollos para ejercitar los derechos fundamentales son más graves cuando se ejercen por miembros de comunidades minoritarias o que son estructuralmente discriminadas. Las personas transexuales encuentran serios problemas jurídicos para dar el primer paso hacia su libre determinación de identidad de género, que es el reconocimiento del Estado en sus actas de nacimiento y en sus documentos personales. Cuando el género que voluntariamente ejercen no se corresponde con el sexo bilógico que consta en sus documentos, es menester rectificarlo. Empero, cuando los órganos del Estado traban ese camino, por falta de legislación o prácticas administrativas que lo impiden, debe imponerse un remedio en aras de la eficacia de los derechos humanos.

\section{CONCEPTOS RELACIONADOS CON LA COMUNIDAD TRANS}

El sexo de una persona se determina por un binarismo fisiológico, que es identificado desde los ultrasonidos pélvicos durante la gestación. Para definir el sexo han de considerarse las diferencias biológicas entre el hombre y la mujer, diferencias que generan características genéticas, hormonales, anatómicas y fisiológicas sobre cuya base una persona es clasificada al nacer como hombre o mujer. ${ }^{5}$

En concreto, los genitales de la persona determinan si es hombre o mujer, y a partir de ahí se determina el entorno social que determina su personalidad con base en el sexo que le corresponde. Es de considerarse que existen teorías disruptivas que critican el binarismo del sexo, pues también existen personas intersexuales que la anatomía sexual de la persona no se ajusta físicamente a los estándares culturalmente definidos para el

5 Corte Interamericana de Derechos Humanos, Opinión Consultiva OC-24/17, del 24 de noviembre de 2017, solicitada por la República de Costa Rica, Identidad de género e igualdad y no discriminación a parejas del mismo sexo. 
cuerpo femenino o masculino. ${ }^{6}$ Inclusive, los componentes del sexo han sido disgregados para analizarlos desde el punto de vista cromosómico, morfológico, hormonal, psicológico o social, ${ }^{7}$ lo que revela que el término no es de fácil identificación.

En cambio, el concepto género adquiere más complejidad, porque se refiere a las identidades, funciones y atributos construidos socialmente de la mujer y el hombre, y al significado social y cultural que se atribuye a esas diferencias biológicas. ${ }^{8}$ En otras palabras, el género se refiere a la construcción de un comportamiento que se determina por los patrones del comportamiento de una persona. ${ }^{9}$

En el caso de personas transgénero, existe una diferencia bien definida entre su sexo biológico y la propia identidad de género que ejerce. Cuando el sexo biológico de una persona no se corresponde con los patrones psicosociales que siente o vive, se considera que es una persona trans.

Hablar de la comunidad trans implica referirse a un concepto sombrilla que recibe dentro de él a una pluralidad de expresiones de la diversidad sexual. Independientemente de un tratamiento médico o intervenciones quirúrgicas, el común denominador es la no conformidad entre el sexo asignado al nacer de la persona y la identidad de género que ha sido tradicionalmente asignada a éste. Una persona transgénero o trans puede identificarse con los conceptos de hombre, mujer, hombre trans, mujer trans y persona no binaria, o bien con otros términos como hijra, tercer género, biespiritual, travesti, fa' afafine, queer, transpinoy, muxé, waria y meti. ${ }^{10}$

La gran variedad de vivencias internas de la comunidad trans revela la complejidad del tema y cómo ha sido disruptivo de la tradicional concepción binaria de hombre y mujer. La cultura queer nacida en la década de los ochenta hace énfasis en deconstruir conceptos tradicionales de la cultura y del derecho mediante posturas del transgenerismo. ${ }^{11}$

6 Elósegui Itxaso, María, “El TJCE y el matrimonio de transexuales. Una interpretación «Ultra vires»”, Unión Europea Aranzadi, España, núm. 5, 2004, pp. 13-24.

7 Gerry-Vernières, Stéphane, "Droit à la vie privée et familiale. Le soft law dans le domaine des droits fondamentaux", Revue trimestrielle des droits de l'homme, Paris, núm. 110, 2017, pp. 307-349.

8 Corte Interamericana de Derechos Humanos, Opinión consultiva OC-24/17, op. cit.

9 De Montalvo Jääskeläinen, Federico, "Problemas legales acerca del tratamiento médico de la disforia de género en menores transexuales", Revista General de Derecho Constitucional, Madrid, núm. 24, 2017.

10 Corte Interamericana de Derechos Humanos, Opinión consultiva OC-24/17, op cit.

11 Elósegui Itxaso, María, "El TJCE y el matrimonio de transexuales...", op. cit. 
Hacia 1912, en Berlín, Alemania, se realizó la primera cirugía de cambio de sexo en el mundo, ${ }^{12}$ y en 1970 ocurrió lo propio en el Hospital General de la Ciudad de México. ${ }^{13}$ Una expresión mexicana de transexualismo está arraigada en la comunidad zapoteca de Juchitán, Oaxaca, con los muxe. Se trata de una persona que nace sexuado hombre, pero que en el transcurso de su vida se reconoce a sí mismo como distinto a los hombres y a las mujeres, el llamado tercer género indígena. ${ }^{14}$ La cuestión central es resaltar la autonomía de la persona para tomar decisiones en su vida con la correlativa protección del aparato estatal. ${ }^{15}$

Al margen de posiciones ideológicas, religiosas o de moralidad pública, el debate debe centrarse en una cuestión de derechos. Las personas que vivifican una identidad de género que difiere con su sexo biológico deberían tener vías jurídicas libres para ejercer sus derechos fundamentales en un plano de igualdad y libertad.

Tan no estamos acostumbrados a lidiar con el fenómeno del transexualismo, que hay problemas en la alusión a la persona promovente de acciones administrativas o judiciales para la reasignación de género, plantea dificultades. El español es una lengua que distingue los géneros, y el masculino agrupa también al femenino. Cuando se empleen sustantivos con acepciones de género al referirse a personas trans, es conveniente usar el término que corresponda con la identidad de género que siente, y no al sexo original. Esto ha planteado problemas, porque en el amparo directo 6/2018, que se analizará más adelante, la Suprema Corte reiteradamente hizo alusión a "el quejoso", cuando quien promovía era una persona con identidad de género femenino. Ni qué decir del uso corriente del lenguaje hacia personas trans en México. Recientemente trascendió en los medios

12 De Montalvo Jääskeläinen, Federico, "Problemas legales acerca del tratamiento médico...", cit.

13 Consejo para Prevenir y Eliminar la Discriminación de la Ciudad de México, Población LGBTTTI, actualización mayo 2018, disponible en: https://copred.cdmx.gob.mx/ storage/app/uploads/public/5b1/ff9/f94/5b1ff9f945326665643161.pdf, el 14-08-2019, 12:06 hrs.

14 Urbiola Solís, Alejandra et al., "Expresión y trabajo de los muxe' del istmo de Tehuantepec, en Juchitán de Zaragoza, México", Nova Scientia, Revista de Investigación de la Universidad de la Salle Bajío, León, México, vol. 9, núm. 19, 2017, pp. 502-527.

15 Monereo Atienza, Cristina, Diversidad de género, minorías sexuales y teorías feministas: superposiciones entre las teorías de lesbianas, gays, bisexuales y transexuales y el feminismo en la reformulación de conceptos y estrategias político-jurídicas, Madrid, Dykinson-Universidad Carlos III, Instituto de Derechos Humanos, 2015, p. 81. 
el caso de una mujer transgénero a quien el barista de una cafetería escribió un nombre masculino en su bebida, a pesar de que la cliente trans tiene aspecto de mujer y expresamente le manifestó su nombre en femenino. ${ }^{16}$

En suma, el libre desarrollo de la personalidad se proyecta sobre la imagen y se desarrolla dentro de un ámbito de privacidad, sin invasiones ni injerencias ilegítimas. ${ }^{17}$ Sin embargo, el derecho no ha respondido a cabalidad con el problema, de ahí la pertenencia de reflexionar en vías jurídicas para cristalizar el derecho a la identidad de personas trans.

\section{NORMATIVA EN MÉXICO}

Históricamente, los actos del registro civil pertenecían al dominio de la Iglesia católica. El nacimiento, bautismo, matrimonio o defunción de las personas estuvieron a cargo del clero hasta las leyes de reforma impulsadas por el presidente Benito Juárez. Particularmente la Ley Ocampo fijó la separación de la Iglesia en los actos del registro civil, al establecer la titularidad del Estado para los actos del registro civil. ${ }^{18}$

Es importante destacar el texto original de la Constitución mexicana de 1917 (artículo 130, párrafo tercero) que establecía que los actos del registro civil son de exclusiva competencia de los funcionarios y autoridades del orden civil en los términos prevenidos por las leyes. La actual redacción de esa cláusula constitucional está en el penúltimo párrafo del artículo 130, que prevé que los actos del estado civil son de la exclusiva competencia de las autoridades administrativas en los términos que establezcan las leyes.

Dos aspectos saltan a la vista: la competencia de las autoridades administrativas, que no judiciales, para desempeñar el registro civil, y el principio de reserva de ley, por cuanto el tema debe regularse en una norma jurídica con rango formal y material de ley. Asimismo, al no estar previsto el registro civil como un ámbito competencia exclusivo del Congreso fe-

\footnotetext{
16 Dina, Eduardo y Espejel, Citlalli, "Si ahora soy Ofelio, soy el más bonito que existe", El Universal, 11 de agosto de 2019.

17 Sentencia del 22 de junio de 2009 de la Sala Primera del Tribunal Superior de Justicia de la Comunidad de Madrid (La Ley 7261, del 14 de octubre de 2009). Estimación de la demanda de rectificación registral de nombre y sexo formulada por un varón que no se ha sometido a cirugía de reasignación de sexo (La Ley 9917/2009).

18 Torres López, Erasmo Enrique, "El registro civil en el norte de México", El Diario de Coahuila, 1 de agosto de 2019.
} 
deral, por la cláusula residual del artículo 124 constitucional, las entidades federativas han asumido las atribuciones del registro civil.

También existe una cláusula constitucional que, como expresión del federalismo, dota de validez a los actos del registro civil de una entidad federativa para que sean válidos en todo el país (artículo 121, fracción IV). Esta vía ha permitido articular un sistema de prevalencia de los derechos relacionados con la diversidad sexual. La Ciudad de México ha sido pionera en regular la libertad de las personas para establecer su proyecto de vida, y en el aspecto de matrimonio entre personas de mismo sexo o transexualidad ha emitido legislación señera. Esto ha permitido que cualquier mexicano, aun sin residir en la capital del país, acuda a la Ciudad de México a ejercer los actos de la diversidad sexual que ahí están legislados. Luego, por la cláusula de validez federal, esos actos jurídicos adquieren fuerza en su lugar de residencia.

La institución del registro civil permite al Estado, controlar aspectos elementales de las personas, tales como el nacimiento, parentesco, reconocimiento, adopción, matrimonio, divorcio o defunción. A esto se debe considerar la complejidad propia de enlazar la información de treinta y dos direcciones estatales del registro civil, una por cada entidad federativa, a fin de que los datos sean homogéneos, no se crucen, ni se disipen.

En 1997 se plasmó la aspiración del gobierno federal para que los registros civiles de las entidades federativas unifiquen sus procedimientos, dentro de un plan mayor encaminado a implementar una cédula nacional de ciudadanía. ${ }^{19} \mathrm{Al}$ día de hoy no se ha cristalizado esa aspiración, y el programa continúa siendo una asignatura pendiente.

La identificación de las personas en México muestra complejidades debido a la falta de un documento idóneo, gratuito y seguro para acreditar la existencia de las personas habitantes del territorio mexicano. Usualmente una persona mayor de edad utiliza la credencial para votar, emitida por la autoridad electoral, que contiene los datos personales de nombre, domicilio, edad, sexo, estado y fotografía de quien posee la credencial. Este documento es elaborado y gestionado por un organismo constitucional autónomo como el Instituto Nacional Electoral, cuya vocación es la organización del sistema electoral. Sin duda, la ratio de esta autoridad no es la administración del repositorio de identidad de los ciudadanos mexicanos.

\footnotetext{
19 Acuerdo sobre el programa de establecimiento del registro nacional de ciudadanos y la expedición de la cédula de identidad ciudadana, Diario Oficial de la Federación, 30 de junio de 1997.
} 
La falta de una cédula de identidad ciudadana genera problemas para conocer los datos personales de una persona, censar el número de ciudadanos, identificar a los menores de edad y establecer avances tecnológicos para la identificación plena de una persona - como el registro del iris o de huellas digitales - que evite el robo de identidad.

El derecho positivo prevé la existencia de una cédula de identidad ciudadana, pero se trata de letra muerta. La Ley General de Población (artículos 97 y 111), la Ley de Migración (artículo 36, fracción II) y el Acuerdo sobre el programa de establecimiento del registro nacional de ciudadanos y la expedición de la cédula de identidad ciudadana, ${ }^{20}$ se refieren al deber jurídico de tener un documento único de identificación.

El citado Acuerdo, en su punto 1.3.1, establece que el registro civil es la fuente más importante de información para establecer el registro nacional de ciudadanos, y propone que se legisle sobre la variedad de conceptos en las codificaciones civiles de las entidades federativas. Un especial énfasis se pone en los excesivos trámites para los registros extemporáneos de nacimiento, multiplicidad de criterios y procedimientos para asentar anotaciones marginales, disparidad de criterios y procedimientos para la aclaración y rectificación de actas del estado civil de las personas.

Sin duda, las mismas deficiencias del registro civil no han sido corregidas después de dos décadas, pues la regulación del registro civil continúa estando pendiente. Además, actualmente ha emergido una problemática que trasciende al derecho administrativo en cuanto a sus prácticas o procedimientos. La obstaculización para que personas transgénero accedan plenamente al ejercicio de su identidad de género y corrijan sus actas de nacimiento es un tópico que cae en el ámbito del derecho fundamental a la identidad, y en la contracara se encuentra un régimen de prácticas estatales que limitan el derecho de un grupo social discriminado.

Un instrumento, quizá el único, para la identificación global de los mexicanos es la CURP (clave única de registro de población), cuya expedición está a cargo de la Secretaría de Gobernación federal. ${ }^{21}$ Se trata de una secuencia alfanumérica de dieciocho caracteres que se asigna de forma individual a mexicanos y extranjeros residentes. La manera en que se compone está determinada por las letras iniciales de los apellidos y

\footnotetext{
20 Idem.

21 Instructivo normativo para la asignación de la Clave Única de Registro de Población, Diario Oficial de la Federación, 18 de junio de 2018.
} 
nombres; seis números, correspondientes a dos dígitos por el año, mes y día de nacimiento; la letra del sexo, $\mathrm{H}$ para hombre y M para mujer; la entidad federativa de nacimiento, y una secuencia de números individuales.

En caso de que una persona trans efectúe su reasignación de género, necesariamente habrá un escollo en el cambio de las iniciales del nombre de pila y la letra del sexo. Por una parte, no se prevén procedimientos para que la CURP sea modificada, y de hacerlo no quedaría registro alguno en poder del gobierno federal — salvo los registros propios del registro civil o del expediente judicial abierto al efecto, que por cierto no están debidamente articulados con los repositorios de consulta del Estado- para cohonestar la primera identidad de la persona trans con la clave poblacional en que conste el nuevo sexo.

Si la CURP no se modifica, se dejan datos que permitirían identificar la anterior identidad de la persona trans, pues en cualquier trámite que presente la clave fácilmente se detecta que las iniciales del nombre y la letra del sexo no se corresponden con la identidad que ejerce la persona.

Como se verá más adelante, el sigilo y secrecía absoluta en la reasignación de género de personas es un principio que debe cumplirse. Inclusive, el Pleno de la Suprema Corte otorgó un amparo para evitar que la anotación marginal en el acta de nacimiento de una persona trans deje entrever en cualquier acto futuro la reasignación sexo genérica. ${ }^{22}$

Esta diferencia hace notoria la necesidad de articular un modelo en que el Estado no pierda el control absoluto sobre la identificación de las personas, para mantener la identidad de las personas en los registros estatales. Inclusive, un voto particular del ministro Silva Meza razonó sobre la necesidad de que el Estado no pierda ese control a través de la anotación marginal levantada en las actas de nacimiento primigenia de personas trans que han modificado su identidad de género. ${ }^{23}$ La anotación marginal debiera surtir efectos para que la autoridad conozca, con absoluta reserva, las identidades de los habitantes; si bien la propia anotación es reservada ante terceros.

En la práctica, cuando una persona trans desea modificar su acta de nacimiento, y después el resto de documentos personales, tiene dos vías. El ordenamiento jurídico civil, tanto el federal como el particular de cada

22 Sentencia del Pleno de la Suprema Corte de Justicia de la Nación, amparo directo 6/2008, 6 de enero de 2009.

23 Voto particular del ministro Juan N. Silva Meza, contra la sentencia del Pleno de la Suprema Corte de Justicia de la Nación, amparo directo 6/2008, cit. 
entidad federativa, disponen estos dos mecanismos para la rectificación de actas del registro civil. La primera es la vía administrativa ante el propio registro civil, para modificar errores simples, como errores mecanográficos o de transcripción de documentos. La segunda es la vía jurisdiccional ante los jueces, para modificar aspectos esenciales, como la modificación de un nombre que cause afrenta a la persona o cambios en sus ascendientes tras reconocimientos de paternidad.

La persona que reasigna su sexo modifica dos cosas: su nombre, para hacerlo coincidir con un nombre que se ajuste a la identidad femenina o masculina que ejerce, y el sexo, para que corresponda con su identidad de género. Ciertamente, el cambio de nombre y sexo puede considerarse como una modificación esencial que amerita la intervención de un juez para dotar de seguridad jurídica el procedimiento; pero la tendencia normativa es simplificar y facilitar la reasignación de género a través de un procedimiento administrativo.

La producción normativa en el siglo XXI ha alcanzado niveles estratosféricos, que hacen ardua la labor de identificación de los contenidos que el operador jurídico necesita utilizar. En sistemas jurídicos del common law, que también tienen normas jurídicas positivas a pesar de que el precedente judicial es preponderante, se lleva a cabo una consolidación normativa para agrupar las regulaciones. ${ }^{24}$ En países de tradición civil, los códigos refundidos son un intento por volver a organizar la pluralidad de normas que han sido aprobadas. El código fue el instrumento normativo protagonista del siglo XX, pero actualmente ha sido desplazado por un alud de normas especiales, generales, marco o regulatorias, muchas de ellas con mala calidad técnica desde el punto de vista del legislative drafting. ${ }^{25}$

La realidad ha rebasado a las normas jurídicas, pues los cada vez más comunes procedimientos de reasignación de sexo ponen de manifiesto que la normativa es insuficiente para satisfacer el reclamo de igualdad y libertad de una comunidad minoritaria. Podría pensarse que, otra vez, es necesario una reforma constitucional ad hoc para generar una ley federal en materia de reasignación de género de personas transexuales. $\mathrm{O}$ entrando más en las prácticas mexicanas del constituyente permanente, dejar en un artículo transitorio la buena voluntad de emitir futuras normas en ese tema.

24 Samuel, Alec, “Consolidation: A plea", Statute Law Review, Oxford, vol. 59, 2005, p. 26.

25 Pizzorusso, Alessandro, "Recientes tendencias del parlamentarismo", Revista Vasca de Administración Pública, Bilbao, núm. 39, 1994, pp. 105-125. 
Parece más adecuado cesar con la sangría interminable de reformas constitucionales que han hecho que la ley suprema mexicana sea una Constitución de supuestos y especificidades, una Constitución atrapatodo. Los 239 decretos de reforma constitucional - que implican 732 modificaciones, actualizado hasta el 10 de agosto de $2019 £^{26}$ son elocuentes para mostrar que la intención contemporánea de México es crear derecho positivo a partir de cláusulas constitucionales, en lugar de desarrollar normas mediante el completo y complejo alud de principios que ya se tienen.

Inclusive, la Constitución federal ha impuesto al Congreso de la Unión la obligación de expedir leyes generales que armonicen y homologuen la organización y el funcionamiento de los registros civiles (artículo 73, fracción XXIX-R). Esta reforma se publicó el 5 de febrero de 2017, y entre los ámbitos que deben regularse aparecen los mecanismos de atención de grupos en situación de especial vulnerabilidad y marginación, y la simplificación de procedimientos de corrección, rectificación y aclaración de actas.

Hay otras cláusulas constitucionales que inciden en la identidad de personas trans, como el principio de progresividad (artículo 1o., tercer párrafo), el derecho a la igualdad (artículo 4o., octavo párrafo), la prohibición de todo acto de discriminación (artículo 1o., último párrafo), el derecho a la identidad (artículo 4, primer párrafo), los principios de competencia administrativa y reserva de ley que rigen al registro civil (artículo 130, penúltimo párrafo) y el mandato al Congreso de la Unión para armonizar y homologar los registros civiles (artículo 73, fracción XXIX-R). Como se ve, existe un andamiaje suficiente para crear una sentencia estructural.

Sin duda, existen suficientes insumos constitucionales para reconocer y desarrollar la identidad de género que asumen las personas trans, y en consecuencia movilizar la labor de diversas autoridades del Estado mexicano.

Los contenidos específicos de esa ley general deberían atender la cuestión del derecho de identidad de género de personas trans. Mientras eso ocurre, la Suprema Corte puede, mediante una sentencia estructural, movilizar el material constitucional que ya se tiene a fin de propiciar una regulación que tenga un piso mínimo de derechos para este grupo social.

26 Datos extraídos de la base de datos de la Cámara de Diputados del Congreso de la Unión, disponible en: $h t t p: / / w w w . d i p u t a d o s . g o b . m x / L e y e s B i b l i o / i n d e x . h t m$, consultado el 13-08-2019, a las 12:00 hrs. También se toma en cuenta el conteo de Fix-Fierro, Héctor et al., Constitución política de los Estados Unidos Mexicanos. Texto reordenado y consolidado, México, UNAM, 2016, p. 2. 


\section{Precedentes Judiciales en MÉXiCO}

La Suprema Corte ha resuelto casos relacionados con la rectificación de actas de nacimiento de personas trans que han decidido ejercer su derecho a la identidad de género, ya sea mediante la prosecución de juicios que ulteriormente llegan a la Corte mediante el amparo directo, o a través del planteamiento de inconstitucionalidad de códigos civiles que limitan la rectificación de actas de nacimiento, que llega a la Corte mediante el amparo en revisión.

En 2009, el Pleno resolvió el amparo directo $6 / 2008,{ }^{27}$ un caso donde una persona transexual promovió un juicio civil para rectificar su acta de nacimiento, y los órganos judiciales resolvieron que solamente procedía la modificación del nombre - cambiando un nombre masculino por uno femenino-, pero no así el sexo; además que el cambio debía plasmarse en una nota al margen levantada en su acta de nacimiento. El Pleno analizó un precepto del Código Civil del entonces Distrito Federal, que preveía la imposición de una nota marginal en el acta del registro civil que ha sido rectificada. El mismo precepto, con matices, está previsto en las normas de los estados que regulan la rectificación de los asientos del registro civil, normalmente el código civil o la ley del registro civil.

Una apretada mayoría de seis votos estableció que el precepto que regula la anotación marginal es apegado a la Constitución, pues permite dar seguimiento a la identidad de las personas, y así evitar trasgresiones al orden público y fraudes a terceros. El eje argumentativo giró sobre la interacción del derecho de identidad de género y los actos administrativos de registro civil, pues al mismo tiempo la reasignación sexogenérica se mantiene en un ámbito de privacidad, prohibiéndose la publicidad hacia terceros, como de control estatal, para evitar perder el registro de la identidad de los ciudadanos.

La mayoría en el Pleno zanjó el planteamiento de inconstitucionalidad mediante un tecnicismo muy fino: no se declara inconstitucional el precepto que regula la anotación marginal, toda vez que durante el trámite del juicio de amparo se reformó el sistema normativo civil para establecer una reforma que autoriza el procedimiento de reasignación sexogenérica. Así, el Pleno exigió a los tribunales ordinarios que realizaran una inter-

27 Sentencia del Pleno de la Suprema Corte de Justicia de la Nación, amparo directo 6/2008, cit. 
pretación integradora del ordenamiento civil a efecto de incorporar a sus resoluciones los lineamientos de la nueva normativa.

Asimismo, la sentencia estableció que los actos realizados por una persona transexual bajo su anterior identidad, que generaran o pudieran generar obligaciones o responsabilidades al individuo, le serán exigibles en los términos de las leyes aplicables. De igual manera, sus derechos tampoco se extinguen por la reasignación de sexo, tales como los derechos de sucesión, contratos civiles, o antigüedad en el trabajo. Sin duda, esta reflexión debiera llevarse a una legislación sobre la materia, que articule la manera en que los derechos y obligaciones adquiridos por la persona trans no desaparecen por su reasignación de género.

Tiene particular relevancia el voto particular del ministro Silva Meza, ${ }^{28}$ quien afirmó que la anotación marginal sí debe subsistir, pero sólo para que la autoridad ejecute un control absoluto del historial de cada individuo; en cambio, la anotación marginal desaparece para los particulares, toda vez que debe expedirse una nueva acta de la persona trasgénero, sin mención alguna sobre el cambio y sin permitir la publicidad a terceros.

Años después, ya durante la décima época, la Primera Sala resolvió el amparo en revisión 1317/2017. ${ }^{29}$ La materia de estudio versó sobre un control concentrado de constitucionalidad del sistema normativo civil del estado de Veracruz, que distingue entre una vía administrativa y una vía judicial para realizar las modificaciones a las actas del registro civil. El asunto trae cuenta de una persona trans que ante el registro civil solicitó la rectificación de su acta de nacimiento para adecuarla a su género. $\mathrm{Su}$ petición se desestimó aduciendo que ese tipo de rectificaciones deben tramitarse por la vía judicial y no ante el registro civil.

Esto permitió a la Primera Sala, fijar qué vía procedimental — la administrativa ante el registro civil, o la jurisdiccional ante un juez- es la más idónea para que la persona transgénero promueva la modificación de su acta de nacimiento. La manera de construir la sentencia fue peculiar. Se tomó como referencia que en el estado de Veracruz el acto jurídico de reconocimiento de un padre a un hijo es posible realizarlo en sede administrativa ante el oficial del registro civil. El acta de reconocimiento, sin duda, modifica el apellido y parentesco del menor, con lo cual se trata de una modificación esencial en la identidad del reconocido. El mismo efecto

\footnotetext{
28 Op. cit.
}

29 Primera Sala de la Suprema Corte de Justicia de la Nación, sentencia dictada en el amparo en revisión 1317/2017, 17 de octubre de 2018. 
de modificación esencial acontece con el levantamiento de una nueva acta de nacimiento con motivo de la reasignación de género, toda vez que hay cambios en el nombre y sexo del registrado.

A la luz del derecho a la igualdad, existe un trato legal diferenciado y desproporcional, toda vez que por una parte se autoriza que, por ejemplo, el reconocimiento se efectúe ante el registro civil, pero la reasignación de género se reconduce a una vía jurisdiccional. Este sistema normativo no superó el test de proporcionalidad y fue declarado inconstitucional por la Primera Sala.

Esta sentencia reproduce totalmente las consideraciones de la Corte Interamericana de Derechos Humanos en la Opinión consultiva 24/17. El tribunal interamericano estableció un marco referencial de cinco requisitos, que deben cubrirse en los procedimientos del registro civil encaminados a la reasignación de sexo en casos de personas transexuales, a saber: i) un procedimiento que sea adecuado e integral; ii) el consentimiento libre e informado de la persona transexual; iii) que el procedimiento sea confidencial; iv) que sea expedito y tienda a la gratuidad, y v) que no se exija acreditar operaciones o tratamientos médicos para la reasignación de sexo.

El mismo catálogo de requisitos fue reiterado por la Primera Sala, que si bien no estaba obligada a aplicar la opinión consultiva, tuvo el mérito de incorporar al sistema jurídico nacional, por la vía del soft law, estándares internacionales de apreciación, interpretación y validez en un tema técnico y políticamente sensible.

Respecto a la calidad del procedimiento adecuado e integral, en el párrafo 124 de la citada opinión consultiva, la Corte Interamericana estableció que basta con la rectificación ante el registro civil para que se evite una pluralidad de trámites de la persona trans, a fin de evitar un trámite por cada documento personal que se desee corregir. Se reconoció la libertad configurativa de cada Estado parte, pero en el párrafo 159 se fijó que el procedimiento que mejor se ajusta es de índole administrativa. Esto fue retomado por la Primera Sala, y se concluyó que el procedimiento más idóneo para la reasignación sexogénerica es la vía administrativa, a fin de evitar las excesivas demoras y costos de una vía jurisdiccional.

Pasó desapercibido para la Suprema Corte, que una clave argumentativa que hubiera reforzado enormemente la sentencia es el artículo 130, penúltimo párrafo, de la Constitución federal, que establece la competencia de las autoridades administrativas, y no judiciales, para conducir los actos del registro civil. 
En otro aspecto, las resoluciones judiciales en México sobre el tema también han provenido de tribunales colegiados de circuito, que fungen como órganos terminales en materia de legalidad y dotan al sistema jurídico nacional de interpretaciones cotidianamente aplicadas en todo el país. En la competencia de los tribunales colegiados hay interpretaciones yuxtapuestas. Se trata de un claro ejemplo en que una laguna legislativa tampoco ha sido aclarada pacíficamente por la jurisprudencia.

Respecto a un tópico tan elemental como la vía procesal para llevar a cabo la reasignación de sexo, hay un tratamiento judicial disímil, según la entidad federativa en que se plantee. Por una parte, el Pleno del decimoséptimo circuito estableció en una contradicción de tesis - es decir, hubo criterios divergentes dentro del propio circuito - que la legislación de Chihuahua sobre rectificación de actas del registro civil debe interpretarse en el sentido de que la vía administrativa es la más congruente para tutelar el derecho de identidad de género. ${ }^{30}$ Este criterio tiene efectos vinculantes, y debe ser cumplido (artículo 217, párrafo tercero, de la Ley de Amparo), y por lo menos la práctica demuestra que los órganos judiciales del fuero común dialogan con más asiduidad con los criterios de sus propios circuitos que con la Suprema Corte.

Por el contrario, un tribunal colegiado de Guanajuato estableció una jurisprudencia por reiteración —es decir, el mismo criterio reiterado en cinco sentencias - respecto a que el establecimiento de una vía jurisdiccional para la rectificación de actas de reasignación de sexo supera el test de proporcionalidad y no lesiona derechos fundamentales. ${ }^{31}$

La diferencia es notoria: en el estado de Chihuahua se ha interpretado que la vía administrativa, es decir, ante el propio registro civil, es indis-

30 Pleno del Decimoséptimo Circuito, sentencia en la contradicción de tesis 6/2018, del 9 de abril de 2019. De esta contradicción de tesis surgió la jurisprudencia PC.XVII. J/20 A (10a.), Gaceta del Semanario Judicial de la Federación, Décima Época, libro 67, junio de 2019, tomo V, p. 4274, de rubro: "Identidad de género auto-percibida. Los artículos 48, 130 y 131 ter del Código Civil del Estado de Chihuahua, transgreden los derechos a la igualdad, a la identidad y al nombre de las personas transgénero, al contener una discriminación normativa".

31 Primer Tribunal Colegiado en Materia Administrativa del Décimo Sexto Circuito, jurisprudencia XVI.1o.A. J/47 (10a.), Gaceta del Semanario Judicial de la Federación, Décima Época, libro 56, julio de 2018, tomo II, p. 1421, de rubro: "Reasignación sexogenérica. El establecimiento de un procedimiento jurisdiccional para modificar las actas de nacimiento, a efecto de hacerla constar, supera el test de proporcionalidad en sentido estricto (legislación del Estado de Guanajuato)". 
pensable para tutelar el derecho de identidad de género; mientras que en el estado de Guanajuato se han decantado por la vía jurisdiccional. Ciertamente, la jurisprudencia de Chihuahua es compatible con el criterio de la Primera Sala en el amparo en revisión 1317/2017, pero el criterio de Guanajuato aún no ha sido superado mediante una contradicción de tesis.

Por su parte, en el estado de Jalisco un tribunal colegiado estableció que la omisión de expedir una nueva acta de nacimiento a la persona que ha reasignado su sexo es violatoria de derechos fundamentales. ${ }^{32}$ De nueva cuenta, se corrigió la práctica del registro civil local en no reexpedir una nueva acta de nacimiento para la persona trans, que esté incólume de datos que revelen su anterior condición sexual.

La legislación del estado de Veracruz se declaró inconstitucional por la Primera Sala en el amparo en revisión 1317/2017. Mientras que en el amparo directo 6/2008 el Pleno declaró constitucional la anotación marginal regulada en el entonces Distrito Federal, cuya ratio normativa aparece en todas las codificaciones del país.

Otro aspecto relevante es que en juicios de amparo promovidos por personas trans surgió una contradicción de tesis para dilucidar la especialidad que deben tener los órganos jurisdiccionales que conozcan juicios de amparo interpuestos contra actos u omisiones del registro civil. La jurisprudencia 1a./J. 36/2019 (10a.) de la Primera Sala estableció que si bien el registro civil es una autoridad administrativa, pues orgánicamente depende del Poder Ejecutivo de las entidades federativas, lo cierto es que sus actos versan sobre el registro de las personas, cuyo contenido es de naturaleza civil. ${ }^{33}$ Así, la especialización de los órganos judiciales es de materia civil, y no administrativa.

32 Cuarto Tribunal Colegiado en Materia Civil del Tercer Circuito, sentencia en el amparo en revisión 153/2018, del 8 de junio de 2018. De esta sentencia surgió la tesis III.4o.C.45 C (10a.), Gaceta del Semanario Judicial de la Federación, Décima Época, libro 60, noviembre de 2018, tomo III, p. 2378, de rubro: "Reconocimiento de identidad de género. Las disposiciones del Código Civil y de la Ley del Registro Civil del Estado de Jalisco, al no prever la posibilidad de expedir un acta de nacimiento en la que se haga constar aquella situación, en ejercicio del control de convencionalidad, deben inaplicarse".

33 Tesis 1a./J. 36/2019 (10a.), Gaceta del Semanario Judicial de la Federación, Décima Época, libro 69, agosto de 2019, tomo II, p. 1045, de rubro: "Competencia para conocer del juicio de amparo indirecto cuando se impugnen actos u omisiones de las autoridades del registro civil relacionados con el estado civil de las personas. Corresponde al juez de distrito en materia civil, cuando se dé la especialización”. 
A los problemas de interpretación propios de cualquier tema jurídico novedoso se añade un problema endémico de México derivado de la ausencia de un sistema sólido de obligatoriedad de los precedentes dictados por la Suprema Corte. No es este el lugar para profundizar sobre las causas y efectos, ${ }^{34}$ pero baste decir que la vinculación de la jurisprudencia de la Suprema Corte está determinada por el tipo de asunto donde emite el fallo. Por ejemplo, si dicta sentencia en las acciones y controversias del artículo 105 constitucional o en contradicciones de tesis, se genera una jurisprudencia de observancia obligatoria; en cambio, si dicta una sentencia en cualquier otro proceso del amplio abanico competencial que tiene, solamente se origina una tesis aislada que jurídicamente no vincula.

Según la propia Suprema Corte, una tesis es la expresión por escrito, en forma abstracta, de un criterio jurídico establecido al resolver un caso concreto; no es un extracto, una síntesis o un resumen de la sentencia. ${ }^{35} \mathrm{Si}$ no se publican tesis de una sentencia, prácticamente la doctrina constitucional pasa desapercibida para los operadores jurídicos. Esto provoca que, por ejemplo, las tesis aisladas emitidas en el amparo directo $6 / 2008$ y en el amparo en revisión 1317/2017 sean el único insumo que la Corte otorga al foro jurídico; y el resto de argumentos de la sentencia, así se trate de ratio decidendi, pasan desapercibidos.

El sistema de obligatoriedad todavía está pensado en términos de una corte de casación que unifica la jurisprudencia de los órganos inferiores, y no como un tribunal constitucional que tiene la última palabra en la interpretación de la Constitución, y sus sentencias vinculan y dialogan con todos los poderes del Estado.

Hay otro problema de enorme gravedad: la jurisprudencia no es obligatoria para autoridades del orden administrativo, siendo únicamente vinculante para aquellas que ejercen jurisdicción. ${ }^{36}$ En un ordenamiento en el que

34 Orozco Pulido, Jesús Manuel, "La Suprema Corte de Justica de México y su sistema de creación jurisprudencial: defectos y retos", en Cucarella, Luis (coord.), Derecho procesal convencional. El nuevo desafio de la justicia constitucional, Bogotá, Ediciones Nueva Jurídica, 2016, pp. 487-492.

35 Acuerdo General 20/2013, del 25 de noviembre de 2013, del Pleno de la Suprema Corte de Justicia de la Nación, relativo a las reglas para la elaboración, envío y publicación en el Semanario Judicial de la Federación y su Gaceta, de las tesis que emiten la Suprema Corte de Justicia, los Plenos de Circuito y los Tribunales Colegiados de Circuito.

36 Tesis 2a./J. 38/2002, Semanario Judicial de la Federación y su Gaceta, Novena Época, 186921, tomo XV, mayo de 2002, p. 175, de rubro: “JURISPRUDENCIA SOBRE IN- 
pululan los organismos autónomos que fungen como entes regulatorios o de control, amén de la pluralidad de autoridades administrativas del orden federal, estatal o municipal —incluidos aquí todos los oficiales del registro civil del país- es necesario repensar la conveniencia de que una sentencia de la Suprema Corte guíe el actuar de todas las autoridades nacionales.

Una sentencia del tribunal constitucional evita que una pluralidad de causas particulares se ralenticen en una cadena judicial que, después de años de cansado litigio, llegue a órganos terminales en que sí se aplique una jurisprudencia que desde el inicio hubiera superado el escollo.

La doctrina constitucional que ha emanado de los amparos resueltos por la Suprema Corte en materia de identidad de género de personas trans se ciñe a siete tesis aisladas del amparo directo 6/2008, y seis del amparo en revisión 1317/2017, mientras que los criterios emanados de Chihuahua y Guanajuato sí son jurisprudencia obligatoria, y técnicamente no puede existir una contradicción de tesis entre un pleno o tribunal colegiado de circuito y la Suprema Corte.

En la práctica, el operador jurídico adscribe un mayor valor a una tesis de la Suprema Corte que a una jurisprudencia de un tribunal colegiado de circuito. Sin embargo, no parece adecuado que haya diversidad de criterios en un tema sensible que incide en un derecho fundamental básico de un grupo social discriminado. Recordemos que la opinión consultiva 24/17 del tribunal interamericano hace énfasis en la celeridad y rapidez en los procedimientos de reasignación de género, por lo que las autoridades administrativas del registro civil debieran ceñirse a cualquier criterio jurisprudencial en que la Suprema Corte dé directrices a su actuar.

Es importante discutir sobre la obligatoriedad de la jurisprudencia del tribunal constitucional mexicano, particularmente hacia autoridades administrativas. Por ejemplo, como se verá en el apartado siguiente, la Corte Constitucional de Colombia ordenó a la superintendencia competente la emisión de una circular para que los notarios ajustaran sus procedimientos a la sentencia constitucional, respecto a la reasignación de género de una persona trans menor de edad.

La expeditez y prontitud en el establecimiento de los derechos de la persona transgénero es crucial. Hay efectos perniciosos en la vida cotidiana de una persona trans que, al no tener sus documentos personales que co-

CONSTITUCIONALIDAD DE LEYES. LAS AUTORIDADES ADMINISTRATIVAS NO ESTÁN OBLIGADAS A APLICARLA AL CUMPLIR CON LA GARANTÍA DE FUNDAR Y MOTIVAR SUS ACTOS”. 
rrespondan a su identidad, irrogan problemas para celebrar actos jurídicos tan elementales como inscribirse a una universidad, abrir una cuenta bancaria o celebrar contratos civiles y laborales. No es justo que una persona cotidianamente ejerza actos con documentos que no se corresponden con la identidad que libremente decide ejercer.

Esto conduce a repensar el rol que la Suprema Corte mexicana podría jugar en la eficacia y cumplimiento del derecho a la identidad de género en los actos del registro civil. Una vía pertinente para irradiar la interpretación protectora de derechos humanos de la comunidad trans, y dotar a la doctrina constitucional de la Corte con mayor eco y eficacia, es la emisión de una sentencia estructural que atienda el tema.

\section{EXPERIENCIA NORMATIVA Y JUDICIAL EN PAÍSES EXTRANJEROS}

Existen normas jurídicas y precedentes judiciales en América Latina y Europa que muestran que el camino por cristalizar derechos a miembros de la comunidad trans ha sido difícil, pero hay avances. ${ }^{37}$ Por vía de ejemplo, los avances en el derecho alemán han sido perfilados por sentencias del tribunal constitucional federal que han fijados estándares de protección a los derechos de la comunidad trans. ${ }^{38}$

Diversas normas jurídicas han señalado requisitos que, una vez anulados en la jurisdicción constitucional, han sido eliminados por el legislador. Tal ha sido el caso de la fijación de una edad mínima de veinticinco años para llevar a cabo la reasignación de género, el requerimiento de no estar casado para proceder a la nueva identidad, o exigir pruebas médicas que acrediten una incapacidad de reproducción y tratamientos médicos para la reasignación de género. ${ }^{39}$ El legislador libremente crea el derecho positivo

\footnotetext{
37 En las páginas 90 a 96 de la sentencia del Pleno de la Suprema Corte de Justicia de la Nación, en el amparo directo 6/2008, resuelto en sesión del 6 de enero de 2009, se citan una pluralidad de normas jurídicas y precedentes judiciales de Italia, Alemania, Reino Unido, Holanda, España, Argentina, Francia, Colombia, Perú y Chile.

38 Von Stritzky, Johannes, "El desarrollo de la protección jurídica de las personas homosexuales, bisexuales, transexuales e intersexuales (LGBT) en Alemania”, Revista General de Derecho Constitucional, España, núm. 17, 2013, p. 6.

39 Idem.
} 
con su margen de apreciación, pero la jurisdicción ha anulado normas que no respetan los cánones constitucionales.

Por su parte, en 2002 el Tribunal de Derechos Humanos de la Unión Europea se pronunció sobre el derecho de identidad de personas transexuales, en el caso Goodwin v. Reino Unido; mientras que el Tribunal de Justicia de la Unión Europea reconoció el derecho de matrimonio y de pensiones de viudedad a parejas transexuales, en el caso K.B. v. Reino Unido en 2004. ${ }^{40}$ El diálogo judicial europeo ha levantado críticas, aduciéndose que las cortes de justicia internacionales generan derechos sin tener en cuenta los procedimientos formales de creación de derecho positivo de los Estados miembros. ${ }^{41}$ Sin duda, se trata del debate perenne sobre activismo judicial, la maximización de derechos y la autorrestricción.

Respecto del derecho a la identidad de personas transexuales, la Corte Constitucional de Colombia ha establecido criterios innovadores y sagaces en acciones de tutela que reconocen a personas transexuales estándares de protección y reconocimiento a sus derechos. Tres sentencias merecen un comentario específico.

A pocos años de su establecimiento tras la Constitución de Colombia de 1991, la alta jurisdicción constitucional emitió la sentencia T-477/95 que otorga una tutela a quien siendo menor de edad fue sometido a tratamientos médicos para remodelar sus genitales, que aparentemente fueron cercenados por la mordedura de un perro. ${ }^{42}$ Sin tener el consentimiento pleno e informado del menor ni de sus padres, quienes carecían de instrucción dada su vida campesina, los médicos tratantes decidieron efectuar una meatotomía para paliar el cercenamiento de los genitales masculinos del niño. Seis años después, otra vez sin tener un consentimiento pleno e informado del paciente, efectuaron una cirugía de reasignación de sexo para que el paciente tuviera genitales femeninos. Pasados los años, en el paciente emergió su condición biológica masculina, manifestándose en sus rasgos fenotípicos, en su comportamiento social y psicológico y en su identidad de género. De esta manera, la vulneración en sus derechos se materializó, porque la reasignación de sexo no le fue consultada, lo que a la postre de-

\footnotetext{
40 Navarro Batista, Nicolás, "Los transexuales en la jurisprudencia europea: comentario al asunto K.B. (sentencia del TJCE de 7 de enero de 2004, as. C-117/01)", Revista General de Derecho Europeo, núm. 4, 2004.

41 Elósegui Itxaso, María, "El TJCE y el matrimonio de transexuales...", cit.

42 Sentencia de la Corte Constitucional de Colombia, T-477/95, 23 de octubre de 1995.
} 
rivó en un choque frontal entre su identidad de género y los genitales que médicamente le fueron confeccionados.

La sentencia inició citando a John Locke como fundamento de la libertad individual, que adquiere mayor relevancia en el cuerpo humano como expresión básica de las decisiones personales. Se fijó que el ser humano no es un juguete de experimentos médicos, por lo que en casos de procedimientos médicos para la reasignación sexogenérica debe tenerse en cuenta el consentimiento libre, informado y reforzado del paciente, que se extiende a sus padres cuando es menor de edad.

En 2017, la Corte Constitucional colombiana emitió sentencias de enorme valía para la comprensión de los derechos de personas transexuales. En la T-498/2017 se fijaron los parámetros que debe tener el consentimiento informado de un menor de edad transgénero para proceder a adecuar su identidad de género: i) la clara voluntad del menor y de sus padres; ii) la proximidad a la mayoría de edad; iii) los informes o tratamientos médicos; iv) la consideración de que la reasignación sexogenérica en sus documentos personales podría ser revertida. ${ }^{43}$ Este último requisito, tomando en cuenta que el decreto 1217 de 2015 del Ministerio de Justicia y del Derecho autoriza la corrección transcurridos diez años desde la emisión de la escritura de reasignación, y limita la corrección a dos ocasiones. ${ }^{44}$

Por su parte, la T-675/2017 versó sobre la negativa notarial en realizar el cambio en la partida de nacimiento en los apartados de nombres y sexo, a fin de readecuarlos a la identidad de género de un menor de edad..$^{45}$ El quid fue analizar el requisito de mayoría de edad del decreto 1217 de 2015 del Ministerio de Justicia y del Derecho, que prevé que la petición de reasignación de género debe realizarse por persona mayor de edad. El requisito de mayoría de edad, si bien expresamente no está previsto en el decreto, de forma implícita subyace por el deber de acompañar a la petición de reasignación de sexo la cédula de ciudadanía, que es un documento expedido solamente a los mayores de edad. Mutatis mutandis, igual escenario acontecería en

\footnotetext{
43 Sentencia de la Corte Constitucional de Colombia, T-498/17, 3 de agosto de 2017.

44 Ministerio de Justicia y del Derecho de Colombia, Decreto 1217 del 4 de junio de 2015, por el cual se adiciona una sección al Decreto 1069 de 2015, Único Reglamentario del Sector Justicia y del Derecho, relacionado con el trámite para corregir el componnte sexo en el Registro del Estado Civil.

45 Sentencia de la Corte Constitucional de Colombia, T-675/2017, 15 de noviembre de 2017.
} 
México si se requiriera exhibir la credencial para votar, que también solamente se expide a los adultos.

La sentencia estableció que las personas menores de edad tienen derecho a ejercer su identidad de género si concurre en el menor un grado de autonomía que sea directamente proporcional a su nivel de desarrollo y madurez. El concepto del consentimiento se estudió a la luz del cuerpo del individuo, es decir, los elementos relevantes de los rasgos fisonómicos que expresa el organismo - donde es relevante, pero no exigible, la realización de tratamientos médicos hormonales o incluso cirugías de reasignación de sexo - ; la identidad de género que la persona proyecta hacia sí y en sus relaciones sociales, y las manifestaciones o expresiones que revelen el ejercicio de su identidad de género, como el proyecto de vida o la autoconsideración del género que se desea ejercer. El requisito de mayoría de edad se pasó por un tamiz de proporcionalidad, y se concluyó que la exigencia de mayoría de edad resulta desproporcional con el derecho humano de identidad.

Sin duda, la T-675/2017 es una sentencia aditiva que añade un supuesto de procedencia para la rectificación de documentos personales en atención a la identidad de género de una persona trans. La norma jurídica no prevé la procedencia del trámite ante menores de edad, pero la jurisdicción constitucional estima apegado a derechos fundamentales que sí se autorice en menores de edad. Inclusive, un efecto peculiar de la sentencia fue ordenar a la Superintendencia Nacional de Notariado y Registro que en un plazo de treinta días emitiera una circular dirigida a todas las notarías del país para que, a la luz de la jurisprudencia constitucional, se aclare el alcance del precepto analizado y se ajusten sus actos a la sentencia.

Es particularmente relevante que en las sentencias T-477/95 y T-675/ 2017 se practicaron pruebas periciales médicas y se escuchó con atención el parecer, el proyecto de vida y la autoconcepción de la persona trans. Esto propició que el análisis constitucional no se centrara en un debate de derechos o concepciones filosóficas, sino que se centrara a datos objetivos y vivencias reales de la persona que buscaba justica.

Tal situación no se realiza en la alta jurisdicción constitucional mexicana, a excepción del señero caso de seropositividad de amparos de militares que conoció el Pleno de la Suprema Corte en 2007, donde celebró audiencias públicas con participación de expertos en materia de salud. ${ }^{46}$ La regla

\footnotetext{
46 Silva García, Fernando, "VIH y militares (criterios jurisprudenciales de la SCJN)", Cuestiones Constitucionales, México, núm. 18, 2008, pp. 309-325.
} 
de litis cerrada del juicio de amparo — que exige que los actos de autoridad se analicen tal como están probados ante la autoridad responsable- y la jurisprudencia que limita la práctica de pruebas en el recurso de revisión a casos específicos que usualmente van en contra de los intereses del justiciable - como pruebas supervinientes para acreditar la improcedencia del amparo, o rebatir la presunción de existencia del acto reclamado- ${ }^{47}$ han hecho que el trabajo de la Corte sea de índole revisionista y casacionista, en lugar de erigirse como un órgano de justicia viva.

Otro ejemplo de sentencias extranjeras de relevancia se encuentra en la reciente sentencia del Pleno del Tribunal Constitucional de España (STC 99/2019), a quien le fue cuestionada la constitucionalidad de un precepto de la Ley 3/2007, del 15 de marzo, reguladora de la rectificación registral de la mención relativa al sexo de las personas, que prevé como requisito la mayoría de edad de la persona trans. ${ }^{48} \mathrm{El}$ caso, iniciado por los padres de un menor transexual, encontró en los órganos judiciales de primera y segunda instancia una desestimación, por carecer de legitimación en la causa, toda vez que para acceder a la reasignación sexogenérica el legislador precisó el requisito de la mayoría de edad.

Llegado el caso al Tribunal Constitucional, por la vía de una cuestión de inconstitucionalidad que planteó la sala civil del Tribunal Supremo, se dictó una sentencia aditiva. La norma que exige la mayoría de edad para proceder a la rectificación de documentos del registro civil no es inconstitucional siempre que no sea aplicada a menores de edad con suficiente madurez y que se encuentren en una situación estable de transexualidad. Lamentablemente, esta sentencia fue dictada tras cinco años de iniciado el litigio, caso en la antesala que el menor transexual cumpliera la mayoría de edad. Ello revela la imperiosa necesidad de aclarar la vía de tramitar esta

\footnotetext{
47 Cfr. las tesis 2a./J. 64/98, Semanario Judicial de la Federación y su Gaceta, Novena Época, 195615, tomo VIII, septiembre de 1998, p. 400, de rubro "Pruebas en la revisión. Deben tomarse en consideración las supervenientes, Si se relacionan con la improcedencia del juicio de garantías"; y 2a./J. 60/2002, Semanario Judicial de la Federación y su Gaceta, Novena Época, tomo XVI, julio de 2002, p. 352, de rubro "Pruebas en la revisión. Deben tomarse en cuenta las documentales aportadas para desvirtuar la omisión de rendir informe justificado que se imputa en la sentencia recurrida a la autoridad responsable recurrente".

48 STC 99/2019, sentencia del Pleno del Tribunal Constitucional de España, Boletín Oficial del Estado, núm. 192, 12 de agosto de 2019.
} 
clase de asuntos, según el adagio de que la justicia tardía equivale a una denegación de justicia.

Una peculiaridad debe resaltarse: no se declara la inconstitucionalidad de la norma con efectos erga omnes, pues daría lugar a un vacío legal incluso para personas mayores de edad que pretendan adecuar sus documentos según su identidad de género. La fórmula que utilizó el tribunal constitucional español es declarar la inconstitucionalidad, pero no la nulidad, del precepto materia de la cuestión.

Esta manera de resolver fue duramente criticada en un voto particular de la vicepresidente del Tribunal, quien pone de manifiesto que se tocan ámbitos regulatorios que sólo corresponden al legislador. ${ }^{49}$ También expresa una legítima preocupación por los efectos confusos del fallo, al no precisar si se trata de una sentencia aditiva, una declaración de inconstitucionalidad parcial, una mera interpretación de la norma, o una sentencia monitoria que sugiere al legislador nuevas formas de regular un tema. El voto particular razona sobre la incertidumbre pragmática que generará la sentencia, pues no se expone qué entidad valora la suficiente madurez del menor de edad trans, bajo qué canon probatorio se acredita, o cómo se define la situación estable de transexualidad.

Las normas jurídicas de Colombia y España sobre el tema tampoco están exentas de críticas. En España, la Ley 3/2007, del 15 de marzo, reguladora de la rectificación registral de la mención relativa al sexo de las personas, en su artículo 4.1 prevé como requisito para la rectificación del sexo que haya sido "diagnosticada disforia de género y que ha sido tratada médicamente durante al menos dos años para acomodar sus características físicas a las correspondientes al sexo reclamado". Este precepto cae en una categoría sospechosa de inconstitucionalidad, y posiblemente será materia de futuras sentencias, pues parece una intromisión ilegítima al desarrollo de la personalidad que a una persona trans se le exijan documentos médicos para comprobar un ideario personal e interno como la vivencia de género. Además de que la redacción y el contenido normativo del artículo 4.1 parecen tratar la reasignación de género como una cuestión patológica que amerita comprobación y tratamiento médicos.

En cuanto a la normativa de Colombia, existe una regulación peculiar en el decreto 1217 de 2015 del Ministerio de Justicia y del Derecho, pues

49 Voto particular de la magistrada Encarnación Roca Trías en la STC 99/2019, sentencia del Pleno del Tribunal Constitucional de España, Boletín Oficial del Estado, núm. 192, 12 de agosto de 2019. 
el artículo 2.2.6.12.4.6 impone límites a la corrección de actas del registro civil, ya que no se podrá solicitar una corrección dentro de los diez años siguientes a la expedición de la reasignación, y esto sólo podrá corregirse hasta en dos ocasiones. ¿Es correcta la medida que racionaliza el número de veces que una persona puede adscribirse una identidad de género? ¿Es una invasión desproporcionada al desarrollo de la libre personalidad? Seguramente habrá batallas judiciales que respondan las cuestiones, pero basta ahora con mostrar que el legislador nacional ejerce un amplio margen de apreciación para regular los aspectos torales de la vida gregaria.

Un punto en común de las normas de España y Colombia, en el cual México debe poner especial atención, es la inmutabilidad en el número de identificación personal. No obstante que la persona trans modifique los componentes de nombre y sexo en su acta de nacimiento y demás documentos personales, no es jurídicamente posible que se cambie el número que el Estado asigna a la persona para controlar sus derechos y obligaciones. El artículo 2.2.6.12.4.3 del decreto colombiano dispone que la corrección no modifica el número único de identificación personal (NUIP), mientras que el artículo 6.2 de la española Ley 3/2007, del 15 de marzo, dispone que en todo caso se conservará el mismo número del documento nacional de identidad.

Como se apuntó líneas arriba, la CURP es el único dato alfanumérico que dispone el gobierno federal de México para controlar la identidad de las personas, pero en sus componentes se incluyen letras que revelan el nombre y el sexo de la persona, los cuales serían modificados en casos de reasignación de género. Ésta es una asignatura pendiente que debe ser zanjada por el legislador.

Finalmente, existen ejemplos en que el soft law ha propiciado normas jurídicas estatales para la protección jurídica de la comunidad transexual. Los contenidos del soft law, si bien ausentes de la cualidad de heteronomía que caracteriza a las normas jurídicas duras (hard law) que se imponen obligatoriamente al operador jurídico, han permeado para mejorar los estándares de protección de los derechos de las personas. Por ejemplo, la resolución 2048 de la Asamblea parlamentaria del Consejo de Europa fue tomada en consideración por Francia para modificar su legislación y prácticas jurisprudenciales. ${ }^{50}$ Esta resolución, en cuanto al derecho de identidad de personas trans, en su punto 6.2.1 hizo un llamado a los Estados

\footnotetext{
50 Gerry-Vernières, Stéphane, "Droit à la vie privée et familiale...", cit.
} 
europeos para prever procedimientos rápidos, transparentes y accesibles, basados en la autodeterminación personal, para que las personas cambien su nombre y sexo en documentos personales. ${ }^{51}$

Como se ve, diversos países tienen discusiones más avanzadas en la materia, y en México los pasos son exiguos y se han dado básicamente por la actividad casuística de los tribunales federales a través del juicio de amparo. Las discusiones en México han versado sobre si el procedimiento administrativo o judicial es el más adecuado, cuando en el resto de países la modificación trans se realiza ante autoridades administrativas, como el registrador civil o un notario público. Hemos discutido en México si se impone una anotación marginal o no; o inclusive qué especialización debe tener el tribunal de amparo que resuelve las controversias del registro civil en casos de personas trans.

El retraso normativo que padece México, antes de desalentar o tomarse como un tercermundismo jurídico, debiera motivar al Poder Legislativo para actualizar los códigos y ser más sagaces en la creación de normas jurídicas con contenidos que atiendan los desafíos que exige la vorágine tecnológica en que vivimos inmersos. México es una potencia económica, una de las veinte economías más grandes del mundo, que, por ejemplo, carece de regulación sobre calentamiento global, comercio electrónico, o gobierno digital, o acciones afirmativas específicas para favorecer a comunidades desventajas.

\section{HACIA UNA SENTENCIA ESTRUCTURAL DE LA SuPREMA CORTE DE JUSTICIA DE LA NACIÓN}

El comportamiento de los tribunales constitucionales ha sido objeto de fecundos estudios por la literatura constitucional. Hay un incesante debate sobre el activismo judicial y la self restraint que debe prevalecer en la práctica judicial..$^{52}$ Jueces constitucionales han expresado que debe existir un control constitucional vigoroso, pero prudente y responsable, y que los tribunales constitucionales viven un dilema trágico: o la osadía extrema,

51 Asamblea Parlamentaria del Consejo de Europa, Resolution 2048, Discrimination against transgender people in Europe, 22 de abril de 2015.

52 Torres, Luis Fernando, "El activismo judicial en la era neoconstitucional", Iuris Dicto. Revista del Colegio de Jurisprudencia de la Universidad San Francisco de Quito, año 13, vol. 15, 2013, pp. 65-80. 
incluso irresponsable, o la moderación excesiva, que equivale a veces a un retiro cobarde. ${ }^{53}$

¿Hasta qué grado un tribunal constitucional debe anular normas jurídicas creadas por el legislador? En la medida en que pueda salvarse la presunción de constitucionalidad de la norma, ésta debe preservarse, pues el tribunal no busca la inconstitucionalidad de la norma, sino que la presume apegada a la Constitución. La deferencia al legislador sugiere considerar al Poder Legislativo como el órgano donde se solventan las discrepancias políticas mediante la representación democrática. El lugar para debatir sobre los temas que provocan un mayor dilema moral es el parlamento, y no el tribunal constitucional. ${ }^{54}$

¿Interpretar un precepto permite a la jurisdicción constitucional, en vez de anular la norma, fijar interpretaciones adicionales no previstas en el texto? La respuesta es afirmativa, y por eso los tribunales constitucionales han desarrollado una pluralidad de efectos en sus sentencias para que se respete el ordenamiento constitucional y no se generen vacíos legales.

En un grado más avanzado de osadía judicial, ¿pueden los tribunales constitucionales dar lineamientos e imponer plazos al legislador para que cree normas jurídicas? En este aspecto, las sentencias estructurales se ponen en relieve, y deberían ser utilizadas como catalizador de los derechos fundamentales de las personas, sobre todo de grupos sociales que padecen discriminación, marginación o exclusión.

Ante un ordenamiento legal configurado por el Poder Legislativo, el tribunal constitucional extrae significados y los dota de eficacia. Se reitera, en el tema de la identidad de personas transgénero salta a la vista que con las normas jurídicas constitucionales que reconocen el principio de progresividad (artículo 1o., tercer párrafo), el derecho a la igualdad (artículo 4o., octavo párrafo), la prohibición de todo acto de discriminación (artículo 1o., último párrafo), el derecho a la identidad (artículo 4o., primer párrafo), los principios de competencia administrativa y reserva de ley que rigen al registro civil (artículo 130, penúltimo párrafo) y el mandato al Congreso de la Unión para armonizar y homologar los registros civiles (ar-

\footnotetext{
53 Martínez Caballero, Alejandro, "Tipos de sentencias en el control constitucional de las leyes: la experiencia colombiana”, Revista de Estudios Socio-Jurídicos, Bogotá, vol. 2, núm. 1, 2000, pp. 8-32.

54 De Lora, Pablo, “Justicia constitucional y deferencia al legislador", en Laporta, Francisco (ed.), Constitución: problemas filosóficos, Madrid, Centro de Estudios Políticos y Constitucionales, 2003, pp. 345-370.
} 
tículo 73, fracción XXIX-R), se tiene un andamiaje suficiente para que la Suprema Corte sea creativa, osada y emita una auténtica acción afirmativa para resolver una violación constante de derechos fundamentales.

Una sentencia puede ser leída como la culminación de un proceso que es puesto al conocimiento de un tribunal, pero en materia constitucional la sentencia es sobre todo la voz emitida por un órgano del Estado de enorme envergadura. ${ }^{55}$ Hay diversos ejemplos en que causas judiciales llevadas por ciudadanos han propiciado cambios profundos en la producción normativa o en la corrección de prácticas administrativas o judiciales, particularmente en la consecución de derechos sociales. ${ }^{56}$ Inclusive, una jurisprudencia laxa con el respeto de los derechos humanos daña sistemáticamente las prerrogativas ciudadanas, y el desaseo judicial se traduce en actos atroces para la persona. Esto sucedió en México, por ejemplo, con las tesis emitidas en el sistema penal inquisitorio, en que los derechos del imputado se desplazaron por privilegiar los actos de investigación del Ministerio Público o la formalidad tramposa de los tribunales penales. ${ }^{57}$

La jurisdicción constitucional, más que enmarcarse en el añejo sistema de pesos y contrapesos, debe trascender a un diálogo democrático con el resto de poderes del Estado. Según Gargarella, el control de poder en términos de pesos y contrapesos se gestó con la intención de evitar la guerra que surgiría si un poder asume el control del resto de decisiones de la vida pública, imponiendo su voluntad al resto de ramas del gobierno. ${ }^{58}$ Entonces, la justicia constitucional debe pisar otros terrenos para motivar una auténtica interacción entre todos los órganos de poder político.

Es posible fijar una tipología de las sentencias del tribunal constitucional cuando efectúa el control abstracto de validez constitucional de normas generales. Para este efecto se sigue a Rosario Serra. ${ }^{59}$

55 García Roca, Javier, El conflicto entre órganos constitucionales, Madrid, Tecnos D. L., 1987, pp. 175-178.

56 Gargarella, Roberto, "Justicia dialógica en la ejecución de los derechos sociales: Algunos argumentos de partida", en Yamin, Alicia Ely et al. (coord.), La lucha por los derechos de la salud: ¿puede la justicia ser una herramienta de cambio?, Buenos Aires, Siglo XXI, 2013, pp. 279 a 294.

57 Magaloni, Ana Laura, "El ciudadano olvidado", en Vázquez, Rodolfo (coord.), Corte, jueces y politica, México, Fontamara, 2007, pp. 111-120.

58 Gargarella, Roberto, "El papel del poder judicial dentro del nuevo 'constitucionalismo dialógico'”, en González, Felipe et al. (coord.), ¿Quién manda aquí?: la crisis global de la democracia representativa, Barcelona, Debate, 2017, pp. 85-102.

59 Serra Cristóbal, Rosario, La guerra de las cortes, Madrid, Technos, 1999, p. 60. 
Existen sentencias correctoras o adequatrici, en que la norma no es inconstitucional si se le atribuye un significado compatible con los valores constitucionales. Aquí encontramos, por ejemplo, la interpretación conforme, a fin de evitar la declaración de inconstitucionalidad de una norma y poner en su lugar una reinterpretación corregida.

Hay sentencias manipulativas cuando se extraen dos interpretaciones de una disposición y se expulsa una de ellas, la que no es compatible con la Constitución. Por ejemplo, históricamente la Suprema Corte interpretó el artículo 133 constitucional para poner de manifiesto que el control difuso no es permitido por la Constitución, aun cuando expresamente la Constitución sí lo autoriza. ${ }^{60}$ Este malabar jurídico fue abandonado por el Pleno el 2011, al resolver el expediente Varios 912/2010.

Las sentencias acumulativas o aditivas declaran inconstitucional una norma, pero deducen del texto una nueva interpretación, que trae como consecuencia la creación de una norma positiva. Esto ocurrió en el amparo en revisión 1317/2017 de la Primera Sala, en que se declaró inconstitucional el sistema normativo de rectificación de actas del registro civil del estado de Veracruz, por no proveer un trato igualitario a casos de reasignación sexogenérica. Se declaró que las normas civiles son inconstitucionales, y a la vez se dedujo que la vía administrativa es la adecuada.

Son sustitutivas las sentencias que señalan otra norma que debe ponerse en lugar de la contenida en el texto de la norma declarada inconstitucional. Como ejemplos pueden citarse las jurisprudencias 1a./J. 46/2015 (10a.) ${ }^{61}$ y 1a./J. 10/2019 (10a.), ${ }^{62}$ ambas de la Primera Sala, que respectivamente declararon inconstitucionales las legislaciones estatales que no autorizan

60 Tesis P./J. 74/99, Semanario Judicial de la Federación y su Gaceta, Novena Época, 193435, tomo X, agosto de 1999, p. 5, de rubro "Control difuso de la constitucionalidad de normas generales. No lo autoriza el artículo 133 de la Constitución”. Cfr. Gudiño Pelayo, José de Jesús, "Lo confuso del control difuso de la Constitución. Propuesta de interpretación del artículo 133 constitucional", Revista de la Facultad de Derecho de México, México, núm. 244, 2005, pp. 79-110.

61 Tesis 1a./J. 46/2015 (10a.), Gaceta del Semanario Judicial de la Federación, Décima Época, 2009922, libro 22, septiembre de 2015, tomo I, p. 253, de rubro: "Matrimonio entre personas del mismo sexo. No existe razón de índole constitucional para no reconocerlo".

62 Tesis 1a./J. 10/2019 (10a.), Gaceta del Semanario Judicial de la Federación, Décima Época, 2019365, libro 63, febrero de 2019, tomo I, p. 493, de rubro: "Inconstitucionalidad de la prohibición absoluta al consumo lúdico o recreativo de marihuana prevista por La Ley General de Salud". 
el matrimonio entre personas del mismo sexo y la prohibición absoluta del consumo lúdico de marihuana. Los alcances de estos fallos consistieron en imponer al derecho positivo hipótesis de procedencia que el legislador no reguló.

Las sentencias-delegación declaran la ilegitimidad constitucional de una norma e indican una serie de principios que la nueva ley reguladora de la materia habría debido tener en cuenta para resultar compatible con la Constitución. La vocación de este tipo de sentencias se plasmó en el amparo directo 9/2018 de la Segunda Sala, que ambiciosamente ordenó la creación paulatina de un programa especial de seguridad social para trabajadoras domésticas — con coberturas de riesgos de trabajo, enfermedades, maternidad, guardería, invalidez y retiro--, pues han sido un grupo social vulnerable e invisible para el estado de bienestar. ${ }^{63}$

La tipología de sentencias del tribunal constitucional ayuda a evidenciar que el control abstracto de leyes no es una cuestión sencilla ni intelectualmente cómoda. Los efectos de una posible anulación de una norma serían perniciosos si se deja un vacío legal entretanto el legislador corrige la norma defectuosa, y por eso hay que ser cautos con la solución dada a los casos. ${ }^{64}$

Las sentencias correctoras tienen su origen en el contencioso-administrativo para señalar qué órgano del Estado asume la titularidad de una competencia o función pública. ${ }^{65}$ Trasladada esta idea a la jurisdicción constitucional, se propicia el diálogo entre un poder del Estado con los otros. Muchas sentencias constitucionales no debieran sólo agotar la instancia de un particular proceso con efectos inter partes, sino propulsar una coordinación con diversas instituciones del Estado.

A efectos de esta investigación, consideremos que pura y duramente se declare inconstitucional la vía jurisdiccional para la rectificación de actas

63 Segunda Sala de la Suprema Corte de Justicia de la Nación, sentencia dictada en el amparo directo 9/2018, en sesión del 5 de diciembre de 2018. De esta sentencia surgió la tesis 2a. XXX/2019 (10a.), Gaceta del Semanario Judicial de la Federación, Décima Época, libro 66, mayo de 2019, tomo II, p. 1544, de rubro: “Trabajo del hogar. El artículo 13, fracción ii, de la Ley del Seguro Social es inconstitucional al excluir a los trabajadores domésticos de ser sujetos de aseguramiento al régimen obligatorio, debido a que viola el derecho humano a la seguridad social en igualdad de condiciones".

64 Martínez Caballero, Alejandro, "Tipos de sentencias en el control constitucional de las leyes...", cit.

65 García Roca, Javier, El conflicto entre órganos constitucionales, cit. 
del registro civil, por estimarla contraria a la igualdad en casos de personas trans. Futuros casos se verían mermados, por la falta de normas reguladoras, para quien tuviera la necesidad de modificar el acta para cuestiones relacionadas con correcciones ortográficas de nombres, o fijación de parentescos tras juicios de paternidad. Una norma es inconstitucional aplicada en un cierto contexto, pero sus efectos ilegítimos desaparecen en otro ámbito de aplicación.

De igual forma, si se declarara inconstitucional la anotación marginal que se plasma en el acta de nacimiento de personas trans — anotación en la que constan los datos de corrección que tuvieron lugar por la reasignación sexogénerica - se quitaría al Estado su función controladora de los actos del registro civil, pues sería prácticamente imposible dar seguimiento a las personas que han reasignado su sexo. Sin rastro ni registro alguno, ciertamente se tendrían escenarios regresivos por la falta de identificación de personas y su posible evasión de obligaciones adquiridas — de la índole penal, tributaria, civil o patrimonial - o pérdida de derechos que correspondan -laborales, sucesorios o prestacionales-.

La Suprema Corte mexicana paulatinamente ha explorado la diversidad de sentencias que puede emitir como tribunal constitucional. Poco a poco, aunque todavía sin lograrlo de lleno, se ha abandonado una visión casacionista, pues en los últimos años es más común escuchar en las deliberaciones de los ministros en el Pleno o leer en las sentencias, la autoalusión de ser el tribunal constitucional de México y la importancia que tendrán los efectos de las sentencias.

La innovación en los efectos de las sentencias también ha cambiado, a fin de paulatinamente repensar la fórmula de Otero. El primer caso de omisión legislativa en México versó sobre la ausencia de legislación reglamentaria del artículo 134 constitucional en materia de gastos de comunicación social gubernamental, a lo cual estaba conminado el Congreso de la Unión por mandato expreso de la Constitución. Una asociación civil promovió un juicio de amparo, que al llegar a la Primera Sala permitió reflexionar sobre el deber del Poder Legislativo en cumplir con los deberes de producción normativa que la Constitución le impone. ${ }^{66}$ Así, se concedió

66 Primera Sala de la Suprema Corte de Justicia de la Nación, sentencia dictada en el amparo en revisión 1359/2015, resuelto en sesión del 15 de noviembre de 2017. De esta sentencia surgió la tesis 1a. LVIII/2018 (10a.), Gaceta del Semanario Judicial de la Federación, Décima Época, 2017065, libro 55, junio de 2018, tomo II, p. 965, de rubro: "Juicio de amparo indirecto. Es procedente contra omisiones legislativas". 
el amparo para señalar una fecha límite a la legislatura federal para que emita la legislación que constitucionalmente estaba obligada, tal como lo preveía el artículo tercero transitorio de la reforma del 10 de febrero de 2014.

Otro efecto innovador se dio en la Segunda Sala, en la antes reseñada sentencia estructural, que obligó al Instituto Mexicano del Seguro Social a generar un programa piloto para la seguridad social de trabajadoras domésticas. Un juicio laboral que como muchos más pudo resolverse inter partes para reconocer a una trabajadora, prestaciones e indemnizaciones económicas, dio un viraje para visibilizar a un grupo social estructuralmente discriminado.

En materia de reasignación de sexo o de respeto a la identidad de género en miembros de la comunidad trans, ciertamente no existe un mandato constitucional expreso que obligue a legislar sobre la materia, ni están dados los linderos conceptuales ni la temporalidad a la que está sujeta una legislatura. Propiamente hablando no estamos ante una omisión legislativa.

Sin embargo, sí existe un deber constitucional plasmado en la reforma del 5 de febrero de 2017, para que el Congreso de la Unión ejerza la facultad del artículo 73, fracción XXIX-R, sobre legislación general de homologación de registros civiles, reforma cuyo artículo tercero transitorio ordena que particularmente se atienda a grupos en situación de especial vulnerabilidad y marginación. En este marco, sin duda, debiera tener cabida una legislación nacional que permita la reasignación de género para quien libremente ha decidido hacerlo.

Como se apuntó líneas arriba, con los elementos constitucionales que actualmente se tienen es posible que la Suprema Corte emita una sentencia estructural para que gubernamentalmente se atienda el derecho a la identidad de este grupo social, desde la legislación y desde las prácticas administrativas.

La idea de sentencia estructural deviene de los structural injuctions de la jurisprudencia estadounidense, en que algunos jueces adoptaron medidas para remediar situaciones graves y generalizadas que resultan contrarias a la Constitución. ${ }^{67}$ El caso prototipo es Brown vs. Board of Education,

67 Osuna, Néstor, "Las sentencias estructurales. Tres ejemplos de Colombia", en Bazán, Víctor (ed.), Justicia constitucional y derechos fundamentales, Bogotá, núm. 5, 2015, pp. 90-116. 
que en 1954 incidió en abatir la segregación racial estadounidense en materia de educación pública. ${ }^{68}$

Siguiendo a Néstor Osuna, las sentencias estructurales en la jurisdicción constitucional de Colombia han contribuido en mejorar el statu quo en materia de hacinamiento carcelario, desplazamiento de víctimas de conflictos armados internos, o la precariedad en los servicios de salud.

El contexto en que se dictan aparece: i) la vulneración masiva y generalizada de derechos fundamentales; ii) una prolongada omisión de las autoridades competentes en la materia; iii) prácticas que son contrarias a la Constitución; iv) la ausencia de medidas legislativas, reglamentarias o presupuestales para atender la problemática; v) un problema social que implica la participación de diversas entidades, y vi) el litigio individual de cada persona agraviada generaría un congestionamiento judicial y la ralentización en la protección del derecho vulnerado.

Estos aspectos aparecen en la situación de personas transexuales que pretenden reajustar sus documentos personales para que su identidad corresponda con el género que libremente sienten y viven. Si bien no existen datos oficiales sobre el número de personas transexuales, la litigiosidad de sus derechos y la falta de unicidad en las soluciones dejan entrever que su derecho a la identidad personal no es respetado. Hacen falta normas jurídicas que regulen la manera en que su reasignación de género en documentos personales se ejerce, así como una regulación específica que homologue actuaciones y prácticas en los registros civiles de las entidades federativas que no solucionan el problema. La falta de atención y cobertura del derecho a la identidad implica una patente vulneración a su derecho fundamental, que se hace más fuerte al recaer sobre individuos pertenecientes a un grupo social culturalmente discriminado.

La solución implica la participación de una pluralidad de autoridades, el Congreso de la Unión para emitir legislación general sobre la materia, si bien cada congreso estatal puede adecuar su legislación. La Secretaría de Gobernación, para adecuar la CURP de las personas o, de una vez por todas, dar pasos serios y continuados para el cumplimiento del mandato legal de tener una cédula de identidad ciudadana con registros de todos los mexicanos.

Sendas autoridades administrativas deben adecuar sus procedimientos para que la persona que ha reasignado su sexo, sin dilaciones ni necesidad

68 Brown et al. vs. Board of Education of Topeka, sentencia de la Corte Suprema de los Estados Unidos, 17 de mayo de 1954, caso 347 U.S. 483. 
de aportar mayores pruebas, corrija sus documentos personales. Por vía de ejemplo, el Instituto Mexicano de Seguridad Social para la protección a la salud o las prestaciones económicas de seguridad social; las secretarías de educación, tanto federal como estatales, para la corrección de documentos escolares o cédulas profesionales; universidades públicas o privadas, para la emisión de un título universitario; el Servicio de Administración Tributaria, para la continuidad de las obligaciones fiscales; las procuradurías federal y estatal donde nació o resida la persona, para control de posibles responsabilidades penales; fiscalías y supremos tribunales de justicia de las entidades federativas, para la continuidad de derechos y obligaciones contraídas o futuras. Sin duda, esta información ha de manejarse con absoluta reserva y confidencialidad, accediendo a la misma por requerimiento judicial o ministerial.

Asimismo, el litigio individual de cada persona ralentiza enormemente la cristalización del derecho a la identidad de la persona trans, además de lesionar la gratuidad. La fórmula de Otero es un pilar característico del juicio de amparo mexicano, la que dota a la sentencia de amparo con efectos inter partes, es decir, solamente para proteger a quienes personalmente han litigado esa causa.

Sin embargo, la actividad contemporánea de los tribunales constitucionales sugiere tener más osadía para motivar un diálogo público en causas específicas que atañen la lucha por los derechos fundamentales. Ya hubo visos de este tipo de resoluciones en materia de seguridad social de empleadas domésticas, y esta actitud debiera reiterarse. Existen elementos fácticos y jurídicos de peso que revelan la necesidad de dictar una sentencia estructural para salvaguardar genuinamente el derecho a la identidad de la comunidad trasnsexual.

Un aspecto distintivo de las sentencias estructurales es el mecanismo de cumplimiento. No se trata del procedimiento común de ejecución de las sentencias de amparo - por ejemplo, de restituir derechos individuales, anular el acto viciado o retrotraer las actuaciones de un juicio-sino más bien de propiciar un diálogo abierto y fecundo con otros órganos del Estado. En las sentencias estructurales, las órdenes de cumplimiento son abiertas, a fin de motivar un cambio en el sistema jurídico nacional, respetando el margen de apreciación de cada órgano y el despliegue de sus competencias. ${ }^{69}$

69 Osuna, Néstor, "Las sentencias estructurales...", cit. 
Asimismo, son particularmente relevantes los mecanismos de cumplimiento que implementa el tribunal constitucional para verificar que la sentencia estructural ha sido cumplida, imponiendo requisitos laxos para ser deferente con el legislador o las agencias del Ejecutivo, o siendo rigurosos con la creación de Salas ad hoc dentro del tribunal que den seguimiento a cumplimientos complejos. ${ }^{70}$

La doctrina Chevron de la Suprema Corte estadounidense incorporó el principio de deferencia a la administración pública para que interpreten y apliquen el derecho administrativo en las agencias gubernamentales. ${ }^{71} \mathrm{Si}$ bien el órgano Judicial ostenta la última palabra en la interpretación de la ley, son las agencias gubernamentales las que proyectan el contenido legal en actos específicos, y de manera cotidiana dotando de significado y practicidad a las normas abstractas.

Esta deferencia también debe tomarse en cuenta por la Suprema Corte mexicana, pues no parece adecuado que se den órdenes estrictas para homologar o rectificar las prácticas de treinta y dos direcciones del registro civil que existen en México. Tampoco es conveniente que el tribunal constitucional entre en discusiones que despiertan posiciones morales intrincadas, que sin duda se levantan al hablar de grupos de la diversidad sexual y la lucha por los derechos que indudablemente tienen por el solo hecho de ser personas. ${ }^{72}$ La palestra pública es el parlamento, y ahí deben librarse las batallas conceptuales y políticas, no en el tribunal constitucional.

La Suprema Corte debería asumir un activismo judicial moderado para zanjar la incertidumbre jurídica que prima en los actos del registro civil de personas que han decidido libremente reasignar el sexo. Pero, en atención a la separación de poderes y la deferencia al legislador, por ningún motivo debe llegar al grado de definir el contenido específico de las normas.

Como se muestra en los datos de derecho comparado plasmados en este ensayo, el debate de derechos de la comunidad trans se encuentra en el

70 Cruz Rodríguez, Michel, "Decisiones estructurales y seguimiento judicial en Colombia (1997-2017)", Revista Española de Derecho Constitucional, Madrid, núm. 117, 2019, pp. 167-202.

71 Vázquez Alonso, Víctor, "Deferencia judicial hacia las agencias federales y deferencia hacia el legislador: la interpretación de la ley defectuosa y el principio democrático en la sentencia King v. Burwell”, Revista General de Derecho Constitucional, España, núm. 26, 2018.

72 De Lora, Pablo, Justicia constitucional y deferencia al legislador, cit. 
derecho a la adopción, ${ }^{73}$ en la posibilidad de que menores de edad ejerzan la reasignación de sexo, en la validez de exigir el acreditamiento de procedimientos médicos para reasignar el sexo, o en el consentimiento que los padres deben dar en casos en que un menor de edad decida ejercer su libre vivencia de género. ${ }^{74}$

No es conveniente que la Suprema Corte abruptamente pase de la concesión de amparos individuales para restituir los derechos de personas trans, a la exigencia de inmediatamente aprobar legislación con ciertos contenidos. El activismo también debe respetar la división de poderes, permitiendo que las agendas legislativas se desarrollen en los procedimientos formales de creación del derecho. Podría exhortarse a los entes legitimados por el artículo 71 constitucional para la iniciativa legislativa, que se propongan los contenidos específicos.

En suma: el derecho a la identidad es uno de los aspectos más elementales del ser humano, pues incide en aspectos tan básicos como la identificación plena ante el Estado y particulares, la correspondencia de documentos personales con la identidad propia de la persona, y su legítima intención de vivir plenamente en el género que se ha elegido. La cada día más frecuente judicialización de casos individuales hace necesario que se atienda estructuralmente la cuestión, para dar un paso realmente importante en la materia.

Una propuesta de sentencia estructural sobre el derecho de identidad de personas transgénero podría tener los siguientes efectos:

1. Exhortar al Congreso de la Unión para que en un plazo razonable emita una ley general que armonice y homologue la organización y funcionamiento de los registros civiles, con particular énfasis en un grupo vulnerable como la comunidad transgénero. Esto, conforme el artículo tercero transitorio de la reforma constitucional publicada el 5 de febrero de 2017, respecto al artículo 73, fracción XXIX-R de la Constitución federal.

2. Exhortar a los entes legitimados para la iniciativa de ley enunciados en el artículo 71 de la Constitución federal — presidente de la República, diputados y senadores del Congreso de la Unión, legislaturas

73 Von Stritzky, Johannes, "El desarrollo de la protección jurídica de las personas homosexuales, bisexuales, transexuales e intersexuales (LGBT) en Alemania", cit.

74 De Montalvo Jääskeläinen, Federico, "Problemas legales acerca del tratamiento médico de la disforia de género en menores transexuales", cit. 
estatales y a la iniciativa ciudadana- a través de una publicación en el Diario Oficial de la Federación para que, en el marco de sus competencias y agendas políticas, presenten iniciativas que doten de contenido a la ley general de registro civil, en cuanto a los procedimientos de reasignación sexo genérica.

3. Exhortar a las legislaturas de las entidades federativas para que, en el marco de sus competencias, tomen en consideración las consideraciones vertidas en la sentencia estructural de la Suprema Corte, y que modifiquen la normativa que limite o restrinja el derecho de identidad de personas trasngénero en los procedimientos de reasignación sexogenérica.

4. Exhortar a las legislaturas de las entidades federativas para que ajusten la normativa local a los contenidos de la futura ley general de registro civil que emita el Congreso de la Unión conforme el artículo 73, fracción XXIX-R, de la Constitución federal.

5. Exhortar a la Secretaría de Gobernación para que, en el marco de sus competencias y presupuestos, promueva un programa nacional e integral para la implementación de la cédula de identidad ciudadana prevista en la Ley General de Población (artículos 97 y 111) y la Ley de Migración (artículo 36, fracción II ); sugiriendo que se tome en consideración el Acuerdo sobre el programa de establecimiento del registro nacional de ciudadanos y la expedición de la cédula de identidad ciudadana, publicado en el Diario Oficial de la Federación el 30 de junio de 1997.

6. Exhortar a la Secretaría de Gobernación para que considere qué medidas administrativas implementar para la corrección de datos de la CURP en personas que han ejercido su reasignación de género, teniendo en cuenta que en la clave alfanumérica de la persona transgénero debe corresponder la letra del sexo con su nueva identidad de género.

7. Exhortar la creación de un comité integrado por las secretarías federales de Gobernación, de Relaciones Exteriores, y de Seguridad Pública y Seguridad Ciudadana; la Fiscalía General de la República, y el Consejo de la Judicatura Federal, para que en el marco de sus competencias y presupuestos generen una base de datos que resguarde los procedimientos administrativos y resoluciones jurisdiccionales sobre personas que han reasignado su condición sexogenérica. 
Asimismo, que en la creación, implementación y acceso de la base de datos tengan participación activa y eficaz las fiscalías, las direcciones del registro civil y los supremos tribunales de justicia de las treinta y dos entidades federativas.

8. Exhortar a las direcciones del registro civil de las entidades federativas para que, en el marco de sus competencias, tomen en cuenta las consideraciones vertidas en la sentencia estructural de la Suprema Corte, y, en consecuencia, reajusten las prácticas que limiten o restrinjan el derecho de identidad de personas transgénero en los procedimientos de reasignación sexogenérica.

Una sentencia estructural no es cómoda para el poder político ni para la Suprema Corte, pues los pone en un plano protagónico en temas que encienden debates morales en la conservadora sociedad mexicana. Sin embargo, una sentencia estructural cubre tres propósitos: permite a la Suprema Corte afianzar su rol de tribunal constitucional, la hace dialogar frontalmente con todos los poderes del Estado y aproxima los derechos humanos a la vida cotidiana de las personas. Tres propósitos que, indudablemente, ameritan la sagaz intervención de nuestro tribunal constitucional.

\section{EPÍLOGO}

Después de la investigación y redacción de este ensayo, la Segunda Sala de la Suprema Corte resolvió una contradicción de tesis sobre criterios de tribunales colegiados que han sido analizados en este ensayo. ${ }^{75} \mathrm{La}$ sentencia aún no se publica, pero la versión taquigráfica de la sesión revela que se estableció que, según las legislaciones de Chihuahua y Guanajuato, la rectificación de actas del registro civil en casos de reasignación sexogenérica debe tramitarse en la vía administrativa y no en la judicial. Incluso la tesis de jurisprudencia aprobada en la sesión está redactada en ese sentido.

Este criterio no zanja la cuestión planteada en este ensayo. Solamente fija un criterio jurídico respecto a dos entidades federativas, aclarando en qué vía debe tramitarse la corrección de las actas del registro civil. Inclusive, como se ha planteado en este ensayo, la jurisprudencia de la Suprema Corte carece de obligatoriedad para órganos distintos que los judiciales,

75 Segunda Sala de la Suprema Corte de Justicia de la Nación, sentencia dictada en la contradicción de tesis 346/2019, en sesión del 21 de noviembre de 2019. 
por lo que podría esperarse que los oficiales del registro civil y las legislaturas de los estados actúen en una vía distinta. Ello obligaría, otra vez, a la promoción individual de amparos indirectos para que la jurisprudencia se aplique por los jueces de distrito y, ahora sí, se respete la vía administrativa para la adecuación de las actas del registro civil.

La propuesta de una sentencia estructural continúa vigente para intentar resolver a fondo el problema. El hecho de que la Corte a posteriori a esta investigación haya resuelto otro caso de manera casuística, sin atajar el problema global, sólo revela que es insuficiente la emisión de sentencias con aplicación minimalista, en este caso ceñidas a la legislación de dos entidades federativas.

La reciente sentencia de la Segunda Sala tampoco agota el tema. Tratándose de derechos fundamentales y su garantía en los tribunales, las respuestas y propuestas deben seguir fluyendo para enriquecer el debate público sobre temas tan complejos e interesantes.

\section{BIBLIOGRAFÍA}

CAntoral Domínguez, Karla. "El derecho a la identidad del menor: el caso de México", Revista Boliviana de Derecho, La Paz, núm. 20, 2015.

CONSEJO PARA PREVENIR Y ELIMINAR LA DISCRIMINACIÓN DE LA CIUDAD DE MÉXICO, Población LGBTTTI, actualización mayo 2018, disponible en: https://copred.cdmx.gob.mx/storage/app/uploads/public/5b1/ff9/ f94/5b1ff9f945326665643161.pdf, el 14-08-2019, 12:06 hrs.

CRUz RodríGUEZ, Michel, "Decisiones estructurales y seguimiento judicial en Colombia (1997-2017)", Revista Española de Derecho Constitucional, Madrid, núm. 117, 2019.

DE LORA, Pablo, "Justicia constitucional y deferencia al legislador", en LAPORTA, Francisco (ed.), Constitución: problemas filosóficos, Madrid, Centro de Estudios Políticos y Constitucionales, 2003.

De Montalvo JÄÄSKelÄInen, Federico, "Problemas legales acerca del tratamiento médico de la disforia de género en menores transexuales", Revista General de Derecho Constitucional, Madrid, núm. 24, 2017.

DINA, Eduardo y ESPEJEL, Citlalli, "Si ahora soy Ofelio, soy el más bonito que existe", El Universal, 11 de agosto de 2019. 
ELÓSEGUi ITXASO, María, "El TJCE y el matrimonio de transexuales. Una interpretación «Ultra vires»”, Unión Europea Aranzadi, España, núm. $5,2004$.

FIX-FIERro, Héctor et al., Constitución política de los Estados Unidos Mexicanos. Texto reordenado y consolidado, México, UNAM, 2016.

GARCÍA ROCA, Javier, El conflicto entre órganos constitucionales, Madrid, Tecnos, 1987.

GARGARELlA, Roberto, "Justicia dialógica en la ejecución de los derechos sociales: Algunos argumentos de partida", en YAMIN, Alicia Ely et al. (coord.), La lucha por los derechos de la salud: ¿puede la justicia ser una herramienta de cambio?, Buenos Aires, Siglo XXI, 2013.

GARGARElla, Roberto, "El papel del Poder Judicial dentro del nuevo «constitucionalismo dialógico»", en GONZÁLEZ, Felipe et al. (coord.), ¿Quién manda aquí?: la crisis global de la democracia representativa, Barcelona, Debate, 2017.

GERRY-VERNIÈRES, Stéphane, "Droit à la vie privée et familiale. Le soft law dans le domaine des droits fondamentaux", Revue trimestrielle des droits de l'homme, Paris, núm. 110, 2017.

GudiÑo Pelayo, José de Jesús, "Lo confuso del control difuso de la Constitución. Propuesta de interpretación del artículo 133 constitucional", Revista de la Facultad de Derecho de México, México, núm. 244, 2005.

GuILABERT, Aurelien, "Identidad y salud TTTranserval", El Sol de México, 12 de agosto de 2019.

MAgAloni, Ana Laura, "El ciudadano olvidado", en VÁZQUEZ, Rodolfo (coord.), Corte, jueces y politica, México, Fontamara, 2007.

MARTínez CABAllero, Alejandro, "Tipos de sentencias en el control constitucional de las leyes: la experiencia colombiana", Revista de Estudios Socio-Jurídicos, Bogotá, vol. 2, núm. 1, 2000.

MiLl, John Stuart, Sobre la libertad, trad. de Pablo de Azcárate et al., México, Gernika, 1991.

Monereo Atienza, Cristina, Diversidad de género, minorías sexuales y teorias feministas: superposiciones entre las teorias de lesbianas, gays, bisexuales y transexuales y el feminismo en la reformulación de conceptos y estrategias politico-jurídicas, Madrid, Dykinson-Universidad Carlos III, Instituto de Derechos Humanos, 2015. 
NAVARro BATISTA, Nicolás, "Los transexuales en la jurisprudencia europea: comentario al asunto K.B. (sentencia del TJCE de 7 de enero de 2004, as. C-117/01)", Revista General de Derecho Europeo, núm. 4, 2004.

Orozco Pulido, Jesús Manuel, "La Suprema Corte de Justica de México y su sistema de creación jurisprudencial: defectos y retos", en Cucarella, Luis (coord.), Derecho procesal convencional. El nuevo desafio de la justicia constitucional, Bogotá, Ediciones Nueva Jurídica, 2016.

OsunA, Néstor, "Las sentencias estructurales. Tres ejemplos de Colombia”, en BAZÁN, Víctor (ed.), Justicia constitucional y derechos fundamentales, Bogotá, núm. 5, 2015.

Pizzorusso, Alessandro, "Recientes tendencias del parlamentarismo", Revista Vasca de Administración Pública, Bilbao, núm. 39, 1994.

SAmuel, Alec, "Consolidation: A plea", Statute Law Review, Oxford, vol. 59, Oxford University Press, 2005.

SERra CRIstóbal, Rosario, La guerra de las cortes, Madrid, Tecnos, 1999.

SILVA GARCÍA, Fernando, "VIH y militares (criterios jurisprudenciales de la SCJN)", Cuestiones Constitucionales, México, núm. 18, 2008.

Soberón MAInero, Miguel, "Personalidad", Diccionario jurídico mexicano, México, UNAM, t. VII, P-Reo, 1984.

TORRES LóPEZ, Erasmo Enrique, "El registro civil en el norte de México", El Diario de Coahuila, 1 de agosto de 2019.

TORRES, Luis Fernando, "El activismo judicial en la era neoconstitucional", Iuris Dicto, Revista del Colegio de Jurisprudencia de la Universidad San Francisco de Quito, año 13, vol. 15, 2013.

Urbiola Solís, Alejandra et. al., "Expresión y trabajo de los muxe' del istmo de Tehuantepec, en Juchitán de Zaragoza, México", Nova Scientia, Revista de Investigación de la Universidad de La Salle Bajío, León, México, vol. 9, núm. 19, 2017.

VÁZQUEZ AlONSO, Víctor, "Deferencia judicial hacia las agencias federales y deferencia hacia el legislador: la interpretación de la ley defectuosa y el principio democrático en la sentencia King v. Burwell", Revista General de Derecho Constitucional, Madrid, núm. 26, 2018. 
VON STRITZKY, Johannes, "El desarrollo de la protección jurídica de las personas homosexuales, bisexuales, transexuales e intersexuales (LGBT) en Alemania", Revista General de Derecho Constitucional, Madrid, num. 17, 2013.

Fecha de recepción: 15 de noviembre de 2019.

Fecha de aceptación: 12 de diciembre de 2020. 


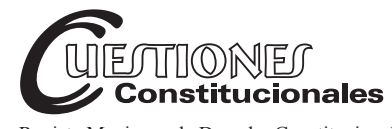

Revista Mexicana de Derecho Constitucional Núm. 43, julio-diciembre 2020

Argumentación jurídica de las sentencias de los tribunales constitucionales como método para lograr la constitucionalización del proceso jurisdiccional (Una lectura a partir de la acción de tutela en Colombia)*

Legal argumentation of the rulings of the rulings of the constitutional courts as a means to achieve the constitutionalization of the jurisdictional process (An approach to the tutela action in Colombia)

\author{
Liliana Damaris PABÓN GIRALDO** \\ Luis Orlando TORO GARZÓN*** \\ Andrés Felipe Zuluaga JARAMILLO****
}

RESUMEN: El presente trabajo aborda el tema de la argumentación jurídica y la racionalidad de la decisión jurisdiccional en un Estado constitucional, específicamente por parte de tribunales constitucionales, y de la forma como éstos, a través de la sobreinterpretación; esto es, de la extracción de normas implícitas o adscritas, pueden llegar
ABSTRACT: This paper addresses the issue of legal argumentation and the rationality of the jurisdictional decision in a Constitutional State, specifically by constitutional courts and how they can through over-interpretation, that is to say, the extraction of implicit or implied norms, reach to a decision as rational, objective, and fair as possible.

* Este artículo de investigación es producto del proyecto de investigación institucional denominado "Implicaciones de la teoría de la argumentación jurídica para un debido proceso probatorio", financiado por la Universidad de Medellín y desarrollado por los autores del mismo.

** Docente investigadora de la Facultad de Derecho de la Universidad de Medellín. Líder del Grupo de Investigaciones en Derecho Procesal de la misma institución. Colombia. Correo electrónico: ldpabon@udem.edu.co. ORCID: http://orcid.org/0000-00018561-7357.

*** Docente de la Facultad de Derecho de la Universidad de Medellín. Colombia. Correo electrónico: 1toro@udem.edu.co. ORCID: https://orcid.org/0000-0003-4571-8991. **** Docente de la Facultad de Derecho de la Universidad de Medellín. Colombia. Correo electrónico: afzuluaga@udem.edu.co. ORCID: https://orcid.org/0000-0002-16015325 . 
a una decisión lo más racional, objetiva y justa posible. Para ello, se aborda la argumentación jurídica, sus funciones al interior del proceso y cómo a través de ella se puede llegar a una mejor decisión; igualmente, se hace un acercamiento al concepto de racionalidad y a su relación con el derecho, especialmente en un Estado social y democrático de derecho, lo que implica un replanteamiento de la función del juez. Posteriormente, se hace referencia a la constitucionalización del proceso y la manera como se puede llegar a este resultado empleando la argumentación jurídica y la interpretación constitucional; para culminar con un estudio de caso en Colombia, en donde haciendo uso de la acción de tutela como mecanismo constitucional existente para la protección de derechos fundamentales y que atendiendo a algunas causales procede contra providencia judicial, se pueden extraer normas adscritas.

Palabras clave: argumentación jurídica, racionalidad, tribunal constitucional, decisión jurisdiccional, normas adscritas.
In this regard, legal argumentation, its functions within the process, and how a better decision can be reached is addressed. Likewise, it is also discussed the concept of rationality and its relation to the law, particularly in a democratic rule of law State, which implies revisiting the role of the judge. Afterwards, reference is made to the constitutionalization of the process and how this result can be achieved using legal argumentation and constitutional interpretation. Lastly, the Colombian experience is debated. Admittedly, under the Tutela action judicial rulings can be challenged on the grounds of failure to respect fundamental rights which in turn offers a rather good example on how implicit rules can be extracted through legal argumentation.

Keywords: legal argumentation, rationality, constitutional court, jurisdictional decision, ascribed norms.

\begin{abstract}
SUMARIO: I. Introducción. II. La argumentación jurídica como presupuesto de la decisión racional y justa en el Estado constitucional. III. La constitucionalización del proceso jurisdiccional a partir de la argumentación jurídica y la racionalidad. IV. Estudio de caso: procedencia de tutela contra providencia judicial como forma de constitucionalización en Colombia. V. Conclusiones. VI. Bibliografía.
\end{abstract}

\title{
I. INTRODUCCIÓN
}

Las decisiones que profieren los funcionarios jurisdiccionales en Latinoamérica en ocasiones no son justificadas, o lo son de forma insuficiente o contradictoria, lo cual ha generado falta de credibilidad en el sistema y poca aceptabilidad de lo decidido por los sujetos procesales a quienes se dirige. Esto hace necesario el uso de la argumentación jurídica, y, por

Esta obra está bajo una Licencia Creative Commons

Atribución-NoComercial-SinDerivar 4.0 Internacional, IIJ-UNAM. 
tanto, de la racionalidad en la decisión, a fin de que la misma cuente con una mayor corrección por parte de los funcionarios jurisdiccionales y exista mayor posibilidad de control por los ciudadanos.

La argumentación jurídica como herramienta del derecho procesal contemporáneo se convierte así en un requisito de solidez y de legitimidad de la decisión jurisdiccional, que se debe predicar de todos los órganos jurisdiccionales, en mayor o menor grado de conocimiento, a fin de que con su uso se constitucionalice el proceso. Para lograr tal objetivo, el funcionario empleará la racionalidad, como presupuesto fundamental para lograr la eficiencia y la eficacia de las decisiones jurisdiccionales. Lo anterior, porque la decisión será racional si se edifica válidamente desde el método lógico-abductivo, deductivo o inductivo, construyendo formalmente cada premisa y valorando cada una de ellas, a fin de lograr un sustento real de la conclusión a la cual llegue el funcionario jurisdiccional. Y esa racionalidad conlleva a que el juez dé razones de la decisión en armonía con criterios de consistencia, ilación, coherencia, objetividad, ausencia de subjetividad y presencia permanente de proporcionalidad.

Así las cosas, surge el siguiente interrogante: ¿de qué forma la argumentación jurídica de las sentencias de los tribunales constitucionales sirve como método para lograr la constitucionalización del proceso jurisdiccional, a partir del estudio de caso de la acción de tutela en Colombia? Se sostendrá así, que la argumentación jurídica como método para la constitucionalización del proceso jurisdiccional implica: i) una construcción racional y argumentada de reglas adscritas por parte de los tribunales constitucionales; ii) la aplicación argumentada de tales reglas a los casos concretos por todos los funcionarios jurisdiccionales, y iii) el uso de las reglas adscritas para que la acción de tutela o amparo proceda contra sentencia judicial, para así lograr una evaluación y control de la sentencia a la luz de la Constitución.

En ese orden de ideas, este trabajo se divide en tres acápites: se parte de la argumentación jurídica como presupuesto para la decisión racional y justa en un Estado constitucional; se aborda la constitucionalización del proceso jurisdiccional a partir precisamente de la argumentación jurídica y la racionalidad, para culminar con un estudio de caso, frente a la procedencia de tutela contra providencia judicial como forma de constitucionalización en Colombia. 


\section{LA ARGUMENTACIÓN JURÍDICA COMO PRESUPUESTO DE LA DECISIÓN RACIONAL Y JUSTA EN EL ESTADO CONSTITUCIONAL ${ }^{1}$}

\section{La argumentación jurídica como requisito} de la decisión jurisdiccional

Conforme al nuevo rol que debe asumir el funcionario jurisdiccional a la hora de adoptar una decisión, uno de los requisitos fundamentales de la misma en un Estado constitucional es su justificación, a fin de que el proceso se desarrolle como método de debate dialéctico entre los sujetos procesales que en él participan, y así convertirse en una garantía para las partes.

Argumentar implica expresar razones de la decisión, bajo criterios racionales, de tal forma que se llegue a una solución, que si no la correcta, la más convincente de las posibles; es decir, aquella que logre un mayor grado de adhesión del auditorio, buscando una mayor aceptabilidad de la misma. Al respecto, expresa Habermas, "Sólo se puede considerar que un enunciado es un enunciado verdadero racionalmente fundamentado si todos los interlocutores potenciales pueden llegar a un acuerdo sobre ese enunciado en una discusión que cumpla las condiciones de la situación del discurso ideal", 2 que para él consiste en el consenso fundamentado.

Argumentar es dar razones con claridad, coherencia, precisión y pertinencia de las ideas por medio de las cuales se pretende solucionar un problema. Argumentar es dar razones en la decisión y de la decisión. La primera constituye las razones internas; esto es, la corrección lógica o formal de los argumentos, lo que se denomina "la justificación interna"; en tanto la segunda son las razones externas, encargadas de la fundamentación de las premisas; esto es, la justificación externa. Sólo así, cuando se haga uso de una justificación interna y de una justificación externa, tal

\footnotetext{
1 Para este tema se toma en cuenta lo publicado en Pabón Giraldo, Liliana Damaris, "La argumentación jurídica como presupuesto de legitimidad de la decisión jurisdiccional en el Estado Constitucional", en Barrios González, Boris y Barrios Chávez, Luris (coords.), La administración de justicia en el Estado constitucional, Bogotá, Ediciones Nueva Jurídica y Librería \& Editorial Barrios \& Barrios, 2015, pp. 17-37.

2 Feteris, Eveline T., Fundamentos de la argumentación jurídica. Revisión de las teorías sobre la justificación de las decisiones judiciales, trad. de Alberto Supelano, Bogotá, Universidad Externado de Colombia, 2007, p. 107.
} 
como la clasifica Wròblewski, ${ }^{3}$ es cuando se puede afirmar que en la decisión se aplicó una argumentación jurídica.

Por lo tanto, la argumentación jurídica constituye una condición necesaria en el proceso, pues sólo a través de ella se logrará realmente un control frente a las decisiones jurisdiccionales adoptadas, en tanto se dan razones suficientes, convincentes y pertinentes que apoyan la conclusión.

\section{Y ¿qué funciones cumple la argumentación jurídica?}

Si la argumentación jurídica busca un mayor grado de aceptabilidad de la decisión y permite un mayor control de la misma, significa, que "sirve como medio de investigación o de descubrimiento de razones para la toma de una mejor decisión. La argumentación permite la detección de errores fácticos y lógicos". ${ }^{4}$ Por tanto, cumple diversas funciones, tales como controlar la discrecionalidad, descartar respuestas incorrectas y eliminar soluciones irracionales.

Con relación a la primera función, la discrecionalidad no está llamada a hacer parte de la argumentación jurídica, por cuanto el funcionario jurisdiccional debe ir en búsqueda de la legitimidad de la decisión, entendida ésta como acuerdo, ${ }^{5}$ reconocimiento, consenso, aceptación y adhesión de los destinatarios a la norma. ${ }^{6}$ Es decir, la argumentación jurídica debe rechazar el autoritarismo, lo cual "no significa carecer de criterios de decisión. Al contrario, significa tener criterios de decisión pero que éstos estén sustentados en argumentos y contraargumentos que giren a través de una plataforma común aceptada y no en una posición de verdad impositiva".?

3 Wróblewski, Jerzy, Sentido y hecho en el derecho, México, Doctrina Jurídica Contemporánea, 2003, p. 52.

4 Moreno Cruz, Rodolfo, “Argumentación jurídica, por qué y para qué”, Boletín Mexicano de Derecho Comparado, México, nueva serie, año XLV, núm. 133, enero-abril de 2012, p. 187, disponible en: https://revistas.juridicas.unam.mx/index.php/derechocomparado/article/view/4738. Fecha de acceso: 23 de agosto de 2019, doi: http://dx.doi. org/10.22201/iij.24484873e.2012.133.4738.

5 García, Eloy, El último triunfo de la libertad: la democracia constitucional ante su momento maquiavélico, Bogotá, Universidad Externado de Colombia, Instituto de Estudios Constitucionales Carlos Restrepo Piedrahita, 2000, p. 34.

6 Jongitud Zamora, Jacqueline, "Legalidad, legitimidad y legitimación. Implicaciones éticas", en Cáceres, Enrique et al. (coords.), Problemas contemporáneos de la filosofía del derecho, México, UNAM, 2005, disponible en: http://biblio.juridicas.unam.mx/ libros/4/1650/21.pdf, p. 1. Fecha de acceso: 23-agosto-2019.

7 Moreno Cruz, Rodolfo, op. cit., p. 183.

Esta obra está bajo una Licencia Creative Commons Atribución-NoComercial-SinDerivar 4.0 Internacional, IIJ-UNAM. 
Al respecto, para Ferrero la legitimidad "no es otra cosa que la obediencia, el consentimiento libremente expresado - de manera consciente o inconsciente - por los gobernados respecto de los gobernantes", y según Eloy García "la legitimidad se caracteriza, por tanto, como una forma de obediencia construida en el consentimiento, en la aceptación pacífica del gobernante por el gobernado". ${ }^{9}$ Por su parte, Juan Antonio García Amado ${ }^{10}$ considera que la legitimidad tiene relación con la idea de obediencia política, y cuando esa obediencia deriva de una justificación determinada. De donde deduce que será legítimo aquello en donde exista una "expresión de la voluntad libre de los ciudadanos, voluntad que se forma de acuerdo con unas reglas procedimentales que aseguran la ausencia de distorsión, manipulación o coacción". ${ }^{11}$ Por lo tanto, para lograr tal finalidad se requiere de un diálogo, de una argumentación intersubjetiva, de un intercambio de razones entre los sujetos, del consenso o acuerdo general entre los interlocutores.

Frente a las soluciones irracionales, la argumentación jurídica debe eliminar éstas, porque sólo será racional lo que "se alcance en el seno de una argumentación regida por el respeto de cierto procedimiento en el que determinadas reglas formales, que son reglas de la argumentación racional garantizan la igual libertad y los iguales derechos argumentativos de todos los interlocutores reales o potenciales". ${ }^{12}$ Como consecuencia, sólo la decisión racional es la decisión argumentada.

Y finalmente, con la argumentación se descartan respuestas incorrectas, es decir, que se busca una decisión correcta; esto es, la mejor de las posibles. Por consiguiente, la decisión debe ser proferida por quien tiene jurisdicción y competencia, quien haciendo uso de la dialéctica y la discusión debe proferir una decisión racional, la que debe ser legítima, estar basada en pruebas válidas y sin omisión de las que son esenciales para adoptar una decisión lógica; esto es, adecuada a las reglas del pensamiento lógico

\footnotetext{
8 García, Eloy, op. cit., p. 21.

9 Ibidem, p. 36.

10 García Amado, Juan Antonio, "Legitimidad y derechos humanos", en Soriano Díaz, Ramón L. et al. (coords.), Diccionario crítico de los derechos humanos, La Rábida, Universidad Internacional de Andalucía, Sede Iberoamericana, 2000, disponible en: http://www.geocities.ws/jagamado/pdfs/legitimidad_y_dchoshnos.pdf, p. 1. Fecha de acceso: 23 de agosto de 2019.
}

11 Ibidem, p. 6.

12 Ibidem, p. 7.

Esta obra está bajo una Licencia Creative Commons Atribución-NoComercial-SinDerivar 4.0 Internacional, IIJ-UNAM. 
y la experiencia común; motivada, tener una derivación razonada del derecho vigente con relación a la pretensión esgrimida y en función de los hechos probados en el proceso; congruente, o sea, versar exclusivamente sobre lo pretendido y resistido por las partes; correcta, esto es, que sea una decisión que genere credibilidad y confianza, pero por parte de la mayoría, porque engloba los valores de un Estado constitucional democrático, y porque busca decisiones justas para todos, y no decisiones buenas para algunos, figura que sólo se consigue a través del Estado constitucional o democrático de derecho.

\section{La racionalidad y su relación con el derecho}

El término "racionalismo" tiene un significado amplio. Se llama racionalista a toda posición filosófica donde prima el uso de la razón, frente a otras instancias, como la fe, la autoridad, la vida, lo irracional o la experiencia. ${ }^{13}$ La razón, por su parte, se define como facultad de discurrir o acto de discurrir el entendimiento; igualmente, como argumento o demostración que se aduce en apoyo de algo. ${ }^{14}$

Al respecto, Manuel Segura expresa que no existe una idea precisa de lo que debe entenderse por racionalidad; sin embargo, ha dicho que la racionalidad pretende despertar en los sujetos una actitud favorable, la racionalidad refuerza el rigor del discurso..$^{15}$ En ese orden de ideas, la racionalidad, como expresión lingüística, significa todo aquello que es coherente con la razón, lo que está conforme a la lógica, todo lo que se corresponde con la realidad, y lo que se identifica con la aceptación del común de la sociedad. Lo racional no es solamente un aspecto jurídico del pensamiento, ${ }^{16}$ dado

13 Echegoyen Olleta, Javier, "Historia de la filosofía, filosofía medieval y moderna", Diccionario filosófico de Voltaire, filosofía moderna, Edinumen, vol. 2, disponible en: https://www.e-torredebabel.com/Historia-de-la-filosofia/Historia-de-la-Filosofia.htm. Fecha de acceso: 23 de agosto de 2019.

14 Real Academia Española, Diccionario de la lengua española, edición del tricentenario, Madrid, 2019, disponible en: http://www.rae.es. Fecha de acceso: 23 de agosto de 2019.

15 Segura Ortega, Manuel, La racionalidad jurídica, Madrid, Tecnos, 1998, p. 9.

16 Haba, Enrique, "Racionalidad y método del derecho ¿eso es posible?", Doxa, Alicante, núm. 7, 1990, p. 169, disponible en: file://C:/Users/ldpabon/Downloads/racionalidad-y-mtodo-para-el-derecho-es-eso-posible-0\%20(1).pdf. Fecha de acceso: 23 de agosto de 2019. 
que desde el punto de vista práctico la racionalidad también tiene evidente materialización.

Unificar criterios acerca del diálogo temático y filosófico entre racionalidad y derecho no deja de ser un escenario poco pacífico, dadas las formas alternativas con que se aborda el tema por los diferentes estudiosos de la filosofía, la sociología jurídica y la dogmática jurídica. Además, dada la evolución de la sociedad y de su regulación en la contemporaneidad, el escenario del lenguaje, a pesar de ser una conquista del positivismo lógico y de ser reconocido como componente universal del diálogo entre la filosofía y las diferentes ciencias del conocimiento y, por ende, la ciencia del derecho, en el caso del ámbito jurídico dicho lenguaje no es totalizador ni finito desde su concepción primaria o desde su interpretación, como acertadamente lo postula y define Gadamer. ${ }^{17}$

La sociedad ha marcado un derrotero a fin de tener un instrumento regulador en aras de buscar equidad y bienestar individual y colectivo. Precisamente esa herramienta es el derecho, de forma pluridimensional y viviente, aplicable de forma uniforme, con posibilidad de adaptación interpretativa y argumentativa, tanto a los casos de aceptación o de solución común como a los casos de mayor complejidad, donde se acentúa la controversia por los desacuerdos cotidianos, en los cuales se debe actuar sin posibilidad de denegación de justicia.

Y son las Constituciones contemporáneas precisamente las que dejan abierta la posibilidad de dinamizar el derecho a partir de las interpretaciones de disposiciones normativas creadas por las autoridades competentes, asegurando normativamente que tal interpretación inicie desde la cúspide constitucional como parada obligatoria antes de ir a la ley donde convergen dilemas de atribución de fuerza normativa absoluta de la Constitución y/o fuerza relativa, por su delegación de autoridad normativa a los instrumentos internacionales sobre derechos humanos y derecho internacional humanitario, sin desconocer la obligatoriedad de armonización de las realidades sociales y los fines del Estado constitucionalizado.

Estas premisas son indicativas de que el derecho tiene como presupuesto la racionalidad como criterio de optimización y legitimación, desde la labor de creación de disposiciones jurídicas por las autoridades como en la actividad jurisdiccional ejercida a la hora de seleccionar e interpretar el supuesto

17 Gadamer, Hans Georg, Verdad y método, Salamanca, Ediciones Sígueme, 2005, pp. 567-570. 
jurídico y los hechos en concreto, así como en la calificación, concreción de la decisión y ejecución de la misma. Desde el componente argumentativo, el juez contemporáneo, ante la evidente constitucionalización del derecho y la falta legislativa de completud normativa e incapacidad configurativa de un lenguaje jurídico que comunique a todas las personas y todos los entornos de diversidad social y cultural, está llamado de manera obligatoria a esculpir la codificación de real significado e integrar el derecho en los juicios jurídicos y fácticos ante los conflictos o peticiones ciudadanos que se le presentan, contando para ello con herramientas contemporáneas, como la argumentación jurídica, y a su vez haciendo uso de la racionalidad, específicamente desde la denominada razón práctica como ámbito parcial de su clasificación, postulada entre otros por Robert Alexy, la cual se encuentra acorde a las exigencias del derecho, por ser una ciencia positivizada y de regulación de relaciones sociales.

Como consecuencia, es plenamente aceptable desde la filosofía y el derecho, que la racionalidad sea un atributo de fortalecimiento humano y un instrumento filosófico de mejoramiento de la comunicación entre las personas, que orbita en el continente del razonamiento, y que debe estar siempre presente en la expresión de autoridad judicial, cuando se argumenta o se decide a través de mandatos de dar, hacer o no hacer y en los procesos decisorios de constitucionalidad o inconstitucionalidad, de amparo o no amparo, frente a las acciones constitucionales de protección especial, o como medio para fortalecer la responsabilidad y lealtad de los demás actores del proceso jurisdiccional.

\section{La racionalidad como presupuesto para una decisión correcta}

Indudablemente, el proceso judicial, desde sus estadios de evolución, se ha ido inspirando y orientando paulatinamente hacia el robustecimiento de los principios, reglas y garantías que lo gobiernan, desde una postura de poco interés estatal en la protección de derechos y garantías judiciales, hasta llegar a un movimiento jurídico globalizado. Esta idea ha estado soportada en la constitucionalización del derecho para satisfacción oportuna y equitativa de la realidad social, direccionándose hacia la humanización de las decisiones, en búsqueda de justicia de forma integral y por tanto de una decisión correcta. 
Así, el derecho pasa a otro paradigma; ello es, desaparece la centralización legislativa e interpretativa y se realza la exigencia de un jurista con suficientes cualidades personales y competencias profesionales para interpretar el lenguaje jurídico de manera objetiva, con integración de las fuentes del derecho base de todo ordenamiento jurídico democratizado, y con actitud humana para contextualizar el derecho a la realidad social; pero además con cualificación suficiente para argumentar con eficientismo la decisión, así como la aceptación o rechazo de las tesis o antítesis aportadas al debate por las partes o adversos, que le permita soportar con firmeza y solidez decisoria las impugnaciones que emanan como consecuencia del derecho de bilateralidad, pues su pretensión debe ser el obtener racionalmente la respuesta judicial más acertada posible.

En la actualidad, dadas las complejidades de los conflictos sociales que enfrentan las personas en los estrados judiciales, las incapacidades judiciales de demostración fáctica y las falencias legislativas, se deben procurar decisiones de respuesta jurisdiccional en el plano de lo razonable, dándose con ello protagonismo a los consensos jurídicos, sociológicos, éticos y académicos como tamiz de evaluación de los razonamientos internos o externos imperantes en las mismas. Es la decisión el escenario concreto y legítimo de expresión de autoridad judicial, ya que una decisión será tanto o más aceptable en la medida en que logre las mayores adhesiones posibles al razonamiento, buscando en todo caso una correcta tutela judicial, que no se logra sólo con una adecuada interpretación de la disposición jurídica general ni con la aplicación al caso individualizado, sino con un modelo de juez dinámico y activo. Este juez, que puede denominarse "juez racional", lo será desde la conformación de las premisas, desde la elaboración inferencial adecuada, con el respeto a las reglas del proceso, a la regulación constitucional, a los métodos y criterios de interpretación jurídica y fáctica. Además, será racional si busca en todo caso llegar a la sociedad, a la academia, a la administración de justicia y a aquellos actores que trascienden la esfera interna del proceso, con la decisión que mejor satisfaga los intereses en disputa. Ante este panorama, surge el siguiente interrogante: ¿será posible con estos cambios de pensamiento jurídico, de armonización constitucional y desde la dinámica exigida al juez, que éste asuma una posición racional desde la argumentación, y que en ese orden llegue a una única decisión correcta? 
Para responder a este interrogante, se debe recurrir a los retos de la sociedad actual y del Estado constitucional, en donde todo funcionario debe actuar con base en lineamientos democráticos, tal como se abordará en el siguiente acápite, haciendo uso de la justificación de su decisión, tanto interna como externa, pues sólo así, por consenso doctrinal, se llega con mayor proximidad a la decisión correcta.

Dworkin indica que en los casos difíciles sí existe la posibilidad de brindar una única respuesta correcta. ${ }^{18}$ Es así como para Dworkin resulta entendible que desde el razonamiento adecuado en los casos difíciles (lo que incluye la debida interpretación del ordenamiento jurídico), se llegue a una respuesta jurídica correcta, siempre que se cumpla con un presupuesto fundamental, y es que se demuestre razonadamente que la decisión adoptada por el funcionario es la que con mayor coherencia y de mejor manera armoniza con el ordenamiento jurídico.

Por su parte, para Robert Alexy, ${ }^{19}$ la única respuesta correcta no es un asunto que sea aceptado fácilmente. Para este autor, la respuesta correcta depende esencialmente de si el discurso práctico lleva a ella y si su aplicación garantiza siempre el consenso. Para Alexy, existe respuesta correcta si se dan cinco condiciones ideales, a saber: tiempo ilimitado, información ilimitada, claridad lingüística conceptual ilimitada, capacidad y disposición ilimitada para cambio de roles, carencia de prejuicios ilimitada. De ello se infiere que es posible aceptar la existencia de respuestas correctas desde el razonamiento práctico, pero no con la reiteración que predice Dworkin.

Atienza, ${ }^{20}$ por su parte, indica que la tesis de la única respuesta correcta no es pacífica, dado que es una de las cuestiones más debatidas en el derecho contemporáneo. Afirma que la discusión sólo se da en la argumentación judicial; ello es cuando se trata de la aplicación de la norma general a casos concretos o para determinar la comparación de normas en búsqueda de la predominante. Igualmente, expresa que el tema de la única respuesta correcta no pasa por decir sí o no a la tesis de la única respuesta correcta,

18 Dworkin, Ronald, “Realmente no hay respuesta correcta en los casos difíciles?”, en Casanovas, Pompeu y Moreso, José Juan (eds.), El ámbito de lo jurídico, Barcelona, Crítica, 2000, pp. 475-512.

19 Alexy, Robert, Derecho y razón práctica, México, Fontamara, 2010, pp. 7-91.

20 Atienza, Manuel, Curso de argumentación jurídica, Madrid, Trota, 2013, pp. 551-553. 
sino que es más bien un tema que pasa diferentes niveles o graduaciones según el asunto a resolver.

Acorde a lo expuesto y en armonía con la concepción y propósito de la decisión judicial correcta, los jueces, incluidos los tribunales constitucionales, deben actuar de conformidad tanto con las reglas procesales como con los principios y valores constitucionales, con los derechos y sus niveles de protección superior y con las jerarquías normativas de las fuentes del derecho, así como con el derecho internacional o bloque de constitucionalidad cuando se trate de interpretación constitucional. Ello, porque un Estado social de derecho contemporáneo se revitaliza cuando el censor judicial se dirige a todos los ciudadanos y no sólo a las partes del proceso, con códigos comunicativos de respeto, de consideración, de objetividad y de convencimiento razonable de haber llegado a la mejor respuesta para el caso de su estudio.

\section{Desde la argumentación jurídica hacia una decisión justa en un Estado constitucional}

Un Estado constitucional posee tres principios básicos: ser un Estado democrático, liberal y con una supremacía constitucional, aspectos todos que implican legitimidad. Al respecto, Josep Aguiló ${ }^{21}$ indica que para hablar de Estado constitucional debe existir una Constitución, una limitación del poder y una garantía de los derechos, y que esa Constitución, esa limitación y esa garantía sean practicadas. En ese orden de ideas, un Estado constitucional es aquel en donde existe una Constitución democrática que establece límites al poder y da garantía a las libertades y derechos de sus ciudadanos; es el que indica que el orden jurídico se basa en la Constitución.

Al respecto, se ha indicado que

No todo Estado en la configuración moderna constituye en sí mismo un Estado constitucional, toda vez que se impone no sólo la existencia de un Ordenamiento jurídico fundamental, que sea la norma de normas, causa mo-

21 Aguiló Regla, Josep, "Sobre la Constitución del Estado constitucional”, Doxa, Cuadernos de Filosofía del Derecho, Universidad de Alicante, núm. 24, p. 43, disponible en: https://doxa.ua.es/article/view/2001-n24-sobre-la-constitucion-del-estado-constitucional. Fecha de acceso: 23 de agosto de 2019, doi: https://doi.org/10.14198/DOXA2001.24.16. 
tor del Estado, sino que tal Ordenamiento debe estar impregnado de valores humanistas en favor de los derechos y libertades fundamentales y de todo el conjunto de técnicas y procedimientos que hacen posible su existencia y disfrute ante la invasión, intromisión o actuaciones nugatorias...22

Por su parte, la decisión jurisdiccional de fondo ha de ser un resultado de un proceso garantista, que respete esos derechos fundamentales y que tenga por fundamento el derecho. Ello, porque el proceso es un sistema de garantías de los derechos de los ciudadanos es el medio jurídico para que las partes debatan en condición de igualdad y contradicción sus conflictos, de tal forma que se abandone el proceso que tenga como eje principal el autoritarismo y se erija como una garantía de los sujetos procesales en él intervinientes. El proceso debe convertirse en un método de debate dialogal, en donde se erradique la fuerza, se asegure la paz y la convivencia. ${ }^{23}$ Por lo tanto, hoy en un Estado constitucional debe propenderse por un proceso que sirva de tutela de los derechos y garantías constitucionales y controle además al poder; sólo de esta forma la función jurisdiccional aunada a la argumentación jurídica será el motor que otorgue confianza a la comunidad.

Para ello, la teoría de la argumentación jurídica es una herramienta racional, que juega un papel fundamental en la decisión, buscando que ésta se ajuste a un modelo procesal garantista, que se convierta en sustento de los procesos de elaboración lógica y dialéctica de las decisiones. En el campo jurídico, es una herramienta que ayudará a que los funcionarios jurisdiccionales tomen en cuenta su discrecionalidad y límites en sus decisiones, pero sin caer en la arbitrariedad; es dar un mayor sentido argumentativo y valorativo a los hechos y medios de prueba existentes en un proceso para proferir con base en éstos una decisión racional. Por eso, la decisión jurisdiccional debe ser producto de un debido proceso que le imprima un sello de racionalidad, pero además debe ser formalmente correcta, ${ }^{24}$ esto

22 Ainaga Vargas, María del Carmen, "Nota sobre el Estado constitucional democrático de derecho", Letras Jurídicas, México, núm. 7, enero 2003, p. 1, disponible en: http:// www.letrasjuridicas.com.mx/Volumenes/7/ainaga7.pdf. Fecha de acceso: 23 de agosto de 2019.

23 Alvarado Velloso, Adolfo, Garantismo procesal contra actuación judicial de oficio, Tirant lo Blanch, 2005, p. 47.

24 Artículo 1, Constitución Política de Colombia de 1991: "Colombia es un estado social de derecho organizado en forma de República unitaria, descentralizada, con au- 
es, objetiva, racional y libre, pues el funcionario jurisdiccional en su tarea de procesar y decidir, debe hacerlo de tal forma que su decisión sea la mejor de las posibles. Argumentar exige entonces aportar razones sólidas y convincentes que descarten cualquier factor de arbitrariedad del funcionario jurisdiccional. ${ }^{25}$ Debe éste tomar en cuenta que se siente observado por un auditorio, y ello lo debe inducir necesariamente a poner más cuidado en la decisión que profiera. ${ }^{26}$ Es así como en este proceso el auditorio es un factor muy importante.

En efecto, el juez, al motivar la sentencia, no está simplemente señalando su criterio personal sobre lo justo, o mostrando que se atuvo a la ley, sino que está suministrando las razones de su decisión y refutando (o intentando refutar) las objeciones que le hayan sido o le puedan ser opuestas. Motivar es justificar la decisión tomada proporcionando una argumentación convincente e indicando lo bien fundado de las opciones que el juez efectúa. ${ }^{27}$

El proceso entonces es deliberativo, ya que busca una solución a través de un debate preestablecido sobre bases racionales, para llegar a una respuesta racional e imparcial de la controversia, lo que coadyuva necesariamente al ideal democrático, ${ }^{28}$ ideal que exige que en una comunidad, no obstante existir grupos que consideran algo bueno o malo, correcto o incorrecto, la mayoría debe ser entendida como una universalidad, no por azar, sino que consideran que la decisión es la mejor solución de las posibles.

tonomía de sus entidades territoriales, democrática, participativa y pluralista, fundada en el respeto de la dignidad humana, en el trabajo y la solidaridad de las personas que la integran y en la prevalencia del interés general".

25 Gascón Abellán, Marina, Los hechos en el derecho. Bases argumentales de la prue$b a$, Madrid-Barcelona, Marcial Pons, Ediciones Jurídicas y Sociales, 1999, p. 225.

26 Ghirardi A., Olsen et al., La naturaleza del razonamiento judicial: el razonamiento débil, Córdoba, Ediciones Alveroni, 1993, p. 42.

27 Uprimny Yepes, Rodrigo, "La motivación de las sentencias y el papel del juez en el Estado social y democrático de derecho", Pensamiento Jurídico, Bogotá, núm. 4, 1995, p. 136, disponible en: http://www.revistas.unal.edu.co/index.php/peju/article/view/38998. Fecha de acceso: 23 de agosto de 2019.

28 Álvarez Álvarez, Fernando D., "Legitimidad democrática y control judicial de constitucionalidad (refutaciones al carácter contra mayoritario del Poder Judicial)", Díkaion, Lo justo, Bogotá, año 17, núm. 12, p. 168, disponible en: http://dikaion.unisabana.edu.co/index.php/dikaion/article/view/1252/1364. Fecha de acceso: 23 de agosto de 2019. 
Relacionando por lo tanto este aspecto con la función jurisdiccional que se cumple en un Estado constitucional, lo primero que cabe decir es que ésta implica necesariamente el estudio de la jurisdicción, que como función delegada por el Estado se constituye en un instrumento que otorga confianza en la comunidad de su eficacia, en cuanto a que esté dirigida a asegurar la justicia. $^{29}$

Así las cosas, el proceso tendrá una doble función: una privada, como instrumento que tiene todo individuo para lograr la solución de su conflicto, y otra pública, como aquella "garantía que otorga el Estado a todos sus habitantes en contrapartida de la prohibición impuesta respecto del uso de la fuerza privada", ${ }^{30}$ tomando en cuenta que la decisión tiene diversos destinatarios, no sólo las partes procesales, sino la opinión pública, la academia, la comunidad investigativa, los demás funcionarios jurisdiccionales, entre otros. He aquí la razón por la cual la argumentación jurídica es fundamental en un Estado constitucional, porque "Nada hay sin una razón suficiente". ${ }^{31}$

\section{LA CONSTITUCIONALIZACIÓN DEL PROCESO JURISDICCIONAL A PARTIR DE LA ARGUMENTACIÓN JURÍDICA Y LA RACIONALIDAD}

\section{1. ¿Qué es la constitucionalización del proceso jurisdiccional?}

Para responder a este interrogante, se hace necesario partir de lo que se ha entendido por constitucionalización de un modo general. Así las cosas, "Se trata de un proceso al término del cual el derecho es «impregnado», «saturado» o «embebido» por la Constitución: un derecho constitucionalizado se caracteriza por una constitución invasiva, que condiciona la legislación, la jurisprudencia, la doctrina y los comportamientos de los actores políticos".32

29 Agudelo Ramírez, Martín, "Jurisdicción”, Revista Internauta de Práctica Jurídica, Valencia, núm. 19, enero-junio de 2007, disponible en: https://www.uv.es/ajv/art_jcos/ art_jcos/num19/RIPJ_19/EX/19-9.pdf. Fecha de acceso: 23 de agosto de 2019.

30 Alvarado Velloso, Adolfo, op. cit., p. 52.

31 Ghirardi A., Olsen et al., op. cit., p. 26.

32 Commanducci, Paolo, "Constitucionalización y neoconstitucionalismo", en Carbonell, Miguel y García Jaramillo, Leonardo (comps.), El canon neoconstitucional, Bogotá, Universidad Externado de Colombia, 2010, p. 175.

Esta obra está bajo una Licencia Creative Commons Atribución-NoComercial-SinDerivar 4.0 Internacional, IIJ-UNAM. 
Se colige, por tanto, que la constitucionalización implica una expansión de la Constitución a los diferentes ámbitos que atraviesa el derecho. Se suele decir que donde hay sociedad hay derecho (ubi societas ibi ius), brocardo que ya se queda corto y a la luz de las Constituciones de los Estados onstitucionales democráticos; se debería decir: "donde hay sociedad, hay derecho constitucionalizado".

Un punto importante abordado por Guastini es la manifestación de una Constitución "que condiciona", y ésta es la mejor expresión para comprender la constitucionalización del ordenamiento jurídico, y servirá de giro para comprender la constitucionalización del proceso jurisdiccional. La pregunta es ¿qué condiciona? La Constitución se vuelve un condicionante de la validez formal y material de los diversos actos jurídicos producidos en el sistema de fuentes del ordenamiento jurídico, y además de ello condiciona la legitimidad de actuación de los diversos actores políticos.

Igualmente, el jurista italiano ha descrito unas condiciones para poder considerar a un ordenamiento jurídico como constitucionalizado, a saber: 1. Una Constitución rígida, 2. La garantía jurisdiccional de la Constitución, 3. La fuerza vinculante de la Constitución, 4. La "sobreinterpretación" de la Constitución, 5. La aplicación directa de las normas constitucionales, 6. La interpretación conforme de las leyes, 7. La influencia de la Constitución sobre las relaciones políticas. ${ }^{33}$

Para efectos de lo que interesa en este acápite acerca de la constitucionalización del proceso jurisdiccional, en lo que sigue se desarrollará únicamente la condición cuatro, sin desconocer a las otras condiciones como necesarias. Guastini expresa que la ‘sobreinterpretación' de la Constitución conlleva una interpretación extensiva "de manera tal que se le extraigan innumerables normas implícitas, no expresas". ${ }^{34}$ Sin la sobreinterpretación, la Constitución sería prácticamente un texto inerte, condenado a ser desarrollado por el legislador, mientras que con la "sobreinterpretación" la letra de la Constitución cobra vida, se torna un texto dinámico, su irradiación será producto de la interpretación constitucional, especialmente de aquella realizada por los tribunales constitucionales. En otras palabras, en la medida en que se puedan extraer normas de la Constitución por vía interpretativa, la misma impregnará el ordenamiento jurídico y lo

33 Guastini, Riccardo, Estudios de teoría constitucional, México, UNAM-Fontamara, 2001, pp. 154 y ss.

34 Ibidem, p. 159.

Esta obra está bajo una Licencia Creative Commons

Atribución-NoComercial-SinDerivar 4.0 Internacional, IIJ-UNAM. 
condicionará. Así, la interpretación de la Constitución deviene una sobreinterpretación extractora de normas jurídicas implícitas que hacen hablar al texto constitucional para permear el ordenamiento jurídico.

\section{La argumentación jurídica y la interpretación constitucional como método para la constitucionalización del proceso jurisdiccional}

Las normas jurídicas implícitas en el lenguaje de Alexy se denominan "normas adscritas" o indirectamente estatuidas; acerca de ellas expresa el autor: "una norma adscripta de derecho fundamental es una norma para cuya adscripción es posible aducir una fundamentación iusfundamental correcta". ${ }^{35}$ De esta noción del jurista alemán se destaca lo relevante de la argumentación jurídica para la extracción de normas adscritas, es decir, no basta con sobreinterpretar, sino que se requiere fundamentar por qué esa norma adscrita pertenece al ordenamiento jurídico del cual se pretende extraer.

Y surgen los siguientes interrogantes: ¿cuántas reglas pueden ser adscritas a una Constitución? Todas aquellas que puedan interpretarse y argumentarse con pretensión de corrección. ¿Dónde ubicar estas normas implícitas? Éstas se encuentran especialmente en la ratio decidendi de las sentencias de los tribunales constitucionales, y en la medida en que el precedente constitucional sea vinculante, los demás jueces deberán utilizar estas normas indirectamente estatuidas.

Bernal Pulido expresa que "El texto lapidario de las cláusulas constitucionales regula muy poco o casi nada, no establece casi ningún supuesto de hecho"; 36 no obstante, lo que a primera vista parece una debilidad es la potencia del texto constitucional de proyectarse semánticamente a través de la interpretación constitucional para regular por medio de normas adscritas diversos comportamientos; normas adscritas cuya estructura remite a un supuesto jurídico. Por ello, se sostiene que la expansión de la Constitución al ordenamiento jurídico tiene como una de sus condiciones la sobreinterpretación para la extracción de normas jurídicas adscritas justificadas que condicionen la validez material y formal de las normas jurí-

\footnotetext{
35 Alexy, Robert, Teoría de los derechos fundamentales, 2a. ed., Madrid, Centro de Estudios Políticos y Constitucionales, 2012, p. 78.

36 Bernal Pulido, Carlos, El derecho de los derechos. Escritos sobre la aplicación de los derechos fundamentales, Bogotá, Universidad Externado de Colombia, 2005, p. 166. 
dicas. Así, "la carta fundamental se ha integrado de manera paulatina por un acervo muy numeroso de lo que la doctrina ha calificado como normas subconstitucionales, es decir, las creadas por las sentencias de los jueces constitucionales de última instancia". ${ }^{37}$

Por otra parte, la interpretación constitucional es la actividad de atribuirle significado a los textos normativos constitucionales y a las demás disposiciones normativas a la luz del texto constitucional. La anterior noción se basa en la distinción de Vigo en el objeto de la interpretación constitucional, pues hay una interpretación "de" la Constitución y una interpretación "desde" la Constitución; en la primera, se determina el significado de una disposición constitucional, y en la segunda, se busca "fijar el sentido de una norma o de un comportamiento en relación a la Constitución". ${ }^{38}$

Además, la interpretación constitucional para ser realmente operativa se realiza en concreto, es decir, "el proceso de concretización debe venir determinado por el objeto de la interpretación — la Constitución-y por el problema en cuestión". ${ }^{39}$ Lo anterior implica una dinámica de doble mirada; esto es de los textos normativos hacia los hechos, y de los hechos hacia el texto; de esta manera, se logra otorgar un sentido acorde con la Constitución y significativo para resolver el caso concreto. ${ }^{40}$ Así las cosas, interpretar la Constitución es determinar su sentido a la luz de una situación concreta; empero, esto no significa caer en la casuística, ya que los significados otorgados en un caso concreto sirven de base para abstraer una norma adscrita.

Con base en lo expuesto, la constitucionalización a partir de la sobreinterpretación conlleva entonces una hermenéutica constitucional para construir normas adscritas al texto constitucional que irradien el ordenamiento jurídico. Por otra parte, "El fenómeno de la constitucionalización del derecho procesal tiene como exclusiva finalidad lograr la tan pretendida

37 Fix-Zamudio, Héctor, "Lineamientos esenciales de la interpretación constitucional", en Ferrer Mac-Gregor, Eduardo (ed.), Interpretación constitucional, t. I, México, Porrúa, 2001, p. 562.

38 Vigo, Rodolfo, Interpretación constitucional, Buenos Aires, Lexis-Nexis, 2004, p. 8.

39 Hesse, Konrad, Escritos de derecho constitucional, Madrid, Centro de Estudios Políticos y Constitucionales, 2011, p. 65.

40 En sentido similar se expresa Quiroga "la interpretación ha de hacerse desde la situación concreta hacia la norma constitucional y no en sentido inverso". Quiroga, Aníbal, "La interpretación constitucional", en Ferrer Mac-Gregor, Eduardo (ed.), Interpretación constitucional, t. II, México, Porrúa, 2005, p. 952. 
justicia”. ${ }^{41}$ Ahora bien ¿cómo lograr la constitucionalización del proceso jurisdiccional para alcanzar la justicia? Es claro por lo ya anotado que no se logra porque la Constitución consagre un artículo extenso al debido proceso; tampoco se logra por el desarrollo que de éste haga el órgano Legislativo en las diversas normas procesales; ni mucho menos por la repetición del contenido del artículo del debido proceso en un código procesal, ${ }^{42}$ lo cual genera redundancia de normas jurídicas sin aportar significados nuevos a las conductas prescritas.

Con base en lo mencionado anteriormente, para la constitucionalización del proceso jurisdiccional se requiere ${ }^{43}$ la sobreinterpretación de la Constitución para extraer reglas implícitas que condicionen la validez de la construcción del proceso jurisdiccional, y especialmente de su reflejo normal, que es la sentencia judicial. La atribución de significado se puede lograr utilizando diversas directivas de interpretación constitucional que tienen especial relevancia en torno al debido proceso, ${ }^{44}$ como el principio de interpretación conforme a la Constitución, la no discriminación e igualdad ante la ley, el principio pro homine o pro persona.

El uso de directivas de interpretación o de cánones interpretativos conduce al plano de la argumentación jurídica, específicamente a la justificación externa, ya que con ellas se da cuenta del significado atribuido a las premisas, como lo expresa Alexy: "una de las tareas más importantes de los cánones consiste en la fundamentación de tales interpretaciones". 45 Esto lleva a que la argumentación jurídica sea otra de las claves para lograr la constitucionalización del proceso jurisdiccional, pues la sobreinterpretación y la adscripción de reglas debe ser fundamentada.

41 Colmenares, Carlos, “Constitucionalización del derecho procesal y los nuevos modelos procesales”, Academia \& Derecho. Bogotá, núm. 1, julio 1, 2010, p. 8, disponible en: https://revistas.unilibre.edu.co/index.php/academia/article/view/2361. Fecha de acceso: 23 de agosto de 2019.

42 Constitución Política de Colombia, "Articulo 29. El debido proceso se aplicará a toda clase de actuaciones judiciales y administrativas... Es nula, de pleno derecho, la prueba obtenida con violación del debido proceso". Código General del Proceso, "Artículo 14. Debido proceso. El debido proceso se aplicará a todas las actuaciones previstas en este código. Es nula de pleno derecho la prueba obtenida con violación del debido proceso".

43 Se usa esta expresión sin desconocer las condiciones ya mencionadas de Guastini.

44 Cardona, Jorge, "Modelo hermenéutico del debido proceso en Colombia", Estudios de Derecho, Medellín, vol. LXIX, núm 153, 2012, pp. 230 y ss.

45 Alexy, Robert, Teoría de la argumentación jurídica, Madrid, Centro de Estudios Políticos y Constitucionales, 2007, p. 226. 
En conclusión, se considera que la argumentación jurídica sirve como método para la constitucionalización del proceso jurisdiccional, por tres razones: i) porque con base en ella se pueden fundamentar las normas. Lo anterior supone la realización de una sobreinterpretación de la Constitución, pero esta actividad por sí sola no es suficiente, pues se deben dar las razones de la determinación del sentido de las disposiciones de derecho fundamental; (ii) se requiere la aplicación razonada de las reglas estatuidas por parte de los funcionarios jurisdiccionales, ya que sin su utilización las subreglas serían un asunto exclusivo de los tribunales constitucionales, y no se reflejaría en el proceso jurisdiccional, y por ende no se lograría justicia; iii) el control de las decisiones judiciales con base en las reglas adscritas desde la Constitución al proceso jurisdiccional, pues si no hay la posibilidad de evaluar desde instancias jurisdiccionales las sentencias de todos los jueces, las reglas adscritas serían letra muerta.

\section{ESTUDIO DE CASO: PROCEDENCIA DE TUTELA CONTRA PROVIDENCIA JUDICIAL COMO FORMA DE CONSTITUCIONALIZACIÓN EN COLOMBIA}

\section{La acción de tutela en Colombia como forma de constitucionalización}

En el ordenamiento jurídico colombiano la constitucionalización del proceso jurisdiccional se ha logrado desde los precedentes establecidos en las sentencias de control de constitucionalidad y de revisión de tutela, ${ }^{46}$ especialmente en aquellas en las cuales se han construido las causales de procedencia de tutela contra providencia judicial. Esto, en la medida en que la Corte Constitucional ha decantado una serie de normas implícitas orientadas a la protección del debido proceso y la justicia. Éstas son pro-

\footnotetext{
46 Regulada como una acción procesal constitucional en el artículo 86 de la Constitución Política de 1991, cuyo objeto es la protección de los derechos constitucionales fundamentales cuanto éstos resulten vulnerados, aspecto al que refiere la Corte Constitucional de Colombia en sentencia SU 217 de 2019 cuando refiere a la procedencia de la acción de tutela, pero adiciona que "siempre que el afectado no disponga de otro medio de defensa judicial, salvo que aquella se utilice como mecanismo transitorio para evitar un perjuicio irremediable". Corte Constitucional Colombiana, sentencia SU-217 de 2019, M. S. Antonio José Lizarazo Ocampo.
} 
ducto de una sobreinterpretación argumentada de la Constitución. ${ }^{47}$ Por otra parte, estas normas adscritas condicionan la validez formal y material de la sentencia judicial, ya que dado el desconocimiento de las mismas la sentencia podrá ser revocada por un juez de tutela.

Por ello, en el proceso jurisdiccional colombiano el juez debe aplicar las normas procesales establecidas por vía legal, las constitucionalmente expresas, y las normas indirectamente estatuidas; esto hace más compleja la actuación judicial, pero busca acercar la sentencia hacia una decisión judicial justa y respetuosa de las garantías constitucionales de un Estado social y constitucional de derecho.

Para comprender mejor esta constitucionalización, cabe mencionar las causales de procedencia de tutela contra providencia judicial en el ordenamiento jurídico colombiano, que se han distinguido en dos tipos de causales: ${ }^{48}$ las genéricas y las especiales (en éstas se encuentran las normas adscritas). Como causales genéricas, se tienen: i) cuestión de relevancia constitucional; ii) que se hayan agotado todos los medios ordinarios y extraordinarios de defensa judicial; iii) que se cumpla el requisito de inmediatez (en promedio seis meses); iv) cuando se trate de una irregularidad procesal, ésta tenga un efecto decisivo o determinante en la sentencia que se imponga; v) identificación de los hechos que generaron la vulneración, los derechos vulnerados y que se hubiera alegado dicha vulneración durante el proceso; vi) que la acción no se interponga contra sentencias de tutela. ${ }^{49} \mathrm{Y}$ dentro de las causales especiales están: i) el defecto orgánico; ii) el defecto procedimental; iii) el defecto sustantivo; iv) el defecto fáctico; v) el error inducido; vi) la decisión judicial sin motivación; vii) el desconocimiento del precedente; viii). la violación directa de la Constitución. ${ }^{50}$

47 Entendida ésta según la Corte Constitucional como la que no se limita a una interpretación literal de la Constitución, sino como la que adopta una interpretación extensiva, interpretación a través de la cual se pueden extraer innumerables normas implícitas, no explícitas, "idóneas para regular casi cualquier aspecto de la vida social y político". Corte Constitucional colombiana, Sentencia C-1047 de 2005. M. P. Jaime Córdoba Triviño. Situación que permite que no queden espacios vacíos.

48 Al respecto véase Corte Constitucional colombiana, Sentencia T 429 de 2011, M. P. Jorge Ignacio Pretelt Chaljub,

49 Quinche Ramírez, Manuel Fernando, Vías de hecho: acción de tutela contra providencias, Bogotá, Universidad Pontificia Javeriana, Facultad de Ciencias Jurídicas, Grupo Editorial Ibáñez, 2012, pp. 154 y ss.

50 Corte Constitucional colombiana, Sentencia C 590 de 2005, M. P. Jaime Córdoba Triviño. 
Cada una estas causales especiales es una regla adscrita a la Constitución, y cada una de ellas tiene a su vez una serie de causales, o, si se quiere, más reglas adscritas. A modo de ejemplo, al defecto fáctico se le adscriben las siguientes modalidades: i) el juez no permite a una de las partes o a ambas solicitar pruebas; ii) el juez no decreta o practica pruebas; iii) el juez no da por probado lo probado; iv) el juez da por probado lo no probado; v) el juez se fundamenta en pruebas impertinentes, insuficientes o inconducentes; vi) el juez no valora las pruebas; vii) el juez valora las pruebas, pero lo hace mal; viii) el juez valora pruebas que no podía valorar. ${ }^{51}$

De este modo, se comprueba que la constitucionalización del proceso judicial en el ordenamiento jurídico colombiano se logra por medio de la adscripción de una serie de normas implícitas por parte de la Corte Constitucional. Es de anotar que en la medida en que estas normas indirectamente estatuidas son un desarrollo de la Constitución, y específicamente de derechos fundamentales, las mismas no son persuasivas, sino que son vinculantes para todos los jueces, y su desconocimiento puede ser amparado por vía de acción de tutela. Por ello, se expresó anteriormente que las normas implícitas en la constitucionalización del proceso son condiciones de validez de la sentencia, ya que si son desconocidas el juez de tutela deberá revocarlas.

\section{Las normas implícitas de procedencia de tutela}

como control argumentativo de la sentencia judicial

El Estado constitucional y democrático de derecho está teóricamente fundado en una cultura dialógica ${ }^{52}$ lo cual implica la proscripción de la arbitrariedad en las decisiones jurídicas, y en especial de la decisión judicial. Ello conlleva una exigencia de argumentación y razonabilidad de la decisión judicial, como ya se ha indicado en este artículo.

Ahora bien, la constitucionalización del proceso jurisdiccional se da desde un triple ámbito argumentativo, así: i) la extracción de las normas

51 Corte Constitucional colombiana, Sentencia T-249 de 2009, M. P. Cristina Pardo Schlesinger; Corte Constitucional colombiana, Sentencia T-713 de 2005, M. P. Rodrigo Escobar Gil; Corte Constitucional colombiana, Sentencia T-580 de 2008, M. P. Humberto Antonio Sierra Porto; Corte Constitucional Colombiana, Sentencia T-266 de 2009, M. P. Humberto Antonio Sierra Porto.

52 Bernal Pulido, Carlos, El derecho fundamental del debido proceso, Medellín, Señal Editora, 2004, p. 9. 
jurídicas se realiza por vía interpretativa y argumentativa; es decir, argumentación a nivel de la Corte Constitucional para la generación de precedentes; ii) en el uso de las normas implícitas por parte del juez de conocimiento, esto es, el juez puede realizar una actividad autocrítica evaluando su sentencia desde estas normas implícitas, y notará que la sentencia está bien argumentada si supera todas las condiciones constitucionales, y iii) como argumento del juez de tutela para revocar una sentencia judicial, la presencia de una de estas causales en la sentencia en estudio dará lugar a que el juez de tutela la deba revocar.

Resumiendo, la argumentación jurídica tiene como componente la racionalidad, y sirve en la constitucionalización del proceso jurisdiccional en la extracción de normas implícitas, en la construcción de decisiones jurisdiccionales o en la revocación de las mismas.

\section{CONCLUSIONES}

De lo expuesto, puedo concluirse que:

Es claro que el proceso jurisdiccional se enriquece desde líneas tan sensibles como las garantías del ser humano, como esencia de la organización estatal y como fin que anima todo su derrotero de derecho público, cuando se constitucionaliza el derecho para fortalecimiento de la defensa social del individuo y la limitación de poderes extremos; y además, cuando se introducen a la estructura de decisión constitucional, componentes de racionalidad como exigencia permanente de posturas argumentativas internas o externas, pues por este sendero existe mayor posibilidad de respuestas estatales correctas a los conflictos ciudadanos.

Para lograr tal fin, se hace necesario hacer uso de la argumentación jurídica, por medio de la cual se busca el mayor consenso, aceptación, adhesión o reconocimiento frente a la decisión jurisdiccional.

Esa argumentación jurídica tiene como componente la racionalidad, y sirve para constitucionalizar el proceso jurisdiccional, a través de la extracción de normas adscritas, esto es, implícitas, que conllevan a una sobreinterpretación de la Constitución, y por tanto hacen hablar al texto constitucional, a fin de permear todo el ordenamiento jurídico.

Y precisamente esa constitucionalización del proceso jurisdiccional colombiano se ha logrado desde las causales de procedencia de tutela contra 
providencia judicial, las cuales son normas implícitas extraídas por vía de interpretación y argumentación.

\section{BIBLIOGRAFÍA}

Aguiló Regla, Josep, "Sobre la constitución del Estado constitucional", Doxa, Cuadernos de Filosofía del Derecho, España, Universidad de Alicante, núm. 24, disponible en: https://doxa.ua.es/article/ view/2001-n24-sobre-la-constitucion-del-estado-constitucional. Fecha de acceso: 23 de agosto de 2019, doi: https://doi.org/10.14198/DO XA2001.24.16.

Agudelo RamíRez, Martín, "Jurisdicción”, Revista Internauta de Práctica Jurídica, Valencia, núm. 19, enero-junio de 2007, disponible en: https://www.uv.es/ajv/art_jcos/art_jcos/num19/RIPJ_19/EX/19-9.pdf. Fecha de acceso: 23 de agosto de 2019.

Ainaga VARGas, María del Carmen, "Nota sobre el Estado constitucional democrático de derecho", Letras Jurídicas, México, núm. 7, enero 2003, disponible en: http://www.letrasjuridicas.com.mx/Volumenes/7/ ainaga7.pdf. Fecha de acceso: 23 de agosto de 2019.

ALEXY, Robert, Teoría de la argumentación jurídica, Madrid, Centro de Estudios Políticos y Constitucionales, 2007.

AlEXY, Robert, Derecho y razón práctica, México, Fontamara, 2010.

AlEXY, Robert, Teoría de los derechos fundamentales, 2a. ed., Madrid, Centro de Estudios Políticos y Constitucionales, 2012.

Alvarado Velloso, Adolfo, Garantismo procesal contra actuación judicial de oficio, Valencia, Tirant lo Blanch, 2005.

Álvarez ÁlVArez, Fernando D., "Legitimidad democrática y control judicial de constitucionalidad (refutaciones al carácter contramayoritario del poder judicial)", Díkaion. Lo justo, Bogotá, año 17, núm. 12, disponible en: http://dikaion.unisabana.edu.co/index.php/dikaion/article/ view/1252/1364, Fecha de acceso: 23 de agosto de 2019.

AtiEnZA, Manuel, Curso de argumentación jurídica, Madrid, Trota, 2013.

Bernal Pulido, Carlos, El derecho fundamental del debido proceso, Medellín, Señal Editora, 2004. 
Bernal Pulido, Carlos, El derecho de los derechos. Escritos sobre la aplicación de los derechos fundamentales, Bogotá, Universidad Externado de Colombia, 2005.

CARdona, Jorge, "Modelo hermenéutico del debido proceso en Colombia”, Estudios de Derecho, Medellín, vol. LXIX, núm. 153, 2012.

Colmenares, Carlos, "Constitucionalización del derecho procesal y los nuevos modelos procesales", Academia \& Derecho, Bogotá, núm. 1, julio 1, 2010, p. 8-23, disponible en: https://revistas.unilibre.edu.co/index.php/academia/article/view/2361. Fecha de acceso: 23 de agosto de 2019.

COMMANDUCCI, Paolo, "Constitucionalización y neoconstitucionalismo", en Carbonell, Miguel y García Jaramillo, Leonardo (comps.), El canon neoconstitucional, Bogotá, Universidad Externado de Colombia, 2010.

DWORKIN, Ronald, “¿Realmente no hay respuesta correcta en los casos difíciles?", en CASANOvas, Pompeu y Moreso, José Juan (eds.), El ámbito de lo jurídico, Barcelona, Crítica, 2000.

ECHEGOYEN OLLETA, Javier, "Historia de la filosofía, filosofía medieval y moderna", Diccionario filosófico de Voltaire, filosofía Moderna, Editorial Edinumen, vol. 2, disponible en: https://www.e-torredebabel.com/ Historia-de-la-filosofia/Historia-de-la-Filosofia.htm. Fecha de acceso: 23 de agosto de 2019.

FETERIS, Eveline T., Fundamentos de la argumentación jurídica. Revisión de las teorías sobre la justificación de las decisiones judiciales, trad. de Alberto Supelano, Bogotá, Universidad Externado de Colombia, 2007.

FIX-ZAMUDIO, Héctor, "Lineamientos esenciales de la interpretación constitucional", en FERRER MAC-GREGOR, Eduardo (ed.), Interpretación constitucional, t. I, México, Porrúa. 2001.

GADAMER, Hans Georg, Verdad y método, Salamanca, Sígueme, 2005.

GARCÍA, Eloy, El último triunfo de la libertad: la democracia constitucional ante su momento maquiavélico, Bogotá, Universidad Externado de Colombia, Instituto de Estudios Constitucionales Carlos Restrepo Piedrahita, 2000.

GARCÍA AMADO, Juan Antonio, "Legitimidad y derechos humanos", en SORIANO DíAZ, Ramón L. et al. (coords.), Diccionario crítico de los derechos humanos, La Rábida, Universidad Internacional de Andalucía, 
Sede Iberoamericana, 2000, disponible en: http://www.geocities.ws/jagamado/pdfs/legitimidad_y_dchoshnos.pdf, p. 1. Fecha de acceso: 23 de agosto de 2019.

GASCÓn ABELlÁn, Marina, Los hechos en el derecho. Bases argumentales de la prueba, Madrid-Barcelona, Marcial Pons, Ediciones Jurídicas y Sociales, 1999.

GHIRARDI A., Olsen et al., La naturaleza del razonamiento judicial. El razonamiento débil, Córdoba, Argentina, Ediciones Alveroni, 1993.

GUASTINI, Riccardo, Estudios de teoría constitucional, México, UNAMFontamara, 2001.

HABA, Enrique, "Racionalidad y método del derecho ¿eso es posible?", Doxa. Alicante, núm. 7, 1990, disponible en: file://C:/Users/ldpa bon/Downloads/racionalidad-y-mtodo-para-el-derecho-es-eso-posi ble-0\%20(1).pdf. Fecha de acceso: 23 de agosto de 2019.

Hesse, Konrad, Escritos de derecho constitucional, Madrid, Centro de Estudios Políticos y Constitucionales, 2011.

JONGITUD ZAMORA, Jacqueline, "Legalidad, legitimidad y legitimación. Implicaciones éticas", en CÁCERES, Enrique et al., (coords.), Problemas contemporáneos de la filosofía del derecho, México, UNAM, 2005, disponible en: http://biblio.juridicas.unam.mx/libros/4/1650/21. $p d f$, p. 1. Fecha de acceso: 23-agosto-2019.

MORENO CRUZ, Rodolfo, “Argumentación jurídica, por qué y para qué”, Boletín Mexicano de Derecho Comparado, México, nueva serie, año XLV, núm. 133, enero-abril de 2012, disponible en: https://revistas.ju ridicas.unam.mx/index.php/derechocomparado/article/view/4738. Fecha de acceso: 23 de agosto de 2019, doi: http://dx.doi.org/10.22201/ iij.24484873e.2012.133.4738.

PABÓN GIRALDO, Liliana Damaris, "La argumentación jurídica como presupuesto de legitimidad de la decisión jurisdiccional en el Estado constitucional", en BARrios GONZÁlez, Boris y BARRIOS CHÁvEZ, Luris (coords), La administración de justicia en el Estado constitucional, Bogotá, Nueva Jurídica y Librería \& Editorial Barrios \& Barrios, julio de 2015.

QUINCHE RAMíREZ, Manuel Fernando, Vias de hecho: acción de tutela contra providencias, Bogotá, Universidad Pontificia Javeriana, Facultad de Ciencias Jurídicas-Grupo Editorial Ibáñez, 2012. 
Quiroga, Aníbal, "La interpretación constitucional”, en FERRER MACGREGOR, Eduardo (ed.), Interpretación constitucional, t. II, México, Porrúa, 2005.

REAl ACADEMIa ESPAÑOla, Diccionario de la lengua española, edición del tricentenario, Madrid, 2019, disponible en: http://www.rae.es. Fecha de acceso: 23 de agosto de 2019.

Segura Ortega, Manuel, La racionalidad jurídica, Madrid, Tecnos, 1998.

UPRIMNY YEPES, Rodrigo, "La motivación de las sentencias y el papel del juez en el Estado social y democrático de derecho", Pensamiento Jurídico, Bogotá, Universidad Nacional, núm. 4, 1995, disponible en: http://www.revistas.unal.edu.co/index.php/peju/article/view/38998. Fecha de acceso: 23 de agosto de 2019.

VIGO, Rodolfo, Interpretación constitucional, Buenos Aires, Lexis-Nexis, 2004.

Wróblewski, Jerzy, Sentido y hecho en el derecho, México, Doctrina Jurídica Contemporánea, 2003.

Fecha de recepción: 31 de mayo de 2018.

Fecha de aceptación: 15 de julio de 2019.

Esta obra está bajo una Licencia Creative Commons Atribución-NoComercial-SinDerivar 4.0 Internacional, IIJ-UNAM. 


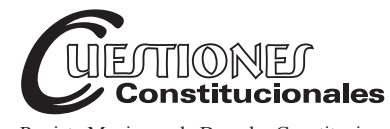

Revista Mexicana de Derecho Constitucional Núm. 43, julio-diciembre 2020

\title{
Las normas de ius cogens como imperativo en los procesos de justicia transicional. Estudio relativo al Tribunal de Jurisdicción Especial para la Paz en Colombia
}

\author{
The rules of ius cogens as an imperative in transitional justice \\ processes: a study relating to Colombia's Special Jurisdiction \\ for Peace Tribunal
}

\section{Yennesit PALACIOS VALENCIA*}

\begin{abstract}
RESUMEN: Colombia se está enfrentando a un proceso complejo de justicia transicional, no solo por la exigencia constante de los movimientos sociales, sino por la presión internacional, la necesidad sentida de justicia y, sobre todo, por el clamor de las víctimas. Lo cual ha permitido el impulso de un conjunto de reformas para cambiar la huella del pasado conflictivo. Lo anterior, soportado en un amplio andamiaje jurídico que intenta responder a las víctimas y a la misma sociedad con criterios de verdad, justicia, reparación y medidas de no repetición, dando como resultado lo que hoy se conoce como el Marco Jurídico para la Paz. En este contexto, los crímenes cometidos en el pasado serán juzgados por un Tribunal Especial para la Paz que, bajo la hipótesis sustentada, deberá ceñirse a las normas de ius cogens como estándar de obligatorio cumplimiento derivado del sistema jurídico internacional.
\end{abstract}

ABSTRACT: Colombia is facing a complex process of transitional justice, not only because of the constant demand of social movements, but also because of international pressure, a felt need for justice and, above all, for the clamor of the victims. This has allowed for a series of reforms to change the footprint of the conflicting past. The above, supported by a wide legal framework that seeks to respond to victims and civil society, with criteria of truth, justice, reparation and measures of nonrepetition, resulting in what is now known as the Legal Framework for Peace. In this context, crimes committed in the past will be judged by a Special Tribunal for Peace, which, under the assumption, should adhere to the norm of ius cogens as obligatory compliance standard derived from the international legal system.

* PhD en Derechos Humanos y Desarrollo de la Universidad Pablo de Olavide (UPO); abogada de la USB Medellín, Colombia. ORCID: 0000-0003-3581-439X. Correo electrónico:yennesit.palacios@gmail.com. 
Palabras clave: crímenes internacionales, Colombia, ius cogens, justicia transicional, Tribunal Especial para la Paz.
Keywords: international crimes, Colombia, ius cogens, transitional justice, Special Court for Peace.

SumARIO: I. Antecedentes generales. II. La función del Tribunal Especial para la Paz con control de convencionalidad. III. El ejercicio del Tribunal Especial para la Paz acorde a los estándares internacionales y a las normas de ius cogens.

IV. Conclusiones. V. Bibliografia.

\section{ANTECEDENTES GENERALES}

El 2012 fue un año en que las Fuerzas Armadas Revolucionarias de Colombia - más conocidas como las FARC o FARC-EP - y el gobierno del expresidente Juan Manuel Santos iniciaron en La Habana, Cuba, diálogos para un proceso de paz que incidiera en la terminación del conflicto armado, ${ }_{1}^{1}$ una ruta que diversos gobiernos habían intentado; no obstante, los resultados sobresalían por el fracaso, la complejidad y la continuidad del conflicto.

Esto ocurrió, como explica Uprimny, ${ }^{2}$ porque el debate sobre cómo enfrentar las violaciones masivas de derechos humanos en el marco de un proceso de paz reviste gran complejidad, por las dimensiones jurídicas, políticas y éticas que suelen presentar profundas tensiones entre sí. Estas tensiones se materializan en el enfrentamiento entre los imperativos jurídicos internacionales, que muestran una tendencia hacia la exigencia del castigo a los responsables de crímenes atroces, por un lado, y las restricciones derivadas de las realidades políticas y de la necesidad de lograr negociaciones exitosas para trascender el conflicto, por otro lado.

En este contexto, tuvieron que pasar alrededor de cuatro años para que la iniciativa liderada por el Premio Nobel de la Paz, Juan Manuel Santos, se concretara, finalmente, en un Acuerdo Paz, acto histórico ratificado el 26 de septiembre de 2016, para intentar acabar con un conflicto que data

1 Uprimny Yepes, Rodrigo et al., Justicia para la paz. Crímenes atroces, derecho a la justicia y paz negociada, Bogotá, Centro de Estudios de Derecho, Justicia y Sociedad, Dejusticia, 2014, p. 146 y ss.

2 Uprimny Yepes, Rodrigo y Botero Marino, Catalina (coords), ¿Justicia transicional sin transición? Verdad, justicia y reparación para Colombia, Bogotá, Centro de Estudios de Derecho, Justicia y Sociedad, 2006, p. 19.

Esta obra está bajo una Licencia Creative Commons

Atribución-NoComercial-SinDerivar 4.0 Internacional, IIJ-UNAM. 
aproximadamente de unos sesenta años, dejando millones de víctimas, muchas de ellas aún desplazadas por la violencia, y otras desaparecidas. ${ }^{3}$

Debe decirse que durante las negociaciones en La Habana ocurrieron acontecimientos inesperados: por un lado, tras casi cuatro años de negociación, dificultades y tensiones, los puntos acordados fueron sometidos a plebiscito, mecanismo de participación ciudadana consagrado en la Constitución Política de Colombia (artículo 103), regulado en la Ley 134 de 1994, como el pronunciamiento del pueblo convocado por el presidente de la República, mediante el cual apoya o rechaza una determinada decisión del Ejecutivo. No obstante, en un hecho excepcional la población colombiana optó por el NO, ante la pregunta por la aceptación de los Acuerdos de La Habana.

Esta situación debilitó los logros conseguidos; sin embargo, finalmente el texto quedó ratificado con seis puntos pactados entre las FARC y el gobierno, de la siguiente manera: punto 1. Sobre el Acuerdo de "Reforma Rural Integral"; unto 2. Acuerdo relativo a la "Participación política de las FARC-EP"; punto 3. Sobre el Acuerdo del "Cese al fuego y de hostilidades bilateral y definitivo y la dejación de las armas"; punto 4. Relativo al acuerdo de "Solución al problema de las drogas ilícitas"; punto 5. Acuerdo sobre las "Víctimas" del conflicto armado, y punto 6. Acuerdo relativo a los "Mecanismos de Implementación y Verificación". ${ }^{4}$

Ahora bien, en lo relativo al punto 5. Sobre víctimas, desde el Encuentro Exploratorio, en 2012, se acordó que el resarcimiento de las víctimas debería estar en el centro de cualquier acuerdo. Es por ello que se estableció la creación del Sistema Integral de Verdad, Justicia, Reparación y No Repetición (en adelante SIVJRNR o Sistema Integral), que contribuirá a la lucha contra la impunidad combinando mecanismos judiciales que permitan la investigación y sanción de las graves violaciones a los derechos humanos y las serias infracciones al derecho internacional humanitario, con mecanismos extrajudiciales complementarios que contribuyan al esclarecimiento de la verdad de lo ocurrido, la búsqueda de los desaparecidos y la reparación del daño causado a personas, a colectivos y a territorios

3 Centro Nacional de Memoria Histórica, Desaparición forzada. Balance de la contribución del CNMH al esclarecimiento histórico, Bogotá, CNMH, 2018.

4 Gobierno colombiano y las FARC-EP, Acuerdo Final para la terminación del conflicto y la Construcción de una paz estable y duradera, 2016, disponible en: https://www. jep.gov.co/Paginas/Normativa/Acuerdo-Final.aspx. 
enteros. Con relación al Sistema Integral, éste estará compuesto por cinco mecanismos y medidas, así:

a) La Comisión para el Esclarecimiento de la Verdad, la Convivencia y la No Repetición (en adelante la Comisión): será un órgano temporal y de carácter extrajudicial, que busca conocer la verdad de lo ocurrido y contribuir al esclarecimiento de las violaciones e infracciones y ofrecer una explicación amplia a toda la sociedad de la complejidad del conflicto; promover el reconocimiento de las víctimas y de las responsabilidades de quienes participaron directa e indirectamente en el conflicto armado, y promover la convivencia en los territorios para garantizar la no repetición.

La Comisión deberá cumplir tres objetivos fundamentales, que en su conjunto contribuyen a la no repetición del conflicto. En primer lugar, deberá contribuir al esclarecimiento de lo ocurrido y ofrecer una explicación amplia de la complejidad del conflicto, de tal forma que se promueva un entendimiento compartido en la sociedad, en especial de los aspectos menos conocidos del conflicto, como el impacto del conflicto en los niños, niñas y adolescentes y la violencia basada en género.

En segundo lugar, como se desprende de lo acordado, la Comisión deberá promover y contribuir al reconocimiento de las víctimas como ciudadanos y ciudadanas que vieron sus derechos vulnerados y como sujetos políticos de importancia para la transformación del país; el reconocimiento voluntario de responsabilidades individuales y colectivas por parte de todos quienes de manera directa o indirecta participaron en el conflicto como una contribución a la verdad, a la justicia, a la reparación y a la no repetición, y en general, el reconocimiento por parte de toda la sociedad de ese legado de violaciones e infracciones como algo que merece el rechazo de todos, y que no se debe ni se puede repetir.

En tercer lugar, la Comisión deberá promover la convivencia en los territorios, en el entendido de que la convivencia no consiste en el simple compartir de un mismo espacio social y político, sino en la creación de un ambiente transformador que permita la resolución pacífica de los conflictos y la construcción de la más amplia cultura de respeto y tolerancia en democracia.

b) Se crea también la Unidad Especial para la Búsqueda de Personas dadas por Desaparecidas en el Contexto y en Razón del Conflicto Armado: que será una unidad de carácter humanitario y extrajudicial, cuyo objetivo es dirigir, coordinar y contribuir a la implementación de acciones humanitarias de búsqueda e identificación de todas las personas dadas por 
desaparecidas en el marco del conflicto que se encuentren con vida y en los casos de fallecimiento, cuando sea posible, la localización y entrega digna de restos.

c) Por otra parte, se demanda una Jurisdicción Especial para la Paz (JEP), constituida por una serie de salas de justicia, entre las que se incluye una Sala de Amnistía e Indulto y un Tribunal Especial para la Paz (TEP), para administrar justicia e investigar, esclarecer, perseguir y sancionar las graves violaciones a los derechos humanos y las graves infracciones al derecho internacional humanitario. La JEP hace parte del Sistema Integral, y en su ejercicio, al ocuparse exclusivamente y de manera transitoria de las conductas relacionadas directa e indirectamente con el conflicto armado, no implica la sustitución de la jurisdicción ordinaria.

La JEP funcionará de manera especial para ejercer funciones judiciales de manera autónoma y preferente sobre los asuntos de su competencia, en especial respecto a conductas consideradas graves infracciones al derecho internacional humanitario o graves violaciones de los derechos humanos. Se aplicará únicamente a conductas cometidas con anterioridad a su entrada en vigor. Sin embargo, lo acordado también plantea que la responsabilidad de los destinatarios del SIVJRNR no exime al Estado de su deber de respetar y garantizar el pleno goce de los derechos humanos y de sus obligaciones, conforme al derecho internacional humanitario y al derecho internacional de los derechos humanos.

d) Como exigencia no menos importante, se instituye la creación de medidas de reparación integral para la construcción de la paz, que buscan asegurar la reparación integral de las víctimas, incluyendo los derechos a la restitución, la indemnización, la rehabilitación, la satisfacción y la no repetición, y la reparación colectiva de los territorios, las poblaciones y los colectivos más afectados por el conflicto y más vulnerables, en el marco de la implementación de los demás acuerdos. Con este fin, se fortalecerán los mecanismos existentes, se adoptarán nuevas medidas y se promoverá el compromiso de todos con la reparación del daño causado.

e) Finalmente, las garantías de no repetición: que serán el resultado, por una parte, de la implementación coordinada de todas las anteriores medidas y mecanismos, así como en general de todos los puntos del acuerdo final, y por la otra, de la implementación de medidas de no repetición que se acuerden en el marco del punto 3 -"Fin del Conflicto"-. ${ }^{5}$

\footnotetext{
5 Idem.
} 
Por lo tanto, teniendo en cuenta lo anteriormente descrito, el fin de este escrito es exponer al lector un acercamiento jurídico de fondo, sobre el escenario colombiano, en lo atinente al proceso de justicia transicional. El temario se concentra esencialmente en la función atribuida al Tribunal Especial para la Paz. Este ejercicio, a juicio de la autora, debe hacerse bajo el llamado que la jurisprudencia hace a los jueces, para que en la administración de justicia ejerzan control de convencionalidad teniendo en cuenta el imperativo de las normas de ius cogens.

No es gratuito que la Ley 1820 de 2016, "por medio de la cual se dictan disposiciones sobre amnistía, indulto y tratamientos penales especiales y otras disposiciones", consagre que no serán amnistiables las graves violaciones a los derechos humanos y las serias infracciones al derecho internacional humanitario cometidas en el contexto del conflicto armado, estándar internacional respetado por la comunidad internacional y ratificado por los diferentes sistemas de protección de los derechos humanos, de los cuales hace parte el Estado colombiano.

En esta coyuntura, en marzo de 2018, la Plenaria de la Jurisdicción Especial para la Paz, en ejercicio de la facultad conferida en el artículo transitorio 120 de la Constitución Política (Acto Legislativo 1o. de 2017, artículo 1o.), por el cual se adopta el Reglamento General de la Jurisdicción Especial para la Paz, adoptó las siguientes disposiciones normativas, entre las cuales destaca en su artículo 2o., que:

La JEP...; administra justicia de manera transitoria, independiente y autónoma y conoce de manera preferente sobre todas las demás jurisdicciones y de forma exclusiva de las conductas cometidas con anterioridad al 1 de diciembre de 2016, por causa, con ocasión o en relación directa o indirecta con el conflicto armado, por quienes participaron en el mismo, en especial respecto a conductas consideradas graves infracciones al Derecho Internacional Humanitario o graves violaciones de los Derechos Humanos...

En consecuencia, no se puede entonces excusar la comisión de conductas que vulneran claramente la conciencia misma de la humanidad, como los homicidios arbitrarios, las torturas, los tratos crueles, las tomas de rehenes, las desapariciones forzadas, los juicios sin garantías o la imposición de penas ex-post facto. ${ }^{6}$

6 Corte Constitucional, Sentencia C-225/95. Revisión de constitucionalidad del "Protocolo adicional a los Convenios de Ginebra del 12 de agosto de 1949, relativo a la 
Como corolario, se asume como hipótesis central que el Tribunal Especial para la Paz, máxima instancia de la JEP, deberá ceñirse, acorde a los estándares internacionales, a las normas de ius cogens y a las obligaciones internacionales contraídas en su nexo con el bloque de constitucionalidad y el control de convencionalidad, por varias razones; entre ellas aparecen estándares internacionales con efecto erga omnes y obligatoriedad, razón por la cual deben ser acatadas por todos los operadores jurídicos.

\section{LA FUNCIÓN DEL TRIBUNAL ESPECIAL PARA LA PAZ CON CONTROL DE CONVENCIONALIDAD}

\section{El Tribunal Especial para la Paz tendrá como función básica correspon-} der con los derechos de las víctimas a la verdad, justicia, reparación, y con ellos, a medidas de no repetición; el instrumento aplicable será el Marco Jurídico para la Paz, ${ }^{7}$ a propósito de la Ley de Amnistía e Indultos y otros tratamientos penales especiales, Ley 1820 de 2016, que no regirá para los delitos de lesa humanidad, genocidio y graves crímenes de guerra - esto es, toda infracción grave al derecho internacional humanitario cometida de forma sistemática - la toma de rehenes u otra privación grave de la libertad, la tortura, las ejecuciones extrajudiciales, la desaparición forzada, el acceso carnal violento y otras formas de violencia sexual, la sustracción de menores, el desplazamiento forzado, además del reclutamiento de menores, todo ello conforme a la tipología emanada del Estatuto de Roma (ER), de $1998,{ }^{8}$ instrumento del cual es parte el Estado colombiano.

Tampoco serán amnistiables, conforme lo establece la Ley 1820 de 2016, en su artículo 23, los delitos comunes que carecen de relación con la rebelión; es decir, aquellos que no hayan sido cometidos en el contexto

protección de las víctimas de los conflictos armados sin carácter internacional (Protocolo II)", 18 de mayo de 1995.

7 V. g. Congreso de la República, acto legislativo 01/2012, por medio del cual se establecen instrumentos jurídicos de justicia transicional en el marco del artículo 22 de la Constitución Política, y se dictan otras disposiciones, Bogotá, julio 21 de 2012; Acto legislativo 01, "por medio del cual se crea un título de disposiciones transitorias de la Constitución para la terminación del conflicto armado y la construcción de una paz estable y duradera y se dictan otras disposiciones", Bogotá, 4 de abril de 2017; Ley 1820 de 2016 , por medio de la cual se dictan disposiciones sobre amnistía, indulto y tratamientos penales especiales y otras disposiciones, Bogotá, 30 de diciembre de 2016.

8 Aprobado en Colombia mediante el decreto 2764 de 2002. 
y en razón de la rebelión durante el conflicto armado, o cuya motivación haya sido obtener beneficio personal, propio o de un tercero. Ahora bien, sólo serán amnistiables los delitos políticos y conexos, entendiendo por tales, aquellos en los cuales el sujeto pasivo de la conducta ilícita es el Estado y su régimen constitucional vigente. Lo establecido en este artículo no obsta para que se consideren delitos conexos con los delitos políticos aquellas conductas que hayan sido calificadas de manera autónoma como delitos comunes, siempre y cuando éstas se hubieran cometido en función del delito político y de la rebelión.

La Ley 1820 de 2016 que regirá para la jurisdicción especial para la paz es contemplada como un mecanismo de extinción de la acción penal, disciplinaria, administrativa y fiscal, que se concederá por los delitos políticos de "rebelión”, "sedición”, "asonada", "conspiración” y "seducción, usurpación y retención ilegal de mando" y los delitos que son conexos con éstos de conformidad con esta ley, ${ }^{9}$ lo cual no extingue el derecho de las víctimas a recibir reparación. En consecuencia, así como está estipulado en el Acuerdo sobre las Víctimas del Conflicto Armado, la responsabilidad de los destinatarios del SIVJRNR no exime al Estado de su deber de respetar y garantizar el pleno goce de los derechos humanos conforme al sistema jurídico internacional.

Así, la Ley 1820 consagra en su artículo 9 el deber del Estado de investigar, esclarecer, perseguir y sancionar conforme a los estándares internacionales en la materia, conexo a la figura del control de convencionalidad y el bloque de constitucionalidad. Esta última, como parámetro desarrollado por la misma Corte Constitucional en reiteradas sentencias, ${ }^{10}$ para incorporar de manera automática todos los tratados que versen sobre derechos humanos y áreas conexas al ordenamiento jurídico interno, y por el mandato de las normas de ius cogens, a todas las normas imperativas que no admiten acuerdo en contrario.

Así,

el bloque de constitucionalidad está compuesto por aquellas normas y principios que, sin aparecer formalmente en el articulado del texto constitucional, son utilizados como parámetros del control de constitucionalidad de las leyes, por cuanto han sido normativamente integrados a la Constitución, por diversas

9 Ley 1820 de 2016, artículo 15.

10 Corte Constitucional, sentencia T-878 de 2014; sentencia C-067 de 2003; sentencia C-582 de 1999; sentencia C-225 de 1995. 
vías y por mandato de la propia Constitución. Son pues verdaderos principios y reglas de valor constitucional, esto es, son normas situadas en el nivel constitucional, a pesar de que puedan a veces contener mecanismos de reforma diversos al de las normas del articulado constitucional stricto sensu. ${ }^{11}$

Esta corporación, en las sentencias citadas y en concordancia con la más autorizada doctrina y jurisprudencia internacionales, ha considerado que las normas de derecho internacional humanitario son parte integrante del ius cogens, así como también las normas imperativas derivadas del derecho internacional de los derechos humanos. Surge entonces

una verdadera integración jurídica entre el derecho interno de los países, en cuya cúpula se halla la Constitución Política y el derecho internacional cuando está de presente su ius cogens, dado que éste por representar valores superiores, inalienables e inajenables del individuo como son los Derechos Humanos, se coloca por encima de la misma normación internacional que pudiera desconocerlos y al mismo ius cogens habrá de acomodarse la legislación interna de los países. ${ }^{12}$

En efecto, la Corte Constitucional ha señalado que, salvo remisión expresa de normas superiores,

sólo constituyen parámetros de control constitucional aquellos tratados y convenios internacionales que reconocen derechos humanos (i) y, que prohíben su limitación en estados de excepción (ii). Es por ello que integran el bloque de constitucionalidad, entre otros, los tratados del derecho internacional humanitario, tales como los Convenios de Ginebra, los Protocolos I y II y ciertas normas del Pacto de San José de Costa Rica. ${ }^{13}$

Al mismo tiempo, a los Estados les rige el deber de adecuar no sólo su normativa interna conforme a los instrumentos internacionales en la materia, sino que los operadores jurídicos deben tener en cuenta las decisiones derivadas del sistema internacional de los derechos humanos por la figura del control de convencionalidad, que asiste la obligación correspondiente a los jueces y órganos vinculados a la administración de justicia, para fallar

\footnotetext{
11 Ibidem, sentencia C-225 de 1995.

12 Ibidem, sentencia C-027 de 1993.

13 Ibidem, sentencia C-582 de 1999.
} 
y actuar en la praxis jurídica conforme a la aplicación que del derecho internacional de los derechos humanos hacen los tribunales internacionales. Por tal razón, la misma Corte Constitucional ha reconocido que "el poder judicial está internacionalmente obligado a ejercer control de convencionalidad ex officio entre las normas internas y la Convención Americana". ${ }^{14}$

Al respecto, en el caso Boyce y otros vs. Barbados, ${ }^{15}$ la Corte Interamericana de Derechos Humanos (en adelante, Corte IDH) contextualizó de forma específica de qué manera debe ser implementado el control de convencionalidad en el ámbito interno. Explicó que los tribunales nacionales no sólo deben limitarse a realizar un examen de constitucionalidad de su normatividad, sino también de convencionalidad. En esta tarea, los jueces y órganos vinculados a la administración de justicia deben tener en cuenta no solamente los tratados que versen sobre derechos humanos, sino también la interpretación que del mismo ha hecho la Corte IDH como intérprete última, en este caso, de la Convención Americana de Derechos Humanos o Pacto de San José de Costa Rica (en adelante entiéndase Convención Americana). De tal manera, como se expresó en los casos Radilla Pacheco, ${ }^{16}$ Fernández Ortega ${ }^{17}$ y Rosendo Cantú, ${ }^{18}$ es necesario que las interpretaciones constitucionales y legislativas se adecuen al derecho internacional de los derechos humanos. ${ }^{19}$

Con lo cual, la hipótesis más fuerte que se asume es que el Tribunal Especial para la Paz (TEP) debe seguir, en estricto sentido, las normas de ius cogens y las obligaciones internacionales contraídas en su nexo con el bloque de constitucionalidad y el control de convencionalidad, pues la jurisprudencia emanada de los tribunales internacionales es parámetro de observancia, no sólo para los magistrados que constituyan el Tribunal Especial para la Paz, sino para cualquier operador jurídico.

14 Ibidem, sentencia C-500 de 2014.

15 Corte IDH, caso Boyce y Otros vs. Barbados, sentencia de excepción preliminar, fondo, reparaciones y costas, del 20 de noviembre de 2007, serie C, núm. 169.

16 Corte IDH, caso Radilla Pacheco vs. México, sentencia de excepciones preliminares, fondo, reparaciones y costas, del 23 de noviembre de 2009, serie C, núm. 209.

17 Fernández Ortega vs. México, sentencia de excepción preliminar, fondo, reparaciones y costas, del 30 de agosto del 2010, serie C, núm. 215.

18 Rosendo Cantú vs. México, interpretación de la sentencia de excepción preliminar, fondo, reparaciones y costas, 15 de mayo de 2011, serie C, núm. 225.

19 Caso Cabrera García y Montiel Flores vs. México, sentencia de excepción preliminar, fondo, reparaciones y costas, del 26 de noviembre de 2010, serie C, núm. 220. 
Por lo tanto, concluyentemente, a falta de estos parámetros, y, en ausencia de criterios de justicia, verdad y reparación, la implementación del Marco Jurídico para la Paz, con ellos los Acuerdos de La Habana, el proceso de paz podría correr el riesgo de ser un proceso fallido e ineficaz.

Recuérdese que el auge del derecho internacional de los derechos humanos y la influencia que ha tenido en los procesos de justicia transicional, entendiéndose por tal el corpus iuris creado en sociedades que han sufrido el impacto desproporcionado de múltiples manifestaciones de violencia, que se aplica excepcionalmente y de manera extraordinaria por tribunales ad hoc, para garantizar la consolidación de la paz, de manera estable y duradera - sin que ello implique el amparo de la impunidad o desatención de los estándares internacionales - ha permitido impregnar la normatividad existente no sólo a nivel constitucional, sino internacional, a través de la jurisprudencia y los mismos tratados internacionales — como pactos de obligatorio cumplimiento - . De esta manera, la configuración de los mismos se ha desarrollado de forma progresiva; por ello, los textos constitucionales suelen ser, por lo general, catálogos "vivos", de textura abierta, pues deben ir a la par de los fenómenos sociales, adecuándose también a la realidad social, razón por la cual se exige del derecho una transformación permanente y continua. De hecho, el artículo 93 de la Constitución colombiana, en consonancia con lo consagrado en el artículo 94, enlaza la figura del bloque de constitucionalidad con el control de convencionalidad, así:

Art. 93. Los tratados y convenios internacionales ratificados [entiéndase aprobados] por el Congreso, que reconocen los derechos humanos y que prohíben su limitación en los estados de excepción, prevalecen en el orden interno. Los derechos y deberes consagrados en esta Carta se interpretarán de conformidad con los tratados internacionales sobre derechos humanos ratificados por Colombia.

Art. 94. La enunciación de los derechos y garantías contenidos en la Constitución y en los convenios internacionales vigentes, no debe entenderse como negación de otros que, siendo inherentes a la persona humana, no figuren expresamente en ellos.

Lo anterior es capital precisarlo, toda vez que los diferentes convenios internacionales en materia de derechos humanos y otras áreas conexas otorgan pautas a seguir, de ahí el efecto impregnación que surten en el 
derecho doméstico, siendo una herramienta fundamental en cualquier proceso que afecte derechos humanos fundamentales, para moldear los textos normativos acorde a la realidad y necesidades actuales. Es por ello que las víctimas de graves violaciones a los derechos humanos e infracciones al derecho internacional humanitario, en el contexto colombiano, cuentan con un amplio y comprensivo corpus iuris internacional, que irradia a su vez los derechos emanados de la Constitución; es, por tanto, necesaria la aplicación de los respectivos estándares internacionales en materia de protección de derechos humanos por los operadores jurídicos.

En tal sentido, aunque algunos derechos no se encuentran de forma expresa en las Constitución como norma de normas, eso no quiere significar que no existan con contenido propio, máxime cuando tienen amplio desarrollo jurisprudencial y convencional en materia de derechos humanos. Esto es lo que explica por qué la exigencia del control de convencionalidad siempre se mantiene vigente como deber atribuido a los Estados en cabeza de los operadores jurídicos.

Sobre el particular, como exigencia derivada para los Estados aparecen en el derecho internacional de los derechos humanos, y particularmente en la Convención Americana, los derechos a las garantías judiciales y a la protección judicial, en sus artículos 8 y 25, respectivamente, derechos que tienen un fuerte contenido semántico en la lucha contra la impunidad, definida por la Corte IDH como "la falta en su conjunto de investigación, persecución, captura, enjuiciamiento y condena de los responsables de las violaciones de los derechos protegidos por la Convención Americana". ${ }^{20}$ La consecuencia inmediata es que como parámetro de control de convencionalidad, la Convención Americana se superpone como norma primaria superior, esto de conformidad con su artículo 2, que reza así: "los Estados están obligados a adoptar con arreglo a sus procedimientos constitucionales y a las disposiciones de esta Convención, las medidas legislativas o de otro carácter que fueren necesarias para hacer efectivos tales derechos y libertades".

Lo cual, para el caso sub examine, obliga al Estado colombiano a combatir la impunidad, aun el Marco Jurídico para la Paz, por todos los medios legales disponibles, pues la impunidad propicia la repetición crónica de las violaciones de derechos humanos y la total indefensión de las víctimas

20 Corte IDH, caso del Tribunal Constitucional vs. Perú, sentencia de fondo, reparaciones y costas, del 31 de enero de 2001, serie C, núm. 71; caso Bámaca Velásquez vs. Guatemala, sentencia de fondo, del 25 de noviembre de 2000, serie C, núm. 70. 
y de sus familiares. ${ }^{21}$ En tal sentido, la falta de recursos efectivos no sólo para combatir la impunidad, sino para garantizar el acceso a la justicia, contraviene un cúmulo de derechos, entre ellos el derecho a la verdad, que ha sido desarrollado vía jurisprudencial ampliamente a la luz de la Convención Americana.

Ante esta realidad, la Comisión Interamericana de Derechos Humanos $(\mathrm{CoIDH})$ ha sostenido que el derecho a la verdad no debe ser coartado a través de medidas legislativas o de otro carácter, como las leyes de amnistía. ${ }^{22}$ Así, en el caso de las Masacres de El Mozote y Lugares Aledaños, la Corte IDH dispuso que

El Salvador tendría que asegurar que la Ley de Amnistía General para la Consolidación de la Paz, cesara de representar un obstáculo para la investigación de los hechos materia del... caso, ni para la identificación, juzgamiento y eventual sanción de los responsables de los mismos y de otras graves violaciones de derechos humanos similares acontecidas durante el conflicto armado en El Salvador. ${ }^{23}$

Nótese que la Corte IDH obliga a seguir como parámetros de control de convencionalidad impedimentos fácticos o legales, tales como la expedición de leyes de amnistía y el acceso a la información sobre los hechos y circunstancias que rodean la violación de un derecho fundamental, que impida poner en marcha los recursos judiciales de la jurisdicción interna, porque resultan incompatibles con el derecho a la protección judicial previsto en el artículo 25 de la Convención Americana. El proceso destinado a establecer la verdad requiere del libre ejercicio del derecho a buscar y recibir información y la adopción de las medidas necesarias para habilitar al Poder Judicial a emprender y completar las investigaciones correspondientes. ${ }^{24}$

21 CoIDH, Verdad, justicia y reparación: cuarto informe sobre la situación de los derechos humanos en Colombia, OEA/Ser.L/V/II. Doc. 49/13, 31 diciembre 2013, párr. 201. Recuperado de: https://www.oas.org/es/cidh/docs/pdfs/justicia-verdad-reparaciones.pdf

22 Caso Barrios Altos vs. Perú, sentencia de fondo, 14 de marzo de 2001, serie C, núm. 75; caso Almonacid Arellano y otros vs. Chile, sentencia de excepciones preliminares, fondo, reparaciones y costas, 26 de septiembre de 2006, serie C, núm. 154.

23 Masacres de El Mozote y lugares aledaños vs. El Salvador, sentencia de fondo, reparaciones y costas, 25 de octubre de 2012, serie C, núm. 252.

24 CoIDH, Verdad, justicia y reparación..., cit., párr. 205.

Esta obra está bajo una Licencia Creative Commons Atribución-NoComercial-SinDerivar 4.0 Internacional, IIJ-UNAM. 
Igualmente, el control de convencionalidad obliga a seguir la interpretación que ha hecho la Corte IDH en sentido amplio respecto de los derechos amparados bajo la Convención Americana. Algunos de ellos constituyen aspectos claves en los procesos de justicia transicional, entre ellos el derecho a la verdad, asociado implícitamente con los derechos a las garantías judiciales y protección judicial, derechos que en determinados supuestos guardan relación con "el derecho de acceso a la información sobre graves violaciones de derechos humanos que se encuentran en instalaciones y archivos estatales". Siguiendo a la CoIDH y a la Corte IDH, también comprende una doble dimensión:

En primer lugar, se reconoce el derecho de las víctimas y sus familiares a conocer la verdad con respecto a los hechos que dieron lugar a graves violaciones de los derechos humanos... En segundo lugar, se ha consolidado la noción que este derecho no sólo corresponde a las víctimas y sus familiares, sino también a la sociedad en su conjunto... ${ }^{25}$

Recuérdese que el Comité de Derechos Humanos, el Tribunal Europeo de Derechos Humanos, la Corte IDH, la CoIDH y la Comisión Africana de Derechos Humanos y de los Pueblos han considerado que el hecho de no proporcionar información sobre violaciones de derechos humanos, y en específico "sobre la suerte y el paradero de los desaparecidos o sobre las circunstancias de una ejecución y el lugar exacto en el que se enterró a las víctimas, puede equivaler a tortura o maltrato. Sin embargo, el derecho a la verdad sigue siendo un derecho autónomo con su propia base jurídica". ${ }^{26}$

En consecuencia, acogiendo las bases que se derivan de los órganos e instrumentos internacionales, junto con la obligatoriedad de los operadores jurídicos para interpretar conforme a ellos, no se pueden desconocer los principios rectores originados de los tratados internacionales, pues marcan la pauta para el goce y ejercicio de los derechos contemplados en los distintos textos constitucionales, entre otras cosas, por una suerte de

25 CoIDH, Derecho a la verdad en Las Américas. OEA/Ser.L/V/II.152.Doc.2. 13 de agosto de 2014, párr. 15, disponible en: http://www.oas.org/es/cidh/informes/pdfs/Derecho-Verdad-es.pdf.

26 ONU, Promoción y protección de los derechos humanos. Estudio sobre el derecho a la verdad, E/CN.4/2006/91, de enero 9 de 2006, párr. 42, disponible en: http://www. concernedhistorians.org/content_files/file/to/120.pdf. 
constitucionalización del derecho internacional de los derechos humanos, vía control de convencionalidad y bloque de constitucionalidad en sede interna. Además, el principio pacta sunt servanda estipulado en la Convención de Viena de $1969^{27}$ impone como deber a los Estados, cumplir con las obligaciones derivadas de los tratados, puesto que en caso de incumplimiento procede responsabilidad internacional para el Estados parte.

En efecto, cuando un Estado es parte de un tratado internacional como la Convención Americana, todos sus órganos, incluidos sus jueces, están sometidos a aquél, lo cual les obliga a velar por que los efectos de las disposiciones de la Convención no se vean mermados por la aplicación de normas contrarias a su objeto y fin, por lo que, en conclusión, los jueces y órganos vinculados a la administración de justicia, en todos los niveles, están en la obligación de ejercer ex officio un "control de convencionalidad" 28 entre las normas internas y la Convención Americana, evidentemente, en el marco de sus respectivas competencias y de las regulaciones procesales. ${ }^{29}$

El Tribunal Especial para la Paz debe seguir ese imperativo, pues su ejercicio está amparado no sólo en el orden constitucional vigente, sino en las convenciones sobre derechos humanos, que dan sustento al mismo ordenamiento jurídico, junto con toda la normativa derivada, que exige verdad, justicia, reparación y medidas de no repetición, junto con la supresión de leyes de amnistía por la comisión de crímenes internacionales, en cuyo caso, en Colombia, la misma Ley de Amnistía e Indulto 1820 de 2016 estipula que le asiste al Estado como obligación derivada del derecho internacional de los derechos humanos, el deber de investigar, pues si con su actuación o en ausencia de ella las violaciones a los derechos humanos quedan impunes y no se restablece el daño causado, no estaría garantizando la protección efectiva de las personas bajo su tutela.

Por tanto, en garantía a los derechos de las víctimas, el Marco Jurídico para la Paz tuvo que ser objeto no sólo de control de constitucionalidad, sino de convencionalidad, habida cuenta que los tratados que versan sobre derechos humanos y la jurisprudencia derivada de las cortes inter-

\footnotetext{
27 Artículo 26.

28 Corte IDH, caso Heliodoro Portugal vs. Panamá, sentencia de excepciones preliminares, fondo, reparaciones y costas, 12 de agosto de 2008, serie C, núm. 186, párr. 180.

29 Caso Gelman vs. Uruguay, párr. 193; caso Rosendo Cantú y otra vs. México, párr. 219; caso Radilla Pacheco vs. México, párr. 339.
} 
nacionales prohíben las leyes de amnistía por la comisión de crímenes internacionales; por ello, sólo serán objeto de amnistía u otros eximentes de responsabilidad aquellos delitos considerados como políticos y conexos.

En tipología ha sido un concepto normativo empleado con tres fines plenamente diferenciables:

(i) permitir que a los condenados por estas conductas les sea otorgada una amnistía o les sea concedido un indulto; ejemplo de ello, es la consagración que desde 1991 se hizo en el numeral 17 del artículo 150 de la Constitución. (ii) Impedir que los perseguidos por conductas que se consideren delito político sean extraditados, tal y como lo prevé el tercer inciso del artículo 35 de la Constitución. (iii) Permitir que los condenados por estas conductas participen en política, específicamente para que puedan acceder a cargos públicos y ejercer el derecho de sufragio pasivo. ${ }^{30}$

Al tener en cuenta esta diferenciación, la Corte Constitucional ha establecido que resulta evidente que en instrumentos internacionales que forman parte del bloque de constitucionalidad y en diversas sentencias que conforman la jurisprudencia constitucional relativa a la materia se consagran límites respecto de: "i) la concesión de amnistías e indultos, así como ii) la prohibición de extradición de delincuentes por parte del Estado colombiano; límites que a su vez determinan cuáles delitos podrán considerarse como políticos o conexos a delitos políticos cuando estas categorías sean utilizadas con dichos fines". ${ }^{31}$ La particularidad de esta tipología de delitos en el ordenamiento jurídico colombiano es que no generan inhabilidad para el acceso a cargos públicos, como sí lo hacen los delitos comunes que implican pena privativa de la libertad.

Ahora bien, la misma Corte Constitucional, en sentencia C-579/13, tuvo que analizar si el "Marco Jurídico para la Paz" era incompatible con el pilar esencial que exige respetar, proteger y garantizar los derechos de la sociedad y de las víctimas, a través del cumplimiento de las obligaciones de investigar, juzgar y en su caso sancionar, las graves violaciones a los derechos humanos y al derecho internacional humanitario, justamente por el imperativo del control de convencionalidad.

\footnotetext{
30 Corte Constitucional, sentencia C-577 de 2014.

31 Idem.
} 
Al respecto, expresó:

existe un pilar fundamental de la Constitución que consiste en el compromiso del Estado social y democrático de derecho de respetar, proteger y garantizar los derechos de la sociedad y de las víctimas. En virtud de este mandato, existe la obligación de: (i) prevenir su vulneración; (ii) tutelarlos de manera efectiva; (iii) garantizar la reparación y la verdad; e (iv) investigar, juzgar y en su caso sancionar las graves violaciones a los Derechos Humanos y al Derecho Internacional Humanitario.

Consideró que para alcanzar una paz estable y duradera es legítimo adoptar medidas de justicia transicional, como los mecanismos de selección y priorización. La Sala examinó si la posibilidad de centrar esfuerzos en la investigación penal de los delitos de lesa humanidad, genocidio y crímenes de guerra cometidos de manera sistemática garantiza el cumplimiento de las obligaciones internacionales asumidas por Colombia, y concluyó que, en virtud de los instrumentos de derechos humanos y del derecho internacional humanitario, y los pronunciamientos de sus intérpretes, es legítimo que se dé una aplicación especial a las reglas de juzgamiento, siempre y cuando se asegure que, como mínimo, se enjuiciarán aquellos delitos. ${ }^{32}$

En cuanto a imputar los delitos sólo a sus máximos responsables, la Corte Constitucional consideró que el Estado no renuncia a sus obligaciones, por las siguientes razones:

(i) La concentración de la responsabilidad en los máximos responsables no implica que se dejen de investigar todos los delitos de lesa humanidad, genocidio y crímenes de guerra cometidos de manera sistemática, sino que permite que sean imputados solo a quienes cumplieron un rol esencial en su comisión; y (ii) se contribuye eficazmente a desvertebrar macroestructuras de criminalidad y revelar patrones de violaciones masivas de derechos humanos, asegurando en últimas la no repetición.

También analizó la renuncia condicionada a la persecución penal, y al respecto aclaró que la figura se encuentra limitada, por cuanto no aplica para los máximos responsables de los delitos de lesa humanidad, genoci-

32 Corte Constitucional, sentencia C-579 de 2013.

Esta obra está bajo una Licencia Creative Commons Atribución-NoComercial-SinDerivar 4.0 Internacional, IIJ-UNAM. 
dio $^{33}$ y crímenes de guerra cometidos de manera sistemática, conforme con los estándares internacionales.

Finalmente,

explicó que la renuncia condicionada a la persecución penal se justifica al ponderar la obligación de investigar, juzgar y en su caso sancionar, con el deber de prevenir futuras violaciones a los derechos humanos en la búsqueda de una paz estable y duradera... siempre que se encuentren orientados a satisfacer los derechos de las víctimas a la verdad, la justicia, la reparación y la no repetición, con observancia de los deberes estatales de investigación y sanción de las graves violaciones de los derechos humanos y el Derecho Internacional Humanitario. ${ }^{34}$

La jurisprudencia invocada evidencia de forma clara y contundente cómo opera la subsidiaridad del derecho internacional y su armonización a través del derecho interno, habida cuenta del necesario control de convencionalidad. No obstante, en virtud del principio de complementariedad, en caso de que el derecho vigente con la constitución de la JEP no sea suficiente para el esclarecimiento de los hechos con criterios de verdad, justicia y reparación, ora porque se desconocen los estándares internacionales en la materia, ora porque las FARC-EP incumplan lo pactado en los Acuerdos de La Habana, la intervención de los órganos del sistema interamericano - incluso los del sistema universal - y la competencia de la Corte Penal Internacional, siempre estará vigente, precisamente por tratarse de graves transgresiones a los derechos humanos y al derecho internacional humanitario, en cuya circunstancia, tales violaciones no prescriben.

\section{EL EJERCICIO DEL TRIBUNAL ESPECIAL PARA LA PAZ ACORDE A LOS ESTÁNDARES INTERNACIONALES Y A LAS NORMAS DE IUS COGENS}

Una vez aclarado lo anterior, es necesario invocar puntualmente la aplicabilidad de las normas de ius cogens en el marco del TEP, habida cuenta que el derecho internacional de los derechos humanos designa reglas de

\footnotetext{
33 Recuérdese la consagración de la tipología en la Convención para la Prevención y la Sanción del Delito de Genocidio de 1948.

34 Corte Constitucional, sentencia C-579 de 2013.
} 
carácter imperativos que no admiten acuerdo en contrario bajo la pena de nulidad absoluta. Por ello, estas normas ${ }^{35}$ tienen la característica de ser inderogables, obligatorias, con efecto erga omnes, es decir, rigen para todos los Estados, entre ellas el principio de igualdad y no discriminación, la prohibición de la tortura, ${ }^{36}$ los principios básicos de protección de los derechos humanos, la proscripción del uso de la guerra, la prohibición del delito de genocidio y de crímenes contra la humanidad, y con ellos, la prohibición de la desaparición forzada ${ }^{37}$ de personas y las leyes de amnistía, indultos y otros eximentes de responsabilidad, cuando contravengan bienes jurídicos superiores.

También son parte integrante del ius cogens

los principios del derecho internacional humanitario plasmados en los Convenios de Ginebra y en sus dos Protocolos, por el hecho de constituir un catálogo ético mínimo aplicable a situaciones de conflicto nacional o internacional, ampliamente aceptado por la comunidad internacional. En consecuencia, su fuerza vinculante proviene de la universal aceptación y reconocimiento que la comunidad internacional de Estados en su conjunto le ha dado al adherir a esa axiología y al considerar que no admite norma o práctica en contrario... Conviene tener en cuenta que tanto los tratados de derechos humanos en

35 Cepeda Rodríguez, Emerson, “Interrelación entre el ius cogens y el derecho blando. Derechos sociales y responsabilidad social corporativa en la justicia transicional", Revista de Derecho Público, Universidad de los Andes, Colombia, núm. 36, junio 2016, pp. 1-16. DOI: disponible en: http://dx.doi.org/10.15425/redepub.36.2016.02; Cançado Trindade, Antonio Augusto, Derecho internacional de los derechos humanos. Esencia y trascendencia del derecho internacional de los derechos humanos (votos en la Corte Interamericana de Derechos Humanos 1991-2006), México, Porrúa-Universidad Iberoamericana, 2007, pp. 82-83 y ss.; Cherif Bassiouni, Mahmoud, "International Crimes: «Jus Cogens» and «Obligatio Erga Omnes»", Law and Contemporary Problems, vol. 59, num. 4, Accountability for International Crimes and Serious Violations of Fundamental Human Rights, autumn, 1996, pp. 63-74; Cebada Romero, Alicia, "Los conceptos de obligación erga omnes, ius cogens y violación grave a la luz del nuevo proyecto de la CDI sobre responsabilidad de los Estados por hechos ilícitos", Revista Electrónica de Estudios Internacionales, núm. 4, junio 2002, obtenido de: http://www.reei.org/index. php/revista/num4/archivos/Cebada.PDF.

36 Convención contra la Tortura y otros Tratos o Penas Crueles, Inhumanos o Degradantes de 1984 y la Convención Interamericana para Prevenir y Sancionar la Tortura de 1985.

37 Convención Interamericana sobre Desaparición Forzada de Personas de 1994 y la Convención Internacional para la Protección de Todas las Personas contra las Desapariciones Forzadas de 2006. 
sentido estricto, como los convenios de derecho humanitario son normas de ius cogens que buscan, ante todo, proteger la dignidad de la persona humana. Son pues normatividades complementarias que, bajo la idea común de la protección de principios de humanidad, hacen parte de un mismo género: el régimen internacional de protección de los derechos de la persona humana. ${ }^{38}$

Las normas de ius cogens, siguiendo a Gómez-Robledo y Witker, ${ }^{39}$ soportan el orden público internacional; esto es, normas y principios generales que constituyen su fundamento estructural, y por esta razón no pueden ser remplazadas ni sustituidas sin que el sistema pierda sus características definitorias. ${ }^{40}$ En tal sentido, Cançado Trindade ${ }^{41}$ entiende que el acceso a la justicia y las garantías judiciales en el sentido de los artículos 25 y 8 de la Convención Americana, tomados conjuntamente, hacen parte del dominio del jus cogens. ${ }^{42}$

Con estas características, la Convención de Viena de 1969 estipula en su artículo 53, que todo tratado que en el momento de su celebración esté en oposición con una norma imperativa (jus cogens) de derecho internacional general será nulo, entendiendo por tal una norma aceptada y reconocida por la comunidad internacional de Estados en su conjunto ${ }^{43}$ como norma que no admite acuerdo en contrario, y que sólo puede ser modificada por una norma ulterior de derecho internacional general que tenga el mismo carácter. Por tanto, las potestades derivadas para el TEP no son ajenas a los

\footnotetext{
38 Corte Constitucional, sentencia C-225 de 1995.
}

39 Gómez-Robledo, Alonso y Witker Velázquez, Jorge (coords), Diccionario de derecho internacional, México, UNAM-Porrúa, 2001, p. 252.

40 Gómez-Robledo, Antonio, El ius cogens internacional. Estudio historico-critico, México, UNAM, Instituto de Investigaciones Jurídicas, 2003, p. 60.

41 Cançado Trindade, Augusto, "Reflexiones sobre los tribunales internacionales contemporáneos y la búsqueda de la realización del ideal de la justicia internacional”, Cursos de Derecho Internacional y Relaciones Internacionales de Vitoria-Gasteiz, Universidad del País Vasco, 2010, p. 35. Disponible en: www.ehu.eus/cursosderechointernacionalvitoria/ponencias/pdf/2010/2010_1.pdf. También puede consultarse Cançado Trindade, Augusto, "La ampliación del contenido material del ius cogens", 2007, p. 8, disponible en: http://www.oas.org/es/sla/ddi/docs/publicaciones_digital_XXXIV_curso_derecho_in ternacional_2007_Antonio_Augusto_Cancado_Trindade.pdf.

42 Corte IDH, caso de la Masacre de Pueblo Bello vs. Colombia, sentencia de fondo, reparaciones y costas, 31 de enero de 2006, serie C, núm. 140. párr. 64.

43 Díaz Tolosa, Regina, "El reconocimiento del ius cogens en el ordenamiento jurídico chileno", Revista Chilena de Derecho, 41, núm. 2, 2014, p. 560, disponible en: http:// www.scielo.cl/pdf/rchilder/v41n2/art07.pdf. 
mandatos jurídicos internacionales; dicho de otra forma, las normas de ius cogens se imponen a la soberanía estatal, por cuanto los derechos humanos aparecen como límite al ejercicio del poder.

La naturaleza jurídica del Tribunal Especial para la Paz, que ya quedó descrita en acápites anteriores, y con ella la normativa derivada del Marco Jurídico para la Paz, da tratamientos especiales en materia penal a los integrantes de las FARC-EP, siempre y cuando las conductas infringidas sean delitos políticos y conexos. Este sería el máximo umbral de aplicación de la Ley de Amnistía e Indultos, pues para los crímenes internacionales está la prohibición tajante de aplicación de amnistías y otros eximentes de responsabilidad.

La cuestión es que, a pesar de la constitución de dicho marco normativo, hay delitos, como la desaparición forzada de personas, cuya prohibición está contemplada como una norma de ius cogens, que, de quedar impunes, abren la puerta no sólo a los órganos del sistema interamericano de derechos humanos, sino a la activación de la Corte Penal Internacional, teniendo en cuenta que por su naturaleza es un delito continuado que sólo culmina cuando aparece la presunta víctima o se tiene indicio de su paradero.

La caracterización pluriofensiva y continuada o permanente de la desaparición forzada, en el sistema interamericano,

se desprende no sólo de la propia definición del artículo III de la Convención Interamericana sobre Desaparición Forzada de Personas, los travaux préparatoires a ésta, su preámbulo y normativa, sino también de otras definiciones contenidas en diferentes instrumentos internacionales que, asimismo, señalan como elementos concurrentes y constitutivos de la desaparición forzada: a) la privación de la libertad; b) la intervención directa de agentes estatales o por la aquiescencia de éstos, y c) la negativa de reconocer la detención y de revelar la suerte o paradero de la persona interesada. ${ }^{44}$

Por tanto, implica de base un conjunto de violaciones simultáneas a diferentes derechos. Esta tipología requiere de un análisis sistémico y comprensivo, en razón de la pluralidad de conductas que, cohesionadas por un único fin, vulneran mientras subsistan, bienes jurídicos protegidos por el derecho internacional de los derechos humanos de manera permanente. ${ }^{45}$

\footnotetext{
44 Caso Radilla Pacheco vs. México, 2009, párr. 140.

45 Caso González Medina y Familiares vs. República Dominicana, 2012, párr. 129.
} 
Así, la Corte DIH ha establecido que la desaparición forzada de personas constituye una violación múltiple, ${ }^{46}$ que inicia con una privación de libertad contraria al artículo 7 de la Convención Americana. ${ }^{47}$ La Corte IDH instituyó a su vez, que el sometimiento de detenidos a cuerpos represivos oficiales, agentes estatales o particulares que actúen con su aquiescencia o tolerancia, que impunemente practiquen la tortura y el asesinato, representa, por sí mismo, una infracción al deber de prevención de violaciones a los derechos a la integridad personal y a la vida. Esto es lo que obliga una conexión necesaria entre la desaparición forzada con la violación simultánea de diferentes derechos humanos.

Los tribunales penales internacionales anteriores a la CPI también se han pronunciado invocando normas de ius cogens, entre ellas la prohibición de la tortura. El Tribunal Penal Internacional para la ex Yugoslavia (TIPY), por ejemplo, en el caso prosecutor (fiscal) vs. Furundzija afirmó:

cabe señalar que la prohibición de la tortura establecida en los tratados de derechos humanos consagra un derecho absoluto, que nunca puede ser derogado, ni siquiera en caso de emergencia (por este motivo la prohibición también se aplica a situaciones de conflicto armado). Esto está vinculado al hecho..., que la prohibición de la tortura es una norma imperativa o jus cogens. Esta prohibición es tan extensa que incluso el derecho internacional impide a los Estados expulsar, devolver o extraditar a una persona a otro Estado cuando existan motivos fundados para creer que la persona estaría en peligro de ser sometida a tortura. ${ }^{48}$

Estas disposiciones de los tratados imponen a los Estados la obligación de prohibir y castigar la tortura, así como de abstenerse de practicar la

\footnotetext{
46 Caso Gomes Lund y Otros ("Guerrilha do Araguaia”) vs. Brasil, 2012, párr. 103.

47 Ibidem, párr. 122.

48 International Tribunal for the Prosecution of Persons Responsible for Serious Violations of International Humanitarian Law Committed in the Territory of the Former Yugoslavia since 1991. Presecutor vs. Furundzija, case IT-95-17/1-T. Judgement. 10 december 1998, párr. 144. It should be noted that the prohibition of torture laid down in human rights treaties enshrines an absolute right, which can never be derogated from, not even in time of emergency (on this ground the prohibition also applies to situations of armed conflicts). This is linked to the fact, discussed below, that the prohibition on torture is a peremptory norm or jus cogens. This prohibition is so extensive that States are even barred by international law from expelling, returning or extraditing a person to another State where there are substantial grounds for believing that the person would be in danger of being subjected to torture (versión original).
} 
tortura a través de sus funcionarios. En el derecho internacional de los derechos humanos, que se refiere a la responsabilidad de los Estados más que a la responsabilidad penal individual, la tortura está prohibida como delito penal y es sancionada por la legislación nacional. Además, todos los Estados partes en los tratados pertinentes han reconocido y están obligados a ejercer la jurisdicción para investigar, perseguir y castigar a los infractores. Por lo tanto, en la legislación de derechos humanos también la prohibición de la tortura se extiende y afecta directamente la responsabilidad penal de las personas. ${ }^{49}$

Ahora bien, la prohibición de la tortura es tan estricta que para prevenir su ocurrencia no basta con intervenir después de la imposición de la tortura, cuando la integridad física o moral de los seres humanos ya ha sido irremediablemente dañada.

Los Estados están obligados a poner en práctica todas las medidas que puedan prevenir la perpetración de la tortura, tal como lo expresó el Tribunal Europeo de Derechos Humanos en Soering vs. Reino Unido, el derecho internacional tiene la intención de prohibir no sólo las infracciones reales, sino también las violaciones potenciales de la prohibición de la tortura (así como cualquier trato inhumano y degradante).

De esto se desprende que las normas internacionales prohíben no sólo la tortura, sino también (i) la falta de adopción de las medidas nacionales necesarias para aplicar la prohibición (ii) y el mantenimiento en vigor o la aprobación de leyes contrarias a la prohibición. ${ }^{50}$

Esta exigencia se mantiene latente y vigente en todos los sistemas de responsabilidad, tanto para los Estados en el sistema regional y universal como para las personas en el ámbito de la Corte Penal Internacional (CPI), situación que explica cómo la no aplicación de estos principios básicos activaría no sólo el sistema penal derivado del ER, sino la responsabilidad para los Estados en los diferentes sistemas de protección de los derechos humanos.

Ahora bien, teniendo en cuenta el carácter de ius cogens del acceso a la justicia y las garantías judiciales — recuérdese que Colombia tenía una reserva que fue propuesta durante el gobierno del expresidente Andrés Pastrana, que se ratificó durante el gobierno del expresidente Álvaro Uribe-

\footnotetext{
49 Ibidem, párr. 145

50 Ibidem, párr. 148.
} 
en relación a la competencia de la CPI para conocer de crímenes de guerra, bajo el pretexto de impulsar un acuerdo de paz que diera terminación al conflicto, $\mathrm{y}$, por tanto, la jurisdicción de la CPI no se convirtiera en un obstáculo para dicho propósito, lo cual impidió que en el marco del ER la CPI pudiera investigar por un lapso de siete años crímenes de guerra para el caso de Colombia, terminándose dicha reserva en 2009.

Sin embargo, la competencia de la CPI estuvo vigente desde 2002 en relación con crímenes de lesa humanidad y genocidio, hecho que deja otra ventana abierta, en caso de que no se satisfaga con el Tribunal Especial para la Paz el derecho de las víctimas con criterio de justica, para que la CPI reabra investigaciones por estos dos crímenes, pues conforme al artículo 17, relativo a las cuestiones de admisibilidad, el ER prevé que no haya litispendencia, y que no opere la cosa juzgada, ${ }^{51}$ pues la CPI no puede fallar, entre otras cosas, con base en los mismos hechos y delitos incoados por otro tribunal competente, recuérdese el artículo 20 del ER:

1. La Corte no procesará a nadie que haya sido procesado por otro tribunal en razón de hechos también prohibidos en virtud de los artículos 6 , 7 u 8, a menos que el proceso en el otro tribunal:

a) Obedeciera al propósito de sustraer al acusado de su responsabilidad penal por crímenes de la competencia de la Corte, o

b) No hubiera sido instruido en forma independiente o imparcial de conformidad con las debidas garantías procesales reconocidas por el derecho internacional o lo hubiera sido de alguna manera que, en las circunstancias del caso, fuera incompatible con la intención de someter a la persona a la acción de la justicia.

Con relación a lo anterior, la CPI puede valorar si la decisión adoptada por el Tribunal Especial para la Paz ha sido, dado el caso, con el propósito de sustraer a la persona de que se trate de su responsabilidad penal por crímenes de la competencia de la Corte para proceder a investigar conforme lo estipula el ER.

Otro asunto de sumo cuidado es el retardo injustificado con relación al llamado de justicia de las presuntas víctimas, pues si en un plazo razonable, teniendo en cuenta la complejidad del asunto y la gravedad de los hechos, no hay decisión de fondo por el Tribunal Especial para la Paz, queda la interpretación abierta sobre si la Fiscalía de la CPI podría investigar motu proprio, debido al retardo injustificado. La Corte IDH, por ejemplo,

\footnotetext{
51 Artículo 20 del ER.
} 
en el caso Las Palmeras vs. Colombia, basándose en casos anteriores, por ejemplo, Genie Lacayo vs. Nicaragua ${ }^{52}$ estipuló que un término superior a cinco años rebasa los límites de la razonabilidad prevista por el artículo 8.1 de la Convención; por lo tanto, entendió que la víctima no estaba obligada a soportar la negligencia por la mora en la administración de justicia.

Acorde a lo anterior, la Corte IDH ha señalado que no pueden considerarse efectivos aquellos recursos que, por las condiciones generales del país o incluso por las circunstancias particulares de un caso dado, resulten ilusorios. Ello puede ocurrir, por ejemplo, cuando su inutilidad haya quedado demostrada por la práctica, porque el órgano jurisdiccional carezca de la independencia necesaria para decidir con imparcialidad o porque falten los medios para ejecutar sus decisiones; por cualquier otra situación que configure un cuadro de denegación de justicia, como sucede cuando se incurre en retardo injustificado en la decisión. Esta garantía de protección de los derechos de los individuos no supone sólo el resguardo directo a la persona vulnerada, sino, además, a los familiares, quienes, por los acontecimientos y circunstancias particulares del caso, son quienes ejercen la reclamación en el orden interno. Además, la Corte IDH ha manifestado que del artículo 8 de la Convención Americana se desprende que las víctimas de las violaciones de los derechos humanos, o sus familiares, deben contar con amplias posibilidades de ser oídos y actuar en los respectivos procesos, tanto en procura del esclarecimiento de los hechos y del castigo de los responsables como en busca de una debida reparación. ${ }^{53}$

En el mismo sentido, la CPI podría basarse en los precedentes del sistema interamericano para hacer la misma interpretación, si fuera el caso, teniendo en cuenta no sólo la complejidad del asunto, sino los parámetros perseguidos con el artículo 17.2 del ER, pues consagra que procede la admisibilidad de un caso, siempre,

... b) Que haya habido una demora injustificada en el juicio que, dadas las circunstancias, sea incompatible con la intención de hacer comparecer a la persona de que se trate ante la justicia; c) Que el proceso no haya sido o no esté siendo sustanciado de manera independiente o imparcial y haya sido o esté siendo sustanciado de forma en que, dadas las circunstancias, sea incompatible con la intención de hacer comparecer a la persona de que se trate ante la justicia.

52 Caso Genie Lacayo vs. Nicaragua, 1997, párr. 81.

53 Caso Las Palmeras vs. Colombia, 2000, párr. 59.

Esta obra está bajo una Licencia Creative Commons Atribución-NoComercial-SinDerivar 4.0 Internacional, IIJ-UNAM. 
Por otra parte, los criterios de la CPI respecto a su admisibilidad y competencia por crímenes internacionales pueden, vía interpretación, ser extensivos, conforme a los precedentes de otros tribunales, toda vez que el ER, en su artículo 21, estipula, con relación al derecho aplicable, que

1. La Corte aplicará:

a) En primer lugar, el... Estatuto, los Elementos de los crímenes y sus Reglas de Procedimiento y Prueba;

b) En segundo lugar, cuando proceda, los tratados aplicables, los principios y normas del derecho internacional, incluidos los principios establecidos del derecho internacional de los conflictos armados;...

2. La Corte podrá aplicar principios y normas de derecho respecto de los cuales hubiere hecho una interpretación en decisiones anteriores.

3. La aplicación e interpretación del derecho de conformidad con el presente artículo deberá ser compatible con los derechos humanos internacionalmente reconocidos...

La conclusión inmediata es que debido a los imperativos derivados de las normas de ius cogens, el TEP, con la aplicación de la Jurisdicción Especial para la Paz, debe vincular, en interpretación extensiva, los precedentes de la CPI, con los restantes en la materia, en otros tribunales penales internacionales y cortes de protección de derechos humanos por control de convencionalidad, siempre que esos principios no sean incompatibles con el derecho interno ni con el orden internacional ni con las normas y estándares internacionalmente reconocidos.

\section{CONCLUSIONES}

Lo explicado deja suficiente claridad con relación a que el derecho internacional de los derechos humanos, el derecho internacional humanitario y el sistema del ER son un todo armonioso que rigen de manera íntegra en la coyuntura actual colombiana, con lo cual, su observancia, por todo lo expuesto, es obligatoria, teniendo cuenta la fuerza de las normas de ius cogens y la principialística derivada. Máxime, cuando la CPI y la Corte IDH no están exentas de intervenir, en caso de que se diera cualquiera de las circunstancias anteriormente explicadas: 
1. Retardo injustificado en las decisiones del Tribunal Especial para la Paz;

2. Incompatibilidad en la tipología de crímenes con las leyes de amnistía;

3. Falta de independencia e imparcialidad del Tribunal Especial para la Paz;

4. Y, por último, y no menos importante, incongruencia en las decisiones con relación a los derechos de verdad, justicia, reparación y medidas de no repetición, de conformidad con los estándares internacionales en la materia.

En suma, este escrito es una descripción sensata y no menos rigurosa, en el estudio jurídico posible, sobre la aplicabilidad de las normas de ius cogens en las providencias del Tribunal Especial para la Paz, pues en todo caso estas normas se imponen sobre el Marco Jurídico para la Paz, bajo la pena de responsabilidad internacional. Esto implica, por tanto, que investigar y sancionar crímenes por graves violaciones a los derechos humanos e infracciones al derecho internacional humanitario conforme a los estándares internacionales no es una opción, es una obligación.

Por otra parte, se hace hincapié en que la JEP, acorde a su mandato, no sustituirá a la jurisdicción ordinaria, si bien asumirá casos con ocasión o en relación directa o indirecta con el conflicto armado, por quienes participaron en el mismo, sólo serán amnistiables los delitos políticos y conexos. Esto, se reitera, no exime al Estado de su deber de respetar y garantizar los estándares internacionales emanados del derecho internacional de los derechos humanos, concretados en múltiples tratados internacionales, que en Colombia hacen parte del bloque de constitucionalidad, y que bajo la jurisprudencia de la Corte IDH también vinculan al Estado por la figura del control de convencionalidad.

Finalmente, los estándares internacionales en la materia son claros, al demandar la creación de medidas de reparación integral para asegurar la reparación integral de las víctimas, incluyendo los derechos a la restitución, la indemnización, la rehabilitación, la satisfacción y la no repetición, elementos indispensables para garantizar el éxito de los Acuerdos de La Habana y, con ellos, la Jurisdicción Especial para la Paz. 


\section{BiBLIOGRAFÍA}

Cançado Trindade, Antonio Augusto, "Reflexiones sobre los tribunales internacionales contemporáneos y la búsqueda de la realización del ideal de la justicia internacional", Cursos de derecho internacional y relaciones internacionales de Vitoria-Gasteiz, País Vasco, Universidad del País Vasco, 2010. Disponible en: www.ehu.eus/cursosderechointernacionalvitoria/ponencias/pdf/2010/2010_1.pdf.

Cançado Trindade, Antonio Augusto, Derecho internacional de los derechos humanos. Esencia y trascendencia del derecho internacional de los derechos humanos (votos en la Corte Interamericana de Derechos Humanos 1991-2006), México, Porrúa-Universidad Iberoamericana, 2007.

CAnÇAdo Trindade, Antonio Augusto, "La ampliación del contenido material del ius cogens", 2007. Disponible en: http://www.oas.org/es/ sla/ddi/docs/publicaciones_digital_XXXIV_curso_derecho_internacional_2007_Antonio_Augusto_Cancado_Trindade.pdf.

CeBADA Romero, Alicia, "Los conceptos de obligación erga omnes, ius cogens y violación grave a la luz del nuevo proyecto de la CDI sobre responsabilidad de los Estados por hechos ilícitos", Revista Electrónica de Estudios Internacionales, núm. 4, junio 2002. Disponible en: http:// www.reei.org/index.php/revista/num4/archivos/Cebada.PDF.

Centro Nacional de Memoria Histórica, Desaparición forzada. Balance de la contribución del CNMH al esclarecimiento histórico, Bogotá, CNMH, 2018.

CEPEDA RodríGuez, Emerson, "Interrelación entre el ius cogens y el derecho blando. Derechos sociales y responsabilidad social corporativa en la justicia transicional", Revista de Derecho Público, núm. 36, Colombia, Universidad de los Andes, 2016, DOI: http://dx.doi.org/10.15425/ redepub.36.2016.02.

Cherif BASsiouni, Mahmoud, "International Crimes: «Jus Cogens» and «Obligatio Erga Omnes»", Law and Contemporary Problems, vol. 59, núm. 4, Accountability for International Crimes and Serious Violations of Fundamental Human Rights, 1996.

Comisión Interamericana De Derechos Humanos, Derecho a la verdad en Las Américas. OEA/Ser.L/V/II.152.Doc.2. 13 de agosto de 
2014. Disponible en: http://www.oas.org/es/cidh/informes/pdfs/Derecho-Verdad-es.pdf.

COMISIÓn INTERAMERICANA DE DEREChOs Humanos, Verdad, justicia y reparación. Cuarto informe sobre la situación de los derechos humanos en Colombia. OEA/Ser.L/V/II. Doc.49/13. Disponible en: https://www. oas.org/es/cidh/docs/pdfs/justicia-verdad-reparacion-es.pdf.

DíAz TolosA, Regina, "El reconocimiento del ius cogens en el ordenamiento jurídico chileno". Revista Chilena de Derecho, 41, núm. 2, 2014, pp. 555-587. Disponible en: http://www.scielo.cl/pdf/rchilder/ v4ln2/art07.pdf.

GómEZ-RoBledo, Alonso, El ius cogens internacional. Estudio históricocrítico. México, UNAM, Instituto de Investigaciones Jurídicas, 2003.

Gómez-Robledo, Alonso y Witker VelÁzQuez, Jorge (coords), Diccionario de derecho internacional, México, UNAM-Porrúa, 2001.

ORgANIZACIÓN DE NACIONES UNIDAS, Promoción y protección de los derechos humanos, Estudio sobre el derecho a la verdad, E/CN.4/2006/91, 2006. Disponible en: http://www.concernedhistorians.org/content_files/file/to/120.pdf.

UPRIMNY YEPES, Rodrigo et al., Justicia para la paz. Crímenes atroces, derecho a la justicia y paz negociada, Bogotá, Centro de Estudios de Derecho, Justicia y Sociedad, Dejusticia, 2014.

UPRIMNY YEPES, Rodrigo y BOTERO MARINO, Catalina, ¿Justicia transicional sin transición? Verdad, justicia y reparación para Colombia, Bogotá, Centro de Estudios de Derecho, Justicia y Sociedad, 2006.

Fecha de recepción: 16 de noviembre de 2018.

Fecha de aceptación: 14 de octubre de 2019.

Esta obra está bajo una Licencia Creative Commons Atribución-NoComercial-SinDerivar 4.0 Internacional, IIJ-UNAM. 


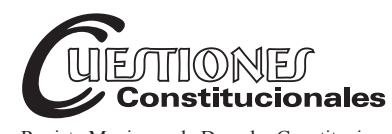

Revista Mexicana de Derecho Constitucional Núm. 43, julio-diciembre 2020

\section{Ponderações e críticas sobre a eficácia vinculante dos motivos determinantes}

\section{Ponderation and criticism on the binding effectiveness of the determinants}

\section{Flávio PANSIERI* Otávio Augusto BAPTISTA DA LuZ**}

RESUMO: O presente artigo tem por objetivo analisar as ponderações e críticas sobre a eficácia vinculante dos motivos determinantes. Adentra-se nas teorias importadas do direito alemão para a compreensão de suas acepções na realidade brasileira. Para a formação desse entendimento, subdivide-se o estudo em abordagens sobre o suposto engessamento da evolução constitucional; da violação ao princípio da congruência; do diálogo institucional e dos motivos Determinantes e Obiter Dicta. Por fim, estuda-se a jurisprudência reiterada, expectativa qualificada e a proteção da confiança. Conclui-se que a modulação de efeitos é um verdadeiro dever da Corte para com o jurisdicionado, este dever está vinculado a força normativa à Constituição, que não pode ignorar a complexidade de interesses que esta abarca, e nesse sentido, deve buscar o equilíbrio objetivando a máxima efetividade de seus dispositivos.
ABSTRACT: The purpose of this papper is to analyze the weights and criticisms about the binding effectiveness of the determinant motives. It is introduced in the imported theories of the German law for the understanding of its meanings in the Brazilian reality. For the formation of this understanding, the study is subdivided in approaches on the supposed plastering of the constitutional evolution; from the violation of the principle of congruence; of the institutional dialogue and of the determinants and Obiter Dicta. Finally, it is studied the reiterated jurisprudence, qualified expectation and the protection of the trust. It is concluded that the modulation of effects is a true duty of the Court to the jurisdiction, this duty is bound by normative force to the Constitution, which can not ignore the complexity of interests that it covers, and in that sense, it must seek balance by objectifying the maximum effectiveness of your devices.

* Professor adjunto de direito constitucional (Pontifícia Universidade Católica do Paraná), Brasil. ORCID: 0000-0003-4025-4534. Correo electrónico: flavio.pansieri@pucpr.br.

** Advogado associado no escritório Pansieri Campos Advogados, bacharel em Direito pela Pontifícia Universidade Católica do Paraná, pós-graduando em Direito Constitucional pela Academia Brasileira de Direito Constitucional (ABDConst). Brasil. ORCID: 0000-0003-4025-4534. 
Palavras chave: crímenes internacionales, Colombia, ius cogens, justicia transicional, Tribunal Especial para la Paz.
Keywords: binding effectiveness, jurisprudence, effectiveness.

\begin{abstract}
SUMÁRIO: I. Introdução e premissas. II. Os motivos determinante. III. Quatro críticas à eficácia vinculante dos motivos determinantes. IV. Jurisprudência reiterada, expectativa qualificada e proteção da confiança. V. Conclusão. VI. Referências.
\end{abstract}

\title{
I. INTRODUÇÃO E PREMISSAS
}

Dentre os problemas metodológicos do Direito, certamente não um problema recente, porém inegavelmente atual, é a questão da fundamentação da decisão jurídica. Diversos autores debruçaram-se, e ainda tratam do tema, passando por clássicos como Hart, Dworkin, Alexy e MacCormick, até nomes mais afastados da literatura nacional, como Aulis Aarnio, Henry Prakken e Jaap Hage.

A virada ontológico-linguística imposta pela filosofia de Wittgenstein implicou efeitos nos mais diversos ramos do conhecimento, sendo que o Direito não permaneceu inerte ao impacto do filósofo austríaco. Brevemente, considerando que o texto é sujeito a um contexto, e assim sujeita-se à espécie de jogo de linguagem $^{l}$ — sendo caracterizado por aquilo que Hart chama de textura aberta ${ }^{2}$ - o texto é dotado de uma zona de indeterminação. ${ }^{3}$ Desse problema de indeterminabilidade é inegável que comandos

1 A definição de jogos de linguagem não é dada num conceito fechado por Wittgenstein, contudo, há passagem em que afirma: “...falar uma língua é parte de uma atividade ou de uma forma de vida”. Deste modo, compreender uma sentença-frase (Satz), envolve a compreensão de uma linguagem-discurso (Sprache), e a compreensão de uma linguagem-discurso necessita do domínio de uma técnica (Technik), daí quando afirma: "Einen Satz verstehen heißt eine Sprache verstehen. Einen Sprache verstehen, heißt eine Technik beherrschen".

2 "Nada pode eliminar esta dualidade de um núcleo de certeza e de uma penumbra de dúvida, quando nos empenhamos em colocar situações concretas sob as gerais. Tal atribui a todas as regras uma orla de imprecisão, ou uma «textura aberta», e isto pode afectar a regra de reconhecimento que especifica os critérios últimos usados na identificação do direito, tanto como duma lei concreta". Hart, H. L. A., O Conceito de direito, tradução de A. Ribeiro Mendes. 3a. ed., Lisboa, Fundação Calouste Gulbenkian, 2001, p. 134.

3 Manuel Atienza expõe que o significado duvidoso, pode resultar de determinados fatores (ou a combinação de fatores): 1. Ambiguidade, vagueza; 2. Lacunas e antinomias; 
genéricos e abstratos padecem desta "natureza", contudo, comandos concretos também podem ser afetados —e nestes é centrada a investigação de Wittgenstein, quando o mesmo afirma que um comando, por mais concreto que possa parecer_ "Platte", "Platte!", "Platte?" - terá seu significado dependente e variável. Hart em grande parte influenciado por Wittgenstein e von Wright, afirma:

Boa parte da teoria do direito deste século tem-se caracterizado pela tomada de consciência progressiva (e, algumas vezes, pelo exagero) do importante facto de que a distinção entre as incertezas da comunicação por exemplos dotados de autoridade (precedente) e as certezas de comunicação através da linguagem geral dotada de autoridade (legislação) é de longe menos firme do que sugere este contraste ingénuo. Mesmo quando são usadas regras gerais formuladas verbalmente, podem, em casos particulares concretos, surgir incertezas quanto à forma de comportamento exigido por elas. ${ }^{4}$

Uma das missões da dogmática jurídica nesse cenário é promover o estabelecimento de bases metodológicas que propiciem, com o mínimo de racionalidade exigível, alguma objetividade. A busca por tais parâmetros, conforme bem aponta Humberto Ávila, implica em responder aos critérios que compõe a fundamentação da decisão jurídica: O que é feito; como é feito; com base no que é feito; porque é feito. Cada qual deve ser passível de avaliação objetiva, de modo que o intérprete, ao analisar uma decisão tenha segurança suficiente quanto ao método aplicado no caso concreto para implicar no resultado determinado, possibilitando ou contentar-se com a decisão já prestada, ou buscar reformá-la de modo a torná-la adequada. ${ }^{5}$

3. Não é clara a intenção legislativa; 4. Dificuldade na análise da teleologia da norma; 5. Pluralidade de possibilidades na integração da norma à ordem objetiva de valores. Ocorre que indeterminação não se confunde com indeterminabilidade, isto é, com a habilidade - possiblidade - de determinar um significado. Atienza, Manuel, Interpretación constitucional, Bogotá, Universidad Libre, 2010, p. 9.

Tércio Sampaio leciona que as normas não se confundem com seus relatos - texto sendo o resultado da interpretação, carregadas de "discursos heterológicos, decisórios, estruturalmente ambíguos, que instauram uma meta-complementaridade entre orador e ouvinte", Ferraz jr., Tercio Sampaio, Teoria da norma jurídica: ensaio de pragmática da comunicação normativa, Rio de Janeiro, Forense, 2006, p. 131.

4 Hart, H. L. A., O Conceito de direito, tradução de A. Ribeiro Mendes. 3.ed. Lisboa, Fundação Calouste Gulbenkian, 2001, p. 139.

5 Ávila, Humberto Bergmann, Segurança jurídica: Entre permanência, mudança e realização no direito tributário, São Paulo, Malheiros, 2011, p. 73. 
A reformulação da teoria da decisão, com o estabelecimento de bases metodológicas ${ }^{6}$ - efetivamente, as regras do jogo da fundamentaçãoleva a dois efeitos: redução da carga de trabalho nos tribunais superiores; garante maior segurança jurídica aos particulares, que não mais veriam decisões completamente discrepantes para casos semelhantes.

Deste modo, utiliza-se como premissa a concepção alternativa das normas, ao revés da concepção unívoca, de modo que uma determinada norma poderá contar com diversos sentidos possíveis. ${ }^{7}$ A textura aberta, nessa concepção alternativa, leva Hart à exposição acerca da discricionariedade, ${ }^{8}$ ou seja, a escolha entre múltiplas respostas que encontram fundamento normativo — sendo, portanto, válidas.

Ocorre que, aceita a tese de que não há de se confundir texto e norma, ${ }^{9}$ sendo que a norma jurídica é produto de um processo argumentativo racio-

6 Hart aponta que os cânones da interpretação não podem eliminar a incerteza, vez que são eles mesmos interpretáveis. Hart, H. L. A., O conceito de direito, tradução de A. Ribeiro Mendes, 3a. ed., Lisboa, Fundação Calouste Gulbenkian, 2001, p. 139.

Jaap Hage, ainda em 2001: "There is not one kind of formal logic, but there are many different logics. ...I have seldom seen a dispute concerning the right of any of these logics". Hage, Jaap, "Legal Logic. Its Existence, Nature and Use", Bart Verheij et al. (eds.), Legal Knowledge and Information Systems, Jurix 2001, The Fourteenth Annual Conference, Amsterdam: IOS Press, 2001, pp. 89-102. Não haverá "a resposta universalmente válida" -, porém permitirá a demonstração da incorreção de muitas das soluções inválidas propostas. Hart, H. L. A., O conceito de direito, tradução de A. Ribeiro Mendes, 3 a. ed., Lisboa, Fundação Calouste Gulbenkian, 2001, p. 140.

"A jurisprudência demonstra como vários são os sentidos possíveis de serem construídos a partir dos mesmos dispositivos normativos e a metódica jurídica tributária deve se preocupar com esse tipo de situação. Assim, a concreção normativa parte do texto normativo e, mediante processos cognitivos ligados à situação específica, por meio de recursos interpretativos, obtém-se o programa da norma. Diante dele, elabora-se área da norma, que é a estrutura básica do segmento da realidade regulada e obtida no programa da norma. Essa porção de realidade pode ser construída pelo direito (prazos, prescrições) ou não construídas, mas reconhecidas por ele (casamento, família)", Andrade, José Maria Arruda de, "Do texto à norma e da norma ao texto", in Schoueri, Luis Eduardo (coord.), Direito tributário. Homenagem a Paulo de Barros Carvalho, São Paulo, Quartier Latin, 2008, p. 90.

8 “...não devemos acarinhar, mesmo como um ideal, a concepção de uma regra tão detalhada, que a questão sobre se se aplicaria ou não a um caso particular estivesse sempre resolvida antecipadamente e nunca envolvesse, no ponto de aplicação efectiva, uma escolha nova entre alternativas abertas.". Andrade, José Maria Arruda de, "Do texto à norma e da norma ao texto", in Schoueri, Luis Eduardo (coord), Direito tributário. Homenagem a Paulo de Barros Carvalho, São Paulo, Quartier Latin, 2008, p. 96.

9 "O texto é, assim, um evento. Ele deve dizer respeito a algo enquanto algo (etwas 
nal do intérprete, ${ }^{10}$ verifica-se que há a necessidade de estabelecimento de alguns limites - já que não há grau zero de interpretação. Há uma necessária comunicação entre norma e fato, conforme aduz Jan Schapp: "o universal e o singular devem ser levados a uma correspondência recíproca". ${ }^{11}$

Não se pode admitir a completa desvinculação do universal, não o tendo como autônomo, posição do realismo do conceito —ultrarrealismo-, quando o consideram como "plena e adequadamente cognoscível", no dizer de Schapp. ${ }^{12}$

De outro lado certamente incorreto ignorar qualquer significado mínimo do universal, em posição puramente nominalista. $\mathrm{O}$ universal não é um simples conceito desvinculado e amorfo, se o fosse estaria descaracterizado o próprio sentido de lei, em sua universalidade. ${ }^{13}$

A lei é garantia de significados mínimos e de método: o universal, premissa maior, que quando confrontado ao individual —em contínua reconstrução de sentido - será aplicado às séries individuais concretas (pluralidade de casos individuais unidos por vínculo material).

É certo que o texto legal não regulará todas as situações possíveis. O legislador não é onisciente. Sempre ocorrerão situações, impulsionadas pela marcha do tempo, que não terão soluções plenamente reguladas. $\mathrm{O}$

als etwas). E a interpretação do texto deve ser a busca pelo significado desse evento em si, como coisas mesmas (die Sache Selbst)", Nery, Carmen Lígia. Decisão judicial e discricionariedade: a sentença determinativa no processo civil, São Paulo, Revista dos Tribunais, 2014, p. 115.

10 "Retira-se da obra de Peter Häberle a observação segundo a qual não existe norma jurídica, senão norma jurídica interpretada (Es gibt keine Rechtsnormen, es gibt nur interpretierte Rechtsnormen). Interpretar um ato normativo nada mais é do que coloca-lo no tempo ou integrá-lo na realidade pública (Einen Rechssatz «auslegen» bedeutet, ihn in die Zeit, d.h. in die öffentliche Wieklichkeit stellen —um seiner Wirksamkeit willen). Por isso, Häberle introduz o conceito de pós-compreensão (Nachverständnis), entendido como o conjunto de fatores temporalmente condicionados com base nos quais se compreende «supervenientemente» uma dada norma. A pós-compreensão nada mais seria, para Häberle, do que a pré-compreensão do futuro, isto é, o elemento dialético correspondente da ideia de pré-compreensão". Mendes, Gilmar Ferreira; Vale, André Rufino do. "O pensamento de Peter Häberle na jurisprudência do Supremo Tribunal Federal", Filosofia e direito: ética, hermenêutica e jurisdição, Cunha, Ricarlos Almagro Vitoriano (org.), Vitória, Seção Judiciária do Espírito Santo, 2014, p. 125.

11 Schapp, Jan, Problemas fundamentais da metodologia jurídica, tradução de Ernildo Stein, Porto Alegre, Sergio Antonio Fabris Editor, 1985, p. 14.

12 Ibidem, p. 14.

13 Idem. 
legislador tem a competência e a vontade de regular, com o universal, estabelecendo um princípio geral (ou uma regra que referencia um princípio geral), mediante o qual estabelece uma solução a uma situação hipotética. Como coloca Schapp: "A exposição desta razão segue, em regra geral, de forma muito abreviada, de tal modo que a lei praticamente somente fornece balisas para uma fundamentação que o jurista deve então por sua vez desdobrar". ${ }^{14}$

O caso individual concreto, contudo, só se materializa enquanto juridicamente apreensível na decisão judicial, conforme estabelece Schapp, ${ }^{15}$ e é essa a baliza necessária para avaliar a eficácia vinculante dos motivos determinantes: o pulo do contexto hipotético (legislativo) para o caso individual concreto (e a série individual concreta).

É com base nessas premissas adotadas da teoria do Direito que se propõe a avaliação da aplicabilidade da tese da eficácia vinculante dos motivos determinantes na atual conjuntura legislativa brasileira, perpassando pela conceituação do objeto de estudo, pelas críticas realizadas à tese, pelas pontuais respostas (ou provocações) que merecem atenção dos críticos, e, ao fim, pela aceitação da existência de um objetivo válido para a tese e pela inexistência de empecilhos plenos à adoção do modelo, considerado o atual estágio de abstrativização do controle concentrado de constitucionalidade.

\section{OS MOTIVOS DETERMINANTES}

A teoria da eficácia vinculante dos motivos determinantes fora emprestada do direito alemão —onde não é menos problemática—, sendo introduzida no Brasil em muito por influência do Min. Gilmar Ferreira Mendes.

Defende Mendes que efeito vinculante das decisões do Supremo Tribunal Federal não é cedido apenas à parte dispositiva da decisão, mas também aos fundamentos determinantes que levaram à edição do dispositivo,

\footnotetext{
14 Ibidem, pp. 67 y 68.

15 "Chegamos agora a outra questão de como o fundamento, a razão da decisão do caso individual se relaciona com o próprio caso. Aqui parece impor-se o pensamento de que o caso como tal é algo individual inapreensível que somente é tipificado como caso juridicamente apreensível pelo fundamento da decisão... O caso e a razão ou o fundamento de sua decisão não podem ser separados ou opostos de algum modo que faça sentido". Schapp, Jan, Problemas fundamentais da metodologia jurídica, tradução de Ernildo Stein, Porto Alegre, Sergio Antonio Fabris Editor, 1985, pp. 69 y 70.
} 
vinculando, portanto, as cortes inferiores e administrativas à caracterização dada pela Suprema Corte, ao menos no que diz respeito ao chamado direito constitucional especifico - spezifisches Verfassungsrecht, sendo a decisão oponível contra, inclusive, órgãos constitucionais.

A posição defendida pelo Bundesverassungsgericht estabelece que a interpretação da qual resulta o princípio, e sua extensão normativa, devem ser respeitados pelas Cortes e demais autoridades administrativas em casos futuros, respeitando-se assim os fundamentos determinantes da decisão, ${ }^{16}$ aplicando assim o efeito vinculante como decorrência do $\S 31$ para. 1 da $B \operatorname{Ver} G G \cdot{ }^{17},{ }^{18}$ Portanto, pela argumentação do BVerfGG não apenas ao dispositivo se dá o efeito vinculante, pois o dispositivo não é apartado aos motivos que levaram à prolação da decisão, de modo que de nada adiantaria uma decisão — um dispositivo - sem que este pudesse ser interpretado de acordo com a matéria que fora enfrentada. Tal posição fora explicitada em BVerfGG 36, 1 [36], onde assentou-se que todos os fundamentos da decisão são necessários para o estabelecimento, compreensão e aplicação da força vinculante da decisão - dispositivo. ${ }^{19}$

16 Tal fora afirmado em BVerfGE 19, 377. Na exposição original da corte: "BVerfGG eine über den Einzelfall hinausgehende Bindungswirkung, insofern die sich aus dem Tenor und den tragenden Gründen der Entscheidung ergebenden Grundsätze für die Auslegung der Verfassung von den Gerichten und Behörden in allen künftigen Fällen beachtet werden müssen".

17 Dispõe, basicamente, que as decisões da Corte Constitucional vinculam as autoridades públicas — administrativas - de nível Federal e Estadual, bem como os demais tribunais e órgãos constitucionais (como o Bundesrat e o Bundestag).

${ }^{(1)}$ Die Entscheidungen des Bundesverfassungsgerichts binden die Verfassungsorgane des Bundes und der Länder sowie alle Gerichte und Behörden.

18 BVerfGE 20, 56: Im Tenor des Urteils vom 24. Juni 1958 sei zwar nur über die Verfassungswidrigkeit steuerrechtlicher Vorschriften entschieden worden. Die für alle Verfassungsorgane geltende Bindungswirkung der Entscheidung nach § 31 Abs. 1 BVerfGG erstrecke sich jedoch auch auf die tragenden Gründe. Der jetzige Antrag der hessischen Landesregierung werfe dieselbe Rechtsfrage mit den gleichen rechtlichen Erwägungen abermals auf, denen sich das Bundesverfassungsgericht im Urteil vom 24. Juni 1958 nicht angeschlossen habe.

19 "Aus dem bisher Dargelegten ergibt sich, daß der Vertrag als ein Vertrag, der auf Ausfüllung angelegt ist, rechtlich außerordentlich bedeutsam ist nicht nur durch seine Existenz und durch seinen Inhalt, sondern vor allem auch als Rahmen für die künftigen Folgeverträge. Alle Ausführungen der Urteilsbegründung, auch die, die sich nicht ausschließlich auf. den Inhalt des Vertrags selbst beziehen, sind nötig, also im Sinne der Rechtsprechung des Bundesverfassungsgerichts Teil der die Entscheidung tragenden Gründe". 
O efeito vinculante, segundo Klaus Vogel, deveria abarcar o que chama de "norma decisória concreta" (konkrete Entscheidungsnorm), resultado de um processo interpretativo que leva ao estabelecimento de uma decisão com fundamento na norma - subjacente ao resultado. ${ }^{20}$ Para Vogel, portanto, o conceito de efeito vinculante alcança não apenas o dispositivo, mas a norma concreta aplicada ao caso, guardando necessária correlação ao julgado. Pela perspectiva de Vogel, não há como cindir-se o que se decidiu do porquê se decidiu, daí a lição de Streck: ${ }^{21}$ a argumentação não é simplesmente um elemento acidental que, vez encerrado, cria uma decisão que é autossustentada puxando-se pelos próprios cabelos. O entendimento de Vogel, é de que a fundamentação é algo mais do que um meio para um fim. Ela dá forma à matéria, é a estrutura na qual a decisão se firma. Uma ponte do texto à norma. Do caso individual concreto à série de casos individuais concretos. ${ }^{22}$

Nesse sentido, a eficácia vinculante dos motivos determinantes não aparenta ser muito distante da tese dos precedentes, reforçada no Brasil a partir da virada metodológica trazida com a Lei 13.105/2015, que instituiu o Novo Código de Processo Civil. Streck define, e com muito acerto, o modo de aplicação do precedente, no qual a holding —a decisão judicial em si — pode, e deve — por força do stare decisis — ser constituída de força vinculante, de modo a obrigar os demais tribunais submetidos a seguir

20 "Er konzipiert die Bindungswirkung grundsätzlich als eine Erstreckung der Rechtskraft. Das gilt nicht nur in personaler, sondern auch in sachlicher Hinsicht. Es bindet nicht nur die konkrete Entscheidung alle staatlichen Organe, sondern darüber hinaus die dieser Entscheidung zugrunde liegende konkrete. Entescheidungsnorm. Diese «konkrete Entscheidungsnorm» i Sinne von Vogel muß aber fallnahe gebildet werden. Darüber hinausgehende allgemeine Erwägungen des BVerfG nehmen an der Bindungswirkung nicht teil. Das bedeutet natürlich nicht, das sie angesichts des Ranges des Gerichtes bei entsprechender Qualität der Argumentation nicht verbreitet freiwillige Gefolgschaft finden könnten und würden”. Schapp, Jan, Mehtodenlehre und System des Rechts, Tübingen, Mohn Siebeck, 2009, p. 89.

21 A "norma decisória concreta" é: "a ideia subjacente à formulação contida na parte dispositiva, que concebida de forma geral, permite não só a decisão do caso concreto, mas também a decisão de casos semelhantes". Streck, Lenio Luiz, Jurisdição constitucional e decisão jurídica, 4a. ed., São Paulo, Revista dos Tribunais, 2014, p. 733.

22 "A lei no entanto não pode decidir nenhum tipo de caso, porém, somente o caso individual como tal e com ele, segundo nosso modo de ver, a igualmente concreta série de casos individuais concretos." Schapp, Jan, Problemas fundamentais da metodologia jurídica, tradução de Ernildo Stein, Porto Alegre, Sergio Antonio Fabris Editor, 1985, p. 18. 
o precedente existente. Ocorre que a holding somente se manifesta caso as particularidades do leading case forem comprovadas. ${ }^{23}$

Importante reparar, pois, que o sistema de precedentes prevê — de maneira até certo ponto inovadora, visto que hoje é um tema pacífico-a impossibilidade de total separação entre norma e fato, eis que o direito deve ser conduzido de modo a observar as situações semelhantes, sempre atento à matéria fática apresentada.

Desse ponto, portanto, necessário afirmar que uma vez que o Supremo Tribunal Federal decide acerca da inconstitucionalidade de determinado dispositivo, pois contrário à conteúdo de determinado direito fundamental, ou ainda, estabelece que em determinado caso, far-se-á modulação dos efeitos temporais da sentença, o Tribunal emite um juízo de valor, promovendo uma atribuição de significado ao direito fundamental - determinando o alcance de seu conteúdo - ou ao termo aberto previsto na legislação infraconstitucional, gerando consigo a criação de um precedente que virá a guiar decisões futuras.

Desse ponto de partida, toda decisão jurídica é fruto de um processo dialético, que deve considerar, necessariamente, os fatores de seu próprio tempo, como forma de preenchimento do conteúdo da norma legal.

A manutenção da segurança jurídica, e da coerência e integridade do ordenamento jurídico é missão desenvolvida, em último caso, pelos tribunais superiores, particularmente por seu caráter próprio de órgãos máximos de interpretação. Deste modo, o Supremo Tribunal Federal, ao aplicar uma norma determinada, com sentido determinado, a um caso determinado, acaba, inevitavelmente, gerando expectativa no particular que preencha as mesmas condições essenciais - dados de série - do caso já julgado, e que ensejou a aplicação da norma decisória, implicando em expectativa qualificada, que deve permanecer inalterada até que razões de gravidade venham a alterar o contexto normativo através das situações extratextuais.

\section{QUATRO CRÍTICAS À EFICÁCIA VINCULANTE DOS MOTIVOS DETERMINANTES}

A teoria da eficácia vinculante dos motivos determinantes certamente não é consenso. Autores relevantes, dentre os quais destacam-se Klaus Schlai-

23 Streck, Lenio Luiz, Jurisdição constitucional e decisão jurídica, 4a. ed., São Paulo, Revista dos Tribunais, 2014, pp. 726-737.

Esta obra está bajo una Licencia Creative Commons Atribución-NoComercial-SinDerivar 4.0 Internacional, IIJ-UNAM. 
ch e Stefan Korioth, ou ainda Rui Medeiros e Georges Abboud, apresentam importantes questionamentos em face da tese.

Tais críticas foram apresentadas tanto na Alemanha quanto no Brasil, seguindo o mesmo destino do problema na Alemanha, ${ }^{24}$ demonstrando alguns problemas que exsurgem da tese da vinculatividade.

Georges Abboud, ${ }^{25}$ em sua dissertação de mestrado, expõe alguns problemas que considera essencialmente impeditivos em tal instituto, debruçando-se, em especial, sob os textos de Rui Medeiros. ${ }^{26}$

24 Dois dos argumentos apresentados, de maneira reiterada, pela doutrina — seja em Portugal, com Rui Medeiros, seja no Brasil, com Georges Abboud— foram apresentados originalmente na Alemanha.

Com efeito, Schlaich e Korioth já criticavam decisões do BVerfG nas quais, de maneira rasa, estabeleceram quais seriam as razões fundamentais do julgado na ementa - que, segundo a doutrina, não teria capacidade de descrever os tragenden gründe, tão somente aponta-los. Abboud, Georges, Jurisdição constitucional e direitos fundamentais, São Paulo, Revista dos Tribunais, 2011.

O segundo argumento, é quanto à canonização das razões fundamentais, com o consequente engessamento do direito constitucional, que é apontado de forma constante por Häberle.

25 Abboud, Georges, Sentenças interpretativas, coisa julgada, e súmula vinculante: alcance e limites dos efeitos vinculante e erga omnes na jurisdição constitucional, tese de mestrado da Pontifícia Universidade Católica de São Paulo, 2009

26 Dentre os argumentos utilizados, cita-se ainda a resistência de Rui Medeiros quanto à vinculação aos motivos determinantes, eis que: “...o Tribunal Constitucional careceria de competência qualificada para interpretação da Lei Ordinária à margem da interpretação dada na decisão recorrida". Medeiros, Rui y Miranda, Jorge, Manual de direito constitucional, tomo VI, 3a. ed., Coimbra, Coimbra Editora, 2008, p. 83.

Quanto à extensão da vinculatividade da argumentação — caracterização normativateve azo no que o Bundesverfassungsgericht qualifica como efeito vinculante do direito constitucional específico (spezifisches Verfassungsrecht), pressuposto de intervenção, via Reclamação Constitucional (Verfassungsbeschwerde), sendo manifestado pelo tribunal no julgamento da BverfGE 18, 85 que o Tribunal Constitucional só pode intervir, via Reclamação Constitucional, no caso de violação do direito constitucional específico, o que não significa que uma decisão — proferida em tribunal ordinário - mesmo que incorreta, venha a ser analisada. $\mathrm{O}$ erro no julgamento deve referir-se à inobservância, em específico, dos direitos fundamentais.

Quanto ao que são tais motivos, em mesmo julgado, apontou a corte que será revista a decisão que basear-se numa visão fundamentalmente incorreta do significado de um direito fundamental, especialmente da abrangência de sua área de proteção, e aqueles que imponham ao caso concreto necessária revisão.

Dispõe ainda que não se considera uma infração —ou seja, respeita-se a decisãoquando esta for discutível em função de sua objetividade ou equidade. Martins, Leo- 
As críticas podem ser resumidas em quatro teses: $i$ ) que a aplicação do efeito vinculante engessaria a evolução do sistema constitucional; ii) que a atribuição desse efeito pelo STF implicaria em alteração do pedido da ação; ${ }^{27}$ iii) que é difícil distinguir-se entre fundamentos determinantes e obter dicta ${ }^{28}$ e $i v$ ) que haveria diminuição do diálogo entre cortes ordinárias e Corte Constitucional..$^{29}$

\section{Do suposto engessamento da evolução constitucional}

Sustentam os críticos que a eficácia vinculante dos motivos determinantes violaria gravemente o princípio da independência decisória dos juízes, e o próprio princípio da jurisdição, vez que o judiciário encontrar-se-ia vinculado a comandos autômatos e rígidos.

Primeiramente, considerando que a eficácia vinculante dos tragenden Gründe, tomada a posição de Vogel, é uma decorrência direta da interpretação e estabelecimento de conteúdo de uma norma - a concretude da norma decisória - é inviável aceitar a primeira preocupação esboçada por Abboud e Rui Medeiros.

Não se trata de vincular qualquer caso à uma norma geral,,$^{30}$ mas sim da vinculação de um determinado conteúdo à determinado texto quando em determinada situação, um pressuposto de equidade, portanto, ${ }^{31}$ aplicável à

nardo. Cinqüenta anos de Jurisprudência do Tribunal Constitucional Federal Alemão. Montevidéu, Konrad Adenauer Stiftung, 2005, pp. 142-144.

Canotilho analisando o sistema português de controle de constitucionalidade, afirma que o parâmetro avaliativo é a ordem constitucional global, entendido como regras e princípios escritos e também os implícitos, englobando ainda tudo aquilo que pode ser considerado como bloco de constitucionalidade, de modo que alarga-se esse parâmetro de controle quando reclamados o "espírito" e "valores" da ordem constitucional. Gomes Canotilho, José Joaquim, Direito constitucional e teoria da Constituição, 7a. ed., Coimbra, Almedina, 2003, p. 980.

Crê-se, deste modo, refutada a tese de Rui Medeiros pelo modus de avaliação do spezifisches verfassungsrecht).

27 Medeiros, Rui, A decisão de inconstitucionalidade, Lisboa, Universidade Católica Editora, 1999, p. 817.

28 Ibidem, pp. 817 y 818 .

29 Ibidem, p. 816.

30 Nesse sentido, Streck, Lenio Luiz, Jurisdição constitucional e decisão jurídica, 4a. ed., São Paulo, Revista dos Tribunais, 2014, pp. 734 y 735.

31 Schapp presta esclarecimento no sentido de que as tarefas de juiz e legislador são, particularmente, a resolução do caso individual. Contudo, a resolução proposta pelo le- 
série individual concreta — decorrência da identidade material de diversos casos individuais concretos.

Assim parece descabida a sugestão de Abboud, no ponto que empresta de Rui Medeiros, ${ }^{32}$ no sentido de que os precedentes, ao contrário dos motivos determinantes ${ }^{33}$ não teriam aplicação mecânica e rígida. Essa observação não é verdadeira, pois leva à uma consideração lógica de que a adoção da eficácia vinculante dos motivos determinantes desonera o juiz de qualquer raciocínio acerca da incidência ou não de — para não se usar o termo holding - pressupostos de aplicação da norma decisória concreta. ${ }^{34}$ Esses pressupostos implicam naquilo que Streck chama de "busca do

gislador - e na realidade brasileira, pela súmula vinculante- nunca terão o condão de abarcar todas as situações possíveis, restando, portanto, uma distinção entre casos claramente decididos pelo legislador, e casos "não claramente decididos". Schapp considera que em ambos os casos, contudo, há uma decisão legislativa, porém, ocorre no segundo caso, a "ação do juiz na decisão definitiva do caso individual concreto possui um peso muito maior que nos casos que foram decididos com certeza pelo legislador". Schapp, Jan, Problemas fundamentais da metodologia jurídica, tradução de Ernildo Stein, Porto Alegre, Sergio Antonio Fabris Editor, 1985, pp. 19 y 20.

Deste modo tem-se não apenas uma aplicação, mas uma fundamentação teórica muito diversa da vinculação de primeira ordem da lei.

32 Medeiros, Rui, A decisão de inconstitucionalidade, Lisboa, Universidade Católica Editora, 1999, pp. 813 y 814.

33 A afirmação de Rui Medeiros, que, sustentando-se em Castanheira Neves, faz a distinção entre as razões determinantes e os precedentes do common law não é, contudo, aceita de maneira unânime. Ressalta-se que há na doutrina aqueles que caracterizam nesta eficácia transcendente dos fundamentos exatamente como uma consagração da força dos precedentes. Canotilho, J. J. Gomes; Mendes, Gilmar F. et al., Comentários à Constituição do Brasil, São Paulo, Saraiva/Almedina, 2013, p. 1401.

34 Cite-se aqui, também, que o próprio Rui Medeiros, que critica os tragenden Gründe, faz ressalva: "No que diz respeito às relações entre o Tribunal Constitucional e a jurisdição ordinária, é indiscutível que, independentemente do problema da vinculação jurídica dos tribunais aos motivos determinantes dos acórdãos com força obrigatória geral nada impede e tudo recomenda, quando o dispositivo não se apresenta suficientemente claro, o recurso aos motivos da decisão para captar o verdadeiro sentido desta. Também se afigura insofismável que, na prática, a jurisprudência constitucional tem um claro valor persuasivo. Ou seja, mesmo que não se possa falar entre nós de uma vinculação de iure, nunca se pode esquecer que a prática aplicação do direito é influenciada, e mesmo normativamente fundamentada, pelos precedentes". Medeiros, Rui, A decisão de inconstitucionalidade, Lisboa, Universidade Católica Editora, 1999, p. 811.

É imperioso afirmar, inclusive, que apesar da divergência doutrinária acerca do tema, na própria Alemanha há de se reconhecer que, em determinadas hipóteses —acordandose às possibilidades de variantes dos dispositivos, conforme desenvolvido naquele país- 
DNA da decisão, do caso e do direito", ${ }^{35}$ ou como ensinam Benda e Klein como interpretação genética. ${ }^{36}$

Logo, quando Abboud afirma que o efeito vinculante, nos termos do art. 102, §2o. da Constituição da República, restringe-se ao dispositivo da decisão, não se pode concordar. Admitir isso parece implicar em uma completa separação entre dispositivo e fundamentação, o que é impraticável com o pressuposto adotado. Cumpre ressaltar que até mesmo na Alemanha, originadora da tese e da crítica, a literatura especializada parece chegar no consenso afirmando que, no caso de interpretação conforme a constituição (verfassungskonforme Auslegung), é virtualmente impossível desconsiderar-se as razões que levaram o tribunal à decisão, ${ }^{37}$ já que o texto certamente permanece o mesmo, mas o que mudou, pela interpretação do julgado, foi a norma.

Outro ponto importante é assegurar que a eficácia vinculante não se dá em face do Poder Legislativo. Ao menos não de modo absoluto, sendo meramente uma vinculação prima facie. ${ }^{38}$ Explica-se isso mediante a tese

as razões do julgamento não podem ser cindidas daquilo que foi julgado, sendo recurso de socorro ao intérprete. Nesse ponto, leciona Leonardo Martins:

"Polêmica é a extensão dos efeitos da coisa julgada material aos argumentos constantes nas razões da decisão (Entscheidungsgründe), principalmente no caso do dispositivo fazer expressa menção a elas ("nach Maßgabe der Gründe" - "na medida das razões" ou "nach Maßgabe der in den Gründen gennanten Kriterien"- "segundo a medida dos critérios denominados nas razões", entre outros). ... Não obstante, tanto a jurisprudência do TCF, quanto a opinião dominante na literatura especializada, admitem a participação, na coisa julgada, de elementos constantes nas razões somente quando estes forem necessários para o esclarecimento do sentido do dispositivo, sobretudo quando neste consta apenas que o pedido foi indeferido de plano ou não ("...wird verworfen" ou "....wird zurückgewiesen")". Martins, Leronardo, Direito processual constitucional alemão, São Paulo, Atlas, 2011, pp. 115 y 116.

35 Streck, Lenio Luiz, Jurisdição constitucional e decisão jurídica, 4a. ed., São Paulo, Revista dos Tribunais, 2014, p. 734.

36 Benda, Ernst et al., Verfassungsprozessrecht, 3a. ed., Heidelberg, C. F. Müller, 2012, pp. 120 y 121 .

37 "Entretanto hay acuerdo acerca de que, em casos de interpretacíon conforme, unicamente puede ser vinculante el veredicto acerca de interpretaciones contrarias a la Constituicíon [BVerfGE 40, 88 (93, s)]”. Simon, Helmut, La jurisdicción constitucional, en Benda, Ernst et al. (org.), Manual de derecho constitucional, tradução de Antonio López Pina, Madrid, Marcial Pons, 1996, p. 843.

38 É necessário, contudo, abrir-se exposição acerca da crítica de Schlaich e Korioth, para os quais, ao instituir-se uma vinculação do legislador, criando-se a proibição de repetição (Wiederholungsverbot) — com a ressalva que foi feita no corpo do texto acer- 
da proibição de repetição (Normwiederholungsverbot), que demonstra que caso o Legislador assim o entender plausível poderá, no exercício de sua função típica, emitir ato normativo geral e abstrato que tenha por consequência afastar a interpretação do Supremo Tribunal Federal, impondo novo texto para o qual deverá haver nova interpretação. ${ }^{39}$ Essa posição aparentemente é compartilhada por Leonardo Martins, que vê nessa vinculação prima facie uma forma de encaminhar o legislador à busca de novos meios adequados, principalmente quando frente à normas de proteção à liberdade individual. ${ }^{40}$

Por outro lado, o argumento também é enfraquecido pela possibilidade de mutação constitucional, ${ }^{41}$ vez que não sendo o texto expurgado do or-

ca da alteração fática - gera um monopólio do poder de interpretação da Grundgesetz, ferindo o dever que esta institui acerca da fidelidade entre os órgãos constitucionais (Verfassungsorgantreue). Martins, Leonardo, Cinqüenta anos de jurisprudência do Tribunal Constitucional Federal Alemão, Montevidéu, Konrad Adenauer Stiftung, 2005, p. 12.

${ }^{\circ}$ Bundesverfassungsgericht, contudo, não tem entendimento unânime acerca da matéria, eis que o Segundo Senado, fixando-se ao texto, impõe a proibição de repetição, enquanto o Primeiro Senado rejeita tal tese, exigindo do legislador uma justificação excepcional para a reedição da norma, sem ignorar os fundamentos da decisão da corte.

39 Esta parece ser a interpretação de Helmut Simon, que afirma:

“...resulta esencialmente correcta dado que objeto del juicio de constitucionalidad es siempre sólo u determinado acto por acción u omisión de un poder público, y porque el precepto legal ordinario del $\S 31$ BVerfGG no puede impedir al legislador aprobar uma nueva regulacíon materialmente idéntica a la anterior. Este punto de vista, defendido ya en una primera fase, lo ha hecho suyo el Bundesverfassungsgericht con una argumentacíon convincente [BVerfGE 77, 84 (103 s.)]", Simon, Helmut, "La jurisdicción constitucional", en Benda, Ernst et al. (org.), Manual de derecho constitucional, tradução de Antonio López Pina, Madrid, Marcial Pons, 1996, pp. 842 y 843.

40 Martins, Leonardo, Cinqüenta anos de jurisprudência do Tribunal Constitucional Federal Alemão, Montevidéu, Konrad Adenauer Stiftung, 2005, pp. 124 y 125.

41 Mendes e Streck fazem a observação que no caso de declaração de inconstitucionalidade, por meio de ADI, ainda deve ser tomada com reserva a questão da mutação constitucional. Uma lei afastada do ordenamento jurídico por padecer de inconstitucionalidade pode, futuramente, ser reeditada — com texto idêntico — pelo legislador, sem que com isso encontre obstáculo absoluto na proteção da coisa julgada na Ação Direta de Inconstitucionalidade. Canotilho, J. J. et al., Comentários à Constituição do Brasil, São Paulo, Saraiva/Almedina, 2013, p. 1398.

"Não há, pois, um caráter absoluto na decisão que declara, de forma direta ou indireta, a constitucionalidade de um ato normativo, uma vez que a mutação do contexto social-histórico pode acarretar uma nova interpretação. Por isso — como já referido anteriormente - a hermenêutica de matriz fenomenológica pode contribuir para a elucidação dessa problemática, uma vez que o processo de interpretação é sempre produtivo 
denamento, sua interpretação (a norma, propriamente) poderá ser revisada oportunamente - caso surjam motivos que apontem à alteração do estado de coisas. ${ }^{42}$

Ao fim, essa crítica somente teria mais força caso a Corte Constitucional fosse vinculada à própria decisão, ${ }^{43}$ tratando-se de tese já analisada pelo próprio Vogel. ${ }^{44}$

\section{Da violação ao princípio da congruência}

Sustentam os críticos que a eficácia vinculante dos motivos determinantes implicaria em violação ao princípio da congruência (princípio do pedido), que indica que o Supremo Tribunal Federal está vinculado ao pedido, não podendo invertê-lo. A expansão do efeito vinculante aos motivos determinantes implicaria em possibilidade de atuação voluntariosa (ex officio) pela Suprema Corte, afetando inclusive a tese da inércia jurisdicional.

(Sinngebung), e não meramente reprodutivo (Auslegung). Uma lei pode ser constitucional em um dado momento histórico e inconstitucional em outro.”. Canotilho, J. J. et al., Comentários à Constituição do Brasil, São Paulo, Saraiva/Almedina, 2013, p. 1398. "Não se controverte, pois, sobre a necessidade de que se considere eventual mudança das «relações fáticas». Nossos conhecimentos sobre o processo de mutação constitucional exigem, igualmente, que se admita nova aferição da constitucionalidade da lei no caso de mudança da concepção constitucional (Verfassungsverständnis)”. Mendes, Gilmar Ferreira, Jurisdição constitucional: o controle abstrato de normas no Brasil e na Alemanha, 6a. ed., São Paulo, Saraiva, 2014, p. 320.

42 "Finalmente, os limites temporais reservam as dificuldades mais sérias de definição. Segundo a unânime lição da jurisprudência do TCF e da literatura especializada, os limites temporais da coisa julgada "constituem-se do fato de que a decisão transitada em julgado do tribunal somente será normativa enquanto não mudarem os pressupostos fáticos e jurídicos existentes no momento da decisão". Em havendo, portanto, mudanças da situação fática ou jurídica, revogar-se-ia, segundo essa definição, o vínculo à coisa julgada material.”. Martins, Leonardo. Cinqüenta anos de Jurisprudência do Tribunal Constitucional Federal Alemão, Montevidéu, Konrad Adenauer Stiftung, 2005, p. 116.

43 Streck, Lenio Luiz, Jurisdição constitucional e decisão jurídica, 4a. ed., São Paulo, Revista dos Tribunais, 2014, pp. 737 y 738.

44 "Natürlich wird die Rechtsprechung des Verfassungsgerichts, so wie sie in der Vergangenheit unterschiedliche Phasen durchlaufen hat, auch weiterhin nicht unverändert bleiben. Niemand kann coraussagen, wie das Gericht in näherer oder fernerer Zukunft über die heute von mir behandelten Fragen entscheiden wird". Vogel, Klaus, Verfassungsrechtsprechung zum Steuerrecht, Berlin, Walter de Guyter, 1999, p. 23. 
Quanto a esse segundo argumento, relativo à violação do princípio da congruência, ${ }^{45}$ autores como Streck ${ }^{46}$ e Gilmar Mendes ${ }^{47}$ afirmam que a Corte Suprema, ainda que se pronunciando sobre matéria sem que haja provocação específica (ex officio), não violará tal princípio. Em realidade, apesar de que por vezes esse princípio de processo civil seja afastado, entende-se que isso é "um risco que decorre do próprio sistema constitucional". ${ }^{48}$ A jurisdição constitucional tem como característica afetar direta ou indiretamente todo o sistema jurídico, ${ }^{49}$ de modo que não é viável que o tribunal fique adstrito à causa de pedir, nem aos fundamentos das partes..$^{50}$ A própria natureza abstrata do procedimento de controle de constitucionalidade reforça tal posição.

45 Quanto à impossibilidade de utilizar-se de um argumento estritamente processual, como forma de cercear a atuação da Corte num processo que, de certo modo, não é em todo convencional, veja-se que na Áustria, país onde era aceita essa limitação ao pedido das partes, foi necessária uma reforma constitucional, realizada em 1975, para superar esse entendimento que se mostrava prejudicial às atividades do Tribunal. Favoreu, Louis, As cortes constitucionais, tradução de Dunia Marinho Silva, São Paulo, Landy Editora, 2004, p. 51.

46 Streck, Lenio Luiz, Jurisdição constitucional e decisão jurídica, 4a. ed., São Paulo, Revista dos Tribunais, 2014, p. 736.

47 Mendes, Gilmar F. y Streck, Lenio L., “Comentário ao artigo 102, § 2o.”, in Canotilho, J. J. et al., Lenio L. (coords.), Comentários à Constituição do Brasil, São Paulo, Saraiva/Almedina, 2013, p. 1402.

48 Streck, Lenio Luiz, Jurisdição constitucional e decisão jurídica, 4a. ed., São Paulo, Revista dos Tribunais, 2014, p. 736.

49 O STF, ao analisar ação direta de inconstitucionalidade, por vezes, extrapola os limites do pedido, praticando a declaração de inconstitucionalidade "por arrastamento". Gilmar Mendes aponta que, mesmo no caso de julgamento de Recurso Extraordinário, que, portanto, teria em disputa uma lide não-abstrativizada, baseada e que busca efeitos em um caso concreto, o Supremo Tribunal Federal vem, de longa data, apontando à consideração da "causa de pedir aberta", de modo que o juízo poderia manifestar-se acerca da validade normativa ainda que esta não fosse estritamente relevante à resolução da causa. Mendes, Gilmar Ferreira, Direitos fundamentais e controle de constitucionalidade, 4a. ed., São Paulo, Saraiva, 2012, pp. 768 y 769.

Veja-se, ainda, o voto do Min. Gilmar Mendes em sede de ADI 2.182, em questão de ordem suscitada pelo Min. Marco Aurélio, na qual, em voto-vista muito elucidativo do Min. Gilmar Mendes, este reitera que, no controle concentrado de constitucionalidade, a causa de pedir é aberta, podendo ser observado em sede de RE 388.830 que a posição quanto à causa de pedir aberta estende-se, também, ao controle de difuso de constitucionalidade, posição coerente frente à contínua manifestação do Min. Gilmar Mendes quanto à abstrativização do controle concreto de constitucionalidade.

50 Sarlet, Ingo Wolfgang et al., Curso de direito constitucional, São Paulo, Revista dos Tribunais, 2012, pp. 944-949. 
Vale também observação feita por Häberle ${ }^{51}$ no sentido de que a própria jurisprudência do Bundesverfassungsgericht leva à consideração que o "tribunal é o próprio dono do processo", de modo que o processo constitucional não deve ser avaliado sob as mesmas diretrizes e princípios que seriam aplicáveis aos processos ordinários portanto. Apesar de não serem normativas desconexas, sob prismas diversos, ${ }^{52}$ o processo constitucional deve ser impelido de autonomia, distanciado das demais normas processuais..$^{53}$

\section{Quanto ao diálogo institucional}

Sustentam os críticos que a eficácia vinculante dos motivos determinantes reduziria o diálogo entre os tribunais de piso, e as cortes superiores, reduzindo o âmbito de participação das cortes locais na construção e na interpretação das normas, reduzindo e automatizando seu papel -o que, no longo prazo, implicaria em redução do papel dos próprios tribunais superiores.

Trata-se de um argumento complexo. É certo que haverá certa verticalização no exercício do poder interpretativo. Contudo é certamente drástico afirmar que será promovida a completa desconexão entre as instâncias judiciais.

Situações não abarcadas, ou que sofreram alterações significativas em seu status, ainda serão devidamente analisadas pelo Supremo Tribunal em momento oportuno.

Não se afasta o sistema recursal com a adoção da eficácia vinculante dos motivos determinantes, apenas impõe um dever argumentativo qua-

51 Häberle, Peter, "O recurso de amparo no sistema germânico de justiça constitucional”, Direito Público, Brasília, núm. 2, 83-137, outubro-novembro-dezembro 2003, p. 98 .

52 "O processo de controle abstrato de constitucionalidade não é, nem poderia ser regido pelas mesmas diretrizes ou especificidades do processo comum. Assim, no estudo deste tema é preciso proceder com extrema cautela para não desnaturar o perfil próprio do processo objetivo". Tavares, André Ramos, Curso de direito constitucional,10a. ed., São Paulo, Saraiva, 2012, p. 268.

53 Häberle, Peter, "El derecho procesal constitucional como derecho constitucional concretizado frente a la judicatura del Tribunal Federal Constitucional alemán”, Revista Iberoamericana de Derecho Procesal Constitucional, México, núm 1, 15-44, 2004, p. 24. 
lificado. Ainda, tomando aqui a crítica nos termos de Rui Medeiros,${ }^{54} \mathrm{em}$ muito devida a Peter Häberle, ${ }^{55}$ há de se ressaltar que pela lógica processual, não há razão para dar azo à crítica.

Se o tribunal ordinário, ao analisar o caso concreto, afasta indevidamente o conteúdo da norma decisória concreta, então não só se estaria a violar a decisão do Supremo Tribunal, como também a noção de equidade, e ao fim seria necessariamente reformada, para que fosse mantida a coerência na jurisprudência e a uniformidade entre as decisões prolatadas aos jurisdicionados.

Não o fazer significaria reconhecer que a Suprema Corte pode decidir casos indefinidamente, sem que suas decisões tenham o mínimo de eficácia perante os tribunais ordinários, ${ }^{56}$ novamente, ignorando o juízo de

54 "Depois, mesmo que se entendesse que a admissibilidade de um efeito vinculativo em relação aos tribunais não contraria o princípio da independência decisória dos juízes, afigura-se indiscutível que a existência de uma vinculação aos motivos determinantes da decisão reduziria significativamente o âmbito de participação dos tribunais em geral no processo de interpretação das normas constitucionais e introduziria uma grave ruptura no diálogo que em matéria constitucional deve existir entre o Tribunal Constitucional e os demais órgãos de controlo neste domínio. Numa palavra, a Kanonnisierung der tragenden Gründe subtrairia ao Tribunal Constitucional o elixir da vida fornecido pela jurisprudência ordinária”. Medeiros, Rui, A decisão de inconstitucionalidade, Lisboa, Universidade Católica Editora, 1999, p. 816.

55 "A mesma idéia de abertura deveria decidir o debate sobre se a eficácia vinculativa do art. 31o. 1 da LTCFA afecta apenas o acórdão ou também a ratio decidendi ou fundamentos jurídicos nos quais ele se apoia. O TCFA inclina-se para esta segunda postura na medida em que ele próprio alude muitas vezes (e de forma consciente) à sua função de «intérprete determinante e guardião da Constituição» (E 40, 88 [93]). Esta «canonização» da ratio decidendi deve ser recusada, segundo a tese aqui defendida de uma compreensão processual, dinâmica da Constituição. Caso se estenda a força vinculativa das decisões também à ratio decidendi, o 'diálogo jurídico' seria afectado, os restantes tribunais perderiam a coragem para efectuar outras interpretações da Constituição e a força inovadora dos eventuais votos dissidentes seria minimizada. A sociedade aberta dos intérpretes da Constituição ficaria, pelo menos em parte, «fechada»". Häberle, Peter, "O recurso de amparo no sistema germânico de justiça constitucional”, Direito Público, Brasília, núm. 2, 83-137, outubro-novembro-dezembro 2003, p. 129.

56 "Não há dúvida, portanto, de que o Tribunal, no julgamento de mérito da ADI 1.662-SP, decidiu que a superveniência da EC 30/00 não trouxe qualquer alteração à disciplina dos sequestros no âmbito dos precatórios trabalhistas, reiterando a cautelar que o saque forçado de verbas públicas somente está autorizado pela Constituição Federal no caso de preterição do direito de precedência do credor, sendo inadmissível quaisquer outras modalidades.

Se assim é, qualquer ato, administrativo ou judicial, que determine o sequestro de verbas públicas, em desacordo com a única hipótese prevista no artigo 100 da Constituição, 
equidade, ou até mesmo a unidade do direito, como coloca Castanheira Neves. ${ }^{57}$ É preciso abandonar a noção de que as instâncias ordinárias detém autonomia integral, sem se vincular aos juízos das cortes de vértice.

\section{Motivos determinantes e obiter dicta}

Sustentam os críticos que a eficácia vinculante dos motivos determinantes seria inviável, vez que é extremamente dificultoso distinguir-se entre ratio decidendi e obiter dicta. Isto é: é difícil estabelecer o que numa decisão determinada é relevante suficientemente a ser revestida de efeito vinculante.

revela-se contrário ao julgado e desafia a autoridade da decisão de mérito tomada na ação direta em referência, sendo passível, pois, de ser impugnado pela via da reclamação. Não vejo como possa o Tribunal afastar-se dessa premissa. No caso, a medida foi proposta por parte legítima e o ato impugnado afronta o que decidido de forma definitiva pela Corte, razão pela qual deve ser conhecida e provida, sob pena de inventivo ao descumprimento sistemático das decisões da mais alta Corte do País, em especial, essas que detém eficácia vinculante, o que é inaceitável...

${ }^{\text {A }}$ questão fundamental é que o ato impugnado não apenas contrastou a decisão definitiva proferida na ADI 1.662, como, essencialmente, está em confronto com seus motivos determinantes. A propósito, reporto-me à recente decisão do Ministro Gilmar Mendes (RCL 2.126, DJ de 19/08/02), sendo relevante a consideração de importante corrente doutrinária, segundo a qual a «eficácia da decisão do Tribunal transcende o caso singular, de modo que os princípios dimanados na parte dispositiva e dos fundamentos determinantes sobre a interpretação da Constituição devem ser observados por todos os Tribunais e autoridades nos casos futuros», exegese que fortalece a contribuição do Tribunal para preservação e desenvolvimento da ordem constitucional". Mendes, Gilmar Ferreira y Branco, Paulo Gustavo Gonet, Curso de direito constitucional, 9a. ed., São Paulo, Saraiva, 2014, p. 1556.

57 "Nestes temos, enunciaremos como princípio capital o seguinte: ao objectivo da mera uniformidade da jurisprudência deve substituir-se o objectivo da unidade do direito —ou, se quisermos, aquela «uniformidade» deverá passar a entender-se de modo a ver-se nela a manifestação jurisprudencial desta unidade e para o cumprimento da sua específica perspectiva normativo-intencional.

...E diremos que, uma vez proferida a solução daquela segunda hipótese, o Supremo Tribunal só deverá aceitar intervir em ordem à unidade do direito, tal como a definimos, quando esta, nos seus momentos integrantes e regulativos, constitutivos e reconstitutivos, verdadeiramente o exigir: para estabilizar com a sua auctoritas uma orientação jurisprudencial suficientemente amadurecida, ... para superar uma divergência jurisprudencial que a indispensável experimentação ou amadurecimento problemáticos já não justifique”. Castanheira Neves, Antonio, O instituto dos assentos e a função jurídica dos supremos tribunais, Coimbra, Coimbra, 1983, pp. 656 y 666. 
Quanto a esse argumento, a crítica parece certamente exagerada. Conforme afirma Lenio Streck: "Não há direito sem história simplesmente porque não há linguagem que não seja história. Em sendo o direito linguagem, o seu componente histórico é indevassável"..$^{8}$

A suposta dificuldade em definir-se e separar o que são as razões fundamentais não passa de mais do que uma dificuldade geral de interpretação do Direito, não devendo, portanto, ser considerada como um elemento por si só capaz de implicar em prejuízo à adoção do efeito vinculante dos motivos determinantes.

Não apenas isso é um problema genérico de interpretação, como também parece ainda mais agudamente quando analisada a interpretação do texto de lei puro. Os motivos determinantes, por implicarem necessariamente em correlação muito estrita para com caso concreto, acaba sendo mais facilmente analisável, e de aplicação mais igualitária, vez que apresenta requisitos mais definidos e de conteúdo menos amplo. Novamente, a norma decisória concreta só se faz quando presentes os requisitos explícitos da série de casos individuais concretos, ao passo que é contraposto ao texto de lei, que é, em si, uma norma abstrata — universal, como já apontou Schapp.

\section{JURISPRUDÊNCIA REITERADA, EXPECTATIVA QUALIFICADA E PROTEÇÃO DA CONFIANÇA}

Consideradas tais circunstâncias, analisadas ainda as teses contrapostas à viabilidade da adoção da eficácia vinculante dos motivos determinantes, há de se concluir pela viabilidade da vinculação dos tribunais ordinários à interpretação do Supremo Tribunal Federal, respeitando-se o cunho da norma decisória concreta de Vogel. Trata-se de uma forma de evitar a interpretação isolada de dispositivo legal, gerando a obrigatoriedade da observação e fundamentação qualificada pelo magistrado que pretende se desviar do padrão decisório já estabelecido.

Se, como proposto, é necessária a vinculação aos motivos determinantes, há de se reconhecer que as decisões do Supremo Tribunal Federal têm a capacidade de gerar, além das duas consequências processuais tradicio-

\footnotetext{
58 Streck, Lenio Luiz, Jurisdição constitucional e decisão jurídica, 4a. ed., São Paulo, Revista dos Tribunais, 2014, p. 736. 
nais apontadas por Theodor Maunz, ${ }^{59}$ também a capacidade de impelir no particular expectativa qualificada. ${ }^{60}$

Partindo da exposição até este ponto efetuada, não é possível considerar que de um texto, por si só, infere-se uma norma. O texto nada mais é do que uma fonte analisada pelo intérprete para que este promova a determinação de sentido e alcance dessa fonte - e ele o faz de inúmeras formas, podendo se falar em interpretação extensiva, restritiva, estativa, originalista, evolutiva, declaratória, corretiva, de modo que o texto nunca conterá, por si, todas as razões necessárias a determinar-lhe finalmente o conteúdo.

Por isso a alteração de entendimento, pelo Supremo Tribunal Federal, deve ser considerada inclusive como uma hipóteses de aplicação da modulação de efeitos temporais. O particular tem o dever de observar a presunção de constitucionalidade que reveste todas as leis, partindo também de uma presunção que a interpretação do Supremo Tribunal Federal deve ser observada - isso implica também que o fenômeno de mutação consti-

59 Streck, Lenio Luiz, Jurisdição constitucional e decisão jurídica, 4a. ed., São Paulo, Revista dos Tribunais, 2014, p. 736.

60 Não é novidade que os Tribunais consideram, pela interpretação teleológica do artículo 97, da Constituição da República, que no caso de existência de precedente do Supremo Tribunal Federal declarando a inconstitucionalidade de lei fica dispensada a reiteração de incidente de inconstitucionalidade, prática que fora positivada no artículo 481 do Código de Processo Civil, conforme alteração da Lei 9.756/98. Zavascki, Teori Albino, Eficácia das sentenças na jurisdição constitucional, 3a. ed., São Paulo, Revista dos Tribunais, 2014, p. 36.

Zavascki aponta, ainda, como reforço à noção da força vinculante dos precedentes que: “... têm, entre as suas principais funções, a de uniformização da jurisprudência, bem como a função, que se poderia denominar nomofilácica — entendida a nomofilaquia no sentido que lhe atribui Calamandrei, destinada a aclarar e integrar o sistema normativo, propiciando-lhe uma aplicação uniforme- , funções essas com finalidades «que se entrelaçam e se iluminam reciprocamente» e que têm como pressuposto lógico inafastável a força expansiva ultra partes dos seus precedentes". Zavascki, Teori Albino, Eficácia das sentenças na jurisdição constitucional, 3a. ed., São Paulo, Revista dos Tribunais, 2014, p. 43.

"Dessa forma, o precedente judicial nesse modelo constitui fonte primária do Direito, cuja eficácia vinculante não decorre nem do costume e da doutrina, nem da bondade e da congruência social das razões invocadas, mas da força institucionalizante da interpretação jurisdicional, isto é, da força institucional da jurisdição como função básica do Estado. Vale dizer o precedente constitui uma «authority reason», uma «must-source», atuando, portanto, como verdadeira "exclusionary reason" na formação da decisão judicial". Mitidiero, Daniel, Cortes superiores e cortes supremas, São Paulo, Revista dos Tribunais, 2014, p. 75. 
tucional ${ }^{61}$ é uma hipótese de aplicação de modulação de efeitos temporais. Ao particular somente é viável a exigência do presente, não cabendo a ele imaginar o imaginável: como norma determinada será interpretada no futuro.

Nesse tema, ainda, é necessário esclarecer que de modo algum quer-se aqui estabelecer uma vinculação plena do Supremo Tribunal Federal à sua própria jurisprudência. ${ }^{62}$ Não se afirma que um tribunal possa mudar seu entendimento. O que se afirma é que a norma decisória concreta implica em dois efeitos: primeiro, ela vincula; segundo, ela cria expectativas. Não é possível ignorar que uma decisão da Corte Suprema, expondo conteúdo normativo em diretriz jurisprudencial, gera no particular expectativas justificadas e que tem impacto direto em seu agir habitual, a isso se reputa o predicado no termo expetativa qualificada.

61 Por homenagem à completude, faz-se referência às definições dadas por Gilmar Mendes, e por Ingo Sarlet, ao fenômeno de mutação constitucional (Verfassungswandlung), ou ainda o que qualifica Karl Larenz como alteração na situação normativa:

“...Ocorre que, por vezes, em virtude de uma evolução na situação de fato sobre a qual incide a norma, ou ainda por força de uma nova visão jurídica que passa a predominar na sociedade, a Constituição muda, sem que suas palavras hajam sofrido modificação alguma. O texto é o mesmo, mas o sentido que lhe é atribuído é outro. Como a norma não se confunde com o texto, repara-se, aí, uma mudança da norma, mantido o texto. Quando isso ocorre no âmbito constitucional, fala-se em mutação constitucional.

A nova interpretação há, porém, de encontrar apoio no teor das palavras empregadas pelo constituinte e não deve violentar os princípios estruturantes da Lei Maior; do contrário, haverá apenas uma interpretação inconstitucional". Mendes, Gilmar Ferreira y Branco, Paulo Gustavo Gonet, Curso de direito constitucional, 9a. ed., São Paulo, Saraiva, 2014, p. 170 .

"A noção de mutação constitucional, assim como a de reforma constitucional, guarda relação com a concepção que, em determinado sentido, uma constituição é um organismo vivo, submetido à dinâmica da realidade social, e que, portanto, não se esgota por meio de fórmulas fixas e predeterminadas. Consoante Hsü Dau-:in, imprimindo um sentido ampliado à noção de mutação constitucional, esta consiste na modificação do conteúdo das normas constitucionais sem alteração do texto constitucional, em virtude da incongruência entre a constituição escrita e a realidade constitucional. Em sentido seminal, na acepção cunhada por Karl Loewenstein, a mutação constitucional pode ser conceituada como uma transformação no âmbito da realidade da configuração do poder político, da estrutura social ou do equilíbrio de interesses, sem que tal atualização encontre previsão no texto constitucional, que permanece intocado". Sarlet, Ingo Wolfgang et al., Curso de direito constitucional, São Paulo, Revista dos Tribunais, 2012, p. 147.

62 Novamente recai-se aqui a crítica da Häberle, a qual foi confrontada no item anterior, ao tratar-se da problemática do efeito vinculante dos motivos determinantes. 
Expectativas qualificadas têm fundamento em uma diversidade de princípios constitucionais, como, em sentido amplo, o princípio da segurança jurídica ou, ao fim, o princípio do Estado de direito. Se uma a decisão da Corte Suprema atribui a determinado texto uma determinada norma, o Tribunal induz no particular um sentido de calculabilidade no objeto - norma aplicada de modo determinado a caso determinado com base em texto determinado - de modo que terá o dever de portar-se no sentido aquiescido sem que altere sua jurisprudência de modo arbitrário (surpresa). Ou seja, quando de um rol de sentidos possíveis a decisão fecha em um único (norma decisória concreta), cria "verdadeira expectativa normativa de comportamento para todos, integrantes do mesmo grupo de casos", ${ }^{63}$ de modo que as decisões que se voltem contra esse sentido serão impingidas de maior carga argumentativa, para que, sob novas premissas, possa reformar o entendimento anteriormente esposado (Ávila, 2011, p. 151), ${ }^{64}$ sempre reformando o futuro, para que não se atinja o tradicional estado de coisas brasileiro, em que até o passado é incerto — como diria Stanislaw Ponte Preta.

Dois fatores devem ser observados aqui. Primeiramente, a vinculação à norma decisória concreta, a eficácia vinculante dos motivos determinantes conforme já tratado; segundo, a chamada "abstrativização do controle concreto de constitucionalidade" ou "objetivação do recurso extraordinário", ${ }^{65}$ que torna o acesso ao Supremo Tribunal Federal um mecanismo

63 Aqui vê-se a importância da eficácia vinculante dos motivos determinantes. O que se tem como "mesmo grupo de casos" pode, num sentido estritamente processual, significar as lides sobrestadas pelo procedimento de julgamento de Recurso Extraordinário sob regime de repercussão geral. Contudo, serve para abarcar ainda todas as lides que tratam, essencialmente, de casos semelhantes, e que, portanto, deverão ser tomadas na mesma linha definida pelas cortes superiores, sob pena, então, da usurpação da autoridade das decisões do Supremo Tribunal Federal, conforme já apontava Schapp no seu conceito de série.

Ávila, Humberto Bergmann, Segurança jurídica. Entre permanência, mudança e realização no direito tributário, São Paulo, Malheiros, 2011, p. 150.

64 "No entanto, aceitando que as consequências jurídicas dependem, essencialmente, de um processo argumentativo reconstrutor de seu significado normativo, a segurança jurídica não tem por objeto uma norma, ou pelo menos, não a tem por objeto exclusivo; ela tem por objeto, em vez disso, um processo argumentativo". Ávila, Humberto Bergmann, Segurança jurídica. Entre permanência, mudança e realização no direito tributário, São Paulo, Malheiros, 2011, p. 151.

65 "No Contexto das mudanças, não há como deixar de destacar a função decisiva do instituto da repercussão geral para a racionalização das competências constitucionais 
restrito, mas, por outro lado, mais efetivo para a caracterização da norma decisória concreta. Diz-se isso pois, tomado o atual entendimento sobre o controle de constitucionalidade, não há maiores impedimentos para que a norma decisória concreta seja observável também no pronunciamento do Supremo Tribunal Federal quando da análise do recurso extraordinário ${ }^{66}$ - talvez seja caso ainda mais explícito de necessidade de vinculação, por tratar de situações concretas efetivamente.

Há inúmeras críticas à “abstrativização", amplamente apresentadas por Lenio Streck, Marcelo Cattoni e Martonio Barreto Lima ${ }^{67}$ em análise dos votos dos Ministros Gilmar Mendes e Eros Grau, em sede de Reclamação Constitucional 4.335/AC. Em que pese tais críticas, há de se discordar em específico quando estes afirmam que, na possibilidade do Supremo Tribunal Federal julgar como positivo o cabimento de reclamações constitucionais contra suas teses, e não contra as decisões proferidas, haveria o deslocamento da "discussão jurídica para os discursos de fundamentação (Begründungsdiskurs), elaborados de forma descontextualizada. Passam a ser "conceitos sem coisas". ${ }^{68}$

da Corte. Esse novo modelo processual-constitucional traduz, sem dúvida, avanço na concepção vetusa que caracteriza o recurso entre nós. O recurso extraordinário deixa de ser caráter marcadamente subjetivo ou de defesa de interesse das partes para assumir, de forma decisiva, a função de defesa de ordem constitucional objetiva. Pode-se falar, mesmo, em processo de objetivação do recurso extraordinário.

Trata-se de orientação que os modernos sistemas de Corte Constitucional vêm conferindo ao recurso de amparo e ao recurso constitucional (Verfassungsbeschwerde). Nesse sentido, destaca-se a observação de Häberle segundo a qual "a função da Constituição na proteção dos direitos individuais (subjetivos) é apenas uma faceta do recurso de amparo", dotado de "dupla função", subjetiva e objetiva, "consistindo esta última em assegurar o Direito Constitucional objetivo"”. Mendes, Gilmar Ferreira, Estado de direito e jurisdição constitucional - 2002-2010, São Paulo, Saraiva, 2011, pp. 128 y 129.

66 O Supremo Tribunal Federal, apesar de não necessariamente aplicar o termo aqui empregado, faz uso da vinculação dos motivos determinantes, veja-se, por exemplo: Brasil, 1999; Brasil, 1997; Brasil, 2003a; Brasil, 2003b; Brasil, 2003c.

67 Streck, Lenio Luiz et al., A nova perspectiva do Supremo Tribunal Federal sobre o controle difuso: mutação constitucional e limites da legitimidade da jurisdição constitucional, disponível em: <http://www.conjur.com.br/2007-ago-03/perspectiva_stf_controle_difuso>.

68 Streck, Lenio Luiz et al., A nova perspectiva do Supremo Tribunal Federal sobre o controle difuso: mutação constitucional e limites da legitimidade da jurisdição constitucional, disponível em: <http://www.conjur.com.br/2007-ago-03/perspectiva_stf_controle_difuso>. 
Essa a crítica não pode ser mantida diante da atual situação. O próprio conceito de norma decisória concreta, com extensão do efeito vinculante, amplamente discutido no BVerfG ${ }^{69}$ e aqui defendido, é uma forma de inibir as tentativas de descontextualização — da usurpação da identidade do julgado. A norma decisória concreta só se demonstra aplicável quando passada por um processo hermenêutico, através da identificação das $r a$ zões fundamentais que levam à aplicação da norma sob prisma " $x$ ".

\section{CONCLUSÃO}

Analisando as questões metodológicas atinentes aos efeitos das decisões do Supremo Tribunal, particularmente tomando por base os conceitos de norma decisória concreta e série, vê-se que os tribunais, e as supremas cortes em especial por seu caráter próprio de órgãos máximos de interpretação constitucional, devem observar a coerência de sua jurisprudência, aplicando uniformemente o direito. Isso é uma decorrência não só do princípio da igualdade, como também da própria unidade do direito.

Deste modo, o Supremo Tribunal Federal, ao aplicar uma norma determinada, com sentido determinado, a um caso determinado, acaba, inevitavelmente, gerando expectativa no particular que preencha as mesmas condições essenciais do caso já julgado — dados de série, no conceito de Schapp. Isso enseja a aplicação da norma decisória como forma de tentativa de minorar a enchente de normas singulares desconexas. Tal conceito foi denominado de expectativa qualificada.

Desta expectativa qualificada, que se funda nos deveres de igualdade e unidade, surge o dever de resguardo da estabilidade da jurisprudência, particularmente no que concerne à norma decisória concreta. A alteração de entendimento pela mutação constitucional, não pode implicar em coop-

69 "Das Bundesverfassungsgericht hat stehts derauf bestanden, dass binded nicht nur der Tenor seiner Entscheidungen, sondern auch derem tragende Gründe sind, Es hat ferner für sich dan Recht in Anspruch genommen, festzulegen, welche Gründe die tragenden sind. Im Vermögenstverbeschluss werden die Auführungen zur Substanz besteerungen und zur «ausdrüchlich als tragende Gründe bezeichnet; der Senat hebt dabei noch besonders hervor das er auch für die Einkommensteuer zuständig sei. Hiernach scheint mir klar, dass es nict nur ein obiter dictum handelt, wie manche meiner, die die Entscheigung wahrscheinlich nicht genau genung gelesen haben»". Klaus Vogel apud Streck, Lenio Luiz, Jurisdição constitucional e decisão jurídica, 4a. ed., São Paulo, Revista dos Tribunais, 2014, p. 734. 
tação de situações jurídicas consolidadas, não sendo um simples ato de vontade do julgador. A norma decisória concreta deve permanecer inalterada até que razões de gravidade venham a alterar o contexto normativo através das situações extratextuais, mas mesmo tal alteração não deve ter o condão de alterar o passado, de forma que situações consolidadas devem permanecer inalteradas sob a perspectiva prévia.

A conjugação das premissas metodológicas, estabelecidas pela teoria do Direito adotada, indicam evidente aproximação entre a tese da eficácia vinculante dos motivos determinantes, e o sistema de precedentes (tipicamente atribuído aos modelos de common law), o que indica maior relevo e necessidade de avaliação no Brasil quando tomando como premissas o atual movimento de abstrativização do controle concreto de constitucionalidade, e pela virada metodológica imposta pela Lei 13.105/2015, que encarta o Novo Código de Processo Civil.

Esse atual movimento de aproximação torna necessário perquirir e reavaliar as antigas teses e críticas à eficácia vinculante dos motivos determinantes, particularmente aquelas relativas à suposta violação aos princípios da jurisdição, e da independência decisória dos magistrados — argumento que, diante dos novos desenvolvimentos do ordenamento, tornam-se desprovidos da qualidade retórica de outrora.

\section{REFERÊNCIAS}

ABBoud, Georges, Sentenças interpretativas, coisa julgada, e súmula vinculante: alcance e limites dos efeitos vinculante e erga omnes na jurisdição constitucional, tese de mestrado da Pontifícia Universidade Católica de São Paulo, 2009.

ABBoud, Georges, Jurisdição constitucional e direitos fundamentais, São Paulo, Revista dos Tribunais, 2011.

ANDRADE, José Maria Arruda de, "Do texto à norma e da norma ao texto", in SchOUerI, Luis Eduardo (coord), Direito tributário. Homenagem a Paulo de Barros Carvalho, São Paulo, Quartier Latin, 2008.

ATIENZA, Manuel, Interpretación constitucional, Bogotá, Universidad Libre, 2010.

ÁvilA, Humberto Bergmann, In: Cueva, Ricardo Villas Bôas (cood.), Seminário Teoria da Decisão Judicial, 23, 24 e 25 de abril de 2014, 
Brasília, DF/ Conselho da Justiça Federal, Centro de Estudos Judiciários; coordenação científica Ricardo Villas Bôas Cueva. - Brasília, CJF, 2014.

ÁvilA, Humberto Bergmann, Segurança jurídica. Entre permanência, mudança e realização no direito tributário, São Paulo, Malheiros, 2011.

BENDA, Ernst et al., Verfassungsprozessrecht. 3a. ed., Heidelberg, C. F. Müller, 2012.

CASTANHEIRA NeVES, Antonio, O Instituto dos assentos e a função jurídica dos supremos tribunais, Coimbra, Coimbra, 1983.

FAVOREU, Louis, As cortes constitucionais, tradução de Dunia Marinho Silva, São Paulo, Landy Editora, 2004.

FERRAZ J. R., Tercio Sampaio, Teoria da norma jurídica: ensaio de pragmática da comunicação normativa, Rio de Janeiro, Forense, 2006.

Gomes Canotilho, José Joaquim, Direito constitucional e teoria da Constituição, 7a. ed., Coimbra, Almedina, 2003.

HÄBERLE, Peter, "El derecho procesal constitucional como derecho constitucional concretizado frente a la judicatura del Tribunal Federal Constitucional alemán", Revista Iberoamericana de Derecho Procesal Constitucional, núm. 1, 2004.

HÄBERLE, Peter, "O recurso de amparo no sistema germânico de justiça constitucional”, Direito Público, Brasília, núm. 2, outubro-novembro-dezembro 2003.

HAge, Jaap, "Legal Logic. Its Existence, Nature and Use", in Bart VerHeIJ et al. (eds.), Legal Knowledge and Information Systems, Jurix 2001, The Fourteenth Annual Conference, Amsterdam, IOS Press, 2001.

HART, H. L. A., O conceito de direito, 3a..ed., tradução de A. Ribeiro Mendes, Lisboa, Fundação Calouste Gulbenkian, 2001.

MARTINS, Leonardo, Cinqüenta anos de jurisprudência do Tribunal Constitucional Federal Alemão, Montevidéu, Konrad Adenauer Stiftung, 2005.

MARTINS, Leonardo, Direito processual constitucional alemão, São Paulo, Atlas, 2011.

Maunz, Theodor, in CANOTILHO, J. J. Gomes et al., Comentários à Constituição do Brasil, São Paulo, Saraiva/Almedina, 2013.

MedeIROs, Rui, A decisão de inconstitucionalidade, Lisboa, Universidade Católica Editora, 1999. 
MedeIRos, Rui, in MirandA, Jorge. Manual de direito constitucional, t. VI, 3a. ed., Coimbra, Coimbra Editora, 2008.

Mendes, Gilmar F.; STRECK, Lenio L., "Comentário ao artigo 102, § 2o.”, en CAnotilho, J. J. Gomes et al. (coords.), Comentários à Constituição do Brasil, São Paulo, Saraiva/Almedina, 2013.

MENDES, Gilmar Ferreira, Estado de direito e jurisdição constitucional 2002-2010, São Paulo, Saraiva, 2011.

MENDES, Gilmar Ferreira, Direitos fundamentais e controle de constitucionalidade, 4a. ed., São Paulo, Saraiva, 2012.

MENDES, Gilmar Ferreira, "Interpretação constitucional e «pensamento de possibilidades», Revista Jurídica do Ministério Público do Estado do Paraná, Curitiba, núm., 2015.

MENDES, Gilmar Ferreira. Jurisdição constitucional: o controle abstrato de normas no Brasil e na Alemanha, 6a. ed., São Paulo, Saraiva, 2014.

Mendes, Gilmar Ferreira y BRAnCo, Paulo Gustavo Gonet, Curso de direito constitucional, 9a. ed., São Paulo, Saraiva, 2014.

Mendes, Gilmar Ferreira; VAle, André Rufino do, "O pensamento de Peter Häberle na jurisprudência do Supremo Tribunal Federal”, in CUNHA, Ricarlos Almagro Vitoriano (org.), Filosofia e direito: ética, hermenêutica e jurisdição, Vitória, Seção Judiciária do Espírito Santo, 2014.

Mitidiero, Daniel, Cortes superiores e cortes supremas, São Paulo, Revista dos Tribunais, 2014.

NERY, Carmen Lígia, Decisão judicial e discricionariedade: a sentença determinativa no processo civil, São Paulo, Editora Revista dos Tribunais, 2014.

SARLET, Ingo Wolfgang et al., Daniel, Curso de direito constitucional, São Paulo, Revista dos Tribunais, 2012.

SCHAPP, Jan, Mehtodenlehre und System des Rechts, Tübingen, Mohn Siebeck, 2009.

SCHAPP, Jan, Problemas fundamentais da metodologia jurídica, tradução de Ernildo Stein, Porto Alegre, Sergio Antonio Fabris Editor, 1985.

SimON, Helmut, "La jurisdicción constitucional", en BENDA, Ernst et al. (org.). Manual de derecho constitucional, tradução de Antonio López Pina, Madrid, Marcial Pons, 1996.

STRECK, Lenio Luiz, Jurisdição constitucional e decisão jurídica, 4a. ed., São Paulo, Revista dos Tribunais, 2014. 
STRECK, Lenio Luiz et al., "A nova perspectiva do Supremo Tribunal Federal sobre o controle difuso: mutação constitucional e limites da legitimidade da jurisdição constitucional", Conjur, 2007. Disponível em: $<$ http://www.conjur.com.br/2007-ago-03/perspectiva_stf_controle_difuso $>$.

TAVAres, André Ramos, Curso de direito constitucional, 10a. ed., São Paulo, Saraiva, 2012.

VoGEL, Klaus, Verfassungsrechtsprechung zum Steuerrecht, Berlin, Walter de Guyter, 1999.

ZAVASCKI, Teori Albino, Eficácia das sentenças na jurisdição constitucional, 3a. ed., São Paulo, Revista dos Tribunais, 2014.

Fecha de recepción: 25 de marzo de 2019.

Fecha de aceptación: 6 de octubre de 2019.

Esta obra está bajo una Licencia Creative Commons Atribución-NoComercial-SinDerivar 4.0 Internacional, IIJ-UNAM. 


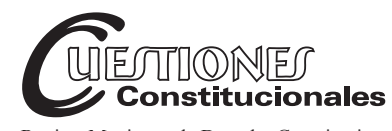

Revista Mexicana de Derecho Constitucional Núm. 43, julio-diciembre 2020

\title{
La democracia participativa, respuesta a la crisis de la democracia representativa
}

\author{
Participatory democracy, a response to the crisis \\ of representative democracry
}

\section{Emilio RABASA GAMBOA*}

RESUMEN: La tesis central del artículo consiste en argumentar que la crisis de la democracia representativa, debido a una fatiga política que ha generado el descontento y la desconfianza de los ciudadanos representados, con sus representantes, ha provocado el surgimiento, sobre todo en este siglo, de diversos mecanismos de democracia directa, como la consulta popular, el referéndum, el plebiscito, la revocación del mandato y otras que se analizan en el texto.

Para fundamentar teóricamente la tesis, se incluyen varios autores de actualidad que han abordado el tema de la crisis de la democracia y las elecciones, como Levitsky y Ziblatt (Cómo mueren las democracias), Yasch Mounk (El pueblo vs la democracia), Temelkuran (Cómo perder un país), Cadena Roa y López Leyva (El malestar con la representación en México) y Van Reybrouck (Contra las elecciones - cómo salvar la democracia). De igual manera, se analiza a mayor profundidad el origen de esa crisis en la génesis de la democracia representa-
ABSTRACT: The central thesis of this article consists in argueing that the actual crisis of representative democracy, due to a political fatigue that has caused a descontent and mistrust of the represented citicenship by their representatives, has provoked mainly in this century, the emergence of diverse mechanisms of direct democracy such as popular consultation, referendum, plebiscite, mandate recall and others analized in the text.

To provide theoretical foundation to my thesis, several updated authors that have researched the crisis of democracy and elections, are included such as Levitsky y Ziblatt (How Democracies Die), Yasch Mounk (The People vs Democracy), Temelkuran (How to lose a country), Cadena Roa y López Leyva (The disconfort with representation in Mexico) y Van Reybrouck (Against elections, how to save democracy). In the same token and at more depth, the present crisis is analyzed through the genesis and design of representative democracy with autors such

* Licenciado y doctorado en derecho por la UNAM; maestría en Cambridge University, Inglaterra, en Filosofía y Ciencia Política. Actualmente es investigador del Instituto de Investigaciones Jurídicas y docente en la UNAM. ORCID: 0000-0003-2845-1420. México. Correo electrónico: erabasa@unam.mx. 
tiva y su diseño, con autores como Benjamin Constant, Hans Kelsen y Roberto Gargarella, a fin de argumentar que esta crisis tiene su origen desde el siglo XVIII, pero ahora se ha acentuado por el cambio de las condiciones económicas, como la caída del creciente bienestar de los treinta a los ochenta del siglo pasado; sociales, como la creciente migración y nueva composición pluriétnica de las sociedades modernas, y la revolución de las comunicaciones con el Internet y las redes sociales.

En seguida, se analizan los distintos tipos de democracia (representativa, directa, deliberativa y radical), a fin de proponer la fusión armónica de diversos componentes de la democracia representativa con otros de la democracia participativa) como una solución a la crisis política actual. Se incluye un análisis comparativo de otros países latinoamericanos que lo han intentado, como Venezuela, Ecuador y Bolivia, y se presentan los mecanismos de democracia directa vigentes en México tanto en la Constitución federal (incluida la reforma de diciembre del 2019) como en la Constitución de la Ciudad de México y de otras entidades federativas, como sustento a la tesis central del artículo.

Se concluye contraargumentando sobre las dificultades de una ingeniería constitucional que fusionara los dos tipos de democracia.

Palabras clave: democracia representativa, fatiga democrática, democracia participativa, crisis de la democracia actual, modalidades de democracia directa en México (consulta popular, referéndum, plebiscito, revocación de mandato), la fusión democrática. as Benajmin Contant, Hans Kelsen and Roberto Gargarella, in order to argue that its origin lies in the XVIII Century, but has now become more acute due to changing economic condictios in societies fallen wellbeing that grew during last century's 30 s and 80s; social such as the growth of migration and the new pluriethnic changes in modern societies composition, and the comunicaions revolution with internet and social media.

Next is included an analysis of democracy's types (representative, direct, paritipatory, deliberative and radical) with the purpose of proposing an armonic fusion of representative democracy's diverse components with others of participatory democracy, as a solution to the present political crisis. Other countries'experience in that road in Latin America such as Ecuador, Venezuela and Bolivia are included to grasp a comparative view. Finally Mexico's direct democracy's mechanisms in force in the federal constitution (including the recent constitucional reform of December 2019) Mexico's City constitution and other states, are presented to support the main thesis of this article.

Closing remarks include counter-argument about the difficuties of constitutional engeniering for melting together both types of democracy.

Keywords: representative democracy, democratic fatigue, participatory democracy, democracy's present day crisis, Mexico's direct democracy types (popular consultation, referendum, plebiscite, mandate recall) democratic melting. 
Hoy en día las democracias occidentales se enfrentan tanto a una crisis de legitimidad como de eficiencia. Es algo excepcional: la situación ha dejado de ser una simple marejada para convertirse en el preludio de una tempestad

David VAN REYBROUCK

\begin{abstract}
SUMARIO: I. Introducción: la crisis de la democracia representativa. II. Las críticas a la democracia representativa. III. Tipología de la democracia. IV. Modalidades de democracia directa en México. V. Conclusiones. VI. Bibliografía.
\end{abstract}

\title{
I. INTRODUCCIÓN: LA CRISIS DE LA DEMOCRACIA REPRESENTATIVA
}

El desencanto que ha venido provocando desde la alborada del siglo presente la democracia representativa, la forma de gobierno más extendida ${ }^{1}$ en el planeta, debido a un agotamiento prematuro, ${ }^{2}$ que con gran acierto el filósofo belga David van Reybrouck ha caracteriza como "el síndrome de fatiga democrática", ${ }^{3}$ ha ocasionado el surgimiento de diversos tipos de respuestas políticas al desinterés ciudadano cada día más generalizado por esa gobernanza. El incremento en el abstencionismo electoral, combinado con una mayor fluctuación partidista y la sensible disminución en la afiliación ciudadana en los partidos políticos, ha generado una crisis de legitimidad y eficiencia en la democracia representativa. ${ }^{4}$

1 Según el reporte de Freedom House, Freedom in the World, 2013, Democratic Breakthroughs in the Balance, Londres 2013, pp. 28 y 29, en 1972 había 44 Estados libres, y 73 en 1993. Hoy ya son 117 de 195. Citado por Van Reybuck, David, 2017, p. 12. El autor (Brujas, 1971) es doctor por la Universidad de Leiden. En 2011 lanzó el G1000, una cumbre ciudadana y organización que funciona como plataforma para la innovación democrática en Bélgica.

2 Prematuro, porque la tercera ola de democratización (Samuel Huntinghton) apenas tiene aproximadamente treinta años de haberse iniciado. Véase mi libro Rabasa Gamboa, Emilio, 1993, en donde se explica la transición de más de treinta países de diferente grado de desarrollo económico y social de diversas formas de autoritarismo a la democracia representativa.

3 Van Reybruck, David, op. cit., 2017, pp. 49 y 51.

4 Sintomatología de la crisis de la democracia representativa según David van Reybuck, en ibidem, pp.17-27. 
La crisis de la fatiga democrática no es privativa de un país o de un grupo de países de características comunes, pues se ha extendido a los cuatro continentes, y abarca a naciones de diferentes antecedentes y contextos históricos y culturales. El "desmoronamiento de la aceptación pública" (deslegitimidad) y el "deterioro de la capacidad de resolución" (ineficiencia) ${ }^{5}$ son globales, y su causa última, según el autor citado, es que "nos hemos convertido en fundamentalistas electorales. Despreciamos a los elegidos pero idolatramos a las elecciones". ${ }^{6}$

Deseo argumentar como hipótesis básica de este artículo, que la crisis del agotamiento de la democracia representativa, cada vez más evidente en el siglo presente, ha generado como reacción o respuesta una reactivación política de los representados, que cada día desconfían más de sus representantes, a través de mecanismos de democracia directa; esto es, vivimos un momento de reconvención política. No se trata de una simple tensión entre ambas formas de democracia, sino de toda una reingeniería constitucional de la primera con la segunda.

El problema del desencanto con la democracia representativa se inserta en un marco de debate de mayor amplitud y profundidad, que se refiere a la subsistencia misma de la democracia. Al filo de la primera década de este siglo ha surgido una amplia literatura sobre la amenaza y el ocaso democrático ligado al surgimiento del populismo en no pocos países. Es importante vislumbrar ese horizonte, que permitirá entender mejor la hipótesis central de este trabajo.

Dos profesores de Harvard, Steven Levitsky y Daniel Ziblatt publicaron en 2018 How Democracies Die. ${ }^{7}$ Para estos autores, la "erosión de la democracia es casi imperceptible", ${ }^{8}$ ya que "la población no cae inmediatamente en la cuenta de lo que está sucediendo". ${ }^{9}$ Las quiebras democráticas desde fines del siglo pasado y en el presente no responden a los paradigmas tradicionales, como golpes de Estado, asonadas u otras formas de usurpación violenta; al contrario, más bien se trata de procesos de desmantelamiento de las normas e instituciones democráticas a partir de la vía pacífica electoral; "en la actualidad el retroceso democrático comienza en

5 Ibidem, pp. 16 y 21.

6 Ibidem, pp. 53 y 54.

7 Traducción al español, Cómo mueren las democracias, Barcelona, Ariel, 2018.

8 Ibidem, p. 14.

9 Idem. 
las urnas", ${ }^{10}$ y precisan que "No hay tanques en las calles. La Constitución y otras instituciones nominalmente democráticas continúan vigentes. La población sigue votando. Los autócratas electos mantienen una apariencia de democracia, a la que van destripando hasta despojarla de contenido", ${ }^{11}$ pero en forma paulatina o gradual y no de un solo golpe. No obstante que su análisis está dirigido preponderantemente al caso de los Estados Unidos con la llegada de Donald Trump, lo enriquecieron con un enfoque comparativo con otros países, como Venezuela con Chávez y Maduro, Ecuador con Correa, Perú con Fujimori, Turquía con Erdogan, Hungría de Orban, Polonia con Kaczynski, entre otros; estiman que hay una suerte de patrón común en la descomposición democrática en los países de quiebre democrático, que se ajusta a cuatro indicadores: 1) el rechazo o la débil aceptación de las reglas democráticas del juego; 2) la negación de la legitimidad de los adversarios políticos; 3) la tolerancia o fomento de la violencia, y 4) la predisposición a restringir las libertades civiles de la oposición, incluidos los medios de comunicación. ${ }^{12}$ Estos indicadores subvierten lo que ellos denominan los "guardarraíles de la democracia", que en esencia identifican como reglas no escritas de la "tolerancia mutua" y la "contención institucional". ${ }^{13}$ Concluyen que en el caso de los Estados Unidos, Trump de sobra ha roto esas reglas, por lo que juzgan necesario una recomposición del sistema de partidos para cancelar su polarización actual y el desarrollo de todo un sistema de alianzas o coaliciones horizontales. ${ }^{14}$

Otro texto en la misma dirección es el de Ece Temelkuran, intitulado Cómo perder un país, ${ }^{15}$ en el que esta periodista describe el proceso de demolición democrática de Turquía a partir de la llegada al poder, también por la vía democrática, de Recep Tayyip Erdogan, mediante un proceso que abarca varios pasos, que van desde la creación de un movimiento político, con el que se trastoca la lógica y se altera el lenguaje público; pasa por el desmantelamiento gradual de los mecanismos judiciales y políticos que pueden obstaculizar la concentración del poder del gobernante autoritario, y llega hasta el diseño de una "ciudadanía" diferente y la "reconstrucción" de su propio país.

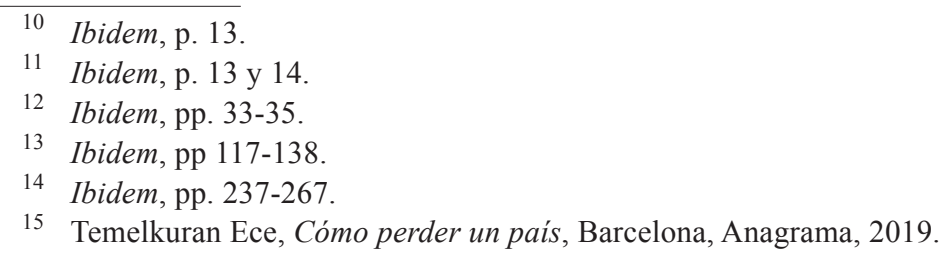


Otro interesante análisis es el que nos ofrece Yascha Mounk en The People vs. Democracy. ${ }^{16}$ Estima que vivimos en "una era de incertidumbre radical" ${ }^{17}$ en la que la democracia (el gobierno popular electo por el voto ciudadano) liberal ${ }^{18}$ (que reconoce y hace efectivos derechos y libertades fundamentales) se está descomponiendo:

de un lado, las preferencias de la gente son crecientemente iliberales: aumenta la impaciencia de los votantes con las instituciones independientes, y están cada vez menos dispuestos a tolerar los derechos de minorías étnicas y religiosas. Del otro lado, las élites están controlando el sistema político y haciéndolo insensible: los poderosos cada vez están menos dispuestos a aceptar la visión del pueblo. Como resultado, el liberalismo y la democracia, los dos elementos clave del sistema político están entrando en conflicto. ${ }^{19}$

En lugar de la democracia liberal están emergiendo dos nuevos regímenes: la democracia iliberal (democracia sin derechos) y el liberalismo indemocrático (derechos sin democracia).

En opinión de Mounk, la transformación del escenario de la democracia liberal obedece a que cambiaron las tres condiciones en las que descansaba esta forma de gobierno: 1) prosperidad económica que prevaleció entre los treinta y sesenta del siglo pasado y se revirtió con la crisis de 1985; 2) preponderancia de un grupo étnico o racial sobre los demás, que se ha modificado con la migración, y 3 ) la comunicación masiva antes controlada por elites políticas y financieras con el dominio de los medios electrónicos, ahora sustituida por la expansión comunicativa gracias al Internet y a las redes sociales.

Ésas han sido las causas del desmantelamiento de la democracia liberal. Consecuentemente, su solución está en enfrentarlas con reformas económicas nacionales e internacionales que reduzcan la desigualdad social

16 Mounk, Yascha, The People vs. Democracy - why are Freedom is in Danger \& how to sabe it, Harvard University Press, 2018. Mounk es profesor de la Universidad de Harvard.

17 Ibidem, p. 25.

18 Monk define a la democracia liberal como "un sistema político que es liberal y democrático que protege derechos individuales [como la libertad de expresión, creencia religiosa, prensa y asociación] y traduce la visión popular en política pública”, ibidem, p. 27.

19 Ibidem, p. 13.

Esta obra está bajo una Licencia Creative Commons

Atribución-NoComercial-SinDerivar 4.0 Internacional, IIJ-UNAM. 
mediante una distribución equitativa del ingreso nacional; resolver la composición multiétnica de la democracia con derechos iguales para todos, $\mathrm{y}$ finalmente hacer segura la era digital para la democracia tanto en el emisor como en el receptor de los mensajes. ${ }^{20}$ Concluye Mounk: "A pesar de que los frutos de nuestro esfuerzo permanezcan inciertos, haremos lo que podamos para salvar a la democracia liberal". ${ }^{21}$

Este diagnóstico sobre el estado de la democracia en el siglo XXI ha de complementarse con otro específico al caso de México si hemos de entender por qué la fatiga democrática también alcanza a nuestro país. "El malestar con la representación en México"22 abarca no sólo a la representación política, sino también a la social. Comprende tanto al sistema de partidos como a las organizaciones sociales, y de manera destacada a los sindicatos: "Hay una carencia de agentes de intermediación entre las instituciones y la ciudadanía, agregada en múltiples organizaciones con diferente grados de representatividad, y otra en organizaciones secuestradas por intereses diferentes a los de sus representados". ${ }^{23}$ De acuerdo con este diagnóstico, tanto la política institucional (sistema de partidos e instituciones electorales) como la no institucional (movimientos sociales y organizaciones sociales diversas) se han ido aislando y caminando por rutas y en direcciones distintas, incluso a veces opuestas, y en consecuencia:

\footnotetext{
$20 \quad$ Ibidem, pp. 16-18.

21 Ibidem, p. 266. La traducción de todas las citas de este autor son de mi autoría.

22 Título del nuevo libro de Jorge Cadena-Roa y Miguel Armando López Leyva editado por la UNAM, el Instituto de Investigaciones Sociales y el Centro de Investigaciones Interdisciplinarias en Ciencias y Humanidades, Ficticia Editorial, México 2019. La tesis central de esta obra consiste en argumentar y demostrar que la democratización en México no rompió con el autoritarismo anterior, sino que ha mantenido intercalados a enclaves o "lastres" autoritarios, que hoy en día generan un extendido malestar entre los representados por las recurrentes corrupción, impunidad y violación a los derechos humanos que arrastró el régimen anterior. Véase sobre todo la "Introducción: problemas actuales de la representación social y política en la democracia mexicana" de los dos autores citados pp. 21-51, y el capítulo II “¿En qué momento se malogró la representación en México” de Jorge Cadena Roa, pp. 123-159. Cadena Roa es doctor en sociología por la Universidad de Wisconsin-Madison, investigador titular del CEIICH_UNAM y miembro de la Junta de Gobierno de la UNAM. López Leyva es doctor en ciencias sociales con especialidad en ciencia política por la Facultad Latinoamericana de Ciencias Sociales, y actualmente director del Instituto de Investigaciones Sociales de la UNAM.
}

23 Ibidem, p. 40. 
el alejamiento entre los intereses de los representantes y las demandas de los ciudadanos es uno de los mayores daños que puede hacérsele a una democracia, porque deja de funcionar como un "gobierno del pueblo, por el pueblo y para el pueblo", como dijera Lincoln en su célebre discurso en Gettysburg el 19 de noviembre de 1863, y se transforma en un gobierno de los partidos, por los políticos y para ellos y sus socios, y el sistema económico en un capitalismo de cuates y tráfico de influencias (crony capitalism). ${ }^{24}$

La llamada "democracia participativa", que busca un involucramiento directo de la ciudadanía en la determinación de la agenda pública, y no a través de sus representantes, es una respuesta a esos padecimientos críticos de la democracia representativa. México, aún antes del inicio de la presente administración, y sobre todo con motivo de la Asamblea Constituyente que dio a la Ciudad de México (CdMx) su primera Constitución, no ha estado exento de esta tendencia. En la nueva carta magna de la CdMex se incluyó un catálogo bastante amplio de figuras de democracia directa, a la que se reconoce como "derecho y un deber de participar en la resolución de problemas y temas de interés general en el mejoramiento de las normas que regulan las relaciones en la comunidad, a través de los mecanismos de democracia directa y participativa reconocidos por esta Constitución" (artículo 25.A.1)

Pero el problema de la crisis de la democracia representativa no puede entenderse sólo por las condiciones político-sociales actuales. Deseo agregar a mi argumento central antes expuesto, que el problema presente del desencanto democrático tiene una raíz genético-estructural más antigua. Para decodificarla he incluido a dos autores clásicos: Benjamin Constant (siglo XIX), ${ }^{25}$ y Hans Kelsen (XX),${ }^{26}$ quienes en su tiempo anticiparon las

24 Ibidem, p. 41.

25 Benjamin Constant (1767-1830), cuya vida transcurre entre la segunda mitad del siglo XVIII y la primera parte del XIX, fue un filósofo y político francés de origen suizo, testigo de la Revolución en Francia y el Imperio de Napoleón, por lo que su pensamiento político es una suerte de puente entre dos grandes épocas históricas del antiguo régimen y la modernidad. Se ocupó profusamente del tema de la representación política tanto en su obra Los principios de la política aplicable a todos los gobiernos representativos como en su célebre discurso ante el Atheneé Royal de Paris: "La libertad de los antiguos comparada con la de los modernos".

26 Hans Kelsen (1881-1973), de origen austriaco, fue un jurista y filósofo del derecho y la política. Profesor de derecho en la Universidad de Viena, y al final de su vida en Berkeley, California, Elaboró la nueva Constitución de Austria y fue miembro vitalicio 
limitaciones de la democracia representativa con un enfoque político el primero y jurídico el segundo. Constant activó una certera alarma desde 1819 sobre las consecuencias de dejar el sistema representativo en manos de los políticos. Casi un siglo después, en 1925, Hans Kelsen publicó su Teoría general del Estado, con una crítica a la representación del pueblo por el Parlamento, a la que califica como "una ficción". A estos autores he agregado otro reciente: el argentino Roberto Gargarella, ${ }^{27}$ quien en 1997 escribió Crisis de la representación política, en donde elabora una interesante crítica del sistema representativo de carácter histórico-sociológico, basado en un análisis del diseño a cargo del constituyente de los Estados Unidos en 1787.

Hasta ahí se ha desarrollado una parte de la hipótesis central: la crisis de la democracia representativa. Para completarla con la segunda, la respuesta de la democracia participativa, el artículo incursiona en el análisis de diversas concepciones de la democracia: representativa, directa, participativa y radical, a partir de las cuales se discute la idea de una integración con los elementos de las distintas variantes democráticas, visualizando una nueva forma de incluir a los ciudadanos en la toma de decisiones. Finalmente, se cierra con algunas reflexiones a manera de conclusión, acerca del futuro de la participación democrática y su dificultad para asimilarla al sistema representativo vigente, como una suerte de contraargumentación a la hipótesis fundamental del artículo.

\section{LAS CRÍTICAS A LA DEMOCRACIA REPRESENTATIVA}

Sobre el problema genético de la democracia representativa, fue el ginebrino Benjamin Constant en su famosa alocución en el Athenée Royale de Paris en 1818, intitulada "Discurso sobre la libertad de los antiguos com-

del Tribunal Constitucional austriaco diseñado por él mismo para la defensa de la supremacía constitucional. Autor de La teoría pura del derecho, en la que evita el sincretismo metódico con base en la filosofía de Kant, fue también autor de la Teoría general del Estado, estructurada con un enfoque estático y otro dinámico del Estado identificado con el derecho.

27 Abogado, jurista y sociólogo nació en Buenos Aires, Argentina, en 1964, y actualmente es profesor en la Universidad Torcuato Di Tella y en la Universidad de Buenos Aires. Interesado en buscar alternativas a temas como la pena de muerte y, sobre todo, al sistema de representación elitista con base en una democracia deliberativa en donde prevalezca el debate entre el Estado y la población mayoritaria. 
parada con la de los modernos", ${ }^{28}$ quien lo advirtió al explicar la gran diferencia entre la democracia directa ejercida por los antiguos, que consistía en participar ${ }^{29}$ en las deliberaciones en la plaza pública sobre diversos asuntos de interés colectivo, sobre todo la guerra y la paz, y la democracia representativa de los modernos, cuya sociedad se basaba en el comercio y en la búsqueda de la riqueza personal, dejando en sus representantes la atención de los asuntos públicos.

Es importante recordar ahora ese discurso de Constant, porque a más de un siglo de distancia pudo prever las consecuencias negativas de dejar la política en manos de los políticos-representantes, anticipando con ello el escenario actual:

El peligro de la libertad moderna es que, absortos en disfrutar nuestra independencia privada y en la búsqueda de nuestros intereses particulares, debemos renunciar muy fácilmente a participar en el ejercicio del poder político. Los poseedores de la autoridad sólo están ansiosos de animarnos a obrar así. ${ }^{30}$

A más de un siglo de este pronóstico por el que Constant alertaba sobre las consecuencias del alejamiento del ciudadano de la política, dejándola en manos de sus representantes, debido a su enajenación económica, es en gran medida lo que estamos viviendo: la crisis de la democracia representativa, por la que el ciudadano no se siente, válgase la redundancia, representado por sus representantes, y, por lo mismo, está buscando nuevos y más efectivos canales de participación política.

Quien con mayor claridad expuso el problema jurídico-estructural de la democracia representativa, como una ficción de la representación del pueblo por el Parlamento o el Congreso, fue el jurista vienés Hans Kelsen, al señalar que "La esencia de la democracia representativa — en contradicción con su propio nombre — ${ }^{31}$ consiste en que no es el pueblo sino el par-

28 Véase mi análisis del pensamiento político de Benjamín Constant, y sobre todo su discurso ante el Athenée Royale, en Rabasa Gamboa Emilio, el capítulo "La representación política en el siglo XVIII", 1994, pp. 48-84.

29 Si bien una participación limitada a los ciudadanos varones mayores de edad.

30 Constant, op. cit., p. 78.

31 Contradicción, porque etimológicamente la democracia se entiende como demos=pueblo y kratos= gobierno o poder; esto es, gobierno del pueblo, pero democracia representativa significa gobierno de los representantes, no del pueblo. 
lamento [o congreso] el llamado a legislar, pudiendo realizar esta función con toda independencia del primero". ${ }^{32}$

Para fundamentar su argumento, Kelsen sostiene que no existe un acto jurídicamente vinculante entre la voluntad del elector y la del elegido como su representante por el que pudiera afirmarse que lo que quiere el segundo corresponde exactamente a lo que desea el primero. Y es precisamente esa ausencia de una relación legalmente vinculante lo que permite a los representantes desligarse de los representados, de tal suerte que aquéllos no se encuentran jurídicamente obligados a escuchar y atender las necesidades y reclamos de éstos, y traducirlos en legislación. Consecuentemente, y ante la ausencia de esa vinculación jurídica, los representantes atienden a sus propios intereses o los de su partido.

\section{La argumentación de Roberto Gargarella}

Con base en el diseño del sistema de representación de los Estados Unidos, Gargarella afirma que ya desde antes del Constituyente de Filadelfia había "conflictos contrainstitucionales" debido a la "presencia de instituciones poco receptivas de las demandas del electorado", ${ }^{33}$ sobre todo en las legislaturas estatales, como el caso de Rhode Island en Nueva Inglaterra. Posteriormente, los integrantes de la Convención Constituyente "defendieron el sistema representativo como un medio óptimo para separar a la ciudadanía del ejercicio directo del poder. La democracia directa, en este sentido, no solamente era difícil de practicar, sino [fundamentalmente] indeseable". ${ }^{34}$ Consecuentemente, diseñaron "un sistema en el que las mayorías quedaban inhabilitadas para deliberar de por sí, y prácticamente incapacitadas para ejercer un control efectivo sobre el gobierno". ${ }^{35}$ Este sesgo "contramayoritario" abrió el camino para un sistema representativo de corte elitista que facilitaría

el arribo al poder de individuos de clase alta; y estaría dirigido en tal sentido a la protección de la minoría de aquellos que Hamilton denominara abiertamente "los ricos y bien nacidos" ${ }^{36}$ Esto "permitió que el sistema político

\footnotetext{
Kelsen, Hans, 1965, p. 403.

33 Gargarella, op. cit., 1997, p. 13.

34 Ibidem, p. 47.

35 Idem.

36 Ibidem, p. 48.
} 
resultase más sensible a las presiones privadas que a las presiones públicas, separando a la ciudadanía de sus representantes. ${ }^{37}$

El desapego del ciudadano hacia la política, más interesado en los asuntos privados (Constant), la ausencia de una relación jurídicamente vinculante entre el representante y el representado (Kelsen) y un sistema representativo diseñado para favorecer a una minoría en detrimento de la mayoría (Gargarella), permiten entender mejor la crisis de la democracia representativa, que en el caso de México se acentúa por el malestar extendido con la representación política y social (Cadena Roa). Pasemos ahora al análisis de la segunda parte de la hipótesis central: la respuesta de la democracia representativa, para lo que es necesario detenernos brevemente en las distintas formas de democracia.

\section{TIPOLOGÍA DE LA DEMOCRACIA}

A) La democracia representativa deriva del paradigma liberal, que tiene como principio básico el asentamiento de la soberanía popular; esto es, la elección del gobierno por el pueblo y el reconocimiento de sus derechos y libertades. El consentimiento de los gobernados es otorgado a través de elecciones competitivas y periódicas, donde los individuos pueden aceptar, rechazar, y sólo hasta cierto punto controlar a sus dirigentes. ${ }^{38}$

En esta visión de la democracia, el ciudadano puede llegar a tener un papel pasivo si su participación se reduce exclusivamente a votar en las elecciones, con la finalidad de elegir a una minoría supuestamente capaz de gobernar efectiva y coherentemente. ${ }^{39}$

B) La democracia participativa plantea el involucramiento ciudadano en el proceso de toma de decisiones públicas mediante mecanismos de democracia directa, como la consulta e iniciativa popular, el referéndum, el plebiscito, la revocación de mandato, etcétera, Incluye además a la democracia deliberativa, entendida como espacios de deliberación pública (parlamento, tribunales, la prensa y la opinión pública en redes sociales), y finalmente, la democracia participativa en sentido estricto, con la finalidad

\footnotetext{
37 Ibidem, pp. 78 y 79.

38 Viejo et al., 2009, p. 30.

39 Walker 1966.
} 
de que la ciudadanía se involucre en la formulación, planificación y/o gestión de determinadas políticas públicas, como el presupuesto participativo.

Los argumentos a favor de estas formas de gobierno son:

1) Los ciudadanos son los que mejor conocen sus problemas, y serán más eficaces en la toma de decisiones que los técnicos del gobierno,

2) Se desarrolla el sentido de comunidad, el interés en la cosa pública y la confianza en las instituciones.

C) La democracia radical, que busca dotar a la ciudadanía de capacidades realmente iguales de participación. Se reconoce que nacemos con desigualdades, por lo que las políticas públicas no se deben conducir por principios homogéneos, sino por el reconocimiento de las diferencias que hace indispensable las estrategias de acciones afirmativas

Frente al problema que representa la crisis de la democracia representativa en la actualidad, quizá podría configurarse una teoría que sirviera de fundamento a una nueva praxis política integrando y fusionando algunos de los elementos de cada uno de los tres tipos de democracia antes expuestos, a manera de síntesis, con la finalidad de proporcionar una sólida base y fundamento de la participación ciudadana en el contexto actual del extendido descontento con el sistema representativo.

De la democracia representativa son desde luego asimilables los derechos políticos activos y pasivos, y en general los derechos fundamentales que ha expandido el neoconstitucionalismo. ${ }^{40}$ De la democracia participativa se incluirían las figuras clásicas de las formas de participación ciudadana, como el referéndum, el plebiscito, la consulta e iniciativa popular y la revocación de mandato, al mismo tiempo que se aseguren los espacios de la deliberación pública tanto tradicionales como los nuevos, producto de las nuevas tecnologías de la comunicación e información que generan redes sociales. Más complicados resultan los elementos de la democracia radical por la premisa de la igualdad ciudadana, que requiere la efectiva participación política.

Son cinco los principios de la participación ciudadana que atienden las desigualdades de inicio entre ciudadanos a las que se refiere la democracia radical: descentralización del poder en el gobierno, facilitar la moviliza-

40 Al respecto, véase "Neocostitucionalismos", especialmente el prólogo de Miguel Carbonell, pp. 9-12, el artículo de Luigi Ferrajoli, "Pasado y futuro del Estado de derecho", pp. 13-30, y "Los derechos fundamentales en el Estado constitucional democrático" de Robert Alexy, pp. 31-48, Edición de Miguel Carbonell, México, UNAM-Trotta, 2006. 
ción social, facilitar la discusión de temas, promover las redes y alianzas de ciudadanos, fortalecer la vigilancia de las acciones del gobierno.

Antes de profundizar en las modalidades de la democracia participativa en nuestro país, resulta importante considerar las experiencias de otros países que han intentado introducir medios de participación de democracia directa o radical en sus esquemas de la democracia representativa, en particular los casos de Venezuela, Ecuador y Bolivia, conocidos como "el nuevo constitucionalismo latinoamericano".

De acuerdo con Guadalupe Salmorán, ${ }^{41}$ el nuevo constitucionalismo latinoamericano es un fenómeno que se dio a principios del siglo XXI con la aprobación de nuevas Constituciones en Venezuela, Ecuador y Bolivia, derivadas de procesos de movilización popular, que culminaron en la convocatoria a asambleas constituyentes y referéndums populares para aprobar los textos constitucionales definitivos. El calificativo de "nuevo" proviene de la crítica que hicieron al viejo constitucionalismo, que en su opinión refleja los intereses elitistas de los partidos políticos liberales, y no los del pueblo. Por esta razón, los nuevos textos constitucionales buscaron incorporar mecanismos para asegurar la voluntad popular por encima de los controles contramayoritarios. Para ello reformaron su Constitución e insertaron en ella mecanismos como el plebiscito, el referéndum, la revocación del mandato, la elección directa de los jueces, consultas ciudadanas, iniciativas de ley a propuesta de los ciudadanos, entre otros. Algunas otras características comunes de estas Constituciones son su extensión, la incorporación de ideologías diversas y cosmovisiones indígenas, rigidez para ser modificadas, reconocimiento de nuevos derechos individuales y colectivos, cuyo objetivo sería reducir la exclusión y desigualdad social (derechos económicos, sociales, culturales y ambientales o DESCA), más facultades al Estado en materia económica.

El nuevo constitucionalismo latinoamericano no está exento de críticas. Respecto a la inclusión de los DESCA y de las ideologías y cosmovisiones indígenas, se señala una posible apertura de espacios de discrecionalidad para su interpretación, así como la reducción de la certeza y seguridad jurídica para los ciudadanos. Otra crítica que se ha hecho a los mecanismos

41 Investigadora del Instituto de Investigaciones Jurídicas de la UNAM; doctora en Teoría Política por la Universidad de Turín, Italia. Profesora en el posgrado de Derecho y la Facultad de Ciencias Políticas de la UNAM. Se ha especializado en temas electorales, el populismo y el nuevo constitucionalismo latinoamericano, particularmente en Venezuela, Ecuador y Bolivia. 
de la democracia directa es que, en el caso de los referéndums y consultas populares, quien formula las preguntas generalmente es el Poder Ejecutivo, y la consulta sólo se limita a que los electores contesten con una simple afirmación o negación. En estos procesos, no necesariamente se incluye un espacio deliberativo previo que se da en los parlamentos, en donde se discuten las diferentes posiciones antes de hacer cambios normativos. Además, podría estarse rompiendo el principio de división de poderes, ya que al ser el Ejecutivo el que formula las preguntas, es este poder y no el Legislativo el que, de hecho, está legislando, aun cuando estas preguntas requieran ser aprobadas por las cortes y sometidas a votación por los ciudadanos. Sin embargo, cabe mencionar que no siempre los electores han votado de manera afirmativa a la consulta del Ejecutivo en los plebiscitos y refréndums a los que se les ha convocado. Éste fue el caso de la propuesta de reforma constitucional en Venezuela de 2017, y la propuesta de reelección consecutiva del presidente en Bolivia en 2016. Asimismo, la elección directa de los jueces y la posibilidad de que el Legislativo les revoque su mandato han sido criticadas por la posibilidad de que los órganos jurisdiccionales queden sometidos a la mayoría política que controle al Ejecutivo o al Legislativo. ${ }^{42}$

Con este marco comparativo, veamos ahora las distintas formas de democracia directa que se han venido desarrollando en nuestro país.

\section{MODALIDADES DE DEMOCRACIA DIRECTA EN MÉXICO}

En México, en los últimos años se han dado ya varios pasos en el camino de la democracia participativa, como son las figuras de las candidaturas electorales independientes, la encuesta pública, la iniciativa popular (también conocida como iniciativa ciudadana), el referéndum, el plebiscito y la revocación del mandato. A continuación se presenta una breve exposición de las mismas, lo que da una idea general del avance de nuestra legislación en esta materia, ${ }^{43}$ y nos permite identificar mejor las facilidades (fortale-

42 Salmorán, Guadalupe, 2016, pp. 1-23.

43 Que por muchos años estuvo ausente o dormida ante la preeminencia o casi hegemonía de los mecanismos de la democracia representativa, en auge debido a las reformas constitucionales en materia político-electoral a partir de 1977, descritas ampliamente en mi libro Las reformas constitucionales en materia político-electoral (edición bilingüe del 
zas) y dificultades (debilidades) para su adecuada y armónica integración constitucional en nuestro país.

\section{Las candidaturas independientes}

Se constitucionalizaron en agosto de 2012 en el artículo 35, fracción II, como un derecho político pasivo del ciudadano para

poder ser votado para todos los cargos de elección popular teniendo las calidades que establezca la ley. El derecho de solicitar el registro ante la autoridad electoral, corresponde a los partidos políticos así como a los ciudadanos que soliciten su registro de manera independiente y cumplan con los requisitos, condiciones y términos que determine la legislación. ${ }^{44}$

Esta figura permite la participación electoral directa de los ciudadanos, sin intermediación de los partidos políticos.

\section{La consulta popular}

Establecida en el artículo 35, fracción VIII, mediante una adición constitucional en $2012^{45}$ y reformada en 2014, concede el derecho a los ciudadanos mexicanos a votar en las consultas populares sobre temas de trascendencia nacional, en los términos y condiciones que establece el mismo texto de la Constitución. ${ }^{46}$

La Constitución de la CdMx, en el artículo 25, incisos E y F, establece dos modalidades de la misma figura: la consulta ciudadana y la consulta

Instituto de Investigaciones Jurídicas de la UNAM y la ONU, publicado en 2012). Pero a partir de las reformas constitucionales de 2012, y sobre todo con la nueva Constitución de la CdMx, en 2018, los mecanismos de la democracia directa han cobrado especial atención en el debate político nacional.

44 Para un análisis detallado de las candidaturas independientes véase Figueroa Ávila, Enrique, 2019.

$45 \mathrm{Su}$ antecedente es la reforma y adición de 1983 al artículo 26, tercer párrafo, que estableció la consulta popular, pero exclusivamente para el sistema nacional de planeación democrática.

46 Incisos 1 a 7 de la fracción VIII del artículo 35 constitucional, que indican quién puede organizar la encuesta (Congreso, presidente, legisladores y ciudadanos en el número que se indica), términos para que la consulta sea vinculante, materias o temas no susceptibles de consulta y la intervención del INE. 
popular, si bien la diferencia entre una y otra en cuanto al objetivo de estos instrumentos es bastante nebulosa. La primera es el derechos de las y los ciudadanos a ser consultados sobre "cualquier tema que tenga impacto trascendental en los distintos ámbitos temáticos o territoriales de la Ciudad". La segunda es también el derecho a ser consultados "sobre temas de trascendencia de la Ciudad". Aquélla por cualquier autoridad, y ésta, por el Congreso de la Ciudad, además de un mayor número de requisitos y limitantes en la consulta popular que en la ciudadana. ${ }^{47}$

\section{La iniciativa popular ${ }^{48}$}

Dispuesta en el artículo 71, fracción IV, mediante reforma de 2012, concede el derecho a los ciudadanos en un número equivalente, por lo menos, al cero punto trece por ciento de la lista nominal de electores en los términos que señalen las leyes, para iniciar leyes o decretos.

En la Constitución de la CdMex se denomina "iniciativa ciudadana" al derecho de las y los ciudadanos a iniciar leyes y decretos, así como reformas a la Constitución. ${ }^{49}$ La reforma constitucional no está contemplada para la iniciativa popular en la Constitución federal.

\section{El referéndum}

Introducido en la Constitución junto con la iniciativa popular mediante la reforma político-electoral de $1977^{50}$ en el artículo 73, fracción VI, base 2a., sólo para el entonces Distrito Federal, en los siguientes términos: "Los ordenamientos legales y los reglamentos que en la ley de la materia se determinen, serán sometidos al referéndum y podrán ser objeto de la iniciativa popular, conforme al procedimiento que la misma señale". El referéndum nunca tuvo aplicación en la práctica en el Distrito Federal, y fue derogado en 1987.

\footnotetext{
47 Compárense los numerales 1, letras a) a f), y 2, de la figura de la consulta popular con los numerales 1 y 2 de la consulta ciudadana, ambas en el artículo 25, incisos E y $\mathrm{F}$, de la Constitución de la CdMex.

48 Introducida en la Constitución mediante reforma de 1977.

49 Artículo 25, inciso B, numerales 1 a 5, que regulan los términos y requisitos de este derecho de los ciudadanos habitantes de la Ciudad de México.

50 Rabasa Gamboa, Emilio, 1998, pp. 147-170.
} 
Actualmente es retomado en el capítulo II, artículo 25, Democracia directa, inciso C, de la nueva Constitución Política de la CdMex, en estos términos: "Se reconoce el derecho ciudadano a aprobar mediante referéndum las reformas a esta Constitución conforme a lo establecido en el artículo 69 de esta Constitución, así como a las demás disposiciones normativas de carácter general que sean competencia del Congreso de la Ciudad de México". ${ }^{51}$

Como puede observarse, la nueva Constitución de la CdMex estableció una figura del referéndum con un ámbito de validez material más amplio, que la que en su momento incluyó la reforma a la Constitución federal de 1977, ya que ésta lo limitó a los ordenamientos legales y reglamentos, en tanto aquélla lo extendió a las reformas a la Constitución de la CdMex y las normas generales.

Por su parte, las Constituciones de Tabasco (artículo 8 bis) y Zacatecas (artículo 45) ya contenían desde hace tiempo esta figura que han desarrollado en su respectivos textos ampliamente.

\section{El plebiscito}

No ha figurado en la Constitución federal, pero sí fue incorporado en la Constitución de la CdMex en el artículo 25, inciso D, en los siguientes términos: "Las y los ciudadanos tienen derecho a ser consultados en plebiscito para aprobar o rechazar decisiones públicas que sean competencia del Poder Ejecutivo de la Ciudad o de las alcaldías". Las materias de derechos humanos, penal, tributaria y fiscal no podrán ser objeto de plebiscito.

Las Constituciones de Tabasco (artículo 8 bis) y Zacatecas (artículo 46) contienen estas figuras de tiempo atrás, y las han desarrolla ampliamente en sus respectivos textos.

\section{La revocación de mandato}

Como se asentó anteriormente con la crítica de Hans Kelsen, la democracia representativa no incluye en la figura de la representación del

51 En el citado precepto se incluyen los términos y condiciones de este derecho y la materia (derechos humanos, penal o tributaria) excluida del referéndum. 
pueblo por el Congreso o parlamento la relación vinculante entre el representante y el representado por medio de la cual éste pueda exigirle determinada conducta a aquél. El representante, una vez electo, actúa con total independencia del representado. Sin embargo, la democracia directa ha desarrollado una figura que le permite a este último retirar o revocar el mandato que confirió en el acto de la elección. La legislación no señala las causas por las que el ciudadano puede revocar ese mandato; simplemente expresa que "Las y los ciudadanos tienen derecho a solicitar la revocación del mandato de representantes electos cuando así lo demande al menos el $10 \%$ de las personas inscritas en la lista nominal de electores del ámbito respectivo" (artículo 25, inciso G, 1 de la Constitución de la CdMex). Y agrega que "la consulta para la revocación de mandato sólo procederá una vez, cuando haya transcurrido al menos la mitad de la duración del cargo de representación popular de que se trate" (artículo 25, G2, de la Constitución de la CdMex).

En el ámbito federal esta figura fue objeto de un intenso debate dentro y fuera del ámbito legislativo y de los partidos políticos, debido fundamentalmente a la fecha en que se pretendía llevar a cabo la consulta respectiva. ${ }^{52} \mathrm{~A}$ este respecto, la Constitución de la CdMex es muy clara al prohibir que, con excepción de la consulta popular, ninguna de las figuras de la democracia directa "podrá llevarse a cabo cuando exista proceso electoral" (artículo 25, inciso F, numeral 2). En otras palabras, la Constitución local es contundente en cuanto a la preservación del proceso electoral libre de cualquier medida o instrumento que pudiera contaminar la elección y afectar su resultado.

52 Finalmente, se acordó que se llevaría a cabo después de concluida la elección intermedia, a efecto de no contaminarla con un proceso político distinto por el que se cruzarían el ejercicio principal de la democracia representativa como es la elección, con esta modalidad de democracia directa. El artículo transitorio cuarto de la reforma del 20 de diciembre de 2019 establece que el periodo para la recaudación de firmas para la solicitud de revocación de mandato del presidente de la República electo para el periodo 2018-2024 comenzará en el mes de noviembre y hasta el 15 de diciembre de 2021, y que la petición correspondiente deberá presentarse dentro de los primeros quince días del mes de diciembre de 2021. Si la solicitud es procedente, el INE emitirá la convocatoria dentro de los veinte días siguientes al vencimiento del plazo para la presentación de la solicitud. La jornada de votación será a los sesenta días de expedida la convocatoria. Esto quiere decir que la jornada ocurriría en los primeros meses de 2022, ya lejos de la elección intermedia. 
La reforma constitucional de 2019

E1 20 de diciembre de 2019 se publicó en el Diario Oficial de la Federación la reforma a nueve artículos de la Constitución federal en materia de consulta popular y revocación de mandato, lo que confirma la hipótesis de este trabajo sobre la presencia actual y el avance de la democracia directa en relación con la crisis de la democracia representativa.

\section{Consulta popular}

Respecto de la consulta popular, se agregaron, en adición a los temas de trascendencia nacional, los de trascendencia regional para una o varias entidades federativas. A la lista de asuntos que no podrán ser objeto de consulta popular se adicionaron los tratados internacionales sobre derechos humanos y las garantías para su protección, ${ }^{53}$ la permanencia o continuidad en el cargo de los servidores públicos de elección popular, ${ }^{54}$ el sistema financiero, el presupuesto de egresos y las obras de infraestructura en ejecución.

La reforma amplió la función del INE en la consulta popular, al incluir atribuciones de promoción de la participación ciudadana en la misma de manera imparcial, evitando influir en la preferencia ciudadana. De manera

53 Adición innecesaria, toda vez que ya existía la prohibición de restringir los derechos humanos reconocidos en la Constitución, y el artículo 1o. incluye a los tratados internacionales.

54 Esta prohibición deberá interpretarse de conformidad con lo dispuesto por la parte de la reforma que se comenta en los artículos 81,116 y $122 \mathrm{~A}$, III, que por vez primera introducen la revocación de mandato, respectivamente, del presidente de la República, los gobernadores de los estados y el jefe de gobierno de la Ciudad de México. En el caso del titular del Ejecutivo federal, el proceso será conducido por el INE, pero no mediante consulta popular, sino mediante votación libre, directa y secreta de los ciudadanos y ciudadanas inscritos en la lista nominal (artículo 35, 6.o. y 7o., fracción IX). En los otros dos casos será regulado por las Constituciones locales y de la CdMex. De cualquier manera, es discutible si la revocación de mandato aun mediante sufragio universal y directo entraña o no una consulta sobre la permanencia o continuidad en el cargo de los servidores públicos de elección popular objeto de esta nueva figura constitucional (presidente, gobernadores y jefe de Gobierno de la CdMex). En caso de ser afirmativa la respuesta, estaríamos ante una contradicción constitucional y en el mismo precepto. Afortunadamente, también en el artículo 35 (fracción VIII, numeral 3) se estableció que será la Suprema Corte de Justicia de la Nación la que resuelva sobre la constitucionalidad de la materia de la consulta previa a la convocatoria que realice el Congreso de la Unión. 
acertada se modificó la fecha para realizar la consulta, que antes era el mismo día de la jornada electoral, y ahora será el primer domingo de agosto (numeral 5o.).

\section{Revocación de mandato 55}

En cuanto a la revocación de mandato, se agregó la fracción IX al artículo 35 como un derecho ciudadano, que incluye todo el procedimiento para llevarlo a cabo a cargo del INE; ${ }^{56}$ no obstante, el Congreso emitirá la ley reglamentaria correspondiente. ${ }^{57}$ Pero esta figura también fue agregada en el artículo 36 como una obligación del ciudadano, con lo que al igual que votar en las elecciones queda con un doble carácter de derecho y obligación..$^{58}$

En el artículo 41, referente a las atribuciones del INE, se agregaron las correspondientes a la implementación de la revocación de mandato y la posibilidad de celebrar convenios con las entidades federativas para

55 Curiosamente, el concepto no lo define la reforma en el cuerpo normativo principal, sino en el artículo tercero transitorio: "Para efectos de la revocación de mandato a que hace referencia la Constitución tanto a nivel federal como local, deberá entenderse como el instrumento de participación solicitado por la ciudadanía para determinar la conclusión anticipada en el desempeño del cargo a partir de la pérdida de la confianza".

56 Como elementos constitutivos de esta figura cabe resaltar que sólo procede a petición ciudadana ( $3 \%$ de la lista nominal y por lo menos en diecisiete entidades federativas), ocurrirá sólo en una sola ocasión y tres meses después de la conclusión del tercer año del periodo constitucional, mediante votación libre, directa y secreta; su validez queda sujeta a que haya participado por lo menos el $40 \%$ de los ciudadanos inscritos en la lista nominal de electores, y por mayoría absoluta, el INE tendrá a su cargo la organización, el desarrollo y cómputo de la votación, y sus resultados podrán ser impugnados ante la Sala Superior del Tribunal Electoral del Poder Judicial de la Federación. Este órgano realizará el computo final después de resolver impugnaciones, con lo que estamos en presencia de dos cómputos, el del INE y el del Tribunal. Finalmente, se incluyen una serie de candados para garantizar la imparcialidad de la votación, como la realización de propaganda con recursos públicos y la difusión de propaganda gubernamental, salvo educación, salud y protección civil (artículo 35, fracción IX).

57 Para lo que cuenta con 180 días, seis meses, según lo indica el artículo segundo transitorio de la reforma.

58 Y en todo caso corresponderá a la ley reglamentaria que emita el Congreso de la Unión la que determine si incluye o no sanciones en el caso de que no se cumpla con esa obligación. De no hacerlo, quedaría como una obligación incompleta o imperfecta, ya que la obligación es la conducta contraria al acto antijurídico como supuesto de una sanción. En otras palabras, quien incumple con una obligación (como pagar impuestos) comete un ilícito, que trae como consecuencia una sanción. 
ejecutar esta figura en caso de que decidan no hacerlo los organismos públicos locales. Finalmente, se establece que el sistema de impugnación para asegurar la constitucionalidad y legalidad de los actos y resoluciones electorales se extenderá a los procesos de consulta popular y revocación de mandato.

Fundamental fue la parte de la reforma sobre revocación de mandato al artículo 81, que por vez primera en la historia de México consigna que "el cargo de presidente de los Estados Unidos Mexicanos puede ser revocado", y en caso de que proceda la revocación ocupará la titularidad del Ejecutivo Federal quien ocupe la presidencia del Congreso, ${ }^{59}$ a fin de que este órgano legislativo en no más de treinta días designe a quien concluya el periodo constitucional. ${ }^{60}$

Por su parte, los artículos 116 y 122, también objeto de esta reforma, extienden respectivamente la revocación de mandato a los gobernadores de los estados y jefe de Gobierno de la CdMex, dejando a sus correspondientes Constituciones ${ }^{61}$ la precisión de las normas que regularán estos procesos. $^{62}$

59 Es importante observar que la Constitución no contiene la figura de "Presidente del Congreso", sino únicamente de cada una de sus Cámaras. Es la Ley Orgánica del Congreso la que señala en su artículo 5o. lo siguiente: "Cuando el Congreso sesione conjuntamente lo hará en el reciento que ocupe la Cámara de Diputados y el presidente de ésta lo será de aquél". De modo que en caso de revocación de mandato ocupará temporalmente la presidencia de la República el presidente de la Cámara de Diputados durante los treinta días con que cuenta el Congreso para designar a quien concluya el mandato constitucional, en los términos de la reforma al artículo 81 constitucional.

60 Mediante esta disposición, el sistema constitucional mexicano inserta un elemento que corresponde típicamente al sistema constitucional del parlamentarismo, como es el caso de que el jefe del gobierno (y en México también jefe del Estado) emerge del Poder Legislativo y no del voto popular directo, como es el caso, por ejemplo, de las Constituciones de Gran Bretaña, Italia, España y Alemania en Europa, para sólo mencionar algunas, y, consecuentemente, se aparta del sistema constitucional presidencial fundado por los Estados Unidos en 1787.

61 Con base en esta nueva disposición constitucional federal, deberá ser ajustada la Constitución de la CdMex, porque en la parte correspondiente a la revocación de mandato (artículo $25 \mathrm{G}$ ), esta última carta contempla esta figura para "representantes electos", sin especificar si esto incluye no sólo a los alcaldes, sino también al jefe del Gobierno de la CdMex. Por su parte, el artículo 32 de la Constitución local, relativo a la Jefatura de Gobierno, no incluye (como ahora el numeral 81 de la Federal) la figura de la revocación del mandato para el o la titular de la jefatura.

62 Las entidades federativas cuentan con dieciocho meses siguientes a la entrada en vigor del decreto de la reforma, para garantizar el derecho ciudadano a solicitar la revo- 
Con todas estas figuras de democracia directa, México se suma a las cincuenta naciones en el mundo en que la legislación ha incorporado diversos instrumentos de democracia participativa. En Latinoamérica es el caso de Argentina, Bolivia, Ecuador, Costa Rica, entre otros países. Debe decirse, sin embargo, que su uso ha sido muy limitado en el hemisferio continental. La consulta a la ciudadanía sobre temas fundamentales es el mecanismo de democracia más utilizado en el mundo: 121 países contienen disposiciones al respecto.

En México, la nueva Constitución de la CdMex es sin duda la norma más avanzada en la materia de la democracia participativa. ${ }^{63}$ Todo un capítulo (II) está dedicado a las figuras de la democracia directa que se han comentado, las de la democracia participativa, que incluye la gestión, evaluación y control de la función pública, además del presupuesto participativo (artículo 26, incisos A y B), e incluso también de la democracia representativa, que incluye a las candidaturas sin partido (artículo 27, inciso A) y a los partidos políticos (artículo 27, inciso B). Varias legislaturas de otras entidades federativas incluyen algunas de estas figuras, señaladamente Tabasco y Zacatecas, pero ninguna con la diversidad, amplitud y profundidad que la Constitución de la CdMex, con la que se ha buscado equilibrar las carencias de la democracia representativa con la democracia directa y participativa, al menos en la capital del país y nueva entidad federativa.

\section{CONCLUSIONES}

En este trabajo se ha desarrollado la hipótesis de que el actual desencanto ciudadano con la democracia representativa ha provocado como respuesta el surgimiento de diversas figuras de la democracia participativa o directa citando los casos de Bolivia, Venezuela y Ecuador, y profundizando en las modalidades de México.

Adicionalmente, se ha propuesto la integración de elementos de los diversos tipos de democracia: representativa, participativa y radical, a mane-

cación de mandato y, consecuentemente, reformar sus respectivas Constituciones. El artículo sexto transitorio que establece ese derecho también fija los lineamientos generales para su implementación.

63 Salvo por lo que se refiere a las figuras de la consulta popular y revocación de mandato, conforme a la reforma del 20 de diciembre del 2019 a la Constitución federal, ampliamente comentada en este trabajo. 
ra de una síntesis para una gobernanza que resuelva los problemas generados por la democracia representativa, sobre todo la "fatiga democrática", pero sin prescindir de aquélla, ya que su operatividad sigue siendo válida para estructurar gobiernos en países sobre todo de amplia extensión territorial y gran diversidad o pluralidad social y política, como es el caso de México. La idea no es confrontar ambas formas de gobierno: la democracia representativa versus la democracia participativa, sino encontrar la fórmula adecuada para la fusión de las dos, con una suerte de maridaje de conveniencia mutua. ${ }^{64} \mathrm{La}$ democracia representativa necesita revigorarse frente al presente desencanto ciudadano, con el vigoroso acicate de la democracia participativa o directa. Por su parte, ésta requiere también de la presencia de los representantes. La sociedad comercial actual que describió Constant en su célebre discurso no puede prescindir de ellos y regresar al modelo de la libertad de los antiguos. Para esa fusión es necesario estar conscientes de las desigualdades que inhiben la participación ciudadana con el ánimo de proponer procesos institucionales eficaces, en donde la ciudadanía se involucre en las decisiones públicas que afectan a la comunidad donde viven, pero también al conjunto nacional.

La integración de ambas categorías (democracia representativa y democracia participativa) no es ciertamente una tarea sencilla. Por el contrario, requiere de mucha ingeniería constitucional, con base en una amplia negociación política no sólo con la parte institucional (gobierno y partidos políticos), sino también con la no institucional (organizaciones sociales), pues finalmente lo que se busca es el acercamiento entre los representantes y las demandas de los ciudadanos. Por lo mismo, no se trata tan sólo de insertar las figuras de la democracia participativa en el texto constitucional, sino de acomodarlas armónicamente en el mismo con las ya existentes de la democracia representativa, lo que necesariamente supondrá diversos ajustes y alteraciones en esta última. Por ejemplo, la figura de la revocación de mandato a la mitad del periodo presidencial requiere ponderar sus consecuencias tanto para el caso de una confirmación como de su negativa desde antes de la elección, de tal suerte que el electorado tenga plena conciencia de que elige a un representante presidencial para un periodo de seis años, que puede terminar en tres, y consecuentemente, se activaría un

64 Como ha sido el caso ya mencionado anteriormente de la integración en el mismo texto constitucional de los derechos individuales, los sociales y los colectivos, lo que se logró a partir del Congreso Constituyente de 1917 entre las dos primeras categorías, y a lo largo de su ya cumplido primer centenario entre estas y la tercera. 
mecanismo para concluir el mandato. Igual análisis se requiere para todas y cada una de las modalidades de la democracia directa arriba expuestas.

Con la nueva Constitución de la CdMx, las reformas en las Constituciones locales, y las reformas constitucionales sobre nuevas figuras de democracia directa, en la carta federal, estará a prueba en la práctica, la armonización de la democracia representativa y la democracia participativa en México.

\section{BIBLIOGRAFÍA}

CAdena RoA, Jorge y LóPez Leyva, Miguel Armando, El malestar con la representación en México, México, UNAM, Instituto de Investigaciones Sociales-Centro de Investigaciones Interdisciplinarias en Ciencias y Humanidades-Ficticia Editorial, 2019.

Carbonell, Miguel et al., Neoconstitucionalismo(s), 4a. ed., México, UNAM-Trotta, 2009.

Constant, Benjamin, "Discurso sobre la libertad de los antiguos comparada con la de los modernos", pronunciado en El Ateneo de París, en Curso de Política Constitucional, tomo tercero, traducción de Marcial Antonio López, Madrid, Imprenta de la Compañía, 1820.

Cuenca Botey, Luis Emilio, “Acción, decisión y competencias deliberativas en el presupuesto participativo de Porto Alegre", Rev. Ciencias Sociales, Universidad de Costa Rica. 2008.

Madison, James (1787), The Federalist No. 10, The Utility of the Union as a Safeguard Against Domestic Faction and Insurrection (continued) (puede consultarse su versión electrónica en: http://www.constitution. org/fed/federa10.htm).

Figueroa Ávila, Enrique, Candidaturas independientes en México, déficit de la validez de la legislación 2012-2017 en materia de su registro conforme al sistema interamericano de los derechos humanos, tesis para obtener el grado de doctor en derecho por la Universidad Panamericana, México, 2019.

Gargarella, Roberto, Crisis de la representación política, México, Fontamara, 1997

KELSEN, Hans, Teoría general del Estado, traducción del alemán de Luis Legaz Lacambra, México, Editora Nacional, 1965.

Esta obra está bajo una Licencia Creative Commons Atribución-NoComercial-SinDerivar 4.0 Internacional, IIJ-UNAM. 
LEVITSKi, Steven y ZiBLATT, Daniel, Cómo mueren las democracias, México, Ariel, 2018.

LEPSIUS, Oliver, "El redescubrimiento de Weimar por parte de la doctrina del derecho político de la república federal", "Die Wiederentdeckung Weimars durch die bundesdeutsche Staatsrechtslehere", en CHISTOPH, Gusy (ed.), Weimars lange Schatten - "Weimar" als Argument nach 1945, trad. de Ignacio Gutiérrez, Gutierrez, Baden-Baden, Nomos, 2003.

LINZ, Juan, Democracy: Presidential or Parlamentary. Does it Make a Difference?, Manuscript, Yale University, 1984.

Mounk, Yascha, The People vs Democracy, Cambridge, Harvard University Press, 2018.

Pateman, Carole, Participatory Democracy Revisited, APSA Presidential Address, 2012.

Rabasa GamboA, Emilio, ¿Por qué la democracia? Transiciones de 1974 a 1990, México, UNAM, 1993.

RABASA GAMBOA, Emilio, De súbditos a ciudadanos: sentido y razón de la participación política, México, Miguel Angel Porrúa-UNAM, 1994.

RABASA GAMBOA, Emilio, "Las reformas constitucionales en materia político-electoral", Ochenta años de vida constitucional en México, México, Cámara de Diputados, 1998.

RABASA GAMBOA, Emilio, Las reformas constitucionales en materia político-electoral, edición bilingüe, México, UNAM, Instituto de Investigaciones Jurídicas-ONU, 2012.

SAlmorán, Guadalupe, Bolivia, Ecuador y Venezuela: ¿un nuevo constitucionalismo latinoamericano, o nuevas autocracias plebiscitarias?, Diritto \& Questioni Pubbliche 12 (2), 2016.

Temelkuran, Ece, Cómo perder un país, Barcelona, Anagrama, 2019.

VAN ReYBrouck, David, Contra las elecciones -cómo salvar la democracia, México, Taurus, 2017.

WALKER, Jack, "A Critique of the Elitist Theory of Democracy", The American Political Science Review, vol. 60, núm. 2 (1966).

Fecha de recepción: 24 de julio de 2019.

Fecha de aceptación: 04 de abril de 2020.

Esta obra está bajo una Licencia Creative Commons

Atribución-NoComercial-SinDerivar 4.0 Internacional, IIJ-UNAM. 


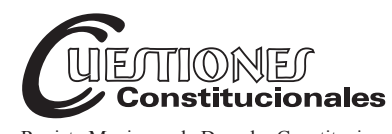

Revista Mexicana de Derecho Constitucional Núm. 43, julio-diciembre 2020

\title{
El precedente judicial en México. Fundamento constitucional y problemas básicos
}

\author{
Judicial precedent in Mexico. Constitutional \\ basis and basic problems
}

\section{Rubén SÁNCHEZ GIL*}

RESUMEN: Aunque el precedente judicial ha sido una figura con creciente importancia en México durante las últimas décadas - sobre todo en materia constitucional一, persiste una concepción tradicional a su respecto. Pero en años recientes, una posición más apegada a la tradición angloamericana se ha introducido en la jurisprudencia mexicana. Trayendo al sistema jurídico mexicano elementos de la teoría del precedente de aquella cultura jurídica, este estudio se pregunta por las bases constitucionales del precedente judicial en México, y echa nueva luz sobre sus dos problemas fundamentales: el uso de "tesis" y el efecto vinculante de los criterios judiciales. Contribuye así a una reanimada apreciación del papel jurídico y político de la judicatura en México, que daría nuevo valor al derecho que elaboran los jueces en este país.

Palabras clave: jurisprudencia, precedente, México, judicatura, aplicación judicial del derecho, efecto vinculante.
ABSTRACT: Though judicial precedent has been a figure with growing importance in Mexico during past decades-specially regarding constitutional law-, a traditional conception towards it persists. But in recent years, a closer to the Anglo-American tradition stance found its way into Mexican caselaw. Bringing elements from the said legal culture to Mexican law, this study asks for the constitutional grounds of judicial precedent in Mexico, and sheds new light upon its two main problems: the use of "thesis" and the binding effect of judicial holdings. Thus, it contributes to a fresh appraisal of the Mexican bench's legal and political role that would give new value to judge-made law in this country.

Keywords: caselaw, case law, precedent, mexico, judicial branch, adjudication, binding effect.

* Doctor en Derecho por la UNAM. Profesor en la Facultad de Derecho de la Universidad Autónoma de Yucatán. Investigador nacional, nivel I, del Sistema Nacional de Investigadores. México. ORCID: 0000-0002-2094-0855 Correo electrónico: ruben. sanchez@correo.uady.mx. 


\author{
SUMARIO: I. Introducción. II. El precedente judicial. III. El \\ sistema jurisprudencial federal en México. IV. Dos problemas \\ mexicanos. V. Reflexiones finales.
}

\title{
I. INTRODUCCIÓN
}

La cultura gestada con base en el derecho romano, de la cual abreva el sistema jurídico mexicano, tradicionalmente se ha pronunciado a favor de la preeminencia de la ley y de un papel limitado de la función jurisdiccional. ${ }^{1}$ El apotegma con el cual Montesquieu señaló que al juez es solamente la "boca de la ley"' ha sido un pilar fundamental de nuestra concepción jurídica.

Sin embargo, gracias al constitucionalismo y al derecho internacional de los derechos humanos, en las últimas décadas se ha transformado la visión de la tradición romanista sobre la función de los jueces y de la importancia de su labor. ${ }^{3}$ Van de la mano el reconocimiento a la labor creativa de la interpretación judicial ${ }^{4}$ y la creciente relevancia (jurídica y política) que la jurisprudencia ha adquirido en países de tradición neorromanista. ${ }^{5}$

Esta misma situación se ha desarrollado en México. Por muchos años la jurisprudencia ha sido en nuestro país, en el mejor de los casos, un elemento meramente auxiliar de la enseñanza y de la práctica jurídicas. Un conjunto de factores propiciaron esa situación: el peso de la tradición

\footnotetext{
1 Merryman, John Henry y Pérez-Perdomo, Rogelio, The Civil Law Tradition. An Introduction to the Legal Systems of Europe and Latin America, 3a. ed., Stanford, Stanford University Press, 2007, pp. 34 y ss.

2 "Pero los jueces de la nación, como es sabido, no son más ni menos que la boca que pronuncia las palabras de la ley, seres inanimados que no pueden mitigar la fuerza y el rigor de la ley misma", Montesquieu, Carlos Luis de Secondat, barón de la Brède y, Del espiritu de las leyes, 13a. ed., trad. de Nicolás Estévanez, México, Porrúa, 2000, lib. XI, cap. VI, p. 108 (cursivas añadidas).

3 Merryman y Pérez-Perdomo, op. cit., nota 1, pp. 37 y 38.

4 Zambrano, Pilar, La inevitable creatividad en la interpretación jurídica. Una aproximación iusfilosófica a la tesis de la discrecionalidad, México, UNAM, Instituto de Investigaciones Jurídicas, 2009, pp. 64 y 78.

5 MacCormick, D. Neil y Summers, Robert S., "Reflexiones generales adicionales y conclusiones", en idem (eds.), La interpretación del precedente. Un estudio comparativo, México, TEPJF, 2016, p. 495 (refiriendo el precedente judicial como "un nuevo tipo de autoridad legal aceptada en los países del derecho civil", que resulta "esencial para la constitución de un caso [jurídicamente] satisfactorio").
} 
neorromanista; una dogmática constitucional que, de modo conveniente para el sistema político, menospreció la labor de los tribunales; ${ }^{6}$ y muy particularmente la insuficiente difusión —en especial en las entidades federativas - del Semanario Judicial de la Federación, que persistió por décadas. ${ }^{7}$ En los últimos lustros, estos factores se han superado gracias al papel relevante que han adquirido la Suprema Corte de Justicia de la Nación y otros tribunales en nuestra transición democrática, y a una más eficiente difusión de la jurisprudencia en nuestro país debida a los esfuerzos informáticos - y económicos — del Poder Judicial de la Federación.

Sin embargo, a grandes rasgos, la creciente importancia de la jurisprudencia en México no ha ido acompañada de un esfuerzo similar por comprender a cabalidad el precedente judicial como fuente jurídica. Muchos problemas que tenemos en la práctica se deben al desconocimiento - por parte de tribunales y de postulantes - de las numerosas implicaciones del empleo del precedente en la argumentación jurídica.

El papel del derecho que los jueces elaboran (judge-made law) va más allá de la obligación de aplicar, bajo determinadas condiciones, las soluciones ideadas por los tribunales para casos previos. El precedente judicial es una figura con muchos más "matices y complicaciones" de los que comúnmente creemos, y se requiere "paciencia y agudeza para superarlos". 8

En los últimos años, los tribunales mexicanos han advertido esta situación y volteado a una teoría del precedente judicial, de obvia confección anglosajona, para subsanar las deficiencias conceptuales de nuestro sistema jurisprudencial, y explicarlo y operarlo con mayor claridad. ${ }^{9}$ Por su parte, sin perjuicio de algunos esfuerzos anteriores que resultaron aislados, muy recientemente la doctrina mexicana ha generado un par de obras que vislumbro como cruciales para ver en este país con diferentes ojos el de-

6 Cossío Díaz, José Ramón, Dogmática constitucional y régimen autoritario, 2a. ed., México, Fontamara, 2000, pp. 68 y 69.

7 Zertuche García, Héctor Gerardo, La jurisprudencia en el sistema jurídico mexicano, 2a. ed., México, Porrúa, 1992, pp. 355 y 356.

8 Garner, Bryan A. et al., The Law of Judicial Precedent, St. Paul, Thomson Reuters, 2016, p. 1 (cursivas añadidas).

9 Aparte de ejemplos señalados abajo, véase Primera Sala, amparo directo 49/2013, sentencia del 19 de noviembre de 2014, con. IV, pp. 29 y 30 (que habla de una "teoría del precedente" y expone la diferencia entre el precedente vinculante y el persuasivo, para concluir que "las tesis aisladas son precedentes no obligatorios"). 
recho de confección judicial, obras que, para comenzar, ya no aluden a la "jurisprudencia", sino al "precedente", cambio terminológico aparentemente inocuo, pero que en realidad parece anunciar un enfoque diferente al que tradicionalmente ha prevalecido en México. ${ }^{10}$

Este trabajo pretende contribuir a la nueva perspectiva sobre la jurisprudencia que se intenta propagar en México. Obviamente, es imposible siquiera presentar aquí un catálogo de todos los problemas que suscita el precedente judicial, tanto de modo general como en particular para nuestro sistema jurídico. En tal virtud, luego de exponer conceptos generales sobre el precedente judicial - primordialmente basados en la tradición del common law-, y apuntar referencias elementales del sistema jurisprudencial de nuestro país, esbozaré tres cuestiones básicas para repensar la concepción jurisprudencial mexicana.

Dichas cuestiones son: 1) el fundamento constitucional del precedente judicial; 2) la relación entre las "ejecutorias" que contienen el precedente y las "tesis" que lo divulgan — tan características de nuestro sistema-, y 3 ) la matizada diversidad de grados de efecto vinculante de los precedentes, muy lejana de la proverbial dicotomía vinculante/orientador imperante en nuestra práctica jurídica. La primera de estas cuestiones no sólo tiene una importancia normativa, sino que también es ineludible para aproximarnos al precedente judicial: determinar los valores constitucionales a que sirve esta figura y sus implicaciones proporciona una visión distinta a la formal y mecánica que ha prevalecido en nuestro país. Las dos restantes, a mi parecer, son los principales problemas prácticos que enfrenta la comprensión del precedente judicial en México.

Reflexionar sobre estos tópicos es imperativo para perfeccionar la aplicación del derecho en nuestro país. La complejidad actual de nuestro sistema jurisprudencial, tanto por la pluralidad de órganos que pueden sentar precedentes como por la variedad de relaciones jurídicas con que se relacionan, exigen una visión actualizada del precedente judicial. Ojalá que este trabajo pueda ser punto de partida para una más amplia discusión sobre el tema, que corresponderá efectuar a toda la comunidad jurídica mexicana.

10 Gómora Juárez, Sandra, Un análisis conceptual del precedente judicial, México, UNAM, Instituto de Investigaciones Jurídicas, 2018, y Bernal Pulido, Carlos et al. (coords.), El precedente en la Suprema Corte de Justicia de la Nación, México, SCJN, Centro de Estudios Constitucionales, 2018. 


\section{EL PRECEDENTE JUDICIAL}

\section{Precisiones conceptuales}

Debido a la "anarquía conceptual"11 en esta materia, es necesario definir los conceptos fundamentales del presente estudio. Una nomenclatura precisa y concreta en torno a los diversos conceptos jurisprudenciales ayudaría en México a superar muchos malentendidos.

Por lo general, y a grandes rasgos, jurídicamente se tiene por "precedente" al criterio jurídico empleado en una resolución judicial que, en términos que adelante precisaré, ${ }^{12}$ debe servir como base para decidir casos futuros referentes a tópicos o hechos similares. ${ }^{13}$ Es posible que el término "precedente" también pueda aplicarse a criterios sentados en ámbitos diferentes de los estrictamente jurisdiccionales, ${ }^{14}$ pero su empleo en tal sentido es muy reducido, por lo que esta acepción resulta prácticamente insignificante.

Por su parte, el término "jurisprudencia” se emplea para designar: 1) el "[c]onjunto de las sentencias de los tribunales, y [de la] doctrina que contienen"; 2) el "[c]riterio sobre un problema jurídico establecido por una pluralidad de sentencias concordes", y 3 ) en un sentido ahora desusado, a la "[c]iencia del derecho". ${ }^{15}$

En los países de tradición neorromanista, como México, cobra especial relevancia el segundo de los anteriores significados. Parece que la desconfianza de los sistemas de nuestra cultura jurídica hacia los juzgadores

\footnotetext{
11 Zertuche García, op. cit., nota 7, p. 86.

12 Infra, § IV.2.

13 Garner et al., op. cit., nota 8, p. 22.
}

14 Gerhardt, Michael J., The Power of Precedent, Nueva York, Oxford University Press, 2011, p. 3 (que integran en un amplio concepto las resoluciones judiciales y las de órganos de distinta naturaleza, y aun prácticas históricas y tradiciones). Hablando de "cierto valor vinculante" del "precedente administrativo", apoyado por jurisprudencia ordinaria, constitucional y comunitaria, y basado en los principios de igualdad, de buena fe y de confianza legítima. Véase García de Enterría, Eduardo y Fernández, Tomás-Ramón, Curso de derecho administrativo I, 10a. ed., Madrid, Civitas, 2000, pp. 76 y 77, y también la obra de Silvia Díez referida infra, nota 61.

15 Real Academia Española, Diccionario de la lengua española, 23a. ed., Madrid, 2014, disponible en: http://dle.rae.es, s. v. "jurisprudencia" (2 de octubre de 2017). Cfr. Muñoz Machado, Santiago (dir.), Diccionario del español jurídico, Madrid, RAE-Consejo General del Poder Judicial, 2016, disponible en: http://dej.rae.es, s. v. "jurisprudencia” (idem). 
llevó a negar cualquier efecto vinculante a sus precedentes "aislados", por lo que les niega la calidad de "jurisprudencia", y exige su reiteración para que la persistencia del criterio judicial sea signo de su corrección. ${ }^{16}$ Pero en el contexto mexicano es usual emplear el término "jurisprudencia" en la primera de las acepciones relacionadas en el párrafo anterior; es decir, en el sentido de "conjunto de decisiones y criterios judiciales" antes señalado; este concepto equivale al concepto de case law anglosajón, ${ }^{17} \mathrm{o}$, en otras palabras, al conjunto de normas jurídicas que resultan de las decisiones judiciales.

En el último sentido usaré en este trabajo el término "jurisprudencia"; con él aludiré como conjunto a las resoluciones, los criterios o los precedentes judiciales, sin reparar en si son de aplicación (absolutamente) imperativa por algún motivo, en particular por su carácter reiterado. En cambio, especificaré con el calificativo "vinculante" o similares cuando me refiera a esta última especie de precedentes.

\section{El precedente en el common law}

Es muy sabido que el uso obligatorio del precedente judicial como elemento de decisión jurídica es el aspecto más característico de la tradición jurídica anglosajona o common law. ${ }^{18}$ Una mirada a la historia de la evolución de esta práctica perfila el trasfondo en que opera el precedente en esta cultura y sus implicaciones.

16 En particular, para México, véase Vallarta, Ignacio L., El juicio de amparo y el writ of habeas corpus. Ensayo crítico-comparativo sobre esos recursos constitucionales, México, Imprenta de Fco. Díaz de León, 1881 (4a. ed. facsimilar, Obras, México, Porrúa, 1989, t. V), pp. 316-322. Para España, véase Ferreres Comella, Víctor, "Sobre la posible fuerza vinculante de la jurisprudencia”, en idem y Xiol Ríos, Juan Antonio, El carácter vinculante de la jurisprudencia, México, Fundación Coloquio Jurídico Europeo-Fontamara, 2010, pp. 104 y 105 (habla del mínimo de dos resoluciones del Tribunal Supremo para que haya "jurisprudencia"); pero en relación con el Tribunal Constitucional, $c f r$. artículo 164.1 de la Constitución de ese país. En Alemania abundan las referencias a la "jurisprudencia constante" (ständige Rechtsprechung), como se califica a los criterios judiciales que han alcanzado un alto grado de reiteración. Véase también Garvey Algero, Mary, "The Sources of Law and the Value of Precedent: A Comparative and Empirical Study of a Civil Law State in a Common Law Nation", Louisiana Law Review, Nueva Orleans, Universidad Loyola, vol. 65, 2005, disponible en: http://bit. ly/2yUmVn4, pp. 787 y ss.

17 Garner et al., op. cit., nota 8, p. 787.

18 Patterson, Edwin W., Jurisprudence: Men and Ideas of the Law, 1953, p. 300, citado por ibidem, p. 16. 
Los primeros tribunales que estableció el rey normando Guillermo el Conquistador resolvían los conflictos sometidos a su decisión con base en las diversas reglas que seguían los pobladores anglosajones, daneses y normandos de la actual Inglaterra. Sin embargo, dichos tribunales elaboraron nuevas normas cuya aplicación se fue extendiendo por todo el reino sustituyendo a las antiguas, formándose así un derecho "general" o "común" a todos los súbditos ingleses. ${ }^{19}$

Por eso, la expresión common law designa al conjunto de decisiones judiciales que contenían esas nuevas normas, y por extensión la jurisprudencia en general de manera sinónima a la locución case law. Pero ella también denomina la tradición jurídica a que dio lugar el sistema jurídico inglés, integrado al comienzo por reglas "no escritas", consuetudinarias, a diferencia del derecho legislado de nuestra tradición, pues los antiguos jueces ingleses —y algunos continúan haciéndolo- sólo anunciaban su decisión sin registrarla por escrito. ${ }^{20}$

Los principios que actualmente rigen la aplicación de la jurisprudencia en los sistemas de common law resultaron de una muy larga evolución. La reiteración de las soluciones a casos previos fue una costumbre de los antiguos tribunales ingleses, y muy probablemente la originó un motivo tan propio del pragmatismo que caracteriza a esta cultura jurídica: aplicar la respuesta que se dio al caso anterior era lo más sencillo, pues " $[\mathrm{n}] \mathrm{o}$ había necesidad de considerar una cuestión de novo si se había decidido recientemente", ${ }^{21}$ lo que quizá se deba al instinto imitativo humano y al "profundamente arraigado sentido de justicia (fairness) y regularidad de la psique humana". ${ }^{22}$ A diferencia de lo que sucede actualmente, a comienzos del siglo XIV, "los casos se usaban sólo como prueba de una costumbre (custom) del tribunal", y de un modo similar al de la tradición romanista, un caso aislado no tenía efecto vinculante, pero "una costumbre bien establecida (probada mediante la invocación más o menos casual de casos) se veía sin duda como fuertemente persuasiva". ${ }^{23}$ Entre los siglos XVI y

19 Rabasa, Óscar, El derecho angloamericano. Estudio expositivo y comparado del “common law", 2a. ed., México, Porrúa, 1982, pp. 67 y 68.

20 Ibidem, pp. 25-26, y Garner et al., op. cit., nota 8, pp. 1 y 789.

21 Plucknett, Theodore Frank Thomas, A Concise History of the Common Law, 5a. ed., Boston, Little, Brown and Co., 1956 (facsímil, Indianápolis, Liberty Fund, 2010), disponible en: http://bit.ly/lGhaheh, p. 342.

22 Garner et al., op. cit., nota 8, pp. 15 y 16.

23 Plucknett, op. cit., nota 21, p. 347. 
XVII se estableció el principio de que un solo precedente podía ser vinculante, pero tal autoridad se concedió únicamente a las decisiones del Tribunal de la Cámara del Tesoro (Court of Exchequer Chamber). ${ }^{24}$

Durante el siglo XVII aún se citaban numerosos casos para demostrar la existencia de una práctica judicial que sirviera de base a una decisión; esto, a diferencia de lo que ocurre en los sistemas desarrollados de precedentes, en los cuales "un caso es tan bueno como una docena si cubre claramente el punto", y en ellos "consecuentemente las citas [de casos] son pocas y puntuales", ${ }^{25}$ lo que precisamente constituye la regla en la tradición anglosajona, en la cual el efecto vinculante del precedente es categórico. ${ }^{26}$ Gracias a diversos cambios institucionales, hasta el siglo XIX se sentaron las bases para consolidar el sistema de precedentes: la exclusión de jueces legos y la profesionalización de la judicatura; la organización de un solo tribunal de apelaciones en lugar de varios, y, last but not least, la estandarización y el carácter semioficial de los reportes de casos. ${ }^{27}$

Estas condiciones permitieron que en Inglaterra $-\mathrm{y}$ por su influencia, en los Estados Unidos ${ }^{28}$ - se consagrara el principio stare decisis,${ }^{29}$ que ordena deferencia a los precedentes judiciales, y que el common law desarrollara técnicas muy elaboradas para manejar los precedentes, que son un aspecto básico de su metodología. ${ }^{30}$ La Suprema Corte norteamericana explicó así la trascendencia de dicho principio:

\footnotetext{
24 Ibidem, p. 348.

25 Ibidem, p. 349.
}

26 Ferreres Comella, op. cit., nota 16, p. 69.

27 Plucknett, op. cit., nota 21, p. 350. Véase también Laporta, Francisco J., "La fuerza vinculante de la jurisprudencia y la lógica del precedente", en Ferreres Comella y Xiol Ríos, op. cit., nota 16, pp. 35 y 36.

28 Rabasa, op. cit., nota 19, pp. 123-126 (expresan diversas precisiones sobre la recepción del derecho inglés en los Estados Unidos).

29 Garner et al., op. cit., nota 8, p. 5. La expresión es una reducción de la frase "stare decisis et non quieta movere" (estarse o atenerse a lo decidido y no mover lo establecido); refiere completa esta locución, véase Townsend v. Jemison, 50 U.S. (9 Howard) 407, 414 (1850). La indicada regla tiene un origen medieval, y se dice que éste es "continental y no anglosajón" (Laporta, op. cit., nota 27, p. 35); cfr. McKean, Jr., Frederick G., "The Rule of Precedents", University of Pennsylvania Law Review, Filadelfia, vol. 76, núm. 5, marzo de 1928, disponible en: http://bit.ly/2fKYC6j, p. 481 (dice que el origen de este principio es "nebuloso" $[$ hazy]).

30 López Medina, Diego Eduardo, El derecho de los jueces, 2a. ed., Bogotá, LegisUniversidad de los Andes, 2009, pp. 231 y 232. 
[Esta] Corte ha reconocido frecuentemente la "fundamental importancia" del stare decisis, el principio jurídico básico que ordena el respeto judicial a las decisiones previas de un tribunal y a las reglas jurídicas que comprenden.... ha apuntado que... "promueve el imparcial, predecible y consistente desarrollo de los principios jurídicos, fomenta la confianza en las decisiones judiciales, y contribuye a la efectiva y percibida integridad del proceso judicial"... El stare decisis evita con ello la inestabilidad y la injusticia (unfairness) que acompañan la interrupción de las expectativas jurídicas establecidas. Por esta razón, el imperio del derecho (rule of law) demanda que adherirnos a nuestra jurisprudencia (case law) previa sea la regla. Apartarse del precedente es excepcional, y requiere "justificación especial". ... Esto es particularmente cierto donde, como aquí, el principio se ha establecido mediante iteración y reiteración (iteration and reiteration) por un largo periodo de tiempo. ${ }^{31}$

\section{3. ¿Hay una "teoría general” del precedente judicial?}

La primera objeción que surge en países romanistas como México contra el precedente judicial es que se trata de una figura ajena a nuestra tradición jurídica, pues corresponde al common law, cuyos jueces siempre han tenido un papel creativo y protagónico, a diferencia del limitado que se ha atribuido a los nuestros. ${ }^{32}$ Pero esta dificultad no es insuperable.

Resulta claro que "el precedente es ahora una parte significativa en la toma de decisiones legales y en el desarrollo del Derecho en [muchos] países y tradiciones legales". ${ }^{33}$ La decisión de los casos particulares siguiendo la respuesta dada a sus similares, o sea, la regla stare decisis, es "un principio común a cualquier sistema jurídico", aunque haya diferencias más o menos significativas entre los diversos ordenamientos —en particular respecto de la intensidad de la vinculación a los precedentes-, pero que finalmente pueden ser contingentes. ${ }^{34}$

\footnotetext{
31 Randall v. Sorrell, 548 U.S. 230, 243-244 (2006).

32 Ferreres Comella, op. cit., nota 16, pp. 47 y 48.

33 MacCormick y Summers, op. cit., nota 5, p. 493. Véase también Alexy, Robert,
} Theorie der juristischen Argumentation. Die Theorie des rationalen Diskurses als Theorie der juristischen Begründung, 4a. ed., Fráncfort del Meno, Suhrkamp, 2001, pp. 334335 (señala el papel del precedente [Präjudiz] como un "aspecto esencial" de la argumentación jurídica, y que su "importancia fáctica ... aun en el derecho continental-europeo... es hoy por todas partes resaltada" [cursivas en el original]).

34 MacCormick y Summers, op. cit., nota 5, pp. 497-507, y Orozco Muñoz, Mar- 
Al cabo, diferencias de algún tipo han existido aun entre los sistemas jurisprudenciales del common law. En los Estados Unidos, el efecto vinculante horizontal — que sujeta al tribunal a su propio precedente - no ha sido una regla rígida, como sí lo fue en Inglaterra desde finales del siglo XIX hasta $1966 .{ }^{35} \mathrm{E}$ incluso puede decirse que es más corta de lo que aparenta la distancia entre los "dos modelos básicos de incorporación de normas de origen judicial", el "precedente" anglosajón y la "jurisprudencia" (por reiteración) romanista: en el primero pueden elaborarse líneas por la concatenación de diversos precedentes, y el último supone como elemento mínimo la existencia de precedentes aislados y sus rationes decidendi. ${ }^{36}$

En la actualidad, quizá presenciamos la incipiente formación de una "teoría general del precedente", que trasciende culturas jurídicas, y éste es uno de los puntos en que la tradición neorromanista se aproxima a la del common law. ${ }^{37}$ La discusión entre estas tradiciones en torno al precedente es propicia para elaborar una porción de un "derecho intercultural" que contenga postulados comunes a ambas culturas jurídicas, ${ }^{38}$ pero por su grado de desarrollo me parece claro que este terreno común deberá cimentarse sobre los postulados que al respecto ha formulado la tradición anglosajona.

Sobre lo anterior hay un punto insoslayable: la necesidad de adoptar un enfoque decididamente comprehensivo y flexible del concepto de "precedente" y del stare decisis. ${ }^{39}$ Michele Taruffo abunda sobre esta inquietud:

Parece, sin embargo, evidente la falta de adecuación de una teoría general del precedente que sea sólo una versión adaptada de la teoría (o de una teo-

tín, La creación judicial del derecho y el precedente vinculante, Cizur Menor (Navarra), Aranzadi-Thomson Reuters, 2011, p. 233.

35 Garner et al., op. cit., nota 8, p. 35.

36 Aguiló Josep, "Fuentes del derecho", en J. Fabra Zamora y V. Rodríguez-Blanco (eds.), Conceptos jurídicos fundamentales y aplicación del derecho, Madrid, UNAM (en prensa), citado por Atienza, Manuel, Curso de argumentación jurídica, Madrid, Trotta, 2013, pp. 332 y 333.

37 Y por su parte, la tradición anglosajona se acerca a la continental en su "mayor confianza en los códigos y [en] el derecho estatutario". MacCormick y Summers, op. cit., nota 5, p. 496.

38 López Medina, op. cit., nota 30, p. 134, y Rivero Evia, Jorge, Fundamentos de derecho intercultural, México, Tirant lo Blanch, 2017, pp. 46 y 47.

39 Bankowski, Zenon et al., "Los fundamentos del precedente", en MacCormick y Summers (eds.), op. cit., nota 5, p. 461. 
ría) del precedente del common law. Una teoría del precedente que aspire a ser general y, por tanto, a tener cualquier utilidad heurística en más [de] un ordenamiento, debería por el contrario partir de la premisa de que el precedente existe en ordenamientos histórica y estructuralmente diferentes, y que el mismo presenta características diferentes en los distintos ordenamientos. Tal teoría debería servirse de conceptos amplios y diferenciados, capaces de conducir a una relativa unidad de fenómenos que representan múltiples peculiaridades. ${ }^{40}$

En efecto, actualmente no contamos con una "teoría general" del precedente judicial que sea cabal y con pretensiones de aplicabilidad universal; en el mejor de los casos, sólo puede decirse que ésta se halla "en construcción". Tal teoría general no podrá elaborarse de la noche a la mañana, ni veremos en los próximos años un esbozo de sus características esenciales. ${ }^{41}$ Pero como muestro más adelante, ya se han identificado conceptos $y$ funciones básicos del precedente judicial, que resultan comunes a diversos sistemas y tradiciones jurídicas, ${ }^{42}$ y que permitirían traer los postulados generales elaborados al respecto por el common law a nuestra cultura romanista, y en particular al sistema jurídico mexicano, aunque con la precaución que sugiere Taruffo.

\section{Fundamento constitucional}

Se han expresado muy diversas razones para que los tribunales sigan sus propios precedentes (efecto vinculante horizontal) o los que establecieron otros de nivel superior (efecto vinculante vertical). ${ }^{43}$ En realidad, antes que

40 Cinco lecciones mexicanas. Memoria del Taller de Derecho Procesal, México, TEPJF, 2003, disponible en: http://bit.ly/2I9Q44M, p. 195 (énfasis añadido).

41 La importante obra que coordinaron MacCormick y Summers (op. cit., nota 5) fue un gran esfuerzo para advertir similitudes entre culturas y sistemas jurídicos con relación al precedente judicial. Pero considerando que su versión original en inglés (Interpreting Precedents: A Comparative Study, Brookfield, Ashgate, 1997) tiene más de veinte años, sin que en éstos se haya dado algún avance significativo en este sentido, no parece probable que veamos el acelerado progreso de una visión compartida sobre el precedente.

42 Gómora Juárez, op. cit., nota 10, pp. 31-33.

43 Sobre los efectos horizontal y vertical del precedente, dicotomía empleada desde los años ochenta del siglo pasado, véase Garner et al., op. cit., nota 8, pp. 27 y ss. Cfr. Gascón Abellán, Marina, "Autoprecedente y creación de precedentes en el Tribunal Supremo”, en Bernal Pulido, Camarena González y Martínez Verástegui (coords.), op. cit., 
por uno solo, el vigor de los precedentes judiciales se explica - y conviene hacerlo- por una combinación de factores con el protagonismo de alguno de ellos en relación con el tipo de precedente de que se trate. ${ }^{44}$ Estos factores pueden basarse en principios jurídicos esenciales al derecho, que incluso se han consagrado como derechos fundamentales, al igual que en la conveniencia de la eficiencia del ordenamiento jurídico. ${ }^{45}$

Como una aproximación inicial, entre los primeros contaré la seguridad jurídica —y sus implicaciones_-, la igualdad en la aplicación de la ley y la imparcialidad judicial; y los segundos a muy grandes rasgos pueden cifrarse en la economía que para los casos particulares conlleva la respuesta previamente "examinada y aceptada" que representa el precedente. ${ }^{46}$ Estos

nota 10, p. 213 (con mayor precisión conceptual al distinguir el "autoprecedente" y el "precedente horizontal" [referente a los emitidos por tribunales homólogos]); y Bernal Pulido, Carlos, "La anulación de sentencias y el defecto sustantivo por desconocimiento del precedente. Dos propuestas de reforma del derecho mexicano para garantizar el respeto del precedente", en idem, p. 186 (repite la clasificación de la anterior autora sin referirla).

44 Caminker, Evan H., "Why Must Inferior Courts Obey Superior Court Precedents?", Stanford Law Review, Stanford, vol. 46, núm. 4, abril de 1994, disponible en: http://bit. ly/2JPJ4ci, p. 873 (concluye luego de una meticulosa crítica de las razones a favor y en contra del stare decisis), núm. 4 (Apr., 1994, vol. 46, núm. 4 (Apr., 1994), pp. 817-873, vol. 46, núm. 4 (Apr., 1994), pp. 817-873

45 Bankowski, MacCormick, Morawsky y Ruiz Miguel, op. cit., nota 39, pp. 453 y 455. Véase también Orozco Muñoz, op. cit., nota 34, pp. 231-240 (expone "[c]uatro principios sustantivos" [seguridad jurídica, igualdad, interdicción de la arbitrariedad e imparcialidad] y "cinco criterios de conveniencia técnica" [economía en la decisión, economía en la justificación, previsibilidad de la confirmación de la sentencia, y enervación de la prevaricación y del error judicial]).

46 Alexy, op. cit., nota 33, pp. 329 y 338. Aunque amerita diversas precisiones imposibles de realizar aquí, véanse "RECLAMACIÓN. PROCEDE IMPONER MULTA AL RECURRENTE BAJO LA HIPÓTESIS DE INTERPOSICIÓN SIN MOTIVO, CUANDO EN LAS CONSIDERACIONES DEL AUTO RECURRIDO SE CITE UNA JURISPRUDENCIA EXACTAMENTE APLICABLE AL CASO PARA JUSTIFICAR SU SENTIDO Y QUE NO HA SIDO INTERRUMPIDA", Primera Sala, Semanario Judicial de la Federación y su Gaceta, 10a. época, lib. IX, junio de 2012, t. 1, tesis 1a./J. 7/2012 (9a.), p. 139; “CONCEPTOS DE VIOLACIÓN INOPERANTES. LO SON AQUELLOS CUYO ANÁLISIS ES INNECESARIO CUANDO SOBRE EL TEMA PLANTEADO EN ELlOS YA EXISTE JURISPRUDENCIA DE LA SuPREMA CORTE DE JUSTICIA DE LA NACIÓN", Gaceta del Semanario Judicial de la Federación, 10a. época, lib. 33, agosto de 2016, t. IV, tesis I.6o.T. J/30 (10a.), p. 2305; y “CONCEPTOS DE VIOLACIÓN INOPERANTES. RESULTA INNECESARIO SU ANÁLISIS, CUANDO SOBRE EL TEMA DE FONDO PLANTEADO EN LOS MISMOS YA EXISTE JURISPRUDENCIA", idem, 10a. época, lib. 35, octubre de 2016, t. IV, tesis XVII.1o.C.T. J/9 (10a.), p. 2546. 
aspectos son dimensiones inescindibles del precedente; corresponden a diferentes valores que se realizan simultáneamente mediante la aplicación jurisprudencial.

Al lado de estos valores se han reconocido como propósitos que justifican la eficacia vinculante del precedente: 1) la economía producida por la simplicidad que tiene el tribunal de ajustarse a una respuesta previamente existente, y 2) lo deseable que resulta admitir que los tribunales tienen el poder de crear normas jurídicas para actualizar, mejorar y completar el ordenamiento. ${ }^{47} \mathrm{Sin}$ negar que ambos fines adquieren importancia en ciertos contextos, ellos no son generalmente admitidos como fundantes del principio stare decisis.

En relación con el precedente, la seguridad jurídica se despliega de varias maneras, como también corresponde a las múltiples vertientes de este principio. El apoyo en criterios judiciales previamente establecidos contribuye a la unidad y a la coherencia del ordenamiento jurídico bajo una interpretación común del derecho que permite unificar las opiniones sobre el significado de la ley, y que abona a la predictibilidad de la aplicación jurídica. ${ }^{48}$ Consecuentemente, esta unificación impide que el juez del nuevo caso imponga arbitrariamente su decisión, por hallarse constreñido en principio a seguir el precedente, lo que a su vez hace previsible su decisión y precisa las expectativas de los justiciables sobre su situación jurídica. ${ }^{49}$

La uniformidad anterior hace que el principio stare decisis sea manifestación de la igualdad en la aplicación de la ley, ${ }^{50}$ en tanto dispone que

47 Respectivamente, Gascón Abellán, op. cit., nota 43, pp. 212 y 213, y Gómora Juárez, op. cit., nota 10, pp. 118 y 119. El desarrollo judicial del derecho (Rechtsfortbildung) es una función judicial perfectamente reconocida en Alemania; por todos véase Larenz, Karl, Metodología de la ciencia del derecho, 2a. ed., trad. de M. Rodríguez Molinero, Barcelona, Ariel, 2001, pp. 359-363.

48 Ferreres Comella, op. cit., nota 16, p. 44, y Bankowski, MacCormick, Morawsky y Ruiz Miguel, op. cit., nota 39, pp. 451-453. En particular, véase "SEGURIDAD JURÍDICA EN MATERIA TRIBUTARIA. EN QUÉ CONSISTE”, Primera Sala, Semanario Judicial de la Federación y su Gaceta, 10a. época, lib. XVI, enero de 2013, t. 1, tesis 1a./J. 139/2012 (10a.), p. 437.

49 Orozco Muñoz, op. cit., nota 34, p. 232, y Garner et al., op. cit., nota 8, pp. 11 y 12.

50 Bankowski, MacCormick, Morawsky y Ruiz Miguel, op. cit., nota 39, p. 453; Ollero, Andrés, Igualdad en la aplicación de la ley y precedente judicial, 2a. ed., Madrid, Centro de Estudios Políticos y Constitucionales, 2005, p. 23; Pérez Portilla, Karla, Principio de igualdad. Alcances y perspectivas, México, UNAM-Conapred, 2005, p. 70; y "AMPARO DIRECTO EN REVISIÓN. ES PROCEDENTE CUANDO EL TRIBUNAL COLEGIADO INAPLICA UNA JURISPRUDENCIA EMITIDA POR LA SUPREMA CORTE DE JUSTICIA DE LA 
"los litigantes en situaciones similares deben ser tratados igualmente"; 51 por ello, su mandato de observancia del precedente puede tenerse por "un principio común a cualquier sistema jurídico" que reconozca jurídicamente aquel valor. ${ }^{52}$ Este aspecto no está claramente reconocido como fundamento del efecto vinculante del precedente en el common law-por lo menos en su versión norteamericana, pese a la trascendencia de la cláusula de protección igualitaria de la enmienda XIV de su Constitución- - ${ }^{53}$ en cambio, paradójicamente, la creciente cercanía de la cultura romanista a la orientación fáctica de aquella tradición combinada con la relevancia que tiene el principio de igualdad en la nuestra, al parecer ha ocasionado el protagonismo en el terreno romanista de una visión influida por este valor fundamental, según la cual la fidelidad al precedente buscaría particularmente "asegurar que bajo iguales circunstancias las personas reciban trato igual". ${ }^{54}$ En México, la Suprema Corte de Justicia de la Nación señaló la "igualdad ante la ley" como fundamento del deber general de los tribunales de "no modificar arbitrariamente sus decisiones en casos que compartan la misma litis, salvo cuando consideren que deben apartarse de sus precedentes". ${ }^{5}$

Aunque más frecuentemente invocado en el ámbito anglosajón, un tercer argumento para fundar el recurso a los precedentes judiciales estriba en que promueve la imparcialidad judicial. La trascendencia que tendrá el

NACIÓN", Primera Sala, Gaceta del Semanario Judicial de la Federación, 10a. época, lib. 5, abril de 2014, t. I, tesis 1a. CXXXIX/2014 (10a.), p. 789.

51 James B. Beam Distilling Co. v. Georgia, 501 U.S. 529, 538 (1991).

52 Orozco Muñoz, op. cit., nota 34, pp. 232 y 233.

53 Garner et al., op. cit., nota 8, pp. 6-12, 21 y 106 (omitie el principio de igualdad entre las bases del stare decisis, pero señala como su fin último "que los problemas jurídicos recurrentes se[an] abordados de manera similar — se[an] tratados de modo igual [equally]_").

54 López Medina, op. cit., nota 30, pp. 233 y 238; Ferreres Comella, op. cit., nota 16, p. 45; Xiol Ríos, Juan Antonio, "Notas sobre la jurisprudencia", en Ferreres Comella e idem, El carácter vinculante de la jurisprudencia, México, Fundación Coloquio Jurídico Europeo-Fontamara, 2010, pp. 99 y 102, y Bankowski, MacCormick, Morawsky y Ruiz Miguel, op. cit., nota 39, pp. 453 y 454.

55 "DEREChO HUMANO A LA IGUALDAD JURÍDICA. RECONOCIMIENTO DE SU DIMENSIÓN SUSTANTIVA O DE HECHO EN EL ORDENAMIENTO JURídiCo MEXICANO”, Primera Sala, Gaceta del Semanario Judicial de la Federación, 10a. época, lib. 49, diciembre de 2017, t. I, tesis 1a./J. 125/2017 (10a.), p. 121. Véase también "IGUALDAD. LÍMITES A ESTE PRINCIPIO", Primera Sala, Apéndice al Semanario Judicial de la Federación y su Gaceta 1917- 2011, t. I, tesis 15, p. 835. 
criterio jurídico de su sentencia orillaría al tribunal a resolver el caso particular con máxima objetividad y corrección, desde una visión general que se aparte de las particularidades del caso concreto, pues desconoce las circunstancias en que se darán los casos futuros y quiénes serán sus partes. ${ }^{56}$ De esta manera, el stare decisis promovería el "respeto por la judicatura como una fuente [jurídica] neutral", ${ }^{57}$ porque la obligaría a serlo.

Pero además, la vinculación al precedente "blindaría" la independencia y la imparcialidad de los tribunales, lo cual —en la modalidad de "autoprecedente" - es particularmente importante para la legitimidad de las decisiones de sedes judiciales terminales, en particular las encargadas de la interpretación definitiva de la Constitución. ${ }^{58}$ Esta sujeción - y sobre todo el desarrollo técnico de los procedimientos que operen sus variaciones $^{59}$ - dificultaría que adopten decisiones a modo, pues tras él podrían parapetarse los órganos jurisdiccionales ante las presiones que se les dirigieran. Por ende, lejos de suponer una debilidad para los tribunales o un óbice para ejercer sus funciones, la vinculación a sus precedentes fortalece a la judicatura en tanto que "la medida de su poder es su capacidad de determinar de antemano los comportamientos de los sujetos a través de la producción de reglas generales, y esta capacidad depende enteramente de la coherencia y de la estabilidad de su jurisprudencia", ${ }^{60}$

56 Ferreres Comella, op. cit., nota 16, p. 46.

57 Garner et al., op. cit., nota 8, p. 10.

58 Ezquiaga Ganuzas, Francisco Javier, La argumentación en la justicia constitucional y otros problemas de aplicación e interpretación del derecho, México, TEPJF, 2006, disponible en: http://bit.ly/1BXZGEc, p. 336.

59 Lo que en México ejemplifica el recurso (a veces implícito) a la "nueva reflexión" de la Suprema Corte. Véanse por ejemplo "Prisión VITALICIA. CONSTITUYE UNA PENA INUSITADA DE LAS PROHIBIDAS POR EL ARTíCULO 22 CONSTITUCIONAL”, Pleno, Semanario Judicial de la Federación y su Gaceta, 9a. época, t. XIV, octubre de 2001, tesis P./J. 127/2001, p. 15; "PRISIÓN VITALICIA. NO ES UNA PENA INUSITADA Y TRASCENDENTAL, POR LO QUE NO VIOLA LA CONSTITUCIÓN FEDERAL", Pleno, idem, 9a. época, t. XXIII, febrero de 2006, tesis P. XIX/2006, p. 1178; "Prisión VITALICIA. No CONSTITUYE UNA PENA INUSITADA DE LAS PROHIBIDAS POR EL ARTÍCULO 22 DE LA CONSTITUCIÓN POLÍTICA De los Estados Unidos MeXiCAnos", Pleno, idem, 9a. época, t. XXIII, febrero de 2006, tesis P./J. 1/2006, p. 6; y Redacción, "El artífice de las extradiciones", Proceso, México, 28 de enero de 2007, disponible en: http://bit.ly/2ysk6g6 (5 de octubre de 2017).

60 Troper, Michel, "Le positivisme et les droits de l'homme", Le droit et la nécessité, París, Presses Universitaires de France, 2011, p. 43. Véanse también Breyer, Stephen, Making our Democracy Work: A Judge's View, Nueva York, Vintage Books, 2010, pp. 149,151 y 156 (resalta la estabilidad de los criterios judiciales como factor para preservar 
De lo anterior puede desprenderse una conclusión muy importante: en ordenamientos que cuentan la igualdad en la aplicación de la ley, la seguridad jurídica y la imparcialidad judicial entre sus principios fundamentales - como el mexicano-, es innecesaria una disposición constitucional o legislativa que especifique la obligatoriedad del precedente judicial para que éste adquiera efecto vinculante en alguna medida. ${ }^{61} \mathrm{~A}$ mi juicio, ni siquiera se requeriría dicha disposición para compaginar el empleo jurisprudencial con nuestro muy estimado principio de legalidad; ${ }^{62}$ para esto último bastarán tales principios jurídicos generales, especialmente si gozan — como sucede entre nosotros — de rango constitucional. ${ }^{63}$ No podría negarse la conveniencia de la existencia de tal disposición y la de sus de-

la "fuerza institucional" de los tribunales por contribuir a su legitimidad, a la confianza en ellos y a la aceptación de sus decisiones); Alexy, op. cit., nota 33, p. 338 (dice que "[a]segurando la estabilidad [del ordenamiento], la utilización de precedentes resulta asimismo en una contribución a... la protección de la confianza en la jurisdicción [Rechtsprechung]"); y Saavedra Herrera, Camilo Emiliano, "El poder de la jurisprudencia. Un análisis sobre el desarrollo y funcionamiento del precedente judicial en México", en Bernal Pulido, Camarena González y Martínez Verástegui (coords.), op. cit., nota 10, p. 291 (alude a la teoría de la path dependence con relación a "generar y preservar la autoridad de los órganos de justicia como cuerpo").

61 Ferreres Comella, op. cit., nota 16, p. 75 (afirma la necesidad de la jurisprudencia para satisfacer dichos principios); Wróblewski, Jerzy, Sentido y hecho en el derecho, trad. de Francisco Javier Ezquiaga Ganuzas y Juan Igartua Salaverría, México, Fontamara, 2003, p. 312 (alude a "fuertes argumentos, prácticos e ideológicos" en este sentido); Gómora Juárez, op. cit., nota 10, pp. 110 y 111, y Díez, Silvia, El precedente administrativo. Fundamentos y eficacia vinculante, Madrid, Civitas, 2008, p. 108, citado por Gascón Abellán, op. cit., nota 43, p. 213 (núm. 8). Por tanto, sería equivocado pensar que la ausencia de apoyo constitucional explícito lleve a tener por irregulares las disposiciones que establecen y regulan la jurisprudencia de tribunales diferentes a los del Poder Judicial de la Federación, opinión que sostienen Zertuche García, op. cit., nota 7, p. 193; y a grandes rasgos, "JUNTA FEDERAL DE CONCILIACIÓN Y ARBITRAJE. AL NO ESTAR FACULTADA PARA INTEGRAR JURISPRUDENCIA, LOS CRITERIOS CON LOS QUE PRETENDE ESTABLECER REGLAS ORIENTADORAS O INTERPRETAR LA LEY NO SON OBLIGATORIOS, EN TÉRMINOS DE LOS ARTÍCUlos 192 Y 193 DE LA LEY DE AMPARO”, Semanario Judicial de la Federación y su Gaceta, 10a. época, lib. XIX, abril de 2013, t. 3, tesis I.6o.T.41 L (10a.), p. 2173.

62 Como expresa Orozco Muñoz, op. cit., nota 34, p. 241.

63 Garner et al., op. cit., nota 8, p. 7; y acuerdo general plenario 4/1996, Semanario Judicial de la Federación y su Gaceta, 9a. época, t. IV, septiembre de 1996, pp. 773 y ss. (dispone tener por jurisprudencia vinculante los criterios sentados al resolverse recursos de reclamación y de queja en controversias constitucionales y acciones de inconstitucionalidad). 
rivadas, y la utilidad de sus precisiones; pero ante la vigencia y supremacía de los referidos principios - aun derechos - fundamentales, no se requieren dichas disposiciones para que exista la obligación de los jueces de atenerse de alguna manera a los criterios jurídicos que ellos mismos o los de rango superior han establecido en sus decisiones.

\section{EL SISTEMA JURISPRUDENCIAL FEDERAL EN MÉXICO}

\section{Apuntes históricos}

Aunque hubo precursores - Ignacio Mariscal y Benito Juárez-,${ }^{64}$ la paternidad de nuestro sistema jurisprudencial se debe sin duda a Ignacio L. Vallarta. El jurista jalisciense sostuvo ambiciosos ideales para el sistema jurídico mexicano y la Suprema Corte de Justicia. Su admiración por los "sabios jueces norteamericanos" 65 le hizo expresarse de esta manera al comparar su ordenamiento con el nuestro:

Así lo han entendido los norteamericanos, y con ménos leyes orgánicas que las que nosotros pedimos, y con más vacíos en su Constitucion que los que la nuestra contiene, poseen en las ejecutorias de sus tribunales la jurisprudencia constitucional más completa que un pueblo puede desear. Allá una opinion de Marshall vale tanto como una ley, y leyes son los leading cases, resueltos por sus tribunales. Centenares de ejecutorias pudieran citarse que fundan sus resoluciones, no en leyes que no existen, sino en ejecutorias anteriores que dirimieron la cuestion constitucional de que se trata... ¿Por qué entre nosotros pasa lo contrario y se dice que las ejecutorias de la Corte no son ni autoridad ni doctrina para resolver casos semejantes?... Confiemos en que mejor conocidos los fines del amparo, no se siga creyendo que él se limita a proteger á un individuo, sino que se comprenda que se extiende á

64 González Oropeza, Manuel, La jurisprudencia: Su conocimiento y forma de reportarla, México, SCJN, 2005, p. 46.

65 Véase en general Mirow, Matthew C., "Marbury in Mexico: Judicial Review's Precocious Southern Migration", Hastings Constitutional Law Quarterly, San Francisco, vol. 35, núm. 1, 2007, disponible en: http://bit.ly/2y3jwlP, pp. 55-65 (trad. de Rubén Sánchez Gil e Isaac Josué Cervantes Castro: “Marbury en México: La precoz migración de la judicial review al sur”, en González Oropeza, Manuel y Báez Silva, Carlos [coords.], El “amparo Justo Prieto”. El control desconcentrado de la constitucionalidad. Homenaje al ministro José de Jesús Gudiño Pelayo, México, SCJN, 2016, pp. 454-469). 
fijar el derecho público por medio de la interpretacion que hace de la ley fundamental. ${ }^{66}$

Pudo Vallarta hacer derecho positivo de sus anteriores ideas. El 15 de agosto de 1881 dirigió a Ezequiel Montes, entonces secretario de Justicia e Instrucción Pública, la versión definitiva del proyecto de Ley de Amparo, con el cual cumplió el encargo que dicho funcionario le hizo al respecto, quien lo presentó al Senado de la República "como epílogo de su obra titulada «El juicio de amparo y el writ of habeas corpus»" ${ }^{67}$ Las principales ideas de ese proyecto legislativo que incumben a nuestro tema, fiel reflejo no sólo de las posturas de Vallarta, sino de sus mismos hábitos profesionales, son las siguientes: los jueces de distrito fundarán sus sentencias en el texto constitucional, para cuya "debida inteligencia" atenderán a las ejecutorias de la Suprema Corte y a las "doctrinas de los autores" (artículo 37); es deber de "los Tribunales" — incluyendo a la Suprema Corte — al "fijar el Derecho Público", considerar a la Constitución, "las ejecutorias que la interpreten", las leyes "emanadas de ella" y los tratados internacionales (artículo 50); y establece sanciones para los jueces que resuelvan un juicio de amparo "contra su interpretación fijada por la Suprema Corte, por lo menos en cinco ejecutorias uniformes" (artículo 73; cursivas añadidas). Salvo el segundo de los preceptos referidos, las anteriores disposiciones pasaron sin mayor cambio a los artículos 34 y 70 de la Ley de Amparo de 1882, que fueron los primeros en regular la obligatoriedad de la jurisprudencia en México. ${ }^{68}$

Lo anterior esclarece un punto muy importante de la historia de nuestro sistema jurisprudencial. Original y muy claramente, las ejecutorias de la Corte vinculaban a los jueces de distrito, y su reiteración sencillamente les daba una obligatoriedad "reforzada". Pero el artículo 786 del Código Federal de Procedimientos Civiles de $1908^{69}$ impuso como "jurispruden-

66 "Amparo pedido contra la sentencia injusta de un juez en negocio civil", Votos, México, Imprenta de Fco. Díaz de León, 1883, t. IV (5a. ed. facsimilar, Obras, México, Porrúa, 1989, t. IV), pp. 497-498 (se respetaron la ortografía y las cursivas del original).

67 Véase el "Apéndice 2" de la edición facsimilar de dicho ensayo de Vallarta, contenida en el tomo V de sus Obras publicadas por la Editorial Porrúa, que contiene la carta dirigida por este jurista al secretario Montes con su proyecto legislativo, al igual que la iniciativa presentada por dicho funcionario.

68 Véase en general Álvarez Montero, José Lorenzo, 150 años de legislación de amparo (1847-1997), Xalapa, Instituto Mexicano del Amparo, 1997, pp. 155 y ss.

69 Ibidem, p. 230. 
cia" sólo aquellos criterios reiterados en cinco ejecutorias y dio cabida a la idea de poderse negar sujeción a aquellos sin esa calidad. No obstante, el precepto siguiente del mismo ordenamiento estableció que la Suprema Corte "respetará sus propias ejecutorias", debiendo expresar sus razones cuando pretendiera apartarse de la opinión sentada en ellas - expresando así el principio de inercia que subyace al stare decisis-.

Las sucesivas leyes que rigieron el juicio de amparo (1919, 1936 y 2013), a las que luego se les agregó la reglamentaria de las fracciones I y II del artículo 105 constitucional, desarrollaron este sistema hasta que se convirtió en el imperante en la actualidad.

\section{Regulación vigente}

El undécimo párrafo del artículo 94 de la Constitución dispone que "[1] a ley fijará los términos en que sea obligatoria la jurisprudencia que establezcan los Tribunales del Poder Judicial de la Federación y los Plenos de Circuito sobre la interpretación de la Constitución y normas generales". La jurisprudencia en México tiene entonces un fundamento constitucional explícito y específico. Sin embargo, como ya manifesté, los términos con que se ha reconocido el principio de igualdad en la aplicación de la ley hacen que no se requiera cláusula constitucional o legal que imponga expresamente la observancia de la jurisprudencia. ${ }^{70}$ Aunque también señalé que por supuesto es preferible que este efecto vinculante se halle claramente establecido en una disposición constitucional o legal.

Por su parte, el artículo 177 de la Ley Orgánica del Poder Judicial de la Federación dispone esencialmente que la jurisprudencia de la Suprema Corte de Justicia de la Nación y de los tribunales colegiados de circuito se regirá por las disposiciones de la Ley de Amparo, "salvo en los casos en que la ley de la materia contuviera disposición expresa en otro sentido". Los numerales 215 a 230 de la Ley de Amparo vigente contienen las disposiciones generales que rigen la jurisprudencia en los términos del precepto anteriormente citado. Y los artículos 43 y 73 de la Ley Reglamentaria de las Fracciones I y II del Artículo 105 Constitucional prescriben lo relativo a la jurisprudencia que sienta la Suprema Corte de Justicia de la Nación a través de los procedimientos que establecen esas porciones

70 Supra, § II.4. 
de la ley fundamental. Y los artículos 232 a 235 de la referida ley orgánica rigen la jurisprudencia del Tribunal Electoral del Poder Judicial de la Federación.

De acuerdo con los preceptos anteriores, la Suprema Corte, los tribunales colegiados y los plenos de circuito ${ }^{71}$ pueden establecer jurisprudencia vinculante por: 1) reiteración del criterio en cinco ejecutorias no interrumpidas, dictadas en diferentes sesiones por las mayorías legalmente establecidas; ${ }^{72}$ 2) resolución de contradicciones de tesis; 3) sustitución de los criterios jurisprudenciales con motivo de un caso concreto, realizada luego de haberse resuelto éste, y 4) en su caso, haber sentado su criterio en controversia constitucional o en acción de inconstitucionalidad.

Finalmente, son muy importantes los acuerdos generales que el Pleno de la Suprema Corte ha emitido desde hace años respecto del Semanario Judicial de la Federación y la jurisprudencia en general. Su fundamento se halla en el artículo 11, fracciones XIX y XXI, de la ley orgánica judicial federal, en relación con los numerales 178 y 179 de la misma. Actualmente, los más relevantes son los números 16/2019 y 17/2019, ambos publicados el 9 de diciembre de 2019 en el Diario Oficial de la Federación, ${ }^{73}$ y tocantes, respectivamente, a la difusión exclusivamente electrónica de dicho reporte jurisprudencial, y a la elaboración, el envío y la publicación de tesis jurisprudenciales.

71 Véanse también los artículos 232 a 235 de la misma ley, relativos a la jurisprudencia del Tribunal Electoral del Poder Judicial de la Federación. Esta rama jurisdiccional, grosso modo también establece criterios vinculantes como los órganos que señalé, salvo por lo que se refiere a la sustitución. Sin embargo, llaman la atención dos cosas a su respecto: 1) su jurisprudencia stricto sensu también obliga a autoridades administrativas como el Instituto Nacional Electoral y sus homólogos locales ("JURISPRUDENCIA. LA DETERMINACIÓN DE SU VIGENCIA CORRESPONDE A LA SALA SUPERIOR”, Sala Superior, Gaceta de Jurisprudencia y Tesis en Materia Electoral, año 8, núm. 17, 2015, tesis XXXVI/2015, pp. 94-95); y 2) muchos de sus precedentes que versan sobre conceptos jurídicos generales, pese a que no vinculan a autoridades diferentes a las electorales, son sumamente ilustrativos y muy útiles.

72 Modalidad básica por ser la regla en la creación jurisprudencial. Véase Rosales Guerrero, Emmanuel Guadalupe, Estudio sistemático de la jurisprudencia, México, SCJN, 2005, p. 215.

73 Véase también el acuerdo general plenario 4/1996, cit., nota 63. El acuerdo general plenario 12/2011 dispuso las bases de la décima época jurisprudencial; la Secretaría General de Acuerdos de la Suprema Corte lo reporta como "vigente" (véase Acuerdos generales plenarios, disponible en: http://bit.ly/2DzT0UL [10 de diciembre de 2019]), pero su contenido ha sido superado por diversos instrumentos posteriores. 


\section{Evolución conceptual}

Especialmente a efecto de la mayor claridad de los párrafos posteriores, me parece necesario reiterar que, a diferencia de la nomenclatura tradicional de nuestro país, ${ }^{74}$ en este trabajo entiendo que dependiendo del contexto el vocablo "jurisprudencia" alude tanto al precedente judicial (absoluta o fuertemente) vinculante como al conjunto de precedentes globalmente considerados, sin importar su obligatoriedad (case law).

A lo largo de décadas, ha variado la concepción mexicana de la "jurisprudencia", entendida como conjunto de precedentes judiciales. Estas variaciones han ido de la mano de diferentes maneras de entender el sistema jurídico y la labor de los jueces que se han dado en el seno de la tradición jurídica romanista a lo largo del siglo $\mathrm{XX} .{ }^{75}$ Son tres las concepciones fundamentales del precedente judicial que han tenido lugar en México: 1) interpretativa o, mejor dicho, exegética; 2) integradora; y 3 ) creativa; ${ }^{76}$ muy al margen de la discusión sobre si la jurisprudencia constituye "fuente del derecho", que ha sido muy poco útil ${ }^{77}$ y ni siquiera es decisiva para caracterizar la jurisprudencia. ${ }^{78}$

Desde el primer punto de vista se considera la jurisprudencia bajo la óptica de un positivismo legalista, propio de la primera mitad del siglo pasado, según el cual "todo el Derecho debe encerrarse en las Leyes [...y] fuera de la Ley no hay criterios jurídicamente válidos”, y los jueces han de resolver conforme a un significado supuestamente inmanente - por ende, "verdadero" - del texto legal, "inquiri[endo] de la Ley la solución

74 Zertuche García, op. cit., nota 7, p. 86 (señala que el término "jurisprudencia" denomina el precedente vinculante y el de "precedente" [a secas] como correspondiente al carente de esa calidad, es decir, a las "tesis aisladas").

75 Véase en general García de Enterría, Eduardo, "La democracia y el lugar de la ley”, en idem, y Menéndez Menéndez, Aurelio, El derecho, la ley y el juez. Dos estudios, Madrid, Civitas, 2000, pp. 44-57.

76 En general, cfr. Zertuche García, op. cit., nota 7, pp. 180-188.

77 Ferreres Comella, op. cit., nota 16, pp. 73-75 (expresa que la jurisprudencia cae en una "zona de penumbra" del concepto de "fuente jurídica").

78 Así, por ejemplo, una visión jurisprudencial exegética, hoy mismo podría sostener - aunque no sin dificultades - que la jurisprudencia es "fuente formal del derecho", como en "JuRISPRUDENCIA. SU APLICACIÓN RETROACTIVA", Gaceta del Semanario Judicial de la Federación, 10a. época, lib. 30, mayo de 2016, t. III, tesis PC.IV.L. J/3 K (10a.), p. 2094. 
debida" ${ }^{79}$ Desde este punto de vista, la jurisprudencia "no es una ley [ni se equipara a ésta], sino la interpretación de ella, judicialmente adoptada"; 80 sería mera exégesis o glosa de la ley, dada a través de la declaración del "correcto" significado de sus disposiciones.

Otro enfoque muy posterior, no completamente apartado del anterior, ${ }^{81}$ ve a la jurisprudencia como un instrumento para llenar lagunas legales, es decir, para "integrarla" y no para declarar su "inexistente" significado en situaciones que no previeron sus disposiciones. ${ }^{82}$ En este sentido, de manera opuesta a una labor meramente "interpretativa", se advierte que la jurisprudencia, o al menos uno de sus tipos, "colma los vacíos de la ley, creando una norma que la complementa". ${ }^{83}$

Finalmente, en años más recientes, y aun de la mano de la creciente aceptación de una "teoría del precedente", se ha reconocido en México el aspecto generalmente creativo de la jurisprudencia, más allá de los casos en que constituye una estricta "integración" legal. ${ }^{84} \mathrm{El}$ punto central de la discusión sobre el carácter innovador de la jurisprudencia y su calidad de fuente jurídica ha sido su posible aplicación retroactiva. ${ }^{85}$ Tradicionalmen-

79 Ibidem, pp. 42-44. Véase también Laporta, op. cit., nota 27, pp. 30-32.

80 "JuRISPRUdENCIA", Primera Sala, Semanario Judicial de la Federación, 6a. época, vol. LXIX, segunda parte, reg. 260868, p. 60; y "JURISPRUDENCIA, ALCANCE DE LA", Primera Sala, idem, 6a. época, vol. LVIII, segunda parte, reg. 260342, p. 38.

81 “JuRISPRUDENCIA, CONCEPTO DE”, idem, 8a. época, t. VII, enero de 1991, reg. 223936, p. 296 (señala que la jurisprudencia es "integradora de las situaciones que no previó el legislador, adecuando la norma al caso concreto").

82 Sobre el concepto de "integración" y su diferencia con la "interpretación”, véase en general García Máynez, Eduardo, Introducción al estudio del derecho, 31a. ed., México, Porrúa, 1980, pp. 129, 130 y 366.

83 “JuRISPRUDENCIA. CONCEPTO, CLASES Y FINES", Semanario Judicial de la Federación y su Gaceta, 9a. época, t. XVIII, octubre de 2003, tesis IX.1o.71 K, p. 1039 (cursivas añadidas). Véase también "JURISPRUDENCIA. CASO EN QUE SU APLICACIÓN ESTÁ SUJETA AL PRINCIPIO DE NO RETROACTIVIDAD”, idem, 9a. época, t. XI, marzo de 2000, tesis IV.1o.P.C.9 K, p. 1002.

84 "Precedentes sobre derechos fundamentales de la Suprema CorTe DE JUSTICIA DE LA NACIÓN. LA DISTINCIÓN QUE DE ÉSTOS HACE UN TRIBUNAL COLEGIADO DE CIRCUITO CONLLEVA UNA MODIFICACIÓN DE SU INTERPRETACiÓN", Primera Sala, Gaceta del Semanario Judicial de la Federación, 10a. época, lib. 25, diciembre de 2015, tesis 1a. CCCXCIII/2015 (10a.), p. 270. Señala que la jurisprudencia entraña una "creación normativa" que "participa de cierta generalidad, abstracción e impersonalidad", pero contradictoria y primordialmente negándole carácter de "ley material". Cfr. Zertuche García, op. cit., nota 7, pp. 173, 198 y 307.

85 Ibidem, pp. 202-216 y 303-310 (particularmente la p. 305, la cual señala que el 
te, se había negado ésta —o, mejor dicho, su ilicitud — considerando que dar efecto a un criterio judicial en relación con hechos pasados no resulta retroactivo en tanto la ley que interprete siga siendo la misma; ${ }^{86}$ pero el artículo 217, último párrafo, de la vigente Ley de Amparo supone un cambio de percepción al respecto: proscribir parcialmente la natural retroactividad jurisprudencial ${ }^{87}$ para dejar sin efecto un criterio que directamente regía cuando se estableció una situación, ${ }^{88}$ implica que el criterio jurisprudencial anterior y el novedoso constituyen normas generales autónomas.

Quizá Carlos de Silva y Nava describió del modo más preciso la naturaleza del precedente judicial:

el Juez aplica una norma abstracta y la hace concreta; ... pero tan hay creación del Juez..., que cuando se vuelve a la abstracción, ya la Jurisprudencia no dice exacta y literalmente lo que decía la Ley, la Ley se adecuó a situaciones especiales; inclusive se hizo evolucionar a la propia Ley, la hizo aplicable a casos que quizá ni siquiera había previsto o podido prever el legislador[;] entonces, si vamos de lo abstracto a lo concreto y de lo concreto a lo abstracto, a través de la creación jurisprudencial, encontraremos que no volvemos al punto de partida[;] de otra manera, saldría sobrando la Jurisprudencia obligatoria. Saldría sobrando, porque sería una simple repetición de lo establecido por la norma que fue aplicada por el Juzgador. ${ }^{89}$

problema de la retroactividad jurisprudencial deriva de "autores que consideran a esta institución, dada su generalidad, abstracción e impersonalidad[,] como ley en sentido material").

86 Por todos véase "JuRISPRUDENCIA. SU APLICACIÓN NO VIOLA LA GARANTÍA DE IRRETROACTIVIDAD DE LA LEY”, Pleno, Apéndice al Semanario Judicial de la Federación 1917-2011, t. I, tesis 150, p. 1071.

87 Gómora Juárez, op. cit., nota 10, p. 92.

88 "JURISPRUDENCIA. ALCANCE DEL PRINCIPIO DE IRRETROACTIVIDAD DE AQUÉLLA TUTELADO EN EL ARTículo 217, PÁRRAFO ÚlTIMO, DE LA LEY DE AMPARO”, Segunda Sala, Gaceta del Semanario Judicial de la Federación, 10a. época, lib. 38, enero de 2017, t. I, tesis 2a./J. 199/2016 (10a.), p. 464. Parcialmente en contra, $c f r$. "USURA. AL RESOLVER EL JUICIO DE AMPARO DIRECTO, EL TRIBUNAL COLEGIADO DE CIRCUITO DEBE APLICAR LA JURISPRUDENCIA QUE ORDENA EL ESTUDIO OFICIOSO DE SU POSIBLE EXISTENCIA, NO OBSTANTE QUE EL ACTO RECLAMADO SE HAYA EMITIDO BAJO LA VIGENCIA DE UN CRITERIO INTERPRETATIVO DIFERENTE", Primera Sala, idem, lib. 36, noviembre de 2016, t. II, tesis 1a./J. 52/2016 (10a.), p. 877.

89 "La jurisprudencia”, en VV. AA., Curso de actualización de amparo, México, UNAM, Facultad de Derecho, 1975, pp. 111 y 112 (se respetaron las mayúsculas del original). 
Esta descripción se apega plenamente a un enfoque hermenéutico contemporáneo. ${ }^{90}$ En mayor o menor medida, toda interpretación jurídica es siempre una actividad creativa, ${ }^{91}$ mas no por completo, porque su resultado es un derivado de las disposiciones jurídicas a las que brinda eficacia en una situación concreta. Reformulando los términos de la disposición a la que adjudica significado, y de la cual depende, la interpretación elabora una norma análoga a ella: no la reproduce "exacta y literalmente", sino que parte de ella para concretizarla en una determinada situación. Esta nueva norma concretizada, más específica, no tiene el mismo grado de abstracción —-mejor dicho: de generalidad-que la disposición interpretada, y por eso se le ha negado equipararse a la ley; ${ }^{92}$ pero expresa también de modo general, abstracto e impersonal un supuesto más específico que el de la ley interpretada. La interpretación tiene el texto como punto de partida, pero en el curso de una "espiral hermenéutica" lo lleva a un punto diferente y más elevado: crea explícita o implícitamente una nueva norma general, abstracta e impersonal, que concretiza la disposición interpretada - y hasta podría decirse que la remplaza ${ }^{93}$ - y que es inmediatamente aplicable a los casos particulares que actualizan su hipótesis más específica.

Esta concepción hermenéutica es particularmente útil para comprender el sistema jurisprudencial mexicano, y en especial los objetivos a que debe servir su tradicional práctica de elaboración de "tesis". De esta manera, la discusión — aparentemente bizantina por ser meramente "teórica"- sobre la naturaleza de la jurisprudencia puede tener importantes repercusiones prácticas en México.

\footnotetext{
90 Véase en general Sánchez Gil, Rubén Antonio, Los principios de la interpretación constitucional y su aplicación por la Suprema Corte de Justicia de la Nación, tesis de doctorado, México, UNAM, Facultad de Derecho, 2008, disponible en: http://bit. ly/ljeqGWK, pp. 15-33; e infra, nota 96.

91 Supra, nota 4.

92 Zertuche García, op. cit., nota 7, pp. 198 y 199.

93 Gómora Juárez, op. cit., nota 10, p. 131. De ahí la vertiente del realismo jurídico que identifica el "derecho" con las resoluciones de los tribunales; véase García Máynez, Eduardo, Positivismo jurídico, realismo sociológico y iusnaturalismo, 4a. ed., México, UNAM, Facultad de Derecho, 1997, p. 89.
} 


\section{Dos PROBLEMAS MEXICANOS}

\section{Ejecutoria, precedente y tesis}

\section{A. Ratio decidendi, holding y obiter dictum}

Es generalizado distinguir las secciones de la sentencia que contiene un precedente con los conceptos de ratio decidendi y obiter dictum. ${ }^{94}$ Esta distinción ha sido elaborada en el ámbito anglosajón, y tiene en él un papel muy destacado. Sin embargo, aunque con mucha menor relevancia, también se le halla en sistemas de otras familias jurídicas - como la nuestra-, o ha sido rudimentaria o informalmente reconocida en ellos. ${ }^{95}$

Esencialmente, la ratio decidendi ("razón de la decisión") es el principio o regla jurídica especifica que sirvió de base a la decisión del tribunal de modo determinante. Se trata de la norma jurídica resultante de la interpretación judicial que reformula un texto legislativo para establecer de modo abstracto las consecuencias que deben realizarse ante un supuesto consistente en los hechos particulares del caso, y que sirve de premisa mayor al silogismo de aplicación jurídica contenido en la decisión del tribunal. ${ }^{96}$ La ratio es la parte de la resolución judicial a la que se atribuye efecto vinculante, y que controlará — por su carácter abstracto - la decisión interpretativa que haya de adoptarse en casos futuros. ${ }^{97}$

94 En lo sucesivo, véanse en general Garner et al., op. cit., nota 8, pp. 44-48; Orozco Muñoz, op. cit., nota 34, pp. 27-30; Zertuche García, op. cit., nota 7, p. 53; López Medina, op. cit., nota 30, pp. 217-220 y 231-237; Taruffo, op. cit., nota 40, pp. 199-200; Rabasa, op. cit., nota 19, pp. 555-557; y Magaloni, Ana Laura, El precedente constitucional en el sistema judicial norteamericano, Madrid, McGraw-Hill, 2001, pp. 81-83.

95 Marshall, Geoffrey, "Lo vinculante del precedente", en MacCormick y Summers (eds.), op. cit., nota 5, pp. 470-473.

96 Sánchez Gil, op. cit., nota 90, pp. 19-22 y 33. Cfr. "JURISPRUDENCIA. SU APLICACIÓN NO PUEDE CONSIDERARSE VIOLATORIA DEL PRINCIPIO DE IRRETROACTIVIDAD, EN TANTO QUE EL HECHO A REGULAR O SITUACIÓN PROCESAL A RESOLVER SEA POSTERIOR A LA VIGENCIA DE LA LEY (INTERPRETACIÓN DEL ARTÍCULO 217, ÚLTIMO PÁRRAFO, DE LA LEY DE AMPARO)", Gaceta del Semanario Judicial de la Federación, lib. 12, noviembre de 2014, t. IV, tesis I.3o.C.54 K (10a.), p. 2995.

97 Larenz, op. cit., nota 47, pp. 429, 430 y 432 (subraya que "[n]o está prejuzgada la resolución del caso particular que ha adquirido fuerza jurídica", sino sólo "la respuesta dada por el tribunal, en el marco de la fundamentación del juicio", pues el aspecto vinculante del precedente consiste en una "máxima de decisión... en cuanto se refiere a una 
En los Estados Unidos se prefiere utilizar el término holding para aludir a "lo establecido o sostenido" por el tribunal, y es habitual tenerlo por sinónimo de la locución ratio decidendi, que se emplea más en Inglaterra. ${ }^{98}$ Pero en realidad no hay identidad en los significados precisos de estas expresiones, y su diferencia, aunque sutil, puede servir para conocer con mayor precisión la naturaleza del precedente. El holding es la determinación que el tribunal realizó concretamente en su resolución - las palabras "exactas" de la sentencia, por así decirlo — $; 99$ en cambio, la ratio decidendi es la formulación abstracta y general del principio en que se basa dicha determinación judicial, y del cual ésta y lo sostenido en ella serían una aplicación concreta. ${ }^{100}$

La ratio decidendi y el holding se sobreponen, y por eso se confunden con tanta facilidad; pero se requieren mutuamente, y por eso aquélla debe tenerse por formulada implícitamente por lo menos. ${ }^{101}$ Como principio general abstracto, la ratio decidendi no trasciende el ámbito ideal, por sí misma carece de efecto jurídico, porque es una mera hipótesis interpretativa, o incluso un simple ejercicio especulativo; lo que le da vida como precedente vinculante es su actualización a través del holding expresado en los precisos términos de la resolución judicial, de la cual surge la necesidad jurídica de reiterar su empleo en casos futuros y dar a éstos el mismo trato, conforme al principio de igualdad en la aplicación de la ley, necesidad que no surgiría en relación con una norma jurídica hipotética. ${ }^{102} \mathrm{Y}$ de acuerdo con el principio de universabilidad (Universalisierbarkeit), cuya observancia es elemento esencial de su corrección material, la decisión

interpretación 'acertada' o [a un] complemento de normas, o concretiza un principio jurídico de modo paradigmático"). Véase también Vallarta, Ignacio L., El juicio de amparo y el "writ of habeas corpus". Ensayo crítico-comparativo sobre esos recursos constitucionales, México, Imprenta de Fco. Díaz de León, 1881 (4a. ed. facsimilar, Obras, México, Porrúa, 1989, t. V), pp. 320-322 (expone que "se confunde la resoluci[ó]n de la sentencia con sus fundamentos", y pone de relieve a la Corte como "final intérprete de [la] suprema ley" y que entre los "fines del amparo" está "fijar el derecho público por medio de la interpretaci[ó]n que [dicho tribunal] hace de la ley fundamental").

98 López Medina, op. cit., nota 30, p. 215 (n. 20), y Magaloni, op. cit., nota 94, pp. 81 y 92 (n. 63).

99 Ibidem, p. 81 (señala que "el holding es la respuesta que el tribunal da a las partes respecto de la cuestión jurídica que el caso plantea" [cursivas en el original])

100 Garner et al., op. cit., nota 8, p. 46.

101 Gómora Juárez, op. cit., nota 10, pp. 69 y 74-76.

102 Orozco Muñoz, op. cit., nota 34, p. 30; y López Medina, op. cit., nota 30, pp. 236 y 237. 
judicial y su holding deben ser expresión de una regla general y abstracta, aplicable a todos los casos que resulten esencialmente similares al que resolvió la primera. ${ }^{103}$ Ratio decidendi y holding no son sinónimos, pero sí se refieren a conceptos estrechamente vinculados: ${ }^{104}$ abstracto y genérico el primero, y concreto e individualizado el segundo. ${ }^{105}$

A diferencia de los conceptos anteriores, el obiter dictum ("dicho de paso") se define por exclusión. Se trata de cualquier consideración en la resolución judicial que no haya determinado su resultado. Ejemplos de este elemento pueden ser: "[u]n ingenioso párrafo de apertura, la información de trasfondo relativa a cómo se desarrolló la ley, [y] las digresiones especulativas", que suelen hallarse en las sentencias. ${ }^{106}$ El hoy retirado juez Richard A. Posner sugirió una manera muy práctica para distinguir entre las porciones vinculantes de la resolución y las que no lo son: dictum sería el razonamiento que podría suprimirse de la resolución sin afectar seriamente los "fundamentos analíticos" del holding; de lo contrario, nos hallaríamos ante una ratio decidendi. ${ }^{107}$

103 Alexy, op. cit., nota 33, pp. 335 y 336. Véanse también Bulygin, Eugenio, “Los jueces ¿crean derecho?”, en Malem, Jorge, Jesús Orozco y Rodolfo Vázquez (comps.), La función judicial. Ética y democracia, Barcelona, Gedisa-TEPJF-ITAM, 2003, pp. 21-37; y Lara Chagoyán, Roberto, "El principio de universalidad en el razonamiento jurídico", Revista de la Facultad de Derecho de México, México, UNAM, t. LVII, núm. 247, enerojunio de 2007, disponible en: http://bit.ly/2yQX2Uh, pp. 221-247.

104 Un tercer concepto, próximo a los mencionados, es el rationale; relativamente común en el habla inglesa, pero a mi parecer poco empleado en relación con la jurisprudencia. El rationale es una "afirmación de razones; específ[icamente], una explicación razonada o una exposición de principios que subyacen a un arte, ciencia, procedimiento, opinión, etc. ... [También puede ser] [1] a base lógica de un procedimiento, hecho, posición, etc.” (Garner et al., op. cit., nota 8, p. 803). Se trata del porqué de la decisión del tribunal, de las razones últimas que éste tuvo para resolver como lo hizo y no de otra manera (cfr. Magaloni, op. cit., nota 98, p. 82); en una palabra, del "propósito" de la decisión del tribunal, que puede ser crucial en la aplicación —o desaplicación — futura del precedente (véase Camarena González, Rodrigo, "La derrotabilidad del precedente constitucional. A propósito de la C.T. 299/2013”, Revista del Centro de Estudios Constitucionales, México, SCJN, año III, núm. 4, enero-junio de 2017, disponible en: http://bit.ly/2J26njX, pp. 334 y 335$)$.

105 Rabasa, op. cit., nota 19, p. 556: "[E]n la práctica se advierte que en la mayoría de los casos el principio general de derecho [que podría constituir la ratio decidendi] en que se funda la decisión o resolución concreta del negocio es mucho más amplio que la decisión misma [holding]".

106 Garner et al., op. cit., nota 8, p. 44.

107 Sarnoff v. American Home Prods. Corp., 798 F.2d 1075, 1084 (7th Cir. 1986), 
Los dicta son acreedores de mucha menor deferencia; a grandes rasgos, por lo general se les niega todo efecto vinculante. La razón para ello es que al no ser fundamentales para la argumentación del tribunal, las consideraciones digresivas no determinaron la decisión, o versan sobre puntos que el tribunal no consideró detenidamente. ${ }^{108}$ Sin embargo, su inferioridad no les priva de utilidad, pues entre otros propósitos servirían para comprender mejor el curso del razonamiento judicial; así, la Suprema Corte norteamericana expresó que los obiter dicta "«pueden ser seguidos si son suficientemente persuasivos», pero no son vinculantes". ${ }^{109}$ La relativa importancia de estos elementos ha sido reconocida en México como posiciones que adopta un tribunal frente a ciertos problemas jurídicos. ${ }^{110}$

Como se les ha aplicado en los Estados Unidos, los dicta no prevalecen sobre un holding aunque sean posteriores, pero si no hubiera un precedente vinculante que regule la cuestión, un dictum "puede ser tan persuasivo como una resolución que [aún] no se haya publicado". Cuando resultan de un trabajo serio y deliberado por parte de los jueces y de su equipo, se les puede otorgar incluso mayor autoridad que a otras fuentes - como los artículos académicos y los ocursos de los litigantes_-. ${ }^{111}$

\section{B. Las tesis mexicanas}

Hay quien piensa que el sistema jurisprudencial mexicano no puede verse con la óptica de la teoría del precedente elaborada por el common law, pues no consiste en el manejo de sentencias, sino en el de tesis abstractas que elaboran nuestros órganos jurisdiccionales a partir de sus reso-

citado por ibidem, pp. 46 y 47; véase también ibidem, p. 53. Una regla similar estableció el Tribunal Constitucional Federal alemán en BVerfGE 96, 375 (404); sobre las críticas a ella, véase Schlaich, Klaus, Das Bundesverfassungsgericht. Stellung, Verfahren, Entscheidungen, 5a. ed. continuada por Stefan Korioth, Múnich, C. H. Beck, 2001, p. 327.

108 Cohens v. Virginia, 19 U.S. (6 Wheaton) 264, 399-400 (1821) (sentencia en que el great chief justice John Marshall trazó muy claramente la línea que separa los conceptos hoy denominados holding y obiter dictum).

109 Central Green Co. v. United States, 531 U.S. 425, 431 (2001) (citando Humphrey's Executor v. United States, 295 U.S. 602, 627 [1935]).

110 “CONTRADICCIÓN DE TESIS. LOS CRITERIOS JURÍDICOS EXPRESADOS «A MAYOR ABUNDAMIENTO» SON DE TOMARSE EN CUENTA PARA RESOLVER AQUÉLlA”, Pleno, Semanario Judicial de la Federación y su Gaceta, 9a. época, t. XXIV, julio de 2006, tesis P. XLIX/2006, p. 12.

111 Véase en general Garner et al., op. cit., nota 8, pp. 65-69. 
luciones. Pero esta impresión se debe más a los hábitos con que aplicamos la jurisprudencia que a una detenida reflexión sobre ésta.

El sistema de tesis abstractas que empleamos los juristas mexicanos es un buen ejemplo del carácter "conceptualista" de la jurisprudencia de países romanistas, en contraste con la orientación fáctica que distingue la de los anglosajones. ${ }^{112}$ Abstracciones semejantes las encontramos en otros sistemas jurídicos pertenecientes a nuestra tradición; muestras de ello son las massime italianas, las súmulas (vinculantes) brasileñas, ${ }^{113}$ los encabezados de las sentencias españolas y los Leitsätze de las alemanas. ${ }^{114}$ Pero tales resúmenes también son una práctica muy común en los Estados Unidos, a cuyas sentencias suele anteponerse un syllabus, que resume sus puntos torales, los cuales normalmente no forman parte de ella y carecen de efectos vinculantes. ${ }^{115}$

El actual sistema de tesis mexicano surgió como una práctica meramente ilustrativa como las señaladas. Durante la vigencia del Código Federal de Procedimientos Civiles de 1897 comenzaron a adjuntarse "sumarios" a las sentencias publicadas en el Semanario Judicial de la Federación, que describían el caso e indicaban el sentido de la resolución. ${ }^{116}$ Prácticamente desde el inicio de su quinta época, ${ }^{117}$ en el Semanario Judicial de la Federación se publicaban las ejecutorias de la Suprema Corte, precedidas de un "sumario", que brevemente expresaba las cuestiones que abordaban para que se conocieran de manera rápida y sencilla. ${ }^{118}$

El artículo octavo del Reglamento del Departamento de Jurisprudencia de la Suprema Corte emitido durante la vigencia de la Ley de Amparo de

\footnotetext{
112 López Medina, op. cit., nota 30, p. 115, y supra, nota 39.

113 Sobre ambas figuras, véase Saavedra Herrera, op. cit., nota 60, pp. 294 y 295.

114 Aunque no sin críticas, a estas sinopsis de las sentencias del Tribunal Constitucional Federal alemán se les atribuye una "especial importancia". Véase Schlaich, op. cit., nota 107, p. 328 (citando como fuente de aquella aseveración a BVerwGE 73, 263; e idem 77, 258).

115 Garner et al., op. cit., nota 8, p. 150.

116 Saavedra Herrera, op. cit., nota 60, p. 303.

117 Guerrero Lara, Ezequiel, Manual para el manejo del Semanario Judicial de la Federación, México, UNAM, Instituto de Investigaciones Jurídicas, 1982, pp. 34 y 35.

118 Atento lo anterior, porque mostraría su carácter derivado, es muy significativo que en la actualidad se estile publicar las tesis de jurisprudencia vinculante después de su ejecutoria y de sus votos particulares (las ejecutorias de las tesis aisladas no suelen difundirse). Véase por ejemplo: Gaceta del Semanario Judicial de la Federación, lib. 47, octubre de 2017, t. I, disponible en: http://bit.ly/2zKX70y, pp. 69 y ss., y 178 y ss.
} 
1919, dispuso que el "sumario de cada ejecutoria" sería conciso, exacto y claro, y que "fij[aría...] las tesis jurídicas sustentadas" por dicho tribunal. ${ }^{119}$ Por diversos motivos, entre los que destaca el gran número de ejecutorias que debían publicarse, la reproducción de las sentencias fue reduciéndose y omitiéndose en ocasiones, hasta que finalmente —a partir del tomo CXXVI de dicha época- sólo fue posible consultar los sumarios. ${ }^{120}$ Bajo nuevas reglas, en la sexta época jurisprudencial (1957) continuó la práctica de publicar estos extractos previamente a la ejecutoria, pero ya teniendo preferencia la divulgación de aquél mientras que la respectiva sentencia sólo excepcionalmente habría de difundirse; y en la séptima época (1968) se consolidó la práctica, vigente hasta la actualidad, de publicación de la ejecutoria sólo cuando se trate de la que conforma jurisprudencia o la contrariase. ${ }^{121}$

Lo anterior explica el origen de nuestro uso jurisprudencial. Siendo reportadas en el Semanario las decisiones judiciales primordialmente a través de dichas "tesis", no extraña que su empleo haya imperado abrumadoramente en nuestra práctica jurídica. Simplemente, casi siempre, no había otra manera de conocer las decisiones de los jueces y de referirlas.

La difusión de esta práctica hizo surgir un sistema jurisprudencial al que se le reprocha que consista en un "conjunto de criterios judiciales dispersos y fragmentados", "desvincula[dos] de los razonamientos de las sentencias de las que emanan", que principalmente se caracteriza por ser "altamente formalista" y por "incentiva[r] a que pasen a un segundo término las sentencias". ${ }^{122}$ Junto con su "rígida regla de reiteración", se dice que esta práctica hace de nuestro sistema jurisprudencial uno "excesivamente

119 Citado por Saavedra Herrera, op. cit., nota 60, p. 305 (observa este autor que "desde entonces se utilizaba la palabra «tesis» para hacer referencia a los criterios de la propia Suprema Corte").

120 Suprema Corte de Justicia de la Nación, El Semanario Judicial de la Federación y sus épocas. Manual para su consulta, México, 2008, pp. 71-77. Guerrero Lara señala que: 1) la ejecutoria sólo se publicaba completa cuando era "trascendental"; 2) si el sumario no bastaba para explicar el asunto estudiado, se incluía la parte considerativa de la sentencia; y 3) en todos los demás casos, en los cuales el sumario "[era] suficiente para la comprensión del negocio resuelto", se omitía la ejecutoria y se publicaba sólo dicha sinopsis (cfr. op. cit., nota 117, p. 42).

121 Saavedra Herrera, op. cit., nota 60, pp. 312-314.

122 Magaloni, Ana Laura, La Suprema Corte y el obsoleto sistema de jurisprudencia constitucional, documento de trabajo, México, CIDE, núm. 57, 2011, http://bit.ly/1fvuaj3, pp. 2, 18 y 20. También criticando la desvinculación de las circunstancias fácticas que 
formal”, que "pas[a] de ser hermenéutico a burocrático, con una enorme pérdida... de la importancia del derecho judicial en el desarrollo del derecho mexicano". ${ }^{123}$

\section{Precedente, ejecutoria y tesis}

Aunado a otras prácticas criticables (como la inadecuada formulación de las tesis, que con mayores cuidados no resultaría difícil enmendar ${ }^{124}$ ), a lo largo del tiempo el desconocimiento de la lógica del precedente judicial extendió en México la idea de que la jurisprudencia consiste solamente en las tesis "promulgadas" en el Semanario Judicial de la Federación, y que éstas se hallan desvinculadas de la ejecutoria de la que proceden. Pero esta idea es insostenible, y lo era también conforme a la abrogada Ley de Amparo de 1936.

Los artículos 222 a 224 de la vigente legislación de amparo establecen que la jurisprudencia será vinculante por reiteración ${ }^{125}$ "cuando se sustente un mismo criterio en cinco sentencias no interrumpidas por otra en contrario, resueltas en diferentes sesiones", con los requisitos de votación que correspondan para el Pleno y las Salas de la Suprema Corte y para los tribunales colegiados de circuito. ${ }^{126} \mathrm{El}$ artículo 218 de la misma ley dispone la elaboración de la tesis respectiva y su publicación en el Semanario. ${ }^{127}$

Sobre la definición de las tesis, y en consecuencia su conformación, ha habido una importante evolución. Aludiré en el último cambio, que es muy significativo.

hicieron surgir una tesis jurisprudencial, véanse González Oropeza, op. cit., nota 64, p. 160; y Saavedra Herrera, op. cit., nota 60, p. 294.

123 López Medina, op. cit., nota 30, pp. 145 y 146.

124 Zertuche García, op. cit., nota 7, pp. 110-111; y González Camarena, Rodrigo, "La creación del precedente en la Suprema Corte de Justicia de la Nación”, en Bernal Pulido, González Camarena y Martínez Verástegui (coords.), op. cit., nota 10, pp. 114-117. Sobre un fenómeno similar en Italia, véase Taruffo, op. cit., nota 40, pp. 200 y 201.

125 Me abocaré a esta figura por su carácter central en el sistema jurisprudencial mexicano. En cierta medida, lo dicho sobre la jurisprudencia por reiteración aplica a la contradicción de tesis. En cambio, la sustitución de jurisprudencia deberá estudiarse junto con la interrupción de la misma, pues ambas corresponden al tema relativo al cambio del precedente, cuyo tratamiento excedería los límites de este trabajo.

126 Artículos 192 y 193 de la abrogada Ley de Amparo de 1936 (texto vigente al 2 de abril de 2013).

127 Artículo 195 idem. 
Los artículos 2o., inciso A, y 4o., inciso A, del acuerdo general 20/2013 del Pleno de la Suprema Corte ${ }^{128}$ establecían lo siguiente sobre la elaboración de las tesis:

La tesis es la expresión por escrito, en forma abstracta, de un criterio jurídico establecido al resolver un caso concreto. En consecuencia, la tesis no es un extracto, una síntesis o un resumen de la sentencia.

[El texto de la tesis deberá] [d]erivar en su integridad de la parte considerativa fundamental de la resolución correspondiente y no contener aspectos que, aun cuando se hayan tenido en cuenta en la discusión del asunto, no formen parte de aquélla. / [Y se] entenderá por parte considerativa fundamental, la concerniente al planteamiento del problema o problemas tratados y las razones de su solución. ${ }^{129}$

Por su parte, ahora los artículos 39 y 41, fracción I, del acuerdo general plenario 17/2019 tratan los mismos aspectos en estos términos:

La tesis hace referencia al criterio jurídico para un caso concreto. La tesis debe ser redactada con estructura de una regla, compuesta por un supuesto de hecho que describa las circunstancias fácticas que constituyen el campo de aplicación de la regla y una consecuencia jurídica donde se establezca la solución normativa. Las cuestiones de hecho y de derecho que no son necesarias para justificar la decisión, en ningún caso deberán incluirse en la tesis. / La tesis no es un extracto, una síntesis o un resumen de la sentencia. ${ }^{130}$

[El texto de la tesis deberá] [d]erivar en su integridad de la parte considerativa de la resolución correspondiente y no contener aspectos que, aun cuando se hayan tenido en cuenta en la discusión del asunto, no formen parte de aquélla.

Con base en la comparación de estas caracterizaciones, puede adelantarse: 1) es un gran acierto que las "circunstancias fácticas" ya sean enfatizadas como elemento integrador del precedente judicial; 2) la aplicación

128 Diario Oficial de la Federación, 12 de diciembre de 2013.

129 Cursivas añadidas. Cfr. título segundo, núm. 1, del acuerdo general 5/2003 del Pleno de la Suprema Corte de Justicia de la Nación (Diario Oficial de la Federación, 8 de abril de 2003). Sobre el origen y evolución de esta definición, véase Saavedra Herrera, op. cit., nota 60, pp. 315-318.

130 Diario Oficial de la Federación, 9 de diciembre de 2019 (cursivas añadidas). 
de este nuevo concepto no debe incurrir en un nuevo formalismo ni excluir la formación de tesis que divulguen criterios puramente normativos pero útiles para la interpretación del ordenamiento, y 3) el éxito de este cambio estribará en la adecuada redacción de las sentencias y de las tesis, y el destierro de hábitos - muy arraigados en México- que las han vuelto habitualmente farragosas y oscuras.

Con todo, de lo anterior se desprende primeramente que las tesis sistematizadas que publica el Semanario deben expresar las rationes decidendi de las ejecutorias de que emanan y no contener obiter dicta, ${ }^{131}$ lo que para comenzar es materialmente un claro guiño a estos conceptos generales relativos al precedente judicial, que últimamente han mencionado los tribunales mexicanos. ${ }^{132} \mathrm{Y}$ enseguida, porque las tesis "emana[n] de las ejecutorias", ${ }^{133}$ que aquéllas no son vinculantes por sí mismas, sino en tanto reflejen con fidelidad el criterio jurídico decisivo que usó el tribunal en sus sentencias.

Sobre lo último, el Pleno de la Suprema Corte de Justicia de la Nación señaló que las tesis "sólo tienen efectos publicitarios", y que su redacción no es indispensable para la obligatoriedad del criterio que expresan; ${ }^{134} \mathrm{en}$

131 Véase supra, § IV.1.A. Sin embargo, especialmente en contradicción de tesis, no resulta extraño ver tesis que sistematizan criterios que carecen de obligatoriedad, por no corresponder al tema cuestionado; pero en no pocas ocasiones - y con la nota de advertencia correspondiente - resultan muy útiles, porque, entre otros, sintetizan prolijos desarrollos jurisprudenciales; un ejemplo de lo anterior es "DEFINITIVIDAD. EXCEPCIONES A ESE PRINCIPIO EN EL JUICIO DE AMPARO INDIRECTO”, Segunda Sala, Semanario Judicial de la Federación y su Gaceta, 9a. época, t. XII, julio de 2000, tesis 2a. LVI/2000, p. 156; cfr. supra, notas 109 y 111.

132 Véanse "SOlicitud DE MOdifiCACiÓn DE JURISPRUdENCIA. PROCEDE CUANDO ÉSTA SE UTILICE EN LA CADENA ARGUMENTATIVA DEL CASO CONCRETO, AUN CUANDO NO CONSTITUYA LA RATIO DECIDENDI DEL ASUnTO", Primera Sala, Semanario Judicial de la Federación y su Gaceta, 10a. época, lib. VIII, mayo de 2012, t. 1, tesis 1a. CCXLVI/2011 (9a.), p. 1114; "PRECEDENTES JURISDICCIONALES. PARA DETERMINAR SU APLICACIÓN Y ALCANCE, DEBE ATENDERSE A Su RAZÓn DECISORIA”, Segunda Sala, Gaceta del Semanario Judicial de la Federación, 10a. época, lib. 36, noviembre de 2016, t. II, tesis 2a. CXII/2016 (10a.), p. 1554; y “CONTRADICCIÓN...”, cit., nota 110.

133 “JuRISPRUDENCIA. CONCEPTO, CLASES Y FINES”, Semanario Judicial de la Federación y su Gaceta, 9a. época, t. XVIII, octubre de 2003, tesis IX.10.71 K, p. 1039.

134 “JURISPRUDENCIA. CUANDO SE ESTABLECE POR REITERACIÓN, SE CONSTITUYE POR LO RESUELTO EN CINCO EJECUTORIAS COINCIDENTES NO INTERRUMPIDAS POR OTRA EN CONTRARIO, POR LO QUE LAS OBLIGACIONES DE REDACCIÓN, CONTROL Y DIFUSIÓN SÓLO PRODUCEN EFECTOS PUBlicitARIOS", idem, 9a. época, t. V, mayo de 1997, tesis P. LXIV/97, p. 166. Véase también "JURISPRUDENCIA. CUANDO SE ESTABLECE POR REI- 
tal virtud, tampoco constituyen por sí mismas el precedente judicial ni son necesarias para su existencia. Por eso, para conocer cabalmente verdadero precedente judicial, es decir, el alcance de una tesis jurisprudencial —no siempre tan "claro" como se quisiera ${ }^{135}$ — y su aplicabilidad, "es necesario estudiar las... sentencias que forman la jurisprudencia invocada". ${ }^{136}$

De esta misma opinión ha sido la Primera Sala del máximo tribunal al establecer que en caso de incongruencia entre ellas "debe atenderse a la ejecutoria y no a la tesis redactada", pues "las tesis se redactan en forma sintética a fin de controlarse y difundirse". ${ }^{137}$ Por su parte, la Segunda Sala de la Corte en algún momento opinó que las tesis, sancionadas por un "acto administrativo irrecurrible", habrían de ser aplicadas "en sus términos" y sin que los juzgadores tengan facultad para "cuestionar el carácter,

TERACIÓN, SE CONSTITUYE POR LO RESUELTO EN CINCO EJECUTORIAS COINCIDENTES NO INTERRUMPIDAS POR OTRA EN CONTRARIO, POR LO QUE LA REDACCIÓN, EL CONTROL Y LA DIFUSIÓN DE LAS TESIS CORRESPONDIENTES SÓLO PRODUCEN EFECTOS PUBLICITARIOS”, Segunda Sala, Apéndice al Semanario Judicial de la Federación 1917-2011, t. II, tesis 1719, p. 1953.

135 El caso más grave de incongruencia es el de la tesis P. LXXVII/99 — posición jerárquica de tratados internacionales - y la ejecutoria del amparo en revisión 1475/98 de la que deriva. En esta sentencia, el Pleno de la Suprema Corte expresamente señaló que los tratados que amplían las libertades de los gobernados - en el caso: el Convenio 87 de la OIT - deben considerarse "como constitucionales", pero aquella tesis no reflejó este matiz. Si lo hubiera hecho, México habría contado con un bloque de constitucionalidad doce años antes de la conocida reforma de derechos humanos del 10 de junio de 2011.

136 “JURISPRUDENCIA. EXAMEN DE LAS SENTENCIAS QUE LA CONSTITUYEN. ANALOGÍA. APLICACIÓN INOPERANTE DE LOS PRECEDENTES JUDICIALES POR ESTE CRITERIO”, Semanario Judicial de la Federación, 7a. época, vols. 217-228, sexta parte, p. 364. Véanse también “ANALOGÍA, APLICACIÓN POR, DE TESIS DEL TRIBUNAL EN PLENO”, Pleno, idem, 7a. época, vol. 39, primera parte, p. 14; "CONTRADICCIÓN DE TESIS. CUANDO ES CONFUSA O INCOMPLETA LA TESIS REDACTADA, DEBE ATENDERSE A LA EJECUTORIA RESPECTIVA", Pleno, Semanario Judicial de la Federación y su Gaceta, 9a. época, t. II, octubre de 1995, tesis P. LXXXI/95, p. 81; “CONTRADICCIÓN DE TESIS. CUANDO ES CONFUSA O INCOMPLETA LA TESIS REDACTADA, DEBE ATENDERSE A LA EJECUTORIA RESPECTIVA”, Segunda Sala, idem, 9a. época, t. XIX, abril de 2004, tesis 2a./J. 31/2004, p. 427; y “CONTRADICCIÓN DE TESIS. CUANDO UNA DE LAS TESIS CONTENDIENTES ES CONFUSA O INCOMPLETA DEBE ATENDERSE A LA EJECUTORIA RESPECTIVA", Primera Sala, Apéndice al Semanario Judicial de la Federación 1917-2011, t. II, tesis 1666, p. 1890.

137 “CONTRADICCIÓN DE TESIS. CUANDO LA TESIS REDACTADA CONTIENE ELEMENTOS O SUPUESTOS JURÍDICOS NO ABORDADOS EN LA EJECUTORIA QUE LA ORIGINÓ, DEBE ATENDERSE A ESTA ÚlTIMA PARA VERIFICAR SU EXISTENCIA", Semanario Judicial de la Federación y su Gaceta, 9a. época, t. XXI, abril de 2005, tesis 1a. XXIII/2005, p. 723. 
contenido y proceso de integración de la jurisprudencia"; ${ }^{138}$ aunque años más tarde y con vigor jurisprudencial, apegándose al parecer del Pleno, la misma sala también concluyó que "debe atenderse a [la ejecutoria] y no a la tesis redactada, puesto que el criterio que sustenta el órgano jurisdiccional se encuentra en las consideraciones de la propia resolución". ${ }^{139}$

La legislación vigente corrobora el carácter meramente divulgativo de las tesis, y el papel constitutivo del precedente que tienen las ejecutorias. La parte final del artículo 221 de la Ley de Amparo dispone que de no haberse publicado tesis sistematizada, para acreditar la existencia de un precedente o de un criterio jurisprudencial vinculante "bastará que se acompañen copias certificadas de las resoluciones correspondientes". A mi juicio, esta acreditación también podría hacerse mediante compulsa con el Sistema Integral de Seguimiento de Expedientes (SISE) del Poder Judicial de la Federación. ${ }^{140}$

Esta última disposición legal corrobora que lo realmente decisivo para establecer un precedente judicial es el empleo de la ratio decidendi en el holding de las resoluciones de los tribunales; y si bien ello se podía desprender de la anterior legislación de amparo, ${ }^{141}$ ésta carecía de una dis-

138 “JURISPRUDENCIA. LOS TRIBUNALES COLEGIADOS DE CIRCUITO SÓLO PUEDEN ANALIZAR SI UN CRITERIO JURÍDICO TIENE O NO TAL CARÁCTER, SI NO ESTÁ REDACTADO COMO TESIS CON RUBRO, TEXTO Y DATOS DE IDENTIFICACIÓN", Apéndice al Semanario Judicial de la Federación 1917-2011, t. II, tesis 1725, p. 1959.

139 "CONTRADICCIÓN...", tesis 2a./J. 31/2004, cit., nota 136; véase también "TESIS PUBLICADA. SIN APEGARSE A LO RESUELTO, SU INEXISTENCIA DEBE SER DIFUNDIDA POR RAZONES DE SEgURIDAd JURÍDICA”, Segunda Sala, Apéndice al Semanario Judicial de la Federación 1917-2011, t. II, tesis 1732, p. 1968. Cfr. tesis P. LXIV/97, cit., nota 134; y "Jurisprudencia. Debe modificarse la de una Sala si el Pleno sustenta una TESIS CONTRARIA, AUNQUE SEA AISLADA", Segunda Sala, Semanario Judicial de la Federación y su Gaceta, 9a. época, t. XXV, abril de 2007, tesis 2a. XXII/2007, p. 561.

140 Por todos véase "Hechos NOTORIOS. TIENEN ESE CARÁCTER LAS VERSIONES ELECTRÓNICAS DE LAS SENTENCIAS ALMACENADAS Y CAPTURADAS EN EL SISTEMA INTEGRAL DE Seguimiento de ExPedientes (SISE)", Pleno, Gaceta del Semanario Judicial de la Federación, 10a. época, lib. 55, junio de 2018, t. I, tesis P./J. 16/2018 (10a.), p. 10.

141 Aparte de las señaladas, así lo indicó la Suprema Corte en otras ocasiones; e. $g$. "JURISPRUDENCIA. NO ES OBJETO DE DECLARACIÓN ABSTRACTA A PETICIÓN ESPECIAL, SINO QUE SE FORMA Y TOMA EN CUENTA AL SUSTENTARSE EN EL NÚMERO DE EJECUTORIAS CON LOS REQUISITOS LEGALES QUE LA DETERMINAN... la jurisprudencia... nace del simple hecho espontáneo de que se reúna el número de precedentes que exige la ley, con los requisitos que la misma fija...", Segunda Sala, Semanario Judicial de la Federación, 7a. época, vol. 18 , tercera parte, p. 85 . 
posición tan clara como el artículo 221, in fine, de la vigente. ${ }^{142}$ Así, hoy resulta indudable que la existencia de la jurisprudencia o de un precedente no depende de un acto formal de elaboración de la respectiva tesis ni de su difusión oficial, que se tratarían de actos meramente declarativos a efecto de "mera" divulgación, y no de uno constitutivo. ${ }^{143}$ Desde luego, tampoco habría impedimento para que los operadores jurídicos acudan a la resolución, y no a la tesis, a efecto de invocar con cabal precisión un criterio judicial. ${ }^{144}$

A lo anterior no se opone que desde diciembre de 2013 el Semanario Judicial de la Federación cada viernes publica tesis y ejecutorias, y que los criterios jurisprudenciales que éstas contienen deben considerarse de "aplicación obligatoria" a partir del día (lunes) hábil siguiente, conforme al punto séptimo del acuerdo general plenario 16/2019. Por el contrario, el último párrafo de la misma disposición confirma la primacía de la ejecutoria y de su mera existencia, al establecer que la obligatoriedad de las tesis se dará sin perjuicio de los artículos 221, parte final, de la Ley de Amparo, y 43, de la Ley Reglamentaria del Artículo 105 Constitucional. ${ }^{145}$ Así, la comprobación del respectivo precedente mediante los medios oficialmente reconocidos al efecto (copia certificada, versión electrónica del SISE, remisión electrónica oficial ${ }^{146}$ o publicación en el Diario Oficial de la Federación), es una excepción a la regla general de que carecen de efecto vinculante los precedentes pendientes de divulgación en el Semanario.

Habiéndose acreditado la existencia de las correspondientes ejecutorias y que contienen cierto precedente, el juzgador ante quien el mismo se invoque

142 Véase en general Rosales Guerrero, op. cit., nota 72, pp. 220-232.

143 En los Estados Unidos hay un "interesante desacuerdo" sobre si, las consideraciones de las sentencias que no han sido publicadas oficialmente constituyen precedentes, y por ende si tienen fuerza vinculante; la respuesta tradicional ha sido proscribir su invocación, pero esta regla se ha "suavizado considerablemente"; cfr. Garner et al., op. cit., nota 8, pp. 142-149. Entre los precedentes relativos a esta polémica, se inclina implícitamente en sentido afirmativo Anastasoff v. United States, 223 F.3d 898, 899 (pp. 4 y ss.) (8th Cir. 2000) (las páginas entre paréntesis se refieren a su versión electrónica en http://bit. ly/2wPblYV), invalidada por improcedencia (moot) por el tribunal pleno (en banc) en 235 F.3d 1054 (8th Cir. 2000).

144 Camarena González, op. cit., nota 124, p. 117.

145 Punto séptimo del acuerdo general 19/2013 del Pleno de la Suprema Corte de Justicia de la Nación (Diario Oficial de la Federación, 29 de noviembre de 2013).

146 Conforme al punto quinto del acuerdo general plenario 17/2019, y artículos 16 y 17 del acuerdo general plenario 20/2013 (Diario Oficial de la Federación, 12 de diciembre de 2013). 
deberá reconocerle el efecto vinculante que le corresponda, aunque a su respecto no se hubiera redactado una tesis sistematizada, o que ésta o las ejecutorias relativas tampoco se hubieran publicado en el Semanario. ${ }^{147}$ Lo que acaso variaría en estas condiciones sería la responsabilidad del juzgador ${ }^{148} \mathrm{y}$ la de las partes ${ }^{149}$ que actuaran contra un precedente cuya existencia ignoraban, y cuya difusión en el Semanario haría inexcusable su desconocimiento. De otra manera, el artículo 221, in fine, de la Ley de Amparo, carecería de sentido por inoperante, y vaciarlo de contenido es una opción interpretativa inadmisible, especialmente porque los acuerdos generales plenarios no pueden contravenir las disposiciones legales que reglamentan. ${ }^{150}$

\section{Tradición y evolución}

No obstante que la propia Ley de Amparo y en ocasiones la Suprema Corte han acercado el sistema jurisprudencial de nuestro país a una "teoría general” del precedente, aún falta camino por recorrer para que en México percibamos habitualmente y con nitidez la verdadera naturaleza y la dinámica jurídica que los jueces crean con sus decisiones. Las anteriores notas llevan a valorar la auténtica jurisprudencia de nuestros tribunales, es decir, la contenida en sus resoluciones, y a reducir la importancia de las tesis sistematizadas a una mera herramienta de difusión, aun con independencia de su publicación en el Semanario u otros medios oficiales. ${ }^{151}$

147 “JuRISPRUdENCIA DE LA SUPREMA CORTE DE JUSTICIA DE LA NACIÓN. LA OBLigATORIEDAD DE SU APLICACIÓN, EN TÉRMINOS DEL ARTÍCULO 217 DE LA LEY DE AMPARO, SURGE A PARTIR DE SU PUBLICACIÓN EN EL SEMANARIO JUdiCIAL DE LA FEDERACIÓN", Segunda Sala, Gaceta del Semanario Judicial de la Federación, 10a. época, lib. 25, diciembre de 2015, t. I, tesis 2a./J. 139/2015 (10a.), p. 391.

148 “JURISPRUDENCIA. LA OBLIGATORIEDAD CONSTITUCIONAL DE LA SUSTENTADA POR EL Poder Judicial de LA FEDERACIÓN, EXIGE DE LOS JUZGADORES ANÁlisis Y SEGUIMIENTO PERMANENTES DE LOS MEDIOS INFORMATIVOS QUE LA DIFUNDEN", Segunda Sala, Semanario Judicial de la Federación y su Gaceta, 9a. época, t. XII, agosto de 2000, tesis 2a. CV/2000, p. 364.

149 "RECLAMACIÓN...", cit., nota 46.

150 Ezquiaga Ganuzas, op. cit., nota 58, pp. 271, y 277 y 278; y Sánchez Gil, Rubén, "Los acuerdos generales plenarios de la Suprema Corte de Justicia de la Nación", manuscrito inédito, 10 de diciembre de 2019 (archivo del autor), en Cossío Díaz, José Ramón y Astudillo, César (coords.), Organización y funcionamiento de la Suprema Corte de Justicia de la Nación (en preparación), § III.3.

151 “ACCIÓN DE INCONSTITUCIONALIDAD. Si EN ELLA SE DECLARA LA INVALIDEZ DE NORMAS GENERALES, LOS ÓRGANOS JURISDICCIONALES DEBEN APLICAR ESE CRITERIO, 
Sin embargo, el sistema mexicano de tesis jurisprudenciales es compatible con una visión más amplia del precedente judicial, y más tradicional desde el punto de vista del common law. Incluso, la primacía de la sentencia en los Estados Unidos no es tan homogénea como creemos en México.

La mayoría de las jurisdicciones están por negar a los syllabi todo efecto vinculante, y por considerarlos un elemento ajeno a la resolución. ${ }^{152}$ En una ya clásica sentencia, por lo que a ella respecta, la Suprema Corte de ese país ha señalado enfáticamente que el encabezado es "labor de quien reporta", no del tribunal, y que se prepara sólo para la "conveniencia" de quien desea informarse de su contenido. ${ }^{153}$ Pero algunas entidades federativas norteamericanas han adoptado la posición de que dicha sinopsis "debería mantener alguna presunta apariencia (some semblance) de precedente" (cursivas originales suprimidas): 1) Kansas atribuye efecto vinculante a los syllabi, y considera que expresan holdings; 2) Minnesota tiene una regulación similar; 3 ) en Virginia occidental, el sumario establece los puntos jurídicos importantes de la decisión, y ambos tienen valor de precedente; los litigantes tienen la libertad de invocar cualquiera, y 4) en Ohio, el "ejemplo más extremo", la ley exige que todo punto jurídico decidido se encuentre en un syllabus, y sólo éste, "y no la sentencia (opinion) en su integridad" tiene carácter de precedente.

Es innegable la gran utilidad que brindan las tesis mexicanas al facilitar la referencia jurisprudencial en nuestra práctica, frente a las desventajas —a veces exageradas — que se les atribuyen. ${ }^{154}$ Jueces, litigantes y académicos empleamos habitualmente las tesis porque facilitan el manejo de los precedentes por permitir identificarlos y localizarlos en función de palabras o frases clave de sus "rubros", en especial a partir de su sistemati-

AUN CUANDO NO SE HAYA PUBLICADO TESIS DE JURISPRUDENCIA", Segunda Sala, Apéndice al Semanario Judicial de la Federación 1917-2011, t. II, tesis 74, p. 4494; y el artículo cuarto, fracción I, inciso D), del Acuerdo General 5/2013 del Pleno de la Suprema Corte de Justicia de la Nación (Diario Oficial de la Federación, 21 de mayo de 2013).

152 Para lo sucesivo en este párrafo, véase Garner et al., op. cit., nota 8, pp. 150-152.

153 United States v. Detroit Timber \& Lumber Co., 200 U.S. 321, 337 (1906) (reconoce, no obstante, que "una regla diferente, es verdad, se prescribe por ley en algunos estados"). Véase también Suprema Corte de los Estados Unidos, Information About Opinions, disponible en: http://bit.ly/2YEvvUm (12 de diciembre de 2019).

154 Camarena González, op. cit., nota 124, p. 116 (afirman que hay tesis que "sí son fieles a la litis y los hechos del caso" [cursivas en el original], o a cuyo respecto "no es difícil inferir una [regla específica] a partir de la tesis"). 
zación informática. ${ }^{155}$ Este sistema es particularmente eficiente cuando en una sola ejecutoria se sientan diversos criterios, pues permite identificar con claridad cada uno de ellos, e incluso sus distintos matices. ${ }^{156}$

Por estos motivos, me parece desafortunado que desde 2016 la Suprema Corte ya no expida tesis derivadas de las ejecutorias que dicta en controversias constitucionales y acciones de inconstitucionalidad. ${ }^{157}$ Con el aval de la Ley de Amparo, ${ }^{158}$ estos elementos divulgativos garantizaban el conocimiento de los criterios sentados también para esta clase de asuntos, sin perjuicio de que el efecto vinculante de sus precedentes derive de la correspondiente ejecutoria. ${ }^{159}$ Asimismo, la redacción de tesis - concebidas como meros instrumentos de difusión, según vimos - tampoco se contrapone a la existencia del sistema de precedentes en controversias constitucionales y en acciones de inconstitucionalidad basado en sus ejecutorias; de hecho, los "rubros temáticos" con que este sistema identifica los criterios jurídicos establecidos en tales resoluciones cumplen la función orientadora que originó nuestro sistema de tesis, y pueden dar lugar a

155 Utilidad que reconoce el artículo 3o., apartados A y C, del Acuerdo General 20/2013 del Pleno de la Suprema Corte de Justicia de la Nación, al prescribir que facilitar la localización de las tesis es uno de los propósitos que debe orientar la redacción de sus rubros.

156 Un buen ejemplo es el amparo directo 35/2014 de la Primera Sala del Máximo Tribunal —el caso Bullying_, del que se desprendieron 33 tesis jurisprudenciales.

157 Desde la modificación del punto tercero del acuerdo general plenario 19/2013 a través del instrumento normativo publicado en el Diario Oficial de la Federación del 18 de abril de 2016, que simplemente eliminó toda alusión a la publicación de las "tesis respectivas" que derivasen de las ejecutorias de dichos procesos. La misma posición adopta el punto tercero del acuerdo general plenario 16/2019, que significativamente omite mencionar las "respectivas tesis jurisprudenciales" procedentes de controversias constitucionales, acciones de inconstitucionalidad y — ahora también — declaratorias generales de inconstitucionalidad, que en cambio sí menciona respecto de la jurisprudencia por reiteración y otras especies. Véase en general Suprema Corte de Justicia de la Nación, El Semanario Judicial de la Federación. Su evolución a un sistema digital de compilación y difusión, México, 2016, pp. 69, 70 y 153-157.

158 Véase el artículo 177 de la Ley Orgánica del Poder Judicial de la Federación.

159 Por mayoría de razón, cfr. "TRIBUNALES COLEGIADOS DE CIRCUITO. AUNQUE LAS CONSIDERACIONES SOBRE CONSTITUCIONALIDAD DE LEYES QUE EFECTÚAN EN LOS JUICIOS DE AMPARO DIRECTO, NO SON APTAS PARA INTEGRAR JURISPRUDENCIA, RESULTA ÚTIL LA PUBLICACIÓN DE LOS CRITERIOS", Pleno, Semanario Judicial de la Federación y su Gaceta, 9a. época, t. VIII, septiembre de 1998, tesis P. LX/98, p. 56. 
la elaboración de éstas en aras de controlar y sistematizar los precedentes sentados en dichos procesos constitucionales. ${ }^{160}$

Es cierto que nuestro sistema de formulación de tesis es perfectible, pero a mi juicio no implicaría mayor esfuerzo que atender a su adecuada redacción para que refleje con mayor claridad los hechos del caso y la ratio decidendi a que corresponda. Y también lo mismo podría decirse de la claridad que debe tener la formulación de las resoluciones judiciales para que su razonamiento pueda fungir como precedente, por ser preciso, diáfano y nítido en cuanto a sus premisas — jurídicas y fácticas - y a su razonamiento. ${ }^{161}$

Advertir que las tesis consisten de un mero reflejo del criterio de una decisión jurídica que se dio en función de determinadas circunstancias que constituyeron uno o varios casos particulares permitirá tener un manejo más adecuado de nuestros precedentes mediante técnicas de manejo jurisprudencial - aplicables de modo general, aunque originadas en el common law-, a las cuales ya se ha referido la Suprema Corte de Justicia de la Nación. ${ }^{162}$ Para que nuestro sistema jurisprudencial funcione mejor, antes que grandes cambios se requiere una diferente perspectiva sobre el precedente judicial que permita algunos ajustes en su comprensión y en su operación. Para llegar a buen puerto, la aplicación jurisprudencial requiere "una determinada manera de leer y [de] escribir sentencias". ${ }^{163}$

El primero de dichos ajustes sería asumir de modo general que las tesis gozan de una presunción iuris tantum de expresar un precedente, y suponer que formulan correctamente la ratio decidendi de la ejecutoria de que emanan, y se relaciona con una mayor precisión en la redacción de las tesis y las ejecutorias a que corresponden. Aunque por esta misma calidad

160 Supra, nota 116; punto cuarto, párrafo segundo, del acuerdo general plenario 16/2019; y punto cuarto, último párrafo, y décimo, del acuerdo general plenario 19/2013 (antes y después de su modificación por el instrumento normativo referido supra, nota 157).

161 Ramírez Alvarado, Julia, ponencia en la mesa panel El Precedente Judicial en México: Retos, Problemas y Debates, Mérida, Casa de la Cultura Jurídica de la Suprema Corte de Justicia de la Nación, 27 de junio de 2019.

162 Véase por ejemplo "PreCEDENTES...", cit., nota 84 (reconoce la técnica de la "distinción" [distinguishing] que aparta el caso actual de la regla establecida en el precedente).

163 Ferreres Comella, op. cit., nota 16, pp. 76 y 77. 
secundaria y por su propósito meramente declarativo y divulgativo, ${ }^{164}$ habríamos de admitir que la ejecutoria correspondiente debe prevalecer a todos los efectos, sea para precisar el significado de la tesis, esclarecer las condiciones de su aplicación o aun determinar el verdadero sentido del criterio jurídico del tribunal. ${ }^{165}$ Entendido así nuestro sistema, el ordenamiento mexicano podría ajustarse a una teoría general del precedente - cuyos aspectos fundamentales ha elaborado el common law - y a la práctica jurisprudencial de otros países pertenecientes a nuestra tradición jurídica, sin abandonar sus peculiaridades tradicionales.

\section{Múltiples efectos vinculantes}

\section{A. La autoridad del precedente vertical}

El empleo del precedente en el razonamiento jurídico es una de las especies del argumento de autoridad o ab exemplo, que Giovanni Tarello define como aquel "por el que a un enunciado normativo le es atribuido aquel significado que ya le había sido atribuido por alguien, y por ese solo hecho". ${ }^{166}$ El precedente "representa un prototipo, un modelo para futuras resoluciones que se refieren a casos similares"; 167 pero no solamente es un "buen ejemplo" — y aun podría ser malo-, sino que es uno dotado de la "autoridad" del órgano judicial que generó la regla que expresa. ${ }^{168}$

Por su "papel central en la explicación del concepto de precedente" y afines, como veremos en secciones posteriores, hay que distinguir claramente las acepciones del término "autoridad". En nuestro contexto, este término alude primordialmente a: 1) el prestigio o crédito reconocido a una persona $u$ órgano por su competencia o calidad, que en adelante calificaré de "material", y 2) la potestad para ordenar o mandar sobre otros, que sucesivamente designaré como "formal". ${ }^{69}$

164 Reconocido desde años atrás, incluso por la Suprema Corte. Véanse Zertuche García, op. cit., nota 7, pp. 131-133, y "JURISPRUDENCIA. NO ES...”, cit., nota 141.

165 Camarena González, op. cit., nota 124, pp. 117 y 118.

166 Ezquiaga Ganuzas, op. cit., nota 58, pp. 325 y 327 (de Tarello este autor cita L'interpretazione della legge, Milán, 1980, p. 372).

167 Larenz, op. cit., nota 47, p. 429.

168 Gómora Juárez, op. cit., nota 10, pp. 104, 105, 114, 115 y 133.

169 Ibidem, pp. 40 y 41. 
El precedente vertical se relaciona con ambas especies de autoridad. En cambio, la autoridad formal señalada carece de relevancia para el llamado precedente "horizontal", porque los tribunales homólogos generalmente carecen de potestad para imponerse uno a otro; aunque es posible que algunas consideraciones sobre el vertical puedan aplicar a esta clase por efecto de su relación con la autoridad materialmente entendida. Y por el contrario, el "autoprecedente" no implica vinculación alguna, sino que más bien consiste en un criterio de racionalidad, que nada tiene que ver con el concepto de "autoridad", y que más bien se relaciona con el principio de universabilidad. ${ }^{170}$ Por estos motivos, en lo sucesivo me ocuparé exclusivamente del arquetípico precedente vertical.

Evidentemente, caracterizar el precedente como un "ejemplo" lo relaciona con la autoridad material, en tanto que hacerlo consistir en una "regla prescriptiva" lo vincula con la formal. Los sendos puntos de vista que resultan de entender la "autoridad" del precedente en uno y en otro sentido permiten ver con claridad su naturaleza y diseccionarla con más precisión.

La ejemplaridad del precedente es la cualidad que le permite proyectarse y servir de modelo para solucionar casos futuros que son análogos a aquel en que se estableció. ${ }^{171}$ Pero esta cualidad nos obliga a ir más allá del argumento analógico, y a cuestionarnos por qué se toma como "norma de referencia" el criterio de determinado tribunal, y no el de otro o cualquier fuente diversa. La analogía tiene una estructura formal - la cual estriba en la semejanza y la búsqueda de una ratio (legis o decidendi, según corresponda) - que en manera alguna indica la norma sustantiva que le sirve de base. ${ }^{172}$ Sin embargo, la ejemplaridad no se agota en la mera analogía, sino que emplea ésta como vehículo para la emulación de acciones, y en especial de las actitudes, de un sujeto al que se atribuye "autoridad material" por su calidad "superior". ${ }^{173}$

Partiendo del supuesto de que los profesionales más capaces y experimentados ocupan las posiciones más altas de la organización judicial, es de esperarse que cuanto mayor altura tenga un tribunal en esta estructura, tanto mayor sería la "calidad" de sus respuestas y su "autoridad material";

${ }^{170}$ Gascón Abellán, op. cit., nota 43, pp. 212 y 214-218.

171 Gómora Juárez, op. cit., nota 10, pp. 103 y 104.

172 Ezquiaga Ganuzas, op. cit., nota 58, pp. 15-19.

173 Amaya, Amalia, "Ejemplaridad y derecho", en Bernal Pulido, González Camarena y Martínez Verástegui (coords.), op. cit., nota 10, pp. 58-62 y 66. 
y que cuanto mayor sea el número de estratos judiciales, tanto mayor será el número de los grados de la escala de calidad y autoridad judiciales. Este factor cuantitativo apunta a la existencia de tantos niveles de jerarquía jurisprudencial como estratos haya en una determinada organización judicial.

Sin embargo, aunque fuera "suprema" la autoridad material de un órgano jurisdiccional, sus opiniones carecerían propiamente de la calidad de "precedentes" de no ser por su autoridad formal. Es decir, la potestad jurídica de calificar y determinar la conducta de tribunales de inferior jerarquía es decisiva para que un criterio judicial sea un "precedente". Desde luego, ambas especies de autoridad pueden coexistir, pero sólo la formal es constitutiva del "precedente", en tanto que la material sólo resulta deseable y ha de presumirse, ${ }^{174}$ pero sin ser materialmente necesaria para que se actualice este concepto. A este respecto, cobra plena aplicación el célebre aforismo del justice Robert H. Jackson, que describe el papel del tribunal supremo norteamericano: "No tenemos la última palabra porque seamos infalibles, sino que somos infalibles sólo porque tenemos la última palabra". ${ }^{175}$

El precedente goza de una autoridad "práctica", no "teórica", pues provee "razones para la acción", impone "razones para decidir", con independencia de que realmente se esté o no de acuerdo con su sentido. ${ }^{176}$ Por ello, para que en su virtud surja un deber jurídico puede prescindirse de la adhesión ideológica del operador jurídico al contenido del precedente. De lo contrario, no podría entenderse la posibilidad de que simultáneamente se critique pero deba seguirse el precedente ${ }^{177}$ ni que pueda darse — de un modo vital para la democracia ${ }^{178}$ — una amplia discusión en el seno de la sociedad sobre tópicos que ya han sido resueltos jurisprudencialmente. ${ }^{179}$

174 Caminker, op. cit., nota 44, p. 868.

175 Brown v. Allen, 344 U.S. 443, 540 (1953) (concurrente): "We are not final because we are infallible, but we are infallible only because we are final".

176 Gómora Juárez, op. cit., nota 10, pp. 41-43, y Laporta, op. cit., nota 27, pp. 36 y 37.

177 Garner et al., op. cit., nota 8, p. 32.

178 Post, Robert y Siegel, Reva, "Roe rage: Democratic constitutionalism and backlash", Harvard Civil Rights-Civil Liberties Law Review, Cambridge, Universidad de Harvard, Escuela de Derecho, vol. 42, núm. 2, verano de 2007, disponible en: http://bit. ly/2xS5Qem, pp. 379 y 389-390.

179 Gómora Juárez, op. cit., nota 10, pp. 43, 44 y 110-112. 
El precedente goza claramente de autoridad formal cuando la disposiciones legales - como las mexicanas - explícitamente otorgan a las opiniones judiciales la potestad de guiar la conducta de otros tribunales. Pero primordialmente por efecto de la organización judicial, dicha especie de autoridad también tendría lugar incluso si tales prescripciones no existieran. ${ }^{180}$

En términos generales, ${ }^{181}$ únicamente a los tribunales terminales — que por definición tienen una jerarquía superior a otros - se les atribuye la capacidad de sentar precedentes, por la simple y sencilla razón de que sus decisiones tienen carácter definitivo, son irrevocables y no pueden ser sustituidas ni superadas por las de otro órgano; aunque pueden existir tribunales intermedios cuyos criterios tienen "meno[r] valor como precedentes". ${ }^{182}$ Por la calidad que se supone en sus integrantes, las decisiones de los tribunales superiores gozan de la presunción de ser "correctas", y en consecuencia sus precedentes controlan - para usar la terminología norteamericana- las decisiones de los inferiores. Actuando conforme a la pretensión de corrección inherente al sistema jurídico, ${ }^{183}$ éstos han de preferir aquella respuesta "correcta" a cualquier otra; si no lo hicieran, resolverían "incorrectamente", y ésta es una opción sencillamente inadmisible. El vigor del precedente como respuesta presuntamente "correcta" se mantiene incluso ante su aparente equivocación (¿según quién?), o ante la posibilidad de que el tribunal que lo estableció variase de opinión; cambiar el sentido

180 Supra, nota 61.

181 Gómora Juárez, op. cit., nota 10, pp. 74 y 82-84.

182 Garner et al., op. cit., nota 8, p. 255. Una peculiaridad del sistema mexicano es la jurisprudencia sobre inconstitucionalidad de normas generales establecida por tribunales colegiados. En amparo directo, esta posibilidad parece estar excluida (véase "TRIBUNALES...", cit., nota 159); pero en virtud de la autoridad delegada en amparos en revisión contra leyes locales y otras normas generales que a dichos tribunales han otorgado los acuerdos plenarios 5/2001 y 5/2013, fungen como órganos terminales capaces de establecer jurisprudencia (por todos véase "SUPLENCIA DE LA QUEJA DEFICIENTE PREVISTA EN EL ARTíCULO 76 BIS, FRACCIÓN I, DE LA LEY DE AMPARO. PROCEDE CUANDO EN EL AMPARO INDIRECTO SE SEÑALEN DIRECTAMENTE COMO ACTO RECLAMADO UNA LEY DECLARADA INCONSTITUCIONAL POR JURISPRUDENCIA DE UN TRIBUNAL COLEGIADO DE CIRCUITO Y COMO RESPONSABLES SUS ÓRGANOS EMISORES", Semanario Judicial de la Federación y su Gaceta, 10a. época, lib. XI, agosto de 2012, t. 2, tesis IV.2o.A.14 K (10a.), p. 1994). Pero aun en estos casos, si ejerciera su facultad de atracción, la Suprema Corte podría superar el precedente de un tribunal colegiado; mas es claro que ésta sería una situación excepcional.

183 Sobre este concepto, véase Alexy, op. cit., nota 33, pp. 264-268, y 428 y 429. 
del precedente judicial es prerrogativa del tribunal superior que lo estableció. ${ }^{184}$

Esta conformidad con la pretensión de corrección del sistema jurídico conlleva satisfacer otros fines cuya realización impulsa principalmente el precedente judicial: seguridad jurídica e igualdad en la aplicación de la ley. ${ }^{185}$ Impedir que los tribunales inferiores se aparten de la respuesta "correcta" que éste representa contribuye a la predictibilidad y la uniformidad del derecho en todas las fases procesales, reforzando su eficacia y evitando la arbitrariedad de los juzgadores. En seguida, favorece la igualdad en la aplicación de la ley, pues asimismo evitará que casos que ameriten la misma respuesta jurídica sean tratados de modo diferente. Sin embargo, el punto clave de la autoridad del precedente y para atribuir esta calidad a un criterio judicial es el siguiente: no se trata de garantizar cualquier predictibilidad e igualdad en la aplicación jurídica, sino que estas características se relacionen con una opinión sobre la cual hay una razonable expectativa de que se ajuste a la del tribunal que tendría la decisión final del caso. ${ }^{186}$

El stare decisis tiende a asegurar que todos los casos se resuelvan siempre de acuerdo con el precedente, es decir, la presuntamente "correcta" opinión del tribunal que tendría la última palabra a su respecto. Y esto justifica que el precedente siempre tenga autoridad formal para ser considerado por los tribunales inferiores al momento de decidir; a la inversa, ello también explica que éstos no se hallen vinculados en modo alguno a las opiniones de tribunales que no ejerzan control sobre ellos. Estos dos sentidos son la base de lo expuesto en las siguientes secciones.

De esta manera, el concepto de "autoridad" es clave para ver con nuevos ojos el sistema jurisprudencial mexicano, y revisar características suyas que sin mayor cuestionamiento hemos dado por firmemente sentadas, cuando en realidad deberíamos reflexionar por qué las concebimos como lo hacemos, para verificar si las llevamos a la práctica como se debería. ${ }^{187}$

${ }^{184}$ Rodriguez de Quijas v. Shearson/American Express, Inc., 490 U.S. 477, 484 (1989). Véase también Garner et al., op. cit., nota 8, pp. 28-30.

185 Pérez Portilla, op. cit., nota 50, pp. 73 y 74.

186 “JURISPRUDENCIA ESTABLECIDA POR UN PLENO DE CIRCUITO. ES OBLIGATORIA TANTO PARA LOS TRIBUNALES COLEGIADOS QUE SE UBIQUEN DENTRO DE ESE CIRCUITO COMO PARA LOS AUXILIARES QUE LOS APOYEN EN EL DICTADO DE SUS RESOLUCIONES, INDEPENDIENTEMENTE DE LA REGIÓN A LA QUE ÉSTOS PERTENEZCAN”, Gaceta del Semanario Judicial de la Federación, 10a. época, lib. 26, enero de 2016, t. IV, tesis (IV Región)2o.8 L (10a.), p. 3356.

187 Caminker, loc. cit., nota 44. 


\section{B. Efecto vinculante y escala de precedentes}

Otro de los postulados que caracterizan la práctica mexicana es la convicción de que existe una categórica separación entre los criterios jurisprudenciales stricto sensu, de aplicación inexorable, y los criterios "aislados", que carecerían absolutamente de efecto vinculante, y cuya importancia - en el mejor de los casos - es meramente académica y especulativa. En la actualidad, esta dicotomía es difícilmente sostenible. ${ }^{188}$

Expresando "razones para decidir" basadas en la autoridad formal y material que lo establece, todo precedente judicial siempre debe ser tomado en cuenta al decidir, aunque ello no implica que su sentido necesariamente haya de prevalecer. ${ }^{189}$ Siendo aplicable para adoptar una decisión, a un precedente debería dársele efecto, con el fin de garantizar los valores jurídicos que representa — seguridad, igualdad, etcétera —; pero existiendo en términos generales la posibilidad de que quien desee apartase de él, para hacerlo válidamente, cumpla con la carga de argumentar que resulta mejor alejarse de su sentido, y es una cuestión diferente que un determinado ordenamiento prevea formalmente la obligación de cumplir con dicha carga. ${ }^{190}$

Lo anterior lleva a asumir que todos los precedentes siempre tienen, con mayor o menor intensidad, un efecto prima facie vinculante, ${ }^{191}$ que en el curso argumentativo podría ser vencido con dificultad o con facilidad, y que sólo de modo excepcional dicho efecto haría que el criterio judicial prevalezca absolutamente. De esta manera, habría que reflexionar de nuevo sobre los puntos de vista tradicionales relativos a: 1) la categórica separación entre precedentes inexorablemente "vinculantes", y los meramente persuasivos u "orientadores", y 2) la impresión de que éstos son una simple guía que potestativamente puede considerarse en el razonamiento jurídico. ${ }^{192}$ Como detallaré en seguida, aquellas proposiciones en realidad se hallan bastante difundidas.

188 Xiol Ríos, op. cit., nota 54, p. 105. Véase también López Medina, op. cit., nota 30, pp. 206 y 207.

189 Laporta, op. cit., nota 27, p. 37.

190 Alexy, op. cit., nota 33, p. 339.

191 Camarena González, op. cit., nota 124, p. 118.

192 Véase por ejemplo "TESIS AISLADAS. LAS EMITIDAS POR LA SUPREMA CORTE DE JUSTICIA DE LA NACIÓN TIENEN CARÁCTER ORIENTADOR, NO GENERAN DERECHOS NI SON SUSCEPTIBLES DEL EJERCICIO DE IRRETROACTIVIDAD”, Segunda Sala, Gaceta del Semanario Judicial de la Federación, 10a. época, lib. 38, enero de 2017, t. I, tesis 2a./J. 195/2016 (10a.), p. 778. 
La mayoría de los sistemas jurídicos, incluso connotados integrantes de la tradición romanista, no trazan una línea tajante entre los precedentes judiciales para separarlos en unos absolutamente vinculantes y otros que carecen de todo efecto. ${ }^{193}$ Más bien, en términos generales, antes que de la "validez" o de la "vigencia" de un precedente, debe hablarse de su "solidez", pues tendrá mayor o menor "peso normativo" según la diferente proporción con que satisfaga ciertas características definidas por el sistema jurídico al que pertenezca.

Generalmente, los sistemas jurídicos no tratan a los precedentes de modo categórico, como si su obligatoriedad fuera cuestión de "todo o nada". En realidad, les atribuyen distintos niveles de vigor, ${ }^{194}$ que van desde reconocerles formalmente un muy fuerte efecto vinculante hasta admitir que tienen una "eficacia normativa persuasiva", que puede superarse con mayor o menor facilidad, pero no ser soslayada. ${ }^{195}$

Algunos autores han formulado escalas con una pluralidad de grados de efecto vinculante de los precedentes judiciales. ${ }^{196}$ Por su precisión, la que elaboró Taruffo ${ }^{197}$ me parece la más atendible. Expondré a continuación la propuesta del mencionado procesalista italiano con ejemplos tomados del derecho mexicano (no todos vigentes, pero sí ilustrativos), y señalaré el calificativo que correspondería al precedente según las cualidades de la vinculación que genere:

1) Absolutamente vinculante. Existe obligación "absoluta y sin excepciones" de seguir el precedente. Tal es hoy el caso de la jurisprudencia vinculante de la Suprema Corte de Justicia de la Nación, que no admite examen de su inconvencionalidad — la cual podría basarse en su contraste con la jurisprudencia interamericana-. ${ }^{198}$

193 Véase en general MacCormick y Summers, op. cit., nota 5, pp. 505 y 506.

194 Gascón Abellán, op. cit., nota 43, p. 212 (habla de un continuum de la eficacia vinculante del precedente conforme a "la mayor o menor fuerza que se atribuya a las razones para seguirlos").

195 "Mientras que la jurisprudencia vinculante (binding caselaw) tiene que seguirse, la persuasiva «no obliga a un tribunal, pero no obstante es acreedora de respeto y de cuidadosa consideración»", Garner et al., op. cit., nota 8, p. 164 (cursivas añadidas; cita Black's Law Dictionary, p. 1367).

196 Véanse por ejemplo MacCormick y Summers (eds.), op. cit., nota 5, pp. 516-518; y Orozco Muñoz, op. cit., nota 34, pp. 191 y 192.

197 Op. cit., nota 40, pp. 204 y 205.

198 “Jurisprudencia de la Suprema Corte de Justicia de la NACión. No ES SusCEPTIBLE DE SOMETERSE A CONTROL DE CONSTITUCIONALIDAD Y/O CONVENCIONALIDAD 
2) Meramente vinculante (binding). El precedente debe seguirse "salvo excepciones previstas". En nuestro derecho doméstico, antes de la resolución mencionada en el inciso anterior, tal era la situación de los criterios de la Corte Interamericana y de los mexicanos que estableció la contradicción de tesis 293/2011: en principio, ambos precedentes exigían igual aplicación, pero se especificaba que en caso de oposición prevalecía el más favorable al derecho humano con que se relacionen. ${ }^{199}$

3) "Máxima" venciblemente vinculante (defeasibly binding). De estos precedentes "el juez sucesivo pued[e] apartarse, siempre que existan razones relevantes para hacerlo, que se pued[e]n determinar libremente, pero que deben ser indicadas y justificadas" (cursivas añadidas). El artículo 196, párrafo segundo, fracción III, de la anterior Ley de Amparo, disponía explícitamente que un tribunal colegiado podía apartarse del precedente vinculante de otro, pero cumpliendo con la carga argumentativa de "expresa[r] las razones por las cuales considera[se] que no debe confirmarse el criterio sostenido en la referida tesis jurisprudencial". ${ }^{200}$ Este caso es un claro ejemplo

EX OFFICIO POR ÓRGANOS JURISDICCIONALES DE MENOR JERARQUÍA", Pleno, Gaceta del Semanario Judicial de la Federación, 10a. época, lib. 13, diciembre de 2014, t. I, tesis P./J. 64/2014 (10a.), p. 8; véase también "REVISIÓN EN AMPARO DIRECTO. ES INOPERANTE EL AGRAVIO TENDENTE A CUESTIONAR EL CRITERIO CONTENIDO EN LA JURISPRUDENCIA EMITIDA POR LA SUPREMA CORTE DE JUSTICIA DE LA NACIÓN, EN EL QUE SE SUSTENTÓ LA SENTENCIA RECURRIDA EN CUANTO AL TEMA DE CONSTITUCIONALIDAD”, Segunda Sala, Semanario Judicial de la Federación, 10a. época, lib. 67, junio de 2019, t. III, tesis 2a./J. 84/2019 (10a.), p. 1978. Cfr. Camarena González, op. cit., nota 104, pp. 339 y ss. (exponiendo cuatro posibles técnicas argumentativas [distinción, circunscripción, inaplicación y desaplicación] para vencer la fuerza vinculante del precedente, incluso en franca oposición a lo resuelto en dicha contradicción de tesis); y "JURISPRUDENCIA. LOS TRIBUNALES DE AMPARO DEBEN ANALIZAR LOS PLANTEAMIENTOS DIRIGIDOS A CUESTIONAR LA VALIDEZ CONSTITUCIONAL DE UNA DOCTRINA REFLEJADA EN AQUÉLLA”, Primera Sala, Gaceta del Semanario Judicial de la Federación, 10a. época, lib. 61, diciembre de 2018, t. I, tesis 1a. CCLVII/2018 (10a.), p. 344.

199 “JURISPRUDENCIA EMITIDA POR LA CORTE INTERAMERICANA DE DERECHOS HUMANOS. ES VINCULANTE PARA LOS JUECES MEXICANOS SIEMPRE QUE SEA MÁS FAVORABLE A LA PERSONA", Pleno, idem, 10a. época, lib. 5, abril de 2014, t. I, tesis P./J. 21/2014 (10a.), p. 204.

200 "JURISPRUDENCIA DE TRIBUNALES COLEGIADOS DE CIRCUITO. SU INOBSERVANCIA POR LAS AUTORIDADES QUE TIENEN OBLIGACIÓN DE ACATARLA CONFORME AL ARTÍCULO 193 DE LA LEY DE AMPARO, NO CONDUCE NECESARIAMENTE AL OTORGAMIENTO DE LA 
del "precedente horizontal" en sentido estricto; ${ }^{201}$ y a esta misma categoría de efecto vinculante se hallaría en México el "autoprecedente", como puede inferirse del artículo 228 de la Ley de Amparo vigente. ${ }^{202}$

4) Débilmente vinculante (weakly binding). En relación con este precedente "sólo hay una expectativa genérica de que el mismo sea seguido", creyéndose "oportuno" que así sea, "pero... no se producen consecuencias de relevancia si esto no pasa[ra]". Las tesis aisladas de la Suprema Corte de Justicia de la Nación contienen "fuertes orientaciones" para los demás tribunales, los cuales deben especial respeto a sus criterios dado su carácter de máximo tribunal, por lo que prima facie hay una expectativa de que sean seguidas; ${ }^{203}$ pero como no se impone explícitamente a éstos la carga de argumentar su decisión de apartarse de dichos precedentes (lo que no significa que metodológicamente carezcan de ella), su obligatoriedad no es tan fuerte como la de los señalados en el inciso anterior. ${ }^{204}$

5) (Meramente) persuasivo. A su respecto existe plena discrecionalidad sobre su seguimiento. En este supuesto se hallan los criterios aislados de los tribunales colegiados en relación con los juzgados

PROTECCIÓN CONSTITUCIONAL SOLICITADA", Semanario Judicial de la Federación y su Gaceta, 9a. época, t. XII, octubre de 2000, tesis XIV.2o.38 K, p. 1305.

201 Supra, nota 43.

202 “JURISPRUdencia DE LA CORTE", Pleno, Semanario Judicial de la Federación, 5a. época, t. XXIII, p. 652 (hay dos tesis con los mismos datos de identificación, registradas con los números 280993 y 280995 ; refiero ambas).

203 “Tesis aisladas de la Suprema CORTE DE Justicia de la NACión. El PRiNCIPIO DE IRRETROACTIVIDAD DE LA JURISPRUDENCIA, PREVISTO EN EL ARTÍCULO 217 , ÚlTimo PÁRRAFO, DE LA LEY DE AMPARO, LES ES APLICABLE”, Gaceta del Semanario Judicial de la Federación, lib. 28, marzo de 2016, t. II, tesis XVI.1o.A.24 K (10a.), p. 1790; y artículo cuarto, fracción I, inciso D), del Acuerdo General 5/2013 del Pleno de la Suprema Corte de Justicia de la Nación. Véanse también "SENTENCIAS DE AMPARO, FUERZA OBLIGATORIA DE LAS, AUNQUE NO SIENTEN JURISPRUDENCIA", Tercera Sala, Semanario Judicial de la Federación, 5a. época, t. LXIX, p. 4087; "SENTENCIAS DE AMPARO, FUERZAS OBLIGATORIAS DE LAS, AUNQUE NO SIENTEN JURISPRUDENCIA", Tercera Sala, ibidem, p. 4088; y "PRECEDENTES DE JURISPRUDENCIA", Tercera Sala, Informe de 1942, p. 45. Cfr. "JURISPRUDENCIA...", cit., nota 139; y "JURISPRUDENCIA DE LAS SAlAS DE LA SuPREMA CORTE DE JuSTICIA DE LA NACIÓN, OBLIGATORIEDAD Y APLICACIÓN PREFERENTE DE LA", idem, 9a. época, t. XIII, mayo de 2001, tesis XXII.1o.27 K, p. 1171.

204 Supra, nota 190.

Esta obra está bajo una Licencia Creative Commons Atribución-NoComercial-SinDerivar 4.0 Internacional, IIJ-UNAM. 
de distrito del circuito judicial que les corresponde. ${ }^{205}$ Se trata de un efecto vertical simple, a diferencia del referido en el inciso anterior, que podríamos calificar de "reforzado", por la máxima jerarquía de la Suprema Corte.

Especialmente respecto de tres últimas especies de la escala anterior, podría alegarse que la vinculatoriedad del precedente es cuestión de perspectiva: si dicha obligatoriedad pudiera ser vencida por su carácter prima facie, no sería tal, y el precedente en cuestión tampoco resultaría "vinculante" en modo alguno; o sea, como sostiene el punto de vista tradicional, afirmar que la vinculatoriedad de un precedente no sea definitiva sería otra manera de decir que el criterio judicial no es imperativo. Pero esta visión no acierta en la clave del problema: establecer a qué obliga especificamente cada precedente según sea provisional o absolutamente vinculante.

El efecto vinculante que prima facie tiene un precedente "persuasivo" - por hablar de la ínfima especie de la escala anterior- no compele a su aplicación incondicionada; pero sí exige respeto y consideración, y una cuidadosa si fuera uno "débilmente vinculante". ${ }^{206}$ El precedente de calidad "persuasiva" en sentido lato no impone que sea seguido de modo absoluto; en cambio, sí obliga a ser considerado en el razonamiento jurídico - especialmente cuando se invoca explícitamente-, y a que el operador jurídico "precis[e] si se acoge al criterio referido o extern[e] las razones por las cuales se separa de él". ${ }^{207} \mathrm{Y}$ un precedente de este género exige

205 Artículo 217, párrafos segundo y tercero, de la Ley de Amparo. Cfr. supra, nota 9. Véanse "TESIS AISLADAS. LAS EMITIDAS POR LA SUPREMA CORTE DE JUSTICIA DE LA NACIÓN TIENEN CARÁCTER ORIENTADOR, NO GENERAN DERECHOS NI SON SUSCEPTIBLES DEL EJERCICIO DE IRRETROACTIVIDAD", Segunda Sala, Gaceta del Semanario Judicial de la Federación, lib. 38, enero de 2017, t. I, tesis 2a./J. 195/2016 (10a.), p. 778; “TeSIS DE LA SUPREMA CORTE QUE NO INTEGRAN JURISPRUDENCIA. ES CORRECTO APOYARSE EN LOS CRITERIOS SUSTENTAdOS EN ELLAS", Apéndice al Semanario Judicial de la Federación 1917-2011, t. II, tesis 2509, p. 2957; u "AMPARO DIRECTO EN MATERIA ADMINISTRATIVA. PROCEDE EN TÉRMINOS DEL ARTÍCULO 170, FRACCIÓN II, DE LA LEY DE LA MATERIA, NO SÓLO CUANDO SE ADUZCAN CUESTIONES DE INCONSTITUCIONALIDAD, SINO TAMBIÉN DE LEGALIDAD, CONFORME AL PRINCIPIO PRO PERSONA", Gaceta del Semanario Judicial de la Federación, 10a. época, lib. 18, mayo de 2015, tesis IV.2o.A.80 K (10a.), p. 2103.

206 Supra, nota 195.

207 “TESIS DE JURISPRUDENCIA, AISLADAS O PRECEDENTES INVOCADOS EN LA DEMANDA DE AMPARO. CORRESPONDE AL ÓRGANO JURISDICCIONAL PRONUNCIARSE SOBRE SU APLICABILIDAD AL CASO CONCRETO, AL MARGEN DE QUE EL QUEJOSO EXPRESE O NO RA- 
cumplir esta carga con una mayor intensidad de tratarse de uno sentado por un órgano judicial de máxima jerarquía, como las tesis aisladas de la Suprema Corte, y requeriría "argumentos cualitativamente superiores" para ser soslayado.

Los precedentes tradicionalmente "no vinculantes" poseen en realidad una "vinculatoriedad dialéctica", que si bien no imposibilita apartarse de su sentido, obliga a que ello no se haga arbitrariamente sino con base en "argumentos objetivos, razonables y públicamente expuestos" con diferentes grados de pormenorización. Esto, en aras de los principios constitucionales a que sirve esta figura, y muy en especial a la seguridad jurídica y su prohibición de arbitrariedad. ${ }^{208}$

De lo anterior podemos concluir que: 1) todo precedente tiene un efecto vinculante prima facie, que se despliega al menos en el sentido dialéctico apuntado imponiendo una carga argumentativa, y su obligatoriedad en términos sustantivos absolutos tiene lugar sólo de modo excepcional; 2) hay distintos grados de efecto vinculante de acuerdo con los estratos en que esté organizado el sistema judicial y otros elementos que determinada el sistema jurídico, y 3) fuera de este casos excepcional, en aras de la seguridad jurídica - en sus vertientes de predictibilidad e interdicción de la arbitrariedady de los demás valores adscritos al stare decisis, para apartarse del sentido de un precedente siempre se requiere una argumentación cualitativamente proporcional al vigor de su efecto dialécticamente vinculante.

\section{El criterio judicial "ejemplar"}

Una figura afín al precedente es el - llamémosle así, pero indebidamente por lo que luego diré- "precedente ejemplar" o simplemente "ejem-

ZONAMIENTOS QUE JUSTIFIQUEN SU APLICACIÓN", Segunda Sala, Gaceta del Semanario Judicial de la Federación, 10a. época, lib. 53, abril de 2018, t. I, tesis 2a./J. 32/2018 (10a.), p. 847. Véase también "TESIS AISLADA O DE JURISPRUDENCIA INVOCADA EN LA DEMANDA DE AMPARO. CORRESPONDE AL ÓRGANO JURISDICCIONAL PRONUNCIARSE EN TORNO A SU APLICABILIDAD O INAPLICABILIDAD AL CASO CONCRETO, INDEPENDIENTEMENTE DE QUE LA QUEJOSA ESGRIMA O NO ALGÚN RAZONAMIENTO AL RESPECTO”, Segunda Sala, Apéndice al Semanario Judicial de la Federación 1917-2011, t. II, tesis 1731, p. 1967.

208 El concepto de "vinculatoriedad dialéctica" fue acuñado por la Suprema Corte de Justicia de la Nación en relación con las iniciativas de leyes de ingresos municipales y su consideración por las legislaturas estatales. Por todos véase Pleno, controversia constitucional 15/2006, sentencia del 26 de junio de 2006, Diario Oficial de la Federación, 9 de febrero de 2007, 1a. sección, con. VI, pp. 11-14.

Esta obra está bajo una Licencia Creative Commons Atribución-NoComercial-SinDerivar 4.0 Internacional, IIJ-UNAM. 
plo". Se trata de un criterio judicial con efectos meramente ilustrativos, que en ocasiones se le confunde con el precedente persuasivo referido en el nivel ínfimo de la escala recién expuesta.

Para construir argumentos de apoyo a una decisión pueden aducirse criterios de tribunales análogos al que controla al juzgador actuante, de tribunales extranjeros o internacionales a cuya jurisdicción nuestro país no esté sometido. ${ }^{209}$ Pero la eventual aplicación de estos criterios no se da por su calidad de "precedentes" sino como "ejemplos", con el propósito de "mostrar un posible significado [con mayor o menor autoridad] de una regla jurídica, pero sin la pretensión de derivar indicaciones influyentes en la decisión del caso sucesivo". ${ }^{210}$ La diferencia entre el "precedente" y el "ejemplo" consiste en que el último carece de autoridad formal, pero a juicio del operador jurídico la tiene con carácter material.

La ratio decidendi sólo tiene calidad de "precedente" en sentido estricto, y tiene autoridad (formal) para influir sobre la decisión del caso posterior, ${ }^{211}$ porque el juez que resuelve éste se halla en alguna medida obligado a seguir su sentido para decidir el caso "correctamente", como probablemente lo haría el tribunal que lo hubiera de resolver definitivamente. Ninguno de los tipos de criterio judicial "ejemplar" mencionados en el párrafo anterior tiene normativamente esta aptitud; sin embargo, atendiendo la calidad de sus razonamientos y la autoridad material con que los reviste, cualquier tribunal podría tomarlos como "ejemplo" y asumir su criterio. Para distinguirlas conceptualmente, más que "persuasivas", las rationes de un criterio judicial ejemplar habrían de concebirse como absolutamente "optativas", ${ }^{212}$ siendo tomadas como modelo por el juzgador actuante al atribuirles una calidad superior que busca emular, es decir,

209 Para profundizar en las últimas dos especies mencionadas, especialmente en torno al problema de la autoridad material de tribunales referentes, véase Ponthoreau, MarieClaire, "La circulación judicial del «argumento de derecho comparado». Algunos problemas teóricos y técnicos a propósito del recurso a precedentes extranjeros por el juez constitucional", trad. de Rubén Sánchez Gil, Revista Iberoamericana de Derecho Procesal Constitucional, México, núm. 14, julio-diciembre de 2010, pp. 225-246.

210 Taruffo, op. cit., nota 40, pp. 197, 198 y 205. Véanse también MacCormick y Summers (eds.), op. cit., nota 5, p. 519.

211 Taruffo, op. cit., nota 40, pp. 198 y 204. Cfr. Gómora Juárez, op. cit., nota 10, pp. 112-116.

212 Ibidem, p. 113 (n. 207) (abordando el recurso comparativo a sentencias de tribunales extranjeros). 
alguna clase de autoridad en sentido material. Los ejemplos "pueden ser respetados por su razonamiento y seguidos en nombre de la uniformidad y de la consideración (comity)", no porque de alguna manera el tribunal que las invoca esté sujeto a ellos. ${ }^{213}$

Una muestra del uso de un "criterio judicial ejemplar" sería el caso de un juez civil de primera instancia que tomara como "parámetro de interpretación" 214 un criterio establecido por el Tribunal Electoral del Poder Judicial de la Federación, ${ }^{215}$ que de ninguna manera vincula su labor. ${ }^{216}$ De acuerdo con los párrafos segundo y tercero del artículo 217 de la vigente Ley de Amparo, otro ejemplo lo daría un juez de distrito que apoyara su resolución sobre la jurisprudencia de un tribunal colegiado correspondiente a un circuito al cual no pertenece, y que por lo mismo no estaría obligado a seguir. ${ }^{217}$

Ningún impedimento existe para que, en las hipótesis anteriores, el juzgador actuante haga suyas las razones de un tribunal cuyo criterio no le obliga en absoluto. En todo caso, podría criticarse la pertinencia de la aplicación de dicho razonamiento, pero de ningún modo sería reprochable la expresión de su origen. Por el contrario, ésta más bien resulta plausible, por contribuir a la transparencia y a la verificabilidad de la decisión judicial.

Una situación muy peculiar puede producirse cuando el tribunal competente para establecer un precedente desaparece o se le priva de alguna de sus atribuciones. Cuando hipotéticamente se ha planteado esta cuestión, ha habido respuestas muy diversas y extremas; pero la solución estaría ubicada en un término medio. En estas condiciones, la mejor opción parece ser

213 Garner et al., op. cit., nota 8, p. 34.

214 Véase "SUSPENSIÓN DEL ACTO IMPUGNADO EN EL JUICIO CONTENCIOSO ADMINISTRATIVO. No LE ES APLICABLE DIRECTA NI SUPLETORIAMENTE LA LEY DE AMPARO", Segunda Sala, Gaceta del Semanario Judicial de la Federación, lib. 43, junio de 2017, t. II, tesis 2a. LXIX/2017 (10a.), p. 1450.

215 Por ejemplo: "Promociones. CUANDo ES EVIDENTE QUE SU LiTERALIDAD SE OPONE A LA CLARA INTENCIÓN DEL SUSCRIPTOR, DEBE PREVALECER ÉSTA”, Sala Superior, Compilación Oficial de Jurisprudencia y Tesis Relevantes 1997-2005, tesis S3ELJ 66/2002, p. 249.

216 Véase el artículo 233 de la Ley Orgánica del Poder Judicial de la Federación.

217 “TESIS DE LOS TRIBUNALES COLEGIADOS QUE NO CONSTITUYEN JURISPRUDENCIA PUEDEN SER APLICADAS POR LOS JUECES DE DISTRITO AUN CUANDO NO PERTENEZCAN AL CIRCUITO DEL TRIBUNAL COLEGIADO QUE LAS SUSTENTÓ", Semanario Judicial de la Federación, 8a. época, t. XV-I, febrero de 1995, tesis X.1o. 34 K, p. 278. 
que los criterios del tribunal extinto carecerían de autoridad formal para imponerse, y los tribunales que antes habrían de seguirlo se encuentran libres de todo vínculo a su respecto, salvo por la necesidad de preservar la seguridad jurídica lato sensu, que los impelería a respetar, y a no soslayar abierta y arbitrariamente dichos criterios, en atención a la autoridad material que les otorgaría el conocimiento experto atribuible al tribunal que los emitió. Sin embargo, esta vinculación no sería inflexible, sino en realidad muy débil, y salvo por imponer una básica carga de argumentación no impediría alejarse del criterio correspondiente. En tal virtud, porque seguir dicho criterio no tendería a encaminar la solución del caso actual a la respuesta que con mayor o menor probabilidad le daría el tribunal que en la actualidad tendría que resolverlo en última instancia, no se estaría ante un precedente propiamente dicho, sino frente a un "ejemplo", uno excepcionalmente muy fuerte, pero al cabo un criterio judicial de seguimiento optativo. $^{218}$

\section{REFLEXIONES FINALES}

Las consideraciones anteriores ponen de manifiesto que en el juego argumentativo jurisprudencial hay más "matices y complicaciones" de los que comúnmente se piensa. ${ }^{219}$ La aplicación de los precedentes judiciales, o de la "jurisprudencia" — como se prefiera—, implica mucho más que la fidelidad irreflexiva a los criterios establecidos por los tribunales. Y la adecuada operación jurisprudencial en México debe atender las particularidades de esta fuente jurídica.

Los dos problemas que expuse —el empleo de tesis, que se traduce en la vinculación del precedente judicial con la configuración fáctica del caso en el que se estableció, y los diferentes grados de efecto vinculante que podría tener-constituyen a mi parecer los más importantes que afrontamos en México en relación con el derecho de elaboración judicial, pero de ninguna manera son los únicos. En distintos aspectos, la Ley de Amparo de

218 Caminker, op . cit., nota 44, pp. 867-869. Cfr. "JURISPRUDENCIA DE LA SUPREMA CORTE. LOS TRIBUNALES COLEGIADOS ESTÁN FACULTADOS PARA MODIFICAR LA ESTABLECIDA CON ANTERIORIDAD AL 15 DE ENERO DE 1988, CUANDO VERSE SOBRE CUESTIONES QUE SEAN DE SU COMPETENCIA EXCLUSIVA", Pleno, Apéndice al Semanario Judicial de la Federación 1917-2011, t. II, tesis 1721, p. 1955.

219 Supra, nota 8.

Esta obra está bajo una Licencia Creative Commons

Atribución-NoComercial-SinDerivar 4.0 Internacional, IIJ-UNAM. 
2013 , los nuevos acuerdos generales plenarios 16/2019 y 17/2019, y otros elementos normativos, han pretendido mejorar el sistema jurisprudencial de nuestro país, pero a su vez suscitan otras dificultades: la cuestión de la irretroactividad de la jurisprudencia ya tiene una importancia renovada, y aún está por definirse con claridad la situación de precedentes que no se hayan divulgado mediante el Semanario, pero sí por otros medios, como el Diario Oficial de la Federación, que permitirían un "grado de certeza aceptable" sobre su existencia. ${ }^{220}$ Asimismo, muchos de los aspectos aquí tratados harán surgir cuestionamientos, objeciones y otra clase de problemas, en especial sobre sus implicaciones (dogmáticas y prácticas) para el ordenamiento mexicano.

De cualquier manera, en México necesitamos repensar la jurisprudencia, partiendo de una sana duda metódica y volver a elaborar en serio nuestros conceptos sobre ella — si alguna vez lo hicimos más allá de lo estrictamente elemental-, comenzando con el mismo fundamento constitucional de esta figura en nuestro sistema jurídico, y reconocer los importantes valores jurídicos a que sirve. Es necesario que los juristas mexicanos conozcamos mejor la naturaleza del precedente judicial; no se pueden resolver correctamente las dificultades que nos plantea si continuamos ignorando el trasfondo sobre el cual tienen lugar, y las implicaciones que pueden tener las distintas soluciones que se les pretenda dar. Indudablemente, adentrarnos en los pormenores del precedente judicial va a presentar dificultades para nosotros, por tratarse de una figura no sólo ajena a nuestra tradición jurídica, sino que históricamente ésta ha menospreciado y aun rechazado.

Adentrarnos en las peculiaridades del derecho jurisprudencial va a exigirnos, primeramente, un cambio de cultura y de mentalidad sobre la labor de los jueces y de las implicaciones de sus decisiones para la construcción del ordenamiento jurídico. Asimismo, nos requerirá un gran esfuerzo y una labor más ardua, porque implica mejorar la calidad de nuestra argumentación.

Sin embargo, creo que antes de arredrarnos y renunciar a un empleo más preciso de los precedentes judiciales, estas dificultades deberían inspirarnos a conocer su naturaleza para controlar más nuestro derecho jurisprudencial, con el propósito de mejorar la calidad de la impartición de

220 Supra, nota 147. 
justicia en nuestro país, especialmente en el ámbito constitucional, cuyo contenido — por las características de sus disposiciones - en buena medida configura la interpretación de los tribunales. Este último fin me parece justificación suficiente para que en México comencemos a estudiar la jurisprudencia con seriedad y precisión técnica.

Fecha de recepción: 4 de septiembre de 2019.

Fecha de aceptación: 6 de enero de 2020.

Esta obra está bajo una Licencia Creative Commons

Atribución-NoComercial-SinDerivar 4.0 Internacional, IIJ-UNAM. 


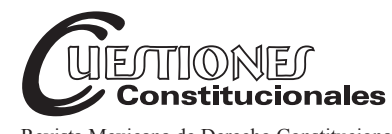

Revista Mexicana de Derecho Constitucional Núm. 43, julio-diciembre 2020

\title{
El amparo judicial y la reforma al sistema de justicia en México (1987-2018)
}

\author{
Judicial amparo and the judicial reform in Mexico
}

(1987-2018)

\begin{abstract}
Alberto Abad SuÁREZ ÁviLA*
RESUMEN: El artículo parte de una pregunta relevante para el constitucionalismo mexicano. Después del intenso periodo de tres décadas de reformas al sistema de justicia ¿cuál es la función principal que tiene el amparo judicial hoy? Para dar respuesta a esta pregunta, se plantea una metodología sociojurídica observando dos variables: 1) la modificación en gran escala al diseño institucional del sistema de justicia, y 2) la modificación al amparo judicial específicamente. La hipótesis principal del artículo es que el proceso de reformas al sistema de justicia tuvo un impacto profundo en las nuevas funciones del juicio de amparo judicial, debido a que trajo consigo una amplia miscelánea de nuevos procesos para resolver conflictos, incluso de debido proceso y otras violaciones constitucionales. La conclusión del artículo es que, desde el análisis del diseño constitucional, se aprecia que la reforma judicial ratificó la función contro-

ABSTRACT: This paper departs from a crucial question to Mexican constitutionalism. After an intense period of three decades of judicial system reform, what is today's Judicial Amparo main role? To answer the former, the author proposes a sociolegal methodology, analyzing two variables: 1) the impact big scale constitutional reform on the system of justice has over Judicial Amparo, and 2) the constitutional reform to the Judicial amparo itself. The main hypothesis of this paper is that both variables are extremely important to understand today's role of Judicial Amparo, due to the enaction of new means of protection and conflict resolution, that could have a relevant effect on due process and other constitutional violations. The paper concludes that the judicial reform ratifies the controlling of the judicial system as the main function of the Judicial Amparo, over other expectations built during the previous years.
\end{abstract}

* Investigador de tiempo completo del Instituto de Investigaciones Jurídicas de la UNAM. Miembro del Sistema Nacional de Investigadores Conacyt, México. Correo: abad@unam.mx ORCID: 0000-0002-0809-3534. El autor agradece las observaciones y recomendaciones recibidas por dos dictámenes anónimos a una versión anterior a este trabajo, así como los comentarios recibidos a esta versión final de Héctor Fix-Fierro y Dulce María Milán Rodríguez. 
ladora del sistema de justicia como la principal del amparo judicial, por encima de otras expectativas construidas en los años previos a su concreción.

Palavras chave: amparo judicial, reforma constitucional, justicia.
Keywords: judicial protection, constitutional reform, justice.

\begin{abstract}
SUMARIO: I. Análisis sociojurídico del proceso de reforma al sistema de justicia en México. De la justicia de elite a la justicia ordinaria (1987-2018). II. La reforma al amparo y sus implicaciones para el amparo judicial. III. Conclusiones. IV. Bibliografia.
\end{abstract}

La intención de este artículo es analizar la función que tiene hoy el amparo judicial en el sistema de justicia en México, tomando como referencia el proceso de rediseño institucional resultado de tres décadas de intensas reformas constitucionales. El amparo judicial es pieza central de la organización y funcionamiento de los poderes judiciales federal y locales por el sistema de doble jurisdicción que mantiene el federalismo mexicano. ${ }^{1}$ A través de esta figura, el Poder Judicial de la Federación puede resolver en última instancia cualquier caso presentado ante el sistema de justicia del país. Por lo mismo, es un tema que genera grandes tensiones entre diversos sectores jurídicos, que, en los extremos, se dividen entre quienes expresan una absoluta dependencia hacia su permanencia dentro del sistema de justicia como garantía de esta última y quienes esgrimen una aguda crítica por el poder que otorga a la jurisdicción federal a costa del derecho local.

Siendo ésta una discusión de varias décadas en el sistema jurídico mexicano, el artículo busca actualizar lo que ha pasado con ella, después del intenso proceso de reformas constitucionales, para conocer en dónde se encuentra la función principal del amparo judicial dentro del sistema de justicia al día de hoy. En un artículo escrito a principios de este siglo intitulado "El futuro del amparo judicial", Héctor Fix-Fierro pronosticaba seis caminos que podría seguir esta institución: el mantenimiento del statu quo, limitar la procedencia del amparo judicial, mejorar la eficiencia y la calidad

\footnotetext{
1 Fix-Fierro, Héctor, "El futuro del amparo judicial”, Bien Común y Gobierno, año 7, núm 81, septiembre, 2001, p. 5

Esta obra está bajo una Licencia Creative Commons

Atribución-NoComercial-SinDerivar 4.0 Internacional, IIJ-UNAM.
} 
de los tribunales ordinarios, crear supremas cortes o tribunales de casación locales, mejorar la formación y el ejercicio profesional de los abogados o cambiar radicalmente el modelo de organización judicial. ${ }^{2}$ En mi opinión, todos estos temas se mantuvieron en tensión durante los años previos a la reforma constitucional de 2011.

Para responder al objetivo del artículo, el tema se aborda desde el análisis sociojurídico del proceso de reformas constitucionales, observando: 1) cómo se modificó el sistema de justicia a lo largo de este periodo, y 2) cómo se modificó el diseño institucional del amparo judicial específicamente. La finalidad de esta metodología es conocer cómo ha interactuado la reforma constitucional en estos dos niveles para proveer un nuevo diseño institucional del sistema de justicia en general, y de esta manera concluir cuál es el espacio y funciones que se le otorgan al amparo judicial en la actualidad. La hipótesis principal de este artículo es que el cambio en el sistema de justicia tiene un impacto muy importante en el lugar que finalmente el proceso de reformas dará al amparo judicial.

El artículo establece como conclusión principal que el proceso de reforma constitucional corroboró la función controladora que tiene el amparo judicial sobre el sistema de justicia, ratificándolo como el elemento unificador del sistema de justicia de doble jurisdicción, sin resolver muchos de los problemas que lo aquejan desde hace tiempo. A pesar de que muchas expectativas estuvieron puestas en que el amparo judicial se ampliara para reconocer competencia a los tribunales locales, o para flexibilizar su acceso, parte de la conclusión de este texto es que muchas de esas expectativas ya podrían estar cubiertas en el diseño institucional, por la miscelánea de opciones de solución de conflictos jurisdiccionales y no jurisdiccionales que el proceso de reforma constitucional ha traído.

El artículo se organiza en tres partes, de la siguiente manera: en la primera, se presenta la explicación del proceso de reforma al sistema de justicia en México de 1987 a 2018, dividido en dos momentos, el de la justicia de elite (1987-2006), y el de la justicia ordinaria (2006-2018). En la segunda parte se analiza la reforma al amparo de 2011 en relación con el amparo judicial. Finalmente, se incluye un breve apartado final, en donde se presentan las conclusiones del estudio mediante la conexión entre las reformas que ha sufrido el sistema de justicia y el amparo judicial.

\footnotetext{
2 Ibidem, pp. 11-16.
} 


\section{ANÁLISIS SOCIOJURÍDICO DEL PROCESO DE REFORMA} AL SISTEMA DE JUSTICIA EN MÉXICO. DE LA JUSTICIA DE ELITE A LA JUSTICIA ORDINARIA (1987-2018)

El más reciente proceso de reformas al sistema de justicia en México inició en 1987, como parte de un movimiento internacional de transformación, que se conoce como la expansión global del Poder Judicial en el mundo, ${ }^{3}$ con un desarrollo significativo en la región latinoamericana. ${ }^{4}$ El proceso de reforma en México se ha llevado paulatinamente a lo largo de tres décadas, a diferencia de lo acontecido en otros países de América Latina, que modificaron sus instituciones de forma concentrada, mediante la provisión de nuevas Constituciones, nuevos tribunales y nuevos procesos, en periodos más cortos. Como resultado de este proceso, se ha modificado el sistema de justicia en prácticamente todos sus aspectos, desde el rediseño institucional del Poder Judicial, fiscalías y defensorías, federal y locales; el establecimiento de nuevos regímenes procesales y medios alternativos de resolución de conflictos hasta, incluso, la modificación de los principios procesales fundamentales. Lo más relevante que puede decirse del proceso de reforma en México es que ha sido muy profundo, al modificar completamente las funciones, la ubicación y la distribución de poder dentro del sistema de justicia.

3 Tate, C. Neal and Vallinder, Torbjörn (eds.) (1995), The Global Expansion of Judicial Power, New York, New York University Press.

4 Helmke, Gretchen y Rios Figueroa, Julio, Courts in Latin America, New York, Cambridge University Press, 2010. De acuerdo con Linn Hammergren, son cinco las principales características del proceso de reforma judicial en América Latina: “1) surgen después de largas décadas durante las cuales los poderes judiciales sufrieron una inusual falta de atención; 2) aunque los cambios legales constituyen un elemento central de las reformas también se incorporaron elementos novedosos como la creación de nuevas organizaciones sectoriales, inversiones en equipos y edificios, una nueva atención hacia la administración y la gestión, así como un énfasis en valores como el mayor acceso a la justicia, su independencia y eficacia; 3) las reformas han sido financiadas, y en muchos casos iniciadas por donadores de agencias internacionales y un grupo muy diverso de patrocinadores locales; 4) el proceso se ha beneficiado de un inusual nivel de contacto e intercambio entre los países participantes. Esto ha ayudado a vencer las resistencias locales al cambio y ha acelerado la adopción de nuevas tendencias a través de los países. 5) La reforma judicial se encuentra cada vez más vinculada a amplios objetivos sociales, incluyendo el crecimiento económico, la lucha contra la pobreza y la democratización". Hammergren, Linn, "Usos de la investigación empírica para el reenfoque de las reformas judiciales. Lecciones desde cinco países en América Latina”, Hoy, abril, año/vol. 39, Salamanca, Universidad de Salamanca, 2005. p. 16. 
Para analizar el proceso de reformas constitucionales al sistema de justicia, se analiza el periodo de 1987 a 2018 en dos momentos. Al primer momento le llamo la reforma a la justicia de elite (1987-2000), debido a que se concentró en la modificación de las estructuras judiciales y en la provisión de medios procesales para permitir que el Poder Judicial de la Federación pudiera convertirse en el resolutor de conflictos entre actores poderosos. Al segundo momento lo nombro la reforma a la justicia cotidiana (2000-2018), caracterizado por enfocarse en la modificación de medios procesales para resolver conflictos cotidianos. ${ }^{5}$

\section{Primera etapa (1987-2000): la justicia de elite}

El primer conjunto de reformas constitucionales al sistema de justicia (1987-2000) se orientó a la construcción de un nuevo perfil de autonomía institucional del Poder Judicial para contribuir a la transición democrática en el país, así como a proveer medios de resolución de conflictos para actores políticos relevantes. ${ }^{6} \mathrm{Si}$ hacemos una similitud con otros procesos sociales, estas fueron reformas hechas a los aspectos macro de la justicia. No sólo se modificó el Poder Judicial de la Federación, sino que, dada la naturaleza de doble jurisdicción de nuestro país, también se modificó el diseño institucional de los poderes judiciales locales para conseguir su autonomía institucional, aunque esto tuvo menor éxito. ${ }^{7}$

5 Esta propuesta de clasificación en el periodo tendrá que ser debatida a mayor profundidad con los estudiosos de la reforma judicial. Pérez-Perdomo, por ejemplo, prefiere clasificarla en a) reforma judicial, Suprema Corte y amparo, y b) justicia ordinaria, atendiendo a un criterio más bien competencial dentro de la doble jurisdicción mexicana (Pérez Perdomo, Rogelio, Gente del derecho y cultura jurídica en América Latina, México, UNAM, Instituto de Investigaciones Jurídicas, 2013). Héctor Fix-Fierro apunta hacia esta problemática al señalar que el caso de la reforma judicial "se trata de una reforma que ha perseguido objetivos diversos y un tanto erráticos en distintos momentos... ha procedido sin basarse en diagnósticos claros y completos, sin seguir un plan sistemático y sin llevar a cabo una discusión pública suficiente" (Fix-Fierro, Héctor, La reforma judicial mexica$n a$, ¿de dónde viene?, ¿hacia dónde va?, México, UNAM, Instituto de Investigaciones Jurídicas, 2002).

6 Domingo, Pilar, "Rule of Law, Citizenship and Access to Justice in Mexico", Mexican Studies/Estudios Mexicanos, vol. 15, núm. 1, Winter 1999, pp. 151-191.

7 Concha Cantú, Hugo Alejandro y Caballero Juárez, José Antonio, Diagnóstico sobre la administración de justicia en las entidades federativas: un estudio institucional sobre la justicia local en México, México, UNAM, Instituto de Investigaciones Jurídicas- 
La reforma judicial en su primera etapa consiguió importantes resultados en la construcción de mayor autonomía institucional para los poderes judiciales federal y locales, y mejores garantías jurisdiccionales para los juzgadores y otros operadores jurídicos. Ilustrativamente, Héctor FixFierro señalaba que "en México, el Poder Judicial, más que tercer poder, era considerado un poder de tercera, es decir, que no actuaba en relación de paridad con el Ejecutivo y el Legislativo, sino que ocupaba un tercer sitio en términos de autoridad institucional, prestigio social y recursos económicos". ${ }^{8} \mathrm{Al}$ cabo de pocos años de las reformas de 1987 y 1994, el Poder Judicial ocupaba ya un nuevo espacio dentro de la distribución de poderes en México.

Entre las características más relevantes del proceso se encuentran la conversión de la Suprema Corte de Justicia de la Nación en un tribunal constitucional, mediante diversas acciones, tales como la pérdida de competencia originaria sobre el amparo directo hacia los tribunales colegiados de circuito en 1987 y su rediseño institucional en 1994.

Son sumamente importantes también la creación del Consejo de la Judicatura Federal, la adopción de nuevas garantías jurisdiccionales para los integrantes del Poder Judicial, como la carrera judicial. También destaca la incorporación del Tribunal Electoral al Poder Judicial de la Federación. En el aspecto procesal sobresale la incorporación de la acción de inconstitucionalidad como nuevo medio de control de constitucionalidad y la reactivación de la controversia constitucional mediante la ampliación de la legitimación a los municipios.

El hecho de que estas reformas se hayan enfocado en el rediseño del Poder Judicial, así como en la promoción de mecanismos judiciales para resolver controversias entre actores políticos relevantes, me hace denominar a este periodo como de reforma a la justicia de elite. En el lado negativo de esta descripción debe decirse que los conflictos diarios no recibieron atención dentro de este proceso de reformas constitucionales, lo que fortalece la idea de una justicia de elite, centrada en los actores poderosos. Entre los temas que se dejaron de lado se encuentra el juicio de amparo.

National Center for State Courts, 2001. Beer, Caroline C., "Judicial Performance and the Rule of Law in the Mexican States", Latin American Politics and Society, vol. 48, Issue 3 September, 2006.

8 Fix-Fierro, Héctor, op. cit., 2003, p. 251. 
La literatura habla de una serie de razones endógenas y exógenas para explicar la racionalidad de este primer conjunto de reformas. ${ }^{9}$ Dentro de las razones exógenas destaca el mencionado proceso de reforma judicial emprendido en toda la región latinoamericana y en otras regiones del mundo como parte de un fenómeno global de promoción o expansión del Poder Judicial. ${ }^{10}$ La expansión del Poder Judicial en el mundo se da en un contexto en el cual la promoción de una economía de mercado avanza acompañada de la promoción de una agenda de democracia liberal y de un Estado de derecho. ${ }^{11}$

En cuanto a las razones endógenas, para varios autores se trató de un proceso mediante el cual el partido hegemónico estableció en el Poder Judicial un reaseguro para su actuación en un contexto de alternancia..$^{12}$ En lo que parece el conjunto de hipótesis más populares, el énfasis estuvo puesto en la construcción de la Suprema Corte de Justicia de la Nación como un tribunal constitucional capaz de resolver conflictos entre actores políticos relevantes en un contexto de gobiernos divididos, que anteriormente le correspondió resolver al presidente de la República.

Veamos este proceso a detalle. El primer evento que observamos en el proceso de reforma al sistema de justicia se inicia con la reforma constitucional del 10 de agosto de 1987, que tuvo como eje principal la construcción de un perfil de tribunal constitucional en la Suprema Corte de Justicia de la Nación, descargándola de la atención de ordinario de muchos de sus asuntos, principalmente de amparos directos o uniinstanciales, denominados de esta forma justamente porque la jurisdicción de la Suprema Corte se asumía directamente en única instancia. En esta reforma se delegó a los tribunales colegiados de circuito la jurisdicción completa respecto del amparo directo, y se dejó a la Suprema Corte de Justicia su atención exclusivamente mediante la revisión por violaciones directas a la Constitución

\footnotetext{
9 El tema de las razones endógenas y exógenas de la reforma se encuentra muy bien discutido en López Ayllón, Sergio y Fix-Fierro, Héctor, “¡Tan cerca, tan lejos! Estado de Derecho y cambio jurídico en México (1970-2000)", Boletín Mexicano de Derecho Comparado, México, año XXXIII, núm. 97, enero-abril, 2000, pp. 155-267.

10 Tate y Vallinder, op cit.

11 Trubek, David M. y Santos, Alvaro, "Introduction: The Third Moment in Law and Development Theory and the Emergence of a New Critical Practice", en Trubek, David M. y Santos, Alvaro, The New Law and Economic Development A Critical Appraisal, New York, Cambridge University Press, 2011.

12 Rios Figueroa, Julio, "Fragmentation of Power and the Emergence of an Effective Judiciary in Mexico", Latin American Politics and Society, Spring, vol. 49, num. 1, 2007.
} 
y la facultad de atracción. ${ }^{13}$ Además, se modificaron los poderes judiciales locales para garantizar su independencia conforme a la reforma a la fracción III del artículo 116 constitucional. ${ }^{14}$

La reforma constitucional de 1994 es la más trascendental del periodo, y se centró en el rediseño institucional de la Suprema Corte de Justicia de la Nación, así como en la previsión y promoción de nuevas formas de control de constitucionalidad. Entre los cambios más relevantes que introdujo se encuentra la reducción a once ministros en la integración del Pleno de la Suprema Corte. También se fusionaron las cuatro salas que funcionaron anteriormente para quedar dos: Civil-Penal y Laboral-Administrativa. Se estableció una nueva regla de quince años de duración para el encargo de ministro, se eliminó la anterior regla de duración vitalicia en el cargo, y se mejoraron los salarios y las condiciones laborales. En el tema más polémico de la reforma se creó un nuevo medio de control de constitucionalidad abstracto denominado "Acción de inconstitucionalidad", con una restringida legitimación para sujetos públicos relevantes, en términos similares a las acciones abstractas de constitucionalidad, propias de los tribunales constitucionales europeos de la posguerra. ${ }^{15}$ Además de la descarga del trabajo jurisdiccional en los tribunales inferiores, se creó el Consejo de la Judicatura Federal con el objetivo de que la Suprema Corte de Justicia de la Nación pudiera descargar su labor administrativa en esta institución. ${ }^{16}$

13 Decreto por el que ese adicionan la fracción XXIX-H al artículo 73, la fracción I-B, al artículo 104, y un párrafo final a la fracción V del artículo 107; se reforma el artículo 94, los párrafos primero y segundo del artículo 97, el artículo 101, el inciso a) de la fracción III, el primer párrafo y el inciso b) de la fracción V y las fracciones VI, VIII y XI del artículo 107; y se derogan los párrafos segundo, tercero y cuarto de la fracción I del artículo 104 y el segundo párrafo de la fracción IX del artículo 107 de la Constitución Política de los Estados Unidos Mexicanos, Diario Oficial de la Federación, 10 de agosto de 1987, pp. 3 y 4.

14 Decreto por el que se reforman los artículos 17, 46, 115 y 116 de la Constitución Política de los Estados Unidos Mexicanos para quedar en los términos que se indican, Diario Oficial de la Federaciónpp. 3 y 4.

15 Brage Camazano, Joaquín, La acción abstracta de inconstitucionalidad, México, UNAM, Instituto de Investigaciones Jurídicas, 2005.

16 Decreto mediante el cual se declaran reformados los artículos 21, 55, 73, 76, 79, $89,93,94,95,96,97,98,99,100,101,102,103,104,105,106,107,108,110,111,116$, 122 y 123 de la Constitución Política de los Estados Unidos Mexicanos. Diario Oficial de la Federación, México, 31 de diciembre de 1994, primera sección, pp. 2-10. 
La primera etapa de reformas concluyó con dos temas importantes. En 1996 se reformó la Constitución de nueva cuenta para incorporar al Tribunal Electoral al Poder Judicial de la Federación. ${ }^{17}$ En 1999 se dio una nueva reforma judicial, que tiene como centro regresar el control del Consejo de la Judicatura Federal a la Suprema Corte de Justicia de la Nación. ${ }^{18}$

Respecto del juicio de amparo en general, su poca presencia en el proceso de reforma al sistema de justicia recibió fuertes críticas. En mi opinión, la más acertada fue la que presentó el profesor Rolando Tamayo, respecto a que no hubo claridad de la función del juicio de amparo en el sistema jurídico mexicano por el poder reformador. El proceso reformador se llevó a cabo sin tener en mente la importancia del juicio de amparo en el sistema constitucional mexicano y las características propias de éste, a pesar de que existían ya muchas voces que pugnaban por una profunda reforma del juicio de amparo. ${ }^{19}$

En su lugar, se alejó a la Suprema Corte de Justicia de la Nación de la atención ordinaria del juicio de amparo y se privilegió la atención de los renovados medios de control de constitucionalidad: la acción de inconstitucionalidad y la controversia constitucional. La reforma de 1994 se enfocó en la construcción de un tribunal constitucional kelseniano, más útil para los actores políticos relevantes que para la resolución de conflictos cotidianos. ${ }^{20}$ Durante varios años, el foro jurídico impulsó una modificación constitucional a la materia de amparo como uno de los elementos esenciales para la mejora del sistema de justicia. Pese a ello, hasta 2011,

17 Decreto mediante el cual se declaran reformados diversos artículos de la Constitución Política de los Estados Unidos Mexicanos, Diario Oficial de la Federación, 22 de agosto de 1996, pp. 2-13.

18 Decreto por el que se reforman los artículos 94, 97, 100 y 107 de la Constitución Política de los Estados Unidos Mexicanos, Diario Oficial de la Federación, 11 de junio de 1999, primera sección, pp. 2-4.

19 Tamayo Salmorán, Rolando, "El poder y la judicatura (breve comentario sobre la jurisdicción de amparo y la función judicial)", Boletín Mexicano de Derecho Comparado, núm. 63, México, 1998.

20 Magaloni, Ana Laura, “¿Por qué la Suprema Corte no ha sido instrumento para los derechos fundamentales?", en Ferrer, Eduardo y Zaldívar, Arturo, La ciencia del derecho procesal constitucional. Estudios en homenaje a Héctor Fix-Zamudio en sus cincuenta años como investigador del derecho, México, UNAM, Instituton de Invstigaciones Jurídicas, 2009. 
como se publicó en un popular artículo a mediados de la primera década del siglo, el gran olvidado fue el juicio de amparo. ${ }^{21}$

El amparo judicial jugó un papel secundario en las intenciones del legislador en este periodo de reforma, ya que se relegó a la atención de los tribunales colegiados de circuito para permitir que la Suprema Corte de Justicia de la Nación se concentrara en la atención de nuevos medios de control de constitucionalidad a su disposición. La función residual que se le dejó a la SCJN en el amparo judicial mediante la facultad de atracción fue escasamente utilizada por ella misma. ${ }^{22}$

\section{Segunda etapa: reforma a la justicia ordinaria (2000-2018)23}

En la segunda etapa del proceso de la reforma judicial en México se ha perseguido conseguir un mayor impacto en la justicia ordinaria. Este segundo conjunto de reformas constitucionales se concentró en la atención de conflictos cotidianos, tanto a nivel federal como local. Entre las modificaciones constitucionales más relevantes se encuentran la reforma procesal penal y de medios alternativos de resolución de controversias, ${ }^{24}$ la reforma a las acciones colectivas, ${ }^{25}$ la reforma en materia de amparo ${ }^{26}$

\footnotetext{
21 Magaloni, Ana Laura y Zaldívar, Arturo, "El ciudadano olvidado", Nexos, México, año 28, vol. XXVIII, núm. 342, junio 2006.

22 Entre 1995 y 2002 apenas se rebasó la veintena de solicitudes de facultad de atracción discutidas. Suárez Ávila, op. cit., p. 64.

23 Karina Ansolabehere (2007) habla de las reformas de las reformas judiciales refiriéndose al conjunto de reformas que "que amplían, rectifican, continúan, complementan o retraen las que tuvieron lugar en la década del 90" en América Latina. Las clasifica como relativas a: a) independencia, b) control político, c) eficiencia, d) acceso a la justicia y e) derechos.
}

24 Decreto por el que se reforman y adicionan diversas disposiciones de la Constitución Política de los Estados Unidos Mexicanos, Diario Oficial de la Federación, primera sección, 18 de junio de 2008. Consultado en: http://dof.gob.mx/nota_detalle.php? codigo $=5046978 \&$ fech $a=18 / 06 / 2008$.

25 Decreto por el que se adiciona un párrafo tercero y se recorre el orden de los párrafos subsecuentes del artículo 17 de la Constitución Política de los Estados Unidos Mexicanos, Diario Oficial de la Federación, primera sección, 29 de julio de 2010. Consultado en http://dof.gob.mx/nota_detalle.php? codigo $=5153572 \&$ fecha $=29 / 07 / 2010$.

26 Decreto por el que se reforman, adicionan y derogan diversas disposiciones de los artículos 94, 103, 104 y 107 de la Constitución Política de los Estados Unidos Mexicanos, Diario Oficial de la Federación, primera sección, 6 de junio de 2011. Consultado en http://dof.gob.mx/nota_detalle.php?codigo $=5193266 \&$ fecha $=06 / 06 / 2011$. 
y la de derechos humanos, ${ }^{27}$ así como las iniciativas presidenciales derivadas del proceso de diálogos para la justicia cotidiana. ${ }^{28}$

La característica principal de este segundo conjunto de reformas constitucionales al sistema de justicia es, como se ha mencionado, la provisión de medios procesales para la atención de la justicia ordinaria. Lo anterior tendrá una gran influencia en los alcances de la reforma al juicio de amparo que se presentó en 2011, muchos años después de iniciado el proceso de cambio. Otra característica relevante de la segunda etapa es que muchas de estas modificaciones, previo a alcanzar el nivel constitucional, fueron emprendidas por la justicia local, en una trayectoria de periferia a centro, como la relativa a la materia penal, o a los mecanismos alternativos de solución de controversias. Son reformas de segunda generación, porque gran parte de la probabilidad de su éxito está fundado en el buen funcionamiento de los cambios y principios introducidos en la primera etapa, principalmente en los temas de diseño institucional de los poderes judiciales, como la construcción de autonomía institucional de la Suprema Corte de Justicia de la Nación y la independencia y profesionalización de los juzgadores.

A pesar de que en el inicio de la segunda etapa de modificaciones constitucionales no se dieron reformas en materia de amparo, el proceso tiene una gran deuda con esta materia, ya que fue en derredor de ella donde se detonaron las discusiones más importantes de la reforma al sistema de justicia. Por ello, considero que el punto de inflexión entre la primera y la segunda etapa se da a finales del siglo pasado, cuando la Suprema Corte de Justicia de la Nación realizó procesos de consulta a la ciudadanía para conocer las necesidades en materia de justicia.

El primero de ellos fue la Comisión de Análisis de Propuestas para la Elaboración de un Anteproyecto de Nueva Ley de Amparo, que sesionó entre 1999 y 2000, y que tuvo una importante respuesta de parte del sector académico y de abogados del país. El segundo proceso fue emprendido en 2003 mediante la Consulta Nacional sobre una Reforma Integral y Coherente del Sistema de Impartición de Justicia en el Estado Mexicano,

27 Decreto por el que se modifica la denominación del capítulo I del titulo primero y reforma diversos artículos de la Constitución Política de los Estados Unidos Mexicanos, Diario Oficial de la Federación, primera sección, 10 de junio de 2011. Consultado en: http://dof.gob.mx/nota_detalle.php?codigo $=5194486 \&$ fecha $=10 / 06 / 2011$.

28 Las conclusiones e iniciativas que se presentaron pueden consultarse en https:// www.gob.mx/justiciacotidiana. 
emprendida por la Suprema Corte de Justicia de la Nación, que produciría el Libro Blanco de la Reforma Judicial. ${ }^{29}$

En el Libro Blanco de la Reforma Judicial se encuentra un ambicioso proyecto que paso a paso busca modificar al sistema de justicia en México a través de tres ejes temáticos: reforma al amparo, fortalecimiento de los poderes locales de las entidades federativas y reforma de la justicia penal. Respecto de la reforma del amparo, la presentan como "una condición previa y necesaria, pero no suficiente, para mejorar sustantivamente la justicia del país, pues ésta es la institución que articula y da congruencia al conjunto del sistema". En el Libro Blanco se establecieron cuatro acciones concretas para lograr dichos objetivos:

1) Reformar el amparo mediante modificaciones legislativas, retomando el proyecto de nueva Ley de Amparo elaborado por la Suprema Corte, o incluso elaborando un Código Procesal Constitucional; 2) reformar al amparo a través de la jurisprudencia; 3 ) mejorar la sistematización de la jurisprudencia simplificando su consulta y mejorando la comprensión de sus alcances y efectos, y 4) adoptar medidas de gobierno judicial para la reforma del amparo (por ejemplo, a través de acuerdos generales) (Caballero, Oñate y López Ayllon, 2006, p. 392). ${ }^{30}$

En 2007, la Primera Sala de la Suprema Corte de Justicia de la Nación tomó la iniciativa de incrementar su participación en la protección de los derechos humanos, mediante la facultad de atracción en el juicio de amparo, lo que representa un momento importante en el comportamiento de la SCJN respecto de la materia. La razón de este cambio puede encontrarse en una nueva integración de la SCJN con ministros más activos, así como en el seguimiento de políticas judiciales específicas para ello desde las recomendaciones sugeridas por el Libro Blanco. ${ }^{31}$ Para entonces, las críticas a la ausencia de un trabajo importante de la SCJN en materia de protección de derechos humanos ya eran muy duras (Ibarra, 2007). ${ }^{32}$

29 Caballero Juárez, José Antonio et al., Libro Blanco de la reforma judicial en México, México, SCJN, 2006.

30 Ibidem, p. 392.

31 Suárez Ávila, Alberto Abad, La protección de los derechos fundamentales en la Novena Época de la Suprema Corte, México, Porrúa, 2015.

32 Ibarra Palafox, Francisco, "La Suprema Corte de Justicia y consolidación democrática en México", en Ferrer, Eduardo y Arturo Zaldivar, La ciencia del derecho procesal 
La primera reforma de gran calado a la justicia ordinaria se da en materia penal en 2008. Mediante esta reforma se sustituyó completamente el sistema procesal penal, en ambas jurisdicciones, transformándolo de un sistema inquisitivo a uno acusatorio, adversarial y oral. Se incluyó un apartado A al artículo 20 constitucional para establecer los principios de contradicción, concentración, inmediación y publicidad que regulan las nuevas formas procesales. Se incluyeron nuevos actores, entre ellos, los más importantes, a los jueces de control, intermedios y de audiencia oral; fiscalías; defensorías públicas y asesores jurídicos de la víctima. Se constitucionalizaron el arraigo domiciliario, la duplicidad de términos y otros medios de combate a la delincuencia organizada. ${ }^{33}$

Gran parte de la reforma procesal fue guiada para hacer más eficiente el proceso, al tiempo que también hubo una relevante intención de alinear los procesos penales en México con los paradigmas internacionales de protección de los derechos humanos. Esto último resulta especialmente importante en la relación que guarda con el amparo judicial, debido a que la reforma atiende muchos de los problemas de violación a los derechos procesales establecidos en la Constitución a través de figuras de atención más temprana, como los jueces de control para garantizar la legalidad de las detenciones, investigaciones y actuaciones tempranas del proceso penal o los defensores públicos como garantía de la prevalencia del principio

constitucional. Estudios en homenaje a Héctor Fix-Zamudio en sus cincuenta años como investigador del derecho, t. II, México, UNAM, Instituto de Investigaciones Jurídicas, 2009.

33 Cierto es que previamente se presentaron otras reformas en materia penal, que tuvieron cierta relevancia, pero ninguna como la de 2008. Cabe destacar algunas de ellas, como la reforma de 1993, que modificó los artículos 16, 19, 20 y 119 constitucionales, y que tuvo como orientación una estructura del sistema finalista (2000-2017). La parte más controvertida de la reforma fue la inclusión del concepto elementos del tipo en lugar del tradicional cuerpo del delito. En 1994 se suprimió el monopolio del ejercicio de la acción penal. En 1996 se constitucionalizó el combate a la delincuencia organizada. En 1999 se reformaron los artículos 16, 19, 22 y 123 para retomar el concepto de cuerpo del delito y la probable responsabilidad del indiciado. En 2000 se reformó la Constitución para establecer las garantías de la víctíma u ofendido del delito, y en 2005 se reconoció formalmente la jurisdicción de la Corte Penal Internacional y la supresión de la pena de muerte. Véase Suarez Ávila, Alberto Abad, "La reforma constitucional en materia penal en México 1993-2008. Una explicación desde la sociología jurídica”, en Luis René Guerrero Galván y Carlos María Pelayo Moller (coords.), 100 años de la Constitución mexicana: de las garantías individuales a los derechos humanos, México, UNAM, Instituto de Investigaciones Jurídicas, 2016. 
de contradicción. Previo a la reforma de 2008, las violaciones al debido proceso eran revisables en el sistema de justicia mexicano sólo hasta el amparo, cuestión que retrasaba la solución final de los conflictos por causas del diseño institucional.

Otro de los temas importantes que contiene la reforma de 2008 es la constitucionalización de los mecanismos alternativos de solución de controversias como forma de solución de conflictos que se persiguen por la vía penal, principalmente para conductas que pudieran ubicarse dentro de los delitos patrimoniales. Los mecanismos alternativos permiten que el sistema de justicia tenga un escape temprano, previo a la formalización de los procesos jurisdiccionales. Con esto, las personas pueden acudir a las instituciones de justicia para resolver sus conflictos sin tener la necesidad de formalizar un proceso de litigio. Los mecanismos alternativos permiten también alterar la visión decimonónica de la justicia, a través de la cual los conflictos deberán resolverse mediante tribunales y leyes previamente establecidos, para permitir formas de composición más amigables y menos formales.

E1 29 de julio de 2010 se reformó el párrafo tercero del artículo 17 constitucional, para incluir las acciones colectivas como competencia de los jueces federales. La idea de la reforma es proveer un medio jurisdiccional para que se puedan proteger y restituir derechos de una colectividad mediante un solo proceso. Las acciones colectivas tradicionalmente se dirigen a ámbitos tales como la protección de los derechos del consumidor de bienes o servicios públicos o privados, servicios financieros y cuestiones medioambientales, pero no se limitan a ellos, sino que pueden extenderse a todo campo en donde pueda protegerse el interés de una colectividad. ${ }^{34}$ El centro de las acciones colectivas se encuentra en la capacidad de tutelar derechos que se ejercen de forma colectiva dentro de un solo proceso, lo que permite mayor claridad tanto en el ámbito material como subjetivo de la acción procesal.

La reforma más importante que ha tenido nuestra Constitución en sus más de cien años de vigencia sin duda es la del 10 de junio de 2011, conocida como la reforma en derechos humanos. Mediante ella no es exagerado señalar que se cambió la esencia del derecho constitucional mexicano. La Constitución reconoce a partir de entonces los derechos humanos de

\footnotetext{
34 Guidi, Antonio, Tutela de derechos difusos colectivos. Hacia un código modelo para Iberoamerica, México, Porrúa, 2004.
} 
fuente nacional e internacional, en lo que se llama el "parámetro de control de la regularidad constitucional", así como nuevos principios interpretativos tales como el principio pro persona y la interpretación conforme. Muy importante también, es que establece una obligación para todas las autoridades del país en la promoción, respeto protección y garantía de los derechos humanos.

Esta obligación en el ámbito jurisprudencial ha sido interpretada por la Suprema Corte como un deber ex officio de aplicar un control de constitucionalidad difuso para todos los juzgadores del país. ${ }^{35}$ Esto quiere decir que se cambia el paradigma anterior, mediante el cual el control de constitucionalidad correspondía en exclusiva a los tribunales federales del país, para obligar ahora a todos y cada uno de los órganos jurisdiccionales a ejercer un control de constitucionalidad ex officio en su labor.

Las implicaciones que tiene esta reforma para el control de la constitucionalidad en México son muy profundas, y vale la pena detenerse un momento en ellas. Tradicionalmente los jueces ordinarios estaban limitados en sus fuentes a la ley y la jurisprudencia, por lo que tenían que renunciar a realizar interpretación de la Constitución en su labor, dejando ésta a los tribunales federales. Esto provocaba que aun cuando el juez ordinario advirtiera la violación a un derecho o una evidente inconstitucionalidad, estaba impedido para decidir con base en ella, porque el ámbito de las fuentes jurídicas a su disposición no incluía la interpretación constitucional. La Constitución mandataba que únicamente correspondía a los tribunales federales dicha acción. De esta forma, un problema de naturaleza constitucional violatorio de derechos humanos podría posponerse para ser abordado por la vía del amparo judicial sólo después de la resolución que pusiera fin en definitiva al juicio.

Con la reforma constitucional al párrafo tercero, es fácil apreciar que el control de constitucionalidad difuso les da un espacio nuevo de acción para corregir problemas de violación de derechos humanos que puedan ad-

35 Expediente Varios 912/2010. Inicialmente el control de constitucionalidad difuso ex officio fue entendido por la Suprema Corte de Justicia de la Nación como la obligación de inaplicar una ley inconstitucional por todos los juzgadores del país. Posteriormente, el máximo tribunal ha trabajado sus criterios en casos posteriores, como la Contradicción de tesis 293/2011 y 22/2011, en donde ha continuado el análisis de las implicaciones de esta labor para llegar a la conclusión de que los juzgadores deben conocer el parámetro de regularidad constitucional en que se sitúa un caso. Véase Contradicción de tesis 293/2011 y Contradicción de tesis 20/2011. 
vertirse desde momentos muy tempranos del proceso, sin necesidad de la eventual intervención del amparo judicial. Al estar señalado el control de constitucionalidad difuso ex officio como una obligación, debemos considerar que es en este nivel en donde se encuentra la primera oportunidad de corregir violaciones a los derechos humanos, pero además, es ésta la más importante. Así, el amparo judicial deja de ser la única vía para el control de violaciones a los derechos humanos en el proceso judicial para ceder al juez ordinario la facultad de advertir violaciones por sí mismo.

El más reciente episodio del proceso de reforma judicial se produjo entre los años 2015 y 2017 mediante los denominados "Diálogos por la Justicia Cotidiana", una consulta y discusión pública a iniciativa tripartita del gobierno federal, el Centro de Investigación y Docencia Económicas y el Instituto de Investigaciones Jurídicas de la UNAM, mediante la cual se realizaron foros con la ciudadanía y mesas de análisis de los resultados con especialistas. ${ }^{36}$

Entre las nueve mesas temáticas que se formaron, la relativa a "Amparo y Resolución del Fondo del Conflicto" concluyó sus trabajos señalando que los problemas más relevantes del juicio de amparo en la actualidad pueden dividirse en cuatro categorías: "1) el uso excesivo del juicio de amparo para resolver temas que no son propiamente de justicia constitucional; 2) limites formales en el acceso al juicio de amparo; 3) deficiencias formales en el proceso, y 4) deficiencias en el uso e interpretación de los nuevos principios por parte del Poder Judicial". ${ }^{37}$

Estas mesas de trabajo trajeron modificaciones importantes en dos rubros. El primero es en la reforma a la justicia laboral, para transitar de un paradigma procesal fundado en la conciliación y el arbitraje o la jurisdicción plena en la materia. Esta reforma es sumamente importante, debido a que los casos de amparo judicial en materia laboral inundan el trabajo de los tribunales colegiados de circuito año con año. El segundo, y que ha sido poco advertido por la academia en general, es el principio de resolu-

\footnotetext{
36 De acuerdo con los Diálogos por la Justicia Cotidiana, la justicia cotidiana "es la justicia mas cercana a las personas. La que vivimos día a día en nuestras interacciones ordinarias, la que facilita la convivencia armónica y la paz social. Es la que reclaman vecinos, trabajadores, padres de familia y la que se vive en las escuelas". Presentación del documento "Diálogos por la Justicia Cotidiana", consultado en www.gob.mx/justiciacotidiana.
}

37 Diálogos por la Justicia Cotidiana. Diagnósticos conjuntos y soluciones, Presidencia de la República-CIDE-UNAM, Instituto de Investigaciones Jurídicas, 2016. 
ción de fondo del conflicto que se incluyó en el artículo 17 de la Constitución, y que obliga a las autoridades a privilegiar la solución del conflicto sobre formalismos procedimentales. ${ }^{38}$

\section{LA REFORMA AL AMPARO Y SUS IMPLICACIONES PARA EL AMPARO JUDICIAL}

El seis de junio de 2011 se dio una reforma constitucional sustantiva en la materia, en donde además se ordenó la emisión de una nueva Ley de Amparo, publicada en 2013. ${ }^{39}$ La modificación en materia de amparo arribó tarde al proceso de reforma judicial en México, lo que ha contribuido a reducir las expectativas de su impacto dentro del sistema de justicia que se tuvieron desde finales del siglo XX. ${ }^{40}$

Los cambios principales que se introdujeron mediante la reforma constitucional refieren a la ampliación de su competencia para incluir los derechos humanos contenidos en tratados internacionales, incorporar el interés legítimo y la defensa de derechos colectivos, la posibilidad de emitir declaratoria general de inconstitucionalidad para que la Suprema Corte de Justicia de la Nación pueda expulsar normas del sistema jurídico, el amparo contra particulares que efectúen actos competencia de la autoridad, el amparo adhesivo y diversas reformas procesales orientadas a reducir la dilatación de los juicios ordinarios mediante el amparo para efectos, entre los más relevantes. ${ }^{41}$

Es importante señalar como primer tema, que no todos los contenidos de la reforma de amparo tocan al amparo judicial. Esto puede ser difícil

\footnotetext{
38 Siempre que no se afecte la igualdad entre las partes, el debido proceso u otros derechos en los juicios o procedimientos seguidos en forma de juicio, las autoridades deberán privilegiar la solución del conflicto sobre los formalismos procedimentales. Decreto publicado en el Diario Oficial de la Federación el 15 de septiembre de 2017.

39 Decreto por el que se reforman, adicionan y derogan diversas disposiciones de los artículos 94, 103, 104 y 107 de la Constitución Política de los Estados Unidos Mexicanos, Diario Oficial de la Federación, México, 6 de junio de 2011, primera sección, pp. 2-6.

40 En el texto Hacia una Nueva Ley de Amparo (Zaldívar, Arturo, México, Porrúa, 2010 , tercera edición) se narran las diez principales propuestas del proyecto de nueva ley de amparo resultado de los seminarios llevados a cabo en 2000 en el Instituto de Investigaciones Jurídicas de la UNAM.

41 Para consultar al detalle la reforma puede consultarse el siguiente vínculo http:// dof.gob.mx/nota_detalle.php? codigo $=5193266 \&$ fecha $=06 / 06 / 2011$.
} 
de comprender, ya que al amparo mexicano hay que entenderlo como una federación de medios de control que incluye diversos procesos con sus propias reglas, orientados a diversos ámbitos de protección regulados por la misma ley. ${ }^{42}$

Con la reforma de 2011, el amparo dejó de ser el gran olvidado del proceso de reforma al sistema de justicia en México. Los cambios que introduce podemos agruparlos en cinco grandes rubros: 1) la ampliación de la competencia material; 2) la ampliación de la puerta de entrada; 3) la ampliación de la resonancia jurisprudencial; 4) nuevos criterios de selectividad, y 5) control del amparo dilatorio o temerario. ${ }^{43}$

El primer tema es la ampliación de competencia material del juicio de amparo. Dicha ampliación se da mediante el cambio al artículo 103 constitucional, en donde se sustituyó el término "garantías individuales" por el de "derechos humanos", en consonancia con la nueva redacción del artículo primero constitucional. De esta forma, el ámbito de protección del amparo se extiende de un universo limitado respecto de las garantías individuales que otorgaba la Constitución, al ámbito mucho más vasto de los derechos humanos reconocidos por la Constitución, a lo que la doctrina llama el "bloque de constitucionalidad", y que hoy la Suprema Corte interpreta como el parámetro del control de la regularidad constitucional.

La ampliación de la puerta de entrada tiene que ver con la manera en que el Poder Judicial de la Federación admite a trámite los amparos. Históricamente, uno de los temas más controvertidos del juicio de amparo fue el limitado reconocimiento de legitimación a los individuos debido a la obligación de promoverse a través del interés jurídico, identificado como derecho subjetivo. ${ }^{44}$ A partir de la reforma constitucional, se introdujo la posibilidad de que el amparo se promueva no solamente por el titular de un derecho subjetivo, sino por quien sostenga tener “...un interés legítimo individual o colectivo, siempre que alegue que el acto reclamado viola los derechos reconocidos por esta Constitución y con ello se afecte su esfera

\footnotetext{
42 Fix-Zamudio, Héctor, Estudio de la defensa de la Constitución en el ordenamiento mexicano, México, Porrúa, 2011).

43 Existen otras clasificaciones importantes. Por ejemplo, Ferrer y Sánchez Gil mencionan a los siguientes como los cambios más relevantes que introduce la reforma: 1) tratados internacionales; 2) declaratoria general de inconstitucionalidad; 3) suspensión ponderativa; 4) amparo directo adhesivo, 5) plenos de circuito. Ferrer y Sánchez Gil, 2013.
}

\footnotetext{
44 Zaldívar, op. cit.
} 
jurídica, ya sea de manera directa o en virtud de su especial situación frente al orden jurídico".

La nueva redacción permite una puerta de entrada más amplia, dado que incluye no solamente la noción de un derecho subjetivo personal y directo, sino que se ensancha para hacerse colectivo, e incluye supuestos en donde el quejoso no sea necesariamente titular de un derecho subjetivo, sino de un derecho de naturaleza difusa. Pese a lo anterior, es importante observar que para el caso del amparo judicial dicha regla no tiene aplicación, y se mantiene el criterio procedimental del interés jurídico para los amparos contra sentencias que ponen fin a un juicio provenientes de tribunales judiciales, administrativos o de trabajo.

El caso de la ampliación de la resonancia jurisprudencial del trabajo del Poder Judicial de la Federación es otro punto destacado de la reforma. La fórmula Otero establece que los efectos de la sentencia en un juicio de amparo se limitan a las partes del litigio, es decir, que la inconstitucionalidad de un acto de autoridad o una norma decretada por un juez o tribunal federal solamente tiene efectos para quienes participen en el juicio. La reforma constitucional mantiene esta fórmula, pero ofrece una válvula de escape para que los efectos que producen las sentencias puedan tener mayor resonancia, a través de un novedoso proceso de creación de jurisprudencia de efectos erga omnes, denominado "declaratoria general de inconstitucionalidad" para el caso del amparo contra leyes.

En el caso del amparo judicial, no existe la posibilidad de acceder a la declaratoria general de inconstitucionalidad. La reforma, sin embargo, incluye la posibilidad de que las resoluciones tengan mayor resonancia y no se limiten a las partes del juicio mediante la figura del amparo adhesivo. Esta figura permite que otros sujetos con interés jurídico similar a los de las partes que intervinieron en el juicio puedan beneficiarse de una sentencia mediante la adhesión al amparo principal, siguiendo la misma suerte procesal que este.

La reforma de amparo de 2011 introdujo nuevos criterios de selectividad para la resolución de contradicción de tesis, al crear a los plenos de circuito como organismos intermedios entre los tribunales colegiados de circuito y la Suprema Corte de Justicia de la Nación. Conforme a la fracción XIII del artículo 107, cuando los tribunales colegiados de un mismo circuito sustenten tesis contradictorias, se puede promover denuncia de la contradicción ante el tribunal correspondiente. Si bien esta nueva facultad va más orientada a la organización de jurisprudencia formal dentro del Poder 
Judicial de la Federación, tiene un impacto positivo indirecto en el amparo judicial, debido a que los criterios formales que toman los tribunales colegiados de circuito en casos reiterados pueden someterse al control de un órgano intermedio antes de llegar a la Suprema Corte de Justicia, que son obligatorios para todos los juzgadores del país, y en muchos casos muy necesarios para orientar su labor.

Respecto a los límites al amparo dilatorio o temerario, la reforma busca desincentivar una práctica común entre los abogados de retrasar el fin de los juicios y la resolución definitiva de la sentencia mediante la interposición de amparos, muchas veces temerarios y sin fundamento, que provocan litigios interminables. Las medidas tomadas al respecto dentro del amparo judicial son varias, entre ellas limitar la suspensión en materias civil, mercantil y administrativa para obligar a garantizar por el quejoso los daños y perjuicios que pudiera ocasionar al tercero interesado o, en su caso, pedir al tercero interesado una contragarantía para asegurar la reposición de las cosas al estado que guardaban si se concediera el amparo.

En cuanto a violaciones acontecidas durante el procedimiento que se quieran hacer valer en amparo directo, se convierte en criterio de procedencia que las mismas hayan sido impugnadas durante la tramitación del juicio mediante el recurso o medio de defensa que señala la ley respectiva, con excepción de algunas personas vulnerables, como menores, incapaces $\mathrm{y}$ algunos otras.

Las reformas al juicio de amparo levantaron expectativas moderadas de una mejor justicia en México mediante una mayor protección de los derechos humanos de la población. Los cinco ejes principales en los que he explicado la reforma al juicio de amparo en relación con el amparo judicial contienen argumentos favorables para pronosticar un impacto positivo en el uso del amparo por las razones expuestas. Pese a lo anterior, también es importante tener presentes los límites que tiene la reforma, pues muestran que es aún incompleta, y que varios de los temas de mayor tensión permanecen presentes.

Algunos de los autores que han analizado el proceso de reforma muestran su descontento con partes del resultado. Pou Giménez señala que entre los problemas de la nueva Ley de Amparo están: que mantiene muchas limitaciones técnicas, como los plazos de interposición, la obligación de identificar a todas las autoridades potencialmente responsables, el incremento de las causales de improcedencia, la regulación de la suspensión 
(farragosa e incomprensible), la ausencia de medidas cautelares diferentes, los procesos tradicionales de ejecución y la ausencia de un lenguaje ciudadano. ${ }^{45}$

Algunas demandas añejas quedaron fuera de la reforma de amparo, por lo cual no puede considerarse el proceso completo, y subsiste una conspicua agenda pendiente. Entre los temas más relevantes que no se modificaron destaca la permanencia de la concentración del juicio de amparo judicial como materia exclusiva de los tribunales federales, a pesar de que varias voces, entre ellas el Libro Blanco de la Reforma judicial, establecieron como una de sus prioridades la expansión de la competencia del amparo hacia los tribunales locales. Tampoco se dio una reforma procesal sustantiva que permitiera quitarle al amparo su carácter técnico especializado y hacerlo más accesible a la población. ${ }^{46}$

El poder reformador mexicano ha sido tímido en darle al amparo una identidad más ciudadana en la protección de sus derechos humanos, cuando en otros países de América Latina la reforma judicial ha traído, fortalecido o innovado medios accesibles de protección. Pero, por otro lado, le asigna una importancia alta, debido a que el juicio de amparo judicial continúa siendo la bisagra cardinal entre los sistemas jurisdiccionales federal y locales. Frecuentemente se encuentra en una tensión entre servir como un medio de protección de derechos humanos para el ciudadano y un medio especializado de control de la constitucionalidad de todo el sistema de justicia.

A pesar de los llamados a que el juicio de amparo se simplifique, hasta el momento el legislador no ha tomado esa dirección en el amparo en general, y tampoco en el amparo judicial. La ausencia de medios idóneos de los derechos que por mucho tiempo sufrió el sistema de justicia mexicano, junto con la tendencia a pensar al amparo como un remedio para todos los

45 Pou Giménez, Francisca, "El nuevo amparo mexicano y la protección de los derechos: ¿ni tan nuevo ni tan protector?”, Anuario de Derechos Humanos, núm. 10, Santiago, 2014, pp. 91-103.

46 Fabián Aguinaco sostiene que "independientemente de lo persuasiva que pudo ser la exposición de motivos relativo a que con la nueva Ley de Amparo se propone «eliminar tecnicismos y formalismos que dificultan el acceso al juicio de amparo», esta aseveración tiene poca fuerza". Aguinaco Bravo, Fabián María, "El juicio de amparo en el Centenario de la Constitución mexicana de 1917. Pasado presente y futuro", en Ferrer Mac-Gregor y Herrera García, Alfonso, El jucio de amparo en el centenario de la Constitución mexicana de 1917. Pasado, presente y futuro, t. I, México, UNAM, Instituto de Investigaciones Jurídicas, 2017. 
males, fortaleció la tesis de que el amparo debería tener un impacto directo en la justicia ordinaria, sobre todo por la gran desconfianza que existe respecto de la capacidad, probidad y eficiencia de las autoridades locales de seguridad y justicia. Para muchos, ha sido una decepción que el amparo no se modificara para ser más accesible a la población, mediante diversas estrategias; por ejemplo, ampliar la competencia a los tribunales locales. Por lo tanto, permanece como una tensión importante saber si el amparo mexicano finalmente consigue configurarse como el recurso judicial efectivo del cual hablan la Declaración Universal de los Derechos Humanos y la Convención Americana de los Derechos Humanos en sus artículos 8 y 25 para la protección de los derechos humanos.

Pese a lo anterior, no debe minimizarse su importancia como controlador del sistema de justicia. En el proceso de modificaciones constitucionales se ha buscado la concurrencia de nuevos procesos de atención de conflictos, tanto jurisdiccionales como no jurisdiccionales, para brindar una diversidad de posibilidades de solución de problemas, más sencillas, eficientes y baratas, en donde el amparo judicial no es ni la primera ni la más deseable forma de resolución. La inclusión de novedosos medios dentro del sistema de justicia ha provocado que incluso varios de los principios procesales con que se han construido estos medios choquen con la estructura de control de constitucionalidad concebida originalmente para el amparo judicial.

En el caso de la reforma procesal penal, existe uno de los ejemplos más claros de las incompatibilidades procesales entre las formas propias de contención de la constitucionalidad en el amparo, frente sus propias formas de contención de la constitucionalidad. ${ }^{47} \mathrm{El}$ caso se presenta más que evidente para el amparo judicial en la aparición del juez de control como un verdadero juez garante de la constitucionalidad del proceso penal. Aún así, la misma Constitución ha resuelto estos problemas señalando la obligación que tienen los quejosos de acudir primero a los medios de solución de esas violaciones que ofrecen los propios procedimientos ordinarios, en lugar de reservarlos al juez constitucional.

Los ejemplos de medios previstos para resolver las fallas en el sistema de justicia se multiplican en los procesos ordinarios. Una situación similar acontece con la reforma en materia de acciones colectivas, que si bien re-

\footnotetext{
47 Ferrer, Eduardo y Sanchez Gil, Rubén, El nuevo juicio de amparo y el proceso penal acusatorio, México, UNAM, Instituto de Investigaciones Jurídicas-IFP, 2013.
} 
sultan en un proceso resuelto también por los tribunales federales, brinda otras posibilidades de acceso a la justicia, sobre todo porque los conflictos no se enderezan en contra de autoridades, sino en contra de sujetos particulares sin necesidad de convertir el tema en una violación de derechos humanos.

El caso más relevante se encuentra con el control de convencionalidad difuso ex officio, el más reciente medio de control de constitucionalidad reconocido por el sistema mexicano, que permite que los temas de constitucionalidad se resuelvan desde un momento procesal más temprano, sin necesidad de establecerse como un procedimiento en sí mismo, sino como una herramienta interpretativa de los juzgadores para poder brindar justicia desde las instancias iniciales mediante la aplicación de un parámetro de regularidad constitucional a los casos concretos.

Del mismo modo, debemos tener en cuenta los mecanismos alternativos para la resolución de controversias, que privilegian formas de composición, como la negociación y la construcción de acuerdos por encima de la judicialización de los conflictos, en una concepción distinta de las formas tradicionales de obtener justicia. $\mathrm{O}$ de la obligación, para todas las autoridades, de aplicar el principio de la resolución del fondo del conflicto desde el primer momento de atención del conflicto.

Aunque entre una buena parte del sector de abogados existe la noción de que el juicio de amparo judicial es el único y verdadero medio de acceso a la justicia disponible para el ciudadano, el sofisticado sistema de justicia mexicano actual lo considera más bien el último recurso, posterior a todos los nuevos medios capaces de resolver violaciones al debido proceso y a otros derechos humanos en la resolución de conflictos.

En el diseño institucional actual, como no existía en el pasado, contamos con un complejo sistema de instituciones para resolver los conflictos cotidianos, por lo cual al amparo se le deben otorgan funciones específicas que lo regresen a una verdadera función de control del sistema de justicia y aleja la necesidad de convertirse en sustituto. Esto permite revalorar el nivel de excepcionalidad del amparo dentro de la justicia mexicana para fortalecer a los medios de nueva creación, que tienen la posibilidad de un impacto positivo desde etapas iniciales del conflicto, de forma más económica y eficiente y así reducir nuestra "amparo-dependencia". 


\section{CONCLUSIONES}

Es cierto que la reforma al juicio de amparo de 2011 llegó tarde, por lo menos diez años después de que sus bases estaban bien cimentadas en la discusión académica y comparada. Ese plazo fue suficiente para hacer que el amparo perdiera centralidad en el diseño institucional del sistema de justicia. Su reforma no tuvo la centralidad que se pensó tendría por mucho tiempo; por ejemplo, la reforma de derechos humanos tomada unos días después cimbró con mayor fuerza al sistema de justicia mexicano. La reforma más importante que sufrió el amparo aparece en los cambios que se realizaron al sistema de justicia mexicano, más que a la modificación de su diseño institucional. La forma adecuada de ver al amparo judicial hoy es como un procedimiento que tiene como función principal organizar la miscelánea de opciones procesales con las que se cuenta en el sistema de justicia desde su lugar especial como medio de control de constitucionalidad formal.

Entender esta función controladora es difícil cuando regionalmente en América Latina se puso énfasis desde hace tiempo en la necesidad de contar con un recurso judicial efectivo como garantía del derecho humano a la justicia. Varios países de la región construyeron un modelo de juicios de tutela y amparo más flexibles que sus figuras procesales previas, así como cortes y tribunales en donde este recurso se facilita en su atención, procedimiento y acceso. ${ }^{48}$

El hecho de que el juicio de amparo sea de jurisdicción concentrada en los tribunales federales es la causa más importante de la situación descrita en el párrafo anterior, y realmente se ve complicado que esto pueda alcanzarse sin eventualmente eliminar la doble jurisdicción del sistema federal mexicano. Con los límites técnicos y el alto nivel de especialización del amparo judicial difícilmente será ese recurso judicial efectivo que exige el derecho internacional.

A pesar de esta situación, el amparo judicial sí puede ayudar a controlar la constitucionalidad de los diversos medios propuestos para la resolución de los conflictos, proveyendo los criterios e interpretaciones orientadores de la función sustantiva de resolución de conflictos cotidianos, tanto por autoridades jurisdiccionales como no jurisdiccionales. Desde esa pers-

\footnotetext{
48 Uprimny, Rodrigo et al., ¿Justicia para todos? Sistema judicial, derechos sociales y democracia en Colombia, Bogotá, Norma, 2006. 
pectiva, el impacto positivo que pueda tener el juicio de amparo para la justicia ordinaria es que efectivamente ayude a controlar el funcionamiento de las demás instituciones del sistema judicial ideadas para la resolución de los conflictos cotidianos de una forma más sencilla y eficiente conforme a los estándares de protección constitucional de derechos humanos.

Además, en el nuevo diseño institucional de la justicia mexicana es necesario dejar de pensar al amparo judicial como sustituto de las instituciones de justicia en México, sino más bien como controlador e impulsor de la vigencia de las nuevas figuras que ha traído el largo proceso de reformas: desde los mecanismos alternativos no jurisdiccionales, hasta los nuevos procesos orales en materias civil, mercantil, penal o laboral. Serían muy malas noticias si ante la nueva miscelánea de opciones de solución de conflictos el amparo judicial necesitara asumir funciones sustitutivas, ante la deficiencia en el funcionamiento de los nuevos procedimientos. Es necesario que el Poder Judicial de la Federación deje crecer al sistema de justicia orientando su crecimiento, pero ya no sustituyéndolo.

Para ello, es necesario que se fortalezca el control difuso de la constitucionalidad que tienen las instituciones de justicia desde 2011, como la clave para construir un sistema de justicia que dependa en menor medida del amparo judicial. El control de constitucionalidad difuso ex officio lo que permite es que los jueces ordinarios aprendan a orientar su labor bajo criterios de constitucionalidad; si cuentan con la ayuda del Poder Judicial de la Federación para esto será muy útil.

Apelando al artículo de Héctor Fix-Fierro al inicio de texto, en donde visualizaba las distintas opciones que podía seguir el amparo judicial en México, es posible advertir que en gran medida se mantuvo el statu quo. De las demás opciones, la impresión que deja la reforma de amparo en el tema es que también de cierta manera hubo un límite a la procedencia del amparo judicial para alejarlo del uso temerario y acercarlo a un uso más institucional. Las opciones de grandes cambios institucionales, como la creación de supremas cortes a nivel local o de una reforma radical, quedaron desechadas. Lamentablemente, no se ha visto una mejora sustancial en la eficiencia y calidad de los tribunales ordinarios (esto, claro, a falta de datos empíricos expresos) ni una mejora sustancial en la formación y el ejercicio profesional de los abogados, que fueron los otros derroteros que el autor sugirió.

Para el futuro, hay opciones de que la reforma se profundice y que finalmente se pudiera tener un recurso judicial efectivo a nivel local parecido al 
amparo judicial. En las mesas de Diálogos de Justicia Cotidiana, el último gran debate nacional sobre el sistema de justicia, una de las conclusiones que quedó fue "fortalecer a los poderes judiciales de las entidades federativas y analizar la viabilidad de crear un recurso local similar al amparo casación que desincentive el abuso del amparo directo para la resolución de juicios de jurisdicción local". ${ }^{49}$

Así pues, no sobra recalcar que el contexto de la reforma en materia de amparo se acompaña de otras reformas (derechos humanos, mecanismos alternativos de solución de controversias, oralidad, tribunales laborales, etcétera) que se dirigen a fortalecer el sistema de justicia ordinaria, a través de los mecanismos institucionales expresamente diseñados para ello. Siendo así, la función actual del amparo judicial se reafirma como controladora del sistema de justicia, es decir, del amparo como forma de custodiar el buen desarrollo del sistema de justicia. En esta perspectiva, es importante observar sobre todo la relación que tiene el amparo con el control de los nuevos mecanismos con que cuenta el sistema de justicia, jurisdiccionales o no jurisdiccionales, traídos por la vasta y, hasta el momento, inconclusa agenda de reforma constitucional.

\section{BIBLIOGRAFÍA}

Aguinaco Bravo, Fabián María, "El juicio de amparo en el centenario de la Constitución mexicana de 1917. Pasado presente y futuro", en FERRER Mac-Gregor y HERRERA GARCÍA, Alfonso, El jucio de amparo en el centenario de la Constitución mexicana de 1917. Pasado, presente y futuro, t. I, México, UNAM, Instituto de Investigaciones Jurídicas, 2017. AnsolabeHERE, Karina, La política desde la justicia. Cortes supremas, gobierno y democracia en Argentina y México, México, Fontamara, 2007.

ANSOlABeHERE, Karina, Cambios en la política y cambios en la justicia: giro a la izquierda y Poder Judicial en América Latina, México, Fundación Friedrich Ebert en México, 2007.

BeER, Caroline C., "Judicial Performance and the Rule of Law in the Mexican States", Latin American Politics and Society, vol. 48, Issue 3 September, 2006.

49 Diálogos por la Justicia Cotidiana. Diagnósticos conjuntos y soluciones, Presidencia de la República-CIDE-UNAM, Instituto de Investigaciones Jurídicas, 2016, p. 234) 
Brage CAMAZANO, Joaquín, La acción abstracta de inconstitucionalidad, México, UNAM, Instituto de Investigaciones Jurídicas, 2005.

Bustillos, Julio, Federalismo judicial a través del amparo, México, UNAM, Instituto de Investigaciones Jurídicas, 2010.

CABAllero JuÁREZ, José Antonio et al., Libro Blanco de la reforma judicial en México, México, SCJN, 2006.

Cossío DíAz, José Ramón, Cambio social y cambio jurídico, México, Miguel Ángel Porrúa-ITAM, 2001.

Domingo, Pilar "Rule of Law, Citizenship and Access to Justice in Mexico", Mexican Studies/Estudios mexicanos, vol. 15, núm. 1, Winter 1999.

FERRER MAC-GREGOR, Eduardo, "Hacia un derecho procesal constitucional local en México", Anuario de Derecho Constitucional Latinoamericano, 2003, Montevideo, Konrad Adenauer Stiftung, 2003.

FERrer MAC-Gregor, Eduardo y SÁNCHEZ GIL, Rubén, El nuevo juicio de amparo y el proceso penal acusatorio, México, UNAM, Instituto de Investigaciones Jurídicas-IFP, 2013.

FERrer MAC-Gregor, Eduardo y VEGA HERNÁNDEZ, Rodolfo (coords.) Justicia constitucional local, Querétaro, FUNDAP-Gobierno del Estado de Coahuila, 2002.

FERRER, Eduardo y ZALDIVAR, Arturo (coords), La ciencia del derecho procesal constitucional: Estudios en homenaje a Héctor Fix-Zamudio en sus cincuenta años como investigador del derecho, t. II, México, UNAM, Instituto de Investigaciones Jurídicas, 2009.

FIX-FIERRO, Héctor, "Entre la eficacia autoritaria y la incertidumbre democrática”, en PÁSARA, Luis (comp.), En busca de una justicia distinta. Experiencias de reforma en América Latina, México, UNAM, 2009.

FIX-FIERRO, Héctor, Tribunales, justicia y eficiencia. Estudio sociojuridico sobre la racionalidad económica en la función judicial, Mexico, UNAM, Instituto de Investigaciones Jurídicas, 2006.

FIX-FIERRO, Héctor, La reforma judicial mexicana, ¿de dónde viene? ¿hacia dónde va?, México, UNAM, Instituto de Investigaciones Jurídicas, 2002.

FIX-FIERRO, Héctor et al., Entre un buen arreglo y un mal pleito, Encuesta Nacional de Justicia, México, UNAM, 2015. 
FiX-ZAmudio, Héctor, Estudio de la defensa de la Constitución en el ordenamiento mexicano, México, Porrúa, 2011.

LARA, Roberto et al., “¿De verdad deseamos una Corte redentora?”, $\mathrm{Ne}$ xos, núm. 372, diciembre de 2008.

LOPEZ AYLLÓN, Sergio y FIX-FierRo, Héctor, “¡Tan cerca, tan lejos! Estado de Derecho y cambio jurídico en México (1970-2000)", Boletín Mexicano de Derecho Comparado, México, año XXXIII, núm. 97, enero-abril de 2000.

MAGALONI, Ana Laura, “¿Por qué la Suprema Corte no ha sido instrumento para los derechos fundamentales?", en FERRER, Eduardo y ZALDIVAR, Arturo, La ciencia del derecho procesal constitucional. Estudios en homenaje a Héctor Fix-Zamudio en sus cincuenta años como investigador del derecho, t. II, México, UNAM, Instituto de Investigaciones Jurídicas, 2009.

MAGALONI, Ana Laura y ZALDÍvAR, Arturo, "El ciudadano olvidado", $\mathrm{Ne}$ xos, México, año 28, vol. XXVIII, núm. 342, junio de 2006.

PÁSARA, Luis (comp.), En busca de una justicia distinta. Experiencias de reforma en América Latina, México, UNAM, 2009.

PÉrez Perdomo, Rogelio, Gente del derecho y cultura jurídica en América Latina, México, UNAM, Instituto de Investigaciones Jurídicas, 2013.

Pou GiMÉnEZ, Francisca, "El nuevo amparo mexicano y la protección de los derechos: ¿ni tan nuevo ni tan protector?”, Anuario de Derechos Humanos, núm. 10, Santiago, 2014.

Rios FigueroA, Julio, "Justicia constitucional y derechos humanos en América Latina” Revista Latinoamericana de Política Comparada, vol. 3, enero de 2010.

Rios FigueroA, Julio, "Fragmentation of Power and the Emergence of an Effective Judiciary in Mexico", Latin American Politics and Society, Spring, vol. 49, num. 1, 2007.

SuAREZ ÁvilA, Alberto Abad, La protección de los derechos fundamentales en la Novena Época de la Suprema Corte, México, Porrúa, 2015.

TAFOYA HERnÁNDEZ, J. Guadalupe (coord.), Elementos para el estudio del juicio de amparo, México, SCJN, 2017.

TAMAYO SALMORÁN, Rolando, "El poder y la judicatura (breve comentario sobre la jurisdicción de amparo y la función judicial”, Boletín Mexi- 
cano de Derecho Comparado, núm. 63, México, UNAM, Instituto de Investigaciones Jurídicas, 1998.

TAte, C. Neal y VAlLinder, Torbjörn (eds.), The Global Expansion of Judicial Power, New York, New York University Press, 1995.

Tortolero Cervantes, Francisco y Pérez VÁzQuez, Carlos (coords.), El juicio de amparo en la Declaración Universal de los Derechos Humanos, México, SCJN, 2014.

UPRIMNY, Rodrigo et al., ¿Justicia para todos? Sistema judicial, derechos sociales y democracia en Colombia, Norma, 2006.

ZALDÍVAR, Arturo, Hacia una nueva Ley de Amparo, México, UNAM, Instituto de Investigaciones Jurídicas, 2002.

Zaldívar, Arturo, Diálogos por la Justicia Cotidiana. Diagnósticos conjuntos y soluciones, Presidencia de la República-CIDE-UNAM, Instituto de Investigaciones Jurídicas, 2016.

Fecha de recepción: 20 de noviembre de 2018.

Fecha de aceptación: 14 de diciembre de 2019. 
Esta revista forma parte del acervo de la Biblioteca Jurídica Virtual del Instituto de Investigaciones Jurídicas de la UNAM http://www.juridicas.unam.mx

https://biblio.juridicas.unam.mx

https://revistas.juridicas.unam.mx

DOI: http://dx.doi.org/10.22201/iij.24484881e.2020.43.15198

COMENTARIOS

JURISPRUDENCIALES 


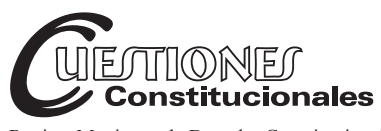

Revista Mexicana de Derecho Constitucional Núm. 43, julio-diciembre 2020

\section{El matrimonio infantil y la dispensa de edad*}

\section{Child marriage and age dispensation}

\section{Juan Luis GonZÁLEZ AlCÁNTARA**}

RESUMEN: Voto concurrente que formula el ministro Juan Luis González Alcántara en la Acción de inconstitucionalidad 22/2016, fallada por el Pleno de la Suprema Corte de Justicia de la Nación el 26 de marzo de 2019. La pregunta constitucional recayó en saber si era constitucional la eliminación de la dispensa de edad por causas graves y justificadas para que personas menores de edad pudieran contraer matrimonio. La mayoría consideró que la reforma impugnada era constitucional. El voto concurrente se aparta respecto de la argumentación en torno a la distribución competencial sobre el establecimiento de la "edad mínima" para contraer matrimonio, la conceptualización de la eliminación de la dispensa como una "restricción", así como la eliminación de la institución de la emancipación del ordenamiento estatal.

Palabras clave: matrimonio infantil, dispensa de edad, distribución de competencias, restricciones constitucionales, emancipación de menores.
ABSTRACT: Concurring opinion by Justice Juan Luis González Alcántara in the Unconstitutional Action 22/2016, decided by the full court of the Supreme Court of Justice of the Nation on March 26th, 2019. The constitutional issue related to the derogation of the age dispensation for minors to marry for serious and justified causes. The majority opinion considered that the challenged reform was constitutional. The concurring opinion departs from the argumentations regarding to the distribution of competences for the establishment of the "minimum age" to marry, the understanding of the derogation of the dispensation as a "restriction", as well as the derogation of the institution of emancipation in the state law.

Keywords: child marriage, age dispensation, allocation of powers, constitutional restrictions, emancipation of minors.

* Voto concurrente que formula el ministro Juan Luis González Alcántara en la Acción de inconstitucionalidad 22/2016, fallada por el Pleno de la Suprema Corte de Justicia de la Nación el 26 de marzo de 2019.

** Ministro de la Suprema Corte de Justicia de la Nación e investigador honorario del Instituto de Investigaciones Jurídicas de la UNAM. Agradezco en la elaboración de este voto a Daniela Carrasco Berge y Fernando Sosa Pastrana, México. 
SUMARIO: I. Introducción. II. Argumentos de la Comisión de Derechos Humanos de Aguascalientes. III. Argumentos de la mayoría. IV. Razones del disenso.

\section{INTRODUCCIÓN}

En sesión del 26 de marzo de 2019, el Pleno de la Suprema Corte resolvió la Acción de inconstitucionalidad 22/2016, promovida por la Comisión de Derechos Humanos del Estado de Aguascalientes en contra de la reforma al artículo 145 del Código Civil de Aguascalientes, y, en consecuencia, de la derogación de diversas disposiciones del propio Código expedidas mediante los decretos 309 y 310, expedidos por la LXII Legislatura del Estado de Aguascalientes, ambos publicados en el Periódico Oficial de la propia entidad, el 22 de febrero de 2016 en la primera sección.

Antes de la reforma, el artículo 145 del Código Civil local establecía la facultad del juez para conceder la dispensa para contraer matrimonio por causas graves y justificadas, a personas mayores de catorce años, pero menores de dieciocho. Después de la modificación legislativa, se suprimió esta potestad judicial, que permitía el matrimonio infantil. ${ }^{1}$

La pregunta constitucional recayó en saber si era constitucional la eliminación de la dispensa de edad por causas graves y justificadas para que menores de edad pudieran contraer matrimonio.

\section{ARgumentos De LA COMISIÓN DE DEREChOS HUMANOS DE AGUASCALIENTES}

La Comisión Estatal de Derechos Humanos argumentó que la reforma al artículo 145 del Código Civil de Aguascalientes violentaba el derecho a contraer matrimonio establecido en los artículos 16 de la Declaración Universal de Derechos Humanos, 23 del Pacto Internacional de Derechos

1 Con motivo de dicha reforma, la disposición que antes preveía:

“Artículo 145.- La edad mínima para contraer matrimonio será de 18 años. El Juez, puede conceder dispensa de edad por causas graves y justificadas, pero nunca se podrá dispensar a menores de catorce años".

Ahora dispone:

Artículo 145. La edad mínima para contraer matrimonio será de 18 años. 
Civiles y Políticos y 17 de la Convención Americana sobre Derechos Humanos, ya que si bien es cierto que esas disposiciones establecen que las leyes internas fijarán la edad y condiciones para contraer matrimonio, lo cierto es que también el artículo 2 de la Convención sobre el Consentimiento para el Matrimonio, la Edad Mínima para Contraer Matrimonio y el Registro de los Matrimonios prevé que la autoridad competente podrá dispensar el requisito de la edad por causas justificadas y en interés de los contrayentes.

Así también, para la Comisión Estatal, cuando se prohíbe que una persona se case, no sólo se le priva de ejercer el derecho de contraer matrimonio, sino también del disfrute de los demás derechos que derivan, como los beneficios fiscales; beneficios de solidaridad; beneficios por causa de muerte de uno de los cónyuges; beneficios de propiedad; beneficios en la toma subrogada de decisiones médicas, y beneficios migratorios para los cónyuges extranjeros, tal como se ha reconocido por la Primera Sala de la Suprema Corte de Justicia de la Nación en la jurisprudencia 1 ${ }^{\mathrm{a}}$./J. 46/2015 (10a.).

Incluso, la institución del matrimonio trae aparejados derechos para los hijos que nacen de quienes se encuentran en una relación de este tipo, como la presunción de paternidad, que conlleva a la filiación, y con ella los derechos a obtener alimentos, a la convivencia, a gozar de las medidas de protección por parte de su familia, a la identidad, a obtener un nombre propio y apellidos de los padres, a la nacionalidad, a gozar de la patria potestad y la guarda y custodia, a heredar, etcétera. Y por contrapartida, se genera también la consecuente responsabilidad de los ascendientes de satisfacer esos derechos.

Si bien una de las tendencias a prohibir el matrimonio infantil atiende a una problemática generada por matrimonios forzosos, que se da principalmente en el África subsahariana y en Asia meridional, según documentos del Fondo de las Naciones Unidas para la Infancia, lo cierto es que en Aguascalientes, según estadísticas del Instituto Nacional de Estadística y Geografía (INEGI), específicamente en el cuadro 3.9 del Anuario estadístico y geográfico de Aguascalientes 2015, la incidencia de madres menores de diecinueve años en 2013 fue de $18.68 \%$ de las entrevistadas, mientras que en 2014 fue de $19.64 \%$, lo que refleja la necesidad de que se legisle en protección de los y las adolescentes que se convierten en padres y madres a temprana edad y de los hijos e hijas que tengan, procurando siempre el interés superior de los menores de edad. 
La reforma impugnada afecta el artículo 1o. constitucional, pues el legislador no atendió a los principios de universalidad y progresividad de los derechos humanos, en tanto que la eliminación de la posibilidad de otorgar dispensa constituye una regresión en el orden jurídico mexicano convencional. La porción normativa controvertida tampoco se puede considerar una restricción necesaria, pues para cuidar que los menores de dieciocho años no sean víctimas de matrimonios en detrimento de sus derechos existen medidas menos lesivas, como la que estaba establecida antes de la reforma, que garantizaba que tanto los adolescentes que se casaran como los hijos que les nacieran, en caso de que los hubiera, pudieran gozar de los derechos que las leyes del estado les reconocen a los cónyuges y a los hijos de matrimonio.

\section{ARGUMENTOS DE LA MAYORÍA}

La mayoría consideró que la reforma impugnada era constitucional, ${ }^{2}$ es decir, que la derogación de la facultad del juez para otorgar dispensa de edad para contraer matrimonio era válida.

El engrose hace un recuento completo y muy ilustrativo en el considerando sexto respecto de la evolución en el ámbito internacional de la prohibición del matrimonio infantil, incluyendo a título orientador, observaciones y recomendaciones especializadas, en algunas ocasiones dirigidas al Estado mexicano. En particular, el método de interpretación armónico y sistemático que es empleado para desentrañar el sentido de la expresión "edad núbil", ${ }^{3}$ contenida en el artículo 16 de la Declaración Universal de los Derechos Humanos (1948) y en el preámbulo de la Convención sobre el Consentimiento para el Matrimonio, la Edad Mínima para Contraer Matrimonio y el Registro de los Matrimonios (1962), me parece asertivo y preciso. Utilizándolo, la propuesta llega por un lado a la conclusión de que "edad núbil" no puede equivaler a "edad púber", y que, por otro lado, son los propios organismos nacionales e internacionales las que "han precisado la edad que debe considerarse como apta para contraer matrimonio".

2 El ministro Alberto Pérez Dayán votó en contra, al considerar que la legislación local era inconvencional. Véase "Contenido de la versión taquigráfica de la sesión pública ordinaria del Pleno de la Suprema Corte de Justicia de la Nación, celebrada el lunes 25 de marzo de 2019", p. 47.

3 Apartado 2.2 del engrose, pp. 54-61. 
Este recuento sirve a su vez para acotar la litis al análisis de la eliminación de dispensas en Aguascalientes a menores de dieciocho años, excluyendo con ello el análisis relativo a la posibilidad abstracta de establecer una edad mínima para contraer matrimonio. ${ }^{4}$

Para dar respuesta a la litis planteada, el estudio de fondo contenido en el considerando séptimo se divide en seis apartados:

1. ¿El legislador de Aguascalientes violó el artículo 2 de la Convención sobre el Consentimiento para el Matrimonio, la Edad Mínima para Contraer Matrimonio y el Registro de los Matrimonios al eliminar la posibilidad de otorgar dispensas —en casos graves y justificados - a menores de edad para contraer matrimonio?

El engrose responde en sentido negativo a esta pregunta, ya que la eliminación de ese tipo de dispensas constituye un acto legislativo que encuentra asidero en el marco de potestades convencionales con que contaba el legislador local, de conformidad con el marco normativo-convencional.

\section{2. ¿La eliminación de la posibilidad de otorgar dispensa a menores} de edad para contraer matrimonio constituye una medida razonable en relación con la finalidad perseguida por el legislador?

Para responder a esta pregunta, se aplica en el engrose un test de razonabilidad, que a su vez se subdivide en dos preguntas:

a) ¿La medida adoptada por el legislador cumple con una finalidad constitucional, convencional o de importancia para el Estado?

4 Página 86 del engrose. A su letra establece: "En atención a ello, sólo será materia de análisis el conjunto de reformas que afectó al sistema normativo relacionado con la posibilidad excepcional que, hasta antes del veintidós de febrero de dos mil dieciséis, tenían los jóvenes mayores de catorce años y menores de dieciocho para que en casos graves y justificados, según la autoridad judicial, pudieran ejercer el derecho a contraer matrimonio en el Estado de Aguascalientes, así como de todas las disposiciones que pudieran implicar el reconocimiento o permisión del matrimonio de menores, como el otorgamiento de dispensas, la emancipación, los esponsales, la capacidad para administrar bienes y otorgar capitulaciones, las causas de nulidad de los matrimonios de menores y sus excepciones". 
b) Si la respuesta a la pregunta anterior fuera afirmativa, entonces se tendría que dilucidar si la reforma legislativa está vinculada con la finalidad que se persigue.

A la primera pregunta se responde afirmativamente, ya que la restricción establecida por el legislador cumple con una finalidad válida desde el punto de vista constitucional, consistente en proteger a niños, niñas y adolescentes de una práctica que ha sido considerada como nociva para ese sector de la sociedad tanto en el ámbito nacional como internacional, como lo es el matrimonio infantil, lo cual, debe decirse, tiene también apoyo constitucional y convencional en el interés superior del menor.

La segunda pregunta se responde también en sentido afirmativo, ya que la restricción legislativa sí está vinculada con la finalidad constitucional buscada, pues, como se dijo, el objetivo de las reformas fue precisamente proteger a los menores - sector constitucionalmente considerado como vulnerable-, y en especial a las niñas, de las consecuencias nocivas y perniciosas que, dada su especial situación, resienten cuando por sometimiento o por "voluntad propia" contraen matrimonio.

Por lo tanto, al responderse de manera afirmativa ambas preguntas, se concluye que el conjunto de reformas que se analizan sí resultan razonables y acordes con el fin buscado.

En esta parte el engrose también hace mención a la estadística sobre madres menores de diecinueve años en el estado de Aguascalientes. Al respecto, se señala que los embarazos prematuros no se "solucionan" casando a las madres menores de dieciocho años, sino brindándoles todo el apoyo y protección que el Estado, sus padres, tutores o custodios estarán obligados a proporcionar a todas las niñas, niños y adolescentes.

\section{Conceptos de invalidez relacionados con la violación al libre desarrollo de la personalidad}

En este apartado se afirma que con la eliminación de la figura de la dispensa para contraer matrimonio no se restringe el libre desarrollo de la personalidad de las y los menores, sino que, por el contrario, se contribuye a garantizar con mayor seguridad ese derecho. Ello, pues con la reforma impugnada se salvaguarda el interés superior de niñas, niños y adolescentes, al impedir que sean sometidos a costumbres como el matrimonio 
infantil, así como a presiones sociales, que, en atención a la especial situación de vulnerabilidad en que se encuentra este sector de la sociedad, en especial las niñas, por razón de su edad, así como de su situación económica, social y cultural, sólo les generan consecuencias nocivas.

\section{Conceptos de invalidez en los que se aduce violación al principio de progresividad de los derechos humanos}

Al respecto, se afirma que el conjunto de reformas impugnadas, y en especial la eliminación de las dispensas, tuvieron como finalidad esencial no restringir, sino incrementar el grado de tutela de los derechos y protección en general de niños, niñas y adolescentes, además de que la afectación que alega la parte actora solamente es temporal, no definitiva, por lo que se concluye que no se puede sostener en el presente caso que se infringió el principio de progresividad de los derechos humanos, dado que existen razones lo suficientemente sólidas para justificar la eliminación de las dispensas para que los menores puedan contraer matrimonio.

\section{Conceptos de invalidez relacionados con la afectación a los derechos de los hijos nacidos fuera del matrimonio}

Se considerarán infundados estos conceptos, ya que todos los niños y niñas, con independencia de las circunstancias o estado civil de sus padres ( si estaban casados o no), cuentan con los mismos derechos, y sus padres, madres, o quienes tengan a su cargo la patria potestad, tutela o custodia, están obligados a proporcionarles, dentro de sus posibilidades y medios económicos, las condiciones de vida suficientes para su sano desarrollo.

\section{Conceptos de invalidez relacionados con la afectación a otros derechos a los que se tiene acceso a través del matrimonio}

La posibilidad de obtener alguno o algunos de los beneficios derivados del matrimonio no puede considerarse como razón suficiente para justificar y/o permitir que se exponga a un menor a las consecuencias nocivas y perjudiciales del matrimonio infantil, máxime que las niñas, los niños y los adolescentes, por el simple hecho de serlo, tienen acceso a muchos más 
derechos y beneficios sociales y familiares que aquellos que refiere la parte accionante, pues atendiendo al interés superior del menor, este sector de la población tiene una protección reforzada por parte del Estado y de quienes los tienen a su cuidado, que conlleva garantizar la satisfacción plena de todas las necesidades que tengan los niños y adolescentes, a fin de lograr su óptimo desarrollo integral en los términos que señala el artículo 40. constitucional, y en los tratados internacionales abordados en la presente resolución.

\section{RAZONES DEL DISENSO}

Aunque compartí el sentido de la resolución y aplaudí la incorporación de la primera parte del proyecto, en donde se hace un recuento de los avances en la materia, con un especial enfoque de género, emito el presente voto concurrente para dejar a salvo mi criterio sobre la argumentación en torno a la distribución competencial sobre el establecimiento de la "edad mínima" (a) y la conceptualización de la eliminación de la dispensa como una "restricción" y la consecuente aplicación de un test de razonabilidad (b). A través del presente voto me gustaría aclarar igualmente, mi postura en torno a la eliminación de la institución de la emancipación del ordenamiento estatal y del reconocimiento de validez genérico que llevamos a cabo en la sentencia (c).

\section{La Ley General de Derechos de Niños, Niñas y Adolescentes no termina con la concurrencia en materia del estado civil de las personas}

En la ejecutoria que da lugar al presente voto se parte de la base de que en los tratados internacionales en la materia se ha dejado libertad configurativa a los Estados para definir la edad mínima del matrimonio. La sentencia afirma que, "para el caso del Estado Mexicano, la edad mínima ha sido fijada en dieciocho años, de conformidad con el artículo 45 de la Ley General de Derechos de Niños, Niñas y Adolescentes". ${ }^{5}$

En esa afirmación se advierte implícita la aseveración de que en la distribución competencial que rige el federalismo mexicano corresponde al

\footnotetext{
5 Página 63 del engrose.
} 
Congreso de la Unión (en este caso al emitir la ley general en cuestión) el establecimiento de la edad mínima para contraer matrimonio; sin embargo, advierto que en materia del estado civil de las personas, la concurrencia de los estados viene dada fundamentalmente y desde 1917, por el artículo 121 constitucional. ${ }^{6}$ Posteriormente, con la reforma del 12 de octubre de 2011, se facultó al Congreso para expedir leyes que "establezcan la concurrencia" de los distintos órdenes de gobierno en materia de niños, niñas y adolescentes.

Esta facultad fue enfática en establecer que el Congreso no podría establecer bases mínimas o distribuir competencias en sentido estricto, sino guardar y atender "el ámbito de sus respectivas competencias".?

En este sentido, desde mi punto de vista, no se facultó al legislador federal para que, con la emisión de una ley general alterara el mecanismo competencial asignado directamente desde la Constitución, en este caso, en el artículo 121. Esta anotación me parece de suma relevancia, pues si bien en el asunto que nos ocupa existe una coincidencia entre el contenido de la Ley General en su artículo 45 y el artículo impugnado, en cuanto ambas establecen los dieciocho años como la mayoría de edad, podría no ser el caso, y eso no tornaría a este último inconstitucional, o por lo menos no por esa razón. Razones similares adoptó la Primera Sala de esta Suprema Corte al resolver la Controversia constitucional 72/2019. ${ }^{8}$

Respetuosamente considero que ante la multiplicación de "leyes generales" en el ordenamiento jurídico mexicano, parece conveniente empezar a hacer distinciones respecto de la función y el alcance de cada instrumento en lo particular, con la intención de tutelar la distribución competencial en el federalismo mexicano. En similares términos me he pronunciado,

\footnotetext{
6 Artículo 121. En cada entidad federativa se dará entera fe y crédito de los actos públicos, registros y procedimientos judiciales de todas las otras. El Congreso de la Unión, por medio de leyes generales, prescribirá la manera de probar dichos actos, registros y procedimientos, y el efecto de ellos, sujetándose a las bases siguientes:

$(\ldots)]$

IV. Los actos del estado civil ajustados a las leyes de una entidad federativa, tendrán validez en las otras".

7 Artículo 73. XXIX-P.- "Expedir leyes que establezcan la concurrencia de la Federación, los Estados, el Distrito Federal y los Municipios, en el ámbito de sus respectivas competencias, en materia de derechos de niñas, niños y adolescentes, velando en todo momento por el interés superior de los mismos y cumpliendo con los tratados internacionales de la materia, de los que México sea parte" (las cursivas son nuestras).

8 Asunto fallado el 9 de octubre de 2019 por la Primera Sala de la Suprema Corte de Justicia de la Nación.
} 
por ejemplo, en el voto concurrente que formulé a la Acción de inconstitucionalidad 45/2016. ${ }^{9}$

\section{Las dispensas para el matrimonio entre menores no pueden ser entendidas como un derecho humano}

No me parece que sea posible considerar que las dispensas constituyan un derecho humano reconocido a favor de los niños, niñas y adolescentes. Creo que se le dota al término de un significante que ni siquiera históricamente existió. ${ }^{10}$

En el proyecto de resolución discutido en el Pleno se hacía la pregunta sobre si las dispensas de edad podían considerarse una restricción constitucionalmente válida al ejercicio del derecho a contraer matrimonio, y finalmente en el engrose se reformuló el cuestionamiento en el sentido de si la dispensa de edad era una medida razonable para conseguir un fin válido. ${ }^{11}$ Por lo tanto, ya no debería plantearse la eliminación de la dispensa como una "restricción". Sin embargo subsisten en el engrose referencias a la dispensa como restricción o limitación al ejercicio de un derecho humano. ${ }^{12}$ Estimo que aquí subyace forzosamente la premisa de que las dispensas son un derecho humano, aun si en la resolución ya no se llega a esa conclusión.

Considero que el artículo 1o. constitucional es claro al establecer que los derechos humanos no podrán restringirse, "salvo en los casos y bajo las condiciones que esta Constitución establece”, de lo que se extrae que sólo a ella le correspondería, en su caso, establecer restricciones y condicionar el alcance de las mismas. No creo que sea acorde, ni con la literalidad ni con la interpretación que el tribunal pleno realizó al resolver la Contradicción de tesis 293/2011, considerar que una entidad federativa, a través de una ley local, pudiera establecer una restricción constitucionalmente válida, como tampoco podría hacerlo una ley general.

9 Asunto fallado el 9 de abril de 2019 por el Pleno de la Suprema Corte de Justicia de la Nación.

10 Pothier, R. J., Tratado del contrato de matrimonio, trad. por Elías de Molins, Madrid, t. IX. Particularmente, el capítulo IV, "De las dispensas de los impedimentos de matrimonio que se encuentran en las personas", y el párrafo 332.

11 "Contenido de la versión taquigráfica de la sesión pública ordinaria del Pleno de la Suprema Corte de Justicia de la Nación, celebrada el 26 de marzo de 2019”, pp. 3 y 4, así como la p. 109 del engrose.

12 Páginas 62 y 63 del engrose. 
Del mismo recuento que hace la sentencia en los apartados previos, concluyo que no existe un elemento que vincule al Estado mexicano a expedir dispensas para que menores puedan contraer matrimonio. Al contrario, hay elementos suficientes para considerar que existen obligaciones convencionales para el Estado mexicano, ${ }^{13} \mathrm{y}$, a la par, un exhorto generalizado en el ámbito internacional y emitido por órganos especializados justamente en la defensa de los derechos de niñas, niños y adolescentes (soft law),$^{14}$ para combatir la práctica del matrimonio infantil. Creo que una lectura de los mismos resulta orientadora y muy útil, cuando nos enfrentamos a la interpretación del artículo 2 de la Convención sobre Consentimiento para el Matrimonio, la Edad Mínima para Contraer Matrimonio y el Registro de los Matrimonios, suscrita en 1972, que prevé la posibilidad de que la autoridad competente, por causas justificadas y en interés de los contrayentes, dispense el requisito de la edad para contraer matrimonio. ${ }^{15}$ Si bien el tiempo no agota los efectos de una convención ratificada por el Estado, la interpretación de la misma sí debe ceder al principio de especialidad y de progresividad. ${ }^{16}$

En este caso, el desarrollo de instrumentos vinculantes y de instrumentos orientadores, especializados en el interés superior del menor y la defensa de las mujeres, debe ser tomado en cuenta para interpretar armónica y sistemáticamente el artículo 2 de la Convención referida.

13 Citadas por la resolución en el apartado 2.2 Normas internacionales que establecen el derecho a contraer matrimonio y la edad a partir de la que se puede ejercer este derecho, pp. 54-61.

14 Citadas por la resolución en el apartado 3. "Informes, observaciones, recomendaciones y resoluciones formuladas por organismos internacionales en relación con la necesidad de erradicar los matrimonios de niños, niñas y adolescentes", pp. 64-80.

15 "Artículo 2. Los estados parte en la presente Convención adoptarán las medidas legislativas necesarias para determinar la edad mínima para contraer matrimonio. No podrán contraer legalmente matrimonio las personas que no hayan cumplido esa edad, salvo que la autoridad competente, por causas justificadas y en interés de los contrayentes, dispense el requisito de la edad".

16 Para mayor referencia sobre el entendimiento de los tratados como "instrumentos vivos", véase Dijk, P. van y Hoof, G. J. H. van, Theory and Practice of the European Convention on Human Rights, 3a. ed., La Haya, Kluwer Law International, 1998, p. 77, y Wildhaber, Luzius, "The European Court of Human Rights in action", Ritsumeikan Law Review, Japón, núm. 21, marzo de 2004, p. 84. Esta doctrina ha sido desarrollada por el Tribunal Europeo de Derechos Humanos desde el caso Tyrer v. The United Kingdom (1978), cuyo párrafo 31 señala "El Tribunal recuerda además que el Convenio es un instrumento vivo que hay que interpretar - la Comisión lo ha puesto de manifiesto debidamente - a la vista de las actuales circunstancias de vida". 
E1 Estado mexicano se encuentra obligado a resguardar la progresividad de los derechos humanos, sobre todo a la luz de la reforma de 2011. Esta misma progresividad, inherente a los derechos humanos, debe tener un impacto en la interpretación que se da a los tratados ratificados. Aun si estas razones son exploradas en las páginas 121 a 125 de la sentencia, cuando se da respuesta al concepto de invalidez en el que se aduce la violación a este principio, considero que debió tomarse en cuenta al momento de interpretar el artículo convencional antes referido. Esquemáticamente, creo que deberían ser tomadas las siguientes consideraciones para interpretar el artículo 2 de la Convención sobre el Consentimiento para el Matrimonio:

- El objetivo y el contexto de la propia Convención. ${ }^{17}$ Particularmente, el preámbulo de la Convención sobre el Consentimiento para el Matrimonio estableció que ésta tenía como objetivo, con el que todos los Estados debían comprometerse, abolir "totalmente" el matrimonio de los niños.

- Las convenciones posteriores. ${ }^{18}$ Notoriamente, la Convención sobre la Eliminación de todas las formas de Discriminación contra la Mujer, ratificado por México en 1981, establece que "no tendrán ningún efecto jurídico los esponsales y el matrimonio de niños" en el artículo 16.2. Conjuntamente, la Convención sobre Derechos del Niño de 1989 dispone que "se entiende por niño todo ser humano menor de dieciocho años de edad". De todos los instrumentos internacionales vinculantes citados por la sentencia, se extrae la necesidad de que exista un pleno y libre consentimiento de las partes.

- Deferencia y consulta a órganos internacionales especializados.

Estos puntos son relevantes y suficientes para contestar a la pregunta constitucional que, desde mi punto de vista, se planteaba, y que giraba, esencialmente, sobre la interpretación del artículo 2 de la Convención so-

17 Esto es acorde a lo dispuesto por el artículo 31 de la Convención de Viena sobre el Derecho de los Tratados, que a su letra dispone: "1. Un tratado deberá interpretarse de buena fe conforme al sentido corriente que haya de atribuirse a los términos del tratado en el contexto de éstos y teniendo en cuenta su objeto y fin".

18 En este punto, la Convención de Viena establece en su artículo 30: “3. Cuando todas las partes en el tratado anterior sean también partes en el tratado posterior pero el tratado anterior no quede terminado ni su aplicación suspendida conforme al artículo 59, el tratado anterior se aplicará únicamente en la medida en que sus disposiciones sean compatibles con las del tratado posterior". 
bre el Consentimiento para el Matrimonio. No veo lugar para centrar este asunto en uno relacionado con restricciones a los derechos humanos de los menores, y, con ello, aplicar un test de razonabilidad para preguntarnos si la medida cumplía con una finalidad constitucional, toda vez que no existe un derecho a la dispensa ni tampoco un derecho para que los menores contraigan matrimonio. ${ }^{19}$

\section{Voto aclaratorio respecto de la emancipación y su dependencia con la figura del matrimonio entre menores}

En la acción de inconstitucionalidad que nos ocupa se planteó la invalidez del decreto de reformas al Código Civil de Aguascalientes, por derogar la posibilidad para los menores y bajo ciertas circunstancias, de contraer matrimonio. Este decreto no solamente reformó el artículo 145, que contenía anteriormente esta previsión, sino que eliminó la figura de la emancipación, entre otros cambios. El proyecto que se nos presentó centró la litis en la constitucionalidad de eliminar la posibilidad de contraer matrimonio para los menores, y realizó, de esta forma, un estudio sistemático, pero no pormenorizado, de los artículos reformados.

Este contexto dio lugar a que, en la sesión del 26 de marzo de 2019, a la ministra Norma Lucía Piña Hernández le surgiera la duda sobre si debimos haber estudiado la constitucionalidad de los demás artículos, y específicamente, de la supresión de la figura de la emancipación, o bien, como prefirió la mayoría, reconocer la validez, en vía de consecuencia, de estos artículos, sin haberlos estudiado pormenorizadamente. ${ }^{20}$

19 "Contenido de la versión taquigráfica de la sesión pública ordinaria del Pleno de la Suprema Corte de Justicia de la Nación, celebrada el 26 de marzo de 2019”, p. 15.

20 "Señora Ministra Piña Hernández:... El legislador de Aguascalientes dijo que derogaba todo lo relativo a la emancipación y así quedó establecido en el proyecto que dijo el Pleno: — ahí me aparté — que el legislador eso quiso hacer, pero lo que hizo fue derogar la emancipación.

Aquí el problema es éste, que creo que es otra cosa muy diferente a efectos. Están impugnados todos los artículos que hablan de la emancipación, concretamente se impugnó este artículo que estuvimos analizando, en razón de que establecía la dispensa, eliminó la dispensa de adolescentes y, en vía de consecuencia, todos los artículos que el legislador incluyó.

Mi duda es - y desde ayer se la planteé y se lo comenté al Ministro ponente-: dentro de esta derogación, el legislador de Aguascalientes derogó artículos que no tenían nada que ver con el matrimonio de adolescentes, los incluyó; esos artículos están impugnados, 
Cuestionamiento que compartí en la sesión mencionada. ${ }^{21}$ En ese sentido, acompañé tal interrogante, porque a pesar de que en mi intervención expresé que la institución de la emancipación regulada en la codificación civil del estado de Aguascalientes está íntimamente vinculada con el matrimonio infantil, al ser efecto y consecuencia directa de éste, ${ }^{22}$ también se puede apreciar que existía en tal legislación una porción normativa que era autónoma e independiente a las provisiones matrimoniales, ${ }^{23}$ previo a la reforma impugnada.

Me refiero al artículo 457 del Código Civil del Estado de Aguascalientes, que establecía lo siguiente: "Cuando por la ley o por la voluntad del padre, el hijo tenga la administración de los bienes, se le considerará respecto de la administración como emancipado, con la restricción que establece la ley para enajenar, gravar o hipotecar bienes raíces".

En estas circunstancias, me parece que, al no haberse planteado conceptos de invalidez que cuestionaran la supresión de la institución de la emancipación, y al existir efectivamente especificidades en este tema, distintas a la litis, hubiéramos podido sobreseer en los artículos 85, 86, 87, $88,435,457,460,464,465$ 495, 473, 521, 647, 660, 663, 667 y 755 del Código Civil para el estado de Aguascalientes, sin reconocer su validez en vía de consecuencia, como lo hicimos. Sin embargo, coincidí finalmente con la propuesta del ministro José Fernando Franco González Salas, por-

no hay conceptos de violación y no tienen nada que ver con el matrimonio de adolescentes, pero son actos impugnados en consecuencia, de oficio, porque es acción de inconstitucionalidad.

¿Vamos a analizar si esa derogación que realizó el legislador de Aguascalientes es constitucional o no? Porque ahorita, al reconocerla ¿esto por qué trasciende? Si reconocemos la validez del artículo que se impugnó, en vía de consecuencia, ¿también vamos a reconocer la validez de diversos preceptos que no tienen nada que ver con el tema que tratamos, y que por un error, el legislador de Aguascalientes, incluyó esa derogación? Ese es mi punto...", ibidem, pp. 52 y 53.

21 Ibidem, pp. 53 y 54.

22 Aunque en el derecho civil decimonónico mexicano la emancipación también se había regulado para permitir a los menores de edad llevar a cabo la administración de un acervo patrimonial o la ejecución de un trabajo, arte o profesión, sin requerir la intervención de interpósita persona, esto no fue obstáculo para siempre considerarlo como "....un efecto inmediato y necesario, de esencia del matrimonio". Cfr. Mateos Alarcón, Manuel, Lecciones de derecho civil, México, J. Valdés y Cueva, 1885, p. 428.

23 En efecto, está porción normativa podría entender como un derivado residual de la regulación primigenia de la emancipación en nuestro país; a mayor abundamiento, consúltese Mateos Alarcón, Manuel, op. cit., nota 22. 
que considero que la institución de la emancipación sí está esencialmente vinculada a la del matrimonio entre menores, o, en todo caso, así debiera estarlo, en atención al interés superior del menor.

En suma, consideró que el artículo 45 de la Ley General de Derechos de Niños, Niñas y Adolescentes no puede válidamente federalizar la edad mínima para contraer matrimonio, ya que el artículo 73, fracción XXIX-P, de la Constitución, facultó al Congreso de la Unión para legislar en la materia, pero atendiendo el ámbito de competencias de la Federación, estados y municipios, por lo que se dejó intocada la distribución de competencias en materia de estado civil de las personas, establecido en el artículo constitucional 121, fracción IV. Así también, una interpretación evolutiva del artículo 2 de la de la Convención sobre el Consentimiento para el Matrimonio hubiera bastado para reconocer la validez de la reforma impugnada, haciendo innecesaria, por tanto, la aplicación de un test de razonabilidad, en tanto que no existe un derecho a la dispensa ni tampoco un derecho para que los menores contraigan matrimonio. Por último, considero que la emancipación debiera ser una figura dependiente del matrimonio infantil, que es inconstitucional, ya que su autonomía sería contraria al interés superior de la niñez.

Por todo lo anterior, es por lo que aunque comparto el sentido de la resolución al declarar la validez de los decretos impugnados, me aparto respetuosamente de las consideraciones de la sentencia que aquí se han precisado. 


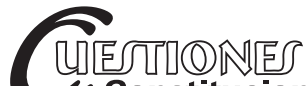 Constitucionales}

Revista Mexicana de Derecho Constitucional Núm. 43, julio-diciembre 2020

\section{Caso Marielle Franco - Tensão entre o segredo de justiça e a liberdade de imprensa (proposta de distensionamento entre os princípios constitucionais)}

\section{Marielle Franco Case - Tension between the secret of justice and press freedom (proposal for socio-legal dialogue between constitutional principles)}

\section{Artur César SouZA*}

RESUMO: A morte da vereadora brasileira do PSOL (Partido Solicialista e Liberdade), Marielle Franco, e de seu motorista, Anderson Gomes, ocorrida em 14 de março de 2018, no Rio de Janeiro, Brasil, ganhou repercussão nacional e internacional, em especial pelas dúvidas existentes quanto à legitimidade do procedimento investigatório realizado pela polícia brasileira. Há suspeita de que o assassinato foi encomendado por inimigos políticos à milícia do Rio de Janeiro, gerando graves danos aos direitos humanos e ao sistema democrático brasileiro. A partir deste caso, pretende-se analisar a proibição de divulgação dos elementos probatórios inseridos no inquérito policial em razão do segredo de justiça decretado pelo magistrado brasileiro que conduz o procedimento criminal, ensejando certa tensão entre os princípios da liberdade de imprensa e do devido processo legal. Ao final, resguardando-se a higidez e a eficácia de ambos os princípios, apresenta-se (sub censura) uma
ABSTRACT: The death of Brazilian PSOL Councilwoman Marielle Franco and her driver Anderson Gomes on March 14, 2018 in Rio de Janeiro, Brazil, has gained national and international repercussions, especially because of doubts. legitimacy of the investigative procedure carried out by the Brazilian police. It is suspected that the murder was commissioned by political enemies from the Rio de Janeiro militia, causing serious damage to human rights and the Brazilian democratic system. From this case, it is intended to analyze the prohibition of disclosure of the evidential elements inserted in the police investigation due to the secret of justice decreed by the Brazilian magistrate that conducts the criminal proceeding, causing some tension between the principles of freedom of the press and due process. cool. Finally, safeguarding the health and effectiveness of both principles, we present (sub-censorship) a possible socio-legal solution in which the essence of one

* Professor do Curso de Mestrado e Doutorado da Universidade de Marília - UNIMAR. Brasil. ORCID: 0000-0001-5280-6549. Correo electrónico: artur.souza@trf4.jus.br. 
possível solução sócio-jurídica na qual a essência de um dos princípios não seja subjugada pelo outro. Nesse sentido, ao mesmo tempo em que não se apóia qualquer censura prévia aos meios de comunicação, sustenta-se que a divulgação de conteúdo probatório resguardado pelo segredo de justiça (devido processo legal) pode caracterizar a inutilidade da prova. Para tanto, vale-se de uma metodologia indutiva e de uma revisão bibliográfica de direito comparado como forma de se dar sustentação aos fundamentos apresentados para a solução da questão.

Palavras chave: Marielle Franco, liberdade de imprensa, devido processo legal, prova, inutilidade. of the principles is not subjugated by the other. In this sense, while not supporting any prior censorship of the media, it is argued that the disclosure of probative content protected by the secrecy of justice (due legal process) may characterize the uselessness of the evidence. To this end, it uses an inductive methodology and a bibliographic review of comparative law as a way to support the foundations presented for the solution of the question.

Keywords: Marielle Franco, freedom of the press, due process of law, proof, uselessness.

\begin{abstract}
SOMÁRIO: I. Introdução. II. Caso Marielle Franco - tensão entre liberdade de imprensa e o devido processo legal. III. As narrativas favoráveis à liberdade de imprensa. IV. Narrativas favoráveis ao devido processo legal e ao segredo de justiça. V. Da liberdade de imprensa e do devido processo legal - tese para a distensão do conflito com base no resguardo da essência eficacial de cada um dos princípios. VI. Uma proposta de solução mediante a manutenção simultânea da eficácia normativa dos princípios de liberdade de imprensa e de um processo público com todas as garantias. VII. Conclusão. VIII. Bibliografia.
\end{abstract}

\title{
I. INTRODUÇÃO
}

O assassinato da Vereadora Marielle Franco, juntamente com o seu motorista, Anderson Gomes, ocorrido no Rio de Janeiro, em 14 de março de 2018, comoveu o Brasil e outras nações internacionais, tanto pelo ataque brutal aos direitos humanos, quanto pelo risco imposto à democracia brasileira.

O assassinato ocorreu em um bairro do Rio de Janeiro, quando o veículo da vereadora, conduzido por seu motorista, Anderson Gomes, que também veio a falecer no local, foi literalmente alvejado por diversos tiros de fuzil, ensejando um verdadeiro fuzilamento da vereadora e do seu motorista, num dos mais belos cartões postais brasileiros. 
A repercussão da morte da vereadora foi imediata.

Na América Latina, o portal e os noticiários do canal multiestatal teleSUR reforçam que Marielle foi "uma das vozes mais combatentes contra a ocupação militar das favelas do Rio de Janeiro" e que sua morte "comoveu a nação sul-americana por seu inesperado assassinato". Outros meios alternativos latino-americanos, como o Nodal, os argentinos Notas Periodismo Popular, Marcha Noticias e Resumen Latinoamericano, o colombiano Colombia Informa e o uruguaio La Diaria repercutiram com destaque em suas páginas principais. Jornais estrangeiros de diversos matizes políticas também noticiaram o caso. O espanhol El País trouxe no título: "Comoção no Brasil pelo assassinato de Marielle Franco, vereadora e ativista do Rio"; e o, também espanhol, El Confidencial estampa: "Jovem, negra e feminista: Marielle Franco, a vereadora assassinada no Rio de Janeiro". Já o inglês The Guardian noticiou "Marielle Franco, vereadora e crítica da polícia, morta a tiros em crime encomendado no Rio"; e a $B B C$, do mesmo país, traz que: "Vereadora do Rio, Franco, morre em tiroteio". New York Times e Washington Post, dos Estados Unidos, reproduziram nota da Associated Press que, além do texto noticiando o assassinato de Marielle, ilustram com foto da comoção e tristeza daqueles que foram até o local do crime, na noite dessa quarta-feira (15). Na Itália, o RaiNews apresentou no título: "Ela lutou contra a violência policial nas Favelas: assassinada a ativista do Rio Marielle Franco". O francês Le Figaro e Le Parisien também trouxeram o assassinato da vereadora socialista em seus sites. ${ }^{1}$

As repercussões políticas e sociais da morte da vereadora Marielle Franco ensejam diversas análises institucionais e acadêmicas.

Porém, especificamente à problematização deste trabalho, procedeu-se a um corte epistemológico, restringindo-se o objeto de análise a uma questão sócio-jurídica de extrema importância constitucional.

Pretende-se neste trabalho verificar a proibição de divulgação dos elementos probatórios inseridos no inquérito policial em razão do segredo de justiça decretado pelo magistrado brasileiro que conduz o procedimento criminal, ensejando certa tensão entre os princípios da liberdade de imprensa e do devido processo legal.

Não obstante o subtítulo deste trabalho fale em tensão (razão pela qual pode ser superada), tensão não tem o mesmo significado de conflitos ou

1 Disponible en: https://www.brasildefato.com.br/2018/03/15/midia-internacionalrepercute-assassinato-de-marielle-destacando-sua-luta-politica/ acesso em 13/11/2019. 
atropelamento; assim mesmo, não obstante a tensão, é possível sustentar a manutenção da essência de cada princípios, sem que haja uma submissão de um em relação a outro.

E por que é necessária essa harmonia e compatibilidade? Justamente pelo fato de que os direitos fundamentais (liberdade de imprensa e devido processo legal) têm por finalidade proteger e fazer efetiva a dignidade da pessoa humana. Por isso, entre eles não pode existir nenhum enfrentamento, nem conflito, sem harmonia e compatibilidade. ${ }^{2}$

Ao final, resguardando-se a higidez e a eficácia de ambos os princípios, apresenta-se (sub censura) uma possível solução (tese) sócio-jurídica na qual a essência de um dos princípios não seja subjugada pelo outro. Nesse sentido, ao mesmo tempo em que não se apoia qualquer censura prévia aos meios de comunicação, sustenta-se que a divulgação de conteúdo probatório resguardado pelo segredo de justiça (devido processo legal) pode caracterizar a inutilidade da prova.

\section{CASO MARIELLE FRANCO - TENSÃO ENTRE LIBERDADE DE IMPRENSA E O DEVIDO PROCESSO LEGAL}

Como se afirmou, pretende-se analisar a tensão sócio-jurídica constitucional existente no caso Marielle Franco entre a liberdade de imprensa e o devido processo legal (segredo de justiça dos elementos probatórios)

Em determinado momento do caso Marielle Franco, tornou-se evidente a tensão existente entre a liberdade de imprensa e o devido processo legal.

A tensão entre a liberdade de imprensa e o devido processo legal surge a partir do momento em que o magistrado da Quarta Vara Criminal do Rio de Janeiro (juiz encarregado de conduzir o procedimento criminal da vereadora Marielle Franco) deferiu pedido da Divisão de Homicídios da Polícia Civil e do Ministério Público para que uma das maiores emissoras de televisão brasileira, Rede Globo de Televisão, fosse proibida de divulgar o conteúdo probatório de qualquer parte do inquérito policial que apura os assassinatos da vereadora Marielle Franco e do motorista Anderson Gomes, sob o argumento de que o vazamento do conteúdo dos autos seria prejudicial às

2 Salazar Ugarte, Pedro y Gutiérrez Rivas, Rodrigo, El derecho a la libertad de expresión frente al derecho a la no discriminación. Tensiones, relaciones e implicaciones, México, UNAM, Instituto de Investigaciones Jurídicas-Consejo para Prevenir la Discriminación, 2008, p. 149. 
investigações, bem como exporia a danos pessoas e testemunhas envolvidas com o caso.

A decisão proferida pelo Juízo da Quarta Vara Criminal do Rio de Janeiro proíbe a emissora de televisão, Rede Globo, de divulgar termos de declarações, mesmo sem a identificação das testemunhas, assim como dados técnicos e procedimentos sigilosos usados na investigação, conteúdos de gravações de áudios de pessoas investigadas ou não; conteúdos telemáticos, ou seja, de áudios e mensagens extraídos de contas de e-mails e telefones das vítimas, testemunhas e investigados, e, ainda, qualquer outro conteúdo do inquérito.

A Rede Globo de Televisão noticiou que iria cumprir a determinação judicial, porém, por considerar excessiva, iria recorrer da decisão, sob o argumento de que a restrição imposta pela justiça feriria gravemente a liberdade de imprensa e o direito de o público se informar, em especial quando o crime investigado é de alto interesse público no Brasil e no estrangeiro.

Não há dúvida de que a tensão entre princípios Constitucionais ficou perfeitamente evidenciada quando o magistrado proíbe de forma peremptória a divulgação de elementos do inquérito policial pela imprensa brasileira, subjugando a liberdade de imprensa em prol do segredo de justiça.

Diante dessa tensão entre princípios Constitucionais, liberdade de imprensa e sigilo de dados inseridos em procedimento de inquérito ou em processo jurisdicional, pretende-se, neste trabalho, avaliar se a decisão proferida pelo juízo da Quarta Vara Criminal do Rio de Janeiro respeito ou não a essência do princípio da liberdade de imprensa e do devido processo legal, e se haveria outra solução possível e plausível para compatibilizar os princípios Constitucionais tensionados no caso Marielle Franco.

\section{AS NARRATIVAS FAVORÁVEIS À LIBERDADE DE IMPRENSA}

A imprensa constitui um fenômeno social próprio do mundo moderno, sem precedentes diretos históricos muito mais antigos, tendo em vista que é um fenômeno que depende das condições sociais do mundo moderno. ${ }^{3}$

3 Fontán, Antonio, Prensa, democracia y libertad, Ciudad de Mèxico, Fondo de Cultura Económica, 2017, p. 33. 
A primeira obra clássica em defesa da liberdade de expressão e, por consequência, de imprensa, foi Aeropagítica, escrita por John Milton, em 1664. Trata-se de um escrito dirigido ao Parlamento inglês contra a Ordem de 14 de junho de 1643, que, entre outras questões, instaurou a censura prévia, proibindo-se a importação de livros estrangeiros sem autorização, bem como exigiu prévia permissão para a impressão das obras. John Milton levou em consideração que o ser humano é um ser livre e racional, razão pela qual a liberdade de expressão seria um instrumento para conseguir a verdade. Segundo Milton, a verdade somente poderia ser alcançada a partir do livre contraste de ideias ou aportações com respeito ao contraditório. A ausência de censura na divulgação das ideias e dos fatos seria a garantia de que a verdade é fruto da dialética e não das opiniões que se consideram verdadeiras 'a priori' por quem se crê infalível. ${ }^{4}$

Spinoza, já no século XVII, preconizava no capítulo XX do Tratado teológico político: "Observa-se que num Estado livre é lícito a cada um, não somente pensar o que queira, senão dizer aquilo que pensa". ${ }^{5}$

A liberdade de imprensa, portanto, modernamente, pode ser reconhecida como um dos pilares de sustentação do Estado democrático de direito.

Segundo James Curran, analisando o processo democrático na Inglaterra, podem-se apontar cinco narrativas favoráveis aos meios de comunicação em massa, a saber: Na história liberal, o sucesso da liberdade dos meios de comunicação dotou de poderes ao povo. Na história populista, o povo exigiu e obteve o entretenimento que buscava nos meios de comunicação. Na história feminista, os meios de comunicação responderam à crescente libertação da mulher. Nas explicações libertárias e antropológicas, os meios de comunicação chegam a proporcionar uma maior tolerância social e a representar a nação de uma forma mais inclusiva. ${ }^{6}$

$\mathrm{O}$ respeito à independência dos meios de comunicação em massa e o reconhecimento do direito fundamental de liberdade de imprensa, expressos no artigo 19 da Declaração Universal dos Direitos Humanos, são ele-

4 Magdaleno Alegría, Antonio, Los limites de las libertades de expresión e información en el Estado social y democrático de derecho, Madrid, Congreso de los Diputados, 2006, p. 26.

5 Cabrera, Carmen Sáez y Saltor, Carlos Eduardo, "Spinoza y la libertad de opinión", Revista de la Facultad de Derecho de la Universidad Complutense, Madrid, núm. 91, 1998, p. 267.

6 Curran, James, Medios de comunicación y poder en una sociedad democrática, trad. de Moan Quesada, Barcelona, Hacer Editorial, 2002, p. 55. 
mentos essenciais para a transparência e o respeito à lei. Esses princípios são de igual importância em países ricos e pobres, em tempos de guerra e de paz. ${ }^{7}$

Na realidade, e tal como enfatizou a Declaração de Chapultepec, ${ }^{8}$ uma imprensa livre é condição fundamental para que as sociedades resolvam seus conflitos, promovam o bem estar e protejam sua liberdade.

A narrativa liberal nos oferece uma visão coerente dos distintos modos pelos quais os meios de comunicação, cada vez mais livre, fortaleceram e fortalecem o processo democrático.

A liberdade de imprensa, por ser um dos pilares da democracia, é reconhecida na jurisprudência de distintos países. Entre as liberdades que a Constituição consagra, "a da imprensa é uma das que possui maior importância, em último caso pode-se dizer que sem sua devida proteção existiria tão somente uma democracia em declínio ou puramente nominal...”. (Corte Suprema Argentina, caso 'Abal c/ Diário La Prensa', Fallo 248:291, cons. 25)"). ${ }^{9}$

Sobre a importância da liberdade de imprensa e, por sua vez, da liberdade de expressão, pronunciou-se o Tribunal Constitucional espanhol na Sentença, 6/81, no sentido de que o artigo 20 da Constituição espanhola, em seus distintos incisos, garante a manutenção de uma comunicação pública livre, sem a qual ficariam viciados de conteúdo real outros direitos que a Constituição consagra, reduzidas a formas vazias as instituições representativas e absolutamente falseado o princípio da legitimidade democrática que enuncia o artigo 1.2 da Constituição espanhola, e que é a base de toda a ordenação jurídica-política... A liberdade de expressão que proclama o artigo 20.1. a) é um direito fundamental de que gozam por igual todos os cidadãos e que lhes protege frente a qualquer ingerência dos poderes públicos que não estejam apoiados na Lei, e inclusive frente à própria Lei quando esta tente fixar outros limites além daqueles que a própria Constituição (arts. 20.4 e 53.2) admite. Outro tanto cabe afirmar em relação ao direito de comunicar e receber informação verdadeira (art.

\footnotetext{
7 Matsuura, Koichiro, Liberdade de imprensa, UNESCO, Brasília Office, 2004, p. 18.

8 Declaração de Chapultepec, 1994 sobre a liberdade de expressão e de imprensa. Foi redigida por 100 especialistas a pedido da Sociedade Interamericana de Imprensa (SIP). O documento ataca a censura prévia e a violencia contra jornalistas.

9 Gullco, Hernán. V. "La libertad de expresión y el discurso basado en el odio racial o religioso", Libertad de prensa y derecho penal, Buenos Aires, Editores del Puerto, 1997, p. 37.
} 
20.1, d.), fórmula que, como é óbvio, inclui dois direitos distintos, porém intimamente conectados. O direito a comunicar que, em certo sentido, pode considerar-se como uma simples aplicação concreta da liberdade de expressão e cuja explicitação diferenciada somente se encontra em textos constitucionais recentes, é direito de que gozam também, sem dúvida, todos os cidadãos, ainda que na prática sirva, sobretudo, de salvaguarda a quem faz da busca e difusão da informação sua profissão específica; o direito a receber é, a rigor, uma redundância (não há comunicação quando a mensagem não tem receptor possível), cuja inclusão no texto constitucional justifica-se, contudo, pelo propósito de ampliar ao máximo o conjunto dos legitimados para impugnar qualquer perturbação da livre comunicação social.

Não se pode desconhecer, conforme afirmou o ministro do Supremo Tribunal Federal brasileiro, Celso de Melo, que a liberdade de imprensa, enquanto projeção da liberdade de manifestação de pensamento e de comunicação, reveste-se de conteúdo abrangente, por compreender, entre outras prerrogativas relevantes que lhe são inerentes, (a) o direito de informar, (b) o direito de buscar a informação, (c) o direito de opinar e (d) o direito de criticar. ${ }^{10}$

Ainda que muitas vezes a informação apresentada pelos meios de comunicação, e, acima de tudo, pelos singulares órgãos de comunicação em massa seja em parte unilateral e possivelmente distorcida, a liberdade dos meios de comunicação é um valor socialmente muito elevado e que representa uma importante característica da democracia moderna. ${ }^{11}$

Segundo H. Kury, a liberdade de imprensa está efetivamente reconhecida entre os direitos humanos, sendo que "in Germania è fissata nella Costituzione (Grundgesetz), nell'art. 5 co. 1, a livello europeo nell'art. 10 della Convenzione Europea sui Diritti dell’Uomo, cosí come nell'art. 11 della Carta Europea dei diritti Fondamentali". ${ }^{12}$

O direito à liberdade de expressão e, por consequência, de imprensa, é fruto da interpretação formulada ao artigo 13 da Convenção Americana sobre Direitos Humanos, que diz:

10 Disponible en: http://www.stf.jus.br/arquivo/cms/noticiaNoticiaStf/anexo/PremioANJminCM.pdf, acesso em 14/11/2019.

11 Kury, Helmut, "Mass media e criminalità: l'esperienza tedesca", trad. Carlo Ruga Riva e Arianna Cremona, La televisione del crimine, a cura di Gabrio Forti e Marta Bertolino, Milano, V\&P Università, 2005, p. 325.

12 Idem. 
La libertad de expresión es una piedra angular en la existencia misma de una sociedad democrática. Es indispensable para la formación de la opinión pública... Es, en fin, condición para que la comunidad, a la hora de ejercer sus opciones, esté suficientemente informada. Por fin, es posible afirmar que una sociedad que no esté bien informada, no es plenamente libre. ${ }^{13}$

A Convenção Europeia de Direitos Humanos, em seu artigo 10, ns. 1 e 2, garante a liberdade de expressão nos seguintes termos:

1. Toda persona tiene derecho a la libertad de expresión. Este derecho comprende la libertad de opinión y la libertad de recibir o comunicar informaciones o ideas sin que pueda haber inferencia de autoridades públicas y sin consideración de fronteras. El presente artículo no impide que los estados sometan las empresas de radiodifusión, de cinematografía o de televisión a una autorización previa. 2. El ejercicio de estas libertades, que entrañan deberes y responsabilidades, podrá ser sometido a ciertas formalidades, concesiones, restricciones o sanciones, previstas por la ley, que constituyan medidas necesarias en una sociedad democrática, para la seguridad nacional, la integridad territorial o la seguridad pública, la defensa del orden y la prevención del delito, la protección de la salud o de la moral, la protección de la reputación de los derechos ajenos, para impedir la divulgación de informaciones confidenciales o para garantizar la autoridad y la imparcialidad del poder judicial. ${ }^{14}$

A publicidade, nas palavras de Ferrajoli, é a "alma da justiça”, não só porque é a mais eficaz garantia dos testemunhos, mas principalmente porque favorece a "probidade" dos juízes, servindo como freio a um poder que se torna facilmente alvo de abusos, além de assegurar a confiança do público em seus juízes. ${ }^{15}$

Em "Chandler vs. Florida” (449 US 560 (1981)), ressalta-se o voto proferido pelo juiz Burger da Suprema Corte americana, relator da decisão da maioria. Nesta decisão, observou-se que não obstante exista certo peri-

13 Bertoni, Eduardo A. "La crítica política y su relevancia para los tribunales internacionales", Libertad de prensa y derecho penal, Buenos Aires, Del Puerto, 1997, p. 32.

$14 \mathrm{O}$ n. 2, do artigo 10, da Convenção Européia, prevê que o direito fundamental à liberdade de imprensa pode ser legitimamente limitado quando necessário para garantir a autoridade e imparcialidade do poder judiciário (Bertoni, E. A., ibidem, p. 23).

15 Ferrajoli, Luigi, Derechos y garantias. La ley del más débil, Madrid, Trotta, 2001, p. 493. 
go ao imputado a eventual cobertura jornalística, esse perigo não justifica uma proibição genérica da cobertura televisiva dos julgamentos penais. Salientou-se, também, que a cobertura dos meios de comunicação não interfere com os procedimentos judiciais. ${ }^{16}$

$\mathrm{Na}$ realidade, ao se censurar os meios de comunicação de massa, de certa forma está também limitando a própria liberdade da opinião pública.

Diante dessas considerações, as narrativas favoráveis à liberdade de imprensa deve prevalecer como fundamento para refutar qualquer controle do Poder Judiciário concernente à censura prévia do conteúdo informativo obtido pelos meios de comunicação em massa.

É bem verdade que na sociedade moderna a crítica política realiza-se por meio maciço da comunicação, constituindo-se, muitas vezes, verdadeiras empresas multinacionais que escondem, por detrás de uma máscara que postula a liberdade de imprensa, interesses mesquinhos e totalmente dissociados dos interesses do povo. Mas, mesmo diante desse aspecto, a experiência tem demonstrado que, em muitos casos, deve-se permitir a crítica, ainda que ela esconda interesses escusos, uma vez que assim, pelo menos, há uma mínima possibilidade de controle por parte da opinião pública (no caso: “...Observer and Guardian vs. UK (1991), la Corte Europea de Derechos Humanos consideró precisamente que el papel de la prensa era de controlador público)". ${ }^{17}$

É importante reconhecer que a liberdade de imprensa, qualificada por sua natureza essencialmente constitucional, assegura aos profissionais de comunicação social, inclusive aos que praticam o jornalismo digital, o direito de buscar, de receber e de transmitir informações e ideias por quaisquer meios, ressalvada, no entanto, a possibilidade de intervenção judicial —necessariamente "a posteriori" — nos casos em que se registrar prática

16 Contudo, é importante assinalar que a Suprema Corte voltou a analisar outros casos, e nesses precedentes passou a ter um comportamento diverso. Várias decisões afirmam que a imprensa não tem um direito constitucional de acesso privilegiado às fontes de informação ("Branzburg vs. Hayes"), e que a Constituição não outorga à imprensa um direito de acesso especial à informação distinto da do público em geral ("Pell $v s$. Procunier"). Igualmente, decidiu-se que nem o público e nem a imprensa podem invocar um direito constitucional de um julgamento público ("Richmond Newspaper Inc. vs. Virginia"), e que não há um direito constitucional de gravar e difundir um testemunho produzido em juízo ("Nixon vs. Warner Communications Inc."). (Decisões citadas in Bovino, Alberto, "Publicidad del juicio penal: la televisión en sala de audiencias", Libertad de prensa y derecho penal, Buenos Aires, Del Puerto, 1997, pp. 139 e 140).

17 Bertoni, E., op. cit., p. 16. 
abusiva dessa prerrogativa de ordem jurídica, resguardado, sempre, o sigilo da fonte quando, a critério do próprio jornalista (e deste, apenas), ele assim o julgar necessário ao seu exercício profissional. ${ }^{18}$

\section{NARRATIVAS FAVORÁVEIS AO DEVIDO PROCESSO LEGAL E AO SEGREDO DE JUSTIÇA}

O magistrado da Quarta Vara Criminal do Rio de Janeiro (juiz encarregado de conduzir o procedimento criminal da vereadora Marielle Franco) ao deferir pedido da Divisão de Homicídios da Polícia Civil e do Ministério Público para que uma das maiores emissoras de televisão brasileira, Rede Globo de Televisão, fosse proibida de divulgar o conteúdo probatório de qualquer parte do inquérito policial que apura os assassinatos da vereadora Marielle Franco e do motorista Anderson Gomes, sob o argumento de que o vazamento do conteúdo dos autos seria prejudicial às investigações, bem como exporia a danos pessoas e testemunhas envolvidas com o caso, fez uma opção principiológica, dando prevalência ao princípio do devido processo legal, em razão do segredo de justiça decretado no procedimento investigatório.

A divulgação dos elementos probatórios, muitos deles que poderiam envolver a intimidade ou alguns direitos fundamentais do acusado, poderia de alguma forma comprometer o devido processo legal e o princípio da inocência.

O sacrifício do princípio da liberdade de imprensa, mediante censura prévia, na ótica do juiz do magistrado singular, teve por motivação o resguardo de um processo público com todas as suas garantias. ${ }^{19}$

A Corte Constitucional italiana, quando chamada a se manifestar sobre a constitucionalidade do artigo 164, inc. I, do Código de Processo Penal de

18 Disponible em: http://www.stf.jus.br/arquivo/cms/noticiaNoticiaStf/anexo/Premio ANJminCM.pdf, acesso em 14/11/2019.

19 No que se refere à incidência do direito a um processo com todas as garantias, ver a Sentença do Tribunal Constitucional espanhol 81/1998, confirmada posteriormente pelas SSTC 49/1999, 94/1999.

A doutrina da Sala 2 do Tribunal Supremo espanhol, de 18 junho de 1992 (R. Ar. 6102) declarou no caso Naseiro, que ninguém nega na Espanha a impossibilidade constitucional e legal da valoração da prova obtida com infração aos direitos fundamentais por colidir com o direito a um processo com todas as garantias e a igualdade das partes (art. 24.2 e 14, C.E.). 
1930, em confronto com o artigo 21 da Constituição italiana, realçou que a proibição de divulgação dos atos instrutórios asseguraria a serenidade e independência do juiz, protegendo-o de toda e qualquer influência que possa ter a imprensa na investigação, bem como na valoração do resultado, evitando, também, alguns comportamentos estranhos que possam obstaculizar a formação do livre convencimento. É oportuno observar, contudo, que a decisão do tribunal italiano visou, principalmente, ao direito de crítica e não especificamente ao direito de crônica judiciária, uma vez que o problema não é aquele de evitar ou não à imprensa e aos outros meios de difusão do pensamento a divulgação correta e fiel daquilo que no processo foi dito ou feito, mas, sim, aquele de evitar a interferência de um processo jornalístico no processo penal ainda em curso. ${ }^{20}$

Porém, há outros fatores de natureza sociológica que justifica a decisão proferida pelo magistrado singular, restringindo a liberdade de imprensa em prol do devido processo legal, e que diz respeito ao papel mais significativo dos serviços midiáticos sobre o crime, papel esse que deriva do fato de pertencerem os meios de comunicação em massa ao sistema de 'controle social', reproduzindo e representando a ordem social.

Apesar das narrativas favoráveis aos mass media, James Curran afirma que existe uma narrativa contraposta que dificulta o caminho para uma tentadora síntese liberal positiva em favor dos meios de comunicação em massa, isto é: "a história radical dos meios de comunicação. Esta nos conta uma história bem diferente, na medida em que o desenvolvimento dos meios de comunicação trouxe mais trevas que luz". ${ }^{21}$

Os modernos meios de comunicação sucumbiram à influência das relações públicas, à publicidade e às grandes empresas. Enquanto que no século XVIII a imprensa facilitava a participação racional num debate público, os novos meios de comunicação em massa propiciaram a apatia do consumidor, apresentando a política como um espetáculo, e oferecendo um pensamento de mera conveniência.

Ocorreu, ainda, segundo James Curran, a incorporação dos meios de comunicação de massa pelas elites, como consequência da alteração da produção periodística artesanal para a produção industrial dos meios de comunicação,

\footnotetext{
20 Giostra, Glauco, Processo penale e informazione, 2a. ed., Milano, Giuffrè, 1989, p. 86 .

21 Curran, J., op. cit., p. 56.
} 
aumentando com isso a dependência da publicidade e o desenvolvimento do oligopólio. ${ }^{22}$

Há, ainda, o mecanismo moderno de controle social realizado pelos dos meios de comunicação em massa, representado pelo etiquetamento das pessoas que possivelmente praticaram ou poderiam praticar uma infração penal, reforça a necessidade da opinião pública em apoiar medidas que servem de instrumentalização e de concretização das políticas desenvolvidas pelo denominado direito penal do inimigo.

Esse etiquetamento midiático é resultado da nova criminologia preconizada pela modernidade tardia, que, nas palavras de David Garland, comercializa com imagens, arquétipos e ansiedades, em lugar de estar fundada em uma análise meticulosa e nos descobrimentos da investigação científica. Ao intentar deliberadamente fazer eco das preocupações públicas e dos preconceitos dos meios massivos de comunicação e sua concentração em ameaças mais inquietantes, esta criminologia, com efeito, resulta ser um discurso político do inconsciente coletivo, ainda quando, em linhas gerais, proclama ser realista e 'de sentido comum' frente às 'teorias acadêmicas'... Com esta imagem, os indivíduos delinqüentes passam a ser visualizados como 'delinqüentes de carreira', 'dependentes das drogas', ‘jóvens rudes e agressivos' e 'violentos' com poucas possibilidades de se redimirem e escasso valor social. Alguns, particularmente os pedófilos, os 'predadores sexuais' e os jóvens 'superpredadores' - são evocados de uma maneira em que aparecem como escassamente humanos, sendo essencializada a sua conduta 'malvada' ou 'ignominiosa' mais além de toda compreensão humana. Comunidades inteiras são anatematizadas; fala-se de uma 'subclasse' que nada merece, encerrada em uma cultura e num modo de vida que são tão estranhos como ameaçadores. Estas não são pessoas reais, muito menos categorias criminológicas. São figuras imaginárias que operam como símbolos em um processo político que explora o que Mary Douglas chamou de 'os usos políticos do perigo'. Os perigos, ao que se percebe, são colocados e inseridos, as ansiedades que geram, a sensação de desamparo que produzem; tudo isso funciona reforçando a necessidade de imposição da ordem e a importância de uma resposta estatal firme. Tampouco são essas figuras representativas dos reais perigos que o delito indubitavelmente pode implicar, já que seu inventário de perigo se concentra quase exclusivamente no delito de rua, esquecendo-se dos sé-

\footnotetext{
22 Idem.
} 
rios danos que produzem as organizações criminosas, os delinqüentes de colarinho branco ou, inclusive, os condutores de automóveis embriagados. Cada figura, alternadamente, é selecionada por sua utilidade como inimigo 'conveniente', uma utilidade não somente para a justiça penal estatal em sua forma soberana, senão também para uma política social conservadora que acentua a necessidade da autoridade, dos valores familiares e da ressurreição da moralidade tradicional. ${ }^{23}$

O etiquetamento negativo massificado pelos meios de comunicação em massa possibilita a construção daquilo que atualmente os penalistas reconhecem como o "diritto penale del nemico" em contraposição ao "diritto penale dell'amico". Ao lado dessa perspectiva teórica, mais recentemente já se fala do "nemico del diritto penale".

Contudo, diante de uma sociedade dita democrática e civilizada não deveria haver nem "nemici", nem "amici", "ma soltanto 'innocenti' e 'colpevoli', secondo un diritto penale e un processo 'giusti'. ${ }^{24}$

Em face desse etiquetamento midiático, há uma preocupação dos meios de comunicação em massa não tanto com o fato penal em si e sua correspondência - verdade ou falsidade, e muito menos com a aplicação dos princípios da culpabilidade e presunção de inocência, mas com o imediato etiquetamento do suposto autor do crime, descrevendo-o como sendo uma ameaça constante à ordem sistêmica social e econômica, e sugerindo uma imediata atuação do Poder Judiciário no sentido de segregá-lo do meio social como forma de prevenção geral e especial, pouco importando se futuramente possa chegar-se à conclusão de que se tratava de um inocente.

O que se pretende com a informação midiática massificada pelo fato delituoso por meio dos meios de comunicação em massa é concretizar a teoria funcionalista-consequencial da decisão judicial e promover a eficácia do direito penal do inimigo aplicando uma sanção exemplar, exigindo-se de plano e imediatamente segregação e neutralização do acusado, sem qualquer preocupação com as instâncias dialógico-reeducativas. ${ }^{25}$ Não havendo uma imediata resposta do órgão jurisdicional nesse sentido,

23 Garland, David, La cultura del control, trad. Máximo Sozzo, Barcelona, Gedisa, p. 228.

24 Mantovani, Ferrando, "Il diritto penale del nemico, il diritto penale dell'amico, il nemico del diritto penale e l'amico del diritto penale", Rivista Italiana di Diritto e Procedura Penale, Milano, 2/3, apr-sett, 2007, p. 470.

25 Ibidem, pp. 471 e 472. 
desencadeia-se no âmbito da opinião pública um sentimento de frustração e de perplexidade, a ponto de por em dúvida a própria legitimidade do Poder Judiciário.

Como bem afirmou Vega Ruiz:

En ese sentido, la reiteración de noticias sobre sucesos judiciales importantes, de múltiples formas, supone una lícita y encomiable actividad profesional. El juicio paralelo, por motivos políticos, económicos, sociales o demagógicos, supone un acoso a la labor judicial (recordar el caso 'Nani' o el 'juicio de Alcaser'). El juicio paralelo implica una presión manifiesta sobre los jueces porque dia a dia analiza las pruebas, critica las declaraciones testifícales o los dictámenes periciales. El juicio paralelo trata de suplantar al juez opinando caprichosa, imprudente y alegremente de todo cuanto al juicio real se refiere. El daño es evidente porque aún cuando no influya sobre la decisión de los jueces (al menos no debe influir), sí proyecta un mensaje sobre la sociedad, cuya opinión manipula ostensiblemente. El juez que se sienta presionado debe, si no abandonar la función judicial sí al menos denunciar ante el Consejo General del Poder Judicial tal evento. Mas independientemente de ello, se prejudica la credibilidad en la Justicia si el fallo de los jueces non coincide con el fallo que el juicio paralelo defiende, ampara y protege. Esto es lamentable, ciertamente. ${ }^{26}$

Para Cristina de Maglie, a prova do sucesso da justiça penal está na modificação e na construção de condições sociais que reconheçam o Eu possível, e não na conquista e na eliminação do 'outro Eu' ${ }^{27}$

Sob o aspecto processual, a massificação dos fatos delituosos e o etiquetamento do acusado previamente estabelecido estimulam, mesmo que de forma subliminar, "certe distorzione in materia di perquisizioni, sequestri, confische, intercettazioni, misure cautelari personali, di garanzie probatorie, in accelerazini dei tempi processuali, in meccanismi di pressione-compensazione verso forme di collaborazione", em outras palavras, legitimam os meios de combate e de eliminação do suposto inimigo. ${ }^{28}$

A hiper-efetividade que caracteriza a custódia cautelar, considerada pela doutrina italiana um verdadeiro risco penal, é decorrente dessa influência

26 Vega Ruiz, José Augusto de, Libertad de expresión información veraz juicios paralelos medios de comunicación, Madrid, Editorial Universitas, 1998, p. 61.

27 Maglie, Cristina de, Società multiculturali e diritto penale: la cultura defense, Milano, Giuffrè, 2006. p. 222.

28 Mantovani, F., op. cit., p. 472. 
dos meios de comunicação em massa, e é acompanhada pelo aplauso social que legitima a antecipação do meio processual de fins punitivo. ${ }^{29}$

Aquelas pessoas cujo fato delituoso não foi objeto de exposição massificada pelos meios de comunicação em massa encontram-se inseridas no denominado "diritto penale del cittadino", que corresponde ao direito penal normal. Trata-se de um direito penal voltado ao delinqüente "normale", e que reserva a ele todos os direitos ou "status" de cidadão, não havendo qualquer oposição à sua reintegração no pacto social. ${ }^{30}$

Já a pessoa cujo fato delituoso é massificadamente exposto pelos meios de comunicação em massa passa a ser etiquetada como "non persona", porque se coloca fora e contra o ordenamento jurídico-social, passando a ser considerada uma constante ameaça ao pacto social. A partir deste momento, assim como na guerra, não haverá mais um diálogo com o inimigo, mas se propugnará por uma efetiva neutralização de sua pessoa. A imprensa propõe um direito penal que olha para o futuro: 'per neutralizzare la pericolosità del nemico". ${ }^{31}$

Os autores de infração penal (inimigos sociais) são tratados pelos meios de comunicação numa perspectiva maniqueísta, orientada pelo paradigma dicotômico (bom-mau) - (nós e eles). O criminoso seria etiquetado, por assim dizer, como um sujeito antropologicamente indecifrável, movido por um instinto anti-social obscuro e profundo. Sobretudo, a transmissão midiática deixa como mensagem a ilusão de que o autor da infração penal não pode ser recuperado socialmente, mas pode e deve ser apenas combatido e encarcerado. ${ }^{32}$

A mídia, por meio desse processo de etiquetamento, concede aos autores dos crimes contra a pessoa, por exemplo, um tratamento muito deformante, no intuito de os caracterizar como uma figura desumana, para que as pessoas que compõem o círculo social também os vejam desta forma. O paradoxo é que os meios de comunicação valem-se dos casos extremos, os quais não representam de fato o tipo normal de tal criminalidade, mas

29 Giunta, Fausto, 'L'effettività della pena nell'epoca del dissolvimento del sistema sanzionatorio", Rivista Italiana di Diritto e Procedura Penale, nuova serie - anno XLI, Milano, Giuffrrè, 1998, p. 429.

30 Mantovani, F., op. cit.

31 Idem.

32 Paliero, Carlo Enrico, "La maschera e il volto (percezione sociale del crimine ed 'effetti penali' dei media)", Rivista Italian di Diritto e Procedura Penale, Milano, nuova serie, anno XLIX, 2006, p. 499. 
como tais são propostos pela mídia. Jovens que matam por desvio de comportamento ou por ódio em situações especiais, muitas vezes são inseridos como caso normal de criminalidade. ${ }^{33}$

O magistrado singular, ao sacrificar o princípio da liberdade de imprensa, resguardou o devido processo legal, mantendo os elementos probatórios em segredo de justiça, tanto para resguardar a eficácia das investigações, como para dar maior significado ao princípio da presunção de inocência, impedindo dessa forma um possível etiquetamento e, conseqüente, um julgamento paralelo por parte dos meios de comunicação de massa.

\section{DA LIBERDADE DE IMPRENSA E DO DEVIDO PROCESSO \\ LEGAL - TESE PARA A DISTENSÃO DO CONFLITO COM BASE \\ NO RESGUARDO DA ESSÊNCIA EFICACIAL DE CADA \\ UM DOS PRINCÍPIOS}

O magistrado da Quarta Vara Criminal do Rio de Janeiro (juiz encarregado de conduzir o procedimento criminal da vereadora Marielle Franco), ao fazer opção pelo princípio do devido processo legal, mediante a manutenção em segredo de justiça dos elementos probatórios inseridos no procedimento criminal, eliminou a essência eficacial do princípio da liberdade de imprensa, o que se refuta na tese formulada neste trabalho. ${ }^{34}$

Essa proibição judicial configura, indubitavelmente, censura prévia ao exercício da liberdade constitucional dos meios de comunicação em massa.

A Constituição Federal brasileira, em seu artigo 220, $\S \S 1$ o. e 2o. estabelece:

Art. 220. A manifestação do pensamento, a criação, a expressão e a informação, sob qualquer forma, processo ou veículo não sofrerão qualquer restrição, observado o disposto nesta Constituição. $\S 1^{\circ}$ Nenhuma lei conterá dispositivo que possa constituir embaraço à plena liberdade de informação jornalística em qualquer veículo de comunicação social, observado o disposto no art. $5^{\circ}, \mathrm{IV}, \mathrm{V}, \mathrm{X}, \mathrm{XIII}$ e XIV. $\S 2^{\circ}$ É vedada toda e qualquer censura de natureza política, ideológica e artística.

33 Ibidem, pp. 501 e 502.

34 Por sua vez, se o magistrado tivesse optado por liberar todo o conteúdo probatório à Rede Globo de Televisão, também teria eliminado a essência eficacial do princípio do devido processo legal e do segredo de justiça.

Esta obra está bajo una Licencia Creative Commons Atribución-NoComercial-SinDerivar 4.0 Internacional, IIJ-UNAM. 
O artigo 5.1 da Constituição da República Federal da Alemanha diz expressamente: "No hay censura alguna", isto é, "no existe una autoridad que, basándose en la ley, limite la libertad de opinión e información, la libertad de prensa y artística realizando una censura previa". ${ }^{35}$

Diante das narrativas favoráveis à liberdade de imprensa, e, por consequência, da liberdade de expressão, chega-se à conclusão de que a censura prévia imposta aos meios de comunicação em massa não seria a melhor solução para a resolução do problema surgido no caso Marielle Franco.

Também não seria a melhor solução permitir que os meios de comunicação em massa, violando decisão judicial consubstanciada no devido processo legal (segredo de justiça) pudesse a qualquer momento divulgar o conteúdo probatório, pondo em risco a eficácia das investigações e o princípio da presunção de inocência (etiquetamento e julgamento paralelo).

Não se pode deixar de observar que há nas Constituições democráticas um importante princípio estrutural da democracia, no caso, o direito fundamental a um processo justo e com todas as garantias. E dentre essas prerrogativas, há a garantia de que as provas colhidas em segredo de justiça não serão divulgadas ao público em geral, a não ser por ordem escrita da autoridade competente.

Em um Estado democrático de direito, a solução para o dilema suscitado no presente trabalho deve respaldar-se nos estritos limites das regras democráticas como forma de distensionamento dos princípios envolvidos.

Por isso, transferindo-se a questão para o campo normativo dos princípios constitucionais, podem ser superadas as restrições de ordem social, cultural, econômica e de legitimação institucional, as quais, até o presente momento, tornaram ineficaz a legislação infraconstitucional sobre a proibição de divulgação de conteúdo probatório advindo da "quebra de sigilo" determinada por autoridade competente no processo penal.

É pela dissipação dessa tensão principiológico e pela harmonização e conservação da eficácia jurídica dos princípios constitucionais referentes à liberdade de expressão e de informação e de garantia ao justo processo que se pretende dar uma resposta jurídica-sociológica satisfatória (sempre sujeita a impugnação e refutação) para esse dilema da sociedade moderna: ao mesmo tempo em que há uma regra jurídica proibindo a divulgação de provas que são objeto de segredo de Justiça, consubstanciada no princípio

35 Kagelmann, H. Jürgen e Wenninger, Gerd, Psicología de los medios de comunicación. Manual de conceptos básicos, Barcelona, Herder, 1986, p. 359. 
do devido processo legal, essas provas tornam-se públicas pelos meios de comunicação em massa, sob a alegação de que estão respaldados pelo princípio constitucional de liberdade de imprensa.

Por sua vez, todas as vezes que se pretende restringir um princípio constitucional tendo por base a normatização de uma regra jurídica, ainda que consubstanciada em outro princípio, a força normativa do princípio constitucional tende a prevalecer.

Por isso, a única forma de se promover o equilíbrio de forças nesse jogo normativo, é deslocar a questão para o âmbito apenas e tão-somente dos princípios constitucionais.

Sobre a constitucionalização dos princípios fundamentais e a relevância de seu significado jurídico, ensina J. J. Gomes Canotilho e Vital Moreira:

...Por um lado, eles assumem força normativo-constitucional dada a superação definitiva da idéia de Constituição como simples 'complexo de directivas políticas' e uma vez rejeitada a idéia de que as normas e princípios constitucionais são meramente programáticos, sem qualquer vinculatividade imediata. Conseqüentemente, toda a Constituição é direito, toda ela é 'lei positiva' e todos os princípios nela consagrados possuem alcance jurídico e compartilham da normatividade própria da Lei fundamental. Estes princípios possuem, em geral, duas dimensões: dimensão constitutiva, dado que os princípios, eles mesmos, na sua fundamentalidade, exprimem, indicam e denotam uma compreensão global da ordem constitucional; -dimensão declarativa, pois estes princípios assumem, noutros casos, o carácter de 'vocábulos designantes' de 'fórmulas sintéticas' utilizadas para designar a 'soma' de outros subprincípios e concretizações normativas constitucionalmente plasmados. ${ }^{36}$

Nessa perspectiva, deve-se ter em mente que tanto o princípio constitucional de liberdade de imprensa e informação quanto o princípio constitucional do processo justo com todas as garantias assumem força-normativa em cada um de seus subsistemas sociais, contribuindo de maneira decisiva para a manutenção da perspectiva autopoietica de cada subsistema.

Evidentemente que a proposta (tese) sugerida neste trabalho é a da manutenção, ao mesmo tempo, da eficácia normativo-constitucional de cada um desses princípios no seu respectivo subsistema social. Essa afirmação, a princípio, poderá gerar certa perplexidade, sob a alegação de que

36 Canotilho, José Joaquim Gomes e Moreira, Vital, Fundamentos da constituição, Coimbra, Coimbra Editora, 1991, p. 73. 
havendo a incidência do princípio concernente à liberdade de expressão e informação, a normatividade do sigilo da prova perderia de plano sua eficácia normativa.

Essa consideração seria válida se a questão estivesse circunscrita ao plano do princípio em relação à regra jurídica. Mas, repita-se, houve um deslocamento de perspectiva; a questão está agora no campo da força normativa dos princípios constitucionais (princípio da liberdade de expressão e princípio do devido processo legal).

Segundo Ronald Dworkin, a diferença entre princípios e regras jurídicas é de natureza lógica, ou seja, os dois conjuntos de padrões apontam para decisões particulares acerca da obrigação jurídica em circunstâncias específicas, contudo distinguem-se quanto à natureza de orientação que oferecem. As regras aplicam-se à maneira de tudo-ou-nada. Uma vez realizados os fatos que uma regra estipula, então ou a regra é válida, e nesta hipótese o resultado que ela fornece deve ser aceito ou não é válida, e nesta hipótese nada se contribui para a decisão. ${ }^{37}$ Já os princípios são aplicados segundo uma dimensão que as regras não têm, ou seja, a dimensão do peso ou importância. ${ }^{38}$

A convivência dos princípios é conflitual, a convivência de regras é antinômica: ${ }^{39}$ os princípios, ao constituírem exigência de optimização, permitem o balanceamento de valores e interesses, sendo que as regras não deixam espaço para qualquer outra solução, uma vez que se uma regra tem validade, deve ser observada exatamente nos seus termos, nem mais nem menos. Os princípios suscitam problemas de validade e peso (importância, ponderação, valia), já as regras estabelecem apenas questão de validade (se elas não são corretas devem ser modificadas).

Para Robert Alexy, o ponto decisivo para a distinção entre regras e princípios é que os princípios são normas que ordenam que algo seja realizado na maior medida possível, dentro das possibilidades jurídicas e reais existentes. Assim, os princípios são "mandados de optimização", ou seja, podem ser cumpridos de diferente grau e que a medida de seu cumprimento depende das condições reais e jurídicas. Ao contrário, as regras são normas que somente podem ser cumpridas ou não. Se uma regra é válida,

37 Dworkin, Ronald, Levando os direitos a sério, São Paulo, Martins Fontes, 2002, p. 39.

38 Ibidem, p. 43.

39 Alexy, Robert, Teoria de los derechos fundamentales, Madrid, Centro de Estudios Constitucionales, 1997, pp. 88 e 89. 
deve-se fazer exatamente o que ela determina, nem mais nem menos. Isto significa que a diferença entre ambos não é de grau, mas qualitativa. ${ }^{40}$

Diante dessas considerações, se a questão estivesse circunscrita ao âmbito das regras jurídicas, a prova divulgada pelos meios de comunicação em massa, cuja divulgação vem respaldada pelo princípio constitucional de liberdade de imprensa e informação, tornaria inválida as regras jurídicas processuais penais, consubstanciadas no princípio do devido processo legal, que proíbem a divulgação de provas que estão sob o manto de segredo de Justiça (por exemplo, art. 114, 240 e 329 do Código de Processo Penal italiano; art. 301 e 302 da LECrim. espanhola). Nesse caso, a prevalência do princípio da liberdade de expressão tornaria inválida a regra jurídica do segredo de justiça e eliminaria a essência eficacial do princípio do devido processo legal.

Alterando a perspectiva normativa, agora para o campo da força-normativa dos princípios constitucionais, pode-se afirmar que tanto o princípio de liberdade de expressão, assim como o princípio do processo público com todas as garantias, nesse confronto de forças, nesse campo de "mandados de optimização", nessa perspectiva de validade e de peso em cada um de seus subsistemas social, devem preservar ao mesmo tempo a sua eficácia normativa. Essa é a tese desenvolvida no presente trabalho.

A proposta inserida no presente trabalho não se enquadra no campo da antinomia de princípios, ou seja, se aplicado um dos princípios o outro automaticamente deve ser considerado ineficaz. A proposta formulada é no sentido de que ambos os princípios tenham eficácia, ou seja, 'liberdade de imprensa' e 'devido processo legal'.

Na simples visão de "mandado de optimização", a divulgação do conteúdo probatório utilizado no processo de comunicação em massa, com o intuito de construir a realidade social (verità) deste subsistema, está efetivamente amparada pelo princípio constitucional de liberdade de expressão e de imprensa, razão pela qual, a única solução ou resposta para essa questão, na hipótese de se causar algum dano ao réu, deveria ser resolvida no âmbito do direito privado de reparação de danos. Porém, isso não traz uma resposta segura, pois dificilmente o dano ao princípio da inocência ou do devido processo legal pode ser reparado por valor monetário.

Para se afastar da simples reparação monetária do dano, deve-se advogar que os princípios constitucionais do justo processo, da imparcialidade

\footnotetext{
$40 \quad$ Ibidem. p. 87.
} 
do juiz, do contraditório na aquisição e utilização da prova, da ampla defesa, da presunção de inocência, os quais são densificados e condensados na regra jurídica que veda a divulgação de conteúdo probatório sujeito a segredo de justiça, também mantêm sua eficácia no subsistema do direito processual penal juntamente com a eficácia do princípio da liberdade de imprensa.

Daí por que a necessidade de se buscar uma solução sócio-juridica em que ao mesmo tempo garante-se a liberdade de expressão e de imprensa e um processo justo com todas as suas garantias, mantendo-se a essencial eficacial simultânea a ambos os princípios constitucionais.

Essa é a proposta formulada neste trabalho, ainda que sujeita a críticas ou reformulações.

\section{UMA PROPOSTA DE SOLUÇÃO MEDIANTE}

A MANUTENÇÃO SIMULTÂNEA DA EFICÁCIA NORMATIVA

DOS PRINCÍPIOS DE LIBERDADE DE IMPRENSA E DE UM PROCESSO

PÚBLICO COM TODAS AS GARANTIAS

A proposta que se apresenta para a solução dessa problemática sócio-jurídica é inovadora, não obstante possa estar sujeita a críticas.

Em primeiro lugar, rechaçasse qualquer tentativa jurisdicional que vise à censura prévia dos meios de comunicação em massa, inclusive no que concerne a elementos probatórios existentes em procedimento penal, ainda que sujeitos a segredo de justiça.

Em segundo lugar, assim como o princípio da liberdade de imprensa deve ser garantido em toda sua normatividade, também o princípio do devido processo legal deve ter plena eficácia normativa, especialmente quando em jogo o princípio da inocência.

A solução para esse dilema está no fato de que o conteúdo probatório inserido em um procedimento ou em um processo sob o crivo do segredo de justiça, uma vez divulgado pelos meios de comunicação em massa, não poderá mais ser usado como fundamento para um decreto condenatório no processo penal, não obstante ter sido esse conteúdo probatório licitamente advindo de um meio de prova autorizado legitimamente por um juiz competente.

Essa proposta de solução, ao mesmo tempo em que dá eficácia normativa ao princípio da liberdade de imprensa, uma vez que não haverá qual- 
quer censura prévia aos meios de comunicação em massa para publicação de elementos probatórios (que estão sujeito ao segredo de justiça), também confere eficácia plena ao princípio do devido processo legal, ao tornar essa prova ilegítima (e não ilegal) para a solução no processo penal.

A partir do momento em que os meios de comunicação em massa promovem a divulgação de conteúdo probatório que está sujeito ao segredo de justiça, respaldados pelo princípio constitucional da liberdade de imprensa e comunicação, tal circunstância deslegitima a construção da realidade social no subsistema do processo penal, uma vez que a sua utilização pelos meios de comunicação em massa põe em risco a garantia constitucional de um justo processo e o princípio da inocência.

Evidentemente que a publicação do conteúdo probatório que se encontra sob segredo de justiça não configura uma "prova ilícita", nem um "fruto da árvore envenenada" - (the fruit of the poisonous tree doctrine). ${ }^{41}$

$\mathrm{O}$ termo prova ilícita ${ }^{42}$ foi introduzido no início do século XX por Beling em sua obra Die beweisverbote als grenzen der Wahrheitserforschung im Strafoprozess (Las prohibiciones probatórias como limites de la investigación de la verdad en el processo penal). Beling considerava que todos os casos que ele denominava "proibições probatórias" constituíam limites ao princípio da averiguação da verdade. Diante das proibições probatórias, o jurista alemão distinguia entre as prescrições (Rechtsätze), as quais impediam decidir sobre um determinado fato (proibições probatórias absolutas) e aquelas que se limitavam a estabelecer a inadmissibilidade de um determinado meio de prova (proibições probatórias relativas). ${ }^{43}$

41 Essa teoria tem sua origem na decisão da Suprema Corte norteamericana no caso Lumber Co. vs. US, de 1920.

42 Entres os mais conceituados juristas espanhóis que dedicaram um estudo específico sobre prova ilícita encontram-se: Diáz Cabiale, José Antonio, Martín Morales, La garantía constitucional de la inadmisión de la prueba ilícitamente obtenida, Madrid, Civitas, 2001; Pastor Borgñon, B., Eficacia en el proceso de las pruebas ilícitamente obtenidas, Justicia, 1986; Asencio Mellado, J. M., Prueba prohibida y prueba preconstituida, Madrid, 1989; López Barja de Quiroga, L., La escuchas telefónicas y la prueba ilegalmente obtenida, Madrid, Akal, 1989; Gonzáles Montes, J. L., "La prueba obtenida ilícitamente con violación de los derechos fundamentales", Judicial Protección of Human Rights at the National and Internacional Level, v. II, Milano, Giuffrè, 1991; Miranda Estrampes, M., El concepto de prueba ilicita y su tratamiento en el proceso penal, Barcelona, José María Bosch Editor, 1999.

43 Guariglia, Fabrício, Concepto, fin y alcance de las prohibiciones de valoración probatória en el procedimiento penal. Una propuesta de fundamentación, Buenos Aires, Editores del Puerto, 2005, p. 8. 
Contudo, essa expressão (prova ilícita) não deixa de ter detratores inclusive dentro da própria doutrina alemã. Segundo J. L. Gómez Colomer, o termo 'prova proibida' é uma tradução incorreta do alemão, pois a doutrina emprega dito termo sempre no plural, refere-se sempre a 'proibições' de prova, dado que existem várias conjecturas e não uma só. De toda forma, como aponta o aludido autor, é um nome cômodo e gráfico para designar aquelas conjecturas nas quais a prova é inadmissível, (ilícita, na terminologia italiana), isto é, não se pode praticar, ou os seus resultados não podem ter aplicação, ser aproveitados no processo. ${ }^{44}$

$\mathrm{O}$ certo é que frequentemente empregam-se diversos termos indistintamente, como por exemplo: "prueba prohibida o prohibiciones probatorias, prueba ilegal o ilegalmente obtenida, prueba ilícita o ilicitamente obtenida, prueba ilegítima obtenida, prueba inconstitucional, prueba nula, prueba viciada, prueba irregular, o incluso el de prueba clandestina" ${ }^{45}$

$\mathrm{Na}$ doutrina espanhola, distingue-se entre a prueba ilícita e a prueba prohibida. Segundo Gimeno Sendra, a primeira é a que infringe qualquer lei (não somente a fundamental, senão também a legislação ordinária), a "prova proibida", por sua vez, é a que surge com violação das normas constitucionais tuteladoras dos direitos fundamentais. ${ }^{46}$

A doutrina espanhola, na realidade, prefere falar em provas obtidas com violação de direitos fundamentais', ao invés de 'provas inconstitucionais', como faz, por exemplo, a doutrina italiana. Sobre a importância da diferença, ver a Sentença do Tribunal Supremo espanhol (Sala Segunda) de 3 julho de 1999.

A divulgação do conteúdo probatório proveniente de uma prova submetida ao segredo de justiça, como se afirmou, não configuraria uma prova ilícita (uma vez que sua introdução ao processo ou ao procedimento penal foi por autorização de um juiz competente), mas, sim, uma prova inconstitucional, ilegítima, proibida e ineficaz para o subsistema do processo

44 Miranda Estrampes, Manuel, El concepto de prueba ilicita y su tratamiento en el proceso penal, 2a. ed., Barcelona, J. M. Bosch Editor, 2004, p. 17.

45 Ibidem, p. 17 e 18; no mesmo sentido: Sabastián Midón, Marcelo, Pruebas ilícitas. Análise doctrinario y jurisprudencial, 2a. ed., Buenos Aires, Ediciones Jurídicas Cuyo, s/d., p. 29; Guariglia, F., op. cit. p. 7.

Ada Pellegrini Grinover, por sua vez, afirma que o conceito de 'prova ilícita' estaria inserido dentro de uma categoria mais ampla das "provas proibidas", havendo entre elas uma relação de gênero e espécie (Grinover, Ada Pellegrini, "Pruebas ilícitas", Derecho penal. Derecho procesal penal, Buenos Aires, Abeledo-Perrot, 1997, p. 306).

46 Miranda Estrampes, M., op. cit., p. 18. 
penal, tendo em vista que viola o direito fundamental a um processo justo com todas as garantias (art. 24 da Constituição espanhola), assim como o art. 5o., inc. LIV da Constituição Federal brasileira (ninguém será privado da liberdade ou de seus bens sem o devido processo legal).

É possível a existência de prova ilícita quando existe lesão a um direito fundamental, porém, nem sempre que um direito fundamental resulta menosprezado numa atuação processual ou procedimental cabe falar de ilicitude do processo ou do procedimento. Por exemplo, se se da leitura em juízo oral de um informe pericial, levado a cabo no procedimento preliminar sem que a defesa pudesse intervir, e sem que se possa realizar o contraditório, lesiona-se o direito de defesa. Há uma lesão de um direito fundamental e se trata de atividade probatória, porém não há prova ilícita. ${ }^{47}$

A prova inconstitucional seria, por sua vez, aquela "prove ottenute attaverso modalità, metodi e comportamenti realizzati in dispregio dei fondamentali diritti del cittadino garantiti dalla Constituzione". ${ }^{48} \mathrm{E}$ dentre esses direitos fundamentais está a garantia de que o processo submetido ao crivo de segredo de justiça não será objeto de conhecimento do público em geral.

A modalidade (quebra de sigilo) é reconhecida pelo ordenamento jurídico, mas o método e comportamento realizados em desprestígio aos direitos fundamentais do cidadão (divulgação massificada pela imprensa do conteúdo probatório, ainda que respaldada pelo princípio da liberdade de imprensa) não, pois, nesse caso, se põe em risco os princípios constitucionais do contraditório na formação da prova e da presunção de inocência ${ }^{49}$, enfim, coloca em risco o processo justo com todas as garantias.

Não só a presunção de inocência pode ver-se comprometida pela intervenção abusiva dos meios de comunicação, mas também e muito frequen-

47 Díaz Cabiale, José A. y Martín Morales, Ricardo, La garantía constitucional de la prueba ilícitamente obtenida, Madrid, Civitas, 2001. p. 22.

48 Allena, G., "Riflessioni sul concetto di incostituzionalità della prova nel processo penal", Rivista Italiana di Diritto e Procedura Penale, aprile/giugno, 1989, pp. 506 e seguintes.

49 "SSTC 127/1996, 54/1996, 86/1995: "El derecho a la presunción de inocencia exige, en último término, que la prueba se realice a través de los medios que sean constitucionalmente legítimos, lo que supone que en su obtención se hayan respectado los derechos fundamentales". Pero también se ha señalado que el encuadre de la exclusión de las pruebas se encuentra en el derecho al proceso con todas as garantías, artículo 24.2, y a la igualdad de las partes, artículo 14, SSTC 49/1996, 114/1984... (Díaz Cabiale, José A. y Martín Morales, Ricardo, La garantía constitucional de la prueba ilícitamente obtenida, Madrid, Civitas, 2001, pp. 29 e 30). 
temente a independência e a imparcialidade dos juízes e tribunais, já que a publicação sobre reais e supostos estados de opinião sobre o conteúdo do processo e o sentido da decisão podem influir na decisão judicial. Proporcionar uma proteção eficaz diante dos 'julgamentos paralelos' constitui a nova fronteira do que há de ser chamado a necessidade de se redefinir a relação entre justiça e opinião pública. É um motivo de constante preocupação doutrinária (Hernández García; Latorre) que se há estendido para a jurisprudência constitucional (STC 132/1999), fazendo-se eco na doutrina assentada na STEDH de 29 de agosto de 1977, caso Worm v. Áustria. ${ }^{50}$

Na doutrina espanhola, Vives Antón aduz que somente a verdade obtida com o respeito às regras básicas constituídas pelos direitos fundamentais pode estimar-se como juridicamente válida. Os direitos fundamentais delimitam o caminho a seguir para obter conhecimentos juridicamente válidos. Os obtidos com vulneração a tais direitos haverão, em todo caso, de ser rechaçados: não é somente que a sua verdade resulte suspeita, senão que nem sequer podo ser levada em consideração. ${ }^{51}$

O Tribunal Constitucional espanhol, na Sentença n. 114/1984, de 29 de novembro, destaca em caráter absoluto a inadmissibilidade processual das provas obtidas por meio de violação de direitos ou liberdades fundamentais. Sustentou-se que a inadmissibilidade dessas provas decorre da superioridade dos direitos fundamentais no ordenamento jurídico e sua condição de inviolabilidade. Essa decisão está de acordo com "la regra de exclusión" 52 prevista no artigo 11.1 de la Ley Orgánica del Poder Judicial ${ }^{53}$

50 López Ortega, Juan J., "Información y justicia", Justicias y Medios de Comunicación, Cuadernos de Derecho Judicial, Madrid, XVI, 2006, pp. 119 e 120.

51 Vives Antón, Tomás S., "Doctrina constitucional y reforma del proceso penal' en Jornadas sobre la Justicia Penal en España”, Revista Poder Judicial, número especial II, pp. 125 e 126 - citação em Miranda Estrampes, M., op. cit., p. 56.

52 "Aunque hay distintas visiones sobre este particular, considero que los primeros desarrollos de la regla de exclusión en el ámbito de los procesos penales federales se produjeron en 1914 con la sentencia dictada en el caso 'Weeks v. Unitad States, 232 U.S. 383 (1914); y el punto de máxima extensión de la misma vino con la sentencia 'Mapp v. Ohio, 367 U.S. 643 (1961)". (Fidalgo Gallardo, Carlos, Las 'pruebas ilegales': de la exclusionary rule estadounidense al artículo 11.1 LOPJ, Madrid, Centro de Estudios Políticos y Constitucionales, 2003, p. 18).

53 "Una revisión de los tres volumenes editados en Madrid, 1986, por las Cortes Generales, con el título 'Ley Orgánica del Poder Judicial. Trabajos parlamentarios, muestra, ante todo, que la cuestión de la ineficacia de fuentes de prueba a causa de la ilicitud en su obtención no es tratada, en ningún sentido, en el Proyecto de Ley enviado por el Gobierno al Congreso de los Diputados. Es la enmienda número 952, presentada por el Grupo 
que diz: "não surtirão efeitos as provas obtidas, direta ou indiretamente, violentando os direitos e liberdade fundamentais".

A decisão proferida na Sentença 64/1986, manteve a perspectiva:

restritiva ou reducionista do âmbito de aplicação e operatividade do artigo 11.1 da L.O.P.J. Na aludida sentença estabeleceu-se que a doutrina da inadmissibilidade das provas obtidas com violação de direitos fundamentais era aplicável unicamente à 'vulneração de direitos fundamentais que se cometa ao obter as provas', porém não à 'que se produza no momento de suas admissão no processo, ou de sua prática nele, pois, em relação a estes últimos momentos, os problemas que se podem colocar reconduzem-se à regra de 'interdicción de la indefensión'. Segundo esta interpretação, o âmbito de aplicação do artigo 11.1. L.O.P.J. ficou limitada, portanto, àquelas violações de direitos fundamentais produzidas por ocasião da investigação dos fatos em sede sumarial, isto é, durante o trabalho de busca e captação de fontes de prova. Pelo contrário, quando a vulneração de direitos fundamentais tenha lugar no momento de sua admissão no processo ou de suas prática no ato do julgamento oral será aplicado a disposição do artigo 238.3 da L.O.P.J., que condiciona a nulidade das atuações processuais à produção de efetiva falta de defesa... Esta interpretação constitucional, avalizada por um setor da doutrina, conduz a que a infração de direitos fundamentais durante o procedimento probatório (proposição, admissão e prática da prova) não pode ser alegada pela via do artigo 11.1 da L.O.P.J., devendo-se recorrer ao regime geral da nulidade dos atos processuais... ${ }^{54}$

Popular, la que propone que, en artículo 11 de dicha Ley Orgánica (LOPJ), aparezca, tras la mención al debido respecto a las reglas de la buena Fe, el siguiente texto: "No surtirán efecto, en ninguna clase de procesos, los medios de prueba obtenidos, directa o indirectamente, de modo contrario a la ética o al Derecho" (vide PP. 527 y 528 del vol. I de ya citada publicación, Ley Orgánica del Poder Judicial. Trabajos parlamentarios).

Esta enmienda no es asumida por la Comisión, pero se mantiene para el Pleno del Congreso, donde, siendo 262 los diputados presentes, se registran 255 votos a favor, 3 en contra y 4 abstenciones. Así, pues, se incorpora al texto de la LOPJ aprobado por la Cámara Baja.

En el Senado, la enmienda número 374, del Grupo Socialista (ibíd., pp,. 1801 y 1802 del vol. II), asumida por la Ponencia, introduce, en lugar del texto que acabo de transcribir, este otro: 'No surtirán efecto las pruebas obtenidas, directa o indirectamente, violentando los derechos o libertades fundamentales'. La justificación es escueta: '...la referencia a las pruebas se acomada a lo declarado por el Tribunal Constitucional en Sentencia dictada en el Recurso 114/84" (De la Oliva Santos, Andrés, Prólogo à obra de Carlos Fidalgo Gallardo, Las "pruebas ilegales": de la exclusionary rule estadounidense al artículo 11.1 LOPJ, Madrid, Centro de Estudios Políticos y Constitucionales, 2003, p. XXIII e XIV).

54 Miranda Estrampes, M., op. cit., p. 69.

Esta obra está bajo una Licencia Creative Commons Atribución-NoComercial-SinDerivar 4.0 Internacional, IIJ-UNAM. 
Não obstante a divulgação à opinião pública do conteúdo probatório, objeto de "quebra de sigilo", possa configurar violação ao direito fundamental de sigilo de correspondência e de telecomunicação previsto na Constituição, a argumentação defendida neste trabalho não está inserida no âmbito interpretativo dado pelo Tribunal Constitucional espanhol na decisão n. 64/1986.

Em primeiro lugar, não se sustenta a ilicitude da quebra de sigilo, muito menos a ilicitude de sua divulgação pelos meios de comunicação em massa (respalda-se a liberdade de imprensa em sua máxima eficacial). A princípio, essa argumentação pode parecer contraditória, mas, na sequência da exposição pretende-se harmonizar esses interesses contrapostos. ${ }^{55}$

$\mathrm{Na}$ verdade, diante da autonomia existente entre o subsistema midiático e o subsistema penal e processual penal não haveria restrição ou censura prévia à publicação da prova que se encontra em segredo de justiça pelo subsistema dos meios de comunicação em massa, uma vez que essa publicação estaria amparada pelo princípio constitucional da liberdade de expressão e informação.

Contudo, uma vez publicada, e agora já no âmbito do subsistema do processo penal e do direito penal, ocorreria a inutilizabilidade (inutilidade) dessa prova como fundamento para respaldar um decreto condenatório, uma vez que a violação do segredo de justiça configuraria violação a um direito fundamental, qual seja, ao princípio do contraditório na formação da prova, à imparcialidade do juiz e à ampla defesa. Há, portanto, a necessidade de harmonização desses interesses contrapostos. ${ }^{56}$

Em segundo lugar, mesmo que a tese aqui defendida estivesse inserida no âmbito de interpretação da Sentença 64/1986, a solução preconizada neste trabalho não estaria em desarmonia com a aludida decisão, uma vez que a obtenção da prova (obtener prova, segundo a expressão do art. 11.1

55 "Es preciso no olvidar, que ese enfrentan en esta material muchos puntos de fricción provocados por intereses contrapuestos: de un lado, el interés del Estado en administrar justicia con independencia e imparcialidad, de otro, el interés del individuo en que se respete su esfera de libertad personal, y por último el interés de la opinión pública en estar informada" (Otero Gonzáles, M. P., op. cit., p. 44). No mesmo sentido, Pisapia, Gian Domenico, Il segreto istruttorio nel proceso penale, Milano, Giuffrè, 1960, pp. 40, 220 e 221.

56 Essa ponderação de interesses foi assim delineada pelo Tribunal Constitucional espanhol na Sentença 114/1984, de 29 de novembro (RTC 1984, 114): "Hay, pues, que ponderar, en cada caso, los intereses en tensión para dar acogida preferente en su decisión a uno u otro de ellos (intereses público en la obtención de la verdad procesal e interés, también, en el reconocimiento de plena eficacia a los derechos constitucionales". 
da LOPJ) em matéria de "quebra de sigilo" não se concretiza apenas no ato processual isolado de autorização do juiz para a quebra de sigilo, mas a sua completude e obtenção em definitivo dependem daquilo que a constituição italiana denomina de contraditório na formação da prova, em outras palavras, a prova somente será considerada obtida e, portanto, legítima, após se dar a oportunidade ao contraditório. Sem contraditório não há prova, sem contraditório não há obtenção de prova.

No caso, a prova colhida licitamente no procedimento ou no processo penal por determinação do juiz, e que se encontra em segredo de Justiça, torna-se imprestável para um decreto condenatório na hipótese de os meios de comunicação divulgarem de forma ilegítima (proibição de mácula a direito fundamental) e não ilícita esse conteúdo probatório.

Nesse sentido, a prova ilegitimamente (ou inconstitucionalmente) divulgada pelos meios de comunicação em massa torna-se inútil para o processo penal.

Conforme bem delineado pela professora de Procedura Penale nell' Università degli Studi di Milano, Novella Galantini, o instituto da "inutilizzabilità" coincide com a sanção delineada pelo artigo 191 do Código de Processo Penal italiano que compreende tanto a inutilizabilidade patológica como a fisiológica, apesar de o conceito de inutilizabilidade ter significado mais amplo, podendo nesse compreender-se além do aspecto sancionatório, também o aspecto de inutilizabilidade como efeito induzido pela violação de limites probatórios que não integram proibições em sentido próprio. Nessa prospectiva, pode-se afirmar que o conceito é único, caracterizando-se por determinados elementos que necessariamente implica (tal qual a exclusão da prova, ou a ideia de relação que isso sugere), apesar de que as espécies são diversas, sendo a inutilizabilidade referida a situações diversificadas, integradas por vícios ou pelo simples limite do ato. ${ }^{57}$

Diante dessa distensão entre princípios constitucionais, o conteúdo probatório divulgado pelos meios de comunicação em massa estaria sob o resguardo do princípio da liberdade de expressão e de comunicação, sendo lícita a sua publicação no âmbito restrito e delimitado do subsistema dos mass media. Contudo, para os efeitos jurídicos do subsistema social do processo penal, que é independentemente do subsistema midiático, a prova, que até então era considerada lícita, passou, a partir de sua divulgação

57 Galantini, Novella, L'inutilizzabilità della prova nel processo penale, Milano, CEDAM, 1992, p. 25. 
pela imprensa, a ser considerada uma prova ilegítima, e, portanto, inútil (inutilizabilidade) para fundamentar um decreto condenatório.

É certo que alguns poderiam por em dúvida essa solução, sob o argumento de que a própria defesa poderia entregar o conteúdo probatório aos meios de comunicação em massa, justamente para caracterizar a imprestabilidade da prova no âmbito do processo penal. Porém, uma vez comprovada má-fé da defesa, como ato atentatório à dignidade da justiça, esse objetivo não poderia ser alcançado em face do princípio geral de direito de que "ninguém pode ser beneficiado da própria torpeza". Provada a má-fé da defesa, a prova entregue aos meios de comunicação em massa poderia servir de base para um decreto condenatório.

Outros questionamentos que poderiam ser trazidos em relação à tese proposta, diz respeito ao princípio 'in dubio pro societatis', efetividade do processo penal e a verdade real, uma vez que a decretação da inutilidade da prova poderia ensejar máculas a esses princípios.

Porém, não há dúvida que o direito fundamental ao 'devido processo legal' deve sobrepor-se ao princípio do 'in dubio pro societatis', à efetividade da decisão condenatória e mesmo à verdade real, pois a presunção de inocência e a efetividade do contraditório são a garantia de um processo legítimo no Estado democrático de direito.

Além do mais, a tese proposta repassa aos meios de comunicação a responsabilidade social quanto ao destino do processo penal, ou seja, muito embora os meios de comunicação em massa possam divulgar algum elemento de prova sujeito ao crivo do segredo de justiça, amparados na liberdade de imprensa, será de sua total responsabilidade a declaração de inutilidade da prova no processo penal, uma vez que essa divulgação fere direito fundamental do acusado a um processo justo com todas as suas garantias

\section{CONCLUSÃO}

A decisão proferida pelo Juízo da Quarta Vara Criminal do Rio de Janeiro, ao proibir a divulgação dos dados obtidos pela emissora de televisão, Rede Globo, não observou o princípio constitucional da liberdade de imprensa conjugado com o da liberdade de expressão, uma vez que estabeleceu censura prévia aos critérios informativos futuros que poderiam ser divulgados pelos meios de comunicação em massa. 
Em face da plena eficácia do princípio da liberdade de imprensa, fica vedado o controle prévio do Poder Judiciário ao conteúdo informativo obtido pelos meios de comunicação em massa.

Porém, a Constituição Federal brasileira, ao garantir ao réu o direito fundamental ao processo público com todas as garantias, conferiu aos litigantes e aos acusados de modo geral a garantia ao devido processo legal, razão pela qual, os elementos de prova que foram publicados pelos meios de comunicação em massa tornam-se imprestáveis para o subsistema do processo penal.

A tese da inutibilidade da prova é a solução proposta para o distensionamento entre o princípio da liberdade de imprensa e do devido processo legal.

\section{BIBLIOGRAFIA}

ALEXY, Robert, Teoria de los derechos fundamentales, Madrid, Centro de Estudios Constitucionales, 1997.

ALLENA, Gianni, "Riflessioni sul concetto di incostituzionalità della prova nel processo penale", Rivista Italiana di Diritto e Procedura Penale, fascículo núm. 2, abril-junio, 1989.

Asencio Mellado, J. M., Prueba prohibida y prueba preconstituida, Madrid, 1989.

BERTONI, Eduardo A., "La crítica política y su relevancia para los tribunales internacionales", Libertad de prensa y derecho penal, Buenos Aires, Del Puerto, 1997.

BINDER, Alberto M., Introducción al derecho procesal penal, Buenos Aires, Ad-Hoc, 1993.

Bovino, Alberto "Publicidad del juicio penal: la televisión en sala de audiencias", Libertad de prensa y derecho penal, Buenos Aires, Del Puerto, 1997.

CABrera, Carmen Sáez e SAltor, Carlos Eduardo, "Spinoza y la libertad de opinión", Revista de la Facultad de Derecho de la Universidad Complutense, Madrid, núm. 91, 1998.

Canotilho, José Joaquim Gomes e Moreira, Vital, Fundamentos da constituição, Coimbra, Coimbra Editora, 1991. 
CURRAn, James, Medios de comunicación y poder en una sociedad democrática, trad. Moan Quesada, Barcelona, Hacer Editorial, 2002.

De Gregorio, Giulio G., "Diritti inviolabili dell'uomo e limiti probatori nel processo penale," Foro Italiano, I, 1992.

DE LA Oliva SAntos, Andrés, prólogo à obra de Carlos Fidalgo Gallardo, Las 'pruebas ilegales': de la exclusionary rule estadounidense al artículo 11.1 LOPJ, Madrid, Centro de Estudios Políticos y Constitucionales, 2003.

Díaz CABIAle, José A. y MARTín Morales, Ricardo, La garantía constitucional de la prueba ilícitamente obtenida, Madrid, Civitas, 2001.

DWORKIN, Ronald, Levando os direitos a sério, São Paulo, Martins Fontes, 2002.

Ferrajoli, Luigi, Derechos y garantias. La ley del más débil, Madrid, Trotta, 2001.

Fidalgo Gallardo, Carlos, Las 'pruebas ilegales': de la exclusionary rule estadounidense al artículo 11.1 LOPJ, Madrid, Centro de Estudios Políticos y Constitucionales, 2003.

Fontán, Antonio, Prensa, democracia y libertad, Ciudad de México, Fondo de Cultura Económica, 2017

GaLANTINI, Novella, L'inutilizzabilità della prova nel processo penale, Milano, CEDAM, 1992.

GONZÁLES MONTES, J. L., "La prueba obtenida ilícitamente con violación de los derechos fundamentales", Judicial Protección of Human Rrights at the National and Internacional Level, vol. II, Milano, Giuffrè, 1991.

Grinover, Ada Pellegrini. "Pruebas ilícitas", Derecho penal. Derecho procesal penal, Buenos Aires, Abeledo-Perrot, 1997.

GuARIGLIA, Fabrício, Concepto, fin y alcance de las prohibiciones de valoración probatória en el procedimiento penal. Una propuesta de fundamentación, Buenos Aires, Editores del Puerto, 2005.

Giostra, Glauco, Processo penale e informazione, 2a. ed., Milano, Giuffrè, 1989.

GuLLCO, Hernán, "V. La libertad de expresión y el discurso basado en el odio racial o religioso", Libertad de prensa y derecho penal, Buenos Aires, Editores del Puerto, 1997. 
Kagelmann, H. Jürgen y Wenninger, Gerd, Psicología de los medios de comunicación. Manual de conceptos básicos, Barcelona, Herder, 1986.

KURY, Helmut, "Mass media e criminalità: l'esperienza tedesca", trad. Carlo Ruga Riva e Arianna Cremona, La televisione del crimine, a cura di Gabrio Forti e Marta Bertolino, Milano, V\&P Università, 2005.

LÓPEZ BARJA DE QUIROGA, L., Las escuchas telefónicas y la prueba ilegalmente obtenida, Madrid, Akal, 1989.

LÓPEZ JiMÉNEZ, Raquel, La prueba en el juicio por jurados. Valencia: Tirant lo Blanch, 2002.

LÓPEZ ORTEGA, Juan J., "Información y justicia", Justicias y Medios de Comunicación, Cuadernos de Derecho Judicial, Madrid, XVI, 2006.

MAGDAlEno AlegríA, Antonio, Los límites de las libertades de expresión e información en el Estado social y democrático de derecho, Madrid, Congreso de los Diputados, 2006.

Miranda ESTRAMPES, M., El concepto de prueba ilícita y su tratamiento en el proceso penal, Barcelona, José María Bosch Editor, 1999.

MuÑOz GÁLVEZ, Luis, La ineficacia de la prueba obtenida con violación de derechos fundamentales. Normas y jurisprudência (TEDH, TC, TS, TSJ y AP) en los âmbitos penal, civil, contencioso-administrativo y social), Navarra, Aranzadi, 2003.

NinO, Carlos Santiago, Fundamentos de derecho constitucional, Buenos Aires, Astrea, 1992.

PASTOR BorgÑON, B., Eficacia en el proceso de las pruebas ilícitamente obtenidas, Justicia, 1986.

PISAPIA, Gian Domenico, Il segreto istruttorio nel proceso penale, Milano, Giuffrè, 1960.

SABASTIÁn Midón, Marcelo, Pruebas ilícitas. Análise doctrinario y jurisprudencial, 2a. ed., Buenos Aires, Ediciones Jurídicas Cuyo, s/d.

SAlazAr Ugarte, Pedro y GutiÉRrez Rivas, Rodrigo, El derecho a la libertad de expresión frente al derecho a la no discriminación. Tensiones, relaciones e implicaciones, México, UNAM, Instituto de Investigación Jurídicas-Consejo para Prevenir la Discriminación, 2008.

VÉlez MARICONDE, Alfredo, Derecho procesal penal, Córdoba, Lerner, t. I. 1986. 


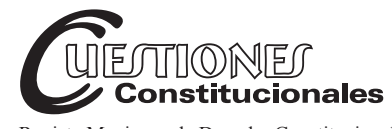

Revista Mexicana de Derecho Constitucional Núm. 43, julio-diciembre 2020

\author{
O Supremo Tribunal Federal do Brasil e o caso das terras \\ ocupadas pelos remanescentes quilombolas. Estudo de caso \\ a partir da ação direta de inconstitucionalidade n. 3.239-DF
}

\author{
The Supreme Federal Court of Brazil and the case of the lands \\ occupied by the kilombolan remanescents. Case study \\ from the direct action of unconstitutionality n. 3.239-DF
}

\title{
Frederico Ribeiro de FReITAS MENDES* Matheus Felipe DE CASTRO**
}

RESUMO: O Supremo Tribunal Federal do Brasil vem enfrentando temas controvertidos em matéria de direitos fundamentais e que envolvem inclusive direitos de povos e culturas numa nação multiétnica e plural. O presente estudo busca contribuir com as discussões jurídicas que envolvem a questão das terras ocupadas pelos remanescentes quilombolas no Brasil. Para tanto, o estudo analisará o julgamento da Ação Direta de Inconstitucionalidade n. 3.239-DF, que tramitou na Suprema Corte brasileira, e os possíveis reflexos jurídicos e sociais provocados pela decisão. Estruturado através do método indutivo, busca descrever o desenvolvimento processual do caso e suas especificidades. Examina o voto condutor do de-
ABSTRACT: The Federal Supreme Court of Brazil has been facing controversial issues in the area of fundamental rights, including the rights of peoples and cultures in a multiethnic and plural nation. The present study aims to contribute to the legal discussions that involve the question of lands occupied by the remaining quilombolas in Brazil. Therefore, the study will analyze the judgment of the Direct Action of Unconstitutionality n. 3,239-DF, which was processed in the Brazilian Supreme Court, and the possible legal and social reflexes provoked by the decision. Structured through the inductive method, it seeks to describe the procedural development of the case and its specificities. It examines the voting vote of the

* Master en Derecho de la Universidad Federal de Santa Catarina (UFSC-BRASIL), Profesor de la Universidad del extremo sur de Santa Catarina (UNESC-BRASIL). Brasil. ORCID: 0000-0002-5896-7519. Correo electrónico: fredericorfm@gmail.com.

** Pós-doutor em Direito pela UNB - Universidade de Brasília (Brasil, 2018) e Doutor em Direito pela UFSC - Universidade Federal de Santa Catarina (Brasil, 2009). Professor na UFSC e no mestrado da UNOESC - Universidade do Oeste de Santa Catarina. Brasil. ORCID: 0000-0002-0534-7981. 
bate, bem como explora os aspectos controvertidos dos votos divergentes. Procede na releitura dos argumentos lançados pelos ministros julgadores e que fundamentaram a decisão final do Supremo Tribunal Federal do Brasil, correlacionando-a com possíveis controvérsias na sua concretização.

Palavras chave: direitos fundamentais, povos tradicionais, demarcação de terras, remanescentes quilombolas, Supremo Tribunal Federal, Brasil. debate, as well as explores the controversial aspects of the divergent votes. Proceed in the re-reading of the arguments launched by the judges ministers and that based the final decision of the Federal Supreme Court of Brazil, correlating it with possible controversies in its accomplishment.

Keywords: fundamental rights traditional people, demarcation of Lands, remaining quilombolas, Federal Court of Justice, Brazil.

SumÁrio: I. Introdução. II. Desenvolvimento processual. III. Fundamentos da ADI n. 3.239-DF. IV. Votos e fundamentos divergentes. V. Considerações críticas. VI. Bibliografia.

\section{INTRODUÇÃO}

A conquista por direitos inerentes à população negra no Brasil, intrinsicamente relacionados com seu modo de viver, existir e de se relacionar com a terra, passou (e passa) por obstáculos no seu reconhecimento. Somado a isso, a proteção normativa nem sempre é dotada da concretude necessária para seu reconhecimento.

O estudo da questão racial no Brasil transpassa mais de 500 anos de regime escravocrata, desde a era "colonial", passando pelo Império, até os dias atuais. A escravidão praticada no Brasil deixou profundas marcas que vão além do contexto jurídico, cujas questões multiculturais, econômicas e sociais demandam um (novo) repensar alicerçado nos discursos ético e multicultural, respeitando as múltiplas diversidades e peculiaridades de cada grupo social.

Consiste na inevitável releitura da questão racial, indissociável de sua natureza (jurídica social, histórica, antropológica ou de qualquer outro ponto de partida) como um direito fundamental, manifestando-se, em casos concretos, na difícil relação dialética entre proteção-implementação.

Nesse contexto, a demarcação de terras ocupadas por remanescentes quilombolas, a despeito de possuir previsão legal no art. 68 dos Atos das Disposições Constitucionais Transitórias (ADCT) da Constituição Federal 
de 1988 e ser regulamentado pelo Decreto n. 4.887/2003, foi objeto da Ação Direta de Inconstitucionalidade (ADI) n. 3.239-DF.

Diante do julgado paradigmático, por meio do método indutivo com viés descritivo e analítico, o presente estudo de caso busca, em um primeiro momento, retratar as peculiaridades processuais da ADI n. 3.239-DF.

$\mathrm{Na}$ sequência, expõe os argumentos do voto revisor da ministra Rosa Weber, que julgou improcedentes os pedidos e foi seguido pela maioria do Supremo Tribunal Federal do Brasil (STF). Ainda, pela importância da ratio decidendi, descreve os fundamentos dos ministros que adotaram posicionamentos divergentes da Ministra Rosa Weber.

Ao final, são sintetizados os argumentos lançados na ADI n. 3.239-DF, bem como analisadas as respectivas fundamentações, correlacionando-as com as possíveis consequências no ordenamento jurídico para as comunidades remanescentes quilombolas em perspectivas atual e pro futuro.

\section{DESENVOLVIMENTO PROCESSUAL ${ }^{1}$}

O Partido da Frente Liberal (atual Partido Democratas) ${ }^{2}$ ajuizou, em 24.06.2003, Ação Direta de Inconstitucionalidade no Supremo Tribunal Federal do Brasil questionando a constitucionalidade Decreto n. 4.887/2003, que regulamenta o procedimento para identificação, reconhecimento, delimitação, demarcação e titulação de terras ocupadas por remanescentes das comunidades quilombolas, conforme prescreve o artigo 68 dos Atos das Disposições Constitucionais Transitórias da Constituição Federal de 1988 (ADCT).

Sustentou que: $i$. o referido decreto seria inconstitucional por ser ato normativo secundário e, por isso, estaria invadindo competência reservada à lei em sentido estrito; ii. o decreto configuraria verdadeira desapropriação inconstitucional, cabendo ao Instituto Nacional de Colonização e

1 As informações do desenvolvimento processual foram extraídas de: Supremo Tribunal Federal, Ação Direta de Inconstitucionalidade n. 3.239-DF, 2018, acesso em 24 maio de 2018.

2 O Partido da Frente Liberal (PFL) foi fundado em 11 de setembro de 1985, logo após a redemocratização do Brasil. Possuía orientação ideológica de "centro-direita" e grande aproximação junto aos grandes proprietários (e produtores) de latifúndios que, dentre outros fatores, explica o porquê do ajuizamento da ação direta de inconstitucionalidade questionando a demarcação de terras ocupadas pelos quilombolas. 
Reforma Agrária (INCRA) a sua realização; iii. a inconstitucionalidade do critério adotado para a identificação dos remanescentes titulares dos direitos mencionados no artigo 68 do ADCT (denominou de "auto-gestão"); e $i v$. a caracterização das terras a serem reconhecidas são excessivamente amplas e sujeitas aos indicativos fornecidos pelos próprios interessados (remanescentes quilombolas).

A inicial foi autuada sob a ADI n. 3.239-DF e distribuída ao relator, ministro Cezar Peluso que, diante da relevância do tema, suscitou urgência na apreciação pelo Colegiado do Supremo Tribunal Federal, nos termos do art. 12 da Lei n. 9.868/99, com imediata notificação à Advocacia Geral da União (AGU) e ao Ministério Público Federal (MPF).

$\mathrm{O}$ advogado geral da União entendeu que $i$. a ADI não deveria ser conhecida por inexistir ofensa direta à Constituição; ii. no mérito, pugnou pela sua improcedência. O Ministério Público Federal, ${ }^{3}$ em parecer lavrado pelo procurador regional da República Daniel Sarmento, divergiu em parte da Advocacia Geral da União (AGU). ${ }^{4}$ Sustentou que a demanda não deveria ser conhecida porquanto o Decreto objeto de questionamento seria fruto de repristinação do Decreto n. 3.912/01, pois “este contém o mesmo suposto vínculo atribuído à norma que o revogou. Como não foi requerida pelo Autor a invalidação do Decreto n. 3.912/01, a hipótese é de não conhecimento da ação". Em sua fundamentação, os seguintes argumentos merecem destaques:

a) o artigo 68 do ADCT é dotado de aplicabilidade imediata;

b) o Decreto 4.887/03 encontra validade na Lei 9.784/99 (legal) e na Convenção 169 da Organização Internacional do Trabalho - OIT (supralegal);

c) a autoaplicabilidade do artigo 68 do ADCT e a Força Normativa da Constituição obrigam a administração pública federal dar efeitos concretos aos mandamentos constitucionais;

d) as propriedades das terras ocupadas pelos remanescentes quilombolas foram transferidas pelo próprio Poder Constituinte; ao Estado cabe apenas concretizá-los;

3 Órgão dotado de autonomia e independência funcional nas suas manifestações cuja missão constitucional, dentre outras, está atrelada a defesa de índios, quilombolas, minorias e grupos em situação de vulnerabilidade.

4 Trata-se de órgão estatal responsável pela defesa judicial e extrajudicial dos interesses da União no Brasil. 
e) atribuir interpretação conforme à Constituição para firmar o entendimento que a transferência de propriedade antecede ao próprio ato desapropriatório, ressalvado o direito de indenização dos antigos proprietários;

f) pugnou pela constitucionalidade do critério de autodefinição dos remanescentes de quilombos, nos termos da Convenção 169 da OIT, até porque não seria o único critério adotado para sua configuração;

g) advogou a constitucionalidade da definição das terras ocupadas em harmonia com o artigo 215 da Constituição de 1988.

Durante o trâmite processual, diversas entidades ingressaram no feito como amicus curiae, destacando-se o Instituto Pro Bono, Conectas Direitos Humanos, Sociedade Brasileira de Direito Público, Confederação da Agricultura e Pecuária do Brasil (CNA, com participação do ministro aposentado do STF Ilmar Galvão), Confederação Nacional da Indústria (CNI), dentre outras. Sobressaiu, ainda, o Parecer lavrado pelo ministro aposentado do STF Carlos Velloso que, dentre outros argumentos, sustentou a impossibilidade de regulamentação do tema exclusivamente por decreto na ausência de lei em sentido material.

Após o regular trâmite processual, com expedição de ofícios e sustentações orais, o julgamento foi iniciado em 18.04.2012 - onze anos após seu ajuizamento. $\mathrm{O}$ relator, ministro Cezar Peluso, rejeitou as preliminares e votou pela procedência dos pedidos (inconstitucionalidade do Decreto n. 4.887/03), especialmente em relação aos seguintes pontos:

a) dos critérios de autoatribuição e autodefinição para caracterizar o que se quem são os remanescentes quilombolas;

b) da fixação do que são terras ocupadas por remanescentes;

c) dos critérios de territorialidade eleitos;

d) que o artigo 68 do ADCT implementou nova modalidade de desapropriação e que, por isso, não houve o devido processo legal em razão de inexistir lei que trate sobre o assunto. Disse residir "a mais flagrante inconstitucionalidade".

e) propôs modulação dos efeitos da inconstitucionalidade, em homenagem ao princípio da segurança jurídica, para considerar como válidos os títulos emitidos até a decisão final do Supremo.

Entretanto, o voto do ministro relator, em que pesem os argumentos, mostrou-se isolado. Por outro lado, o voto da ministra Rosa Weber (revisora), que apresentou seus fundamentos na sequência, foi seguido pela maioria do Colegiado e por isso será descrito com maior profundidade. 


\section{FUNDAMENTOS DA ADI N. 3.239-DF}

A ministra revisora Rosa Weber, iniciou seu voto afastando as preliminares de não cabimento da ADI em razão da natureza autônoma e abstrata do Decreto que regulamenta a matéria, da ausência de cotejo analítico - especificação dos dispositivos questionados e do óbice à cognoscibilidade da ação direta a ausência de pedido de declaração da inconstitucionalidade do ato normativo revogado pelo Decreto n. $4.887 / 2003$, por padecer este de vício formal idêntico ao Decreto n. 3.912/2001.5

No mérito, divergiu integralmente do ministro relator. Com o intuito de melhor apresentar seus fundamentos, estes serão verificados separadamente.

\section{Invasão de esfera reservada à lei (art. 84, IV e VI, “ $a$ ”, $d a C F / 88$ )}

O art. 68 do ADCT da Constituição Federal de 1988 foi regulamentado exclusivamente por meio do Decreto n. 4.887/2003, tratando-se, a priori, de ato normativo secundário. Em outros termos, sua validade estaria condicionada à observância da Constituição e das leis. Por isso, em não havendo lei em sentido estrito para assegurar sua validade dentro do ordenamento, sua edição deveria ser considerada ilegal com imediata suspensão de seus efeitos. ${ }^{6}$

Contudo, a ministra Rosa Weber ${ }^{7}$ sustentou que o art. 68 do ADCT não poderia ser tratado como um preceito genérico, com conteúdo vago, mas sim de norma definidora de direito fundamental de grupo étnico-racial minoritário, dotada, portanto, de "eficácia plena e aplicação imediata, exercível independentemente de integração legislativa".

5 Tratam sobre o procedimento para identificação, reconhecimento, delimitação, demarcação e titulação das terras ocupadas por remanescentes das comunidades dos quilombos de que trata o art. 68 do ato das disposições constitucionais transitórias. O segundo Decreto encontra-se, atualmente, ab-rogado pelo primeiro (em vigor).

6 Pode ser considerado inexistente se partirmos do pressuposto que houve grave violação aos preceitos constitucionais do devido processo legislativo constitucional. Ainda, pode ser visto como inválido se analisado sob a ótica de não guardar correspondência com a Constituição ou com as leis.

7 STF, op. cit., nota 1, p. 3. 
Em análise segmentada do art. 68 do ACDT, apresentou duas categorias jurídicas que denominou de "enunciados constitucionais": 8

a) uma disposição substancial assentando um direito fundamental - um direito de propriedade qualificado ("aos remanescentes das comunidades dos quilombos que estejam ocupando suas terras é reconhecida a propriedade definitiva");

b) uma ordem ao Estado para que pratique determinado ato necessário ao direito fundamental assentado —a expedição dos títulos respectivos (“devendo o Estado emitir-lhes os títulos respectivos").

No primeiro caso, assegurou aos remanescentes quilombolas as propriedades que ocupavam; vedou ao legislador restringir um direito fundamental objetivo, cabendo ao Estado o dever de tutela, de observância e de proteção. Entretanto, asseverou inexistir direito subjetivo à perspectiva pro futuro, esta sim condicionada à lei em razão da incerteza. ${ }^{9}$ Se o Estado é obrigado a agir positivamente para cumprir os mandamentos constitucionais, por condicionantes legislativas, ou por programas implementados pelo Executivo, o Decreto n. 4.887/2003 está no limite constitucional do poder regulamentar da Administração, previsto no art. $84, \mathrm{VI}$, da CF/88. ${ }^{10}$

Importante ressaltar, antes de avançarmos na análise do julgado, que o art. 84, VI, da CF/88 é bastante emblemático na doutrina, ora entendido como decreto autônomo e equiparado a normas primárias, por vezes tratado como decreto regulamentar, ato inferior e sujeito à Constituição e às leis. ${ }^{11}$ De toda forma, como será visto ao final, o texto constitucional brasileiro não menciona expressamente a demarcação de terras — quilombolas ou não- como fundamento para a edição de Decreto Autônomo.

\footnotetext{
8 Constituição da República Federativa, 1988, Brasil.
}

9 Em seu voto, disse ser impossível a utilização de método interpretativo que reduza sem justo motivo, a eficácia dos direitos fundamentais. Cf. Hesse, Konrad, A força normativa da Constituição, trad. Gilmar Ferreira Mendes, Porto Alegre, Sergio Antônio Fabris Editora,1991.

10 STF, op. cit., nota 1, p. 3.

11 Normas primárias são aquelas que possuem previsão expressa na Constituição da República Federativa do Brasil de 1988 e estão sujeitas somente a ela. Normas secundárias são todas as demais normas que devem obediência à Constituição brasileira e também às normas primárias. O termo norma é empregado de forma despretensiosa, no sentido positivo-formal, tratando-se de leis, decretos, regulamentos, dentre outros atos legais e com previsão no ordenamento brasileiro. 
2. Requisito subjetivo: inconstitucionalidade do critério de identificação (autoatribuição)

Outro ponto relevante no voto vencedor refere-se ao pedido de declaração de inconstitucionalidade do art. 2o., caput, e §1a., do Decreto n. $4.887 / 2203: 12$

Consideram-se remanescentes das comunidades dos quilombos, para os fins deste Decreto, os grupos étnico-raciais, segundo critérios de autoatribuição, com trajetória histórica própria, dotados de relações territoriais específicas, com presunção de ancestralidade negra relacionada com a resistência à opressão histórica sofrida.

$\S 1$ 1 Para os fins deste Decreto, a caracterização dos remanescentes das comunidades dos quilombos será atestada mediante autodefinição da própria comunidade.

Após discorrer brevemente sobre o conceito e a evolução histórica do termo "quilombola", a ministra Rosa Weber ${ }^{13}$ sustentou que desde a sua formação, sempre houve resistência, inconformismo e luta pelo seu reconhecimento, afirmação esta somente instituída a nível constitucional pela Constituição Federal de 1988.

Certamente, a interpretação do art. 68 do ADCT não comporta um único significado (até porque se trata de direito fundamental), tampouco pode ser empregado para ampliar em demasia o conceito de "quilombo". Logo, não se pode dizer que alcança toda e qualquer comunidade rural predominantemente afrodescendente sem qualquer vínculo histórico.

Com efeito, a ministra Rosa Weber ${ }^{14}$ tratou o termo como "um fenômeno objetivo - ainda que de imprecisa definição", onde seu reconhecimento e a distribuição seriam "dois vetores da busca da justiça social na sociedade contemporânea".

Por conta disso, o critério de autoatribuição, segundo entendeu em seu voto, não seria arbitrário, caracterizando opção política do Poder Constituinte Originário expresso na Constituição Federal brasileira de 1988 como forma de "vincular a justiça socioeconômica reparadora". ${ }^{15}$

12 Decreto n. 4.887, 2003, Brasil.

13 STF, op. cit., nota 1, p. 3.

14 Idem.

15 Idem.

Esta obra está bajo una Licencia Creative Commons

Atribución-NoComercial-SinDerivar 4.0 Internacional, IIJ-UNAM. 
Destacou, ainda, a Convenção n. 169 da Organização Internacional do Trabalho (OIT) sobre Povos Indígenas e Tribais, aprovada pelo Decreto Legislativo n.134/022 e ratificada pelo Decreto n. 5.051/2004. Em seu art. $1^{\circ}$, itens 1 e 2, pró́be aos Estados negar a identidade de um povo indígena ou tribal que se autorreconheça, consagrando a "consciência da própria identidade".

Vale lembrar que o critério de autoatribução não pode ser usado de forma livre e de má-fé. ${ }^{16}$ Deve ser atestado pela Fundação Cultural dos Palmares, ${ }^{17}$ através de certidão emitida nos termos do art. $2^{\circ}$, III, da Lei n. 7.668/1998. Consequentemente, há controle exercido pela Administração através do exercício do poder de polícia administrativa, tratando-se de presunção relativa.

\section{Requisito objetivo: marco temporal}

No julgado foi fixado o marco temporal de 05 de outubro de $1988,{ }^{18}$ data da promulgação da Constituição Federal de 1988, para o reconhecimento das terras ocupadas pelos remanescentes das comunidades quilombolas. Segundo o que foi firmado no voto vencedor, deve haver uma continuidade na posse ou na luta por ela, ${ }^{19}$ a ser constatada na referida data, de forma estável. ${ }^{20}$

16 O ministro Luís Roberto Barroso também considerou legítimo o critério da autodefinição, lembrando que esse critério não é único, mas o início de todo um procedimento que inclui laudos antropológicos e outros, que tornam possível afastar eventuais fraudes (STF, op. cit., nota 1, p. 3).

17 A Fundação Cultural dos Palmares possui natureza jurídica de fundação autárquica e foi criada pela Lei n. 7.688/88.

18 Foi afastada a data da promulgação da Lei Áurea (13.05.1888) sob o argumento de haver imprecisão histórica na conceituação de remanescentes quilombolas e exatidão do momento em que ela se tornou conhecida em todo território brasileiro, bem como a eficácia a ela dada pelo poder público (ibidem, 2018).

19 Sobre o Renitente Esbulho, o ministro Barroso lembrou em seu voto que, quanto ao marco temporal, além das comunidades que estavam presentes na área quando da promulgação da Constituição de 1988, também fazem jus ao direito aquelas que tiverem sido forçadamente desapossadas, vítimas de esbulho renitente, cujo comportamento à luz da cultura aponta para sua inequívoca intenção de voltar ao território, desde que relação com a terra tenha sido preservada (ibidem, 2018).

20 STF, op. cit., nota 1, p. 3. 


\section{Inconstitucionalidade das terras ocupadas por remanescente das comunidades quilombolas}

A inicial impugnou o art. 2.o., §1o., do Decreto n. 4.887/2003. Conforme consta no decreto, a identificação, medição e demarcação das terras estão sujeitos aos critérios identificados pelos próprios interessados (remanescentes quilombolas) em detrimento da escolha de critérios históricos-antropológicos.

Por meio do emprego de analogia, a ministra Rosa Weber ${ }^{21}$ lembrou que no procedimento de demarcação de terras indígenas, em respeito ao devido processo legal, é imprescindível a participação das partes interessadas no rito demarcatório. Esclareceu que no processo demarcatório a expressão "serão levados em consideração pela administração" não traduz em absoluta vinculação ao ato estatal e, por isso, não possui qualquer ilegalidade.

Em continuidade à análise do caso, afastou a restrição do reconhecimento das terras ocupadas pelos remanescentes quilombolas exclusivamente às terras devolutas ${ }^{22}$ e ratificou que o rito expropriatório a ser observado é o previsto na desapropriação por interesse social da Lei n. 4.132/1962 e não aquele descrito na desapropriação para fins de reforma agrária da Lei n. $8.629 / 1993.23$

\section{Reconhecimento da situação de vulnerabilidade}

Aos remanescentes das comunidades quilombolas foi assegurada a norma transitória do art. 68 do ADCT como "forma veiculadora de direito fundamental de uma população vulnerável" que "não se esgota na dimensão do direito real de propriedade, e sim de direito qualificado como cultural fundamental", mediante implementação de políticas públicas efetivas e concretas. ${ }^{24}$

\footnotetext{
21 Idem.

22 Em sentido contrário, cfr. Bastos, Celso Ribeiro; Martins, Ives Gandra, Comentários à Constituição do Brasil, São Paulo, Saraiva, 2000.

23 STF, op. cit., nota 1, p. 3.

24 Idem.
}

Esta obra está bajo una Licencia Creative Commons

Atribución-NoComercial-SinDerivar 4.0 Internacional, IIJ-UNAM. 


\section{VOTOS E FUNDAMENTOS DIVERGENTES}

Votaram com a revisora os ministros Edson Fachin, Ricardo Lewandowski, Luiz Fux, Marco Aurélio e a ministra Carmen Lúcia. Não votou o ministro Alexandre de Moraes porque ocupa a cadeira deixada pelo ministro Teori Zavaski, que sucedeu ao ministro Cézar Peluso. ${ }^{25}$

Dos fundamentos apresentados, o ministro Marco Aurélio ${ }^{26}$ entendeu que o art. 68 do ADCT é autoaplicável e, por isso, o Decreto n. 4.887/2003 não seria dotado de autonomia e, tampouco, teria inovado no cenário jurídico.

Somado a isso, o ministro Celso de Mello ${ }^{27}$ acrescentou que o decreto impugnado confere efetividade máxima à norma constitucional, vinculado ao postulado da essencial dignidade da pessoa humana, assegurando direito a uma moradia de pessoas carentes e um mínimo necessário para os remanescentes de quilombos.

Por sua vez, além do ministro Cézar Peluso (julgou procedente a ADI), o ministro Dias Toffoli, seguido pelo ministro Gilmar Mendes, divergiram em parte da maioria. Observaram que o decreto impugnado, na verdade, regulamentaria as Lei n. 9.649/1988 ${ }^{28}$ e Lei n. 7.668/1988, ${ }^{29}$ e não a Constituição Federal brasileira de 1988, contrariamente ao entendimento dos demais ministros. ${ }^{30}$

Outro ponto divergente foi a fixação do marco temporal (critério objetivo). Por meio da utilização da técnica de interpretação conforme à constituição, prevaleceu que o art. 2o., §2o., do Decreto n. 4.887/2003 garantiu a titularidade das áreas que estavam ocupadas por remanescentes das comunidades dos quilombos (inclusive as efetivamente utilizadas para a garantia de sua reprodução física, social, econômica e cultural), na data da promulgação da Constituição Federal de 1988.

\footnotetext{
25 Idem.

26 Idem.

27 Idem.

28 Dispõe sobre a organização da Presidência da República e dos ministérios no Brasil.

29 Autoriza o Poder Executivo a constituir a Fundação Cultural Palmares e fixa parâmetros para de promoção da preservação dos valores culturais, sociais e econômicos decorrentes da influência negra na formação da sociedade brasileira.

30 STF, op. cit., nota 1, p. 3.
} 
Contudo, no julgado foram excluídos os casos de apossamentos irregulares contínuos de terras. A comprovação, a ser realizada por todos os meios de provas juridicamente admitidos, da suspensão ou perda da posse em decorrência de atos ilícitos praticados por terceiros, visa a esclarecer se a violação do direito às terras permanece — em outros termos, se é atual— afastando a tese da ocupação remota. ${ }^{31}$

\section{CONSIDERAÇÕES CRÍTICAS}

A questão da demarcação das terras ocupadas por remanescentes quilombolas foi e continua sendo pauta de intensos debates que extrapolam a esfera exclusivamente jurídica. Os votos dos ministros demonstram a complexidade e a amplitude de argumentos que podem ser utilizados para negar, restringir ou ampliar as diversas interpretações possíveis e razoáveis sobre o tema.

A Constituição Federal brasileira de 1988, sensível a necessidade de resguardar e concretizar direitos para pessoas em situação de vulnerabilidade, atribuiu direito originário e reconheceu a titularidade das terras ocupadas por remanescentes quilombolas.

Contudo, art. 68 do ADCT não delimitou questões tidas como essenciais para a caracterização do instituto — talvez até por opção política do constituinte - , deixando o encargo ao Legislador ordinário sua efetiva regulamentação. Ao Judiciário coube, na questão, sanar a lacuna legislativa por meio do emprego da hermenêutica. Vale dizer: o fato concreto é que não existe uma lei (em sentido estrito) que regulamente o mencionado artigo.

Diante deste cenário, podem ser apontadas a inércia do legislador ordinário e a insatisfação de parcela da população interessada, notadamente possuidores de terras como classe fomentadora de pressão política, como principais causas para a provocação da atuação jurisdicional. ${ }^{32}$

O Supremo Tribunal Federal, como demonstrado, julgou improcedente o pedido de declaração de inconstitucionalidade do Decreto n. 4.887/2003. À primeira vista há que se concordar ser a decisão mais acertada, mas não é isenta de questionamentos.

\footnotetext{
31 Idem. ta Crítica de Ciências Sociais, Coimbra, n. 23, set. 1990, pp. 13-74.

32 Santos, Boaventura de Souza, "O Estado, a sociedade e as políticas sociais", Revis- 


\section{Segurança jurídica e eficácia da norma}

A inércia do Legislativo em regulamentar o processo expropriatório e a opção pelo que se entende "comunidades remanescentes quilombolas" cria um débito de segurança jurídica..$^{33}$ Afinal, não se pode dizer que o Decreto n. 4.887/2003 é uma norma procedimental e passível de construção por ato administrativo unilateral.

Consequentemente, a ministra Rosa $W_{e b e r}{ }^{34}$ entendeu que o art. 68 do ADCT possui aplicabilidade imediata e independe de ato normativo secundário para sua regulamentação. Foi além, pois na prática equiparou o Decreto Regulamentar n. 4.887/2003 aos chamados decretos autônomos que, a despeito das divergências, é tratado como ato normativo diretamente vinculado à Constituição.

Houve a ampliação do texto constitucional, porquanto o art. 84, VI, da Constituição de 1988 não prevê a hipótese de regulamentação de processo de demarcação de terra, seja de índios, quilombolas ou qualquer outro grupo marginalizado. Ficou evidente no julgado que o Judiciário, com o objetivo de não deixar desassistidas as populações remanescentes quilombolas, buscando maior efetividade prática para a implementação-proteção dos direitos fundamentais, suprimiu diretamente inércia do legislador ao atribuir efeitos concretos ao decreto mesmo sem previsão taxativa na Constituição brasileira.

O debate sobre a linha tênue entre a atuação jurisdicional e a invasão de matérias entregues pela Constituição Federal brasileira de 1988 a outras funções mostrou-se evidente. Afinal, caberia ao Legislativo legislar (de forma ao menos suficiente) sobre o tema com o fim de evitar divergências mais profundas; ao Executivo, regulamentar, via decreto, a forma concreta de reconhecimento e demarcação das terras ocupadas pelos remanescentes quilombolas.

Evidentemente que o Judiciário não poderia se refutar a dar uma solução ao caso — especialmente nos feitos em que direitos fundamentais de

\footnotetext{
33 De certa maneira, o comportamento social-estatal permanece até hoje, guardadas as proporções, cujo "modelo jurídico hegemônico durante os primeiros dois séculos de colonização foi, por conseqüência, marcado pelos princípios e pelas diretrizes do Direito alienígena — segregador e discricionário com relação à própria população nativa-, revelando, mais do que nunca as intenções e o comprometimento da estrutura elitista de poder" (Wolkmer, Antonio Carlos, História do direito no Brasil, 3ed, ver, atua, Rio de Janeiro, Forense, 2003, p. 45).

34 STF, op. cit., nota 1, p. 3.
} 
parcela da população estão em situação de vulnerabilidade - como assim o fez. O que se pode observar é que o Constituinte originário, ao estabelecer menos que deveria, seja por incompreensão da real profundidade do tema ou por opção (pressão) política, ${ }^{35}$ permitiu que o debate se instaurasse, resultando na convocação do Supremo para sanar as dúvidas que foram construídas.

De todo modo, o caso demonstra a complexidade do sistema jurídico e da atuação das funções dentro do Estado democrático de direito. Em razão da demora em se legislar (aqui não importando as razões para tanto) e a burocracia (no sentido de procedimentos a serem adotados de forma insuficientemente eficaz pelo Estado), a função jurisdicional novamente atuou (com acerto ou erro, a depender do ponto de vista adotado) no limite entre a limitação constitucional e o chamado ativismo judicial.

Dessa forma, questiona-se: qual outra solução poderia ser encaminhada para responder os questionamentos sem que os remanescentes quilombolas, em situação de vulnerabilidade, não ficassem desamparados?

Há dois caminhos para o impasse: o primeiro, por não haver lei votada pelo Congresso Nacional, levaria à invalidade do Decreto n. 4.887/2003, pois art. 68 do ADCT seria dotado de aplicabilidade mediata e, por estar subordinado à lei, não teria qualquer validade, entendimento parcialmente reconhecidos nas razões dos votos dos ministros Dias Toffoli e Gilmar Mendes, apesar de não julgarem procedente a ADI.

O segundo, acompanhado pela maioria do STF, seria atribuir eficácia plena e imediata ao art. 68 do ADCT, dispensando lei em sentido estrito e, por meio de analogia (ou qualquer esforço hermenêutico ampliativo equivalente), aplicar o rito expropriatório para as desapropriações por interesse social previsto na Lei n. 4.132/1962.

A questão envolve a discricionariedade do julgador em decidir casos de complexa solução, sem uma forma obrigatória a ser seguida em razão da (in)completude do ordenamento, no qual há a necessidade de estabelecer previamente os critérios para distinguir o que são regras e princípios, seja pela adoção de uma teoria puramente descritiva que busca a segurança jurídica, cuja a justificação se mostra irrelevante, ${ }^{36}$ ou pela escolha de uma

35 Vale lembrar que os interesses dos grandes proprietários de terras no Brasil fizeram-se presentes na Assembleia Nacional Constituinte brasileira de 1987-1988.

36 Raz, Joseph, The Aauthority of Law. Essays on Law and Morality, Oxford, Oxford University Press, 1979. 
teoria normativa de lei, ${ }^{37}$ onde a justificação moral para a melhor escolha é fundamental. ${ }^{38}$

Por isso, pode-se concluir (e não defendemos que necessariamente seja a melhor resposta) que há diversas interpretações a depender da teoria da argumentação jurídica e, consequentemente, diferentes resultados igualmente corretos, desde que "bem" fundamentados. ${ }^{39}$

Independentemente do caminho a ser percorrido, deve haver o comprometimento por parte do Estado em assegurar os direitos fundamentais especialmente em favor da parcela da população que, historicamente, foi tratada como objeto. A inércia do legislador ordinário não pode ser obstáculo para o reconhecimento do direito às terras ocupadas. Tampouco, o Executivo ou Judiciário, dentro de suas funções estabelecidas, não poderiam ampliar ou restringir desproporcionalmente direitos em prejuízos a outros grupos sociais.

O Estado-juiz, mesmo dentro da margem constitucional, não poderia ampliar desproporcionalmente direitos em prejuízos a outros grupos sociais antagônicos. Deve-se evitar a proibição do excesso (Übermassverbot) e a proibição de proteção deficiente (Untermassverbot) ${ }^{40}$

O decreto, em linhas gerais, é ato eminentemente unilateral, editado pelo Chefe do Executivo para dar fiel cumprimento à lei. Pode ser alterado e produzir efeitos sem a devida discussão, especialmente quando é utilizado para substituir à lei em casos concretos, como no caso em apreço.

Por isso há grandes preocupações no limite da discricionariedade judicial e da utilização da livre convicção. ${ }^{41}$ Ora, os argumentos que serviram

37 Dworkin, Ronald, "Law as Interpretation", Texas Law Review, v. 60. Texas, 1982, pp. 527-550.

38 Dworkin, Ronald, Taking Rights Seriously, New York, Bloomsbury Academic, 2013.

39 MacCormick, Neil, Argumentação jurídica e teoria do direito, trad. Waldéa Barcellos, São Paulo, Martins Fontes, 2006.

40 Streck, Lenio Luiz, Hermenêutica jurídica e $(m)$ crise: uma explocarção hermenêutica da construção do direito, Porto Alegre, Livraria do Advogado, 1999.

41 Austin, John, The Province of Jurisprudence Determined and the Uses of the Study of Jurisprudence, Cambridge, Hakett Publishing Company Inc., 1998; Coleman, Jules, The Practice of Principle: In Defense of a Pragmatist Approach to Legal Theory, New York Oxford University Press, 2001; Ferraz Jr., Tércio Sampaio, Função social da dogmática jurídica, 2a. ed., São Paulo, Atlas, 2015; Gadamer, Hans-Georg, Truth and Method, 2a. ed, rev., trad. Joel Weinsheimer e Donald G. Marshall, New York, Continum, 2006; MacCormick, Neil, Argumentação jurídica e teoria do direito, trad. Waldéa Bar- 
para julgar improcedentes os pedidos também poderiam ser utilizados para julgar procedente a ADI. Bastaria o emprego da hermenêutica jurídica que, diga-se de passagem, ao ser utilizada sem lastro, pode-se chegar a qualquer resultado a depender do interesse a ser perseguido. Por isso, os meios para se chegar a um fim, não são menos importantes que o resultado alcançado.

Chamon Junior, ${ }^{42}$ contrapondo Kelsen e Luhmann, em analogia à mitologia grega, lembra que o deus Cronos acreditava "estar acima das partes e do Direito, acima de todos e seu posto seria legitimado a decidir da maneira que ele acredita ser a solução para o caso". Adverte, em crítica à Luhmann, que é perigosa a criação de soluções e princípios sem qualquer respaldo em outra norma, afinal, "pressupõe nosso juiz-devorador que a solução para os casos há que partir da sua convicção pessoal... e não passam daquilo que gostaria que fosse o Direito". ${ }^{43}$

Em um assunto tão sensível, certamente a segurança jurídica e os direitos fundamentais à proteção dos remanescentes quilombolas atrelados a própria existência física, cultural e do seu modo de viver - indissociáveis ao vínculo que mantêm com suas terras - estão ameaçados. Afinal, o devido processo legal demarcatório pode ser alterado a qualquer momento e unilateralmente pelo Chefe do Executivo, colocando em xeque a segurança das relações jurídicas, os atos consolidados e a não-surpresa.

Contudo, convém destacar que as pessoas que ocupam cargos políticos estão sujeitas a pressões sociais, econômicas e políticas próprias da democracia. Por estas razões, no caso de sua modificação, o tema poderá ser debatido novamente no Supremo, tornando contraproducente - ao menos em uma análise quantitativa - a decisão proferida na ADI n. 3.239-DF.

cellos, São Paulo, Martins Fontes, 2006; Streck, Lenio Luiz, Jurisdição constitucional e hermenêutica: uma nova crítica do direito, Porto Alegre, Livraria do Advogado, 2002; Streck, Lenio Luiz, Teoria da Constituição e jurisdição constitucional, Porto Alegre, Escola da Magistratura do Tribunal Regional Federal da 4a. Região, 2006; Streck, Lenio Luiz, Verdade e consenso: constituição, hermenêutica e teoria discurssiva da possibilidade à necessidade de respostas corretas em direito, 3a. ed. rev., ampl., Rio de Janeiro, Lumen Juris, 2009.

42 Chamon Junior, Lúcio Antônio, Teoria da argumentação jurídica: constitucionalismo e democracia em uma reconstrução das fontes no direito moderno, 2a. ed., Rio de Janeiro, Lumen Juris, 2009, pp. 155-170.

43 Ibidem, pp. 169 e 170.

Esta obra está bajo una Licencia Creative Commons

Atribución-NoComercial-SinDerivar 4.0 Internacional, IIJ-UNAM. 


\section{Critério de autoatribuição (critério subjetivo)}

O critério de autoatribuição para o reconhecimento do que se entende como remanescente quilombola, em um primeiro olhar, não apresenta grandes discussões. No julgado, seguindo orientações da OIT, a autoatribuição se mostrou preponderante em face dos critérios exclusivamente históricos e antropológicos.

Entretanto, a depender da corrente de pensamento, a dimensão do que se entende por quilombo altera-se radicalmente justamente por não haver um consenso - e nem poderia haver. $\mathrm{O}$ respeito aos direitos fundamentais reside exatamente nas diferenças multiculturais. As definições são atribuídas de acordo com as perspectivas de quem propõe e conforme as finalidades perseguidas. O emprego do termo "remanescente", por si só, traz consigo uma ideia de "não é mais, acabou". À vista disso:

...deve ser entendida a categoria remanescentes de quilombos, como um ente vivo, para que possa cumprir o fim a que se propôs e sua ordem constitucional: o reconhecimento da propriedade territorial definitiva e a emissão de seus respectivos títulos. Torna-se necessária a ruptura com o modelo de "pedra e cal" e a elaboração de um novo conceito socioantropológico e jurídico para os remanescentes das comunidades de quilombo, uma vez que o art. 68 do $\mathrm{ADCT}$ não apenas reconheceu o direito que as comunidades remanescentes de quilombos possuem sobre as terras que ocupam, como também criou tal categoria política e sociológica: embora os grupos étnicos beneficiados pela legislação já existissem, não se denominavam com base na categoria remanescentes de quilombos. ${ }^{44}$

Em linhas gerais, cabe a cada pessoa como ser individual e único, inserido em determinada coletividade se autodeterminar e autoafirmar nos limites dos direitos (fundamentais) da personalidade. Como explicou a ministra Rosa Weber, ${ }^{45}$ o Estado possui condições de verificar em cada caso concreto eventuais abusos de direito. Negar o direito de autoatribuição de forma geral e abstrata configuraria uma violação direta aos direitos humanos da personalidade.

44 Marques, Carlos Eduardo, "De Quilombos a quilombolas: notas sobre um processo histórico-etnográfico", Revista de Antropologia, São Paulo, USO, 2009, v. 52, n. 1, mai. 2009 , p. 352.

45 STF, op. cit., nota 1, p. 3. 
O sentido que deve ser atribuído aos remanescentes quilombolas ultrapassa a questão histórica e de libertação. Deve ser entendido como "novos direitos" inseridos em uma nova realidade multicultural que merece a devida proteção ${ }^{46}$ como segmento social que busca alcançar "novos" direitos há muito perdidos —ou nunca conquistados—, inclusive ao de moradia digna, assim como qualquer outro grupo historicamente marginalizado. ${ }^{47}$

\section{Critério temporal (critério objetivo)}

Assim como nas comunidades indígenas, a população quilombola também possui estreitos vínculos com a terra. Aliás, os territórios por eles ocupados dizem muito sobre sua identidade, cultura, costumes e modo de viver: são essenciais a sua própria existência. Por isso, possui especial significado para este e pode ser compreendido como:

espaço de reprodução social e se constitui em uma dimensão material e imaterial — lócus de vida e de reprodução de valores, crenças, dentre outros, mas também espaço de luta, de resistência para continuar se reproduzindo na terra. Os sujeitos sociais da pesquisa são considerados ainda camponeses, na medida em que se reproduzem por meio de valores definidos através do trinômio: terra, trabalho e família, ou seja, são espaços da terra de trabalho e através desse consegue-se a reprodução social da família. ${ }^{48}$

Convém recordar que com a chegada dos portugueses na América, especialmente em decorrência da visão eurocentrista de mundo, as terras, direitos e formas de viver foram expropriadas dos índios ${ }^{49}$ que, posteriormente, refletiu em toda comunidade quilombola que passou a viver no Brasil. ${ }^{50}$

46 Wolkmer, Antonio Carlos, "Pluralismo, justiça e legitimidade dos novos direitos", Revista Sequência, Florianópolis, v. 28, jul. 2007, pp. 104 e 105.

47 Carvalho, José Jorge, "Quilombos: símbolos da luta pela terra e pela liberdade", Cultura Vozes, São Paulo, n. 5, set/out, 1997.

48 Lira, Elizeu Ribeiro y Ribeiro Neto, Olegário B., "O território e a identidade quilombola: o caso da comunidade afrodescendente Mata Grande no município de Monte do Carmo - TO", Revista Produção Acadêmica - núcleo de estudos urbanos regionais e agrários/NURBA, Palmas, v. 2, n. 2, dez. 2016, p. 40.

49 A escravidão dos índios no Brasil foi extinta oficialmente pelo marques de Pombal, que proibiu o trabalho escravo indigenista (Gennari, Emilio. Em busca da liberdade: traços das lutas escravas no Brasil, São Paulo, Expressão Popular, 2011, p. 15).

50 Dussel, Enrique, 1492: o encobrimento do outro: a origem do "mito da modernidade”, tradução de Jaime A. Clasen, Petrópolis, Vozes, 1993. 
Inicialmente a exploração se deu através do Pau-Brasil; posteriormente com o clico do açúcar e, por último, com a exploração do ouro. Por conta das chamadas "grandes navegações", inúmeras pessoas negras foram trazidas ao país na condição de escrava, como forma de sustentar a coroa portuguesa e o respectivo ciclo de exploração.

Durante todo o período escravocrata, os negros no Brasil não assistiram passivamente a sua "submissão", mas foi um período marcado por grandes atrocidades e lutas por reconhecimentos de direitos. ${ }^{51}$

A Constituição brasileira de 1988 reflete, ainda que com suas lacunas (propositais ou não), parcela dos direitos conquistados pelos remanescentes quilombolas. Nesse contexto, a opção pela data da promulgação da Constituição brasileira de 1988 como marco temporal para o reconhecimento das terras ocupadas pelos remanescentes das comunidades quilombolas é intrínseco ao próprio conceito de quilombos, necessário à sua reprodução física e cultural. ${ }^{52}$

No julgado em análise, afastou-se a "retroatividade ao infinito", ${ }_{53}$ assim como decidido no caso Raposa Serra do Sol. ${ }^{54}$ Também foi repelida a tese de fixação do critério temporal retroativo à data da promulgação da Lei Áurea. ${ }^{55}$ A fixação, ainda que possa se alegar "injustiça", busca, em um viés puramente jurídico-dogmático, trazer maior segurança jurídica para as futuras demarcações.

51 Fiabani, Adelmir, Mato, palhoça e pilão: o quilombo, da escravidão às comunidades remanescentes (1532-2004), São Paulo, Expressão Popular, 2012, pp. 290 e 291.

52 Sundfeld, Carlos Ari (org.), Comunidades quilombolas: direito à terra, Brasília, Fundação Cultural Palmares-Ministério da Cultura, Editorial Abaré, 2002, p. 78.

53 A luta pelo reconhecimento do direito quilombola não é recente. Na verdade, "essa luta pela libertação alcança seu momento mais expressivo nos quilombos do sudeste do Brasil, entre os séculos XVII e XVIII. Tal forma do estrutura político-econômica que teve em Palmares o melhor exemplo de organização, florescimento e resistência, enquanto regime comunitário, manteve-se com base na agricultura e na criação de animais de subsistência. Assim, os negros de Palmares, tornando-se auto-suficientes, e criando formas de defesa e sobrevivência ao escravismo colonial, desenvolveram práticas de convivência respaldadas o igualitarismo e na participação comunitária, dirimindo possíveis procedimentos causa dores de atritos e confrontos sociais" (Wolkmer, Antonio Carlos, História do direito no Brasil, 3ed, rev, atua, Rio de Janeiro, Forense, 2003, p. 50).

54 Pet. 3.388-4 RR, Rel. ministro Carlos Britto, julgado em 1903.2009, cuja observância é obrigatória a todos os processos que versam sobre o mesmo tema ( $c f r$. Supremo Tribunal Federal, RMS 29.087 Ed-ED, min. Gilmar Mendes, julgado em 22.04.2016).

55 A Lei Imperial n. 3.353, de 13 de maio de 1888, foi o diploma legal que extinguiu juridicamente a escravidão no Brasil. 
Contudo, há uma questão a ser enfrentada nos casos práticos. Como levar ao conhecimento do Estado - com provas suficientes, mas com grandes dificuldades de produção- que a ocupação já ocorria de fato (e de direito) quando da promulgação da $\mathrm{CF} / 88$ ou que os quilombolas foram removidos de forma forçada de sua terra e, de alguma forma, não conseguiram recuperá-la? Qual o limite entre ocupação remota e renitente esbulho? São questões que provavelmente serão respondidas caso a caso, conforme suas peculiaridades que, afinal:

Trata-se de construir um projeto social e político emancipatório, capaz de reordenar as relações tradicionais entre o Estado e a sociedade civil, entre o universalismo ético e o relativismo cultural, entre a razão prática e a filosofia do sujeito, entre as formas convencionais de legalidade e experiências não formais de jurisdição. Reescrever um novo modo de vida estimula a inserção cultural para outras modalidades de convivência, de relações sociais e regulamentações das práticas emergentes e constituintes. Então o cenário não estará no Estado, nem no mercado, mas sim na sociedade civil. Sociedade civil enquanto novo espaço público, de efetivação da pluralidade democrática. Em sua capacidade geradora, a nova esfera pública proporciona aos horizontes institucionais novos valores culturais, novos procedimentos de prática política e de acesso à justiça, projetando novos atores sociais, como fonte de legitimação do espaço sociopolítico e da constituição emergente de direitos. ${ }^{56}$

De toda forma, a decisão proferida exemplifica a crise jurídica que atravessamos. Warat, há mais de 25 anos, advertia que a expansão do domínio da razão do direito e o projeto de autonomia parecem finalmente estar em crise, afinal:

Vivimos tiempos de ejecutivos desmedidos, que avanzan, sin muchos recaudos, sobre los otros poderes -por que tienen fuerza y complicidades suficientes para hacerlo.

Por esta razón precisamos de un pensamiento que consiga sus propios complices, para poder exigir el equilibrio de poderes, que garanta una condición democratica de gobernabilidad: la estabilidad jurídica como condición mínima de la consolidación democrática.

\footnotetext{
56 Wolkmer, Antonio Carlos, "Mudanças de paradigmas, pluralismo e novos direitos”, Revista Espaço Jurídico, Joaçaba, v. 7, n. 72, jul/dez. 2006, p. 89. 
Los que predican un uso alternativo del derecho no advierten el valor actual del equilibrio de poderes, apuestan en el avance desmedido del poder judicial, con lo que terminan siendo aliados de los poderes ejecutivos que se ilusionan con su omnipotencia.terminan dándose la mano contra los parlamentos que todavia quieren sostener la democracia.El "collorgate" es un buen ejemplo para lo que estoy diciendo un parlamento que consiguió imponerse contra un presidente que queria un uso alternativo del derecho y una población que vistió las calles de negro por que queria una justicia que fuera un componente ética de la política. Un deseo de realización plena del "Estado de derecho". ${ }^{57}$

Em última análise, a decisão do Supremo Tribunal Federal brasileiro, em razão da inércia do legislador pareceu ser a mais acertada porquanto os direitos fundamentais não podem depender exclusivamente da vontade política para a irradiação de seus efeitos concretos.

Por outro lado, a tensão entre as funções do Estado, o emprego cada dia mais presente da hermenêutica sem pesos e freios, ${ }^{58}$ a precariedade do ato jurídico demarcatório - leia-se decreto (regulamentar ou autônomo?) - e seu reconhecimento como ato normativo primário (ou secundário), bem como das questões de fundo que acompanham o julgado demonstram a necessidade de se repensar o tema, projetando o futuro sem esquecer do passado que o acompanha.

Afinal, para fins de reflexão, partindo-se de um estudo decolonial, ${ }^{59}$ seriam tais terras realmente pertencentes ao povo europeu que aqui chegou (invadiu) e impôs seu modo de viver, aniquilando e dizimando culturas inteiras ou elas pertenceriam originalmente as terras ocupadas pelos índios e pelos remanescentes quilombolas que, historicamente, foram incapazes de lutar contra a imposição do modus vivendi e do direito europeu?

57 Warat, Luiz Alberto, "La ciudadania sin ciudadanos: tópicos para un ensyo interminable”, Sequência, Florianópolis, v. 14, n. 26, jul. 1993, pp. 10 e 11.

58 Evidentemente que a hermenêutica jurídica é indissociável do direito, cuja importância para o desenvolvimento da ciência dispensa qualquer comentário adicional. Pontualmente, a crítica refere-se ao seu emprego desenfreado, sem bases pré-estabelecidas e passíveis de mutação ao prazer do intérprete, a depender do fim almejado.

59 Por isso Enrique Dussel entende que ser rompida a ótica colonizadora europeia que impôs seu modo de viver e extinguiu, em boa medida, a diversidade cultural na América Latina, cuja ótica colonizadora e de opressão se mantém viva, especialmente no direito (Dussel, Enrique D., Filosofia da libertação na América Latina, São Paulo, Editora Unimep, 1977, pp. 21, 65-70). 


\section{BIBLIOGRAFIA}

Austin, John, The Province of Jurisprudence Determined and the Uses of the Study of Jurisprudence, Cambridge, Hakett Publishing Company Inc., 1998.

Baggentoss, Grazielly Alessandra y CADEMARTORI, Luiz Henrique Urquhart, "O regime jurídico brasileiro dos bens públicos e direitos fundamentais como parâmetro de um regime de bens fundamentais", in CADEMARTORI, Luiz Henrique Urquhart, SchramM, Fernanda Santos (orgs.), Direito público e hermenêutica: problemas e desafios atuais, Curitiba, Editora Primas, 2017.

BAstos, Celso Ribeiro e MARTIns, Ives Gandra, Comentários à Constituição do Brasil, São Paulo, Saraiva, 2000.

CADEMARTORI, Luiz Henrique Urquhart, Discricionariedade administrativa no Estado constitucional de direito, Curitiba, Juruá, 2002.

CARVAlHo, José Jorge, “Quilombos: símbolos da luta pela terra e pela liberdade”, Cultura Vozes, São Paulo, n. 5. set/out. 1997.

CHAMON JUNIOR, Lúcio Antônio, Teoria da argumentação jurídica: constitucionalismo e democracia em uma reconstrução das fontes no direito moderno, 2a. ed., Rio de Janeiro, Editora Lumen Juris, 2009.

Coleman, Jules, The Practice of Principle. In Defense of a Pragmatist Approach to Legal Theory, New York, Oxford University Press, 2001.

Dussel, Enrique D., Filosofia da libertação na América Latina, São Pau1o, Editora Unimep, 1977.

DusSEL, Enrique, 1492: o encobrimento do outro: a origem do "mito da Modernidade", tradução de Jaime A. Clasen, Petrópolis, Vozes, 1993.

DwORKIN, Ronald, "Law as Interpretation", Texas Law Review, v. 60. Texas, 1982.

DwORKIN, Ronald, Taking Rights Seriously, New York, Bloomsbury Academic, 2013.

FIABANI, Adelmir, Mato, palhoça e pilão: o quilombo, da escravidão às comunidades remanescentes (1532-2004), São Paulo, Expressão Popular, 2012. 
Ferrajoli, Luigi, Direito e razão. Teoria do garantismo penal, 3a. ed., rev., trad. Ana Paula Zoma Zica et al., São Paulo, Revista dos Tribunais, 2010.

FERRAJOLI, Luigi, "Constitucionalismo principialista e constitucionalista garantista", trad. André Karam Trindade, in STRECK, Lênio Luiz y TRINDADE, André Karam (orgs.), Garantismo, hermenêutica e (neo) constitucionalismo: um debate com Luigi Ferrajoli, Porto Alegre, Livraria do Advogado, 2012.

FERraz JR., Tércio Sampaio, Função social da dogmática jurídica, 2a. ed., São Paulo, Atlas, 2015.

GADAMER, Hans-Georg, Truth and Method, 2a. ed. rev., trad. Joel Weinsheimer e Donald G. Marshall, New York, Continum, 2006.

GENNARI, Emilio, Em busca da liberdade: traços das lutas escravas no Brasil, São Paulo, Expressão Popular, 2011.

HESSE, Konrad, A força normativa da Constituição, trad. Gilmar Ferreira Mendes, Porto Alegre, Sergio Antônio Fabris Editora,1991.

LiRA, Elizeu Ribeiro y RiBEIRO NeTO, Olegário B., "O território e a identidade quilombola: o caso da comunidade afrodescendente Mata Grande no município de Monte do Carmo - TO”, Revista Produção Acadêmica - núcleo de estudos urbanos regionais e agrários/NURBA, Palmas, v. 2, n. 2, dez. 2016.

MACCORMICK, Neil, Argumentação jurídica e teoria do direito, trad. Waldéa Barcellos, São Paulo, Martins Fontes, 2006.

MARques, Carlos Eduardo, "De Quilombos a quilombolas: notas sobre um processo histórico-etnográfico", Revista de Antropologia, São Paulo, USO, 2009, v. 52, n. 1, mai. 2009.

RAZ, Joseph, The Authority of Law. Essays on Law and Morality, Oxford, Oxford University Press, 1979.

SANTOS, Boaventura de Souza, "O Estado, a sociedade e as políticas sociais", Revista Critica de Ciências Sociais, Coimbra, n. 23, set. 1990.

STRECK, Lenio Luiz, Hermenêutica jurídica e (m) crise: uma explocarção hermenêtica da construção do direito, Porto Alegre, Livraria do Advogado, 1999.

STRECK, Lenio Luiz, Jurisdição constitucional e hermenêutica: uma nova crítica do direito, Porto Alegre, Livraria do Advogado, 2002. 
STRECK, Lenio Luiz, Teoria da Constituição e jurisdição constitucional, Porto Alegre, Escola da Magistratura do Tribunal Regional Federal da 4a. Região, 2006.

STRECK, Lenio Luiz, Verdade e consenso: constituição, hermenêutica e teoria discurssiva da possibilidade à necessidade de respostas corretas em direito, 3 ed. rev., ampl, Rio de Janeiro, Lumen Juris, 2009.

SundFeld, Carlos Ari (org.), Comunidades quilombolas: direito à terra, Brasília, Fundação Cultural Palmares-Ministério da Cultura, Editorial Abaré, 2002.

WARAT, Luiz Alberto, "La ciudadania sin ciudadanos: tópicos para un ensyo interminable”, Sequência, Florianópolis, v. 14, n. 26, jul. 1993.

Wolkmer, Antonio Carlos, História do direito no Brasil, 3a. ed., ver., atua, Rio de Janeiro, Forense, 2003.

WOLKMER, Antonio Carlos, "Mudanças de paradigmas, pluralismo e novos direitos", Revista Espaço Jurídico, Joaçaba, v. 7, n. 72, jul/dez. 2006.

WOLKMER, Antonio Carlos, "Pluralismo, justiça e legitimidade dos novos direitos", Revista Sequência, Florianópolis, v. 28, jul. 2007. 
Esta revista forma parte del acervo de la Biblioteca Jurídica Virtual del Instituto de Investigaciones Jurídicas de la UNAM http://www.juridicas.unam.mx

https://biblio.juridicas.unam.mx

https://revistas.juridicas.unam.mx

DOI: http://dx.doi.org/10.22201/iij.24484881e.2020.43.15198

COMENTARIOS

LEGISLATIVOS

Universidad Nacional Autónoma de México, IIJ-BJV, 2020

https://revistas.juridicas.unam.mx/index.php/cuestiones-constitucionales/issue/archive 


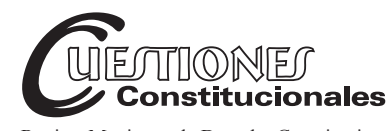

Revista Mexicana de Derecho Constitucional Núm. 43, julio-diciembre 2020

\title{
La falta de garantía de los derechos sexuales en Colombia: ¿cuestión de ineficacia normativa?*
}

\section{The lack of guarantee of sexual rights in Colombia: a matter of normative inefficiency?}

\author{
Alirio Jesús AlZATE JARAMILLO** \\ Carlos Alberto MoJICA ARAQUE***
}

RESUMEN: De los derechos humanos sexuales se reclama constantemente una protección eficaz por parte del poder estatal para poder así verificar una verdadera legitimación de los contenidos constitucionales y legales que se erigen para este propósito. Este artículo analiza las diferentes prescripciones normativas enunciadas a través de la dogmática constitucional y penal, nacional e internacional, que se encauzan para proteger estos derechos, y en donde las diferentes concepciones sobre aquéllos encuentran sin duda una validez en su construcción a partir del concepto de la dignidad humana.
ABSTRACT: Sexual human rights are constantly demanding effective protection by the state power in order to verify a true legitimization of the constitutional and legal contents that are erected for this purpose. This article analyzes the different normative prescriptions enunciated through the constitutional and criminal dogmatic, national and international, that are channeled to protect these rights and where the different conceptions about those find no doubt a validity in their construction from the concept of human dignity.

* El presente artículo es un avance del trabajo de investigación titulado "El delito sexual en Colombia. Un análisis de la afectación en los derechos humanos, de su investigación y juzgamiento" adelantado dentro del programa del doctorado en Derecho de la Universidad de Medellín, en el cual los autores son el estudiante y el asesor temático y metodológico, respectivamente.

** Doctorando en Derecho, magíster en Derecho, especialista en Derecho Probatorio Penal, abogado, experto en Investigación Criminal, y actualmente vinculado con la Procuraduría General de la Nación, Colombia. Colombia. ORCID: 0000-0003-2099-4551. Correo electrónico: aliriojalzate@yahoo.es.

*** Doctor en Derecho, magíster en Relaciones Internacionales (España), magíster en Derecho Procesal, especialista en derecho penal, abogado y profesor del área penal y procesal penal de la Universidad de Medellín, Colombia. Colombia. ORCID: J -3795-2016. Correo electrónico: camojica@udem.edu.co. 
Un análisis crítico de esas normas nos permite constatar en principio lo frágil que resultan el poder y la fuerza del Estado para garantizar estos derechos, cuando desde la misma dialéctica es posible construir también un discurso de ineficacia de aquellas normas. No obstante, aquel calificativo verificado de alguna manera en la praxis parece seguir siendo el resultado de la histórica y poco cambiante conducta irracional de sus destinatarios, lo cual impide consolidar una verdadera barrera frente a la eventual trasgresión. Cuando se supere dicha irracionalidad, será entonces posible constatar lo que teleológicamente anhela el Estado a través del derecho y el poder, que entre otros fines está el respeto por los derechos sexuales ajenos.

Palabras clave: protección, derechos sexuales, eficacia normativa, dogmática, poder, dialéctica, axiología.
A critical analysis of these norms allows us to verify in principle how fragile the power and strength of the State are to guarantee these rights, when from the same dialectic it is also possible to construct a discourse of inefficiency of those norms. However, that qualifier verified in some way in the practice seems to remain the result of the historical and unchanging behavior of its recipients; which prevents consolidating a true barrier against eventual transgression. When this irrationality is overcome, it will then be possible to verify what the State longs for teleologically through Law and power, which, among other purposes, is respect for the sexual rights of others.

Keywords: protection, sexual rights, normative efficacy, dogmatics, power, dialectics, axiology.

\begin{abstract}
SUMARIO: I. Introducción. II. Los derechos humanos sexuales y su olvidada delimitación filosófica. III. Instrumentos jurídicos de protección internacional y nacional de los derechos sexuales: una mirada desde la dogmática constitucional y penal en Colombia. IV. Una revisión al dogma de la garantía de los derechos sexuales. V. Conclusiones. VI. Bibliografía.
\end{abstract}

\title{
I. INTRODUCCIÓN
}

Para las personas, la libertad, la integridad y la formación sexual son derechos humanos de muy alto raigambre que siempre han sido vistos como esa gran posibilidad de disfrute y desarrollo integral del individuo por cuanto maximizan su dignidad humana. Esto, por sí mismo, pone de presente la necesidad de que dichos derechos sean respetados por los integrantes de la sociedad y, en estricto sentido, garantizados por el Estado a través de su ordenamiento jurídico, bajo la más alta aspiración de que no serán vulnerados por ningún motivo. No obstante, como fenómeno criminal y lastimosamente siempre constatado desde los albores de la humanidad, encontramos el delito sexual como un acto que irrumpe profundamente aquella

Esta obra está bajo una Licencia Creative Commons

Atribución-NoComercial-SinDerivar 4.0 Internacional, IIJ-UNAM. 
dignidad humana, y que cada vez más aflige a las personas sin distinción alguna, lo cual deja en sí misma un desalentador y conclusivo panorama que comúnmente denominamos ineficacia normativa, por cuanto pone en cuestión los fines y la filosofía de protección en la cual se fundamenta nuestro Estado social de derecho a través de las normas existentes.

Es por esta compleja paradoja por lo que surge la constante reflexión, pero ahora bajo una seria consideración sobre aquel ser - el hombre-que se presenta como un constante agresor de estos derechos, y que pareciera actuar desde lo más retrógrado de su instinto primitivo de naturaleza humana, poniendo en constante y grave riesgo cualquier intento dogmático de protección y de autoridad estatal en ese sentido, pues con su conducta parece no temerle al poder punitivo del Estado.

En ese orden, llama la atención todo lo concerniente a la obligación que Colombia se trazó desde aquella apuesta de propender por un modelo de Estado social y democrático de derecho, en donde sus instituciones públicas y todos los integrantes de la sociedad quieren ver garantizados sus derechos y libertades, ${ }^{1}$ y de esa forma permitir que impere siempre la legitimación del poder expresado en sus normas jurídicas, finalidad que se traduce cuando se otorgan y se limitan los derechos, entre ellos los de orden sexual; normas que necesariamente también resultan ser de tipo prohibitivo, y que históricamente se apuntalan desde la dogmática penal, en razón de que los límites constitucionales no parecen ser asimilados por el mismo hombre.

A su turno, resulta también obligado aproximarnos a la reflexión sobre la conceptualización de los derechos sexuales a la luz de los derechos humanos y su aspecto natural y normativo, teniendo en cuenta las diferentes clasificaciones que la doctrina viene encauzando sobre esta gama de derechos, desde donde tendremos que sostener que los derechos de índole sexual, que vienen de ser sumamente importantes, porque le dan el cimiento al resto de las dimensiones del ser humano, han de ser de especial interés, y exigen en la actualidad una amplia y constante protección eficaz del Estado.

Bajo este panorama, resultará necesaria la mención precisa y clara sobre la respuesta que jurídicamente el Estado colombiano ha brindado a nivel internacional con miras a cumplir ese encargo de protección y garantía ante cualquier posibilidad de vulneración, lo que para muchos se

1 Molina Betancur, Carlos Mario, Investigación: bicentenario constitucional, Medellín, editorial U de M. 2010, pp. 1-10. 
puede traducir en la actualidad en un cumplimiento formal de ese compromiso supraestatal, porque se refleja a la vez, y paralelamente latente, ese grave incumplimiento a nivel interno a la hora de pretender materializar y garantizar dicha protección. A partir de lo anterior, surge la siguiente situación problemática como una de las aristas que se viene abordando en esta investigación, y que para este trabajo se puede plantear de la siguiente manera: ¿resulta acertado calificar como ineficaz a la Constitución y a la ley por cuanto en la praxis se constata la vulneración de los derechos sexuales de la sociedad? Para acercarnos a una respuesta objetiva de este aspecto, resulta inescindible tratar de conciliar desde la dialéctica, y de manera inicial brindar una posible respuesta a los siguientes interrogantes: ¿qué se debe entender por "eficacia normativa"? ¿Es posible hablar también de una fractura axiológica y sociológica como punto de partida para la trasgresión de los derechos sexuales en la sociedad?

Son estas cuestiones, y sin duda que sobre esta materia existen muchas más, las que motivan estas reflexiones sobre las posturas dogmáticas y filosóficas de protección de los derechos sexuales en Colombia, y nos permiten fundamentar el análisis de una forma objetiva y serena, identificando si nuestra dogmática jurídica constitucional descansa realmente en nuestra sociedad cumpliendo aquel principio de efecto útil para el cual fueron creadas; es decir, materializando esa verdadera concepción finalista que se debe traducir en eficacia normativa; o si, por el contrario, cobran sentido las buenas razones que en gran parte de la sociedad se instalan, cuando sostienen que dicho orden jurídico sólo presenta rasgos de ineficacia al no poder garantizar estos derechos sexuales, y mucho menos desde la norma penal, que tampoco logra disuadir al individuo en su no afectación en todo tiempo y lugar. Lo anterior, nos permitirá considerar seriamente, si de manera silente pueden estar coexistiendo entre estas dos máximas alguna postura intermedia, que extrañamente se ha visto diluyendo con el tiempo, y a la cual se le resta importancia; hablamos de aquella en donde se ubica necesariamente el hombre como el único responsable de este estado de cosas normativamente ineficaces, en el sentido de que a partir de su irracionalidad e inmadurez social viene despreciando no sólo las normas jurídicas, sino también la libertad y la integridad sexual de su congénere, como si aún permaneciera inmerso en un estado de naturaleza humana, lo que termina desdibujando los contenidos axiológicos y sociológicos del mismo sistema normativo. 
Para entender el poder político correctamente, y para deducirlo de lo que fue su origen, hemos de considerar cuál es el estado en que los hombres se hallan por naturaleza. Y es éste un estado de perfecta libertad para que cada uno ordene sus acciones y disponga de posesiones y personas como juzgue oportuno, dentro de los límites de la ley de naturaleza, sin pedir permiso ni depender de la voluntad de ningún otro hombre. ${ }^{2}$

Si cobra sentido la premisa anterior, puede resultar prudente no seguir cuestionando las normas jurídicas por no haber alcanzado el objetivo que algunos teóricos del derecho le han asignado en vieja data, que entre otros es el de generar orden social y regular la conducta humana para poder vivir armónicamente. Lo anterior, habrá de superarse teniendo en cuenta que ni el derecho de las primeras civilizaciones ni mucho menos el moderno o al que muchos llaman postmoderno, han podido lograr dicho propósito en todo su esplendor.

A partir de esta postura filosófica, sería entonces también loable que ese cuestionamiento de ineficacia también lo soporten otras ciencias o disciplinas sociales que se deben al hombre en todas sus dimensiones; es decir, por no haber alcanzado tampoco una última conclusión sobre la correcta conducta en sociedad; claro está, sin pretender descalificar lo que las normas jurídicas han logrado frente al hombre a través los tiempos, pero en su justa proporción. En otras palabras, se quiere poner de relieve que la presunta ineficacia de esas normas jurídicas se puede estar presentando aún, porque más allá de la obediencia y compresión del hombre sobre una concepción o prescripción jurídica, éste elige muchas veces obedecer primero a su estructura natural, claramente irracional, cuando irrumpe en los derechos sexuales del otro, sin dimensionar sus resultados. Esta libertad, humana anteriormente descrita, también ha puesto en constante cuestión los propósitos de otras ciencias sociales que abordan el objeto de conocimiento desde el paradigma positivista, que viene de superar otros estados teóricos del conocimiento, ${ }^{3}$ pretendiendo construir una sociedad y un derecho desde la vida, con todo lo que ello implica, y no desde los textos, como regularmente pasa.

2 Locke, John, Segundo tratado sobre el gobierno civil, trad. española de Carlos Mellizo, Madrid, Alianza Editorial, 1998, p. 36.

3 Comte, Augusto, Primeros ensayos, trad. de Francisco Giner de los Ríos, México, Fondo de Cultura Económica, 1942, p. 107. 
Por lo tanto, para el desarrollo de este artículo se adoptará una metodología descriptiva analítica, que se presentará en dos partes: la primera, se centrará en la fundamentación filosófica de los derechos humanos, en este caso los de índole sexual, y analizando los elementos de fuerza y de poder con los que cuenta el Estado para lograr su verdadera garantía y eficacia en la protección; luego, descenderemos a su conceptualización, la que, sin duda, nos permitirá otros análisis a partir de las marcadas clasificaciones que la misma ley trae consigo dependiendo el tipo de víctimas de agresión sexual y el contexto donde ocurran las mismas; en la segunda parte de este artículo se pondrá en escena todo el orden normativo internacional y nacional que el Estado colombiano ha venido adoptando a partir de ese intento dogmático de protección de los derechos sexuales en la sociedad colombiana, lo que nos permitirá acercarnos a la respuesta de aquellos interrogantes que surgen en esta investigación sociojurídica, y a partir de allí, poder plantear algunas ideas que nos permitan hablar de la eficacia normativa para la protección de los derechos sexuales, desde una postura teórica, que permita rescatar la inescindible relación que debe existir entre el derecho con las demás ciencias sociales que se involucran con el hombre y, por supuesto, con la axiología; por último, se precisarán las conclusiones y las referencias bibliográficas.

\section{LOS DERECHOS HUMANOS SEXUALES Y SU OLVIDADA DELIMITACIÓN FILOSÓFICA}

Una de las principales razones frente a la constante reclamación del respeto por los derechos humanos surge de considerar que los mismos son originarios de un estado de naturaleza, ${ }^{4}$ que trasciende en el derecho natural. Encontramos que este reclamo parece surgir del malestar que se siente cuando encuentran regulada su conducta por un poder y una autoridad que pugna muchas veces con los lineamientos de algún contrato social

\footnotetext{
4 Bobbio, Norberto, Sociedad y Estado en la filosofía politica moderna. El modelo iusnaturalista y el modelo hegeliano-marxiano, México, Fondo de Cultura Económica, 1997, p. 79. Según el autor, la posición de Rousseau era compleja, porque la concepción de la humanidad y su desarrollo no era dual — estado de naturaleza o sociedad civil-, donde el primer momento es negativo, y el segundo, positivo. La teoría de Rousseau es que ha sido tríadica - estado de naturaleza, sociedad civil, república (fundada en el contrato social) - donde el momento negativo, que es el segundo, es puesto entre dos momentos positivos.
} 
ficticio, ${ }^{5}$ al cual se vieron avocados históricamente por aquella necesidad de constituirse como Estado, pues recuérdese que allí se materializaría la idea de una sociedad políticamente organizada.

No obstante, esa reclamación puede ser entendida también como aquella intención de no seguir compartiendo tal relación contractual, dado que la misma implicó desde siempre unas enormes limitaciones en el disfrute de los derechos a partir de las cláusulas que esos cuerpos normativos establecieron, con la finalidad de hallar un equilibrio en la convivencia armónica de la sociedad, es decir, el orden.

Sostener lo anterior conduce a que cobre sentido que ese estado de naturaleza fuera interpretado disyuntivamente a partir de dos posibilidades de asociación política que marcaron ese camino al menos en los albores del siglo XVII: i) un absolutismo que propendía la concentración del poder para el manejo y la restricción de la libertad y la igualdad del individuo dada la desconfianza misma entre aquéllos; recordemos que esa teoría radica en Thomas Hobbes, ${ }^{6}$ y ii) bajo el pensamiento de John Locke, ${ }^{7}$ cuando señalaba que era posible la asociación civil y política entre los hombres y el ejercicio del poder, a partir del reconocimiento y respeto por las leyes y de las propias libertades humanas, lo cual sería posible a través de la razón.

Desde estos ángulos filosóficos, la primera postura se justificaba históricamente, porque era el mismo hombre y sus pasiones los que desenca-

5 Ibidem. pp. $47-122$.

6 Hobbes, Thomas, Leviatán, trad. de M. Sánchez Sarto, México, Fondo de Cultura Económica, 1980, p. 265.

7 “...Así, cuando un grupo de hombres ha consentido formar una comunidad o gobierno, quedan con ellos incorporados a un cuerpo político en el que la mayoría tienen el derecho de actuar y decidir en nombre de todos. Pues cuando un número cualquiera de hombres, con el consentimiento de cada individuo, ha formado una comunidad, ha hecho de esa comunidad un cuerpo con poder de actuar corporativamente; lo cual sólo se consigue mediante la voluntad y determinación de la mayoría. Porque como lo que hace actuar a una comunidad es únicamente el consentimiento de los individuos que hay en ella, y es necesario que todo cuerpo se mueva en una sola dirección, resulta imperativo que el cuerpo se mueva hacia donde lo lleve la fuerza mayor, es decir, el consenso de la mayoría. De no ser así, resultaría imposible que actuara o que continuase siendo un cuerpo, una comunidad, tal y como el consentimiento de cada individuo que se unió a ella acordó que debía ser. Y así, cada uno está obligado, por consentimiento, a someterse al parecer de la mayoría. Vemos, por lo tanto, que en aquellas asambleas a las que se ha dado el poder de actuar por leyes positivas, cuando un número fijo no ha sido estipulado por la ley que les da el poder, el acto de la mayoría se toma como acto del pleno; y, desde luego, tiene capacitad decisoria, pues tiene el poder del pleno, tanto por ley de naturaleza como por ley de razón”. Locke, John, Segundo tratado sobre el gobierno civil, cit., pp. 111 y 112. 
denaban un estado natural de violencia, sin poder hallar en sí mismos una voluntad de reflexión interna y de respeto frente a los otros. En ese sentido, surgía la idea de que dos libertades eran incompatibles entre sí; es decir, los hombres libres y el poder, pues sólo una estaba llamada a prosperar, y para aquella época lo era aquella que representaba el poder. Lo anterior, teniendo en cuenta, además, que ese poder tenía la posibilidad de mantener vigilado el ejercicio de la libertad y los demás derechos de las personas, que en últimas siempre fueron vistos como fuente de pasiones y sin freno alguno, por lo que también estas posturas se asociaban claramente a un egoísmo racional.

Si echamos un vistazo al ángulo filosófico de Locke, se observa como más benevolente con el hombre y su estado mismo de naturaleza humana, al considerarlo con "moral y razón", bajo la idea que éste era capaz de controlar sus propios excesos acudiendo a la prudencia. ${ }^{8}$ Entre tanto, vistos así estos argumentos, implican la coexistencia de dos posturas dialécticamente opuestas: la primera, es la que se estructura en esa petición de libertad para algo que quiere y necesita el hombre, pero que raya cuando esa libertad resultaba siendo exigida posteriormente para otras cosas, y es allí en donde Hobbes justifica la idea de que el hombre debe renunciar a todo, pues de entregarse al hombre dicha libertad en ese todo, ese todo lo mantendría en un constante estado de guerra. Sin embargo, la segunda postura indica que se puede renunciar a algo porque la razón y la prudencia es la que pone límites a esa la libertad, así como lo expresó Locke.

Pero hay otro pensamiento que ahonda aún más en este aspecto. Nos referimos al de Norberto Bobbio, cuando refiriéndose al tema de las obligaciones en correspondencia con la ley, afirma que "...la función primaria de la ley no es liberar, sino oprimir, no ampliar los espacios de libertad

8 “Así, la libertad de un hombre, y la de actuar de acuerdo con su propia voluntad, se fundamenta en que dicho hombre posee una razón que lo capacita para instruirlo en las leyes por las que ha de regirse y para poner en su conocimiento los límites de su voluntad libre. Dejarlo a rienda suelta, sin cortapisa alguna a su libertad, antes de que posea esa razón que puede guiarlo, no es concederle su privilegio natural de ser libre, sino arrojarlo entre las bestias y abandonarlo a un estado tan miserable y tan inferior al hombre como el de aquellas. Esto es lo que pone en manos de los padres la autoridad de gobernar a sus hijos mientras éstos son menores de edad. Dios ha encargado a los padres que cuiden de su descendencia, y ha puesto en ellos las apropiadas inclinaciones de ternura y cuidado para que regulen este poder y para que lo apliquen, según fue designado por la sabiduría divina, al bien de los hijos mientras éstos necesitan estar bajo su tutela". Locke, John, Segundo tratado sobre el gobierno civil, cit., p. 84. 
sino restringir y no dejar crecer el árbol salvaje, sino enderezarlo cuando se tuerce". ${ }^{9}$

Alrededor de estos postulados, podemos inferir prudentemente que nuestra sociedad actual se encuentra aún en un punto medio o gris; es decir, como súbditos y hombres libres, y lo anterior es plausible si se propende mantener un orden. Y es que esta expresión social y política se verifica así, por cuanto debemos tener en cuenta que el poder que brinda la ley para gobernar a los pueblos, en cualquier modelo de Estado y sistema de gobierno posible, se encuentra muchas veces permeado de despotismo cuando se utiliza la ley y el poder para maltratar la libertad de los hombres. Por consiguiente, si se presenta tal proceder, su consecuencia más probable es la constante deslegitimación de ese poder; esta idea termina contrariando ese ideal común al cual se decidió apostarle a partir de ese modelo de sociedad políticamente organizada. En otras palabras, el primario estado de naturaleza humana esperaría así una posible coexistencia armónica entre sociedad y poder, para mantener estable lo que surge de estos dos, que es claramente un Estado con normas y una autoridad que obligan, incluso, bajo amenazas de sanción.

Ahora bien, estos elementos verificados en contexto nos permiten afirmar que quienes deciden vivir en sociedad deben comprender que todos sus derechos y libertades serán regulados por la ley, incluso aun si se predicara del individuo un cierto grado de anarquía.

No se puede perder de vista que aquel fundamento filosófico ha sido una de las grandes justificaciones a través de la historia para que derechos tan caros como la libertad, la integridad y la formación sexual sean protegidos por los Estados con normas jurídicas que buscan disuadir de manera efectiva la conducta anómala de algunos individuos. Todo lo anterior, claro está, para lograr una actitud de respeto y no afectación en el otro bajo el marco de un modelo de Estado social y democrático de derecho, que se propone como máximo pilar el disfrute de los derechos y libertades para la efectiva realización de todos los individuos.

Entre tanto, vemos claramente, y así se puede verificar en el Estado colombiano, que la ley no viene siendo un presupuesto de garantía efectiva para el goce de esos derechos sexuales, pues habrá de tenerse en cuenta que no es ella en sí misma la que garantiza el respeto por aquellos derechos, sino que ha de ser la razón y la reflexión interna del sujeto las que

9 Bobbio, Norberto, El tercero ausente, Madrid, Cátedra, 1997, p. 163. 
tienen que verse reflejadas desde su correcto proceder, es decir, sin perder de vista el constante límite de su libertad que le marca aquella ley y acompañándolo necesariamente de un cierto grado de moralidad.

Al llegar a este punto, resulta obligado considerar aquel afán de muchas personas que resultan afectadas en sus derechos sexuales, cuando naturalmente buscan una respuesta del Estado a partir de esa gama jurídica de protección que quedó establecida en nuestra Constitución política. Después de todo, no parece fortuito entonces que la misma conducta dañina de aquellos hombres, los que aún se mantienen en el retrógrado estado de naturaleza, que no aceptan ni siquiera un mínimo de civilización humana para coexistir armónicamente y con el suficiente respeto hacia los derechos sexuales ajenos, sean los que en últimas pongan en entredicho aquellas doctrinas contractualistas antes enunciadas, por aquello de que el hombre parece no ser capaz de ser libre y estar sometido a la ley al mismo tiempo.

Por consiguiente, se puede en principio sostener serenamente que se hace impensable un Estado en el cual se pretenda que los hombres guarden un equilibrio entre sus pasiones y la razón, pues exigir un propósito como estos implica desconocer la forma natural de la evolución humana, que viene de ser producto de la inicial irracionalidad y desconfianza entre los mismos seres humanos, y que en la actualidad parece no haberse superado totalmente como producto de su egoísmo innato; claro está, se parte de hechos empíricamente constatables en este sentido.

De este modo, el anhelo social de respeto por los derechos sexuales ajenos no recomienda esgrimir argumentos que puedan poner en tensión dialéctica toda una historia llena de teorías filosóficas en constante evolución; por ejemplo, las del iusnaturalismo y el iuspositivismo en materia de origen y concepción de los derechos humanos, pero paradójicamente no replanteadas o destruidas por el tiempo presente; sin dejar de considerar que existen problemas mayores que el derecho actual debe resolver, y por eso no debe quedarse estancado en esas disquisiciones filosóficas e intelectuales. En ese sentido, no resulta ser menos cierto que al fallar el hombre en algo tan natural como lo es la autorregulación de su desbordada lividez, lo conduce también a desestimar al semejante en sus derechos sexuales y, de paso, desprecia la Constitución y las leyes del Estado, que vienen de ser producto de esa presunta racionalidad. En otras palabras, al no escaparse ese sistema jurídico ${ }^{10}$ de ser irrespetado por las propias pasiones

10 Kelsen, Hans, Teoría pura del derecho, México, UNAM, 2002, p. 45. 
y apetitos de sus destinatarios, estas prescripciones normativas en últimas se pueden traducir en un discurso falaz sobre aquel intento dogmático de protección, porque ni las normas jurídicas ni la autoridad o el poder que ellas entregan a los gobernantes logran cumplir con el propósito para el cual fueron creadas.

\section{El poder y la fuerza del Estado como débiles elementos para la garantía de los derechos sexuales}

Es cierto que en la contemporaneidad, Colombia, como Estado social y democráticamente constituido, supone la inexistencia de la fuerza, por cuanto de manera pacífica su sociedad ya viene eligiendo quién y de qué manera deberá gobernar su territorio; es decir, podemos sostener que estamos bajo un modelo de democracia legítima, donde se respetan los derechos fundamentales; ${ }^{11}$ o también, en donde se incluyen a todos los integrantes de la sociedad en una idea de razón pública en la cual también se respetan los principios de justicia. ${ }^{12}$

Lo anterior significa que cuando se delega el poder, ese delegatario debe disponer de una manera recta y eficaz todo su actuar para seguir construyendo, políticamente hablando, una sociedad armónica y en convivencia. A partir de allí, se puede sostener una legitimación en su ejercicio, ya sea de manera tácita o expresa por parte de sus destinatarios, en los cuales recaen las decisiones gubernamentales. Sin embargo, sin dejar de aplaudir aquellos avances, no es menos cierto y se hace necesario recordar, que estos Estados democráticos no surgen de una sola idea política o filosófica, como tampoco de un marco axiológico preestablecido, y mucho menos de la aceptación pacífica de las normas que se estructuran en su interior; por el contrario, son producto de toda una evolución histórica, que en su mayoría de veces se ha visto permeada por el uso de la fuerza de quien pretende ejercer el poder en virtud de un apetecido y prolongado gobierno, que como fenómeno humano constante se expresa al interior de los Estados. ${ }^{13}$

\footnotetext{
11 Kelsen, Hans, Esencia y valor de la democracia, Buenos Aires, Labor, 1984, p. 14.

12 Rawls, John, Liberalismo político, Barcelona, Crítica, 2002, p. 266.

13 "Para la generalidad de estas doctrinas, el Estado es la fuerza del poder político y ésta siempre se ha manifestado por medio de la imposición. La fuerza del Estado pertenece a aquel que se ha sabido imponer sobre los demás. Surgen estas teorías, como oposición a las teorías teológicas, dando preponderancia al poder de dominación o sujeción de las fuerzas sociales, frente a la sumisión a una voluntad divina. La sociología y la 
A primera vista, y considerando la idea anterior, desde esa fuerza para gobernar e imponer las leyes desde una expresión positivista, vemos que se observan formalmente los principios que rigen el modelo de Estado que tenemos, y sobre el cual se orienta a la promoción y garantía de los derechos humanos de índole sexual; no obstante, no debemos olvidar que dicha expresión de creación del derecho en aquellos términos puede eventualmente estar atendiendo una clara fundamentación teórica de las libertades fundamentales ${ }^{14}$ aunque no sea del todo pura. Lo anterior indica que el Estado, basado en sus principios fundamentales que le irradian constitucionalmente, presenta un constante desarrollo en pro de las exigencias internacionales, que invitan a la adquisición de obligaciones en esa materia; con esto permite dejar explícitas unas funciones de protección a partir de un orden supraconstitucional, que se fundamenta en los tratados y convenios internacionales de carácter regional. ${ }^{15}$

Sin embargo, en el Estado colombiano la atención y protección de los derechos sexuales queda adormecido, y ¿por qué no decirlo?, también sumamente descuidados por aquello que sus esfuerzos encuentran una obligada bifurcación por la exigencia social de luchar también internamente contra otros factores y actores generadores de violencia, como lo son el narcotráfico, la corrupción, los grupos de guerrilla, paramilitares, bandas criminales, entre otros, que demandan cada vez más la atención de la fuerza y el poder del Estado, incluso, a la luz de estar buscando salidas negociadas para la terminación del conflicto interno que entre éstos persiste, sin percatarse, en la mayoría de las veces, de que lo anterior resulta siendo un sofisma de distracción del cual se deriva que los delitos sexuales terminen

antropología han puesto en evidencia el poder de coerción que ejercen los hombres entre sí en todas las sociedades humanas, arcaicas o modernas. En realidad, no se concibe el Estado sin el poder que implica la existencia de una autoridad que puede ser opresiva o mesurada. Para poder ejercer esta fuerza se requiere de la coerción, de la presión violenta de la autoridad que necesita en ciertos casos la brutalidad". Molina Betancur, Carlos Mario et al., Derecho constitucional general, Medellín, Universidad de Medellín, 2008, pp. 99 y 100.

14 Fioravanti, Maurizio, Los derechos fundamentales. Apuntes de historia de las constituciones, Madrid, Trotta, 2007, pp. 25-53.

15 En especial, y para nuestra región, se establece en la Convención Americana de Derechos Humanos con su órgano de protección y jurisdicción como la Corte Interamericana de Derechos Humanos, y en otras latitudes, la Corte Europea de Derechos Humanos. Aguirre Arango, José Pedro, "La interpretación de la Convención Americana sobre Derechos Humanos”, Revista de Derechos Humanos, año V, núm. 8, 2007, pp. 73-97. 
siendo desdibujados en estos escenarios, tanto en su misma fundamentación y filosofía de protección como también en su juzgamiento y las garantías de reparación que en estos procesos se predican. ${ }^{16}$

Al llegar a este punto, no resulta ser tarea fácil identificar los argumentos políticos que amparan ese descuido público sobre la debida atención en esta materia, pues los innumerables discursos políticos a partir del ejercicio de poder del gobierno ${ }^{17}$ terminan reducidos a simples falacias, que paradójicamente le generan un blindaje sociopolítico a lo paquidérmico de las acciones positivas que se manifiestan desde el Estado. Por lo tanto, lo que no se explica claramente es cómo los gobernantes rinden informes ante la comunidad nacional e internacional pretendiendo reflejar el cumplimiento efectivo de las obligaciones adquiridas frente a estos derechos de índole sexual, y es bajo este escenario desde donde resulta simple distinguir que la letra formal, escrita con pluma diplomática, logra constantemente distraer la realidad aberrante que aqueja a la sociedad, que cada vez ve más distante ese marco de cumplimiento y garantía de una verdadera libertad, integridad y formación sexual de sus habitantes. Así lo expuso el profesor Carlos Gaviria Díaz al afirmar:

Esa concepción y ese logro que es el Estado de Derecho, sin embargo, ha sido sometido a muchas críticas. La primera de todas las libertades que se consagran, por ejemplo, en la declaración de los derechos del hombre y del ciudadano, son libertades eminentemente formales, lo que significa que se plasman en el papel, pero no garantizan que la persona pueda disfrutar de ellas en la realidad. En el manifiesto comunista de Marx y Engels en 1848 se plasma una crítica a ese tipo de libertades y, por tanto, al Estado Liberal

\footnotetext{
16 Véanse, por ejemplo, las leyes transicionales que ha adoptado Colombia en los últimos tiempos como lo es la Ley 975 de 2005, conocida como Ley de Justicia y Paz, que se expidió para que los grupos al margen de la ley se pudieran reincorporar a la sociedad y contribuyeran al logro de la paz, especialmente para la desmovilización de los denominados "paramilitares", pero donde también se beneficiaron integrantes de grupos guerrilleros. Asimismo, el Acto legislativo 01 de 2012 o Marco Jurídico para la Paz, que aprobó el Congreso de la República de Colombia a partir de las negociaciones de paz entre el gobierno y las Fuerzas Armadas Revolucionarias de Colombia "FARC" en La Habana, Cuba.

17 Van Dijk, Teun A., "Discurso, conocimiento, poder y política. Hacia un análisis crítico epistémico del discurso", Revista de Investigación Lingüistica, Murcia, vol. 13, 2010, pp. 167-215; véase también, Bozo de Carmona, Ana Julia, "Karl-Otto Apel: Reflexiones sobre la teoría de la verdad y la ética del discurso", Revista de Filosofía, Universidad de Zulia, núm. 22, julio-diciembre de 1995, pp. 103-119.
} 
o Estado de Derecho a secas, porque se considera que esas libertades así concebidas y así plasmadas son un engaño. ${ }^{18}$

Dentro de ese contexto, y aceptando a priori que en Colombia ya existe una normativa tendiente a garantizar el ejercicio de los derechos y libertades de orden sexual, surge objetivamente la tesis de que no resulta posible, al menos para este momento histórico, poder calificarlas de eficaces, por el hecho de estar allí inmersas en el cuerpo de la Constitución y desarrolladas ampliamente por el poder político en las leyes; ${ }^{19}$ sostener lo contrario, sería aprobar a la ligera el discurso ampliamente antropocéntrico que le sirvió de base para crear dichas normas; sin entrar a considerar los factores reales, es decir, los delitos sexuales propiamente dichos, que paulatinamente han venido entregado el insumo suficiente para la creación del derecho, pero que pasado el tiempo no ha sido capaz de conjurar.

Dicho en otros términos, la eficacia normativa se ha de constatar cuando con dicha creación jurídica se puede superar el fenómeno social que le dio origen; por ejemplo, evidenciando que día a día disminuyen los índices del delito; mas en este caso la realidad de este momento histórico no permite aprobar el argumento final de eficacia en la medida en que su verificación material no arroja los resultados esperados, ${ }^{20} \mathrm{y}$ en otro sentido, esa

18 Gaviria Díaz, Carlos, "Los temas de la constituyente. El Estado social de derecho y la presión política por el cambio", Revista de Derecho Foro, núm. 7, primer semestre 2007, p. 8.

19 "Falacia politicista y falacia garantista. Es relativamente fácil delinear un modelo garantista en abstracto y traducir sus principios en normas constitucionales dotadas de claridad y capaces de deslegitimar, con relativa certeza, las normas inferiores que se aparen de él. Más difícil es modelar las técnicas legislativas y judiciales adecuadas para asegurar efectividad a los principios constitucionales y a los derechos fundamentales consagrados por ellos. ... En este libro he desarrollado, prevalentemente, una crítica de la que llamaré falacia politicista: es decir, de la idea de que baste la fuerza de un poder bueno para satisfacer las funciones de tutela asignadas al derecho, antes aún, de que pueda existir un poder bueno, es decir, capaz de desempeñar tales cometidos sin la mediación de complejos sistemas normativos de garantías con capacidad de limitarlo, vincularlo, instrumentalizándolo y, de ser necesario, deslegitimarlo y neutralizarlo. Junto a la falacia politicista, puede sin embargo cultivarse también una falacia garantista: es decir, la idea de que basten las razones de un derecho bueno, dotado de sistemas avanzados y actuables de garantías constitucionales, para contener al poder y poner a los derechos fundamentales a salvo de sus desviaciones”. Ferrajoli, Luigi, Derecho y razón. Teoría del garantismo penal, Madrid, Trotta, 1995, pp. 940 y 941.

20 García Obando, Pedro Antonio y Aguirre Román, Javier Orlando, Lógica y teoría de la argumentación, Santander, Universidad Industrial de Santander, 2008, pp. 91-124. 
eficacia se evidenciará al momento de verificar si realmente se cumplen o no los presupuestos para los cuales fue creada la norma bajo tal estructura y propósito, es decir, para mantener incólume la integridad de la dignidad humana que se irradia a partir del goce efectivo de los derechos, ${ }^{21}$ en este caso, los sexuales.

Al evidenciar lo paradójico que resulta ser aquel ámbito dogmático sobre la protección de los derechos sexuales, seguido de su consecuente afectación, esta situación no brinda los elementos necesarios para entrar en comparaciones con respecto a cuál de las manifestaciones delictuales - acceso carnal violento, acto sexual abusivo, entre otros- genera mayor sufrimiento en las personas, pues a lo anterior se le puede restar importancia si lo que se pretende es poner de relieve el valor y la dimensión de aquellos derechos sexuales frente a la denominación lingüística en la tipificación del delito. Lo anterior, teniendo en cuenta que cualquier clasificación que eventualmente pueda darse sobre estos escenarios delictivos deberá pasar a un segundo plano, porque es un delito que toca al ser humano en su núcleo central de la dignidad, y, en clave de sus dimensiones, ninguna de éstas resulta ser más importante que otra, por cuanto de todas requieren su materialización; ergo, poder conservar su integralidad. A partir de lo anterior, surge como necesario que seguidamente se expongan algunos aspectos sobre lo que esto puede significar en la praxis.

\section{La (des)contextualización y (des)clasificación de los derechos sexuales}

Hablar de una posible clasificación de los delitos sexuales no implica necesariamente la categorización de los derechos afectados en ese núcleo esencial; es decir, que por el hecho de ser mínima la agresión sexual resulte posible pensar que se afecta entonces sólo un mínimo de dignidad humana. No obstante, en clave de la paradoja antes enunciada — protección-afectación - frente a la realización de las libertades y derechos sexuales de las personas, sí pareciera vislumbrarse esa especie de categorización o diferenciación, al menos en el contexto de un Estado social de derecho como Colombia. Lo anterior viene siendo explicado por la doctrina, que trata de enseñar que ésa resulta ser el método más indicado para una mejor asimila-

21 Alexy, Robert, El concepto y la validez del derecho, Barcelona, Gedisa, 2004, pp. 172-177. 
ción; es decir, pensarlo así terminaría siendo práctico para poder garantizar en alguna medida aquel núcleo de protección que predican las normas.

...Pero se mantiene, digamos, una categorización dentro de esa terminología, que yo llamaba un tanto desgastada de derechos de primera y segunda generación. Podemos decir que los derechos de primera generación tienen formas de protección más expeditas que los derechos de segunda generación o que las libertades que corresponden al primer paradigma de la dignidad humana, son más fácilmente protegibles que los derechos o la garantía de los derechos que corresponden a ese segundo paradigma de la dignidad humana, digamos las aspiraciones humanas, los deseos, las metas que se van transformando históricamente y por tanto, mirar los derechos de esa manera como correspondientes a distintas concepciones de la dignidad humana, a distintos paradigmas de la dignidad humana, nos permite articular los derechos humanos en la historia. ${ }^{22}$

Se puede advertir, dicha afirmación invita a diferenciar en cuál de estos dos paradigmas de dignidad humana se encuentra la persona respecto a su derecho de realizarse en el ámbito sexual de una manera autónoma y libre, pues no se debe perder de vista que aquellas libertades no se logran materializar, debido a una agresión de tal estirpe, y en donde el Estado y sus autoridades, a través de sus normas, no pudieron garantizar ninguno de los paradigmas de esa dignidad humana.

Ahora bien, no se escapa entonces del anterior argumento, el hecho de que resulta obligado tener en cuenta que para lograr tal diferencia debemos comprender claramente el concepto y alcance de la dignidad humana, que en la práctica de la existencia humana tiene varias connotaciones, porque es necesario

...considerar al ser humano como un fin en sí mismo y no como un instrumento o un medio para la realización de la voluntad o intereses ajenos. El principio de dignidad humana protege "i) la autonomía o posibilidad de diseñar un plan vital y de determinarse según sus características (vivir como se quiere), ii) ciertas condiciones materiales de existencia (vivir bien), iii) la intangibilidad de los bienes no patrimoniales, integridad física e integridad moral (vivir sin humillaciones). ${ }^{23}$

\footnotetext{
22 Gaviria Díaz, Carlos, op. cit., p. 10.

23 Corte Constitucional de Colombia, Sentencia T-881 de 2002, M. P.: Eduardo Montealegre Lynett.
}

Esta obra está bajo una Licencia Creative Commons

Atribución-NoComercial-SinDerivar 4.0 Internacional, IIJ-UNAM. 
En ese orden de ideas, teóricamente esos derechos sexuales están y se deben mantener en la gama de los derechos humanos fundamentales; ${ }^{24}$ es decir, al interior del primero de los paradigmas. No obstante lo anterior, también resultaría posible desde una posición filosófica y axiológica, que ninguna categorización resulta plausible en tratándose de este tipo de derechos de tipo sexual.

Este escenario conceptual tiene su fundamento a partir de la fractura de la dignidad humana que surge después de la agresión de un derecho sexual; así: ¿pueden esos derechos sexuales, en consonancia con la dignidad humana, mantenerse como derecho fundamental en ese primer paradigma después de ese episodio? En clave de la no clasificación y categorización de esos derechos humanos, se diría que sí se pueden mantener en ese primer paradigma. Sin embargo, serenamente se puede dejar planteado también que no, pues frente a lo que implica el concepto y precepto de la dignidad humana, ésta no se reivindica fácilmente por el autor del delito, ni siquiera bajo la idea que aquél solamente afectó un poco de ese principio-derechovalor jurídicamente amparado por el Estado, y tampoco la reivindicarán las autoridades públicas. Nótese, ni siquiera con una decisión judicial de condena o responsabilidad penal en ese sentido. ${ }^{25}$

24 "El concepto de derecho fundamental, pese a inspirarse en la realidad y buscar en cierto modo moldearla, es fruto de la consagración o del reconocimiento del derecho positivo, de suerte que se impone encontrarse en un supuesto comprendido dentro de su ámbito material delimitado o supuesto por el Constituyente para poder gozar de él". Corte Constitucional de Colombia, Sentencia T-240 de 1993, M. P.: Eduardo Cifuentes Muñoz.

25 "El derecho a la dignidad humana no es una facultad de la persona para adquirir su dignidad, ni para que el Estado se la otorgue o conceda, porque la dignidad es un atributo esencial de la persona humana; el derecho fundamental es a que se le dé un trato que respete plenamente la dignidad del ser humano. Es un derecho que implica tanto obligaciones de no hacer como obligaciones de hacer por parte del Estado". Corte Constitucional de Colombia, Sentencia T-702 de 2001, M. P.: Marco Gerardo Monroy Cabra. "La dignidad humana como principio fundante del Estado, es el presupuesto esencial de la consagración y efectividad del sistema de derechos y garantías contemplado en la Constitución. Tiene valor absoluto no susceptible de ser limitado bajo ninguna circunstancia, lo que sí ocurre con derechos que necesariamente deben coexistir con otros y admiten variadas restricciones. El respeto a la dignidad humana no sólo es una declaración ética sin una norma jurídica de carácter vinculante para todas las autoridades. Su acato debe inspirar a todas las actuaciones del Estado. Por lo tanto, la dignidad del ser humano constituye razón de ser, principio y fin último de la organización estatal. Bajo este derrotero, la dignidad se erige como un derecho fundamental, de eficacia directa cuyo reconocimiento general compromete el fundamento político del Estado colombiano". Corte Constitucional de Colombia, Sentencia T-792 de 2005, M. P.: Clara Inés Vargas Hernández; véase 
En virtud de lo anterior, vemos cómo esa principal categorización puede quedar reducida a un simple derecho de carácter transitorio; esto es, se tiene incólume el derecho sexual mientras el Estado brinde formal y materialmente las garantías básicas de su protección. Por lo tanto, teniendo en cuenta que una vez que se produce la trasgresión, y al no poderse reparar en el grado sumo para la víctima, se traslada entonces lo anterior a ese segundo paradigma de garantía; lo que refiere solamente a procurar al menos el mantenimiento de las condiciones básicas de todo tipo, sean éstas sicológicas, sociológicas y jurídicas, para que la persona afectada intente nuevamente desarrollarse armónica e integralmente desde su sexualidad, que sin duda nunca será la misma.

Como se ve, no hay cabida entonces para aceptar jurídicamente que existen derechos humanos más importantes que otros, pero sí concepciones filosóficas y axiológicas diferentes respecto de ellos. ${ }^{26}$ Nótese, por ejemplo, que en muchas partes del mundo la característica de la universalidad de los derechos humanos se desintegra, y una muestra de ello son los regímenes punitivos en los que se dispone la pérdida de la vida como pena capital y a la vez como símbolo de una retribución fuerte al victimario. Desde allí, muchas víctimas y sociedad en general lo ven como una clara manifestación de justicia por el daño que se les causa. No obstante, esas muestras quedan reducidas simplemente a la concepción política, cultural y social de esos Estados, en donde la idea sobre los derechos humanos y su universalidad ${ }^{27}$ no lleva implícito ese sello traducido como la única forma de dar lectura al mundo; al menos en tratándose de aquel principio.

también, Sentencia T-395 de 1998, M. P. Alejandro Martínez Caballero; Sentencia T-389 de 2001, MP. Jaime Córdova Triviño; Sentencia T-576 de 2003, M. P. Alfredo Beltrán Sierra; Sentencia T-701 de 2006, MP. Álvaro Tafur Galvis; Sentencia C-397 de 2006, M. P. Jaime Araujo Rentería.

26 "En las discusiones actuales, pasadas y probablemente también en las futuras sobre los derechos humanos, es dable diferenciar — como muy en general en la filosofía política- cuatro posiciones básicas, que pueden denominarse «aristotélica», «hobesiana», «kantiana», y «nietzscheana», refiriéndolas a arquetipos históricos. ... La concepción liberal de los derechos humanos es la idea política central de la Ilustración y de las revoluciones burguesas. Ella constituye hasta hoy el fundamento de todas las Constituciones de tipo occidental. Con esto, es hasta ahora una de las ideas políticas más exitosas". Alexy, Robert, Teoría del discurso y derechos humanos, Bogotá, Universidad Externado de Colombia, 1995, pp. 63 y 66.

27 "Contra la universalidad de los derechos humanos, se arguye que esos derechos serían en verdad solo elementos de una determinada cultura, o sea la de occidente y con 
Se sostiene lo anterior, porque es sabido que en el campo de las concepciones filosóficas y de la misma naturaleza jurídica de los derechos humanos, como también de su práctica y garantía de protección, no existe un solo universo teórico como el anteriormente planteado en esos regímenes para que se pueda dar este castigo, pues éstos responden en gran medida a la obediencia de una autoridad hereditariamente déspota, que infunde temor en la sociedad, y no necesariamente a la lenta y pasiva evolución históricosocial que hoy se piensa, que no se olvide, también es capaz de estructurar un ordenamiento jurídico que refleje en la virtud de las personas la capacidad de conciliar todas las manifestaciones multiculturales, sin entrar a categorizar los derechos humanos, en este caso especial, la vida misma.

Al lado de ello, esto nos conduce a verificar también la característica de la indivisibilidad de los derechos humanos de contenido sexual, en donde a partir de allí no pareciera plausible clasificarlos. No obstante, al existir en el campo normativo aquellas denominaciones tales como los "derechos civiles y políticos", al menos para la mayoría de los países del mundo, se pone entonces de relieve un amplio margen de su fundamentalidad, porque su protección se puede ver expuesta a un argumento de interpretación constitucional. De cualquier modo, la libertad, la integridad y la formación sexual gozan formalmente de protección en ese sentido, pero, se insiste, la constatación de lo anterior y la aceptación de ese statu quo termina por adormecer cualquier intento de protección material que se pretenda solicitar del Estado en cualquier esfera, pues esa aspiración puede verse truncada y a la deriva por la cambiante interpretación constitucional ${ }^{28}$ que requieren los diferentes casos examinados por los tribunales

ello tendrían si acaso una validez relativa o particular. Todo reclamo de validez universal sería imperialismo adornado de humanitarismo. Alexy, Robert, Teoría del discurso y derechos humanos, cit., p. 67.

28 Atienza, Manuel, "Estado de derecho, argumentación e interpretación”, Anuario de Filosofia del Derecho, vol. XIV, 1997, pp. 465-484; Guastini, Riccardo, Estudios sobre la interpretación jurídica, trad. de Mariana Gascón y Miguel Carbonell, México, UNAM, Instituto de Investigaciones Jurídicas, 1999, p. 5; Galán Juárez, Mercedes, “La interpretación de los derechos fundamentales por parte del Tribunal Constitucional, una argumentación en términos de razonabilidad", Isegoría, núm. 35, 2006, pp. 33-55; Fernández Cruz, José Ángel, "La interpretación conforme con la Constitución: una aproximación conceptual”, Ius et Praxis, año 22, núm. 2, 2016, pp. 153-188; Massé Narváez, Carlos E. y Rivera Hernández, Juan, "La hermenéutica en la interpretación conforme de los derechos humanos en el orden jurídico mexicano", Methaodos Revista de Ciencias Sociales, vol. 2, núm. 1, 2014, pp. 36-44; Grández Castro, Pedro P., "Argumentación jurídica y 
de justicia, lo que viene de ser vigilado por parte de la doctrina cuando pretende que cualquier interpretación en clave de los derechos humanos debe ser siempre sistemática, es decir, eligiendo una hermenéutica conforme con la Constitución. ${ }^{29}$ No obstante, todo es susceptible de cambios, por la inescindible conexión con la argumentación iusfundamental, ${ }^{30}$ que en todos los casos termina marcando el horizonte jurisprudencial en aquellos tribunales al momento de la aplicación normativa al caso concreto, bajo la influencia de los derechos fundamentales. ${ }^{31}$

Ahora bien, dentro de este contexto clasificatorio, la inalienabilidad como característica propia de los derechos humanos de estirpe sexual se adhiere al panorama de irrenunciabilidad de los mismos —a excepción del consentimiento - sin coacción o coerción, que por ningún motivo involucra alguna de las dos, puesto que podría ponerse en entredicho que la dignidad es algo a lo cual se puede renunciar. Bajo esta perspectiva, y considerando los derechos sexuales alrededor de una potencial afectación, aquel panorama sólo conduce a reflejar una cruel encrucijada para las víctimas, porque ellas deben ponderar desde todas sus dimensiones humanas entre las dos únicas opciones posibles que son disyuntivas entre sí, y que terminan siendo totalmente en disfavor de aquéella: la renuncia forzada o la alienación de sus derechos sexuales. Téngase en cuenta, lamentablemente en muchos casos, que las víctimas pierden su vida pretendiendo evitar cualquiera de estas dos.

Después de todo, la mayoría de los argumentos resultan ser válidos, y encauzan la idea de que este especial derecho fundamental no tendría por

derecho constitucional", en Landa Arroyo, César (ed.), Derechos fundamentales, Lima, Palestra, 2018, pp. 109-122.

29 Zavala de Alba, Luis Eduardo, "Gobernanza en derechos humanos: hacia una eficacia y eficiencia institucional", Revue québécoise de droit international, Hors-série, mars 2015, pp. 273-288.

30 “...El resultado es que, en virtud de su base, las argumentación iusfundamental está, por cierto, algo más determinada y estructurada racionalmente, pero que la medida y la fuerza de control que con esto se logra son limitadas. Queda todavía una considerable laguna de racionalidad. Esta laguna de racionalidad la llena el procedimiento de la argumentación iusfundamental: del discurso iusfundamental. El discurso iusfundamental es un procedimiento argumentativo en el que lo que se trata es de lograr resultados iusfundamentales correctos sobre la base presentada". Alexy, Robert, Teoría de los derechos fundamentales, Madrid, Centro de Estudios Políticos y Constitucionales, 2002, p. 553.

31 Anzures Gurría, José Juan, "La eficacia horizontal de los derechos fundamentales", Cuestiones Constitucionales, núm. 22, 2010, pp. 3-51. 
qué verse afectado en ninguna de las formas que la irracionalidad humana despliega. Lo anterior, habida cuenta que la situación anómala, acompañada de las dos opciones antes citadas en las que queda la víctima, no son precisamente las que deben orientar el comportamiento de la humanidad. Sobre estos derechos sexuales, afirma Pabón lo siguiente:

Facultad del ser humano de autodeterminar y auto regular su vida sexual; está unida naturalmente a las finalidades específicas de la sexualidad humana y al concepto de dignidad que gravita sobre todo hombre. Así, la libertad sexual no se ha de entender como posibilidad ilimitada de disposición del propio cuerpo, pues este derecho humano presenta determinaciones y límites naturales.

La libertad sexual es facultad y derecho de elegir, aceptar, rechazar y autodeterminar el comportamiento sexual, con necesaria sujeción a los conceptos éticos de la comunidad y al respeto de los derechos ajenos correlativos. $^{32}$

Así las cosas, los derechos sexuales tendrán siempre el carácter de fundamentales, al menos dentro de los contextos sociopolíticos que quieran mantener íntegra la dignidad humana como fundamento y estructura de un Estado, y también como forma de realización del mismo ser; sin embargo, se podrán hallar argumentos filosóficos, religiosos, e incluso políticos, que permitan dar una clasificación diferente a estos derechos, y lo harán en atención a su misma idiosincrasia. A pesar de lo anterior, se espera que siempre sea en clave del respeto por los derechos sexuales ajenos.

Como ya se hizo notar, para nuestro contexto no en vano Colombia decidió hace muchos años apostarle a la práctica uniforme en el tratamiento de los derechos humanos, y por eso internacionalizó ese propósito, en aras de presentar al mundo su intención de ponerse a tono en el marco del respeto por los mismos. Es así como suscribió y ratificó ante la Organización de Estados Americanos (OEA) aquella Convención Americana de Derechos Humanos, la misma que le permitió asumir una serie de obligaciones en aras de garantizar a sus habitantes el máximo goce y ejercicio de los derechos, y, a la vez, le impuso la obligación de adoptar medidas legislativas para la búsqueda de ese fin especial. No obstante, la clasificación que antes era doctrina hoy ya se encuentra incrustada en las prescripciones

32 Pabón Parra, Pedro Alfonso, Delitos sexuales. La sexualidad humana y su protección penal, Bogotá, Doctrina y Ley LTDA, 2005, p. 126.

Esta obra está bajo una Licencia Creative Commons Atribución-NoComercial-SinDerivar 4.0 Internacional, IIJ-UNAM. 
legales, y así lo viene aceptando la sociedad, lo que posibilita la idea de convencernos de que la afectación de los derechos sexuales, independientemente de su grado o nivel, siempre ha de tocar el núcleo esencial de la dignidad humana; pensarlo diferente, sería claramente desnaturalizar los postulados constitucionales sobre la dignidad humana que continuamente precisa la Corte Constitucional en su jurisprudencia.

\section{INSTRUMENTOS JURÍDICOS DE PROTECCIÓN INTERNACIONAL Y NACIONAL DE LOS DERECHOS SEXUALES: UNA MIRADA DESDE LA DOGMÁTICA CONSTITUCIONAL Y PENAL COLOMBIANA}

Una vez las aquellas bases filosóficas de estos derechos, abordemos ahora este sensible tema poniendo en escena las importantes regulaciones normativas desde donde surgen conceptos o definiciones que permiten identificar aquellos marcos de protección de derechos humanos, teniendo en cuenta los órdenes infra y supraconstitucionales, a partir de los cuales se han puesto en marcha otras políticas de atención en Colombia, así como en otros Estados, con el fin de garantizar de manera efectiva el goce de los derechos sexuales.

La definición de la dogmática viene de ser extensiva de lo que se conoce como dogma: "Fundamentos o puntos capitales de todo sistema, ciencia, doctrina o religión". ${ }^{33}$ Desde este escenario conceptual abordaremos las siguientes reflexiones, considerando los dogmas que dichas fuentes jurídicas traen consigo en tratándose de derechos y delitos sexuales, identificando si lo pretendido por el legislador en términos de eficacia mantienen vigente el sustento teórico en la praxis.

\section{Normas internacionales}

Es necesario recordar que aquel objeto que de antaño le han asignado a las normas jurídicas, especialmente las penales, ha sido el de pretender que sea una garantía de regulación de conductas anómalas de los individuos, trayendo consigo prohibiciones; pues esto se valida, incluso serenamente, como quedó expuesto en líneas precedentes, habida cuenta de la irracional y constante manifestación humana. A su turno, las normas de raigambre

\footnotetext{
33 Diccionario de la lengua española.
} 
constitucional, así expuestas de manera general; es decir, las que no traen distinción en su núcleo de protección, no dejan margen de duda, porque con ellas se expresa la garantía en la protección de derechos humanos, sean éstos de mujeres, hombres, niños, niñas y adolescentes de cualquier origen, filiación poblacional, culto, distinción social y política; lo que resulta atinado, por aquello de que la violencia sexual tampoco tiene en cuenta esas diferenciaciones, pues para el agresor en la mayoría de veces esto le resulta insignificante.

No obstante, las prescripciones en las normas internacionales, en la mayoría de las veces las denominan con títulos que, de entrada, tienen un destinatario específico en su protección. Sin embargo, a pesar de que esto puede causar malestar en los otros sectores que consideran sentirse desprotegidos, es necesario reconocer que aquella normativa atiende al clamor de personas y grupos que vienen siendo víctimas de estos flagelos para ese momento histórico en que se expiden las normas. Después de todo, vemos cómo los fenómenos delictuales terminan abarcando al resto de la población antes no tenida en cuenta allí —en ese título-, y, por aquello del principio de igualdad, se terminan extendiendo sus efectos de protección para éstos. Así las cosas, se enunciará la siguiente normativa sin un estricto orden que pretenda reflejar su jerarquización.

Tenemos entonces la existencia de la Convención Interamericana para prevenir, sancionar y erradicar la violencia contra la mujer, más conocida como Convención de Belém do Pará; ${ }^{34}$ la Convención Americana de Derechos Humanos ${ }^{35}$ y su Protocolo adicional en materia de derechos económi-

34 Es el instrumento internacional que brinda protección a las mujeres frente a la violencia. Fue adoptada en Belém do Pará, Brasil, por la Asamblea General de la Organización de Estados Americanos (OEA) el 9 de junio de 1994. A la fecha cuenta con el mayor número de ratificaciones: de los 34 Estados de la OEA, salvo Estados Unidos y Canadá, lo han ratificado los 32 restantes. Colombia se adhirió a esta Convención el 15 de noviembre de 1995, y fue aprobada en la legislación interna mediante la Ley 248, del 29 de diciembre de 1995. Esta convención define la violencia contra la mujer y consagra el derecho de las mujeres a vivir sin violencia. En el artículo 3, la Convención señala que "[t]oda mujer tiene derecho a una vida libre de violencia, tanto en el ámbito público como en el privado", lo cual incluye el derecho a ser libre de discriminación y a ser valorada y educada libre de patrones estereotipados de comportamiento basados en la inferioridad y la subordinación, como se menciona también en el artículo 6, literales a y b.

35 La Convención Americana sobre Derechos Humanos fue aprobada en Colombia mediante la Ley 16 de 1972. Colombia es Estado parte de la Convención desde el 31 de julio de 1973 cuando depositó el instrumento de ratificación ante la Secretaría General 
cos, sociales y culturales, conocido como Protocolo de San Salvador; ${ }^{36}$ la Declaración de los Principios Fundamentales de Justicia para las Víctimas de Delitos y del Abuso del Poder; ${ }^{37}$ los Principios de Bassiouni, acogidos por la Comisión de Derechos Humanos de la ONU mediante la Resolución 2005/35. Asimismo, se cuenta también con un instrumento que protege especialmente a las mujeres frente a la discriminación y la violencia, denominado Convención sobre la Eliminación de todas las Formas de Discriminación contra la Mujer, conocida también con las siglas "CEDAW"; 38 también instrumentos generales como el Pacto Internacional de Derechos

de la OEA. Esta convención genera obligaciones de los Estados partes, de respetar y garantizar el libre y pleno ejercicio de todos los derechos consagrados en esta convención a toda persona, sin ningún tipo de discriminación, entre otros, por motivos de sexo, y de adoptar las medidas legislativas o de otro carácter que sean necesarias para garantizar la efectividad de los derechos protegidos por la Convención.

36 El Protocolo de San Salvador fue adoptado por la Asamblea General de la OEA el 17 de noviembre de 1988, en la ciudad de San Salvador, El Salvador. El Protocolo fue aprobado en Colombia mediante la Ley 319 de 1996.

37 Adoptada por la Resolución 40/34 de la Asamblea General, del 29 de noviembre de 1985. El principio 6 de la Declaración sobre los Principios Fundamentales de Justicia para las Víctimas de Delitos y del Abuso de Poder establece: "Se facilitará la adecuación de los procedimientos judiciales y administrativos a las necesidades de las víctimas: (a) Informando a las víctimas de su papel y del alcance, el desarrollo cronológico y la marcha de las actuaciones, así como de la decisión de sus causas, especialmente cuando se trate de delitos graves y cuando hayan solicitado esa información".

Véase también el principio 18 de los Principios y directrices básicos sobre el derecho de las víctimas de violaciones manifiestas de las normas internacionales de derechos humanos y de violaciones graves del derecho internacional humanitario a interponer recursos y obtener reparaciones: "Conforme al derecho interno y al derecho internacional, y teniendo en cuenta las circunstancias de cada caso, se debería dar a las víctimas de violaciones manifiestas de las normas internacionales de derechos humanos y de violaciones graves del derecho internacional humanitario, de forma apropiada y proporcional a la gravedad de la violación y a las circunstancias de cada caso, una reparación plena y efectiva, según se indica en los principios 19 a 23, en las formas siguientes: restitución, indemnización, rehabilitación, satisfacción y garantías de no repetición”.

38 La CEDAW fue adoptada por la Asamblea General de la ONU el 18 de diciembre de 1979 y entró en vigor el 3 de septiembre de 1981. En Colombia fue aprobada mediante la Ley 51, del 2 de junio de 1981. La CEDAW, en su artículo 1, define a la discriminación contra la mujer como toda distinción, exclusión o restricción basada en el sexo que tenga por objeto o por resultado menoscabar o anular el reconocimiento, goce o ejercicio por la mujer, independientemente de su estado civil, sobre la base de la igualdad del hombre y la mujer, de los derechos humanos y las libertades fundamentales en las esferas política, económica, social, cultural y civil o en cualquier otra esfera. 
Civiles y Políticos; ${ }^{39}$ y el Pacto Internacional de Derechos Económicos, Sociales y Culturales. ${ }^{40}$ En igual sentido, están la Declaración de Viena sobre la Eliminación de la Violencia contra la Mujer; ${ }^{41}$ las resoluciones del Consejo de Seguridad de Naciones Unidas sobre la protección de las mujeres frente a la violencia y la discriminación en los conflictos armados ${ }^{42}$ y el Estatuto de Roma de la Corte Penal Internacional. ${ }^{43}$

Todo lo anterior, al ser visto desde una perspectiva positiva, nos puede reflejar que existe una enorme garantía formal para todas las personas habitantes en aquellos Estados que se hicieron parte y acogieron para sí estos instrumentos jurídicos, como el caso colombiano.

Después de todo, a la luz de esta normativa tampoco surgen dudas del compromiso internacional de proteger los derechos de la mujer, de manera especial los sexuales. No obstante, no debe olvidarse que de estas normas supraconstitucionales no surge el resultado inmediato al que están convocadas a producir, pues ese intento de protección se presenta inicialmente como un ideal común de los Estados partes en ese campo iusfundamental de las personas, y son éstos los que han de adecuar sus órdenes jurídicos internos para lograr los efectos que se esperan, lo que implica el conocimiento claro de la sociedad que se tiene. Al menos, se cree que lo anterior parece responder a esa estructura tridimensional sobre la cual puede verse el derecho (sociológica, axiológica y jurídica), o, lo que es lo mismo, he-

39 El Pacto Internacional de Derechos Civiles y Políticos fue aprobado por la Asamblea General de la ONU el 16 de diciembre de 1966, y entró en vigor el 23 de marzo de 1976. Fue aprobado en Colombia mediante la Ley 74 de 1968.

40 El Pacto Internacional de Derechos Económicos, Sociales y Culturales fue aprobado por la Asamblea General de la ONU el 16 de diciembre de 1966 y entró en vigor el 23 de marzo de 1976. Fue aprobado en Colombia mediante la Ley 74 de 1968.

41 Adoptada mediante Resolución de la Asamblea General, número 48/104, del 20 de diciembre de 1993. La Declaración reconoce la urgente necesidad de la aplicación universal a la mujer de los principios y derechos a la igualdad, seguridad, libertad, integridad y dignidad.

42 La violencia contra las mujeres en aspectos de género, como también en el marco de los conflictos armados ha sido abordada por instrumentos internacionales, como las resoluciones 1325 de 2000, 1612 de 2005, 1820 de 2008, 1888 de 2009, 1889 de 2009, 1960 de 2010 adoptadas por el Consejo de Seguridad de Naciones Unidas y vigentes para Colombia.

43 Fue adoptado en Roma el 17 de julio de 1998 durante la Conferencia diplomática de plenipotenciarios de las Naciones Unidas sobre el establecimiento de una Corte Penal Internacional. El Estatuto entró en vigor el 1 de julio de 2002. Colombia lo aprobó mediante la Ley 742 de 2002 y depositó el instrumento de ratificación el 5 de agosto de 2002. 
cho, valor y norma, ${ }^{44}$ que pretende atender la visión de un mundo pensado desde todas las dimensiones humanas.

\section{Normas nacionales}

En el orden nacional colombiano fue sólo hasta la Convención de Belém do Pará cuando se dieron signos de regulación normativa con fines de protección de los derechos a "la integridad y el pudor sexual", especialmente de las mujeres, y como ejemplo de ello están los códigos penales de 1837, 1863, 1890, 1936, proyectos de 1974, 1978 y revisión del proyecto de 1979 hasta el Código Penal de 1980. Sin embargo, este último presentaba su regulación un poco arcaica, porque su modo de prohibición obedecía a aspectos morales y religiosos; tanto así, que si cualquiera de los autores o partícipes de una agresión sexual contraía posteriormente un matrimonio válido con el sujeto pasivo — víctima—, procedía jurídicamente la extinción de la acción penal; es decir, aun para esta época dicha posibilidad todavía parecía atender referentes religiosos.

Avanzando en el tiempo, se expidió una nueva Constitución política en 1991, que trajo consigo un marco de tratamiento igualitario y la prohibición de discriminación en su artículo 13, al igual que la protección a la familia en todo su núcleo en el artículo 42. En virtud de esa constitucionalización de derechos, surgió la reforma del código de 1980 bajo la Ley 360 de 1997, en donde cambió de nombre a los bienes jurídicamente protegidos y también aumentó las penas en esos delitos sexuales. Asimismo, tratando de armonizar las obligaciones internacionales adquiridas en materia de derechos humanos, reguló aspectos relativos al tratamiento dentro de las investigaciones penales que se adelantaran, y de manera especial relacionó acertadamente la protección y prevención de enfermedades de transmisión sexual que pudieran ser producto del injusto.

Posteriormente, la Ley 599 de 2000, actual Código Penal de Colombia, redefinió nuevamente el concepto de estos delitos y los denominó "contra la integridad, libertad y formación sexuales", pero rebajando las penas a imponer. Al lado de ellos, con la expedición de la Ley 1236 de 2008 se aumentaron las penas de prisión así: para acceso carnal violento, que estaba de ocho a quince años, fue fijada entre doce y veinte años, el acto sexual

\footnotetext{
44 Reale, Miguel, Teoría tridimensional do direito, São Paolo, Saraiva, 1968, pp. 119-121.
} 
violento, que estaba de tres a seis años, la aumentó dejándola entre ocho y dieciséis años; el acceso carnal o acto sexual violento en persona puesta en incapacidad de resistir, que estaba entre ocho y quince, la aumentó para dejarla entre doce y veinte años; el acceso carnal abusivo con menor de catorce años, que estaba de cuatro a ocho, quedó entre doce y veinte años; los actos sexuales con menor de catorce años, que se castigaba con tres y cinco años, la fijó entre nueve y trece años; el acceso carnal o acto sexual abusivos con incapaz de resistir, era de cuatro a ocho años, y quedó entre doce y veinte años.

Con sano criterio frente a estos delitos, el legislador prescribió que la pena se puede aumentar si el delito produce embarazo o contaminación de enfermedad de transmisión sexual, o si se realizare sobre el cónyuge o sobre la persona con quien se cohabite o se haya cohabitado, o con la persona con quien se haya procreado un hijo. A este propósito se le sumó la expedición de la Ley 1257 de 2008, que quiso garantizar a todas las mujeres una vida libre de violencia en todos los ámbitos, y a su vez se amplió el espectro de interpretación de este delito constituyéndolo también como violencia de género. Del mismo modo, el legislador quiso proteger muchos de esos derechos sexuales que venían siendo atentados bajo el modelo de la trata de personas, y por eso creó la Ley 985 de 2005, introduciendo un nuevo artículo a la legislación penal vigente que contemplara tal fenómeno delictual, y así entonces quedó penalizada con pena de trece a veintitres años de prisión y multa de ochocientos a mil quinientos salarios mínimos legales mensuales vigentes.

A su turno, conviene decir que la Ley 599 de 2000 quiso ponerse a tono en materia de derecho internacional humanitario por aquello de los delitos que se venían cometiendo en el marco del conflicto armado colombiano, y fue por eso que pretendió armonizar su regulación, tocando temas en su título I, denominado "Delitos contra la vida y la integridad personal", y surgió el agravante respecto del embarazo forzado. De la misma manera, plasma en el titulo II, los "Delitos contra personas y bienes protegidos por el derecho internacional humanitario", entre éstos: los delitos de homicidio, lesiones personales, tortura, acceso carnal violento y acto sexual violento en persona protegida, como también los delitos de prostitución forzada y de esclavitud sexual.

Podemos ver también, por ejemplo, los cambios suscitados en la Constitución Política mediante el Acto Legislativo 3 de 2002, que modifica el numeral 6 del artículo 250 constitucional, que diera paso a la vigente Ley 
906/04, actual Código de Procedimiento Penal. Todo esto con el fin de proteger, asistir, reparar y restablecer los derechos de las víctimas en todo el proceso penal, así como lo pudo establecer el legislador en los artículos 11 y 14, y el capítulo IV del título IV de la referida Ley.

Coetáneamente se mantiene vigente la Ley 600 de 2000, también del procedimiento penal, teniendo en cuenta que en ambos procedimientos se resalta la forma de investigar y juzgar esta clase de delitos de manera diferente en cada momento histórico de su vigencia, pero hay que resaltar que el marco sustancial o núcleo de protección es uno solo: la libertad, la integridad y la formación sexuales, los cuales se busca garantizar.

De este modo, se presenta entonces la existencia de una evolución normativa formalmente válida para nuestra sociedad, con miras a lograr los objetivos de protección que constantemente se propone el Estado colombiano; pero si bien todo este esfuerzo legislativo es importante y debe aplaudirse, no podemos alejar de este análisis, que no basta con estos grandes y extensos referentes legislativos que pretenden blindar los derechos sexuales de las personas al interior de un grupo de aquellas que se muestra irracional frente a esta tutela jurídica internacional y nacional, pues la atención que hoy exige nuestra sociedad desde el punto de vista de la protección y la conjuración del fenómeno, es que dichos dogmas de protección no deben llegar a confundirse con la eficacia material que debe ser siempre el efecto útil de las normas jurídicas, a pesar de que se presenten relaciones necesarias sobre este propósito desde su validez formal. ${ }^{45}$

Nótese que todos estos presupuestos jurídicos gravitan alrededor de la dignidad humana, teniendo en cuenta que este es el principio consagrado por nuestra Constitución Política desde su primer artículo, a partir del cual se estructura políticamente a Colombia con una mirada ontológica bajo el modelo de Estado social y democrático de derecho. ${ }^{46}$

Debe quedar claro que el constituyente primario desde su expresión soberana, y el Congreso de la República, como secundario en esa tarea de protección, vienen de ser muy acertados en materia de dignidad humana, y ahora en esa misma clave lo hace y ratifica constantemente la Corte Constitucional, al interpretar que ese principio, derecho o valor que se conoce como dignidad humana se hace notar como un concepto amplio,

\footnotetext{
45 Kelsen, Hans, Validez y eficacia del derecho, Buenos Aires, Astrea, 2005, pp. 49-60.

46 Corte Constitucional de Colombia, Sentencia T-585 de 2008, M. P.: Humberto Sierra Porto.
} 
que de paso le otorga nuevamente vida a la afirmación de Gustavo Zagrebelsky cuando considera que "lo que es verdaderamente importante por el mero hecho de serlo, nunca puede ser puesto, sino que debe ser siempre presupuesto". ${ }^{47}$

Retomando el panorama constitucional interno, vemos otras formas de protección en los artículos 12 y 17, que tratan sobre la prohibición de tratos crueles, inhumanos o degradantes, como la servidumbre, la esclavitud y el tráfico de personas. De igual manera, se protege especialmente a los niños, las niñas y los adolescentes sobre toda forma de abandono, explotación sexual, venta, secuestro, violencia física o moral, explotación laboral y turismo sexual; armonizando lo anterior dentro del marco legal de la Ley 1098 de 2006, que es el vigente Código de la Infancia y la Adolescencia, que en sus artículos 2, 192, 193, 194, 195, 196, 197 y 198 establece procedimientos especiales cuando los menores y adolescentes sean víctimas de delitos.

En ese sentido, Colombia tampoco aplazó su compromiso internacional que permitía armonizar tales intentos de protección expuestos en la parte dogmática de su Constitución Política, y fue por eso que suscribió el Protocolo Adicional de los Convenios de Ginebra de 1949 (Protocolo I), que fue ratificado por el Estado colombiano, y que trata sobre los conflictos armados internacionales. Tal contenido normativo obliga y ordena a los Estados a respetar a las personas, y esto se presenta desde su mejor ámbito de protección cuando prohíbe todo acto contra la dignidad humana, como aquellos basados en los tratos crueles y humillantes, la prostitución forzada y cualquier otro atentado contra el pudor sexual.

\section{La Corte Constitucional: una jurisprudencia del clamor social}

Dentro de este contexto, resulta oportuno referirnos nuevamente a la intervención de la Corte Constitucional en su intento de protección, claro está, ya por la vía judicial. Para lo anterior, nos debemos ubicar en 2008, cuando esa Corte emitió el auto 092, en el cual abordó temas como el desplazamiento forzado y el fenómeno de la violencia sexual ocurrida en el marco del conflicto armado ${ }^{48}$ y a partir de allí ordenó una clase de

47 Zagrebelsky, Gustavo, El derecho dúctil. El derecho por principios, Madrid, Trotta, 2008, p. 9.

48 Corte Constitucional de Colombia, Auto 092 de 2008, M. P.: Manuel José Cepeda Espinosa. En aquel pronunciamiento se pidió al Estado que creara trece programas para 
medidas referentes a la investigación en muchos de los casos presentados, con el fin de evitar la impunidad; además, la intervención judicial también buscó que realmente se pudiera hallar esa atención integral que deben tener aquellas víctimas en caso de no lograr esa protección que se propone el Estado. De la anterior tesis constitucional por vía judicial, se puede extraer nuevamente el mensaje del fracaso en que ha caído el derecho positivo y la institucionalidad para proteger los derechos sexuales de los colombianos.

Lo anterior, implicó necesariamente para el Legislativo, replantear los puntos de partida en busca de ese propósito de protección; por eso, vemos entonces cómo el artículo 5o. del Decreto 4796 de 2011 dispuso que en nuestro país se adoptara un protocolo específico en esa materia, y su justificación se radicó especialmente por tener ya una connotación de problema de salud pública; esto condujo a que desde el Ministerio de Salud y Protección Social se expidiera el Protocolo de Atención Integral en Salud para Víctimas de Violencia Sexual, pretendiendo que las entidades prestadoras de esos servicios tuvieran claro el modelo de atención, el mismo que como un referente ya se encontraba al interior del Convenio 620 de 2010, celebrado entre ese Ministerio y el Fondo de Población de las Naciones Unidas.

De acuerdo con lo anterior, el producto normativo que antecede a la adopción de este protocolo ha involucrado de manera efectiva gran parte de las instituciones del Estado, con miras a lograr el objetivo trazado; así como se puede verificar a través de la Ley 1146 de 2007, que se expide con fines de prevención "de la violencia sexual y atención integral de los niños, niñas y adolescentes abusados sexualmente"; y también la Ley 1257 de 2008, ya referida anteriormente, que prevé normas "de sensibilización, prevención y sanción de formas de violencia y discriminación contra las mujeres", y presenta, a su vez, un catálogo de derechos que le asisten a las víctimas de violencia, y poder así permitirles el acceso a la atención integral por vía de una cobertura médica accesible, suficiente y con calidad.

prevenir la violencia sexual y proteger a las víctimas, y pidió a la Fiscalía General de la Nación que avanzara en la investigación de 183 casos de violencia sexual. Véase también, Mesa de seguimiento al Auto 092 de la Corte Constitucional, Acceso a la justicia para mujeres víctimas de violencia sexual, Cuarto Informe de Seguimiento al Auto 092 de 2008, Bogotá, Antropos, mayo 2011. 
De igual modo, se suma a ese propósito la expedición del Decreto 2734 de 2012, que tiene por objeto "establecer los criterios, condiciones y procedimiento para el otorgamiento de las medidas de atención definidas en el artículo 19 de la Ley 1257 de 2008", y define los lineamientos de los diferentes actores del Sistema General de Seguridad Social en Salud - SGSSS - y las autoridades competentes, para ordenarlas en el marco de las responsabilidades que les fueron asignadas mediante dicha Ley y sus decretos reglamentarios 4796 y 4799 de 2011.

Asimismo, se establecieron en los artículos 19, 21 y 54 de la Ley 1438 de 2011, algunas reformas en el Sistema General de Seguridad Social en Salud, en los que su nuevo diseño estableció derechos y obligaciones respecto de los niños, niñas, adolescentes y mujeres víctimas de la violencia en sus diferentes manifestaciones. Igualmente, la Ley 1448 de 2011, que se conoce como "Ley de víctimas y restitución de tierras", trajo consigo nuevos enfoques diferenciales.

$\mathrm{Y}$ es que en tratándose de medidas eficaces para contrarrestar los delitos sexuales, resulta pertinente relacionar también lo dicho anteriormente por la jurisprudencia constitucional mediante la sentencia C-292/97, en la cual, al hacer un examen de constitucionalidad de algunas normas contenidas en la Ley 360/97, se refirió a la obligación que tienen las autoridades a partir del artículo segundo de nuestra Constitución Política, de no desconocer el clamor de la sociedad cuando la proliferación de los delitos sexuales se hace evidente. Se suma a lo anterior, el llamado para que el legislador, dentro del marco de su discrecionalidad, no sea indiferente para crear y modificar las normas que estima convenientes, y más cuando se trata de menores de edad; teniendo en cuenta que aquellas personas no solamente son víctimas del terrorismo y del desplazamiento forzado, sino también del delito sexual que se presenta de manera constante en esos territorios, y donde los victimarios son los integrantes de los grupos al margen de la ley como también de los agentes del Estado.99

Así, pues, en ese escenario del poder público también se pudo crear la Ley de la República, 1719, de junio 18 de 2014, que reformó algunos artículos de la Ley 599/00 y de la Ley 906/04, que tiene por objeto "la adopción de medidas para garantizar el derecho de acceso a la justicia de las víctimas de violencia sexual, en especial de la violencia sexual

49 Corte Constitucional de Colombia, Sentencia C-292 de 1997, M. P.: José Gregorio Hernández. 
asociada al conflicto armado interno. Estas medidas buscan atender de manera prioritaria las necesidades de las mujeres, niñas, niños y adolescentes víctimas".

Al llegar a este punto, se debe destacar que si bien es cierto que se establecen allí ciertas garantías en materia de investigación y juzgamiento, y un ejemplo de ello lo presenta el contenido de los artículos 13 y 14 de la citada Ley, no es menos cierto que en lo referente para que ese delito cometido al interior del conflicto armado pueda ser o no catalogado como de lesa humanidad, el legislador supeditó dicha posibilidad en el artículo 15 , bajo el contexto en el cual se entenderían como "crimen de lesa humanidad" los actos de violencia sexual cuando se cometan como parte de un ataque generalizado o sistemático contra la población civil y con conocimiento de dicho ataque. Lo anterior, de conformidad con las definiciones del artículo $\underline{7}$ o del Estatuto de Roma y los elementos que esos crímenes así como han quedado desarrollados dentro de ese Estatuto. Por lo tanto, en este contexto resultará de especial atención examinar sociojurídicamente los alcances y riesgos de la investigación criminal y del conocimiento para condenar, por cuanto allí se puede poner en evidencia un problema mayúsculo respecto de los elementos que pueden o no estructurar ese delito para poder catalogarlo como de lesa humanidad, y, de paso, porque los análisis obligarán al estudio de las problemáticas que también surgirán en materia de reparación económica o simbólica, en consonancia con lo que el legislador también ha permitido en su momento mediante leyes transicionales para lograr la paz estable y duradera en nuestro país, especialmente la surgida últimamente con los acuerdos de paz en La Habana, Cuba, con las FARC, en donde no existe una clara separación de estos delitos sexuales; es decir, este delito en tales circunstancias puede verse dentro de la gama de aquellos que son conexos con el conflicto armado, al menos es lo que parece reflejar el acuerdo con este grupo y la ley estatutaria que los materializa, lo que implicaría en tiempo no lejano un antecedente nefasto frente a la sociedad, como también frente a futuros acuerdos con otros grupos al margen de la ley, en donde las víctimas de este delito en aquellos contextos del conflicto armado habrán preferido no nacer, como tampoco lo pudieron hacer sus hijos, algunos producto de relaciones consentidas, pero otros como consecuencia de esos sometimientos y violaciones.

Como antítesis de lo anterior, y considerando nuevamente el contexto de conflicto armado colombiano, el clamor social exige que este aspecto 
no se torne ambiguo, al menos desde la connotación que tienen esos delitos sexuales en aquel posible catálogo normativo dentro de ese escenario, dado que la menor exigencia es que aun si fueron cometidos dentro del conflicto armado no puedan tener la posibilidad de tener beneficios en su juzgamiento alrededor de una justicia especial, pues es apenas justo que así sea, por cuanto aquel fenómeno específico del conflicto ya bastante lo ha soportado gran parte de la población, y ahora se le quieran sumar aquellos atentados contra la libertad sexual que también sufrieron muchas personas en esos contextos armados, y terminen blindándose bajo este panorama legal y judicial aquellos victimarios que creyeron que los derechos sexuales también podían ser trasgredidos, bajo la idea, incluso desdibujada, de que estos delitos hacían parte y son conexos al conflicto armado. No obstante, las evidencias empíricas nos permiten sostener que esto no solamente cabe en la mente de los victimarios, sino que termina siendo otra concesión que conscientemente el gobierno y los legisladores comprometen frente al presunto logro de la paz.

Sin embargo, se puede sostener que frente al derecho insoslayable de la dignidad y la igualdad constitucional que se irradia en un mismo núcleo fundamental de protección, no resulta prudente diferenciarla frente al ser humano y bajo ninguna circunstancia; es decir, no deben ser menos exigentes la investigación y el juzgamiento de ese delito sexual en las condiciones normales que también otras personas lo sufren, valga precisarlo, de aquellas víctimas que sin estar en territorios donde no se verifica de lleno el conflicto armado, también terminan soportando ese flagelo; por ejemplo, los acontecidos en zonas urbanas y semirrurales, incluso, de manera más generalizada. De mantenerse esta diferenciación dentro del ordenamiento jurídico, siempre será probable que se sigan manifestando las tensiones dialécticas, y más si lo que se pretende es darle validez a una dogmática constitucional que categoriza al individuo, como si sólo se tratara de la división coherente de incisos o parágrafos de un artículo, pues esa reflexión sociojurídica, en un tiempo no lejano reclamara con más vehemencia el disfrute de la libertad y la integridad sexual, sin que merezcan tal distinción y tratamiento por parte del mismo legislador. No se olvide, que el victimario parece comprender desde su misma irracionalidad, que se enfrenta a una constante fractura del dogma jurídico de protección de los derechos sexuales del otro. 


\section{UNA REVISIÓN AL DOGMA DE LA GARANTÍA DE LOS DERECHOS SEXUALES}

Debemos por último plasmar algunas ideas que serenamente pretenden dar una mirada diferente al paradigma que sigue sosteniendo que la eficacia en la protección de los derechos sexuales debe ser exigida de un sistema jurídico meramente positivo, cuando las evidencias demuestran sin vacilación que esa garantía de protección también depende de la superación de otros factores reales en la sociedad, y que en los contenidos normativos lentamente se viene reflejando.

Bajo esta línea de argumentación nos podemos referir, claro está, de una manera diferenciada, teniendo en cuenta a la sociedad cuando ha expresado su clamor y ha puesto al legislador en una encrucijada en materia de política criminal con miras a las sanciones penales que requieren este tipo de delitos sexuales; por ejemplo, la exigencia de penas perpetuas, y entre líneas, enervadamente reclaman la pena capital, y lo hacen ante situaciones o casos específicos en los cuales el agresor ha desbordado la irracionalidad, la infamia y la indolencia con sus actos.

Dichas manifestaciones alrededor del anterior panorama punitivo y su conveniencia no se escapan del ejercicio racional en el escenario legislativo y se acompañan de manera regular de los argumentos del ilustre maestro Beccaria, cuando sobre este tipo de sanciones, y a partir de sus axiomas psicológicos, expresó lo siguiente:

No es la intensidad de la pena lo que hace mayor efecto sobre el ánimo humano, sino su duración; porque nuestra sensibilidad es más fácil y establemente movida por mínimas pero repetidas impresiones, que por un fuerte pero pasajero impulso... No es el terrible pero pasajero espectáculo de la muerte de un criminal, sino el largo y penoso ejemplo de un hombre privado de libertad, que convertido en bestia de servicio recompensa con sus fatigas a la sociedad que ha ofendido, lo que constituye el freno más fuerte contra los delitos... ${ }^{50}$

Por lo tanto, considerando cualquiera de los contextos, y si pensamos que las anteriores enunciaciones jurídicas pueden llegar a prescribirse nuevamente en nuestra sociedad, entendida ésta como aquella posibilidad

50 Beccaria, Cesare, De los delitos y las penas, trad. de Francisco Tomás y Valiente, Madrid, Aguilar, 1982, pp. 116 y 117. 
para que el orden constitucional y penal sea realmente eficaz frente a la protección de los derechos sexuales, $\mathrm{y}$, en consecuencia, se logre disuadir al individuo para que comprenda que el respeto en la sexualidad del otro es el comportamiento esperado en sociedad; todo lo anterior tendrá que traer consigo la superación, entre otros aspectos, de los dogmas de la filosofía moral y humanista que irradia ese marco de protección a la libertad y a la vida misma. En otras palabras, deberá verificarse que los presupuestos morales, religiosos, sociales, institucionales y otros más, ${ }^{51}$ se puedan encauzar en el conglomerado creyendo que aquel desarrollo legal propuesto en esos términos puede ser eficaz frente a ese fin que se persigue, es decir, la erradicación definitiva de los delitos sexuales.

A diferencia de lo anterior, resulta evidente desde la misma praxis, que ninguna política criminal en el mundo acompañada incluso de sus divinas y virtuosas leyes, sin olvidar que históricamente han sido drásticas en algunas latitudes,${ }^{52} \mathrm{y}$ en donde el caso de nuestro Estado colombiano no ha sido la excepción, ha podido lograr la erradicación, y tampoco minimizado el flagelo del delito sexual; de hecho, las normas penales, cuando se erigen con su objeto y finalidad sancionatoria frente al delito sexual, se hacen notables también, porque paralelamente vienen acompañadas de aspectos preventivos y de atención integral a las víctimas del mismo, lo cual, desde la dialéctica planteada en su texto, puede tener sentido, pero desde la lógica jurídica presuponen textualmente su ineficacia a partir de su mismo acto creación; es decir, no se corresponde con el dogma de eficacia pretendido, al punto que se puede serenamente afirmar, que ese defecto se predica des-

51 "El deber del magistrado civil consiste en preservar y asegurar a la generalidad del pueblo y a todos y cada uno de sus súbditos en particular, mediante la aplicación imparcial de leyes justas, la justa posesión de aquellas cosas que pertenecen a su vida. Si alguno pretende violar esas leyes y oponerse a la justicia y al derecho, su pretensión se verá restringida por el miedo al castigo, el cual consiste en la privación disminución de esos bienes civiles que normalmente tendría la posibilidad y el derecho de disfrutar. Pero en vista de que ningún hombre soporta voluntariamente ser castigado con la privación de alguna parte de sus bienes y, mucho menos, de su libertad o de su vida, el magistrado se encuentra, por lo tanto, armado con esta fuerza: el apoyo de todos sus súbditos, a fin de castigar a aquellos que violan los derechos de los demás”. Locke, John, Ensayo y carta sobre la tolerancia, trad. española de Carlos Mellizo, Madrid, Alianza Editorial, 1999, p. 56.

52 La ley del Talión. Talión significa tal pena cual delito, y en tal sentido material se aplicó inicialmente. Se enunciaba diciendo "ojo por ojo, diente por diente, miembro por miembro", etcétera. Se le encuentra en la Biblia, en Éxodo, y en el Código de Hammurabi, promulgado por Hammurabi, rey de Babilonia, que reinó de 1955 a 1912 a. C. 
de que el prospecto de norma viene inquietando la mente del legislador, y ésa puede ser una de las razones por las cuales no se aventura a predicar resultados imposibles de logar; sin embargo, no se olvide que desde el populismo político y punitivo muchos legisladores aprovechan las coyunturas del fenómeno delictual para así proponer su creación jurídica.

Se infiere de lo anterior, que en un sistema jurídico como el nuestro esto parece ser lógicamente pensado para diferenciar la validez de la eficacia, pues si bien es cierto que por la observancia de sus procedimientos formales en la creación, como también por la armonía que guarda a través de su sistemática aplicación por parte de los tribunales, no se pone en duda su validez, porque además, ésta ha sido identificada claramente como derecho en esos escenarios judiciales, y no ha sido cuestionada en ese sentido. No obstante, no se debe perder de vista que dichas reglas en muchas ocasiones presentan paralelamente criterios de eficacia, y éstos sí ponen en duda los efectos, no precisamente porque la regla prescriba en sí misma su ineficacia por el desuso, ${ }^{53}$ sino mejor, porque al menos en nuestro contexto, al usarlas, no generan el resultado vinculado en su mismo contenido, que viene de ser indiscutiblemente válido. Asimismo, se puede asociar este aspecto a la posibilidad que existe en el grupo social de ser un mero observador de las normas, sin que ello implique su aceptación, o aceptarlas y tenerlas como guía de acción de su conducta, ${ }^{54} \mathrm{o}$, desde otro ángulo filosófico, este fenómeno puede presentarse porque desde un criterio valorativo no resulta ser moralmente obligatoria la norma por el mero hecho de serlo, así como lo pueden considerar las ideologías seudopositivistas. ${ }^{55}$

Visto lo anterior, la eficacia que contienen las normas jurídicas en materia de protección de los derechos sexuales en Colombia, falaz por antonomasia, viene aparejada también de la desconfianza e inseguridad de que el respeto por los derechos sexuales del otro aún no ha alcanzado el grado de madurez y de razonamiento social suficiente, escenario en el cual nos permite pensar, que más allá de la desbordante creación de las normas jurídicas, lo realmente necesario es la exigente enseñanza y asimilación de

\footnotetext{
53 Hart, H. L. A., El concepto de derecho, Buenos Aires, Abeledo-Perrot, 2007, pp. $125-137$.

54 Ibidem, pp. 110 y 111.

55 Roos, Alf, El concepto de validez y otros ensayos, Buenos Aires, Centro Editor de América Latina, 1968, pp. 21-55; Bobbio, Norberto, El problema del positivismo jurídico, Buenos Aires, Eudeba, 1965, pp. 37-64.
} 
una escala axiológica debidamente empoderada en la sociedad, en donde sea el respeto por los derechos sexuales del otro el que se presente como el principal valor y pueda convertirse en una constante fórmula de protección y barrera frente a la trasgresión.

Como vimos en líneas precedentes, resulta ser amplia la producción normativa internacional y nacional que nuestro Estado colombiano viene adoptando encaminado a proteger los derechos sexuales, evidenciando que aquellas prescripciones pretenden garantizarlos en toda su dimensión a partir de una adecuada sistemática jurídica. Sin embargo, conviene distinguir que el panorama que hasta ahora se nos presenta en sociedad nos desprende la idea de que su eficacia, en clave de protección y disuasión para la no agresión sexual, quedó suspendida en un trayecto de doble vía, valga decirlo, aplazada y desplazada.

Hablamos de aplazada, por cuanto se sigue evidenciando la continuidad del flagelo, y al menos no será esta generación y probablemente muchas más, las que puedan ver cumplidos los fines que se propuso nuestra Constitución y sus leyes; y desplazada, por cuanto al seguirse presentando tal fenómeno, y al haber puesto en cuestión la eficacia de las normas sustantivas, se tendrá que seguir acudiendo a las normas adjetivas de tipo penal que tratan la investigación y el juzgamiento de esos delitos sexuales. Lo anterior, con la esperanza de que aquellos delitos no queden reducidos a la impunidad. No obstante, dicha suspensión en doble vía en los términos descritos parece ser una característica surgida desde los mismos albores de la humanidad, donde coexistieron leyes divinas y humanas, pues, se reitera, los delitos sexuales se constatan de muy vieja data.

Con sano criterio, se puede sostener que una elaboración normativa en la actualidad, que no cumpla con esos presupuestos de eficacia, puede seguir corriendo el riesgo de quedarse simplemente en una mera enunciación jurídica, en donde el único efecto que podrá lograr será el de la eficacia simbólica, que tiene su fundamento a partir del análisis que de la conducta social se hace, con la conducta motivada en la norma, sobre la cual se afirma, aquella con el paso del tiempo pierde su eficacia, e incluso su validez..$^{56}$

56 Botero Bernal, Andrés, Diagnóstico de la eficacia del derecho en Colombia y otros ensayos, Medellín, Biogénesis, 2003, p. 35; véase también Kelsen, Hans, Validez y eficacia del derecho, cit., p. 71; Walter, Robert, Validez y eficacia del derecho, Buenos Aires, Astrea, 2005, p. 10; Bulygin, Eugenio, Validez y eficacia del derecho, Buenos Aires, Astrea, 2005, pp. 106-108; Bulygin, Eugenio y Mendonca, Daniel, Normas y sistemas 
En última instancia, verificada la pérdida de eficacia y validez de la norma jurídica al no lograr materializar su finalidad, ${ }^{57}$ conduce necesariamente a pensar que se verán irrumpidos constantemente aquellos derechos sexuales y, de paso, en la imposibilidad de ver cumplidos los postulados jurisprudenciales en clave iusfundamental, al no poder conocer la verdad real de los hechos victimizantes, así como bien lo ha podido interpretar la Corte Constitucional en la sentencia C-454/06, ${ }^{58}$ y que fuera reforzada posteriormente con la sentencia C-209 de 2007, ${ }^{59}$ que quieren mantener vigente el contenido filosófico y axiológico de la ley, aunque su estructura jurídica varíe con el tiempo.

Para finalizar, una buena clave para asimilar aquella paradoja del derecho, es que puede resultar necesario que aceptemos de una vez por todas, que si bien es cierto su función también es servir de límite al poder, que a veces se expresa mediante la fuerza del Estado, estos dos elementos - poder y fuerza - deben estar siempre unidos y al servicio de la sociedad. Lo anterior, porque la función dual que surge de esta sinergia es precisamente distanciar con todo su rigor a quien irrespeta los derechos sexuales del otro, porque de lo contrario, al imponerse aquél por la falta de cohesión o relación disfuncional entre estos dos, suele ser fatal para un Estado de derecho en el cual sus normas jurídicas siempre gozarán de una presunción de validez, pero sin olvidar que bajo estos contextos siempre estará en duda su eficacia.

normativos, Barcelona, Marcial Pons, 2005, pp. 84-89. En cuanto al tema de la eficacia y lo simbólico de la misma a la hora de pretender resolver problemas sociales en el contexto colombiano, también existen contemporáneos análisis desarrollados por García Villegas y Boaventura de Sousa en el siguiente sentido: "Los gobiernos en Colombia intentan compensar la incapacidad del Estado para tratar demandas sociales en términos políticos, con una fuerte insistencia en la dimensión jurídica de tales problemas... El déficit de maniobra política de los gobiernos propicia el uso simbólico de los discursos legales. Mientras más limitado es el margen de maniobra política de los gobiernos en Colombia y más incontrolable es la violencia, más inclinados están estos a tratar dichos problemas de manera tal que el énfasis institucional se ponga en la legitimación, la comunicación y el uso simbólico del derecho en la obtención de resultados”. De Sousa Santos, Boaventura y García Villegas, Mauricio, El caleidoscopio de las justicias en Colombia, Bogotá, Siglo XXI Editores, 2001, pp. 73-74.

57 Alexy, Robert, El concepto y la validez del derecho, cit., pp. 172-177.

58 Corte Constitucional de Colombia, Sentencia C-454 de 2006. M. P.: Jaime Córdova Triviño.

59 Corte Constitucional de Colombia, Sentencia C-209 de 2007, M. P.: Manuel José Cepeda Espinosa. 


\section{CONCLUSIONES}

Colombia, como Estado social y democrático de derecho, viene atendiendo precisamente esa evolución histórica, jurídica y política, cuando a la hora de pretender proteger derechos humanos fundamentales de estirpe sexual se trata. Para lo anterior, ha mostrado gran producción legislativa interna al introducir además a su ordenamiento jurídico los acertados enunciados jurídicos internacionales que sobre esa materia se establecen, y desde ese ideal, lograr proteger algo tan natural como lo es la libertad, la integridad y libertad sexual de las personas.

No obstante, la mayoría de esas categóricas prescripciones de protección y paralela prohibición han quedado reducidas al ámbito de su validez formal, por cuanto su incumplimiento al interior de la sociedad es evidente, lo que en consecuencia compromete su eficacia jurídica, que lógicamente se busca desde la creación, y que ha de verse reflejada cuando logra conseguir los efectos que se esperan en el comportamiento humano; esto es, inicialmente la comprensión de que existen unos derechos sexuales protegidos o tutelados por el Estado a través de las normas y, por otra parte, la acertada disuasión de esa prohibición para que efectivamente se respeten bajo la afirmación de una sanción penal.

Desde otro ángulo, las autoridades públicas de manera coetánea a esas creaciones normativas deben implementar también mecanismos idóneos y eficientes para que esa protección pueda ser materialmente válida; es decir, produzca los efectos que se propone el Estado y aquellos intentos no se queden en las meras expectativas. Después de todo, porque pareciera que los agresores con esta tendencia delictiva no alcanzan a ser disuadidos con la norma penal que los puede reprimir, o simplemente la debida obediencia a las mismas no logra instalarse en sus conciencias y mejor deciden incumplir el pacto social propuesto para una vida civilizada. En otras palabras, parece que su conducta humana atiende otro tipo de cláusulas sociales: las del desprecio por la dignidad sexual de su semejante.

Como se pudo observar a lo largo de este artículo, no basta con que el legislador sea amable y consciente de que es necesaria la constante actividad dentro de su función creativa de normas, y con esto hacer creer a la sociedad que aquel dogma que se predica de los derechos sexuales como protegidos en todo momento por el Estado, desde sus prescripciones jurídicas de carácter supraconstitucional, constitucional y legal, como 
también desde aquel desarrollo jurisprudencial, resultan ser suficientes, pues el propósito se ve incumplido como claramente lo siente la sociedad de manera constante, y resulta entonces necesario replantear y analizar otros aspectos relativos a la prevención y protección de los derechos sexuales; pero esto debe partir en sentido estricto desde un marco de acción sociológico y axiológico, que para muchos está en segundo plano, o las contemplan aisladamente, sin considerar, para la fortuna de otros, que precisamente por estar relegadas en ese lugar las aprecian desde tiempos pretéritos, porque están seguros de que observar con objetividad lo que realmente necesita esta sociedad, es decir, sus teorías y los métodos para el conocimiento social, merecen especial atención, para poder encauzar el rescate de los valores que hace mucho entraron en crisis.

Es de considerar que no existe una solución ipso facto del flagelo del delito sexual, debido a que la misma parece distanciarse cada día más a pesar de la producción normativa en esa materia, pues ese encargo no parece disuadir aquella irracionalidad por la que actúa ese agresor, y que por la presunción instalada en la sociedad sobre el conocimiento de la ley, sin duda pareciera saber cuál es el número de normas que previenen o prohíben ese delito; pero es evidente que también infiere que las mismas no lo alcanzan, ni en el lugar, como tampoco respecto de la víctima que elija.

Una creencia en la eficacia de este positivismo merece replantearse en la actualidad, además, porque ha de tenerse en cuenta que el Estado, a través del poder que otorga el derecho, ha hecho lo propio para orientar la conducta humana por el camino del respeto de los derechos sexuales del otro. Lo anterior se ha de traducir, entonces, en que se hace necesario dejar de seguir asignando la responsabilidad de esta ineficacia normativa al mismo Estado, como ente que transversaliza la vida misma, que sin duda existe, sino también apostarle a girar paralelamente en una dirección en la que se involucren otras disciplinas e instituciones a partir de un trabajo riguroso en todas las dimensiones del hombre, para que puedan nutrir profundamente el interior de las familias, lo cual habrá de repercutir en una sociedad que refleja una escala de valores bien estructurada, en donde el respeto, más allá de ser un vocablo de gran connotación axiológica, se convierta en la fórmula más eficaz para mantener siempre vigente el orden social y jurídico.

Se advierte que este enfoque pueda resultar obvio para algunos, situación que a la postre no tiene discusión en este momento, por cuanto les asisten buenas razones para considerarlo así; pero es precisamente por esa 
razón que muchos hombres ya han perdido, es decir, porque lo obvio parece no generar ninguna obligación moral ni mucho menos jurídica, pues cuando asumen esa postura, olvidan que ésa también es una ley de la naturaleza, que a la par de su libertad deben también respetar la libertad del otro. En otras palabras, la racionalidad que se reclama de la humanidad es que en la praxis comprenda que en todo momento y lugar se deben respetar los derechos sexuales ajenos. Asimismo, más que aprender a asimilar el mensaje que las normas jurídicas contiene y desde las cuales también se pretende regular el comportamiento humano, todo hombre debe aprender a identificar de una vez por todas aquella razón colectiva que se llama civilización; por tanto, una mirada seria desde la familia, las instituciones y el Estado frente a todas las dimensiones del hombre, será siempre la mejor alternativa de reconstruir el tejido social. La falta de acceso a estas posibilidades no puede seguir siendo la excusa para seguir creyendo que las normas jurídicas serán la salvación, lo cual, sin duda, seguirá siendo entonces un simple dogma deshumanizado al que se adherirán las generaciones futuras sin reparo alguno.

\section{BIBLIOGRAFÍA}

Aguirre ArAngo, José Pedro, "La interpretación de la Convención Americana sobre Derechos Humanos", Revista de Derechos Humanos, año V, núm. 8, 2007.

Aguirre Roman, Javier Orlando y García OBAndo, Pedro Antonio, Lógica y teoría de la argumentación, Santander, Universidad Industrial de Santander, 2008.

ALEXY, Robert, El concepto y la validez del derecho, Barcelona, Gedisa, 2004.

ALEXY, Robert, Teoría de los derechos fundamentales, Madrid, Centro de Estudios Políticos y Constitucionales, 2002.

AlEXY, Robert, Teoría del discurso y derechos humanos, Bogotá, Universidad Externado de Colombia, 1995.

ANZURES GuRRÍA, José Juan, "La eficacia horizontal de los derechos fundamentales", Cuestiones Constitucionales, núm. 22, 2010.

AtIENZA, Manuel, "Estado de derecho, argumentación e interpretación", Anuario de Filosofia del Derecho, vol. XIV, 1997. 
BeCCARIA, Cesare, De los delitos y las penas, trad. de Francisco Tomás y Valiente, Madrid, Aguilar, 1982.

BoBbio, Norberto, El problema del positivismo jurídico, Buenos Aires, Eudeba, 1965.

BobBio, Norberto, El tercero ausente, Madrid, Cátedra, 1997.

BoBbio, Norberto, Sociedad y Estado en la filosofia política moderna. El modelo iusnaturalista y el modelo hegeliano-marxiano, México, Fondo de Cultura Económica, 1997.

Botero Bernal, Andrés, Diagnóstico de la eficacia del derecho en Colombia y otros ensayos, Medellín, Biogénesis, 2003.

Bozo DE CARMONA, Ana julia, "Karl-Otto Apel: reflexiones sobre la teoría de la verdad y la ética del discurso", Revista de Filosofía, núm. 22, 1995.

Bulygin, Eugenio, Validez y eficacia del derecho, Buenos Aires, Astrea, 2005.

Comte, Augusto, Primeros ensayos, México, Fondo de Cultura Económica, 1942.

De Sousa SAntos, Boaventura y GARCía Villegas, Mauricio, El caleidoscopio de las justicias en Colombia, Bogotá, Siglo XXI Editores, 2001.

FERNÁNDEZ CRUZ, José Ángel, "La interpretación conforme con la Constitución: una aproximación conceptual”, Ius et Praxis, año 22, núm. 2, 2016.

FerRAJOLI, Luigi, Derecho y razón. Teoría del garantismo penal, Madrid, Trotta, 1995.

FIORAVANTI, Maurizio, Los derechos fundamentales. Apuntes de historia de las constituciones, Madrid, Trotta, 2007.

GALÁN JuÁREZ, Mercedes, "La interpretación de los derechos fundamentales por parte del Tribunal Constitucional, una argumentación en términos de razonabilidad", Isegoría, núm. 35, 2006.

GAVIRIA DíAz, Carlos, "Los temas de la constituyente. El Estado social de derecho y la presión política por el cambio", Foro, núm. 7, 2007.

Grández CASTRO, Pedro P., "Argumentación jurídica y derecho constitucional”, en LANDA ARroyo, César (ed.), Derechos fundamentales, Lima, Palestra, 2018. 
GUASTINI, Riccardo, Estudios sobre la interpretación jurídica, trad. de Mariana Gascón y Miguel Carbonell, México, UNAM, Instituto de Investigaciones Jurídicas, 1999.

HART H, L. A., El concepto de derecho, Buenos Aires, Abeledo-Perrot, 2007.

Hobbes, Thomas, Leviatán, trad. de M. Sánchez Sarto, México, Fondo de Cultura Económica, 1980.

Kelsen, Hans, Esencia y valor de la democracia, Buenos Aires, Labor, 1984.

KELSEN, Hans, Teoría pura del derecho, México, UNAM, 2002.

Kelsen, Hans, Validez y eficacia del derecho, Buenos Aires, Astrea, 2005.

LocKE, John, Ensayo y carta sobre la tolerancia, trad. de Carlos Mellizo, Madrid, Alianza, 1999.

LOCKE, John, Segundo tratado sobre el gobierno civil, trad. de Carlos, Mellizo, Madrid, Alianza Edit, 1998.

Massé NARVÁEz, Carlos E. y Rivera HernándeZ, Juan, “La hermenéutica en la interpretación conforme de los derechos humanos en el orden jurídico mexicano", Methaodos. Revista de Ciencias Sociales, vol. 2, núm. 1, 2014.

MendoncA, Daniel y Bulygin, Eugenio, Normas y sistemas normativos, Barcelona, Marcial Pons, 2005.

Mesa de seguimiento al Auto 092 de la Corte Constitucional, Acceso a la Justicia para mujeres víctimas de violencia sexual. Cuarto Informe de Seguimiento al Auto 092 de 2008, Bogotá, Antropos, 2011.

Molina Betancur, Carlos Mario, Derecho constitucional general, Medellín, U de M, 2008.

Molina Betancur, Carlos Mario, Investigación. Bicentenario constitucional, Medellín, U de M, 2010.

PABÓN PARRA, Pedro Alfonso, Delitos sexuales. La sexualidad humana y su protección penal, Bogotá, Doctrina y Ley LTDA, 2005.

RAWLS, John, Liberalismo político, Barcelona, Crítica, 2002.

Reale, Miguel, Teoría tridimensional do direito, São Paolo, Saraiva, 1968.

Ross, Alf, El concepto de validez y otros ensayos, Buenos Aires, Centro Editor de América Latina, 1968. 
VAN DiJK, Teun, A., "Discurso, conocimiento, poder y política. Hacia un análisis crítico epistémico del discurso", Revista de Investigación Linguística, Murcia, núm. 13, 2010.

WALTER, Robert, Validez y eficacia del derecho, Buenos Aires, Astrea, 2005.

Zagrebelsky, Gustavo, El derecho dúctil. El derecho por principios, Madrid, Trotta, 2008.

ZAVAla DE AlBA, Luis Eduardo, "Gobernanza en derechos humanos: hacia una eficacia y eficiencia institucional", Revue québécoise de droit international, Hors-série, mars 2015. 
Esta revista forma parte del acervo de la Biblioteca Jurídica Virtual del Instituto de Investigaciones Jurídicas de la UNAM http://www.juridicas.unam.mx

https://biblio.juridicas.unam.mx

https://revistas.juridicas.unam.mx

DOI: http://dx.doi.org/10.22201/iij.24484881e.2020.43.15198

RESEÑAS

BIBLIOGRÁFICAS 


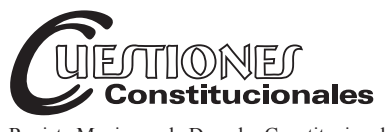

Revista Mexicana de Derecho Constitucional Núm. 43, julio-diciembre 2020

GARCÍA RoCA, Javier, La transformación constitucional del Convenio Europeo de Derechos Humanos, Civitas-Thomson Reuters, 2019, 218 pp.

El profesor Javier García Roca, catedrático de derecho constitucional de la Universidad Complutense de Madrid, es un gran conocedor del sistema europeo de derechos humanos. Nos disculpará el lector si no hacemos aquí referencia a toda su obra académica, puesto que sus numerosas aportaciones sobre la jurisprudencia del Tribunal Europeo de Derechos Humanos (en adelante TEDH) son de sobra conocidas, e inspiran desde hace años a la doctrina española, latinoamericana y mundial. Javier García Roca, observador atento y crítico de la permanente transformación sufrida por este sistema, nos presenta un libro, fruto, precisamente, de varios proyectos de investigación relacionados con ese impacto de la jurisprudencia europea sobre los derechos humanos. El autor demuestra de una manera convincente que la interpretación de las normas del Convenio Europeo de Derechos Humanos (en adelante CEDH) requiere de una comprensión basada en los valores y principios comunes de una open minded society.

Aunque el sistema europeo de protección de los derechos humanos no funciona en el vacío, sino - como observamos actualmente- en el contexto de una profunda crisis que enfrenta el viejo continente, Javier García Roca mantiene una postura más bien optimista, y nos explica cómo hacer de la necesidad virtud. Pese a varios obstáculos de naturaleza política y social, indica que "es preciso hoy centrarse en edificar en el siglo XXI una cultura de los derechos como corazón de la idea europea". No cabe ninguna duda de que nos encontramos ante un gran europeísta, cuya voz debería alimentar el actual debate político y académico. Es lamentable, pero muchas sociedades europeas se han dejado convencer de que el "interés nacional" tiene prioridad frente a la protección de los "enigmáticos" derechos humanos. 
Una de las principales impresiones que tiene el lector después de abordar la lectura del libro del profesor García Roca es que los fundadores del sistema europeo de los derechos humanos nunca hubieran llegado a adivinar la dimensión que iba a alcanzar este sistema. El CEDH ya no es un clásico mecanismo del derecho internacional, sino que posee una triple naturaleza; es tratado, es instrumento constitucional y es pasarela comunitaria. Se trata de una judge made convention, es decir, un derecho espontáneo, construido por los tribunales (ante todo el TEDH) que resuelven conflictos sobre violaciones concretas de derechos, basándose en unos criterios y principios interpretativos estables. La principal finalidad de este fenómeno transicional es garantizar la eficacia de los derechos humanos frente a un abanico de peligros que se ciernen actualmente sobre ellos. No obstante, el libro advierte también que a pesar del desarrollo dinámico del sistema europeo, todavía no se han resuelto dos problemas cruciales: la sobrecarga de las demandas y algunas complicaciones en el cumplimiento y en la ejecución de las sentencias.

El libro está dividido en seis capítulos, en cada uno de ellos, Javier García Roca discute diversos aspectos del sistema europeo - tanto procedimentales como sustanciales-, y describe el punto de partida y el efecto logrado después de seis décadas de su funcionamiento. En el primer capítulo, "Los orígenes y la expansión de la jurisdicción europea", el autor explica el desarrollo histórico del CEDH, y muestra sobre todo las principales reformas llevadas a cabo por los protocolos 11 y 14 . Es entonces cuando se crea un verdadero derecho de acceso directo a la jurisdicción europea que no formaba parte del diseño original del CEDH (pp. 25-29). La nueva organización del sistema europeo se pone en marcha frente a la emergencia provocada por el serio incremento de las demandas, un problema que no se ha solucionado hasta el día de hoy. Desafortunadamente, esta tendencia expansiva, como observa el autor, parece estar frenándose en los últimos años, ya que el proceso de actualización del CEDH (sobre todo mediante la inclusión del protocolo 15, ratificado actualmente por 45 de los 47 Estados miembros del Consejo de Europa) refuerza las doctrinas de la subsidiariedad y del margen de apreciación nacional (pp. 31 y 32). Hay que compartir el escepticismo del autor sobre esta reforma actual, dado que supone sobre todo una concesión a las apuestas políticas de algunos Estados miembros que reprochan al TEDH un excesivo activismo judicial. En realidad, se trata de un veto a los crecientes estándares europeos en materia de derechos humanos. 
En el primer capítulo del libro se encuentra también un interesante análisis de los problemas relacionados con la fallida adhesión de la Unión Europea al sistema del Convenio (pp. 33-40). No cabe ninguna duda de que el autor es partidario de la integración de los dos sistemas, dado que carece de sentido lógico e histórico mantener mecanismos europeos binarios para los Estados miembros de la UE y del Consejo de Europa. En este contexto, se expone una fuerte y razonada crítica al dictamen 2/13 del Tribunal de Justicia de la UE (del 18 de diciembre de 2014, en adelante TJUE), que constituye una verdadera negativa a la adhesión, obstaculizando las necesidades de los Estados miembros, sin resolver problema alguno ni ofrecer salidas. El fallo del TJUE está fundado en un error de perspectiva, resuelve de forma abstracta y general un conflicto preventivo o prematuro, meramente virtual.

En estas primeras páginas del libro se presenta además la idea que constituye la esencia del libro: el diálogo judicial multinivel (pp. 40-53). El punto de partida es el pluralismo constitucional. No se puede negar que actualmente existen diversos ordenamientos jurídicos (nacionales e internacionales), entrelazados o interdependientes, donde los derechos de las personas tienen distintos niveles jurisdiccionales de garantía. Por lo tanto, la adecuada interpretación de los derechos exige una colaboración de los tribunales en la solución de los conflictos y la creación de un dialogo amplio y flexible. Sólo así se pueden multiplicar las garantías de los derechos fundamentales.

Una parte importante del primer capítulo está dedicada al problema del creciente número de demandas y a la acumulación de los asuntos pendientes ante el TEDH (pp. 53-59). Lo importante es que el autor no lo analiza en abstracto, sino que hace referencia a los datos estadísticos, indicando tres tendencias. La primera, relacionada con una seria asimetría procesal respecto de los países demandados donde tienen origen las violaciones. Existe un grupo concreto de Estados que generan la gran mayoría de las demandas. La segunda tendencia está vinculada con el problema de los asuntos repetitivos y causados por violaciones sistemáticas o estructurales del $\mathrm{CEDH}$, mientras que la tercera consiste en que la gran parte de las violaciones se refieren al derecho al proceso debido (artículo 6, CEDH). Esta aproximación de los datos estadísticos permite proponer soluciones más concretas al funcionamiento de la administración de justicia y a las deficien- 
cias en la protección de derechos fundamentales de determinados Estados miembros del Convenio.

Volviendo a la idea de la cooperación judicial, en la última parte del primer capítulo el autor se concentra en el nuevo instrumento del diálogo directo: las opiniones consultivas introducidas por el Protocolo 16, que entró en vigor en 2018 (pp. 60-69). No cabe ninguna duda de que es un mecanismo que se asemeja a las cuestiones de inconstitucionalidad de los tribunales nacionales ante los tribunales constitucionales y a las cuestiones prejudiciales ante el TJUE. Comparto su punto de vista de que las opiniones consultivas en el futuro pueden suponer una alternativa procesal muy eficaz y erigir un filtro racional y objetivo que aminore la sobrecarga de demandas individuales, que distorsiona actualmente el funcionamiento del sistema europeo. Pueden además reconducir el control de la convencionalidad de las leyes, objetivándolo y dotándolo de abstracción y generalidad, en vez de continuar amparando derechos sólo caso a caso y sentencia a sentencia. Por otro lado, para que esto sea así es necesaria la voluntad política, ya que el Protocolo 16 de momento ha sido ratificado solamente por 14 Estados miembros del Consejo de Europa.

El segundo capítulo se titula "De una protección internacional al instrumento constitucional del orden público europeo", y empieza con un subcapítulo "Cuerpo de tratado y alma de Constitución", donde el autor explica el potencial transformador del sistema del CEDH desde su inauguración. Lo pone en el amplio contexto de un doble fenómeno: el de la constitucionalización del derecho internacional y el de la internacionalización de derecho constitucional (pp. 77-80). Es aquí donde el autor analiza los conceptos clave del sistema europeo (entre ellos la teoría de las obligaciones positivas, las garantías institucionales y el concepto de la inversión de la carga de prueba de los hechos) y los ejemplos de la tendencia expansiva del sistema europeo (en relación con las sentencias que declaran la responsabilidad de los Estados miembros del Consejo de Europa por tolerar las acciones de los países terceros en su territorio). La evidencia clara de que el Convenio funciona como instrumento constitucional del orden público europeo la encontramos en la utilización por parte del TEDH de unos criterios e instrumentos habitualmente utilizados por un tribunal constitucional, sobre todo en lo relativo al principio de proporcionalidad (pp. 90-101). En cambio, el instrumento que a veces reduce el potencial unificador del sistema europeo e impacta negativa- 
mente en la universalidad de los derechos es el margen de apreciación. Javier García Roca es autor del libro El margen de apreciación nacional en la interpretación del Convenio Europeo de Derechos Humanos: soberanía e integración que vio la luz en 2010. Javier García Roca es un gran experto en el tema; sus observaciones previas sobre dicho concepto se ven reforzadas y actualizadas en el libro reseñado (pp. 104-128). Diez años más de funcionamiento de la doctrina del margen de apreciación nacional en el sistema europeo permiten confirmar que su construcción es débil. Falta en la jurisprudencia del TEDH una caracterización precisa del margen de apreciación nacional; la jurisprudencia en este punto tiene poca consistencia argumental, y por esta razón es susceptible de aplicaciones variadas y contradictorias. No obstante, el autor toma una posición intermedia en relación con el margen de apreciación nacional. No lo rechaza frontalmente, sino que se opone a aquellos usos que permiten dictar decisiones desprovistas de una verdadera motivación, ya que una cierta discrecionalidad nacional es necesaria en algunas situaciones por la cuestión del pluralismo territorial y del principio de la subsidiariedad. El autor examina los criterios utilizados por el TEDH para aplicar este instrumento, haciendo una crítica constructiva del mismo buscando lograr que su uso sea más previsible.

En relación con el margen de apreciación, el autor analiza la propuesta de sustituirlo por el criterio del procedimiento razonable de decisión, donde se toma en cuenta la calidad del procedimiento democrático (debate parlamentario, calidad de la ley) a través del cual la decisión ha sido tomada a nivel nacional (pp. 128-136). Lo que este criterio exige es que se demuestre que se han ponderado suficientemente los intereses generales y privados en juego a lo largo del proceso de decisión. Con razón, el autor no comparte este punto de vista, indicando que el debate parlamentario es importante, pero no absorbe toda la problemática del margen de apreciación nacional. En este contexto, recuerda la teoría de los vicios de inconstitucionalidad: materiales, formales y competenciales. Enfocarse en las cuestiones formales y procedimentales no significa que no haya una violación del contenido esencial de un derecho fundamental.

En el tercer capítulo "Del filtro de la comisión al acceso individual y directo de las víctimas y la adopción de medidas cautelares", el autor responde a la cuestión fundamental de cómo mantener un sistema de verdadera jurisdicción concentrada europea, fundada en el acceso directo a la 
jurisdicción del TEDH, y salvaguardar al tiempo la viabilidad de la garantía. En este contexto lo más interesante es el análisis de la evolución del instrumento de medidas provisionales (pp. 154-160). Podemos observar los avances importantes que se han producido en esta materia y que han asegurado la obligatoriedad de las medidas provisionales y su adecuado cumplimiento, lo que es un ejemplo de la evolución del sistema hacia la efectividad de las resoluciones del TEDH.

El cuarto capítulo, dedicado al "crecimiento constante de los derechos protegidos y algunos derechos sociales", empieza con la constatación de que en Europa hay una dualidad en la protección de los derechos fundamentales, ya que existen garantías de distinta naturaleza e intensidad. Por un lado, se ha creado una protección judicializada para los derechos civiles y políticos y, por otro, unas garantías más débiles y fundadas en un modelo de informes colectivos para los derechos sociales. Pese a esto, el autor es capaz de demostrar cómo se han desarrollado las garantías individuales en varias esferas y cómo se ha ido ampliando el catálogo de derechos protegidos (pp. 163-172). Sobre todo se hace hincapié en los derechos civiles, que tienen una dimensión de libertad, y además otra dimensión social (o de prestación). En la presente etapa del desarrollo del sistema convencional es difícil aplicar a estos derechos sociales el test de proporcionalidad, pero sin duda podría practicarse la tutela del núcleo mínimo indisponible de los derechos de prestación.

El capítulo quinto se llama "De las sentencias declarativas al restablecimiento íntegro del derecho. Medidas de reparación”, y está dedicado a la cuestión de la fuerza obligatoria de las sentencias, la eficacia de cosa interpretada y el principio de la interpretación vinculante. El punto de partida lo constituye el fuerte impacto transformador de la jurisprudencia sobre los ordenamientos internos. El autor demuestra un cambio de filosofía al respeto, indicando que la ejecución de las sentencias ya no es algo extraño a las competencias del TEDH (pp. 175-179). Además, presenta muchos argumentos a favor de la eficacia general de las sentencias. Sin duda, no es razonable que un Estado miembro diferencie la intensidad de su vinculación a la jurisprudencia del sistema según haya sido o no parte del procedimiento ante el TEDH. Las disposiciones del CEDH dedicadas a la fuerza vinculante de las sentencias (sobre todo el artículo 46.1, CEDH) han experimentado una seria transformación, y ya no pueden leerse literalmente (pp. 180-186). Los fallos del TEDH cada vez se aproximan más a las 
sentencias constitucionales, vinculando a todos los juzgadores y poderes públicos que operan dentro del sistema.

Es cierto que una sentencia del TEDH no puede declarar la nulidad del acto, resolución o disposición nacional que lesionó el derecho, pero puede considerarlos claramente incompatibles con los estándares convencionales. Aquí se evidencia explícitamente la transformación constitucional del $\mathrm{CEDH}$, ya que el Estado, en efecto, está obligado a modificar sus leyes contrarias a las garantías de los derechos fundamentales. Estoy de acuerdo con el autor en que una declaración de incompatibilidad de una ley con el CEDH no es lo mismo que una declaración de nulidad (como haría un tribunal constitucional), pero los resultados finales de estos dos tipos de resoluciones — la eliminación de la norma del sistema legal— ya no son tan diversos.

Otro ejemplo del proceso de la constitucionalización del TEDH, según el autor, son las sentencias piloto, y constituye una innovadora técnica, relacionada con la creciente carga de trabajo que afronta el TEDH (pp. 186-193). Este fenómeno sin duda ha reforzado la autoridad, obligatoriedad y eficacia de las sentencias europeas. Por otro lado, el autor se detiene en explicarnos cómo ha evolucionado el sistema de medidas de reparación individuales y generales: su actual elenco es amplio y variado (pp. 194-203).

El último - sexto - capítulo, "Del papel del comité de ministros al seguimiento judicial de la ejecución”, empieza con la idea de que, al principio, la naturaleza declarativa de las sentencias europeas tuvo un claro reflejo en el procedimiento de ejecución y de supervisión de su cumplimiento, ya que por lo general éste recae en un órgano político (el Comité de Ministros), y no en el TEDH (pp. 205-210). Pero aquí también la lectura del libro reseñado permite entender que la actividad de estos dos órganos durante años ha afectado al sistema de ejecución y supervisión, reforzando mucho su eficacia. Ciertamente, se conserva la naturaleza política, antes que la jurisdiccional, en esta materia, pero podemos observar la expansiva competencia parcial de revisión por parte del TEDH de la ejecución de sus sentencias (pp. 210-214).

En resumen, el libro La transformación constitucional del Convenio Europeo de Derechos Humanos es una lectura obligatoria para las personas interesadas en la actual dimensión de la protección de los derechos fundamentales en Europa. Lo importante es que el trabajo de Javier García 
Roca no es un simple relato descriptivo, sino la presentación de una visión original y congruente de un sistema multinivel de garantías. Después de su lectura, nos damos cuenta de que una gran parte de los tradicionales criterios y principios constitucionales han devenido obsoletas, ya que es incuestionable la transformación del CEDH hacia su conversión en un instrumento constitucional del orden público europeo.

Adam KRZYWON**

* Profesor asistente de derecho constitucional en la Universidad de Varsovia, durante el curso académico 2019/2020 investigador en Madrid Institute for Advanced Studies, profesor visitante en numerosas universidades españolas y latinoamericanas, entre 2010 y 2018 secretario y miembro del Consejo Legislativo del Primer Ministro de Polonia, correo: adam.krzywon@gmail.com, ORCID: 0000-0002-6301-7729. 


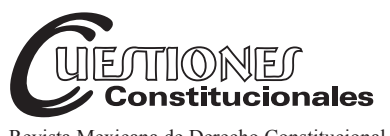

Revista Mexicana de Derecho Constitucional Núm. 43, julio-diciembre 2020

Santos Loyola, R., Carlos, Estado y religión. Comentarios a la Ley de Libertad Religiosa, Lima, Jurista, 2018, 332 pp. ${ }^{1}$

Sin duda ha de saludarse con gusto la aparición del libro Estado y religión. Comentarios a la Ley de Libertad Religiosa (del Perú), coordinado por Carlos R. Santos Loyola y publicado por la editorial Jurista. Se trata, en sustancia, de una serie de reflexiones y comentarios jurídicos en torno a la Ley 29635, Ley de Libertad Religiosa, publicada el 21 de diciembre de 2010 en el Diario Oficial El Peruano.

Digo que ha de saludarse con gusto, por varias razones. En primer lugar, porque siendo tan pocos los libros publicados de este lado del Atlántico que abordan aspectos relevantes de la libertad religiosa y del derecho eclesiástico, es muy gratificante encontrarse con trabajos tan bien hechos como el presente. Tener en las manos un ejemplar así no hace sino renovar el interés - a veces perdido en la disciplina a la que uno le ha dedicado más de veinte años.

En segundo lugar, es motivo también de celebración la aparición del referido libro, porque nos permite conocer de primera mano los más recientes cambios legislativos en materia de libertad religiosa en el Perú, un país cuya cultura jurídica va reposicionándose cada vez más —entre otras cosas - por la seriedad de sus publicaciones jurídicas y sus significativas sentencias judiciales a nivel constitucional. Así, conocer cómo se garantiza y regula el ejercicio del primer derecho fundamental de todo ser humano, como es el de libertad religiosa, es algo que causa pleno entusiasmo.

El tercer motivo de gusto - y quizá éste sea el más importante- es la satisfacción que provoca encontrarse con un texto que trata aspectos significativos del ejercicio de la libertad religiosa, desarrollados por importantes eclesiasticistas iberoamericanos, que abordan con profunda rigu-

1 Más información sobre el libro puede encontrarse en la siguiente dirección electrónica: https://facebook.com/estadoyreligion. 
rosidad científica el contenido de la ley referida. Sobre esto último quisiera insistir especialmente porque el libro y los temas ahí analizados involucran el aspecto más importante del ser humano; esto es, su dimensión espiritual, su ánimo religioso, y el abordaje científico de éste no puede ser hecho con la superficialidad que suele uno encontrar en publicaciones de politólogos que opinan sobre temas religiosos, o de periodistas que aprovechando su espacio en los medios de comunicación calumnian a la Iglesia. La libertad religiosa como objeto de estudio del derecho eclesiástico tiene que ser hecha con la rigurosidad que la ciencia impone.

De este modo, una de las tareas más urgentes para la doctrina es tratar de ubicar, con la mayor precisión posible, cuál es el lugar que la expresión religiosa tiene en el mundo de hoy, cuáles son sus alcances y cuáles sus límites. Esto, porque si echamos un vistazo a nuestro alrededor, podremos constatar cómo cada vez más se va exigiendo - desde distintas posiciones - que la manifestación religiosa sea reducida a su mínima expresión, no sólo en su ejercicio individual, sino también y prioritariamente colectivo. El odio por la expresión religiosa del hombre, motivado por una ideología beligerante, hace que cualquier intento intelectual serio como el libro que reseño sea visto con beneplácito.

El trabajo comienza con un interesante prólogo escrito por el exvicepresidente del Tribunal Constitucional del Perú, Eloy Espinosa-Saldaña Barrera, quien en la primera parte de su escrito destaca cuál ha sido el papel asumido por el Tribunal Constitucional peruano en el tratamiento jurídico de la expresión religiosa. Son varios los aspectos que valdría la pena destacar en esta primera parte del prólogo, pero por razones de espacio sólo mencionaré dos que me han parecido interesantes, por la diferencia que existe con la realidad mexicana cuando trata los mismos temas. Me refiero al espinoso asunto del laicismo y el de la cooperación entre el poder estatal y el fenómeno religioso.

El magistrado señala que no obstante que el Estado peruano se autodefine como laico, el fundamento 49 de la STC 6111-2009-PA/TC ha señalado que

El hecho de que exista una neutralidad del Estado en materia religiosa no significa que los poderes públicos haya de desarrollar una especie de persecución del fenómeno religioso o de cualquier manifestación de tipo religiosa... La incompetencia del Estado ante la fe y la práctica religiosa no significa la promoción del ateismo o agnosticismo con la eliminación de símbolos religiosos de la esfera pública o la imposición de una ideología antirreligiosa, 
ignorando las tradiciones que responden a la formación histórica, cultural y moral del Perú.

Como se puede observar en esta cita, el laicismo estatal no sólo no significa persecución religiosa — como desgraciadamente alguna parte de la historia mexicana demuestra-, sino tampoco significa exclusión del fenómeno religioso del ámbito público, como acertadamente destaca el magistrado Espinosa-Saldaña Barrera citando al Tribunal Constitucional.

El segundo tema es el de la cooperación o colaboración. En la misma sentencia referida, el Tribunal Constitucional peruano ha señalado que suscribir convenios de colaboración con las confesiones religiosas representa la mejor expresión y materialización de cooperar y de promover la expresión religiosa de los ciudadanos (fundamento 32). Así, tal principio de colaboración se encuentra establecido en el artículo 50 de la Constitución peruana, y éste contiene — según el Tribunal Constitucional— "un doble contenido para el Estado: el establecimiento de las relaciones con las confesiones religiosas y que estas sean de colaboración" (fundamento 30).

La segunda parte del prólogo es también especialmente importante y muy llamativa, sobre todo porque el magistrado Espinosa-Saldaña nos presenta un gran resumen de todas las contribuciones aparecidas en el libro, en las que destaca sus puntos más esenciales. Digo que es llamativa porque es de los pocos trabajos - hasta donde yo conozco - que adelantan el contenido esencial del libro, dando cuenta de cada uno de los capítulos que lo integran. Esto ayuda bastante en la elaboración de la reseña, porque permite fijar nuestra atención en aquellos aspectos generales del libro, y no repetir todo el contenido esencial de cada una de las contribuciones que lo integran. Así, nuestro abordaje sólo destacará algunos aspectos de cada una de las aportaciones y aquello que consideré importante de la Ley.

El comentario relativo al artículo primero de la Ley se refiere a lo que podríamos considerar tres de los aspectos jurídicos más relevantes de la libertad religiosa, a saber: su reconocimiento, su protección tanto constitucional como internacional y los límites al ejercicio de este derecho. ${ }^{2}$

2 El articulo 1 de la ley señala: "El Estado garantiza el derecho fundamental de toda persona a la libertad de religión reconocido y amparado por la Constitución Política del Perú y todos los tratados internacionales ratificados por el Estado peruano.

El ejercicio público y privado de este derecho es libre y tiene como único límite tanto la protección del derecho de los demás al ejercicio de sus libertades públicas y derechos fundamentales como la protección del orden, la salud y la moral pública”. 
El análisis parte, como no podía ser de otra forma, de la Constitución peruana, que en su artículo 2, numeral tres, establece el reconocimiento de la libertad de conciencia y religiosa, siendo entonces la ley 29635 su regulación legal. Poco tengo que decir sobre la enunciación que el texto constitucional hace al reconocimiento de esta libertad tanto a nivel nacional como internacional. En rigor, es la misma fórmula que podemos encontrar en otros ordenamientos jurídicos, a saber: que el reconocimiento y protección de la libertad religiosa ha de ser hecha hoy a la luz de los derechos humanos y de los criterios interpretativos que estos derechos establecen. Así, el bloque de protección de este derecho no sólo es nacional, sino también internacional, con lo cual los juristas peruanos - como casi todos los juristas latinoamericanos - no debemos conformarnos con analizar los documentos nacionales que protegen este derecho, sino que debemos voltear la vista a los documentos internacionales de derechos humanos y verlo también desde esa óptica.

En el ejercicio del derecho de libertad religiosa hay, sin embargo, un argumento que aún no se logra precisar, y que es fuente de innumerables polémicas, tanto a nivel académico como jurisprudencial. Es el relativo a los límites en el ejercicio de este derecho. Nociones como el orden público, moral pública, salud, etcétera, son objeto aún de intenso debate.

En rigor, y como sabemos, estos conceptos se conocen como conceptos jurídicos indeterminados, y efectivamente lo son, porque no tienen un contenido específico; la academia y la jurisprudencia les dan significados diversos, y en algunas ocasiones hasta antagónicos. Sin embargo, hemos de decir que el hecho de que sean conceptos indeterminados no significa que no puedan ser determinables a través, principalmente, de la discusión y análisis jurisprudencial que diferentes tribunales han hecho cuando se han tenido que resolver casos concretos, que exigen precisar en qué consiste el ejercicio del derecho de libertad religiosa y cuál es su verdadero alcance. Es entonces el derecho en acción el que casuísticamente va determinando esos conceptos. En este punto la doctrina ha ayudado bastante; por ejemplo, con el principio de razonabilidad y sus conocidos tres subprincipios, instrumento éste que, como sabemos, sirve para conocer cuándo la restricción a un derecho fundamental es legítima. A todo esto vale la pena apunar una cosa, y es que el test de razonabilidad es una importante herramienta; pero es sólo eso, una herramienta, pues hay otras para tratar de saber cuándo el ejercicio de la libertad religiosa es ejercida en sus justos límites. 
El artículo 20. de la Ley peruana de Libertad Religiosa plantea, sin lugar a dudas, uno de los más importantes asuntos en el tratamiento del ejercicio de este derecho. Se trata del tema de la "igualdad ante la ley". Particularmente este tema me ha interesado especialmente, tanto, que en algún otro lugar me he dedicado a estudiarlo detenidamente, ${ }^{4} \mathrm{y}$ al hacerlo he tenido que estudiar también posiciones que afirman que no puede haber una igualdad jurídica cuando el Estado favorece a una Iglesia mayoritaria en detrimento de confesiones minoritarias.

He de reconocer lo ingenioso de los distintos razonamientos que se emplean para justificar la afirmación anterior. Sin embargo, creo que el alcance de dichos argumentos suele ser muy limitado cuando se descalifican, o simplemente se dejan de lado evidencias tan contundentes como los siglos de presencia en el territorio nacional de un país de la Iglesia católica, o los millones de fieles de esa Iglesia que la componen. No dar argumentos para desacreditar tales evidencias hace que se vea cualquier escrito sobre la igualdad ante la ley con bastante escepticismo.

El artículo tercero de la Ley peruana es uno de los más extensos, tanto en su redacción como en su contenido. Comentado por el profesor español Marcos González Sánchez, el artículo se refiere al ejercicio individual del derecho de libertad religiosa; sin duda, uno de los más trascendentales aspectos de este derecho, porque nos muestra las extensiones y límites que el mismo tiene en su ejercicio individual. Mucha tinta ha corrido en la explicación de aquellos derechos contenidos en artículos como éste, tales como el de profesar una creencia religiosa o no profesar ninguna; practicar individual o colectivamente este derecho; hacerlo en privado o en público, etcétera. Me referiré a tres de los muchos aspectos que podrían destacarse, pero que particularmente me han llamado la atención por su inexistencia en la legislación mexicana y por lo vanguardista que en este punto es la legislación peruana.

El primero de ellos es el derecho que tienen las personas de recibir la formación religiosa que esté de acuerdo con sus convicciones, y al lado de éste, el derecho de los menores para que puedan recibir esta misma

3 Artículo 20.: "Toda persona natural es igual ante la ley. Se prohíbe toda acción u omisión que discrimine a una persona en razón de sus creencias religiosas.

El Estado reconoce la diversidad de las entidades religiosas. En igualdad de condiciones, gozan de los mismos derechos, obligaciones y beneficios".

4 Saldaña Serrano, Javier y Orrego Sánchez, Cristóbal, Poder estatal y libertad religiosa, México, UNAM, 2009, pp. 77-106. 
educación cuando vaya de acuerdo con las convicciones de sus padres o tutores. Nadie puede negar que este derecho es ampliamente reconocido a nivel internacional; así, por ejemplo, la Declaración Universal de Derechos Humanos de 1948 lo señala en su artículo 26.3, el Pacto Internacional de Derechos Civiles y Políticos de 1966 en su artículo 18.4, la Convención Americana sobre Derechos Humanos o Pacto de San José de Costa Rica de 1969 en su artículo 12, fracción 4, también lo establece, etcétera. Sin embargo, y pese a este amplio reconocimiento, son muy pocos los países que en el ámbito americano establecen este derecho en su legislación, y hay algunos que definitivamente ni lo mencionan, como es el caso de México. Es relevante este punto, porque la ley peruana se cuenta entre las pocas legislaciones que ya lo establecen en su órbita interna, y nadie podría alegar — como sucede en el caso mexicano- que al no estar en la legislación no puede invocarse.

El segundo tema es igualmente relevante, y como en el punto anterior, la legislación peruana se separa años luz de vetustas legislaciones como la mexicana. Es el tema del respeto al ejercicio de la libertad religiosa en la conmemoración de festividades y días de descanso que se consideren sagrados por la religión de trabajadores y estudiantes, y que deberán armonizarse con las empresas o dependencias de la administración pública y escuelas donde trabajen o estudien. Tema realmente vanguardista que merece la pena destacarse, por la novedad del mismo. El asunto, sin duda, ha sido estudiado por la doctrina con especial detenimiento, pero muy pocas legislaciones en el mundo la han recogido y puesto en su articulado. Por eso creo que la inclusión de este derecho en la legislación representa realmente un verdadero compromiso con el respeto de los auténticos derechos humanos y con su protección legal, y no meros discursos retóricos.

Una última cuestión a destacar — que también advierte Marcos González en su comentario - es el tema de la objeción de conciencia. Y es que uno esperaría que en el amplio catálogo de derechos del artículo 3o. se incluyera el derecho de objeción de conciencia, pero no aparece en este artículo. Sin embargo, como el profesor español señala, la omisión referida en la Ley queda subsanada: "El artículo 8 del Reglamento de la Ley de Libertad Religiosa se refiere al derecho de objeción de conciencia, que es un derecho individual y que no se menciona de forma expresa en el elenco de derechos individuales del artículo de la Ley que comentamos". Así, queda expresamente reconocido el derecho de objeción de conciencia en 
el ordenamiento peruano, no sólo en el Reglamento de la Ley, sino en el propio cuerpo de ésta (artículo 4o.).

En rigor, creo que no haber introducido el derecho de objeción de conciencia en el artículo 3o. de la Ley sino en el 4o., y después en el artículo 8 del Reglamento, tiene su lógica. Ésta es que es mejor reservar un artículo específico a tan importante derecho, que arriesgarse a que éste se pierda en la enumeración de la larga lista de derechos del artículo 3o. En este punto la legislación peruana me parece correcta.

En íntima relación con lo anterior se encuentra el artículo 4o. de la Ley peruana, que establece ya uno de los principales derechos humanos relacionados con el ejercicio de la libertad religiosa. Me refiero a la objeción de conciencia. Conviene destacar este comentario, porque el reconocimiento y ejercicio de este derecho no descansa sobre bases pacíficas.

En primer lugar, se debe destacar y aplaudir que el legislador peruano - asumiendo nuevamente una actitud vanguardista en la protección de los derechos humanos - haya establecido con meridiana claridad este derecho en la Ley de Libertad Religiosa; con esto, no hay duda de que la objeción de conciencia se encuentra como derecho fundamental en el ordenamiento jurídico peruano, no prestándose a confusión sobre su existencia, como sucede en culturas jurídicas, como la mexicana, en donde a pesar de que el artículo 24 de la Constitución establece la libertad de conciencia como derecho fundamental, hay quienes afirman que la objeción de conciencia no existe como derecho humano en la legislación mexicana, llegando a absurdos, como los de la Comisión Nacional de los Derechos Humanos (institución que como su nombre lo indica es el guardián de los derechos humanos) de impugnar ante la Corte de justicia mexicana la inconstitucionalidad de la Ley de Salud por reconocer ésta la objeción de conciencia para el personal sanitario.

Sobre el análisis que se hace al artículo 4 de la Ley peruana, poco tengo que decir, salvo agradecer la exposición tan didáctica que ofrece el comentarista del artículo, la cual comienza por la comprensión elemental de lo que la conciencia es, y llega hasta el análisis de esta figura en la Ley, pasando por su regulación internacional y estableciendo sus alcances y distinciones con figuras afines. Hay, sin embargo, dos breves comentarios que sí me gustaría formular al artículo en cuestión.

El primero de estos comentarios se repite en el trabajo al menos en dos ocasiones, y tiene que ver con la siguiente afirmación: “....La delimitación hecha por el legislador nacional resulta sumamente restrictiva de este de- 
recho, al considerar que la objeción de conciencia solo se podría fundamentar en motivos morales o religiosos, dejando de lado las convicciones éticas o ideológicas que pueden también dar origen a conflictos de conciencia" (p. 93). En la otra referencia igualmente se hace esta observación, agregándose como posible motivo de objeción de conciencia "el conocimiento científico" (p. 110). En principio, creo que legítimamente puede invocarse la objeción de conciencia por este último motivo en el caso de aquellas disciplinas donde el conocimiento científico resulte inobjetable. $\mathrm{Si}$, por ejemplo, la ciencia determina - como lo ha determinado- que en el momento en que el gameto masculino se une al femenino ya hay vida y debe ser protegida, se podría perfectamente invocar la objeción de conciencia en el caso de los médicos que científicamente - no por convicciones religiosas - sepan que no pueden atentar contra la vida humana. Aquí parece que no hay duda; más difícil resultaría la invocación a la objeción de conciencia en aquellas materias opinables, o que aún no cuentan un estatuto epistemológico consolidado.

Como señalé, en el caso del "conocimiento científico" no tengo dudas de que se puede invocar la objeción de conciencia, pero sí las mantengo cuando se invocan "convicciones éticas o ideológicas", como sostiene el comentarista del artículo. ¿Qué se quiere decir con esta expresión? Si tomamos el sentido gramatical de tal expresión — específicamente la ideología-, ésta se entiende como el conjunto de doctrinas filosóficas que tienen su origen en las ideas — de ahí la palabra ideología—, así habrían tantas filosofías como ideas han existido a lo largo de la historia: ¿todas éstas han de ser objeto de protección de la objeción de conciencia? La situación se problematiza aún más si tomamos la expresión "ideología" en su sentido negativo, es decir, como un conjunto de creencias - personales o de grupo- que son defendidas desde la pura voluntariedad y no desde la razón. Por eso creo que dada la problemática que encierra la aceptación de la objeción de conciencia en nuestras legislaciones debemos irnos con prudencia, para no abrir la puerta a una infinidad de causas que motiven la invocación indiscriminada de la objeción de conciencia, pues lo único que esto acarrearía sería la desnaturalización del derecho y su consecuente debilitamiento.

El comentario del artículo siguiente (5o.) tiene que ser visto en relación con el artículo 13 de la Ley Peruana de Libertad Religiosa. Ahí se establece claramente que el Registro de Entidades Religiosas "tiene como finalidad principal el reconocimiento de la personalidad jurídica civil de 
las entidades religiosas, así como facilitar sus relaciones con el Estado". Es claro entonces que para el otorgamiento de la personalidad jurídica las asociaciones civiles con fines religiosos peruanas deben primero constituirse en "entidades religiosas".

¿Lo anterior significa que sólo hasta que una asociación decida inscribirse en el mencionado registro podrá gozar de la libertad religiosa, o ser titular de este derecho? No. El registro es sólo para las asociaciones civiles que decidan ser entidades religiosas y gozar de personalidad jurídica. Para ello deberán inscribirse en el mencionado registro. Dicho de otra forma, una asociación - se entiende religiosa - podría perfectamente seguir disfrutando de la titularidad del derecho de libertad religiosa sin inscribirse en el registro. Sin embargo, convendría señalar que si bien la no inscripción no afecta la titularidad del derecho, sí disminuye su ejercicio, porque como señala el comentarista del artículo, "omitir registrarse podría acarrear la disminución de derechos de la asociación civil” (p. 123).

Como podemos advertir, el tema no es menor, pues lo que está en juego es nada menos y nada más que el ejercicio de la libertad religiosa en su vertiente colectiva; es decir, dependerá de la figura jurídica que se decida establecer en el ordenamiento jurídico el otorgamiento o no de la personalidad jurídica de los grupos religiosos.

Sobre el mismo tópico se debe hacer una aclaración, que tiene que ver con distinguir entre el resto de las entidades religiosas peruanas y la Iglesia católica. Esta última, en el Perú, tiene personalidad jurídica automática por el régimen concordatario firmado entre dicha Iglesia y el Estado peruano en 1980. En el caso de los grupos religiosos distintos al católico, no es automática.

En rigor, yo creo que se ha avanzado bastante en la legislación peruana al considerar cuáles serían las características más generales para identificar a una entidad religiosa como tal. Dichas características la misma legislación las establece diciendo que las entidades deberán contar con un credo, escrituras sagradas, doctrina moral, culto, organización y ministerio propio. Esto, como se sabe, ayuda bastante a determinar con cierta precisión cuándo estamos delante de una asociación religiosa a la que merece la pena otorgarle personalidad jurídica, y cuándo delante de entidades fraudulentas.

En íntima relación con lo señalado hasta ahora, se ofrece una nómina de derechos en el artículo siguiente (6o.), que está dedicado a la dimensión colectiva de las entidades religiosas. ¿Qué derechos se encuentran en este 
artículo? Derechos como la propia personalidad jurídica; la libertad para darse sus normas de organización interna; la creación de fundaciones y asociaciones educacionales, de asistencia social; derecho de elegir libremente a sus ministros de culto o dirigentes; derecho de ejercer libremente el ministerio, divulgar y propagar su credo; solicitar contribuciones voluntarias; mantener relaciones con otras entidades religiosas, etcétera.

En rigor, los derechos reconocidos en la Ley peruana son los típicos derechos que podemos encontrar en otras legislaciones, los cuales están basados en la autonomía que tienen las entidades religiosas. Hay, sin embargo, una breve anotación que convendría hacer, y que ya es señalada por quien hace el comentario respectivo; esto es: la lista de derechos ¿es limitativa?, o ¿habrá otros derechos para las entidades religiosas? La respuesta a estas cuestiones es positiva, pues como dice Milagros Aurora Revilla, la lista de derechos se vendría a completar con los contenidos en los artículos 10 y 11 del Reglamento a la respectiva Ley.

Nosotros agregaríamos también que, como en la propia Ley se destaca, a estos derechos convendría también agregar los que la Constitución peruana les reconoce, y junto a éstos, los que se establecen igualmente en los tratados internacionales protectores de derechos humanos que el Perú haya hecho suyos. Así, los derechos de las entidades religiosas tendrían cuatro fuentes principalmente: la Constitución peruana, los tratados internacionales, la Ley de Libertad Religiosa y el Reglamento de la respectiva Ley.

Otro de los aspectos que vale la pena destacar es el pormenorizado desarrollo hecho en el comentario al artículo siguiente de la Ley (7o.), que se refiere a la dimensión educativa de las entidades religiosas, y que abarca, entre otros aspectos, la posibilidad que tienen dichas entidades de crear y dirigir en forma autónoma sus propios centros de formación para el ministerio religioso; es decir, los propios centros donde sus integrantes - por ejemplo, ministros - se formarán.

Digo que vale la pena destacar esto, por ser un derecho de alto valor, que no en todas las legislaciones ha estado presente a lo largo de la historia; piénsese, por ejemplo, que en legislaciones como la mexicana fue hasta la última década del siglo XX cuando se otorgó este derecho a las Iglesias, siendo reconocidos oficiales los estudios hechos en los centros educativos de la Iglesia católica. En este punto, la legislación mexicana fue tan inquisitorial que impidió a las Iglesias la creación de sus propios centros educativos y la necesidad de emigrar fuera del país para formarse, o la de estudiar en los centros creados por la propia Iglesia, pero sin ningún 
reconocimiento oficial. La paradoja fue que se podría ser un gran filósofo o teólogo — como ha habido muchos en la cultura mexicana - para la Iglesia, pero un don nadie para el Estado.

La legislación peruana plantea un escenario completamente diferente a la mexicana, y su historia también ha sido diferente por el mencionado régimen concordatario que ha regulado este aspecto entre la Iglesia católica y el Estado peruano. Ahora, y para el caso de las entidades religiosas, el artículo 7o. permite este derecho. Así, el comentario nos ayuda a conocer cuál era el escenario anterior a la Ley de Libertad Religiosa peruana y cuál es el escenario actual. El desarrollo legislativo de tal iter nos ayuda a entender cómo se llegó a este derecho y saber cuáles son los derechos que de éste se desprenden.

Una última mención quizá convenga advertir, y es la relativa a señalar que este artículo debemos leerlo en relación con el artículo anterior, en el que se posibilita que las entidades religiosas pueden establecer centros educacionales, que, en principio, serían diferentes a los prescritos por este artículo 7.

Otro de los más importantes temas en el reconocimiento y vivencia del derecho de libertad religiosa es el de aquel derecho con el que cuentan los padres de que sus hijos puedan recibir la educación religiosa y moral que vaya de acuerdo con sus convicciones. Como en muchos otros aspectos, la legislación peruana - antigua y moderna - supera con mucho a la legislación mexicana, que cree que observar este derecho implicaría catequizar a los estudiantes de las escuelas públicas y evangelizar con esto a la sociedad entera, violentando así el Estado laico. Marín Vinces Arbulú, comentando el artículo 8o. de la Ley peruana, pone las cosas en su lugar, al señalar que ni se catequiza ni se viola la laicidad del Estado, sino que se respeta un derecho fundamental de cualquier persona, como es el que observa el Perú, respetuoso de los derechos humanos.

El derecho anterior, que en el Perú ha sido plenamente observado, podía acarrear un riesgo para aquellos hijos y padres de familia que no compartieran la enseñanza de la religión católica — mayoritaria en el Perú—, de ahí que el artículo 8 de la Ley peruana posibilite ahora la "exoneración del curso de religión", en lo que podríamos llamar el "derecho de objeción de conciencia a recibir educación religiosa en las escuelas".

En principio, lo anterior me parece correcto, y hasta vanguardista, siempre y cuando no se vea afectado el derecho de los otros padres que sí deseen que sus hijos puedan recibir educación religiosa y moral que vaya 
de acuerdo con sus convicciones. Esto se debe dejar claro, porque la tendencia de hoy parece ser la contraria; esto es, que ante la exoneración del curso de religión en todas las escuelas, se pretende quitar definitivamente tales clases en las aulas.

Otro tema de especial actualidad es el expuesto en el artículo 9 de la Ley peruana, que se refiere a la protección del ejercicio de la libertad religiosa. No voy a referirme al rico contenido del propio artículo y del comentario al mismo, que, en términos generales comparto plenamente, pero sí quiero insistir en un punto que me parece importante; éste es, el de la garantía del secreto ministerial desarrollado en la página 196 del libro.

E1 secreto ministerial — dice el comentarista - es una especie de secreto profesional, y como tal alcanza no sólo a lo que haya sido objeto de la confesión, "sino a todas las confidencias que el fiel haya hecho al ministro". En el caso de la religión católica, esta referencia alcanzaría entonces no sólo al acto de confesión, sino a todas las otras expresiones que el fiel hubiera hecho a su confesor; por ejemplo, en el ámbito de la asesoría espiritual.

En rigor, el tema anterior es ya de por sí relevante; pero hay otro que considero todavía mayor, y es el que el propio comentarista hace al referirse al fundamento de esta figura, señalando que tal fundamento se encuentra en el derecho a la intimidad o privacidad. En mi opinión, acertadamente el comentarista señala que la materia de este derecho "son confidencias realizadas por el fiel al ministro de culto con la expectativa de que no se hagan públicas, sino que se mantengan en la esfera de privacidad del confidente. Esa confianza se vería traicionada, y el derecho a la privacidad se vería vulnerado, si el ministro de culto hiciera público el contenido de la confidencia” (p. 197). Y concluye verazmente estableciendo

guardar el secreto ministerial es, para el ministro de culto, tanto un derecho como una obligación. La norma analizada plantea el caso como un «derecho» del ministro de culto, pero es también un derecho del fiel/confidente. La violación del secreto es un acto ilícito, que por lo tanto podría dar lugar a una reparación civil y a una sanción penal (idem).

El panorama actual nos muestra la importancia de reflexionar sobre el objeto del derecho protegido anteriormente, porque como todos sabemos, hoy asistimos a una reflexión sobre si se violentaría o no el secreto ministerial/confesión en aquellos casos en lo que se citara como testigo; por 
ejemplo, a un sacerdote que hubiera confesado a un pederasta, ¿se estaría violentado tal secreto ministerial? ¿Tendría que violentar dicho secreto de confesión el sacerdote? La respuesta es obvia: si se obligara a un sacerdote a declarar información conocida a través del secreto de confesión, se estaría violentado sus más íntimo derecho como ministro de culto.

Los tres siguientes artículos de la Ley peruana $(10,11$ y 12) se refieren a lo que podríamos calificar como el aspecto económico de la entidad religiosa, establecido a través del patrimonio de las entidades religiosas; las donaciones y beneficios tributarios, y el destino del patrimonio en caso de disolución. Sin duda, esta parte de la ley constituye uno de los aspectos más relevantes para el ejercicio de la libertad religiosa de los ciudadanos, porque, como es obvio, sin lugares para el culto, sin estímulos económicos y sin una buena administración en caso de extinción de la entidad, simplemente el derecho vería fuertemente limitado su ejercicio.

Poco puedo añadir al rico contenido de los comentarios hechos, por lo cual simplemente haré algunas anotaciones al margen, que han sido motivadas de las lecturas de los mismos, particularmente del artículo 10.

En primer lugar, quiero señalar un punto que en mi opinión no se ha insistido tanto cuando se comenta el tema de los bienes materiales de las entidades o asociaciones religiosas, y es que estos bienes, si bien representan la más importante forma de expresión de una fe religiosa, son mucho más que eso: son obras de interés artístico cuya protección corresponde a todos, creyentes y no creyentes. Ante el odio que hoy se observa por todo lo que representa lo religioso en el mundo occidental, por todos los bienes que en las Iglesias hay (no hace falta sino echar un vistazo a la destrucción masiva de Iglesias en los conflictos sociales, como sucedió en Chile) habría que insistir en que ese patrimonio no es sólo de la confesión religiosa o Iglesia respectiva, sino que es patrimonio de la humanidad entera; en definitiva, que es patrimonio universal, de modo que su protección correspondería a toda la humanidad, comenzado, por supuesto, por las fuerzas del orden estatal, y ante su indiferencia quizá también por fuerzas del orden internacional.

Ésta es la razón por la que se debería insistir en salvaguardar esos bienes, no sólo por su valor histórico-religioso, sino también por su valor artístico; ¿se viene haciendo esto en países como los nuestros? Evidentemente que no, y el comentarista lo señala expresamente, al escribir que "no hay una legislación específica, y tampoco se han celebrado acuerdos entre el Estado y las confesiones religiosas sobre el particular" (p. 207). 
Esto, sin contar que con la protección del patrimonio cultural se actualiza uno de los derechos que más viene siendo reivindicado en el ámbito internacional como es el derecho fundamental al patrimonio cultural de la humanidad.

En el tema de las donaciones y beneficios tributarios (artículo 11) se destacan aspectos especialmente significativos, en los que no es posible entrar aquí. Baste simplemente señalar — como idea central— el hecho de que las entidades, asociaciones religiosas o Iglesias juegan un papel trascendental en la cohesión social, y que como en el caso de las personas, las Iglesias necesitan de condiciones básicas para su subsistencia y desarrollo. Una de estas condiciones se refiere precisamente al aspecto económico, que se basa - entre otros - en el tratamiento fiscal que el Estado da a las entidades religiosas. ¿Es necesario que el Estado conceda beneficios fiscales a las Iglesias? La respuesta desde la ciencia del derecho eclesiástico es que sí. Y esto es así porque como señalábamos, las Iglesias contribuyen al bien común social, a la cohesión de la comunidad y al beneficio de ésta; en definitiva, a la observancia y pleno respeto del derecho de libertad religiosa de sus integrantes. Negar dichos beneficios fiscales implicaría, nada menos y nada más, que negar que los ciudadanos tienen derechos, $\mathrm{y}$, en consecuencia, no observar ni favorecer los mismos.

Ahora bien, el reconocimiento de que las Iglesias deban tener beneficios fiscales está fuera de toda duda. El problema se presenta en saber cuáles serían los mecanismos a través de los cuales se concretarían los beneficios. En rigor, son muchos, y no nos alcanzaría el espacio para mencionarlos, pero cualquiera que fueran éstos, deberían estar basados en el principio de igualdad, que desde Aristóteles conocemos, y que el comentarista del artículo repite, a saber: "tratar igual a los iguales, y desigual a los desiguales". Esto nos lleva a reconocer entonces que participando todas las entidades religiosas de los beneficios fiscales, dicha participación deberá ser hecha de manera proporcional o distributivamente. ${ }^{5}$

Todo lo anterior lo resume acertadamente Percy Orlando Mogollón Pacherre al señalar:

...la razón trascendental del otorgamiento de beneficios tributarios por parte del Estado a favor de las entidades religiosas radica en el deber del Estado de garantizar el desarrollo y formación integral del individuo como persona

\section{Idem.}

Esta obra está bajo una Licencia Creative Commons

Atribución-NoComercial-SinDerivar 4.0 Internacional, IIJ-UNAM. 
humana, dentro del cual se encuentra en toda su dimensión el ejercicio de la liberta religiosa (p. 241).

El artículo 13 ya lo hemos comentado; se refiere al registro de entidades religiosas que posibilita el reconocimiento estatal y la adquisición de la personalidad jurídica. Esta acotación, como sabemos, es distinta en el caso de la Iglesia católica, que no requiere de inscripción, pues goza de los derechos que el acuerdo con el Estado peruano ha firmado la Santa Sede. $\mathrm{El}$ registro es entonces para las otras confesiones religiosas.

El registro, como también dijimos, es voluntario, y tiene como una de sus principales finalidades el "reconocimiento de la personería jurídica civil de las entidades religiosas". Quizá en lo que vale la pena insistir es en que ni la existencia de la entidad religiosa ni la titularidad del ejercicio de la libertad religiosa dependen de su inscripción en el registro, por más importante que éste sea. La titularidad de este derecho y su ejercicio colectivo es anterior a cualquier concesión estatal. Sin embargo, es importante que se cuente con este registro para gozar plenamente del derecho señalado.

Para reforzar lo anterior no hace falta sino leer el penúltimo párrafo de artículo 14 de la Ley, relativo a los requisitos para la inscripción de las entidades religiosas, que a la letra establece: "La denegación de la inscripción no impide su actuación en el marco de las libertades reconocidas en la Constitución Política del Perú ni el ejercicio de los derechos que se reconocen en la presente ley".

Es precisamente el artículo 14 el que establece los requisitos para la inscripción al mencionado registro, que no varían sustancialmente de los requisitos que en otras legislaciones aparecen. Temas como el número de fieles; los lugares de culto; las actividades religiosas; el notorio arraigo; el que no debe ser menor a los siete años en el país y que debe ser comprobado por cualquier medio jurídico, no de cualquier otra índole, etcétera, constituyen los elementos que se requieren para el referido registro ante el Registro Nacional de Entidades religiosas.

Finalmente, el artículo 15 se refiere a los convenios de colaboración que podrá suscribir el Estado peruano con las entidades religiosas que hayan adquirido notorio arraigo con dimensión nacional.

Como a lo largo de toda la legislación, es necesario advertir la diferencia existente entre la Iglesia católica y las otras entidades religiosas, porque como advierte quien comenta el artículo, son dos cosas diferentes. En el caso de la primera, existe el acuerdo con la Santa Sede, y, por otra 
parte, los convenios de derecho interno que celebra el Estado con las diferentes entidades de la religión católica se rigen por ese acuerdo. Este artículo 15 es esencialmente dirigido a las entidades religiosas no católicas, con el propósito fundamental de establecer lazos de cooperación con estas otras entidades, buscado la posibilidad de cubrir el mayor espectro de protección de la libertad religiosa de sus ciudadanos. Este también es un buen ejemplo de cómo opera el principio de igualdad en el ámbito de cooperación de la libertad religiosa: "Trato igual a los iguales, e igual a las desiguales".

La reseña se ha extendido, pero esto no ha tenido otra razón que el profundo interés que me ha despertado el conjunto de artículos de la Ley peruana y las importantes reflexiones que sobre ellos se han escrito, análisis rigurosos que ponen sobre la mesa las discusiones más actuales en materia de libertad religiosa y de derecho eclesiástico. Así, después de leer tan rico contenido, no puedo llegar sino a dos conclusiones, que expreso de manera breve.

La primera tiene que ver con el contenido de la ley, que, más allá de lo que puede ser objeto de corrección, es, en general, una buena Ley, por lo avanzado de la misma al incorporar al menos dos cosas: los tratados internacionales protectores de derechos humanos en aquella parte relativa al ejercicio de la libertad religiosa, y el establecimiento y conjunción con dichos tratados del acuerdo firmado entre la Santa Sede y el Estado peruano en 1980. Como se muestra claramente, el que se tenga un acuerdo firmado con quien representa a la Iglesia mayoritaria en el Perú no es óbice para el respeto de la libertad religiosa de aquellas personas que no profesan esta religión. Esto es, en mi opinión, un verdadero compromiso por el respeto de este derecho. En este punto Perú es, sin duda, un ejemplo para México, país que anquilosado en un pensamiento decimonónico sigue pensando que tanto incorporar los tratados internacionales protectores de derechos humanos en el respeto de la libertad religiosa como firmar un acuerdo con la Santa Sede violentaría el sacrosanto Estado laico.

La segunda conclusión se desprende de la anterior, y alcanza esta vez a los autores de los comentarios y análisis. Particularmente me quiero referir a los de nacionalidad peruana, comenzando por el coordinador del libro, Carlos R. Santos Loyola, pues si no me equivoco, ésta es una nueva generación de eclesiasticistas peruanos, que ya han dado frutos importantes, y que seguirán dando importantes reflexiones, como las que esta vez nos 
ofrecen. Esto llena de esperanza a quienes hemos cultivado esta disciplina por décadas, y nos hace creer que tal vez estemos delante de lo que está llamada a ser la más importante escuela de eclesiasticistas de América Latina, como es la escuela peruana de derecho eclesiástico. En esto también Perú es un ejemplo para México.

Javier SALDAÑA SERRANO ${ }^{6}$

6 Investigador en el Instituto de Investigaciones Jurídicas, UNAM. Profesor de Filosofía del Derecho en la Facultad de Derecho de la UNAM. México. Correo electrónico: javiers@unam.mx. ORCID ID: 0000-0002-2050-034X.

Esta obra está bajo una Licencia Creative Commons Atribución-NoComercial-SinDerivar 4.0 Internacional, IIJ-UNAM. 


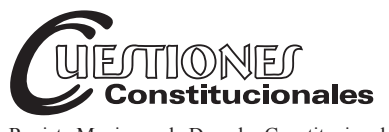

Revista Mexicana de Derecho Constitucional Núm. 43, julio-diciembre 2020

FLORES CALDAS, Edgar C., Libertad religiosa y enseñanza de la religión católica en el ordenamiento jurídico peruano y en el acuerdo con la Santa Sede de 1980, Madrid, Ediciones Universidad San Dámaso, 2018, 577 pp.

Esta obra compuesta por cinco capítulos nos presenta un tema sumamente importante en el ejercicio de los derechos fundamentales de los ciudadanos en cualquier país: la libertad religiosa y la enseñanza de la religión.

En efecto, como señala el artículo 18 de la Declaración Universal de Derechos Humanos, aprobada por la Asamblea General de las Naciones Unidas el 10 de diciembre de 1948:

Toda persona tiene derecho a la libertad de pensamiento, de conciencia y de religión; este derecho incluye la libertad de cambiar de religión o de creencia, así como la libertad de manifestar su religión o su creencia, individual y colectivamente, tanto en público como en privado, por la enseñanza, la práctica, el culto y la observancia.

Por lo tanto, la enseñanza de la religión es uno de los componentes de la libertad religiosa, y todo Estado democrático debe garantizar el acceso a ella para todos sus habitantes.

De ahí que el texto de Edgar Flores Caldas es actual y muy útil para entender y llevar a plenitud la libertad religiosa.

En el prólogo del libro, el doctor Silverio Nieto Núñez, catedrático de la Universidad Católica de Murcia, destaca que la libertad religiosa es anterior a todo derecho positivo, porque se fundamenta en la naturaleza humana; por ello, es un elemento de organización social, que implica el reconocimiento de una inmunidad para practicar la religión elegida y la expresión individual y colectiva libre del acto de fe; por tanto, la libertad religiosa debe ser tratada por el Estado como un derecho humano y ser reconocida, garantizada y fomentada por los poderes públicos. 
Nieto Núñez cita las palabras del papa Francisco del 20 de junio de 2014, donde acentúa que la libertad religiosa "favorece las relaciones de mutuo respeto entre las diversas confesiones y una sana colaboración de ellas con el Estado y la sociedad política, sin confusión de funciones y sin antagonismos" (p. 2 de la obra).

Así, la obra se compone de cinco capítulos, divididos en dos partes, y acompañados con anexos.

En el capítulo primero del libro se explica el concepto, el fundamento, el contenido y los límites de la libertad religiosa; señala las normas jurídicas que la regulan, tanto en el ámbito internacional, el regional europeo, el americano, como en la doctrina de la Iglesia católica.

El autor señala que la libertad religiosa forma parte de las tres libertades fundamentales del ser humano: de pensamiento, de conciencia y religiosa. La libertad de pensamiento o ideológica tiene por objeto el conjunto de ideas, conceptos y juicios sobre las distintas realidades del mundo y de la vida. La libertad de conciencia tiene por objeto el juicio de moralidad y la actuación en consonancia con ese juicio, y la libertad religiosa tiene por objeto la fe como acto y la fe como contenido de dicho acto; ello implica todas sus manifestaciones (individuales, asociadas o institucionales), tanto de forma pública como privada; la enseñanza, práctica, culto, observancia, y cambio de religión.

Para explicar el fundamento, el contenido y los límites de la referida libertad, Flores Caldas hace un recorrido a través de convenciones y tratados internacionales, acuerdos regionales, así como sentencias de tribunales constitucionales. Destacan en el ordenamiento jurídico internacional, los siguientes documentos: Carta de la Organización de las Naciones Unidas aprobada el 25 de junio de 1945 (artículo 13); "Declaración sobre la libertad religiosa" de la I Asamblea del Consejo Ecuménico de Iglesias, reunida en Ámsterdam del 22 de agosto al 4 de septiembre de 1948; Declaración Americana de los Derechos y Deberes del Hombre, adoptada en Santa Fe de Bogotá el 2 de mayo de 1948 (artículo tercero); Declaración Universal de Derechos Humanos, aprobada el 10 de diciembre de 1948 (artículos 2 y 18, así como el segundo considerando del preámbulo); Convenio para la Protección de los Derechos Humanos y las Libertades Fundamentales, firmado por los países del Consejo de Europa el 4 de noviembre de 1950 (artículo 9); Pacto Internacional de Derechos Civiles y Políticos de la ONU, del 16 de diciembre de 1966 (artículo 18). 
Asimismo, el autor refiere otros ordenamientos internacionales que tienen incidencia en la libertad religiosa, a saber: Convención sobre los Derechos del Niño, del 20 de noviembre de 1989 (artículos 14 y 30); Declaración sobre la Eliminación de todas las Formas de Intolerancia y Discriminación Fundadas en la Religión o las Convicciones, proclamada por la Asamblea General de las Naciones Unidas el 25 de noviembre de 1981 (artículo 6); Declaración sobre los Derechos de las Personas Pertenecientes a Minorías Nacionales o Étnicas, Religiosas y Lingüísticas, aprobada por la Asamblea General de las Naciones Unidas el 18 de diciembre de 1992 (artículo 4); Observación general No. 22 del Comité de Derechos Humanos de las Naciones Unidas, relativa al derecho de toda persona a la libertad de pensamiento, conciencia y religión (interpretación del artículo 18 del Pacto Internacional de Derechos Civiles y Políticos), del 20 de julio de 1993.

En el ámbito europeo, el autor analiza las declaraciones contenidas en las actas de la Organización para la Seguridad y Cooperación Europea (OSCE), en sus conferencias de Helsinki 1975 (principio VII), Madrid, 1986 y Viena, 1989 (apartado 16); también, el Convenio para la Protección de los Derechos Humanos y de las Libertades Fundamentales, firmado por los países miembros del Consejo de Europa en 1950 y revisado en conformidad con el Protocolo No. 11, en vigor el 1 de noviembre 1998 (artículo 9), y la Carta de los Derechos Fundamentales de la Unión Europea, proclamada por el Parlamento Europeo, el Consejo de la Unión Europea y la Comisión Europea, el 7 de diciembre de 2000, modificado en 2007 y en vigor en 2009 (artículo 10).

Y en el contorno americano, el autor hace un análisis de la Convención Americana sobre Derechos Humanos (Pacto de San José), firmada el 22 de noviembre de 1969 (artículo 12).

Este recorrido por normas internacionales y regionales permite ver que la libertad religiosa es un derecho fundamental regulado por los Estados, y que debe garantizarse su ejercicio, de acuerdo con los compromisos internacionales.

Respecto al concepto de libertad religiosa en el magisterio de la Iglesia católica, el autor analiza documentos como la declaración Dignitatis Humanae, promulgada por el papa Pablo VI el 7 de diciembre de 1965, documento emanado del Concilio Vaticano II, en el que la Iglesia reconoce y proclama el derecho de toda persona a la libertad religiosa (numeral 2 de la Declaración); también, la exhortación apostólica Evangelii Nuntian- 
di del papa Pablo VI, del 8 de diciembre de 1975 (numeral 39); la carta encíclica Veritatis Splendor, del papa Juan Pablo II, del 6 de agosto de 1993 (numeral 31); la encíclica Centesimus anus, del papa Juan Pablo II, promulgada el 1 de mayo de 1991 (numeral 47); la carta encíclica Deus caritas est, del papa Benedicto XVI, del 25 de diciembre de 2005 (numeral 28); la exhortación apostólica Evangelii gaudium, del papa Francisco, del 24 de noviembre de 2013 (numeral 255), así como numerosos discursos de los pontífices.

Todos estos instrumentos jurídicos y documentos que nos presenta Flores Caldas en el capítulo primero de su obra permiten entender el concepto, el alcance, los límites y las proyecciones de la libertad religiosa en el mundo, ya que son textos que van más allá de lo nacional; por tanto, son útiles para todos los países.

En el segundo capítulo, se estudia la evolución de la protección de la libertad religiosa en el Perú, país de origen del autor. Se revisan las Constituciones históricas, la Constitución actual y la ley de libertad religiosa (Ley 29635), así como algunas decisiones del tribunal constitucional peruano en la materia.

Esta sección ayuda a entender el derecho eclesiástico peruano, y puede ser referente para un análisis comparado de dicha disciplina jurídica con la correspondiente del derecho nacional.

El capítulo tercero se enfoca en la enseñanza de la religión, destacando que la libertad de enseñanza, el derecho a la educación y la enseñanza de la religión son derechos fundamentales. Así lo demuestra con las normas jurídicas internacionales, tanto universales como regionales (europeas y americanas), así como con referencias al derecho canónico.

La libertad religiosa implica el derecho de enseñanza de la religión, que se vincula al derecho a la educación y con el derecho de los padres o tutores a elegir la educación que recibirán sus hijos o pupilos. Para el ejercicio de estos derechos se requiere la participación de los poderes públicos.

Como se destaca en el prólogo del libro, la razón jurídica de que se imparta educación religiosa en el sistema educativo no está en la confesionalidad del Estado, pues no le corresponde a éste decidir la orientación del saber sobre el significado último y total de la vida humana, sino que la razón de la enseñanza de la religión radica en la posibilidad de una formación integral, que como derecho corresponde a los padres decidir en qué valores van a ser educados sus hijos. 
El Estado debe proporcionar la posibilidad de esa enseñanza, y corresponde a los alumnos y a sus padres o tutores el decidir aceptar o no dicha educación.

El capítulo cuarto de la obra aborda la enseñanza de la religión católica en el ordenamiento jurídico peruano, analizando cómo está regulada en dicho país.

En este sentido, destacan los fines de la educación peruana señalados en el artículo 9 de la Ley de Educación, a saber: “a) Formar personas capaces de lograr su realización ética, intelectual, artística, cultural, afectiva, física, espiritual y religiosa... b) Contribuir a formar una sociedad democrática, solidaria, justa, inclusiva, próspera, tolerante y forjadora de una cultura de paz...".

Es decir, el ordenamiento educativo peruano considera como importante el aspecto ético, espiritual y religioso, para contribuir así a formar una sociedad democrática, solidaria, inclusiva y tolerante. De ahí el papel de la enseñanza de la religión como un camino para cumplir dichos fines.

Así, como menciona el autor, el artículo 25 del Reglamento de la Ley de Educación señala que "todo niño gozará del derecho a tener educación en materia de religión conforme con los derechos de sus padres o tutores". Aquí se acentúa el derecho a la educación religiosa, como un derecho fundamental de toda persona independientemente de su situación económica o social; asimismo, en el referido precepto se tutela también el derecho de aquellos que no deseen recibir esta educación, pues está previsto que los padres, tutores o los estudiantes mayores de edad que quieren solicitar la exoneración de la educación religiosa en su currículo educativo lo pueden hacer libremente. Así, se protege el ejercicio de la libertad religiosa tanto de los creyentes como de los no creyentes.

También, es de destacarse que la educación religiosa impartida en las instituciones públicas peruanas reconoce las expresiones religiosas de los pueblos andinos, amazónicos, afroperuanos y otros. Es decir, se garantiza la pluralidad religiosa, y el acceso a la educación religiosa según sus creencias.

Lo anterior muestra que el ejercicio del derecho a la educación de acuerdo con las convicciones religiosas implica necesariamente la intervención del Estado en proporcionar dicha posibilidad de acceso, pues de lo contrario sería un derecho inalcanzable y, por tanto, inexistente.

En este sentido, comparando el ordenamiento peruano con el mexicano, podemos hacer algunas reflexiones. En efecto, en México, aunque está 
regulada la libertad religiosa por el artículo 24 constitucional, no está del todo garantizado el derecho de toda persona a la enseñanza de la religión, pues no todos los habitantes del país tienen acceso a ella, sino sólo aquellos que pueden pagar dicha educación (por ejemplo, alumnos de escuelas privadas), o quienes por su cuenta acuden a las instituciones religiosas para recibirla en la medida de las posibilidades de éstas. Dicha situación restringe el acceso universal a la educación y a la enseñanza de la religión como derecho fundamental. ${ }^{1}$

Por otra parte, está la realidad de la educación pública en México. En efecto, la educación que imparte el Estado por mandato constitucional debe ser laica (artículo tercero); sin embargo, en la práctica se ha malinterpretado y sustituido por una educación atea, antirreligiosa y/o anticlerical, lo cual nada tiene que ver con el concepto de laicidad, que consiste en un ejercicio pleno de libertad religiosa, que garantice a todos la libertad de creer o no creer, de manifestarlo privada y públicamente, de manera individual o colectiva, como lo señala el artículo 18 de la Declaración Universal de Derechos Humanos, previamente citado. Por ende, considero necesario profundizar en el concepto y en los componentes de la libertad religiosa para un ejercicio pleno en México.

Posteriormente, en el capítulo quinto de la obra reseñada, el autor examina el concordato con la Santa Sede y la República del Perú de 1980, considerando la aplicación de dicho instrumento internacional en el ejercicio de la libertad religiosa y la enseñanza de la religión en Perú.

Como se sabe, un concordato es un acuerdo internacional que realiza un país con el Estado del Vaticano (denominado en la religión católica la Santa Sede), donde se establecen lineamientos sobre el ejercicio de la religión católica en dicho país; puede incluir, como en este caso, disposiciones relativas a la enseñanza de la religión y obligaciones de ambas partes.

Un concordato tiene jerarquía de tratado internacional; por tanto, es vinculante para las partes. Así, muchos países a lo largo de su historia han firmado estos acuerdos no sólo con las autoridades de la Iglesia católica, sino también de otras Iglesias cristianas, como la anglicana, ortodoxa,

1 Al respecto puede verse Adame Goddard, Jorge, Estudios sobre politica y religión, México, UNAM, Instituto de Investigaciones Jurídicas, 2008, en especial el capítulo intitulado "El derecho a la educación religiosa en México", disponible en: https://biblio. juridicas.unam.mx/bjv/detalle-libro/2520-estudios-sobre-politica-y-religion. 
episcopaliana, luterana, por citar algunas, o bien con otras denominaciones religiosas como el judaísmo, el islam, el budismo.

Esto nos lleva también a la reflexión de que, ante la creciente heterogeneidad de las sociedades actuales y la incuestionable diversidad religiosa, es necesario adentrarse en temas que permitan entender y ejercer plenamente el derecho fundamental de libertad religiosa de todos los habitantes de un país, garantizando una convivencia sana entre todos los miembros de la sociedad.

Así pues, todos los capítulos del libro reseñado pueden ser útiles para analizar modelos a seguir para el ejercicio del derecho a la educación religiosa, en el contexto de cada país.

Sin duda, esta obra, que fue la tesis doctoral del autor, es una herramienta importante para comprender, analizar y llevar a plenitud el derecho fundamental a la libertad religiosa y la enseñanza de la religión en cualquier país, incluido por supuesto México.

Finalmente, considero que la obra de Edgar Flores también nos invita a reflexionar y desarrollar nuevas líneas de investigación y enseñanza de temas vinculados a derecho y religión, como ocurre en muchos países desarrollados. $^{2}$

En México son todavía pocas las escuelas de derecho donde se llegan a estudiar estas cuestiones; por ejemplo, la Universidad Iberoamericana Ciudad de México, donde se imparte la asignatura "Derecho y religión", o la Facultad de Derecho de la Universidad Nacional Autónoma de México (UNAM), donde se estudia la asignatura optativa "Derecho canónico".

No obstante, juzgo conveniente avanzar más en el estudio de estos temas con la creación de otras asignaturas; por ejemplo: "Derecho comparado de las religiones", ${ }^{3}$ o "Sistemas e instituciones jurídico-religiosas con-

2 Sirvan como ejemplo las siguientes publicaciones, que dan cuenta de dicho análisis y discusión académica: Derecho y Religión editada por la Universidad Autónoma de Madrid y editorial Delta (España); Revista Latinoamericana de Derecho y Religión, por la Pontificia Universidad Católica de Chile; Revista General de Derecho Canónico y Derecho Eclesiástico del Estado, dirigida por catedráticos de la Universidad Complutense y editada por Iustel (España); Journal of Law and Religion, dirigida por catedráticos de Emory University y publicada por Cambridge University Press (Estados Unidos); Oxford Journal of Law and Religion publicada por Oxford University Press (Reino Unido); Brill Research Perspectives in Law \& Religion, editado por Cardif University Centre for Law and Religion y publicado por Brill (Reino Unido).

3 Respecto a esto, he tenido la oportunidad de impartir algunos de estos temas dentro de la asignatura optativa "Derecho comparado" en la Facultad de Derecho de la UNAM. 
temporáneas", "Derecho eclesiástico de Estado", por citar algunas. Esto ayudaría a profundizar en estos temas jurídicos actuales, para un óptimo ejercicio de los derechos fundamentales.

Felicito al autor Edgar Flores por esta magna, ilustrativa, interesante y vigente obra, e invito a los interesados en el tema a consultar el libro reseñado, que está disponible en la Biblioteca "Dr. Jorge Carpizo" del Instituto de Investigaciones Jurídicas de la UNAM, y posiblemente en algunas plataformas por Internet.

\section{Efrén CHÁVEZ HERNÁNDEZ ${ }^{4}$}

Para quien quiera adentrarse en estos tópicos, pueden ser útiles las siguientes obras: Caparros, Ernest (dir.), La religion en droit comparé à l'aube du XXIe siècle, Bruxelles, Bruylant, 2000; Ferrari, Silvio, El espíritu de los derechos religiosos. Judaísmo, cristianismo e islam, traducción de Gilberto Canal Marcos, Barcelona, Herder 2004; Huxley, Andrew (ed.), Religion, Law and Tradition: Comparative Studies in Religious Law, London, Routledge, 2002; Neusner, Jacob and Sonn, Tamara, Comparing Religions Through Law: Judaism and Islam, New York, Routledge, 1999; Martínez-Torrón, Javier y Durham, W. Cole (eds.), Religion and the Secular State; Interim National Reports; Issued for the occasion of The XVIIIth International Congress of Comparative Law, Provo, Utah, Brigham Young University, The International Center for Law and Religion Studies, 2010; Soberanes Fernández, José Luis, Derechos de los creyentes, México, Cámara de Diputados, LVII Legislatura-UNAM, Instituto de Investigaciones Jurídicas, 2000, por citar algunos.

4 Académico de tiempo completo en el Instituto de Investigaciones Jurídicas y profesor de la Facultad de Derecho de la Universidad Nacional Autónoma de México (UNAM). Investigador nacional del Sistema Nacional de Investigadores de Conacyt. <efren.chavez@unam.mx> Orcid: https://orcid.org/0000-0001-9212-2950. 